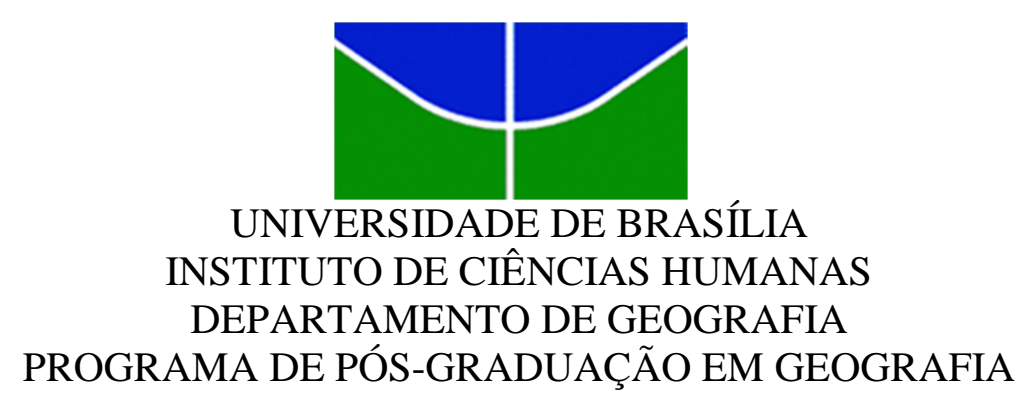

\title{
O USO AGRÍCOLA DO TERRITÓRIO E A INTEGRAÇÃO DA AGRICULTURA FAMILIAR NO AGRONEGÓCIO DO BIODIESEL DE DENDÊ-BAIXO TOCANTINS (PA)
}

Márcio Júnior Benassuly Barros

Tese de Doutorado

Brasília-DF

Novembro/2016 


\author{
UNIVERSIDADE DE BRASÍLIA \\ INSTITUTO DE CIÊNCIAS HUMANAS \\ DEPARTAMENTO DE GEOGRAFIA \\ PROGRAMA DE PÓS-GRADUAÇÃO EM GEOGRAFIA
}

\title{
O USO AGRÍCOLA DO TERRITÓRIO E A INTEGRAÇÃO DA AGRICULTURA FAMILIAR NO AGRONEGÓCIO DO BIODIESEL DE DENDÊ-BAIXO TOCANTINS (PA)
}

\author{
Márcio Júnior Benassuly Barros \\ Orientadora: Prof ${ }^{a}$. Dra. Marília Steinberger \\ Tese de Doutorado submetida ao Departamento de \\ Geografia da Universidade de Brasília, como parte \\ dos requisitos necessários para a obtenção do Grau \\ de Doutor em Geografia, área de concentração \\ Gestão Ambiental e Territorial, opção acadêmica.
}

Brasília-DF

Novembro/2016 
Ficha catalográfica elaborada automaticamente,

com os dados fornecidos pelo(a) autor(a)

BB277u

Barros, Márcio Júnior Benassuly

- uso agricola do territorio e a integração da agricultura familiar no agronegocio do biodiesel de dende-Baixo Tocantins (PA) / Márcio Júnior Benassuly Barros; orientador Marilia Steinberger. -- Brasilia, 2016.

$305 \mathrm{p}$.

Tese (Doutorado - Doutorado em Geografia) - Universidade de Brasilia, 2016.

1. Uso Agricola do Territorio. 2. Agricultura

Familiar. 3. Agronegocio. 4. Biodiesel de Dendê. 5. Baixo Tocantins. I. Steinberger, Marilia, orient. II. Título. 
UNIVERSIDADE DE BRASÍLIA

INSTITUTO DE CIÊNCIAS HUMANAS

DEPARTAMENTO DE GEOGRAFIA

PROGRAMA DE PÓS-GRADUAÇÃO EM GEOGRAFIA

\title{
O USO AGRÍCOLA DO TERRITÓRIO E A INTEGRAÇÃO DA AGRICULTURA FAMILIAR NO AGRONEGÓCIO DO BIODIESEL DE DENDÊ-BAIXO TOCANTINS (PA)
}

\author{
Márcio Júnior Benassuly Barros
}

Tese de Doutorado submetida ao Departamento de Geografia da Universidade de Brasília, como parte dos requisitos necessários para a obtenção do Grau de Doutor em Geografia, área de concentração Gestão Ambiental e Territorial, opção acadêmica.

Aprovado por:

Marília Steinberger - Orientadora (Universidade de Brasília)

Neio Lucio de Oliveira Campos - Membro interno (Universidade de Brasília)

João Santos Nahum - Membro externo (Universidade Federal do Pará)

Mirlei Fachini Vicente Pereira - Membro externo (Universidade Federal de Uberlândia)

Juscelino Eudamidas Bezerra - Membro interno (Universidade de Brasília)

Waleska Valença Manyari - Suplente (Universidade de Brasília)

Brasília-DF, 28 de novembro de 2016. 
À memória de minha mãe Leomarina Benassuly Barros, que não pôde viver para testemunhar a chegada do filho, ribeirinho nascido à beira do rio Santana (Mocajuba, Baixo Tocantins, Pará), a concretizar seu grande sonho, ser doutor! Seu exemplo na educação dos filhos valeu a pena. 


\section{AGRADECIMENTOS}

Esta tese é a expressão de um intenso desejo iniciado na juventude em conhecer meu território abrigo (Baixo Tocantins). Ficava fascinado com as viagens realizadas pelo rio Tocantins na década de 1980 entre minha cidade natal (Mocajuba) e a capital estadual (Belém). As belezas e mistérios despertavam em mim o ardente desejo em conhecer melhor minha região.

$\mathrm{Na}$ parte dos agradecimentos de um trabalho de tese, sempre se corre o risco de esquecer pessoas e instituições que foram importantes para o êxito da pesquisa acadêmica. Desde o início, peço desculpas a pessoas e instituições que por ventura não foram aqui citados e que contribuíram para a realização desta tese.

Em primeiro lugar agradeço a Deus pelo dom da vida. Nos muitos momentos ao longo desta trajetória foi nele que encontrei forças para continuar no caminho.

À minha mãe Leomarina Benassuly Barros (in memoriam), às irmãs Márcia Cristina Benassuly Barros e Daiane Benassuly Barros, esta última juntamente com o sobrinho Alan Sena Barros de Carvalho, fizeram as transcrições das entrevistas realizadas na pesquisa, poupando-me de tempo que foi utilizado em outras etapas da pesquisa. A companheira de longa caminhada Maria Rozete Alexandrino de Moraes pelo carinho, incentivo e paciência, devido a minha ausência constante na família, para dedicar aos estudos e às pesquisas.

À minha orientadora professora Marília Steinberger, pelas orientações e pelo exemplo de dedicação a pesquisa. Aos colegas do grupo de pesquisa Políticas Públicas Espaciais (UNB/CNPq), Suelen Walece Rodrigues Fernandes, Ubajara Berocan Leite, Andrea de Oliveira Nascimento, Renata Callaca Gadioli dos Santos e Vevila Rezende Costa Nascimento.

Aos professores Neio Lucio de Oliveira Campos (UnB) e Waleska Valença Manyari $(\mathrm{UnB})$, pelas sugestões no projeto de qualificação e pelo aceite em participar da defesa final da tese. Aos professores Marcel Bursztyn (UnB) e João Nildo de Souza Vianna (UnB) pelas contribuições no projeto de qualificação.

Ao professor Juscelino Eudamidas Bezerra (UnB) por compor a banca final de tese. Ao professor Mirlei Fachini Vicente Pereira (UFU), que de longa data serve de referência em minhas análises sobre a Amazônia, por compor a banca final de tese.

Ao professor João Santos Nahum (UFPA), cujo trabalho acadêmico tem mostrado novas interpretações das muitas Amazônias, como a Amazônia do dendê. Obrigado por compor a banca final desta tese. Novos caminhos estão à frente. 
Aos professores do doutorado Fernando Sobrinho (mineiro que mantém fortes relações com o Pará), Marília Peluzo e Gloria Vargas, pelos conhecimentos transmitidos por meiodas disciplinas ministradas no curso.

À bibliotecária Selma Castro, da Sudam em Belém, que facilitou meu acesso a diversas informações sobre a temática aqui pesquisada. Agradeço aos agricultores familiares integrados dos municípios de Acará, Baião, Cametá, Mocajuba, Moju e Tailândia, que me receberam em suas propriedades e responderam aos questionários empregados. Agradeço igualmente a pessoas importantes dos hotéis onde fiquei hospedado e que indicaram muitas fontes. Agradeço o apoio dos Sindicatos dos Trabalhadores e Trabalhadoras Rurais de Abaetetuba, Acará, Baião, Barcarena, Cametá, Igarapé Miri, Mocajuba, Moju e Tailândia, que foi fundamental para a realização da pesquisa. Aos muitos taxistas e moto taxistas que me conduziram aos ramais municipais para as entrevistas junto aos agricultores.

Aos colegas da turma 2013 do doutorado, pelo convívio, amizade e confidências, Rafael (SP), Ronei (MT), Lara (GO), Demerson (AC), Osmundo (DF) e Wallace Pantoja, paraense que dá continuidade a presença do Pará no doutorado em Geografia na UnB.

De igual forma sou grato a Universidade de Brasília (UnB), pelas condições encontradas para a realização do curso. Ao Jorge Luiz Pereira e ao Agnelo José Camelo Pereira da Silva, pela ajuda em muitas questões, principalmente quanto já não me encontrava residindo em Brasília.

Ao professor Christian Nunes da Silva (UFPA) pelo auxílio na coleta dos dados cartográficos utilizados nesta tese. Agradeço ao amigo Renan Satiro Miranda, pela elaboração dos mapas, onde vários deles foram ajustados diversas vezes.

À Secretaria Executiva de Estado de Educação do Pará (SEDUC-PARÁ), pela licença aprimoramento no período 2013-2014, cujo apoio foi fundamental para a realização das disciplinas em Brasília.

A todos os professores e estudantes da Universidade Federal do Oeste do Pará (UFOPA), onde trabalho como professor, em particular aos estudantes voluntários dos projetos de pesquisa "Políticas públicas e dinâmicas territoriais: o caso da Flona Tapajós, Belterra, Pará" e "Políticas públicas e dinâmicas territoriais: o caso do Pronaf na comunidade de Boa Esperança, Santarém, Pará" sob minha coordenação na UFOPA. O convívio e as discussões acadêmicas fortalecem a pesquisa no interior na Amazônia.

Ao amigo Albano Gomes, do Núcleo de Altos Estudos Amazônicos (NAEA), que encontrou tempo para a revisão desta tese. 
“O intelectual é o homem que tem o gosto ao risco, sem o qual não há descoberta. $\mathrm{O}$ intelectual é aquele que se dispõe a se indispor com os que o ouvem para trazer a verdade em que acredita naquele momento, que tem a coragem de ir descobrindo que essa verdade não é mais, voltar atrás, isto é, dar um passo a frente trazendo a nova verdade. A necessidade do risco é fundamental [...]”. (Palestra proferida por Milton Santos na V Semana de Geografia da Universidade de Brasília-UnB, em 16 de junho de 1980, publicado na revista Tempo-Técnica-Território, n. 2 . n. 2, 2011, p. 5 , grifo nosso) 


\section{RESUMO}

A criação de políticas públicas como o Programa Nacional de Produção e Uso do Biodiesel (PNPB) em 2004 e do Programa de Produção Sustentável de Óleo de Palma (PPSOP) em 2010 promoveu um conjunto de ações que resultaram na ampliação do uso agrícola do território pelo dendê no Baixo Tocantins (PA). Este estudo tem como objetivo analisar o uso agrícola do território com ênfase na integração da agricultura familiar no agronegócio de dendê no Baixo Tocantins no contexto de políticas públicas que visam à expansão da produção de dendê no Brasil. A metodologia aplicada está amparada em uma pesquisa de métodos mistos tendo como estratégia de investigação o estudo de caso. A coleta dos dados da tese consistiu na utilização da abordagem seqüencial explanatória onde iniciamos a fase da coleta de informações pelos dados quantitativos, seguida por uma pesquisa dos dados qualitativos. Na seqüência os dados foram analisados e interpretados segundo os objetivos da pesquisa. O problema da pesquisa é: como se configura o uso agrícola do território a partir da integração da agricultura familiar no agronegócio de dendê após a instalação das empresas Petrobras (Belém Bioenergia Brasil) e Vale (Biopalma) no Baixo Tocantins a partir de 2010? Os principais resultados apontam para o fato de que o dendê ocupa a maior área colhida do território agrícola do Baixo Tocantins utilizado pela lavoura permanente em 2013, área esta cerca de três vezes maior que o segundo colocado (coco da baia). A implantação dos projetos de agricultura familiar de dendê promoveu uma quebra da solidariedade social existente, pois a dinâmica passou a ter como centralidade a produção familiar de dendê regulada pela empresa. A quantidade produzida e a renda obtida na produção de dendê familiar pesquisado nas empresas Belém Bioenergia Brasil e Biopalma dependem do inicio do plantio e dos cuidados do agricultor para com o dendezal. A implantação do projeto afetou a vida dos agricultores familiares onde a lógica empresarial de mercado impõe uma mudança de hábitos e de uso da terra familiar que tem como centro de comando as normas da empresa integradora. A organização político social dos agricultores é restrita a diálogos em suas localidades.

Palavras-chave: Uso Agrícola do Território. Agricultura Familiar. Agronegócio. Biodiesel de Dendê. Baixo Tocantins. 


\begin{abstract}
The creation of public policies such as the National Program of Production and Use of Biodiesel (PNPB) in 2004, and the Program of Sustainable Production of Oil Palm (PPSOP) in 2010 promoted a group of actions which resulted in the enlargement concerning the agricultural use of the territory by palm in the Low Tocantins (Pará). This study aimed to analyze the agricultural use of the territory with emphasis on the integration of familiar agriculture regarding the palm agro business in the Low Tocantins in the public policies scenario that aim the expansion of palm production in Brazil . The methodology applied is based on a research of mixed methods having as investigation strategy the case study. The theses data collecting consisted in the use of the explanatory sequential approach where the information collecting phase was started by a quantitative data, followed by a research of qualitative ones. Next data were analyzed and interpreted according to the research goals. The research matter is related on how is the agricultural use of the territory shaped from the familiar agriculture integration in the palm agro business after the installation of Petrobras companies (Belém Bioenergia Brasil) and Vale (Biopalma) in the low Tocantins from 2010? The main results point out to the fact that the palm occupies the major harvested area of the agricultural territory of the Low Tocantins used for permanent farming in 2013, an area which is three times larger than the second place (coconut). The implantation of projects concerning the palm familiar agriculture promoted a crash in the existing social solidarity, because the dynamic began to have the palm familiar production controlled by the company as centrality. The amount produced and the income obtained in the production of familiar palm researched at the companies Belém Bioenergia Brasil and Biopalma depend on the beginning of the plantation and the farmer's care when dealing with the palm tree. The project implantation has affected the familiar farmer's life where the market business logic imposes a change of habits and of use of familiar land which has as command center the rules concerning the integrated company. The farmer's social political organization is restricted to dialogues in their districts.
\end{abstract}

Keywords: Agricultural Use of Territory. Familiar Agriculture. Agro Business. Palm Biodiesel. Low Tocantins. 


\section{LISTAS DE FIGURAS}

Figura 1: $\quad$ A fundação de Belém ............................................................................ 54

Figura 2: $\quad$ Forte do Castelo, marco da fundação de Belém pelos portugueses no século XVII ..................................................................... 55

Figura 3: $\quad$ Forte do Castelo e casarios em estilo português, marcos da presença portuguesa em Belém do Pará ................................................. 56

Figura 4: $\quad$ Prospecto da Vila do Cametá, em 1784 ....................................................... 57

Figura 5: Heranças da presença da ação católica em igreja de Cametá ....................... 58

Figura 6: Casarios antigos, herança da presença portuguesa em Cametá .................... 58

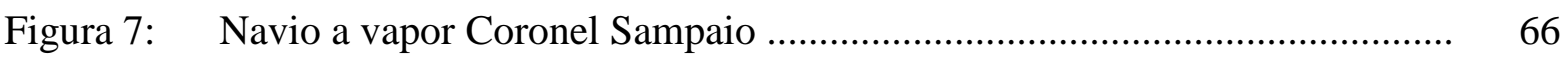

Figura 8: Batelões carregados de cana aguardando a subida do nível das águas para prosseguir viagem em Abaetetuba, Pará .................... 67

Figura 9: $\quad$ Engenho Feliz \& Costa em Abaetetuba ..................................................... 67

Figura 10: Engenho Pacheco, Abaetetuba, Pará ......................................................... 68

Figura 11: Engelho Nazaré em Igarapé Miri ............................................................. 68

Figura 12: Usina Hidrelétrica de Tucuruí, Pará ........................................................ 71

Figura 13: Lavoura de pimenta-do-reino em Baião, Pará ….......................................... 78

Figura 14: Transporte de coco-da-baía pela empresa Sococo S.A., em Moju, Pará ...................................................................................... 79

Figura 15: Lavoura de mandioca em Baião, Pará ….................................................. 80

Figura 16: Transporte de farinha de mandioca no porto da cidade de Acará .................. 81

Figura 17: Cerimônia de lançamento do Programa Nacional de Biodiesel .................... 107

Figura 18 Ações de lançamento e esclarecimentos sobre o programa de produção sustentável de palma de óleo em Belém do Pará, maio de 2010 ... 130

Figura 19: Inauguração da usina de biodiesel da Agropalma, em Belém Do Pará, 2005 150

Figura 20: Agência do Basa em Abaetetuba, 2015 ..................................................... 170

Figura 21: Propaganda do governo paraense sobre a implantação do polo de biodiesel no estado do Pará

Figura 22: $\quad$ Estrutura do viveiro de mudas de dendê em Mocajuba, Pará, em 2015 ........ 181

Figura 23: Sede do polo da Belém Bioenergia Brasil em Tailândia, 2015 .................... 191

Figura 24: Fazenda São Felipe, onde a empresa Belém Bioenergia Brasil possui plantação própria de dendê em Tailândia

Figura 25: Transporte de produção de dendê da empresa Belém Bioenergia Brasil em Tailândia

Figura 26: Coletiva de imprensa durante o lançamento do projeto biodiesel da Vale 
Figura 27: Inauguração da planta de produção de óleo de palma da Biopalma, polo Moju, Pará

Figura 28: Vista geral da planta de produção de óleo de palma da Biopalma,

Moju, Pará

Figura 29: Usina de extração de óleo de palma da Biopalma em

construção no município de Acará, 2015

Figura 30: Sede da Federação dos Trabalhadores e Trabalhadoras na

Agricultura no Estado do Pará em Belém

Figura 31: Cotidiano marcado pela presença de empresas de dendê em Tailândia 222

Figura 32: Ramal do Limãozinho em Baião 229

Figura 33: Aspectos do ramal Patauateua em Cametá 229

Figura 34: Entrada para o ramal Igarapé do Meio em Mocajuba 230

Figura 35: Ramal de acesso a localidade de Nova Paz, PA-150, em Tailândia 231

Figura 36: Aspectos da localidade de Nova Paz, em Tailândia 231

Figura 37: Aspectos da localidade de Betel, km 95 da PA-150, em Tailândia 232

Figura 38: Projeto de dendê familiar na comunidade de Betel, em Tailândia 233

Figura 39: Projeto de dendê familiar na comunidade Nova Paz, em Tailândia 234

Figura 40: Cachos de dendê em estado de colheita, em Baião 235

Figura 41: Agroindústria de beneficiamento de mandioca, comunidade Nova Paz, Tailândia, Pará 238

Figura 42: Sindicato dos Trabalhadores e Trabalhadoras Rurais de Cametá 242

Figura 43: Associação Agrícola dos Moradores da Comunidade Nova Paz, em Tailândia

Figura 44: Vicinal de acesso para o ramal do Ipitinga, em Acará 246

Figura 45: Aspecto da localidade de Ipitinga, em Acará 246

Figura 46: Ramal Bom Futuro, em Moju 247

Figura 47: Aspecto do assentamento Olho D'água I, em Moju 247

Figura 48: Comunidade de Boa Esperança, em Moju 248

Figura 49: Propriedade de dendê familiar no ramal Bom Futuro, em Moju 249

Figura 50: Dendezeiro em fase de colheita no ramal do Ipitinga, em Acará 250

Figura 51: Cachos de dendê familiar a espera de transporte para a Biopalma próximo ao ramal de Bom Futuro, em Moju

Figura 52: Associação dos Pequenos Agricultores do Olho D'água e Vicinal I, I, II, em Moju 


\section{LISTAS DE GRÁFICOS}

Gráfico 1: Área colhida (ha) por lavouras permanentes no Baixo Tocantins (PA), 2013

Gráfico 2: Área colhida (ha) por lavouras temporárias no Baixo Tocantins (PA), 2013

Gráfico 3: Área colhida (ha) por lavouras temporárias no Baixo Tocantins (PA), 2013

Gráfico 4: Área colhida (ha) por lavouras temporárias no Baixo Tocantins (PA), 2013.

Gráfico 5: Evolução da área colhida (ha) dos principais estados produtores de dendê do Brasil (1993 -2013)

Gráfico 6: Evolução da quantidade produzida (t) dos principais estados produtores de dendê do Brasil (1993 -2013) 


\section{LISTAS DE QUADROS}

Quadro 1: $\quad$ População de lugares do Baixo Tocantins, Pará em 1820 ........................... 63

Quadro 2: $\quad$ Engenhos e seus proprietários nos séculos XVIII, XVIII, XIX nos municípios do Baixo Tocantins ………………............................ 63

Quadro 3: Área colhida (ha) da lavoura permanente nos municípios do território do Baixo Tocantins, 2013

Quadro 4: Quantidade produzida (t) da lavoura permanente nos municípios do território do Baixo Tocantins, 2013

Quadro 5: $\quad$ Área colhida (ha) da lavoura temporária nos municípios do território do Baixo Tocantins, 2013

Quadro 6: Quantidade produzida (toneladas) da lavoura temporária nos municípios do território do Baixo Tocantins, 2013

Quadro 7: Uso do território agrícola em hectares nos municípios do território do Baixo Tocantins, 2013

Quadro 8: $\quad$ Área colhida (ha) de dendê no Baixo Tocantins entre 2004-2013

Quadro 9: Quantidade produzida (t) de dendê no Baixo Tocantins entre 2004-2013

Quadro 10: Evolução das aplicações de recurso do Pronaf Eco-Dendê nos municípios do território do Baixo Tocantins, 2010-2014

Quadro 11: Quantidade e valor dos contratos de investimentos do Pronaf Eco Dendê em municípios do Baixo Tocantins, 2010-2012

Quadro 12: Quantidade e valor dos contratos de investimentos do Pronaf Eco-Dendê em municípios do Baixo Tocantins, 2013-2014 96

Quadro 13: $\quad$ Atores presentes no processo de formulação da agenda do PNPB ............. 105

Quadro 14 Motivações regionais na produção de biodiesel no Brasil 109

Quadro 15 Adição de biodiesel ao diesel no Brasil segundo atos normativos 2005-2014

Quadro 16: As vertentes do PNPB

Quadro 17: Regime tributário aplicado ao biodiesel no Brasil

Quadro 18: Principais vantagens do Selo Combustível Social para as empresas de biodiesel no Brasil

Quadro 19: Principais obrigações da empresa de biodiesel como o Selo Combustível Social no Brasil

Quadro 20: Instrumentos para financiamento da produção de palma no Brasil segundo o PPSOP

Quadro 21: Instrumentos e condicionalidades para financiar a expansão da produção de palma de óleo no Brasil

Quadro 22: Características dos níveis de manejo do Zoneamento Agroecológico da Palma de Óleo no Brasil 
Quadro 23: Características das classes do manejo do Zoneamento Agroecológico da Palma de Óleo no Brasil

Quadro 24: Áreas aptas das classes de zoneamento para produção de dendê nível B e C nos estados da Amazônia legal

Quadro 25: Áreas aptas das classes de zoneamento para produção de dendê nível B e C nos municípios do Baixo Tocantins (PA) .................... 143

Quadro 26: Condições do Pronaf Eco-Dendê .............................................................. 145

Quadro 27: Condicionalidades para acesso ao Pronaf Eco-Dendê ................................ 145

Quadro 28: Recursos destinados à mão de obra e assistência técnica do Pronaf Eco-Dendê durante os quatro primeiros anos do projeto ........... 146

Quadro 29: Produção de biodiesel (B100) em $\mathrm{m}^{3}$ no estado do Pará, 2005-2014......... 150

Quadro 30: $\quad$ Principais produtores de óleo de palma do mundo em 2014 ..................... 153

Quadro 31: Produção, importação, exportação e consumo de óleo de palma no Brasil, 2010-2013

Quadro 32: Produção, importação, exportação e consumo de óleo de palmiste no Brasil 2010-2013

Quadro 33: Área e quantidade produzida dos principais estados produtores de dendê no Brasil, 2011-2013

Quadro 34: Área colhida de dendê no estado do Pará entre 2004-2013 157

Quadro 35: Principais empresas produtoras de óleo de palma no Pará em 2014 158

Quadro 36: Capacidade instalada de usinas e produção de óleo de palma e palmiste no Pará em 2012

Quadro 37: Produção agrícola familiar de dendê no Pará em 2012 165

Quadro 38: Distribuição das linhas do Pronaf em 2013 171

Quadro 39: Estabelecimentos por grupo de áreas total segundo municípios do Baixo Tocantins (PA) no censo agropecuário 1995-1996

Quadro 40: Área plantada de dendê pela Belém Bioenergia Brasil 2011-2013

Quadro 41: Adesão de agricultores familiares no polo Tailândia da Belém Bioenergia Brasil

Quadro 42: Área plantada própria e integrada e metas de expansão da Biopalma

Quadro 43: Racionalidade nos territórios da agricultura familiar de dendê regulado pelo agronegócio no Baixo Tocantins (PA), visitados em 2015

Quadro 44: Comportamentos regulados dos agricultores nos territórios da agricultura familiar de dendê regulado pelo agronegócio no Baixo Tocantins (PA)

Quadro 45: Contrarracionalidade nos territórios da agricultura familiar de dendê regulado pelo agronegócio no Baixo Tocantins (PA), visitadas em 2015 
Quadro 46: Característica dos segmentos produtivos agrícolas da cadeia produtiva do dendê

Quadro 47: Tecnologias utilizadas para a produção de dendê pelos segmentos das empresas capitalistas e empresa familiar

Quadro 48: Territórios da agricultura familiar de dendê regulado pela Belém Bioenergia Brasil (BBB) visitado no Baixo Tocantins (PA), 2015

Quadro 49: Territórios da agricultura familiar de dendê regulado pela Biopalma visitados no Baixo Tocantins (PA), 2015 


\section{LISTAS DE MAPAS}

Mapa 1: $\quad$ Território do Baixo Tocantins (PA) …........................................................ 27

Mapa 2: Ocupação e uso do território do Baixo Tocantins a partir do rio

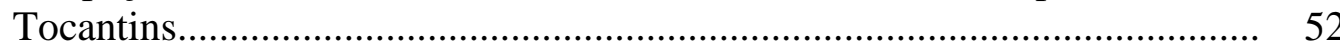

Mapa 3: Uso agrícola do território pela lavoura permanente nos municípios do Baixo Tocantins (PA), 2013

Mapa 4: Uso agrícola do território pela lavoura temporárianos municípios do Baixo Tocantins (PA), 2013

Mapa 5: Uso agrícola do território pela principal lavourapermanente nos municípios do Baixo Tocantins (PA), 2013

Mapa 6: Uso agrícola do território pela principal lavoura temporária nos municípios do Baixo Tocantins (PA), 2013

Mapa 7: Uso agrícola do território pela dendeicultura no Baixo Tocantins (PA), 2013

Mapa 8: Territorialização do Pronaf Eco-Dendê no Baixo Tocantins (PA),

2010-2014.

Mapa 9: Polo de dendê no estado do Pará, MDA-PNPB, 2003..

Mapa 10: Zoneamento agroecológico do dendezeiro nas áreas desmatadas da Amazônia legal, nível de manejo B

Mapa 11: Zoneamento agroecológico do dendezeiro nas áreas desmatadas da Amazônia legal, nível de manejo C

Mapa 12: Zoneamento agroecológico do dendezeiro nas áreas desmatadas da Amazônia legal, estado do Pará- nível de manejo B

Mapa 13: Zoneamento agroecológico do dendezeiro nas áreas desmatadas da Amazônia legal, estado do Pará- nível de manejo C

Mapa 14: Concepção de projetos da Petrobrás Biocombustível no Baixo Tocantins (PA), 2010

Mapa 15: Território de atuação da Belém Bioenergia Brasil e territóriosda agricultura familiar de dendê regulado pela empresano Baixo Tocantins (PA), 2015

Mapa 16: Território de atuação da Biopalma e territórios da agricultura familiar de dendê regulado pela empresa no Baixo Tocantins (PA), 2015 


\section{LISTAS DE SIGLAS}

Albras- Alumínio Brasileiro

Alunorte- Alumínio do Norte do Brasil

Bacen - Banco Central do Brasil

Basa - Banco da Amazônia

BBB - Belém Bioenergia Brasil

CEIB - Comissão Executiva Interministerial do Biodiesel

Contag - Confederação Nacional dos Trabalhadores da Agricultura

Emater - Empresa de Extensão Rural do Estado do Pará

Embrapa - Empresa Brasileira de Pesquisa Agropecuária

Faepa - Federação da Agricultura do Estado do Pará

Fase - Federação de Órgão para Assistência Social e Educacional

Fetagri - Federação dos Trabalhadores e Trabalhadoras na Agricultura no Estado do Pará

Fetraf - Federação dos Trabalhadores da Agricultura Familiar

GTI - Grupo de Trabalho Interministerial

Ibama - Instituto Brasileiro do Meio Ambiente e dos Recursos Naturais Renováveis

IBGE - Instituto Brasileiro de Geografia e Estatística

Incra - Instituto Nacional de Colonização e Reforma Agrária

Iterpa - Instituto de Terras do Pará

MAPA - Ministério da Agricultura, Pecuária e Abastecimento

MDA - Ministério do Desenvolvimento Agrário

MME - Ministério de Minas e Energia

NAEA - Núcleo dos Altos Estudos Amazônicos

Parábiodiesel - Programa Paraense de Incentivo a Produção de Biodiesel

PGC - Programa Grande Carajás

PNA - Programa Nacional de Agroenergia

PNPB - Programa Nacional de Produção e Uso do Biodiesel

Polamazônia - Programa de Polos Agropecuários e Agroindustriais

PPSOP - Programa de Produção Sustentável de Óleo de Palma 
Proalcool - Programa Nacional de Álcool

Probiodiesel - Programa Brasileiro de Desenvolvimento Tecnológico de Biodiesel

Pronaf - Programa Nacional de Fortalecimento da Agricultura Familiar

SPVEA - Superintendência do Plano de Valorização Econômica da Amazônia

STTR - Sindicato dos Trabalhadores e das Trabalhadoras Rurais

Sudam - Superintendência de Desenvolvimento da Amazônia

UFPA - Universidade Federal do Pará

UHT - Usina Hidrelétrica de Tucuruí 


\section{SUMÁRIO}

INTRODUÇÃO

1 CAPITULO 1: OCUPAÇÃO E USO AGRÍCOLA DO TERRITÓRIO DO BAIXO TOCANTINS: DO PASSADO AO PRESENTE

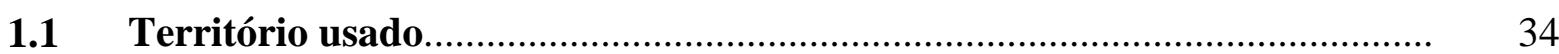

1.2 Uso agrícola do território.......................................................................... 43

1.3 Ocupação e uso agrícola do território do Baixo Tocantins no período prétécnico

1.4 Ocupação e uso agrícola do território do Baixo Tocantins no período técnico 64

1.5 Ocupação e uso agrícola do território do Baixo Tocantins no período técnico- científico-informacional

1.5.1 Uso agrícola do território no Baixo Tocantins: uma ênfase nas lavouras permanentes e temporárias, 2013

1.5.2 Uso agrícola do território pela dendeicultura no Baixo Tocantins: áreas, produtividade e fomento da produção

1.5.3 Fomento da produção agrícola de dendê no Baixo Tocantins: uma ênfase na territorialização do Pronaf Eco-Dendê

2 CAPITULO 2: DO PROGRAMA NACIONAL DE PRODUÇÃO E USO DO BIODIESEL (PNPB) AO PROGRAMA DE PRODUÇÃO SUSTENTÁ VEL DE ÓLEO DE PALMA (PPSOP)..................................... 97

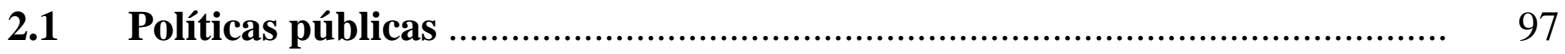

2.2 Antecedentes ligados ao biodiesel no Brasil................................................. 100

2.3 Programa Nacional de Produção e Uso do Biodiesel (PNPB)......................... 107

2.3.1 Arenas decisórias do PNPB: CEIB e Grupo Gestor .............................................. 112

2.3.2 Vertente social do PNPB: o papel do MDA e o Selo Combustível Social ............. 114

2.3.3 Projeto Polos de Biodiesel ............................................................................. 126

2.4 Programa de Produção Sustentável de Óleo de Palma (PPSOP) ..................... 129

2.4.1 Lançamento do PPSOP no contexto político e econômico nacional ...................... 129

2.4.2 Atos normativos e políticas de incentivos para a expansão da produção de dendê no Brasil .............................................................................. 130

2.4.3 Criação da linha Eco-Dendê no Programa Nacional da Agricultura Familiar (Pronaf Eco-Dendê) ..................................................................................... 143

2.4.4 Produção de biodiesel no Brasil ........................................................................ 147

3 CAPITULO 3: CADEIA PRODUTIVA E O PAPEL DO MDA, BASA, EMPRESAS, FETAGRI E AGRICULTORES NA INTEGRAÇÃO DA AGRICULTURA FAMILIAR NO AGRONEGÓCIO DE BIODIESEL DE DENDÊ NO BAIXO TOCANTINS(PA)

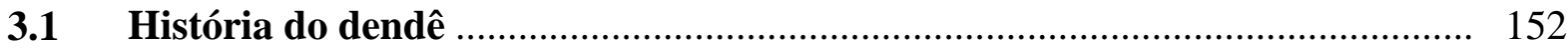

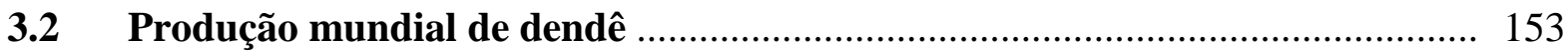

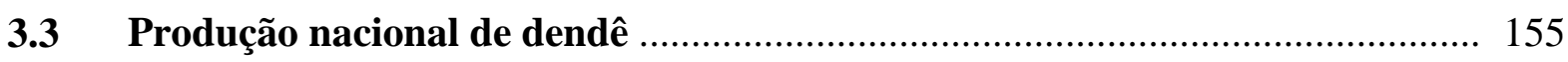

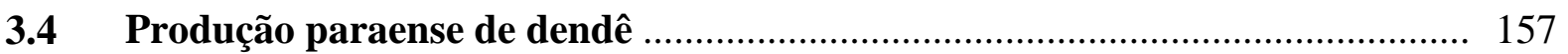


3.5 Cultura do dendê: práticas agrícolas, transporte e beneficiamento................ 159

3.6 Sistema de integração de dendê no Baixo Tocantins ...................................... 161

3.7 O papel do MDA, BASA, Empresas, Fetragri e agricultores na integração agricultura familiar no agronegócio de biodiesel de dendê no Baixo Tocantins.

3.7.1 Ministério do Desenvolvimento Agrário (MDA) ............................................... 166

3.7.2 Banco da Amazônia (Basa) .......................................................................... 169

3.7.3 Empresas integradoras de dendê .................................................................... 175

3.7.4 Federação dos Trabalhadores e Trabalhadoras na Agricultura no Estado do Pará (Fetagri) ................................................................................. 202

3.7.5 Agricultores familiares beneficiários do Pronaf Eco-Dendê ................................ 208

4 CAPITULO 4: TERRITÓRIOS DA AGRICULTURA FAMILIAR DE DENDÊ REGULADOS PELO AGRONEGÓCIO NO BAIXO TOCANTINS (PA): AS EXPERIÊNCIAS DAS EMPRESAS BELÉM BIOENERGIA BRASIL E BIOPALMA

4.1 O sistema de integração da agricultura familiar no agronegócio de biodiesel de dendê como a fase mais recente do uso agrícola do território no Baixo Tocantins (PA)

4.2 Racionalidade das empresas integradoras e dos agricultores familiares integrados de dendê no Baixo Tocantins (PA)

4.3 Experiências de integração da agricultura familiar de dendê da empresa Belém Bioenergia Brasil (Pbio + Galp) no Baixo Tocantins (PA)

4.3.1 Territórios da agricultura familiar de dendê regulados pela Belém Bioenergia Brasil (Pbio + Galp) visitados no Baixo .

4.3.2 Resultados da pesquisa empírica.

4.4 Experiências de integração da agricultura familiar de dendê da empresa Biopalma (Vale + Msp) no Baixo Tocantins (PA)

4.4.1 Territórios da agricultura familiar de dendê regulados pela Biopalma (Vale + Msp) visitados no Baixo Tocantins (PA).

4.4.2 Resultados da pesquisa empírica. 


\section{INTRODUÇÃO}

Por ser um território extremamente complexo e diversificado, na Amazônia existem várias Amazônias (GONÇALVES, 2005). Tomando esta ideia da pluralidade do território amazônico, constatamos em seu processo de ocupação histórico a existência de uma Amazônia dos rios e outra das estradas, que na atualidade fazem parte de um processo dialético, contraditório e desigual. Em muitos de seus territórios, o rio como vetor de transporte foi substituído pelas estradas e em outros coexistem temporalidades que formam uma relação complementar rio-estrada e marcam o que Santos (2006) denomina de eixo das sucessões e das coexistências.

Anderson (1991) refere-se à Amazônia tradicional, acessada pelos rios, onde o solo de várzea predomina e à Amazônia da fronteira, acessada pelas rodovias, onde o solo de terra firme predomina. Esta divisão realizada pelo autor pode ser aplicada na região do Baixo Tocantins onde podemos afirmar a existência de um Baixo Tocantins tradicional e de um Baixo Tocantins da fronteira.

No Baixo Tocantins tradicional, o rio é o principal eixo de ligação inter e intramunicipal. Fração do território de ocupação mais antiga onde foram fundadas as primeiras vilas ribeirinhas, a exemplo da Vila de Viçosa de Santa Cruz de Camutá, em 1635. Ao longo do rio Tocantins e seus afluentes existem populações tradicionais constituídas por ribeirinhos, indígenas, quilombolas, pescadores que vivem um cotidiano marcado por um espaço-tempo do rio onde o ritmo da natureza determina as muitas atividades que são ali desenvolvidas dentre as quais se destacam: a agricultura familiar, a pesca, a coleta de produtos do extrativismo vegetal da floresta. Nesta fração do território o rio comanda o ritmo de vida do habitante ribeirinho, como menciona Leandro Tocantins (1973). A racionalidade das atividades econômicas aí instaladas obedecem a uma lógica de produção para atender o mercado local.

Por sua vez, no Baixo Tocantins da fronteira, as estradas são os principais eixos de integração inter e intramunicipal. Trata-se da fração do território de ocupação mais recente que surge a partir da execução de políticas de integração rodoviária, principalmente depois da década de 1960, quando foram construídas rodovias federais, estaduais e municipais para interligá-la a pontos externos. Estas rodovias promoveram um espaço-tempo da estrada, onde o ritmo do capital determina a implantação de atividades econômicas como a pecuária e a agricultura moderna. A ação estatal ocorreu de forma intensa nesta fração do território do 
Baixo Tocantins mediante a realização de grandes projetos de mineração como a Albrás/Alunorte, em Barcarena, e de projetos agrícolas de dendê, em Moju e Tailândia.

Estes últimos estão inseridos em um dos setores que mais tem recebido atenção do Estado - o agronegócio do dendê, uma vez que o estado do Pará transformou-se no principal polo de produção desta cultura no Brasil. A expansão da produção agrícola empresarial no Pará segue uma orientação de políticas públicas que incentivam a integração da agricultura familiar no agronegócio de dendê. A racionalidade das atividades econômicas aí instaladas (pecuária e agricultura moderna) obedece a uma lógica de produção voltada para o mercado nacional e internacional que têm gerado uma série de transformações socioterritoriais na região.

No Baixo Tocantins coexistem no território uma realidade híbrida onde o tradicional convive como o moderno, o que faz com que a agricultura familiar que utiliza técnicas tradicionais conviva ao lado de uma agricultura moderna empresarial que usa modernas técnicas agrícolas. Assim, a relação dialética entre estes dois modelos de agricultura parece ter encontrado no projeto de integração de dendê uma oportunidade para uma parceria. $\mathrm{O}$ movimento dialético entre o novo e o velho, de que fala Santos (1985), tem na região um ponto central na análise deste encontro e desencontro.

Esta relação entre o velho representado pelos agricultores familiares, herdeiros da prática de uma agricultura secular na região e o novo, materializado pelos empresários ligados ao agronegócio de dendê e suas racionalidades de uma produção em larga escala e voltados para o mercado nacional e internacional, marcam o encontro entre estes personagens no campo do Baixo Tocantins.

Historicamente o Baixo Tocantins sempre funcionou como um território agrícola fornecedor de recursos naturais para o mercado exterior, passando pela exploraçãode cana-deaçúcar, cacau, pimenta-do-reino e dendê. Contudo, o cultivo destes produtos agrícolas pouco beneficiou a agricultura familiar. Os grandes projetos têm promovido uma transformação na vida de pequenos produtores nos locais onde os mesmos têm sido instalados. A chegada do novo representado pelas empresas agrícolas de dendê marca uma transformação no modo de vida do agricultor que tem seu cotidiano alterado. No geral as empresas são caracterizadas como portadoras de uma modernização enquanto que as populações tradicionais são associadas com o atraso. Desta forma, tradicional e moderno passam a conflitar pelo uso do território em questão. O território do Baixo Tocantins vem experimentando um conjunto de transformações sociais, econômicas e territoriais com a chegada de empresas de dendê na 
região que passam a promover um uso agrícola seletivo de frações do território em diversos municípios.

A partir da criação de políticas públicas nacionais ligadas ao setor de agroenergia com destaque para o Programa Nacional de Produção e Uso de Biodiesel (PNPB), em 2004, e do Programa de Produção Sustentável de Óleo de Palma (PPSOP), em 2010, ocorre um aumento da disponibilidade de crédito bancário rural destinado à produção de dendê por agricultores familiares integrados por contratos a empresas na região. Esta particularidade transformou o Baixo Tocantins no principal território de produção agrícola desta lavoura do Pará, onde ocorre o maior número de experiências de plantios de dendê familiar integrada no estado.

A chegada das empresas de dendê e a execução dos contratos familiares de integração de em sua cadeia produtiva promovem uma mudança sem precedentes na condição do agricultor. Desta forma, podemos falar de uma realidade do agricultor na região antes e depois da adesão aos projetos de agricultura integrada. Antes o agricultor familiar tinha a liberdade de decidir como, quando plantar e a cultura agrícola que desejasse. Quando adere ao projeto agrícola de integração, perde esta liberdade de decisão que é transferida para a empresa a que está vinculado. A relação do agricultor à empresa ocorre mediante a celebração de um contrato do Pronaf Eco-Dendê que tem no Banco da Amazônia (Basa) o seu principal operador no Pará. A partir das diretrizes e racionalidades das políticas públicas (PNPB e PPSOP), as empresas de dendê traçam suas ações em que o agricultor é peça fundamental nesta estratégia, pois por meio da integração da produção agrícola familiar à produção empresarial, passam a ter uma série de benefícios fiscais previstos nas políticas anteriormente citadas.

A tese aponta que a integração da agricultura familiar de dendê no agronegócio no Baixo Tocantins é resultado das políticas públicas (PNPB e PPSOP), que por meio de incentivos e instrumentos, passam a criar as condições políticas, econômicas, sociais e ambientais para a sua execução e viabilização. As diretrizes destas políticas públicas criam as condições para que as empresas possam realizar seus investimentos no setor. A parceria entre o Estado e o agronegócio passa a criar condições favoráveis para a viabilização do agronegócio de dendê no estado do Pará, onde a integração da agricultura familiar está contemplada como elemento importante para a geração de renda e emprego no campo. Esta associação resulta em um uso do território como recurso, onde o objetivo maior é a expansão da produção agrícola nacional. Neste sentido, nos territórios de agricultura familiar de dendê regulado pela empresa, as normas promovem um cotidiano regulado e controlado pela 
racionalidade hegemônica empresarial, em que a produção agrícola familiar é incorporada à da empresa.

A partir de 2004, com o PNPB, novas ações são desenvolvidas pelo governo federal para a produção de biodiesel no Brasil, onde na Região Amazônica o dendê foi selecionado como matéria-prima para produção de biodiesel. Desde então, políticas e instrumentos foram criados para ampliar a expansão do cultivo de dendê no Pará. No contexto do PPSOP, posterior a 2010, novos investimentos são realizados no território do Baixo Tocantins. Este processo se intensifica com a chegada de grandes empresas de dendê na região como a Petrobras (Belém Bioenergia Brasil) e a Vale (Biopalma), que passam a investir no cultivo agrícola de dendê visando à produção de biodiesel. A primeira empresa visa a produção de biodiesel para abastecer a região Norte do Brasil e o mercado europeu, em especial Portugal e parte da Espanha. A segunda tem como objetivo atender suas próprias demandas de suas máquinas pesadas (caminhões, locomotivas etc.) do sistema Norte/Nordeste de mineração.

As diretrizes das políticas públicas de expansão do cultivo do dendê (PNPB e PPSOP) estabelecem a integração da produção agrícola familiar na cadeia produtiva do agronegócio, mediante a celebração de contratos de integração. Esta nova realidade só foi possível por meio da criação pelo governo federal no final de 2009 do Pronaf Eco-Dendê como uma nova linha de financiamento da produção agrícola familiar. Com a disponibilidade do crédito bancário para o cultivo desta oleaginosa, muitos agricultores familiares de diversos municípios do Baixo Tocantins firmaram contratos de integração com diversas empresas agrícolas como a Belém Bioenergia Brasil (Pbio + Galp) e a Biopalma (Vale + Msp), objeto de nossas investigações na presente pesquisa.

Assim, o problema da pesquisa é: como se configura o uso agrícola do território a partir da integração da agricultura familiar no agronegócio de dendê após a instalação das empresas Petrobras (Belém Bioenergia Brasil) e Vale (Biopalma) no Baixo Tocantins a partir de 2010 ?O objetivo geral desta pesquisa é analisar o uso agrícola do território com ênfase na integração da agricultura familiar no agronegócio de dendê no Baixo Tocantins no contexto de políticas públicas que visam à expansão da produção dessa oleaginosa no Brasil. Já os objetivos específicos são: a) analisar a integração da agricultura familiar no agronegócio no contexto das políticas públicas de expansão da produção de dendê; b) analisar a racionalidade do Estado-Empresa e possíveis resistências do agricultor a estas diretrizes reguladoras; c) analisar as experiências de integração da agricultura familiar de dendê no agronegócio das empresas selecionadas; d) analisar as práticas de solidariedades entre os agricultores por meio da organização político-social. A hipótese da pesquisa considera que a integração da 
agricultura familiar no agronegócio no biodiesel de dendê é uma orientação de políticas públicas que estabelecem ganhos para as empresas de agronegócio e para os agricultores familiares.

A justificativa da pesquisa tem uma fundamentação existencial e acadêmica com o território do Baixo Tocantins. Nascido em área ribeirinha do município de Mocajuba, convivo de longa data com parte da realidade dos municípios deste território. Esta relação existencial é fortalecida pela presença de familiares em cidades da região como Baião e Cametá, onde sempre que possível realizo visitas. A esta questão existencial, soma-se a experiência acadêmica de ter cursadoa graduação em Geografia no Campus Universitário do Baixo Tocantins da Universidade Federal do Pará (UFPA), localizado na cidade de Abaetetuba, onde participei de muitas pesquisas acadêmicas sobre a região. É nesta época (2001) que ocorre minha primeira experiência na iniciação cientifica por meio de projeto coordenado pela professora Maria Célia Nunes Coelho (UFRJ) que naquele período encontrava-se cedida para o Núcleo de Altos Estudos Amazônicos (NAEA) da UFPA, onde acabei me engajando em pesquisas sobre a atuação do projeto Albrás/Alunorte em Barcarena. Desta forma, sem saber começava ali uma trajetória acadêmica que teria nos anos posteriores o centro de análise frações do território do Baixo Tocantins, principalmente da realidade de Barcarena, onde realizei pesquisas que culminaram em trabalhos acadêmicos de conclusão de curso e mestrado, além de outras publicações divulgadas em eventos científicos no Brasil. Esta trajetória acadêmica continua com o desenvolvimento desta tese de doutoramento.

A base teórica da pesquisa é a teoria espacial proposta por Milton Santos (1994; 1996; 1999), que considera o espaço geográfico (sistemas de objetos e sistemas de ações) como sinônimo de território usado. A presente pesquisa tem como recurso de método, a periodização segundo uma abordagemespaço-temporal como caminho de análise. Para Santos (2006, p. 126), "o modelo sistemas de objetos-sistemas de ações somente se entende como um modelo espaço-temporal", onde teoria e empiria (SANTOS; SILVEIRA, 2001) são pares dialéticos fundamentais no processo de construção do conhecimento geográfico. A opção teórica serviu como guia para a revisão da literatura que consistiu de uma ampla pesquisa sobre o percurso teórico adotado na tese com ênfase no território, território usado, políticas públicas, agricultura familiar e agronegócio. A revisão da literatura procurou privilegiar artigos de periódicos nacionais, trabalhos de pós-graduação ${ }^{1}$, livros especializados além de

\footnotetext{
${ }^{1}$ Busca em periódicos, banco de teses e dissertações do Instituto Brasileiro de Informação em Ciência e Tecnologia (IBICT) com ênfase nos programas de pós-graduação em Geografia da Universidade de São Paulo (USP), da Universidade Estadual de Campinas (UNICAMP) e da Universidade Estadual Paulista (UNESP).
} 
trabalhos de eventos recentes. Este trabalho teve como objetivo identificar o estado da arte de categorias de análises, conceitos e termos adotados na tese, o qual foi condensado no primeiro capítulo deste trabalho que trata das bases teóricas da pesquisa. Propomos nesta pesquisa de tese analisar a relação dialética da integração da agricultura familiar de dendê no agronegócio de biodiesel entendida como a fase mais recente do uso agrícola do território no Baixo Tocantins (PA), tendo no território usado (SANTOS, 1994) a categoria de análise social adotada na presente pesquisa. A seguir tratamos da base metodológica da pesquisa.

Recorte espacial da pesquisa. A presente pesquisa de tese tem como recorte espacial o território do Baixo Tocantins, (Mapa 1) estado do Pará, que é constituído por onze municípios, (Abaetetuba, Acará, Baião, Barcarena, Cametá, Igarapé Miri, Limoeiro do Ajuru, Mocajuba, Moju, Oeiras do Pará e Tailândia) dos quais sete (Abaetetuba, Acará, Baião, Cametá, Mocajuba, Moju, Tailândia) apresentam projetos de agricultura familiar integradas ao agronegócio financiado pelo crédito rural do Pronaf Eco-Dendê. Este território, segundo o Censo Demográfico do IBGE de 2010, tem uma população de 740.045 habitantes.

Recorte temporal da pesquisa. Na pesquisa de tese propomos uma periodização para o entendimento do uso agrícola do território do Baixo Tocantins (PA). Esta periodização considera três períodos, em que analisamos a ocupação e o uso agrícola do Baixo Tocantins: pré-técnico, técnico e técnico-científico-informacional. Esta análise considera o uso agrícola do território desde a sua ocupação pelas primeiras populações indígenas, com destaque para os índios Camutá, até a ocupação agrícola atual pelas empresas de dendê. A ideia desta periodização da ocupação agrícola visa demonstrar os sucessivos usos agrícolas pelos quais passou este território.

A pesquisa empírica enfatiza o uso agrícola do território no período técnico-científicoinformacional tendo como marco temporal o período de 2010-2015. Este período é justificado pela chegada em 2010 das empresas de dendê, Petrobras que anuncia dois projetos para o Baixo Tocantins, o projeto Pará e o projeto Belém, e da Vale, que apresenta seu projeto de dendê tendo suas ações comandas pela empresa controlada Biopalma. A Petrobras por intermédio da Belém Bioenergia Brasil, e a Vale, por meio da Biopalma, possui projetos explícitos para a produção de biodiesel. A análise dos dados secundários teve o ano de 2013, como referencial, pois até dezembro de 2015, estes eram os dados mais atualizados disponíveis na base do IBGE. O marco temporal final da tese é outubro de 2015 quando realizamos as entrevistas com os agricultores familiares integrados de dendê na região. 
Mapa 1: Território do Baixo Tocantins (PA)

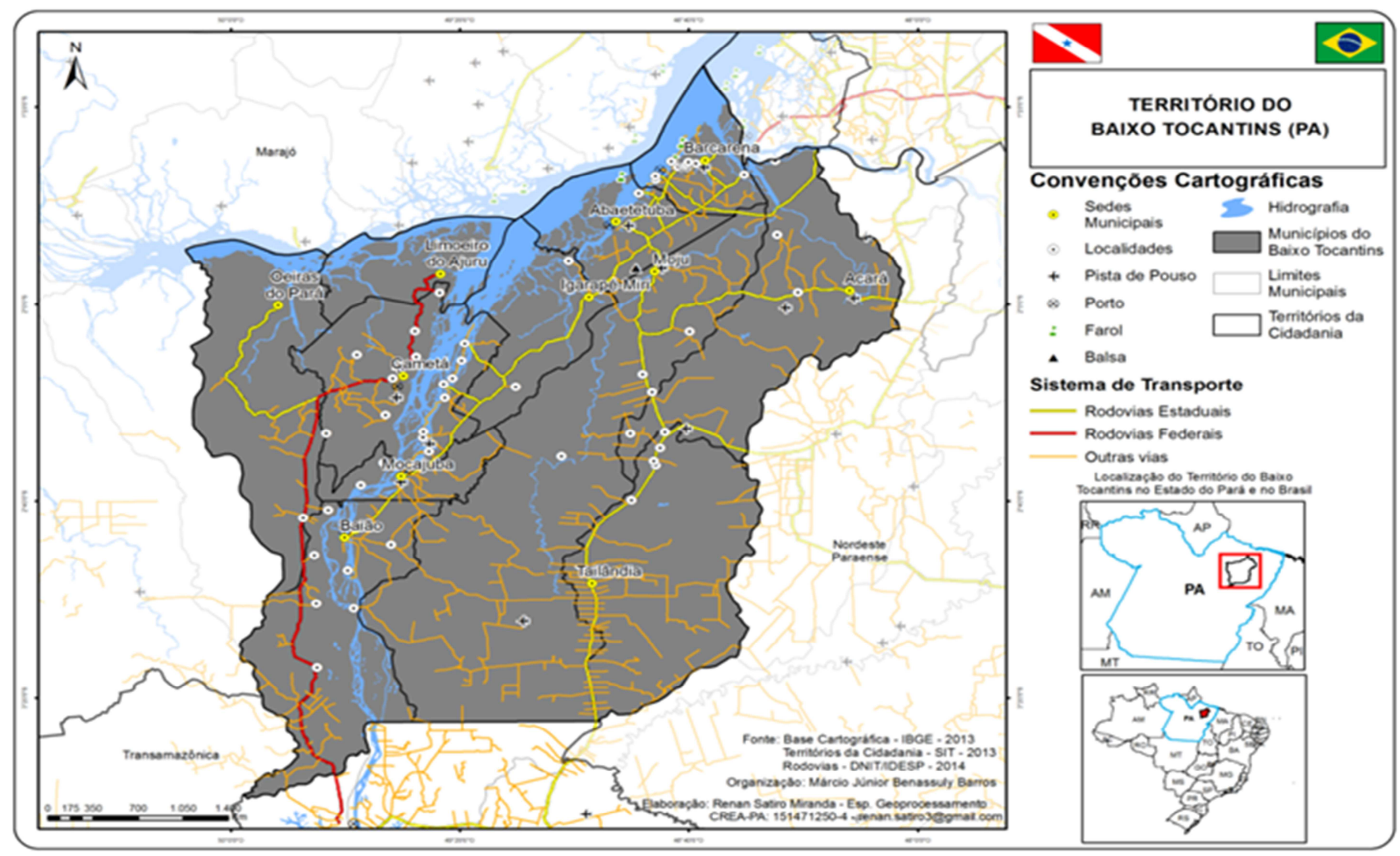


A metodologia empregada na presente pesquisa de tese está amparada em uma pesquisa de métodos mistos, tendo como estratégia de investigação o estudo de caso. A coleta dos dados da tese consistiu na utilização da abordagem seqüencial explanatória (CRESWELL, 2010). Iniciamos a fase da coleta de informações pelos dados quantitativos (secundários), seguida por uma pesquisa dos dados qualitativos (primários). Na sequência, os dados quantitativos foram analizados e interpretados segundo os objetivos da pesquisa de tese.

Planejamento e elaboração dos questionários de entrevistas. Uma vez estabelecidos os objetivos e a seleção dos entrevistados selecionados para a pesquisa, iniciamos o planejamento e a elaboração dos questionários para cada tipo de entrevistado. Nas entrevistas do trabalho de campo, empregamos perguntas abertas (qualitativas). Os questionários de entrevistas aplicados foram elaborados a partir de um planejamento onde foram elaborados sete tipos de questionários que foram aplicados em trabalho de campo (Apêndices). $\mathrm{O}$ questionário destinado às empresas não foi aplicado tendo em vista, a dificuldade de agendar esta entrevista com as duas empresas pesquisadas. Quanto à escolha das empresas, esta seleção deve-se ao fato de que estas se instalaram no Pará no contexto da criação de políticas públicas de expansão do cultivo de dendê (PNPB e PPSOP) possuindo projetos para a produção de biodiesel de dendê.

$\mathrm{Na}$ coleta dos dados da pesquisa adotamos uma amostragem do tipo intencional (CRESWELL, 2010; CRESWELL; PLANO CLARK, 2013), em que foram selecionados intencionalmente os participantes da pesquisa, ou seja, representantes de instituições estatais (Ministério do Desenvolvimento Agrário no Pará, Banco da Amazônia, Secretarias Municipais de Agricultura de Moju e Mocajuba), Empresas, instituições sociais (Federação dos Trabalhadores da Agricultura no Pará, Sindicato dos Trabalhadores e Trabalhadoras da Agricultura de Abaetetuba, Acará, Baião, Barcarena, Cametá, Mocajuba, Moju, Tailândia) e agricultores familiares integrados. Na pesquisa procuramos destacar o papel da cada instutuição e dos agricultores nas experiências de agricultura familiar de dendê pesquisado no Baixo Tocantins.

Coleta de dados. Esta fase foi dividida em quatro partes: observação da realidade local (anotações de campo com uso de um diário de notas), entrevistas (com aplicação de questionários de perguntas abertas) tendo como ênfase os respresentantes de instituições estatais (Ministério do Desenvolvimento Agrário no Pará, Banco da Amazônia, Secretarias Municipais de Agricultura de Moju e Mocajuba) e de instituições sociais (Federação dos Trabalhadores da Agricultura no Pará, Sindicato dos Trabalhadores e Trabalhadoras da Agricultura de Abaetetuba, Acará, Baião, Barcarena, Cametá, Mocajuba, Moju, 
Tailândia),agricultores familiares integrados de dendê, análise de documentos públicos (textos, censos, relatórios, atas, balanços e imagens fotográficas) e análise de documentos privados (textos, relatórios, atas, balanços, imagens fotográficas).

Procedimentos técnicos da pesquisa. Na realização da pesquisa, dividimos os procedimentos de coleta de dados em dois tipos de informação provenientes de fontes primárias e de fontes secundárias. $\mathrm{Na}$ coleta de dados das fontes primárias analisamos e interpretamos os dados do trabalho de campo. No segundo tipo de coleta, levantamos informações estatísticas e documentais em instituições estatais, empresariais e sociais.

As pesquisas das fontes secundárias foram divididas em duas fases, uma pesquisa estatística e outra das fontes documentais. Na pesquisa estatística os dados da presente pesquisa da tese foram coletados junto a instituições estatais, empresariais e sociais, como o Instituto Brasileiro de Geografia e Estatística (IBGE), a Empresa Brasileira de Pesquisa Agropecuária (Embrapa), o Ministério de Minas e Energia (MME), o Ministério da Agricultura, Pecuária e Abastecimento (MAPA), o Ministério do Desenvolvimento Agrário (MDA), o Banco da Amazônia (Basa), o Banco Central do Brasil (Bacen), o Instituto de Desenvolvimento Econômico, Social e Ambiental do Pará (Idesp), a Secretaria de Estado de Agricultura do Pará (Sagri), a Petrobras, a Belém Bioenergia Brasil, a Vale e a Fase Amazônia.

$\mathrm{Na}$ pesquisa das fontes documentais, foram coletados documentos governamentais, relatórios setoriais dos governos federal e estadual onde estão presentes as políticas e ações estatais voltadas para a questão agrícola com ênfase na cultura do dendê no território do Baixo Tocantins. Também analisamos relatórios de pesquisas de ONG que problematizam a questão da integração da agricultura familiar de dendê no agronegócio. Aqui destacamos os estudos realizados pela Repórter Brasil e a Fase Amazônia que tem realizado estudos críticos sobre a relação entre agricultura familiar e o agronegócio de dendê no Pará.

A partir da constatação da existência de uma realidade territorial dialética do Baixo Tocantins, onde rio e estrada são elementos que marcam a dinâmica de uso do território, executamos quatro trabalhos de campo neste recorte espacial da pesquisa de tese.

No primeiro trabalho de campo realizado em julho de 2013, percorremos o Baixo Tocantins dos rios. Seguindo um roteiro de viagem realizado por Moura (1989) ${ }^{2}$, partimos do porto do Sal, em Belém do Pará, em um barco onde percorremos o vale do rio Tocantins até

\footnotetext{
${ }^{2}$ Ignácio Baptista de Moura, a serviço do governo do Estado do Pará, parte de Belém do Pará, em 1896, com a missão de inspecionar o burgo de Itacaiúnas (Marabá) onde percorre todo o vale do rio Tocantins até São João do Araguaia, onde ao longo de seu curso fez inúmeras descrições das cidades, vilas, moradores e da rica paisagem do rio Tocantins.
} 
Tucuruí, primeira cidade do médio Tocantins, que faz limite com o município de Baião. Neste trajeto fluvial percorremos as cidades de Abaetetuba, Cametá, Mocajuba, Baião e Tucuruí, onde o rio Tocantins foi o nosso objeto de observação. Este rio é território de abrigo para as populações tradicionais que habitam na margem direita e esquerda de seu curso. Em Tucuruí visitamos a Usina Hidrelétrica de Tucuruí, projeto energético que afetou o Baixo Tocantins na navegabilidade e na pesca, entre outros. Este primeiro trabalho foi de observações diretas das cidades influenciadas pelo rio.

No segundo trabalho de campo, realizado nos meses de agosto, setembro e parte de outubro de 2015, percorremos o Baixo Tocantins das estradas, vicinais e ramais, com o objetivo de conhecer a realidade empírica do território do Baixo Tocantins, onde foram aplicados questionários para o público selecionado da pesquisa. Esta atividade foi desenvolvida em nove municípios, onde realizamos observações da realidade agrícola, além de visitas a diversas instituições estatais, empresariais, sociais, localidades e agricultores familiares de dendê integrados as empresas Belém Bioenergia Brasil e Biopalma. A ênfase do trabalho de campo foi verificar in loco o uso agrícola do território e o papel da agricultura familiar de dendê integrada à Belém Bioenergia Brasil e à Biopalma. Nestes municípios realizamos observações tanto na área urbana quanto na rural. Nesta etapa da pesquisa percorremos cidades, vilas, estradas, vicinais e ramais de dendê nos nove municípios do Baixo Tocantins (PA), tendo como pontos de apoio hotéis, pousadas e casas de amigos. Na comunidade de Nova Paz, em Tailândia, fiquei hospedado na residência de um agricultor familiar durante os três dias em que permanecemos neste local, realizando as entrevistas com os agricultores familiares. Iniciamos esta etapa de investigação pelo município de Moju, onde em 2002 a Agropalma de forma pioneira implantou o sistema de integração da agricultura familiar de dendê nas suas atividades na comunidade de Soledade, com 50 famílias.

Neste trabalho de campo entrevistamos representantes de instituições estatais e sociais selecionados para a pesquisa como descrito a seguir.

a) Entrevista com os secretários municipais de agricultura de Mocajuba e de Moju, além de entrevistas com representantes dos Sindicatos dos Trabalhadores e Trabalhadoras Rurais de Abaetetuba, Barcarena, Moju, Acará, Tailândia, Mocajuba, Baião, Igarapé Miri e Cametá.

b) Entrevistas com os agricultores familiares de dendê integrados a empresa Belém Bioenergia Brasil (Pbio + Galp). Atividade realizada nas localidades de: ramal do Limãozinho, ramal do Cardoso (Baião), ramal do Patauateua, ramal Livramento (Cametá), ramal Cenira, ramal Igarapé do Meio (Mocajuba), comunidade Nova Paz, comunidade Betel (Tailândia), onde entrevistamos 18 agricultores. 
c) Entrevistas com os agricultores familiares de dendê integrados à empresa Biopalma (Vale + Msp). Trabalho desenvolvido nas localidades de: ramal do Ipitinga (Acará), ramal Bom Futuro, comunidade Boa Esperança, Assentamento Olho D’água I (Moju), onde foram entrevistados 13 agricultores familiares integrados.

A identidade dos agricultores entrevistados das duas empresas pesquisadas será mantida em sigilo como parte de acordo entre o pesquisador e os entrevistados. Esta situação visa evitar possíveis perseguições, intimidações e constrangimentos, uma vez que os mesmos mantêm contratos de integração com as empresas aqui pesquisadas. No total foram entrevistados 31 agricultores familiares integrados das duas empresas.

Durante esta fase da pesquisa realizamos também uma coleta das coordenadas geográficas das localidades visitadas, que denominamos de territórios da agricultura familiar de dendê regulado pela empresa, da localização dos polos das empresas visitadas utilizando um aparelho GPS Etrex10Garmin. Estas coordenadas posteriormente foram utilizadas para a elaboração dos mapas de atuação das empresas Belém Bioenergia Brasil e Biopalma. Nas entrevistas com os informantes, quando autorizado, utilizamos um gravador ICD-PX240 Sony para o devido registro e desgravação posterior.

O terceiro trabalho de campo foi realizado em Belém do Pará, em agosto e outubro de 2015, com o registro fotográfico dos prédios-heranças, verdadeiras rugosidades da ocupação portuguesa da Amazônia colonial, com destaque para o complexo do forte do Castelo, marco da fundação de Belém, em 1616, de onde importantes decisões foram tomadas para a ocupação do vale do rio Tocantins. Em Belém também entrevistamos representantes de instituições estatais e sociais, como descrito a seguir.

a) Entrevista com o representante do Ministério do Desenvolvimento Agrário (MDA) no Pará. Na capital paraense visitamos a Delegacia Federal do Desenvolvimento Agrário (DFDA-PARÁ), que funciona como representação do MDA no estado. A DFDA-PARÁ funciona nas dependências da superintendência do Instituto Nacional de Colonização e Reforma Agrária (Incra) no Pará. Ali fomos informados de que a pessoa mais indicada para conceder entrevista era o consultor de Biocombustíveis da região Norte, Dvandro Pedro de Oliveira. Após realização de contato com o servidor indicado, em função do mesmo encontrar em viagem de trabalho, enviamos os questionários da entrevista para o e-mail indicado que foi imediatamente respondido pelo consultor, em 19.10.2015.

b) Entrevista com o representante do Banco da Amazônia (Basa). Esta entrevista ocorreu na sede da Superintendência Regional do Pará, onde fomos recebidos pelo 
superintendente regional do Pará, Luiz Euclides Feio, que respondeu todas as perguntas por nos formuladas. A entrevistada foi realizada em 18.08.2015.

c) Entrevista com o representante da Federação dos Trabalhadores da Agricultura no Pará (Fetagri). Atividade realizada em Belém, em 19.08.2015, com o presidente da entidade Francisco Dias Assis. Em sua entrevista o sindicalista faz uma análise da atuação da entidade no contexto do Pronaf Eco-Dendê.

O quarto trabalho de campo ocorreu em janeiro de 2016 com o objetivo de realizar uma nova coleta de pontos cartográficos em Moju e Baião, uma vez que os dados coletados, durante o segundo trabalho de campo, não correspondiam à localidade rural pesquisada.

Nos quatro trabalhos de campo realizamos um registro fotográfico, do espaço urbano e rural dos municípios visitados. Além disso, selecionamos outros registros fotográficos representativos de outras fontes que procuram ilustrar determinado fato tratado nesta tese. Após o trabalho de campo, realizamos a análise e a interpretação dos dados coletados nas observações de campo onde utilizamos um diário de anotações, as entrevistas foram transcritas e o seu conteúdo analisado e interpretado segundo a teoria adotada.

Elaboração dos mapas. Com os dados das coletas das fontes primárias e secundárias, foi possível a elaboração dos mapas temáticos. Os dados secundários usados na elaboração dos mapas foram do Instituto Brasileiro de Geografia e Estatística (IBGE), do Programa Territórios da Cidadania (PTC), da Secretaria de Estado de Agricultura do Pará (Sagri), do Instituto de Desenvolvimento Econômico, Social e Ambiental do Pará (Idesp), do Banco da Amazônia (Basa), do Banco Central do Brasil (Bacen), da Petrobras, da Belém Bioenergia Brasil (BBB) e da Vale. Já os dados primários utilizados na elaboração dos mapas foram retirados dos trabalhos de campo realizados em 2013 e 2015.

Os mapas de atuação da Belém Bioenergia Brasil e da Biopalma e os territórios da agricultura familiar de dendê regulado pela empresa foram ajustados em três momentos, pois alguns pontos das coordenadas geográficas coletadas em campo não correspondiam com a localidade pesquisada, o que exigiu retorno em janeiro de 2016 em três localidades dos municípios de Baião e Moju para nova coleta.

O contexto político em que a tese foi desenvolvida (2013-2016) foi um período de grandes mudanças na estrutura do governo federal. No primeiro ano da pesquisa (2013), ainda cursando as disciplinas acadêmicas na UnB, Brasília, foi objeto de grandes manifestações que pediam uma série de medidas no país. Presenciei as manifestações de junho deste ano na capital federal, onde a esplanada dos ministérios foi palco da concentração de pessoas de todas as idades que pediam redução dos preços das passagens de ônibus, fim da corrupção, 
contra os gastos públicos para a Copa do Mundo (2014), mais investimentos em saúde e educação.

A culminância destes protestos foi a ocupação das cúpulas da Câmara dos Deputados e do Senado Federal em 17 de junho de 2013. No último ano da pesquisa (2016), Brasília e o Brasil assistem uma presidenta eleita democraticamente ser objeto de impeachment pelo Congresso Nacional. Com a saída da presidenta e sua substituição pelo vice, uma série de medidas foram colocadas em prática pelo novo governo, como a reforma administrativa responsável pela fusão e extinção de diversos ministérios.

O então Ministério do Desenvolvimento Agrário (MDA) responsável pela agricultura familiar foi inicialmente fundido ao então Ministério do Desenvolvimento Social (MDS), dando origem ao Ministério do Desenvolvimento Social e Agrário (MDSA). Posteriormente a atividade-fim da agricultura familiar foi transferida do MDSA, para a Casa Civil. Em novembro de 2016, quando a presente tese foi defendida o MDA já não existia, porém como a entrevista com o representante deste órgão no Pará foi realizado em 2015, optamos por manter o nome do Ministério do Desenvolvimento Agrário na tese.

A tese está estruturada em quatro capítulos.

O primeiro capítulo discute a categoria de análise território usado e o uso agrícola do território, bem como a ocupação e o uso agrícola do território do Baixo Tocantins em uma periodização que considera três períodos geográficos: o período pré-técnico, o técnico e o técnico-cientifico-informacional.

O segundo capítulo aborda a categoria de análise políticas públicas, onde é analisado as duas políticas públicas selecionadas na pesquisa (Programa Nacional de Produção e Uso do Biodiesel e Programa de Produção Sustentável de Óleo de Palma) que têm induzido a expansão do cultivo de dendê, bem como a integração da agricultura familiar de dendê no agronegócio no Baixo Tocantins.

O terceiro capítulo apresenta a cadeia produtiva e o papel do MDA, BASA, Empresas, Fetagri e agricultores na integração da agricultura familiar de dendê no agronegócio de biodiesel de dendê no Baixo Tocantins.

O quarto capítulo apresenta os resultados da pesquisa empírica onde são discutidos os territórios da agricultura familiar de dendê regulado pelo agronegócio no Baixo Tocantins (PA) pelas empresas Belém Bioenergia Brasil e Biopalma. 


\section{CAPÍTULO 1: OCUPAÇÃO E USO AGRÍCOLA DO TERRITÓRIO DO BAIXO TOCANTINS: DO PASSADO AO PRESENTE}

Este capítulo tem como objetivo analisar a categoria de análise território usado e o uso agrícola do território, bem como a ocupação e o uso agrícola do território do Baixo Tocantins ao longo dos períodos pré-técnicos, técnicos e técnico-científico-informacional. Nesta análise procuramos destacar a contribuição das diversas lavouras durante estes três períodos no que se refere ao uso agrícola do território com destaque para a cultura agrícola do dendê no período técnico-científico-informacional.

\subsection{Território usado}

Milton Santos considera território usado como sinônimo de espaço geográfico, sendo compreendido como uma instância da sociedade (SANTOS, 1994; 1996; 1999; SANTOS et al., 2000; SANTOS; SILVEIRA 2001).

Em 1994, Milton Santos, Maria Adélia de Souza e Maria Laura Silveira organizam o livro Território, globalização e fragmentação, em que no artigo $O$ retorno do território, Milton Santos defende de maneira explícita o território usado como categoria de análise da geografia. Logo no início desta publicação afirma "vivemos uma noção de território herdada da modernidade incompleta e do seu legado de conceitos puros, tantas vezes atravessando os séculos praticamente intocados" (SANTOS, 1994, p. 15). A crítica do autor ao que chama de "conceitos puros" tem transformado o conceito de território em ahistórico, pois não tem levado em consideração as dinâmicas na história.

Para ele, "é o uso do território, e não o território em si mesmo, que faz dele objeto de análise social” (SANTOS, 1994, p. 15). Em seu entendimento "[...] o território usado são objetos e ações, sinônimo de espaço humano, espaço habitado" (p. 16).

Esta constatação feita pelo autor torna o território usado um importante instrumento de leitura da realidade, pois acrescenta uma relação de dinâmica e movimento na análise. Em sua elaboração espacial, objetos e ações possuem uma centralidade na teoria espacial miltoniana.

O território é usado por todos os atores que impõem usos específicos, que vão depender de diferentes condicionantes. A ação dos atores não acontece de forma homogênea. Neste sentido, podemos falar de atores hegemônicos e de atores hegemonizados que fazem usos diferentes do território. Os usos que se fazem de cada território indicam a intenção de cada ator em relação ao território. 
Para Milton Santos, território são formas enquanto que território usado são objetos e ações e que o território usado permite compreender o território em mudança, em movimento, coisa que a consideração do território em si não é capaz de fazer. Desta forma, a relação dialética entre objetos e ações deve orientar as investigações que tenham como base teórica o território usado, concebido por este autor como categoria de análise social.

Em 1996, publica A natureza do espaço: técnica e tempo, razão e emoção. Esta é a obra mais completa do autor, cujo trabalho teria iniciado em 1978 em Por uma Geografia nova (RIBEIRO, 2012, p. 38). A teoria espacial miltoniana enfatiza a relação indissociável entre objetos e ações (SANTOS, 1996). Nesta obra conceitua espaço geográfico, conceito que passou a usar em obras posteriores.

Para ele, “o espaço é formado por um conjunto indissociável, solidário e também contraditório de sistemas de objetos e sistemas de ações, não considerados isoladamente, mas como o quadro único no qual a história se dá" (SANTOS, 1996, p. 51). Nesta obra destaca que a história do espaço geográfico ocorre no que o autor denominou de meio geográfico. De acordo com Santos (1996, p. 187) "podemos admitir que a história do meio geográfico pode ser grosseiramente dividida em três etapas: o meio natural ${ }^{3}$, o meio técnico ${ }^{4}$, o meio técnicocientífico-informacional" ${ }^{5 "}$. A análise do espaço através dos meios geográficos nos permite uma real investigação da periodização da formação da realidade geográfica em estudo.

$\mathrm{Na}$ obra destaca-se ainda o processo de globalização da economia onde se procura enfatizar os espaços da racionalidade no atual período técnico-científico-informacional. Desta forma, com o processo de globalização ampliam-se os "espaços da racionalidade" no território. Para ele, "os espaços da racionalidade funcionam como um mecanismo regulado, onde cada peça convoca as demais a se pôr em movimento, a partir de um comando centralizado" (SANTOS, 1996, p. 239-240). Desta forma, o território na atualidade passa a ser objeto da ação de empresas que possuem uma lógica que tem na obtenção de lucros a sua centralidade.

No atual período a racionalidade hegemônica do capital acaba por impor normas e diretrizes que devem ser cumpridas pelos atores hegemonizados do processo. No entanto, estes atores tendem a resistir a esta imposição em suas vidas. A crítica à "racionalidade hegemônica" deverá conduzir a uma solidariedade entre o segmento envolvido. Apesar da

\footnotetext{
3“"Quando tudo era natural, o homem escolhia da natureza aquelas suas partes ou aspectos considerados fundamentais ao exercício da vida, valorizando, diferentemente, segundo os lugares e as culturas, essas condições naturais que constituíam a base material de existência da vida (SANTOS, 1996, p. 187).

4 "O período técnico vê a emergência do espaço mecanizado" (SANTOS, 1996, p. 187).

5 "[...] se distingue dos anteriores, pelo fato da profunda interação da ciência e da técnica" (SANTOS, 1996, p. 187).
} 
imposição de uma racionalidade por parte dos atores hegemônicos, ocorrem resistências de adesão a este projeto dominante, onde parcelas dos atores hegemonizados resistem e por meio da solidariedade acabam criando formas de resistência a projetos de dominação.

Neste sentido, a solidariedade entre os atores hegemonizados contribui para a fixação de um projeto comum. Para ele, "tal solidariedade se manifesta por uma forma particular de exercício da política, com a defesa de interesses particularistas, ligados ao dia-a-dia dos produtos e dos produtores" (SANTOS, 1996, p. 244). A resistência ao modelo racional imposto pelas empresas hegemônicas encontra resistências dos atores que não conseguem se integrar neste modelo. De tal forma que "objetivamente, pode-se dizer também que, a partir dessa racionalidade hegemônica, instalam-se paralelamente contrarracionalidades" (p. 246). $\mathrm{Na}$ atualidade as resistências a projetos de dominação formam contrarracionalidades a modelos de regulação a partir de um comando de decisão.

No atual período técnico-científico-informacional, o campo brasileiro passa a ser espaço de atuação de grandes grupos empresariais que usam o território como fonte de recursos. De acordo com Santos (1996, p. 242), “com a globalização, a especialização agrícola baseada na ciência e na técnica inclui o campo modernizado em uma lógica competitiva que acelera a entrada da racionalidade em todos os aspectos."

Em 1999, publica em cadernos do Ippur, o artigo O território e o saber local: algumas categorias de análise, onde defende que "o território não é uma categoria de análise, a categoria de análise é o território usado" (SANTOS, 1999, p.18). Nesta publicação, aprofunda as ideias defendidas em 1994 em $O$ retorno do território.

A categoria analítica de território usado está relacionada à dinâmica que ocorre no território, pois para ele "essa idéia de território usado, a meu ver, pode ser mais adequada à noção de um território em mudança, de um território em processo" (SANTOS, 1999, p. 19). A interpretação geográfica deve estar centralizada na análise dos processos que ocorrem no território. São os processos contraditórios que nos revelam a verdadeira totalidade do processo geográfico.

Nesta publicação analisa questões das empresas hegemônicas no campo brasileiro, onde este tipo de agricultura (agronegócio) impõe uma lógica que deve ser seguida por todos os atores. Para o agricultor, esta lógica impõe sua adesão a esta lógica comandada por uma empresa hegemônica. Desta forma para ele "[...] a primeira coisa que o agricultor de uma área moderna terá que fazer se quiser sobreviver, é obedecer, como um exército, à palavra de ordem" (SANTOS, 1999, p. 24). Cita o caso da produção integrada de frangos e porcos nos estados de Paraná e Santa Catarina, onde o pequeno produtor é regulado por uma 
racionalidade hegemônica de grandes empresas agroindustriais. Esta passagem descrita pelo autor demonstra que a ação das empresas agrícolas hegemônicas impõe um conjunto de normas aos agricultores integrados que contribui para a formação de um cotidiano regulado pela empresa.

Desta forma a produção agrícola integrada impõe ao agricultor familiar as normas da empresa, promovendo uma subordinação do produtor às diretrizes da empresa, que controla todas as ações dos agricultores integrados a ela.

Para ele, a "obediência indispensável do produtor a uma cadeia técnica que responde a uma demanda econômica que cria nele comportamentos regulados, de tal forma que excluem a idéia que se possa ter de prática da solidariedade" (SANTOS, 1999, p. 24).

Neste modelo de produção, o agricultor é regulado pelas normas da empresa que transforma a propriedade familiar em unidades produtivas associadas da empresa agrícola hegemônica que passa a comandar as ações na propriedade familiar.

Em 1999 publica na revista Geographia, o artigo $O$ dinheiro e o território, republicado em 2011 em Território, territórios: ensaios sobre o ordenamento territorial onde afirma que "a geografia vive neste fim de século a sua era do ouro, por que a geograficidade se impõe como condição histórica [...] a partir do conhecimento do que é o território" (SANTOS, 2011a, p.13). De fator na atualidade vive-se uma grande fase de expansão dos estudos territoriais na geografia, onde o crescente interesse pelo tema tem contribuído para isto. Nesta publicação reafirma sua posição sobre o território.

Para ele "o território é o lugar em que desembocam todas as ações, todas as paixões, todos os poderes, todas as forças, todas as fraquezas, isto é, onde a história do homem plenamente se realiza a partir das manifestações de sua existência” (SANTOS, 2011a, p.13). Neste sentido, o território é onde ocorre a existência do homem, onde a vida acontece.

Também afirma que "o território usado é o chão mais a identidade [...] o território é o fundamento do trabalho; o lugar da residência, das trocas materiais e espirituais e do exercício da vida" (SANTOS, 2011a, p.14).

Em 2000 concede entrevista a Odette Seabra, Mônica Carvalho e José Correa Leite resultando no livro Território e sociedade publicado pela fundação Perseu Abramo. Esta publicação foi reeditada em 2007 onde o autor faz uma profunda reflexão sobre o Brasil e sua própria trajetória de vida.

O autor afirma que "o território em si, para mim, não é um conceito. Ele só se torna um conceito utilizável para a análise social quando o consideramos a partir do seu uso [...]" (SANTOS, 2007c, p.22). Ao ser questionado sobre a diferença entre espaço e território o 
autor aborda que, "na verdade eu renunciei a busca dessa distinção entre espaço e território. Houve um tempo em que a gente discutia muito isso: "o espaço vem antes", "não, o que vem antes é o território" (SANTOS, 2007c, p.26).

Ele continua sua resposta na entrevista sobre uma possível diferenciação entre espaço e território, "eu uso um e outro, alternativamente, definindo antes o que eu quero dizer com cada um deles. Agora, a retificação que ando fazendo é que não serve falar de território em si mesmo, mas de território usado" (SANTOS, 2007c, p.26).

Em 2000 durante o XII Encontro Nacional de Geógrafos (ENG), realizado em Florianópolis lança com colaboradores ${ }^{6}$, O papel da geografia: um manifesto, reeditado na Revista Território no mesmo ano. A interpretação miltoniana de território é centralizada nos usos que se fazem do território, onde os atores têm um papel de grande importância, "esta parece mais possível de alcançar através de uma perspectiva do território usado, uma vez que estamos levando em conta todos os atores" (SANTOS et al., 2000, p. 106).

Santos et al. (2000), ao apresentarem um manifesto para a Geografia, introduzem uma tipologia de atores dividida em atores hegemônicos e atores hegemonizados. Esta análise apresentada pelos autores parte de uma relação dialética que considera que o território é usado pelos atores hegemônicos e pelos atores hegemonizados.

De acordo com Santos et al. (2000), a análise do território usado deve ser visto como uma totalidade revelando a estrutura da sociedade (atores hegemônicos e atores hegemonizados ) e o uso que se faz do território (uso como recurso e uso como abrigo).

Assim, Santos et al. (2000, p. 108) afirmam que "para os atores hegemônicos o território usado é um recurso, garantia da utilização de seus interesses particulares”. Em contraposição, para eles "os atores hegemonizados têm o território como abrigo, buscando constantemente se adaptar ao meio geográfico local, ao mesmo tempo que recriam estratégias que garantam sua sobrevivência nos lugares" (SANTOS et al., 2000, p. 108). Desta forma, segundo esta concepção teórica, o uso do território ocorre a partir da presença desta tipologia de atores, hegemônicos e hegemonizados, que reflete por sua vez a intencionalidade na forma como se relacionam com o território onde estão presentes.

Para eles, "os distintos atores não possuem o mesmo poder de comando levando a uma multiplicidade de ações, fruto do convívio dos atores hegemônicos com os atores hegemonizados. Dessa combinação temos o arranjo singular dos lugares" (SANTOS et al.,

\footnotetext{
${ }^{6}$ Adriana Bernardes, Adriano Zerbini, Cilene Gomes, Edison Bicudo, Eliza Almeida, Fabio Betioli Contel, Flavia Grimm, Gustavo Nobre, Lídia Antongiovanni, Maíra Bueno Pinheiro, Marcos Xavier, María Laura Silveira, Marina Montenegro, Marisa Ferreira da Rocha, Mônica Arroyo, Paula Borin, Soraia Ramos e Vanir de Lima Belo.
} 
2000, p. 108). Neste trabalho os autores afirmam que o Estado dota o território de objetos que são aproveitados pelas empresas (SANTOS et al., 2000).

Esta complexidade de uso nos revela a grande possibilidade de análises da realidade tendo como referência o território usado. As frações do território constituem-se em análises de usos diversos. Estes diversos usos pressupõem que o território usado seja considerado como um conjunto de objetos e ações. Este entendimento de considerar o território usado como um conjunto de sistemas de objetos e ações tem levado em consideração o espaço geográfico como sinônimo de território usado. Como lembra o autor "foi por isto que propusemos considerar o espaço geográfico não como sinônimo de território, mas como território usado" (SANTOS, 2000 et al., p. 104). Esta interpretação traz a questão da complementaridade e da conflitualidade dos processos, "o território usado constitui-se como um todo complexo onde se tece uma trama de relações complementares e conflitantes. Daí o vigor do conceito" (SANTOS et al., 2000, p. 104).

Em 2001, Milton Santos, em colaboração com María Laura Silveira, publica o livro $O$ Brasil: território e sociedade no início do século XXI. Nesta obra, os autores partem de um conceito central, o uso do território, aplicado à realidade brasileira. Esta obra, segundo os autores, é resultado de um esforço teórico-empírico de 'um projeto ambicioso de fazer falar a nação pelo território'. Nesta publicação fica evidente a análise dos autores em propor uma 'teoria do Brasil a partir do território'. Nesta obra encontramos uma síntese da teoria espacial destacando como abordar a categoria analítica do território usado em pesquisas. Esta teoria considera a interpretação da sociedade por meio do conceito de uso do território, enquanto sinônimo de espaço geográfico (SANTOS; SILVEIRA, 2001).

Os autores destacam nesta obra a necessidade da investigação das intencionalidades no uso do território que ocorre a partir de uma análise que considera a relação entre objetos e ações. Para eles, "o espaço geográfico se define como união indissolúvel de sistemas de objetos e sistemas de ações, e suas formas híbridas, as técnicas, que nos indicam como o território é usado: como, onde, por quem, por quê, para quê" (SANTOS; SILVEIRA, 2001, p. 11). Desta forma, a análise do uso do território pressupõe entender questões da complexidade levantada pelos autores acima.

Segundo eles é importante "pensar o território como ator e não apenas como um palco, isto é, o território no seu papel ativo" (SANTOS; SILVEIRA, 2001, p. 11). Pensar o território como ator pressupõe analisá-lo a partir dos usos que se faz no mesmo. Tal análise leva em consideração os atores e suas intencionalidades no uso do território. 
Segundo eles, "o território revela também as ações passadas e presentes, mas já congeladas nos objetos, e as ações presentes constituídas em ações" (SANTOS; SILVEIRA, 2001, p. 247). Desta forma, a análise do território deve levar em consideração a periodização da formação territorial em questão.

Em 2002 é publicado pela Publifolha O país distorcido: o Brasil, a globalização e a cidadania, livro que resulta dos ensaios que Milton Santos escreveu para o Jornal Folha de São Paulo entre 1981 a 2001. No ensaio intitulado O chão contra o cifrão afirma que "o território não pode ser considerado uma tabua rasa, uma tela neutra, um espelho, porque é indissociavelmente integrado a todas as pessoas, empresas, instituições que o habitam [...]" (SANTOS, 2002, p. 47). Esta afirmação esta embasado no conceito de espaço banal, ou seja, o espaço de todos os atores.

Em 2004 concede entrevista a Jesus de Paula Assis em colaboração com Maria Encarnação Sposito resultando no livro Testamento intelectual, publicado pela editora da UNESP.

Ao ser questionado sobre as categorias espaço e território ele afirma que "a palavra território tem uma força maior do que a palavra espaço, sobretudo porque a palavra espaço você usa como quiser, e território tem uma força, tanto que eu recuso o debate da diferença entre uma coisa e outra. É indiferente, desde que você defina" (SANTOS, 2004, p. 34). Nesta publicação resgata o caráter técnico político do território ao afirma que "essa composição do território, tanto técnica como política [...] é o que chamo território usado. Ele tem um papel ativo, um papel motor. Essa de território usado, se eu tivesse outra, eu usaria" (SANTOS, 2004, p. 34)

Ainda dissertando sobre o enfoque apresentado pelo território usado o autor afirma que “[...] na realidade, o que eu digo é que á uma situação e que a dialética se dá entre os homens, e os homens no território, e não entre os homens e o território como definido classicamente" (SANTOS, 2004, p. 35)

A ideia de território usado lançada por Milton Santos tem sido objeto de análises por diversos estudiosos na Geografia e em outras ciências. María Laura Silveira (2011b), em Território usado: dinâmicas de especialização, dinâmicas de diversidade, afirma que "o território usado é assim uma arena onde fatores de todas as ordens, independentemente da sua força, apesar de sua força desigual, contribuem à geração de situações” (SILVEIRA, 2011b, p. 5). A ideia de território usado pressupõe a ideia de levar em consideração todos os atores da sociedade, onde a categoria espaço banal criada por François Perroux e potencializada por Milton Santos tem sido bastante utilizada. 
Para Silveira (2011a, p. 153), "não há como explicar o território sem sua utilização, não há como explicar o território usado sem projeto. É isso que faz do território usado uma categoria central para a formulação de uma teoria social". A categoria território usado pressupõe a discussão política.

Ainda segundo ela, "o território usado inclui todos os atores e não apenas o Estado, como na acepção herdada da modernidade" (SILVEIRA, 2011a, p. 153). A concepção de território da modernidade tinha no Estado a centralidade da ação das investigações. Esta abordagem pouco levava em consideração os demais atores, pois o Estado acabava centralizando as atenções das investigações realizadas neste período histórico.

No artigo intitulado Economia política e ordem espacial: circuitos da economia urbana, a autora ao se referir ao território usado, afirma que "trata-se de uma permanente reconstrução do território, já usado pelas gerações precedentes, por meio das diversas instâncias da produção e da política, isto é, de sistemas de objetos e normas [...]" (SILVEIRA, 2011c, p. 36). Entender o território usado pressupõe entender as relações de todos os atores presentes na sociedade. A análise territorial seguindo esta abordagem teórica requer uma preocupação com uma periodização da situação geográfica estudada.

Maria Adélia Aparecida de Souza (2002), em Política e território: a geografia das desigualdades, afirma que "o território, modernamente, é entendido não apenas como limite político-administrativo, mas como espaço efetivamente usado pela sociedade e pelas empresas" (SOUZA, 2002, p. 1). Como demonstra a autora, este conceito na modernidade está ligado fundamentalmente à ideia de limites de atuação de uma autoridade pública ou privado. Neste sentido, o território torna-se uma arena de disputa entre os diferentes atores da sociedade que agem segundo racionalidades diferenciadas.

$\mathrm{Na}$ introdução de Território brasileiro: usos e abusos, Maria Adélia Aparecida de Souza (2003) resgata a importância do enfoque da categoria território usado, proposto por Milton Santos, ao afirmar que "quem não entender o sentido abstrato desse precioso conceito, que ele propõe seja assumido como instância social, terá dificuldades para entendê-lo e, consequentemente, não avançará metodológica e epistemologicamente na Geografia" (SOUZA, 2003, p. 17). A autora destaca elementos centrais para a construção de um percurso analítico centrado na categoria território usado, o que necessita de um entendimento que considera o território analisado como uma instância social.

Para ela, "é na discussão sobre o objeto da Geografia, sobre o espaço geográfico, esse sistema indissociável de objeto e ações, colocado como sinônimo de território usado, ou espaço banal, que reside a maior e mais revolucionária contribuição da obra de Milton 
Santos" (SOUZA, 2003, p. 17). Neste sentido, o território usado reflete uma análise que considera uma relação dialética entre objetos e ações, onde todos os atores estão presentes.

Ana Clara Torres Ribeiro (2011), em Território da sociedade: por uma cartografia da ação, afirma que "com o conceito de território usado, Milton Santos procura reinscrever o território na problemática relacional do espaço, que não se submete a uma única dimensão da vida coletiva, porque o espaço é relacional” (RIBEIRO, 2011, p. 27). Para ela, a ideia de território usado aproxima a Geografia da política onde "também as políticas públicas têm sido traçadas em função do território [...]” (p. 26). Desta forma, a potência que a categoria território usado permite em muito supera a velha noção de território em si. Discutir o território usado pressupõe entender os múltiplos usos que se faz do território.

Márcio Antônio Cataia (2011), em Território político: fundamento e fundação do estado, afirma que "porém, paralelo a esta leitura, emerge outra concepção de território, usado não só pelo estado, expressiva da vida de relações e mais próxima do espaço banal" (CATAIA, 2011, p. 119). A abordagem do território usado considera a existência de todos os atores, não apenas o Estado como ator hegemônico. Esta ênfase considera o uso dos territórios pelos atores hegemônicos e hegemonizados.

Márcio Cataia lembra o caráter híbrido do território sendo este formado por um conjunto de objetos naturais e artificiais, onde o seu uso depende de diversas condicionalidades de quem tem poder para fazer o uso do território, desta ou daquela forma. Neste sentido, "o território, um híbrido de objetos naturais e artificiais e ações sociais, pede um tratamento analítico em sistema: as materialidades desses seus usos; usos estes que são ações humanas trabalhadas e politizadas" (CATAIA, 2011, p. 121).

Maiara Gomes, Marília Steinberger e Renan Barbosa (2013, p. 66), em O potencial político da categoria território usado, afirmam que categoricamente "a proposta da categoria de ‘território usado’ nasce implicitamente em 1978 quando Milton Santos, ao considerar o território como um dos elementos do Estado-Nação, diz que a utilização do território pelo povo cria espaço". Ainda na mesma obra os autores argumentam que "durante vários anos, continua a referir-se ao território do Estado-Nação, mas em 1994 começa a discorrer sobre explicitamente sobre o uso do território" (GOMES; STEINBERGER; BARBOSA, 2013, p. 66). A categoria território usado foi construída ao longo de um percurso temporal na obra de Milton Santos, onde o ano de 1994 marca o lançamento do Artigo O retorno do território, onde passa de forma explícita a defender o território usado como categoria de análise social.

Soraia de Fátima Ramos e Ricardo Castillo (2010), em Sistemas técnicos agrícolas do algodão e uso do território brasileiro, argumentam que o tipo de uso que se faz do território 
resulta de uma série de condicionantes que "constituem o uso do território, resultante de um jogo de forças políticas, econômicas e sociais” (RAMOS; CASTILLO, 2010, p. 104).

A questão da compreensão de uma periodização é de grande importância para o estudo da abordagem do uso do território. Estes autores destacam que "a cada um desses períodos correspondem formas predominantes de organização e uso do território nacional" (RAMOS; CASTILLO, 2010, p. 104). O uso do território ocorre segundo diferentes interesses de quem o usa. Um dos usos que podemos destacar é o uso do território pelo Estado, que atua segundo uma série de interesses.

Mirlei Pereira (2011), em Território e política: práxis invertidas e desafios da existência, argumenta que "essa preocupação com o conteúdo e os usos do território de modo algum exime a dimensão política do conceito, pelo contrário - valoriza e reforça a dimensão ao mesmo tempo material e política do território"(PEREIRA, 2011, p. 97).

No enfoque do uso do território temos que levar em consideração uma série de questões que instrumentalizam a questão territorial. Para Pereira (2011, p. 97), "temos que considerar quais são os conteúdos do território; do que ele é constituído; quais os objetos e ações o animam; quais são os seus usos e quais as implicações dele resultantes”. Esta constatação do autor é certamente importante para as análises dos estudos relacionados ao território.

\subsection{Uso agrícola do território}

Nesta seção abordaremos um conjunto de autores que têm discutido o uso agrícola do território no Brasil. Todos os autores aqui abordados têm como opção teórica o território usado. Soraia de Fátima Ramos ${ }^{7}$ (2005), em Uso do território brasileiro e sistemas técnicos agrícolas: a fruticultura irrigada em Petrolina (PE)/Juazeiro (BA), descreve sobre o uso agrícola do território com ênfase em Petrolina (PE) e Juazeiro (BA), examinando este uso a partir das sucessões dos meios geográficos e das mudanças no tempo/espaço nos territórios investigados.

Sua abordagem inicial parte de uma análise dos sucessivos meios geográficos e sua configuração do uso agrícola do território em cada meio geográfico. Em cada novo meio geográfico acrescentam-se novas formas de uso agrícola do território, onde a racionalidade do capital assume papel central nesta discussão.

\footnotetext{
${ }^{7} \mathrm{O}$ presente trabalho é resultante da dissertação de mestrado intitulada Uso do território brasileiro e sistemas técnicos agrícolas: a fruticultura irrigada em Petrolina (PE)/Juazeiro (BA), realizada sob orientação de Milton Santos e apresentada ao Departamento de Geografia da Universidade de São Paulo (USP), em 2002.
} 
Para a autora, "a análise para o uso agrícola do território está alicerçada na idéia de que as técnicas explicam a produção social do espaço geográfico" (RAMOS, 2005, p. 4). A autora tomando como base Milton Santos estabelece uma periodização do uso agrícola de Petrolina e Juazeiro em três períodos históricos: o pré-técnico, o técnico e o técnicocientífico-informacional.

$\mathrm{Na}$ fase do meio pré-técnico, a natureza limita a produção, na fase do meio técnico, ocorre à mecanização da produção e na fase do meio técnico-científico-informacional, ocorre à incorporação da ciência e da informação a produção. Para a autora, "o uso agrícola voltado para o mercado externo, mantém frágil o lugar. Ao longo desses anos, demandas de mercados cada vez mais distantes aos centros de cultivo ditam os tipos de usos agrícolas a serem realizados" (RAMOS, 2005, p. 14). No atual período técnico-científico-informacional ocorre uma modernização do campo com a difusão do crédito agrícola.

Soraia de Fátima Ramos (2011, p. 11) em O uso do território como categoria de análise para compreensão das dinâmicas da agricultura em regiões metropolitanas, reforça esta questão destacando a "ação do Estado com suas políticas públicas norteadoras" para a atividade agrícola. As ações estatais acontecem em diversos seguimentos agrícolas como no campo dos melhoramentos das pesquisas agrícolas. Nascimento Júnior (2009, p. 153-154) destaca inúmeras ações de Estado para a modernização da base técnica da pesquisa, como a criação da Embrapa $^{8}$, responsável por realizar pesquisas com culturas selecionadas, desenvolver novos procedimentos e métodos de produção, tudo para garantir maior eficiência produtiva à agricultura.

Na publicação Uso do território no vale do são Francisco: sistema técnico agrícola da fruticultura irrigada, Soraia de Fátima Ramos (2013a) destaca a modernização seletiva do território agrícola brasileiro em determinadas frações do território nacional. A autora, tomando por base Milton Santos, afirma que a partir da década de 1970 ocorre uma expansão do período técnico-científico-informacional no Brasil. Nesta obra, a autora, tomando como referência Santos (2008b), destaca que a produção do espaço geográfico pode ser dividida em três grandes meios ou períodos, a saber: o meio natural ou pré-técnico, o meio técnico e o meio técnico-cientifico-informacional (RAMOS, 2013a).

Referindo-se à periodização apresentada acima, Ramos (2013a, p. 66) afirma que "todos os lugares seguem esta tendência e recebem próteses resultantes das imbricações entre ciência, ciência e informação, os caracteres da história atual”. Para a autora, no período pré-

\footnotetext{
${ }^{8}$ Empresa criada pelo governo federal em 1973.
} 
técnico a produção agrícola era limitada e não atingia grandes escalas. Com o advento do período técnico e do período técnico-científico-informacional, novos métodos técnicos são acrescentados ao território, o que permitiu uma maior produção agrícola (RAMOS, 2013a). Desta forma a ocupação e o uso agrícola do território ocorrem mediante um conjunto de ações estatais e empresariais que passam a dotar estes territórios de novas funcionalidades.

Maria do Fetal Carvalho Ferreira de Almeida (2007), em Uso agrícola do território e pedagogia do movimento dos sem terra (MST); uma geografia do presente, tendo o território usado como categoria de análise, investiga dentre outras questões a situação das verticalidades do uso agrícola do território, bem como o cotidiano das horizontalidades no processo de formação socioespacial do MST.

Segunda ela, "o uso agrícola do território esta além do modo de produção da agricultura, da renda da terra ou do agrário dos sujeitos do campo" (ALMEIDA, 2007, p. 173). Nesta obra a autora trata o espaço geográfico como instância social, tal como trabalhado por Milton Santos.

Jaqueline do Carmo Silva Gonzaga e Márcio Roberto Toledo (2015), em O uso agrícola do território na microrregião de São João del-Rei (MG): uma análise do cultivo da soja, investigam o uso agrícola do território em Minas Gerais, enfatizando o cultivo da soja no município de São João del-Rei. Neste artigo os autores destacam o papel do Estado na modernização das atividades agrícolas, onde as políticas públicas desempenham um papel de destaque.

Heloisa Santos Molina Lopes (2006, p. 67), em Agricultura, modernização e uso coorporativo do território, ao discutir sobre o uso agrícola do território por empresas afirma que "a questão que se coloca é a viabilidade desse uso do território [...] que torna vulnerável toda uma população que não utiliza esse território como recursos, e sim como abrigo". A questão levantada pela autora reflete a natureza do tipo de uso e quem faz este uso. Como lembra Santos (1994), os atores hegemônicos (empresas agrícolas, por exemplo) utilizam o território como recursos enquanto que os atores hegemonizados (os agricultores familiares, por exemplo) fazem um uso do território como abrigo. Desta forma o uso que se faz do território reflete quem usa e sua intencionalidade.

Elisangela Couto (2007), em As modernizações e as racionalidades na agricultura e o uso do território: temporalidades e espacialidades no município de Ibiúna (SP), busca compreender os usos diferenciados que a agricultura empreende no território. Na obra, a autora destaca que a racionalização da agricultura tornou o território cada vez mais acrescido com os conteúdos da técnica, da ciência e da informação. 
Para a autora, "diante das transformações da agricultura, assim como de outros setores ligados às necessidades do período atual, o espaço geográfico torna-se cada vez mais racional, devido às ações que nele são inseridas" (COUTO, 2007, p. 63). Cabe destacar que a racionalização no período atual obedece a um comando que passa a determinar diretrizes e normas de atuação em setores seletivos da economia. No entanto, esta racionalidade hegemônica é quase sempre contestada por um conjunto de ações que envolvem solidariedades de resistências entre atores hegemonizados. No texto a autora destaca que na atualidade ocorre uma racionalidade do capital que acaba por criar lugares especializados em produções agrícolas para atender centros mais dinâmicos da economia.

Francisco C. Nascimento Junior (2013, p. 95), em Uso agrícola do território e trabalho científico para o campo moderno no Brasil, enfatiza o papel do Estado no processo de modernização agrícola brasileiro. Para ele, "durante o século XX, o Estado brasileiro se firmou como o principal agente promotor do processo de modernização da agricultura nacional, algo que se deu através de políticas especificas [...]". Ainda para o autor "de maneira geral, as políticas de Estado tiveram a finalidade de tornar viável a agricultura capitalista no território brasileiro" (NASCIMENTO JUNIOR, 2013, p. 95).

As afirmativas do autor destacam a importância das políticas de Estado na modernização agrícola nacional, bem como o incentivo ao uso agrícola do território brasileiro pelo setor empresarial organizado. Os setores empresariais são os principais tomadores de créditos agrícolas nas instituições de fomento no país.

Samuel Frederico (2013), em Modernização da agricultura e uso do território: a dialética entre o novo e o velho, o interno e o externo, mercado e o estado em áreas de cerrado, destaca a expansão da fronteira agrícola moderna brasileira, onde enfatiza que na década de 1990 ocorre a emergência da agricultura científica globalizada em determinadas frações do território brasileiro. Este tipo de agricultura caracteriza-se pelo uso intensivo da ciência, da tecnologia e da informação a serviço da produção agrícola. O autor destaca ainda que com a inserção da agricultura científica globalizada os lugares da produção agrícola ficam submissos a uma lógica única que obedece a um comando do mercado externo a estes lugares de produção.

Para este autor, o Estado teve papel central na expansão da fronteira agrícola moderna no Brasil, onde afirma que "o Estado foi o principal articulador e financiador da expansão da fronteira agrícola moderna, por meio de incentivos fiscais e creditícios" (FREDERICO, 2013, p. 47). 
$\mathrm{O}$ autor destaca também que nas últimas décadas do século $\mathrm{XX}$ a agricultura brasileira passou por grandes transformações passando de uma agricultura tradicional de base local para uma agricultura moderna cada vez mais mundializada e dotada de ciência, técnica e informação. No caso particular da modernização da agricultura, segundo ele, estas transformações decorrem de duas mudanças. A primeira desde a década de 1970, com a formação dos complexos agroindustriais (CAI) e a segunda, a partir da década de 1990, com a emergência da agricultura científica globalizada (FREDERICO, 2013).

Em sua tese intitulada $O$ processo recente de atualização do território no sudoeste da Amazônia: lógicas exógenas e dialéticas endógenas em Rondônia e Acre, Mirlei Fachini Vicente Pereira (2009) destaca a dialética entre o campo não moderno e voltado para a produção e consumo local e o campo moderno cuja produção é destinada quase sempre para o consumo externo. Para ele "[...] o território usado revela o quanto a modernidade e a racionalidade hegemônica não alcançam todos os espaços, todos os objetos e todas as ações" (PEREIRA, 2009, p. 214).

Em sua pesquisa, utiliza os pares dialéticos de campo moderno e campo-não moderno para analisar a realidade do uso agrícola do território no sudoeste da Amazônia por parte dos atores hegemônicos (empresas) e hegemonizados (populações tradicionais). Desta forma o território é disputado pelos atores do agronegócio e da agricultura familiar onde cada ator apresenta formas específicas de uso do território.

Para ele, “a idéia de 'campo moderno' aparece aqui como aquele em que estas atividades produtivas são muito orientadas e comandadas pelo e para o mercado externo (um trabalho que não tem origem no lugar) [...]" (PEREIRA, 2009, p. 214). A ideia de campo moderno só pode ser entendida se levarmos em comparação a ideia de campo não moderno. Para ele, "tomamos o termo não-moderno para designar a natureza das atividades agrícolas [...] tecidas e construídas em função dos recursos, das demandas e das gentes do lugar" (p. 214). O campo não moderno no sudoeste da Amazônia inclui populações tradicionais ribeirinhas, extrativistas, camponesas, indígenas, seringueiros que passam a sofrer um conjunto de investidas de forças do campo moderno (PEREIRA, 2009).

Segundo ele, as atividades não modernas na Amazônia estariam ligadas ao passado de atividades que não foram totalmente incorporadas pela modernização capitalista. Neste sentido, afirma que "as atividades não modernas do campo são aquelas remanescentes da história e do espaço anteriores ao projeto de atualização recente do território" (PEREIRA, 2009, p. 215). Estas heranças pretéritas não modernas representam de certa forma uma 
limitação à ação empresarial que tentam impor uma nova forma de racionalidade de uso do território.

Para o autor, "estas populações tradicionais são portadoras de uma organização que revela possibilidades outras de uso do território, com a manutenção do trabalho e da produção simples e muito voltados para o suprimento das demandas locais" (PEREIRA, 2009, p. 225). $\mathrm{Na}$ atualidade podemos afirmar que no Brasil existe uma disputa pelo uso do território comandado por forças do campo moderno que utilizam o território como recurso e de outro lado temos a resistência de forças do campo não moderno que utilizam o território como abrigo, conforme aponta Santos (1994).

Milton Santos (2009), em A urbanização brasileira, destaca a existência no território brasileiro de um Brasil urbano e um Brasil agrícola. Segundo ele, "no Brasil agrícola, há tendência a que a área de exportação, isto é, de produção que procura um mercado distante, seria, sobretudo, a área rural, e isto tanto mais quanto a agricultura regional seja moderna" (SANTOS, 2009, p. 76). O Brasil agrícola de que nos fala o autor está presente em frações do território brasileiro, onde as atividades agrícolas modernas exercem um forte papel na economia e na dinâmica dos municípios onde estão localizadas.

Denise Elias (2006a), em Agronegócio e desigualdades socioespaciais, aborda o agronegócio como resultado da dispersão espacial da agricultura científica (SANTOS, 2000; ELIAS, 2003; 2006a; 2006b; 2011). Para ela, a difusão do agronegócio no Brasil tem provocado uma série de especialização produtiva do território brasileiro.

O desenvolvimento do agronegócio do território brasileiro ocorre de forma excludente, pois é responsável pela concentração de terras sob controle das empresas agrícolas, além de contribuir para a proletarização das relações de trabalho no campo (ELIAS, 2006a). A difusão do agronegócio brasileiro ocorre fundamentalmente a partir da década de 1970 no contexto do período técnico científico-informacional, tendo na globalização e no consumo, seus fundamentos onde novos territórios do Centro-Oeste e da Amazônia são incorporados à produção agrícola nacional.

A expansão do agronegócio no Brasil foi o responsável pela formação de arranjos territoriais produtivos agrícolas a partir do período técnico científico-informacional nas regiões Sul, Sudeste e Centro-Oeste. Nessas regiões estão presentes as maiores empresas agropecuárias hegemônicas nacionais e internacionais com atuação no Brasil. A Amazônia nesta divisão territorial do trabalho agropecuário nacional teria um papel de fronteira agrícola recente e o Nordeste figura como a área mais resistente à modernização no conjunto da agropecuária nacional (ELIAS, 2006a). 
No Nordeste encontramos diversos arranjos territoriais produtivos agrícolas como a produção intensiva de frutas ao longo do Vale do Açu (RN) e do Vale do Jaguaribe (CE) e as experiências de fruticultura irrigada no vale do São Francisco nos municípios de Juazeiro (PE) e Petrolina (BA), a produção intensiva de soja nos cerrados nordestinos (ELIAS, 2006a). A expansão da soja nos cerrados do Nordeste (oeste da Bahia, sul do Maranhão e sul do Piauí) marca um novo tempo para a expansão da fronteira do agronegócio no Brasil, onde estes territórios passam a se articular com a escala mundial da economia.

A realidade nestes arranjos territoriais produtivos agrícolas passa pela existência de uma verticalidade e horizontalidade regida pela racionalidade do agronegócio aí presente. Desta forma, estes territórios produtivos agrícolas obedecem a uma lógica vertical (SANTOS, 1996), pois sua produção está ligada ao mercado consumidor global. A lógica horizontal (SANTOS, 1996) pré-existente destes territórios passa a obedecer a uma lógica vertical de que nos fala o autor.

No Brasil agrícola moderno (SANTOS, 2009), a difusão da agricultura científica e do agronegócio tem contribuído para a especialização produtiva do território onde a urbanização de muitas cidades se deve à presença das atividades ligadas ao agronegócio, o que Milton Santos (2000) denominou de cidades do campo e o que Elias (2006a), mais recentemente denominou de cidades do agronegócio. Nas cidades do agronegócio, a dinâmica local passa necessariamente pela presença das atividades ligadas a este setor.

Denise Elias (2003), em Globalização e agricultura ${ }^{9}$ apresenta uma análise da agricultura no período técnico-científico-informacional no que Milton Santos (2008) chamou de agricultura científica. Para a autora, existiriam no Brasil, frações do território que constituiriam um Brasil agrícola moderno, cuja urbanização deve-se ao desenvolvimento das atividades agrícolas e agroindustriais presentes no território. A modernização da agricultura só foi possível a partir de uma profunda mudança na base técnica, onde foi introduzida na produção agrícola novos elementos da técnica, da ciência e da informação (ELIAS, 2003).

Em outra publicação intitulada Globalização e fragmentação do espaço agrícola do Brasil, Denise Elias (2006c) discorre sobre a dialética da produção agrícola, tratando das características da agricultura científica no Brasil. A autora apresenta uma periodização do desenvolvimento deste tipo de agricultura no país que, segundo ela, estaria dividida em três grandes momentos. O primeiro momento teria ocorrido na década de 1950 com a mudança da

\footnotetext{
${ }^{9}$ Obra publicada a partir da tese de doutorado intitulada Meio técnico-científico-informacional e urbanização na região de Ribeirão Preto (SP), orientada por Milton Santos e defendida em 1996, no Departamento de Geografia da Universidade de São Paulo (USP).
} 
base técnica, o segundo na década de 1960 com o desenvolvimento dos complexos agroindustriais e o terceiro na década de 1970 com a integração de capitais além da forte presença da técnica, da ciência e da informação na produção agrícola (ELIAS, 2006c).

A autora defende a existência de uma dicotomia entre uma agricultura tradicional e uma agricultura científica, esta última com a formação de verdadeiros pontos luminosos (SANTOS, 1996) em frações do território brasileiro (ELIAS, 2006c). Segundo a autora, a lógica modernizadora da agricultura forma verdadeiros arranjos territoriais produtivos agrícolas que estariam distribuídos em pelo menos quatro grupos principais. O primeiro seria formado pela agricultura familiar, a agricultura camponesa, não integrada ao agronegócio. $\mathrm{O}$ segundo formado pela pequena produção integrada ao agronegócio. O terceiro formado pelos médios e grandes empresários agrícolas, integrados ou não à agroindústria. $\mathrm{O}$ quarto grupo seria formado pelas holdings que dominam parte significativa dos segmentos da cadeia produtiva de terminados sistemas agroindustriais (ELIAS, 2006c).

As ideias apresentadas nesta seção são de grande importância para a análise da realidade agrícola empírica desta pesquisa. Na sequência, passamos para a ocupação e uso agrícola do território no Baixo Tocantins nos períodos pré-técnico, técnico e técnicocientífico-informacional.

\subsection{Ocupação e uso agrícola do território do Baixo Tocantins no período pré-técnico}

A configuração territorial do Baixo Tocantins vem passando ao longo do tempo por mudanças com relação aos municípios integrantes deste território. Em 1973, por ocasião dos estudos técnicos realizados pela Sudam para o Plano de Desenvolvimento Integrado da Área da Bacia do Rio Tocantins, este território compreendia sete ${ }^{10}$ municípios. Em 1980, no Estudo de Desenvolvimento Integrado da Bacia do Araguaia-Tocantins (Prodiat), o território do Baixo Tocantins passou a compreender dez ${ }^{11}$ municípios (BRASIL, 1982a). Em 2008, com a criação do território da cidadania do Baixo Tocantins por parte do Ministério do Desenvolvimento Agrário (MDA), este território passa a ser constituído por onze ${ }^{12}$

\footnotetext{
${ }^{10}$ Abaetetuba, Baião, Barcarena, Cametá, Igarapé-Miri, Limoeiro do Ajuru e Mocajuba (SUDAM, 1973a).

${ }^{11}$ Abaetetuba, Baião, Bagre, Barcarena, Cametá, Igarapé-Miri, Limoeiro do Ajuru, Mocajuba, Moju, Oeiras do Pará (BRASIL, 1982b, p.44).

${ }^{12}$ Abaetetuba, Acará, Baião, Barcarena, Cametá, Igarapé-Miri, Limoeiro do Ajuru, Mocajuba, Moju, Oeiras do Pará e Tailândia (BRASIL, 2009b). Esta é a regionalização que adotamos nesta pesquisa.
} 
municípios. Este território recebe o nome de região de integração do Tocantins em regionalização ${ }^{13}$ administrativa do governo do Pará (PARÁ, 2010a).

A ocupação do território ocorre a partir das margens esquerda e direita do rio Tocantins (Mapa 2). Em sua margem esquerda predomina um solo de várzea onde tem destaque uma temporalidade lenta, e prevalece uma dinâmica de vida que tem na natureza um importante elemento de referência. Em muitas localidades do Baixo Tocantins, o acesso é exclusivamente feito pelo rio. Neste sentido, Leandro Tocantins (1973) tem razão em sua importante obra de interpretação da Amazônia quando afirma que em muitos locais da região "o rio comanda a vida". Esta observação do autor pode ainda hoje ser empregada em uma fração do território do Baixo Tocantins, principalmente nos municípios de Cametá, Limoeiro do Ajuru, Oeiras do Pará, onde parte de seus territórios municipais se encontram sob influência do solo de várzea. Em sua margem esquerda, a ocupação e o uso do território do Baixo Tocantins ainda continuam dependentes do Tocantins e seus muitos afluentes que ligam localidades neste território. Como aponta este autor, "o primado social dos rios, trazendo a marca da geografia singular, revela-se nos múltiplos aspectos da vida amazônica" (TOCANTINS, 1973, p. 278). Continua o autor “[...] o rio imprimindo a sociedade rumos e tendências, criando tipos característicos na vida regional” (TOCANTINS, 1973, p. 280).

Nestes territórios de influência das várzeas encontramos populações tradicionais de ribeirinhos que vivem do extrativismo vegetal, com destaque para o açaí, pesca e de uma pequena agricultura, com destaque para o plantio do cacau nas áreas de várzea.

Em muitos destes territórios, a força da racionalidade hegemônica do capital ainda não é dominante, como se observa na margem direita do rio Tocantins, onde predomina um solo de terra firme e onde a estrada permite uma maior fluidez do território. Em muitas localidades da margem esquerda do rio Tocantins o tempo lento de que nos fala Milton Santos (1996) é característico no habitante local. Aí prevalece uma atividade não moderna do campo (PEREIRA, 2009), ligada ao extrativismo vegetal, à pesca e à agricultura familiar para consumo local. Estes habitantes possuem poucos recursos financeiros para desenvolverem estas atividades, que se caracteriza pela pequena intensidade de capital e tecnologia.

\footnotetext{
13 Para fins de planejamento estadual, o governo do Pará organizou o território paraense em 12 regiões de Integração: Araguaia; Baixo Amazonas; Carajás; Guamá; Lago de Tucuruí; Marajó; Metropolitana; Rio Caeté; Rio Capim; Tapajós; Tocantins e Xingu (PARÁ, 2010a).
} 
Mapa 2: Ocupação e uso do território do Baixo Tocantins a partir do rio Tocantins
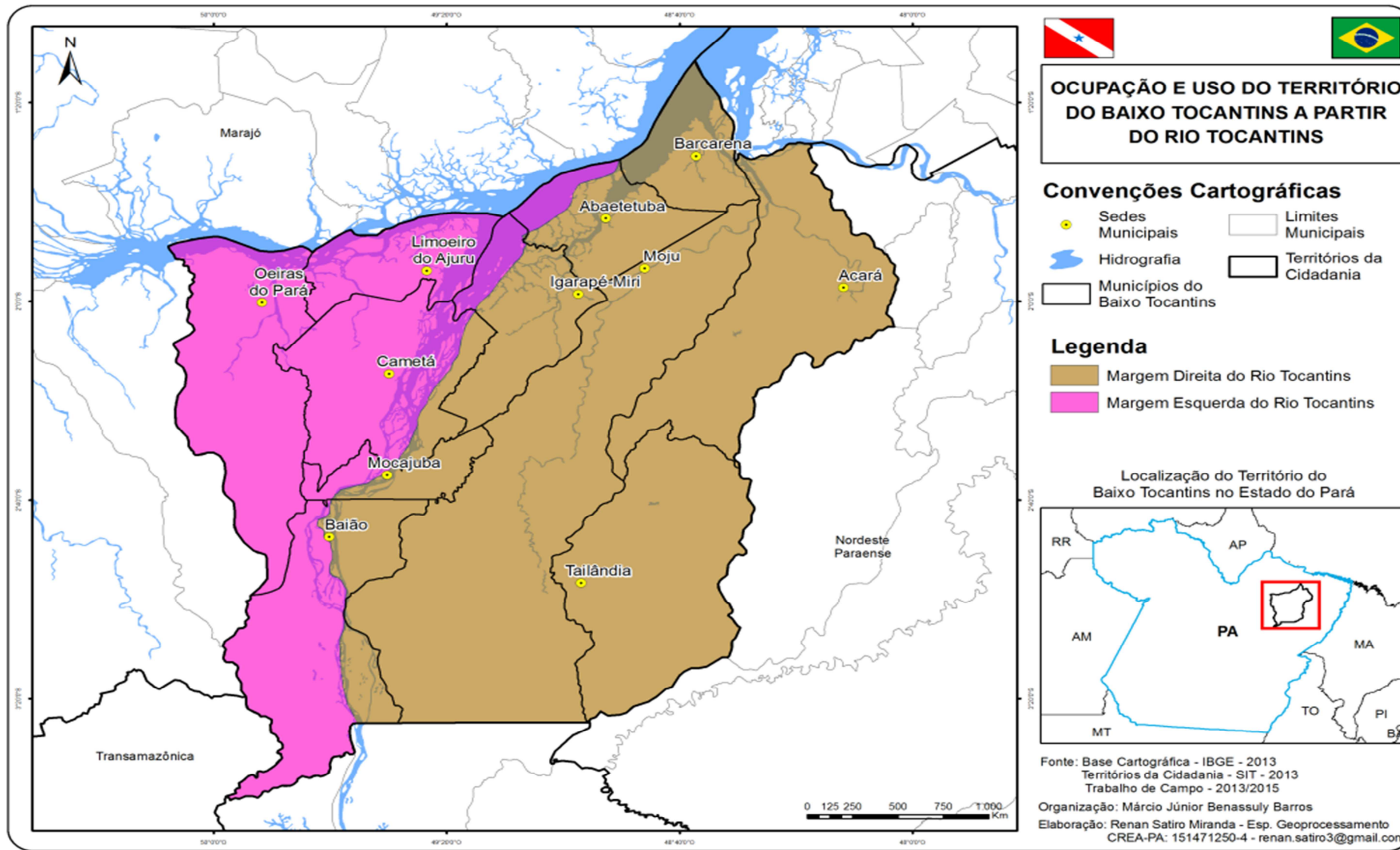

OCUPAÇÃO E USO DO TERRITÓRIO DO BAIXO TOCANTINS A PARTIR DO RIO TOCANTINS

\section{Convenções Cartográficas}

- Sedes

Municipais

Hidrografia

Municípios do

Baixo Tocantins

$\square$ Municipais

$\square$ Cidadania

Legenda

Margem Direita do Rio Tocantins

Margem Esquerda do Rio Tocantins

Localização do Território do Baixo Tocantins no Estado do Pará

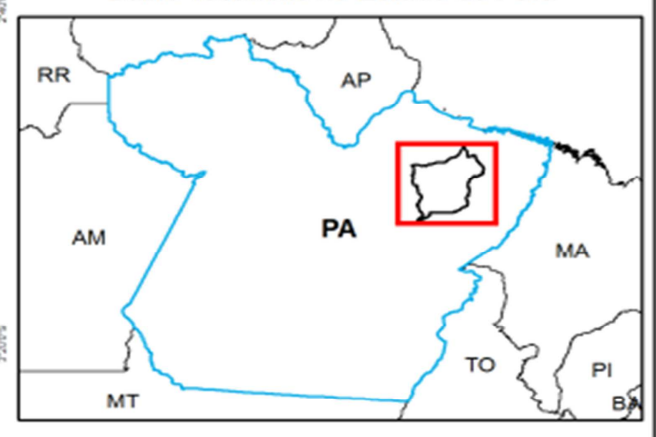

Fonte: Base Cartográfica - IBGE - 2013

Territórios da Cidadania - SIT -201
Trabalho de Campo - 2013/2015

Organização: Márcio Júnior Benassuly Barros

Elaboração: Renan Satiro Miranda - Esp. Geoprocessamento 
Nestes territórios se pratica uma agricultura não moderna, que quase sempre funciona sem apoio governamental de financiamento da produção, sem assistência técnica e com uso predominante de mão-de-obra familiar (PEREIRA, 2009).

$\mathrm{Na}$ margem direita do rio Tocantins, prevalece uma ocupação de terra firme, que com o processo de integração territorial pós-década de 1960 passou a ser beneficiada com a abertura de diversas rodovias que permitiram uma fluidez do território. Nesta fração do território do Baixo Tocantins, devido a suas características naturais, vêm se consolidando diversas atividades modernas do campo, como observa Santos (1991). Na região, estas atividades modernas no campo estão ligadas à agricultura de dendê, praticadas por diversas empresas do setor. Estas atividades modernas do campo respondem a uma racionalidade do capital hegemônico que procura sempre maximizar suas atuações.

O território do Baixo Tocantins ${ }^{14}$ é o produto das ações estatais, empresariais e sociais acumuladas ao longo do tempo. Antes mesmo da ocupação pelos colonizadores portugueses, o vale do rio Tocantins já era habitado por diversos grupos indígenas, entre os quais os Camutá, no entorno da atual cidade de Cametá. A ação colonizadora portuguesa iniciada em 1500 no Brasil impõe uma nova forma de ocupação e uso dos territórios incorporados a Portugal. No Pará esta ação se dá inicialmente por meio da expedição de Francisco Caldeira Castelo Branco que funda a cidade de Belém do Pará, em 1616 (Figura 1). No Baixo Tocantins a presença do Estado português ocorre mediante a fundação da Vila de Viçosa de Santa Cruz de Camutá, em 1635.

Para Milton Santos (1995, p. 699), "nesse período pré-técnico os sistemas técnicos não tinham existência autônoma. Sua simbiose com a natureza resultante era total [...] As motivações de uso eram, sobretudo locais". A ocupação e o uso do território colonial português no Brasil foram inicialmente resolvidos, por meio da criação das capitanias hereditárias na colônia brasileira. Devido à extensão da colônia e as dificuldades de comunicações e transportes entre o extremo Norte do Brasil e a Bahia, onde ficava a capital do governo geral do Brasil, é que, em 1616, é criado o estado do Maranhão ${ }^{15}$ e somente em 1626 é oficializado com a nomeação de Francisco Coelho de Carvalho, primeiro governador do novo estado (REIS, 1993).

\footnotetext{
${ }^{14}$ Área do extremo norte da bacia do rio Tocantins, estado do Pará, que compreende a foz do rio Tocantins até as proximidades de Tucuruí (BRASIL, 1982b).

${ }^{15}$ No período colonial o estado do Maranhão compreendia toda a Amazônia.
} 
Figura 1: A fundação de Belém

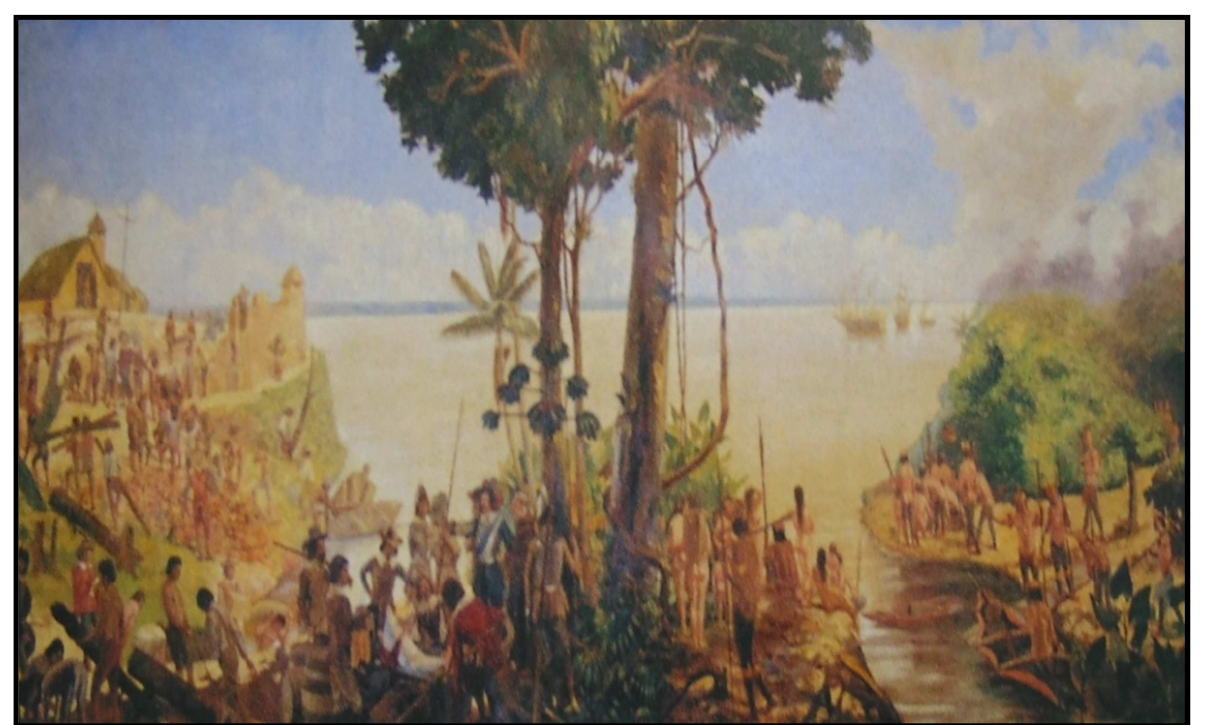

Fonte: Tela de Theodoro Braga. Museu de Artes de Belém

Como ocorreu no estado do Brasil, o estado do Maranhão apresentava grandes extensões de terras que precisavam ser ocupadas. A solução foi a repartição em capitanias. Em 1634 foi criada a capitania do Caeté, doada a Álvaro de Souza. Em 1637 foi criada a capitania de Camutá, doada a Feliciano Coelho de Carvalho. Em 1645 foi criada a capitania do Cabo Norte, doada a Bento Maciel Parente. Em 1655 foi criada a capitania do Marajó, doada a Antonio de Sousa Macedo. Em 1681 foi criada a capitania do Xingu, doada a Gaspar de Souza Freitas (REIS, 1993).

A demora dos portugueses na efetiva ocupação do território do norte do Brasil abre caminho para exploradores franceses, ingleses e holandeses realizarem diversas expedições na região. Os franceses em 1594 se estabelecem no Maranhão onde fundam uma colônia. Do Maranhão organizam diversas expedições no Pará, onde o vale do Tocantins foi objeto de diversas destas expedições. No vale do Tocantins existe registro da presença dos franceses, em 1610, quando La Blanjartier avança no rio, atingindo a cachoeira de Itaboca (VELHO, 1972).

Em 1613, o fidalgo Daniel de La Touche, partindo do Maranhão, aportou no local onde em 1616 os portugueses fundaram Belém, marco da ocupação lusa na Amazônia. Esta mesma expedição francesa em seguida parte em direção ao rio Tocantins atingindo as terras onde seria fundada mais tarde pelos portugueses a capitania de Cametá. Neste local Daniel de La Touche finca a bandeira da França (CRUZ, 1963).

As constantes ações da França no litoral do Maranhão levaram Portugal a organizar expedições para expulsar os franceses do território colonial português. Em 20 de novembro de 
1614 acuado pelas forças portuguesas no Maranhão, Daniel de La Touche foi obrigado a retirar-se do Maranhão. No ano seguinte, tendo como objetivo efetivar o domínio de Portugal no norte da colônia foi destacado Francisco Caldeira Castelo Branco para comandar expedição responsável pela fundação de Belém em 1616, marco da ocupação da Amazônia portuguesa (CRUZ, 1963).

A expedição comandada por Francisco Cadeira Castelo Branco contava com 150 soldados que chegam a Belém em 12 de janeiro de 1616, onde denomina as terras conquistadas de Feliz Lusitânia. Neste ponto foi construindo inicialmente um forte denominado de Presépio, posteriormente mudado para Castelo em homenagem ao descobridor das novas terras, Francisco Cadeira Castelo Branco. Este local era habitado pelos índios Tupinambá que combateram a presença lusa na região. A colonização inicial de Belém foi realizada por colonos açorianos que passaram a desenvolver um núcleo agrícola (CRUZ, 1963). A Figura 2 mostra detalhes do Forte do Castelo, símbolo da presença portuguesa na capital do Pará.

Figura 2: Forte do Castelo, marco da fundação de Belém pelos portugueses no século XVII

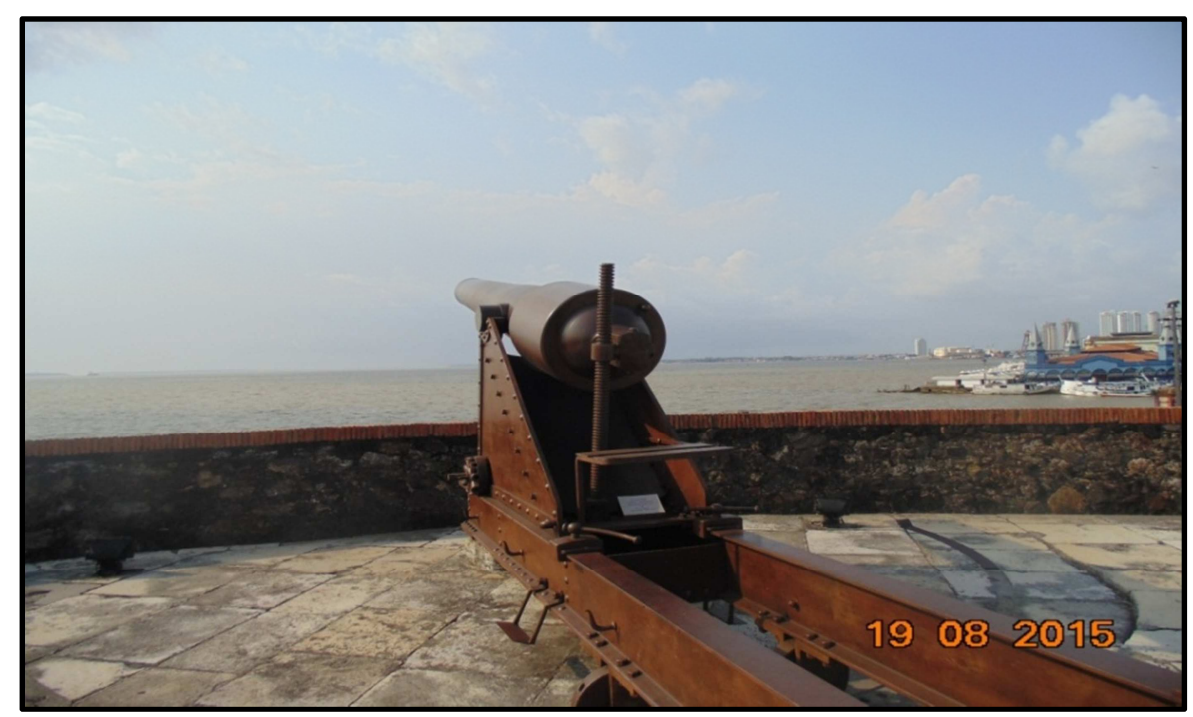

Fonte: Márcio Benassuly (2015)

Visando efetivar o controle definitivo do território colonial do vale amazônico, o Estado português organiza uma série de expedições com esta finalidade. A que obteve a maior repercussão foi a expedição comandada por Pedro Teixeira. Em 28 de outubro de 1637, partia do porto de Cametá a expedição liderada por Pedro Teixeira que promove os primeiros reconhecimentos do interior do vale do Amazonas. Esta expedição chega até Quito no Equador de onde retorna, em 16 de agosto de 1639, para fundar na confluência do Napo com 
o Aguarico o povoado de Franciscana, que viria a marcar os domínios territoriais da Espanha e Portugal no vale amazônico (REIS, 1972). A Figura 3 mostra detalhes do Forte do Castelo e de casarios em estilo português presente no centro histórico de Belém.

Figura 3: Forte do Castelo e casarios em estilo português, marcos da presença portuguesa em Belém do Pará

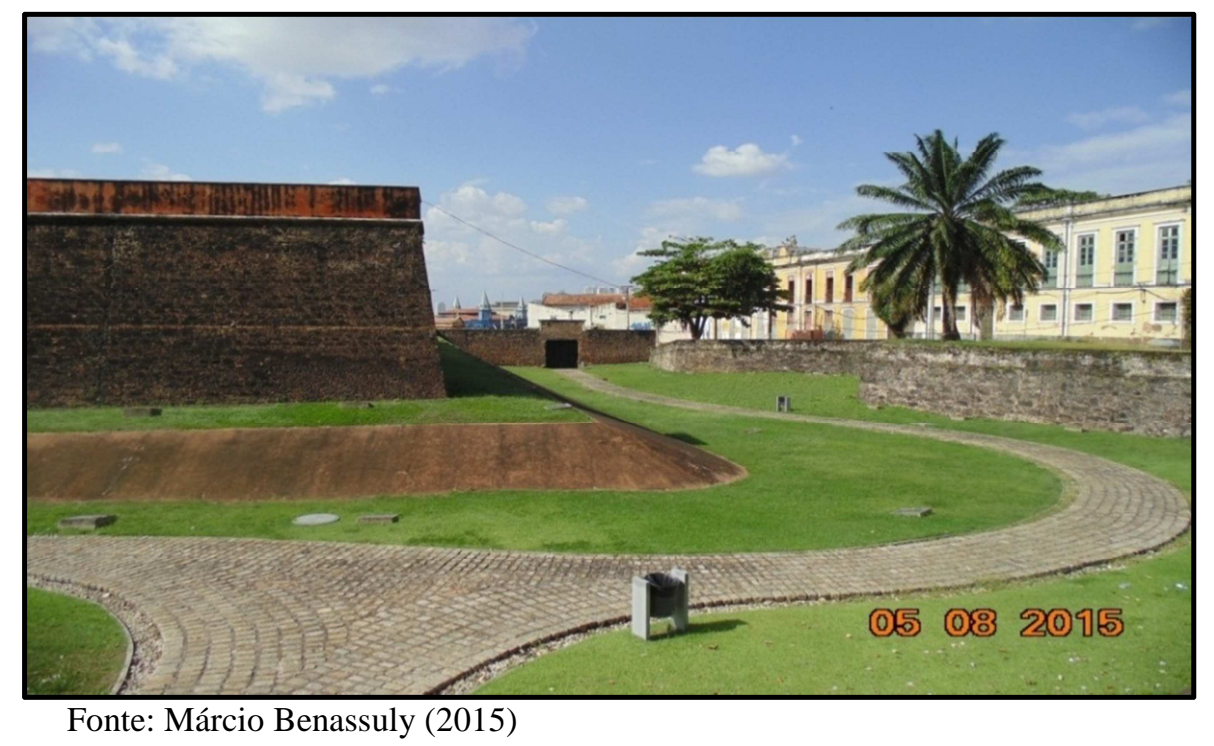

Em 1653, o padre Antonio Viera percorre o rio Tocantins até o rio Itacaiúnas (VELHO, 1872). No final do século XVII o rio Tocantins já havia sido todo percorrido por diversas expedições. Em 1737 tendo como objetivo combater o desvio de metais preciosos no norte através deste rio, o Conselho Ultramarino proibe a navegação pelo rio Tocantins em direção ao trecho goiano, onde desde 1725 havia exploração de ouro (VELHO, 1972).

Historicamente o Baixo Tocantins constitui-se como uma das primeiras áreas de colonização portuguesa na Amazônia datando do século XVII com a fundação do núcleo de Cametá-Tapera (1620) e da Vila de Cametá (1635) onde o rio Tocantins ${ }^{16}$ constitui-se no principal vetor de integração intra e inter-regional (SOUZA, 2011).

Após sete meses da presença de Castelo Branco em solo paraense (1616), chega ao Grão-Pará, Frei Cristovão de São José que se destacaria como grande desbravador de missões de catequese no rio Tocantins. Ao longo do rio lançou os fundamentos da Vila Viçosa de Santa Cruz de Camutá onde seria fundada a capitania de Cametá, por Feliciano Coelho de Carvalho (CRUZ, 1963).

\footnotetext{
${ }^{16} \mathrm{O}$ curso do rio Tocantins é de $2400 \mathrm{~km}$ aproximadamente, e a sua divisão em trechos, comumente adorada é a seguinte: Alto Tocantins (com extensão de $1060 \mathrm{~km}$ ) Médio Tocantins (com extensão de $980 \mathrm{~km}$ ) e Baixo Tocantins (com extensão de $360 \mathrm{~km}$ ) (BRASIL, 1982b).
} 
As ações missionárias de frei Cristovão de São José foram determinantes para a ocupação do território do vale do Tocantins tendo na fundação da Vila Viçosa de Santa Cruz de Camutá (Figura 4) a sua maior referência da presença portuguesa na região. A ação missionária do frei foi diretamente responsável pela descida em 1620 da tribo dos Camutá para o sítio da então Vila de Camutá.

Figura 4: Prospecto da Vila do Cametá, em 1784

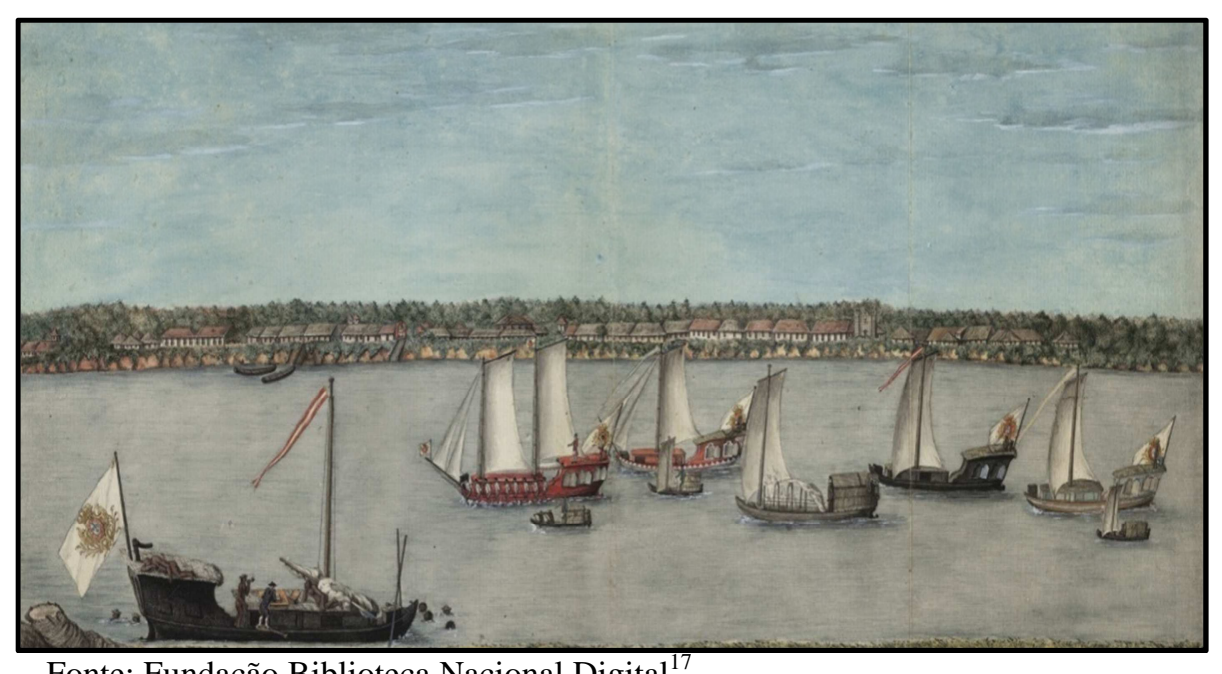

Fonte: Fundação Biblioteca Nacional Digital ${ }^{17}$

Este fato foi destacado por Cruz (1963, p. 39), quando afirmou que "nesse ano a tribo dos Camutá que tamanha ajuda havia de dar a Pedro Teixeira na conquista do Amazonas, deixou a antiga taba e veio localizar-se nas terras cultivadas pelo missionário". Desta forma, a ação missionária foi determinante para a ocupação e os usos do território no início da colonização portuguesa na Amazônia.

Cametá é berço da ocupação no vale do Tocantins, sendo, portanto resultado da ação do Estado português e das ações missionárias na região do rio Tocantins, onde o colonizador fez surgir uma sociedade de fortes laços com a metrópole portuguesa. Segundo Reis (1972, p.48), "no vale do Tocantins, distrito de Cametá, começava se a constitui-se [...] uma pequena sociedade rural, de gestos afidalgados, viver confortável”. A presença da Igreja Católica em Cametá, por intermédio de edificações centenárias é bastante comum na cidade como podemos verificar na Figura 5.

\footnotetext{
${ }^{17}$ Disponível em: <http://objdigital.bn.br/acervo_digital/div_manuscritos/mss1309089/mss1309089.jpg> Acesso em: 15 mar. 2016.
} 
Figura 5: Heranças da presença da ação católica em igreja de Cametá

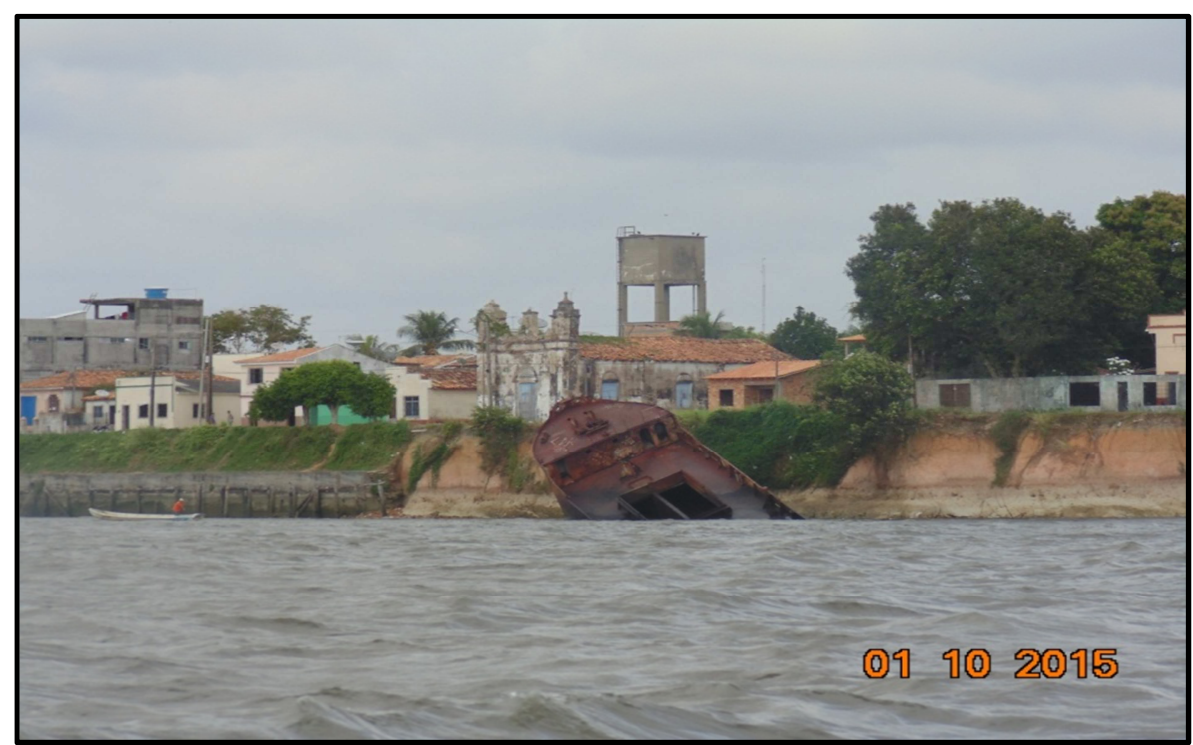

Fonte: Márcio Benassuly (2015)

A presença dos colonizadores portugueses em Cametá deixou marcas na arquitetura, no modo de falar, no comércio local, entre outras contribuições. Quem visita o centro comercial da cidade pode na atualidade constatar a presença de diversos casarios em arquitetura portuguesa (Figura 6).

Figura 6: Casarios antigos, herança da presença portuguesa em Cametá

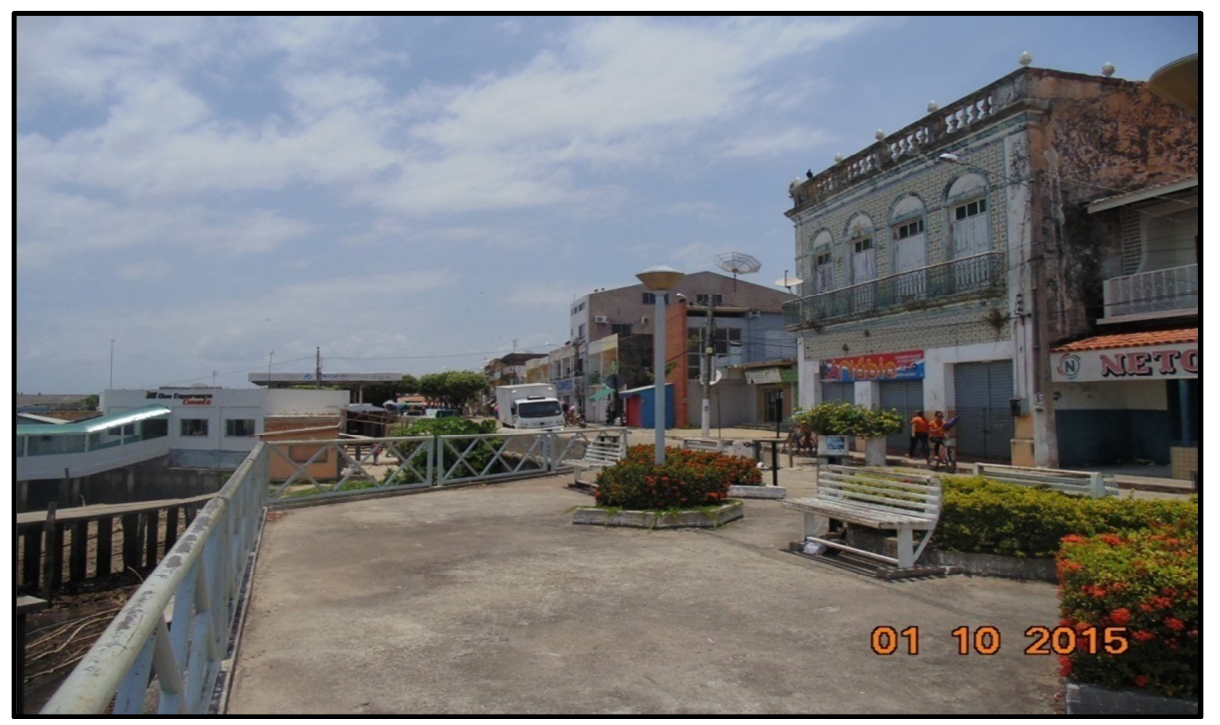

Fonte: Márcio Benassuly (2015)

Maria de Nazaré Angelo-Menezes (1994; 2000), escrevendo sobre o sistema agrário do Vale do Tocantins colonial, no período de 1669-1800, traça um perfil do processo de uso agrícola deste território colonial. Foi ao longo deste vale que teve início a implantação de um 
conjunto de sistemas agrários ${ }^{18}$ para atender o mercado externo ainda no período colonial (ÂNGELO-MENEZES, 2000).

"O vale desponta como as terras para os ensaios de agricultura do cacau em substituição a destinação de extensões em cana de açúcar [...] após a queda do cacau, recompõe-se uma agricultura familiar estacionaria" (ANGELO-MENEZES 2000, p. 101). Nesta publicação a autora procura destacar que foram introduzidas no período colonial no Baixo Tocantins diversas culturas como arroz (Baião e Abaetetuba), cana-de-açúcar (Igarapé Miri), cacau (Cametá) e café (Cametá, Baião e Conde) (ANGELO-MENEZES, 2000).

A ocupação do território ocorreu a partir do rio, todas as dinâmicas do vale ocorrem em função do Tocantins que passou a influenciar a formação de povoados, vilas e cidades. Este padrão de organização do espaço amazônico foi denominado por Carlos Walter Porto Gonçalves (2005) de padrão rio-várzea-floresta que dura até a década de 1960. Neste padrão a Amazônia tem suas dinâmicas definidas pela força do rio, em que suas várzeas abrigam florestas onde eram coletados os recursos naturais (animais e florestais) demandados pelo colonizador português. No Baixo Tocantins este padrão ainda é bastante presente, principalmente nos municípios com grandes áreas de várzea, à exceção apenas de Tailândia, onde a mata de terra firme predomina.

Em 1654, ocorreu a junção dos territórios do Maranhão e Pará, que deu origem ao estado do Maranhão e Grão-Pará, tendo por capital São Luiz (PROST, 1997). Em 1751 ocorreu a transformação do estado do Maranhão e Grão-Pará em estado do Grão-Pará e Maranhão, quando a capital é transferida de São Luiz para Belém (REIS, 1993).

A ocupação portuguesa da Amazônia colonial durante o século XVII ocorreu a partir da trilogia de uma ocupação militar, religiosa e econômica. Os trabalhos de Arthur Cesar Ferreira Reis $(1960 ; 1972 ; 1973 ; 1993)$ apontam para esta interpretação da ação de ocupação portuguesa no vale amazônico, tendo como marco inicial a fundação de Belém do Pará, em 1616, por Francisco Caldeira Castelo Branco.

A ocupação militar do território da Amazônia colonial ocorreu por meio da fundação de fortes militares nas novas terras descobertas. No Grão-Pará se fez principalmente pela fundação de fortes militares nos principais rios da região. No sítio onde foi fundada Belém constrói-se o forte do Castelo de onde foram traçados os primeiros planos de ocupação do território provincial do Pará. No rio Tocantins constrói-se o forte de Nossa Senhora de Nazaré

\footnotetext{
${ }^{18} \mathrm{O}$ termo sistema agrário é empregado para caracterizar, dentro de um espaço, a associação das produções e das técnicas colocadas por uma sociedade em via de satisfazer as suas necessidades (ANGELO-MENEZES, 2000, p. 97).
} 
de Alcobaça, no atual município de Tucuruí. Estes fortes militares faziam o controle do extenso vale do Amazonas garantindo a soberania de Portugal nas terras colonizadas (CRUZ, 1963).

A ocupação religiosa do território da Amazônia colonial ocorreu por meio da ação missionária de franciscanos, carmelitas, jesuítas, mercedários e franciscanos. "Estes religiosos montaram dezenas de pequenos núcleos, amansando a população gentílica” (REIS, 1973, p.11).

A ocupação econômica do território da Amazônia colonial ocorre inicialmente com a procura das drogas do sertão e da mão-de-obra indígena, além da produção agrícola, como defende Chambouleyron (2006). Para Reis (1960), a ocupação econômica da Amazônia colonial passa por dois ciclos econômicos. O primeiro ciclo foi o das "drogas do sertão 19 ", em que os produtos que mais se destacavam eram o cacau, o cravo, a canela e a salsa. $O$ segundo ciclo é o das "experiências agrárias, pecuárias e industriais".

O ciclo das experiências agrárias começa com o consulado pombalino criado no século XVIII e responsável por uma série de intervenções no Pará colonial. Segundo Reis (1960, p. 27), “com o consulado de Sebastião José, essa atividade agrária tomou proporções. Foi uma atividade que objetivou as espécies alimentares, as espécies nativas e os outros tipos agriculturáveis que se entendeu apropriados a região".

Desde 1616, com a ocupação de Belém, o extrativismo das drogas do sertão havia recebido bastante atenção em função das atividades agrícolas na Amazônia colonial. Com o relativo esgotamento da coleta das drogas do sertão, o Estado Português toma a iniciativa da exploração agrícola do território no Pará colonial. Por meio de instruções públicas e secretas de 31 de maio de 1751, o marquês de Pombal ordena a seu irmão, Francisco Xavier de Mendonça Furtado, governador do estado do Maranhão e Grão-Pará que cuide de fazer lavrar a terra com o cultivo de espécies nativas, bem como de espécies que os portugueses chamavam de alienígenas, ou seja, de outra região (REIS, 1960). Cabe destacar que as espécies nativasabordadas pelo autor eram o cacau, o cravo e a salsa; já as espécies alienígenas eram a cana, o algodão, o arroz, o tabaco e o café.

Para a execução desta política de ocupação agrícola, o Estado português procurava incentivar o cultivo da terra por meio da concessão de sesmarias, instrumentos e sementes, bem como normatizar sobre determinadas culturas agrícolas. Para Reis (1973, p. 13), “a

\footnotetext{
19 As drogas do sertão eram a salsaparrilha, o sassafrás, o cacau, a canafístula, a pita, o urucu, a canela, o algodão, o carajuru, o cravo fino e grosso, a baunilha, a quina, o puxuri, a casca preciosa, as sementes oleaginosas e as madeiras (REIS, 1960, p. 23).
} 
Amazônia, no período de Pombal, havia se desenvolvido intensamente. [...] fizera tentativa, cheia de êxito, da exploração agrícola com plantações intensas de cacau, cana, fabricação de açúcar e cultivo de café".

Chambouleyron (2006, p. 3) também reconhece esta fase de investimentos quando afirma "é somente a partir dos anos de 1750, portanto, que a coroa portuguesa empreenderia melhoria da produção, por meio da definição de uma política agrícola e da resolução dos problemas de mão-de-obra”. Desta forma, o século XVIII na Amazônia passa a receber ações estatais da metrópole que têm como ênfase a expansão da produção agrícola.

O período da gestão de Pombal marcar uma fase de grandes investimentos na realização de ações estatais voltadas para o setor agrícola no Grão-Pará colonial. Desta forma, "a experiência agrícola tinha alcançado sucesso espantoso. Em meados do século XIX, todavia, abandonou-se um pouco o esforço agrícola por um novo extrativismo"(REIS, 1973, p.13). A história econômica da Amazônia tem sido marcada pela disputa entre o extrativismo vegetal e a agricultura.

Para Chambouleyron (2006), a ocupação agrícola do território foi um elemento importante na Amazônia colonial ainda no século XVII, principalmente no caso das capitanias privadas como Cametá. Neste aspecto este autor discorda das obras de Reis (1960; 1972; 1973; 1993) que destacam o papel da agricultura na ocupação do território amazônico somente a partir do século XVIII, com a ação das políticas do marquês de Pombal.

Para ele, "o estabelecimento de uma capitania particular significava para a coroa o desenvolvimento de uma ocupação fundada numa vila erigida pelo donatário e dependente da agricultura" (CHAMBOULEYRON, 2006, p. 4). Nesta passagem, o autor procura destacar que a atividade agrícola nas capitanias particulares representou um fator responsável pela ocupação destes territórios coloniais administrados por particulares.

Segundo ele, "a experiência de Cametá revela, a partir das capitanias privadas, que a fundação de uma vila, a instalação de colonos e a produção agrícola também eram elementos da ocupação da fronteira amazônica seiscentista" (CHAMBOULEYRON, 2006, p. 4). A contribuição de Chambouleyron (2006) justifica-se pelo fato de que a ocupação da Amazônia colonial não pode ser pensada apenas pelas ações do Estado Português, da Igreja Católica e dos sertanistas, mas que outros personagens como os donatários, ao fundarem vilas, tiveram um papel de destaque na ocupação do território onde a atividade agrícola foi de grande importância.

Em O naturalista no rio Amazonas, Henri Bates (1944), ao percorrer o rio Tocantins em 1848, fez diversas anotações de sua expedição ao longo deste rio. Em Vista 
Alegre,município de Cametá, registrou em 30 de agosto de 1848 a existência de uma fazenda agrícola, onde "havia uma tosca moenda de cana de açúcar, movida por bois, mas a única coisa que se fazia com o caldo era cachaça” (BATES, 1944, p. 153). Na mesma propriedade agrícola, Bates (1944, p. 153) descreveu a existência de uma "larga estrada através de uma plantação abandonada de café e cacau, levando a vários largos de alpendres, onde faziam farinha". Como registrado pelo naturalista a atividade agrícola em muitas propriedades ao longo do rio Tocantins em meados do século XIX era constituída por diversas lavouras que incluíam cana-de-açúcar, café, cacau e mandioca.

Já em Baião, o naturalista descreveu que "as matas em torno do Baião eram capoeirões, tendo sido o solo anteriormente cultivado. Muitos pés de café e de algodão cresciam no meio do mato" (BATES, 1944, p. 162). Outra cidade localizada às margens do rio Tocantins, Cametá, também foi registrada em sua passagem pela região do Baixo Tocantins. Segundo ele, "do lado oposto de Cametá todas as ilhas estão plantadas de cacau, a arvore que dá a semente para o chocolate" (BATES, 1944, p. 178).

Desde sua fundação, a cidade de Cametá exerceu forte influência política no Pará, inclusive sediando a capital do estado no período de 15 de maio a 25 de junho de 1835 , durante a vice-presidência do cametaense Angelo Custódio Correia. Em 1855, Custódio faleceu de cólera na condição de presidente do estado. Em Cametá nasceram importantes personagens do clero brasileiro como Romualdo Antonio de Seixas, que foi marquês de Santa Cruz e arcebispo da Bahia e Romualdo de Souza Coelho, que morreu em 1860, como primaz do Brasil (BATES, 1944).

Outros naturalistas que percorreram o rio Tocantins foram Spix e Martius (1976), que registraram em sua viagem pelo Pará em 1820, a entrada no rio Moju descrevendo a presença de diversos engenhos, como o de nome Jacuarari. Para eles, “em todo o Pará, esta fazenda que aproveita a cana plantada nos arredores para fabricar açúcar e particularmente cachaça, tem fama de maior eficiência e elegância, e de fato, ainda não havíamos visto outro engenho que lhe pudesse ser comparado" (SPIX; MARTIUS, 1976, p.61).

Estes naturalistas registraram na expedição a presença de diversas culturas agrícolas introduzidas na região, "as margens do Moju prestam-se para qualquer espécie de cultura tropical; além da cana, também há ali café, mandioca, milho e arroz" (SPIX; MARTIUS, 1976, p. 61). Nesta obra, encontramos um registro das populações dos principais lugares do atual Baixo Tocantins. Cametá (8.050) como berço da ocupação da região aparece com o maior contingente populacional, seguido de Espírito Santo de Moju (2.000), Vila de Abaeté 
(1.180), Vila de Oeiras (760), Vila de Beja (380), Vila do Conde (360), Baião (250), Barcarena (240) (Quadro 1).

Quadro 1: População de lugares do Baixo Tocantins, Pará, em 1820

\begin{tabular}{|l|c|l|c|}
\hline \multicolumn{1}{|c|}{ Lugares } & Moradores & \multicolumn{1}{c|}{ Lugares } & Moradores \\
\hline Espírito Santo de Moju & 2.000 & Vila de Abaeté & 1.180 \\
\hline Barcarena & 240 & Vila de Cametá & 8.050 \\
\hline Vila do Conde & 360 & Baião & 250 \\
\hline Vila de Beja & 380 & Vila de Oeiras & 760 \\
\hline
\end{tabular}

Fonte: Organizado pelo autor com base em Spix e Martius (1976)

A plantação de cana-de-açúcar para a produção de cachaça, ao longo do rio Tocantins, dará origem a uma nobreza amazônica. Em Cametá encontramos registros da presença de senhores de engenhos que viviam no mais puro "fausto", como registra Reis (1960, p. 32): “em Cametá, em 1762, o bispo Frei João de São José encontrou a família Morais Bittencourt cercada de fausto régio. A mesa uma prataria notável. Senhoras e senhores vestindo veludo e sedas custosíssimas".

A presença de engenhos no atual território do Baixo Tocantins é registrada desde o século XVII, passando pelo XVIII e XIX, como podemos verificar no Quadro 2.

Quadro 2: Engenhos e seus proprietários nos séculos XVII, XVIII, XIX nos municípios do Baixo Tocantins

\begin{tabular}{|c|c|c|}
\hline Município & Engenho & Proprietário \\
\hline \multirow[t]{2}{*}{ Abaeté } & Fazenda e Engenho São Francisco & Antonio Francisco Correia Caripuna \\
\hline & Fazenda e Engelho São José & José Homório Roberto Maués \\
\hline \multirow[t]{3}{*}{ Acará } & Engenho Real do Acará & João Valente Furtado de Mendonça \\
\hline & Engenho de Itapicuru & - \\
\hline & Engenho de Juassu & Manoel de Morais \\
\hline Camutá & Engenho Curussambaba & Manoel Pastana de Mendonça \\
\hline Barcarena & Engenho São Matheus & Matheus Magno Ferraz de Araujo \\
\hline \multirow[t]{5}{*}{ Moju } & Engenho do Serrão & Jose Pacheco Serrão de castro \\
\hline & Engenho Itaboca & Domingos Monteiro de Noronha \\
\hline & Engenho Real de Ibirajuba & Catarina da Costa \\
\hline & Engenho de Jaguarary & Ambrosio Henriques da Silva \\
\hline & Engenho Juquiri-Assu & Bento Alves da Silva \\
\hline
\end{tabular}

Fonte: Organizado pelo autor com base em Cruz (1963) 
Antônio Ladislau Monteiro Baena (2004), em sua obra Ensaio Corográfico sobre a Província do Pará, a partir de dados do alistamento geral de 1832, faz alguns apontamentos sobre vilas e lugares na província. Sobre o Baixo Tocantins descreve vilas (Beja, Camutá, Conde e Oeiras) e lugares (Barcarena e Baião) existentes ao longo do rio Tocantins e seus afluentes. Sobre as vilas do Baixo Tocantins apontadas por Baena (2004), Beja dará origem ao atual distrito de Beja no município de Abaetetuba e Conde ao distrito de Murucupi em Barcarena, onde atualmente está localizado o complexo Albrás/Alunorte.

Sobre a população de Vila de Camutá, Baena (2004, p.228) afirma que "durante o mais tempo vive dispersa pelas ilhas circunstantes em seus cacoais, roças, onde lavram mandioca, cacau, algodão, arroz, tabaco, urucu, cana-de-açúcar”. A descrição do autor reflete um ambiente de forte influência do rio (ilhas) onde havia uma produção agrícola distribuída por diversas lavouras. Sobre a economia de Baião, Baena (2004, p. 224) afirma que "o cacau, o café, o algodão, o arroz e a mandioca tem ali cultivo regular; alguns moradores são também fazendeiros de gado".

Pelo que foi possível constatar neste período histórico, a ocupação e o uso do território do Baixo Tocantins foram impulsionados pela atividade agrícola, em que cada lavoura teve uma contribuição em tempos e espaços deste recorte espacial analisado.

\subsection{Ocupação e uso agrícola do território do Baixo Tocantins no período técnico}

Para Milton Santos (1995, p. 699) “estamos, aqui, reservando a apelação período técnico à fase posterior a invenção das máquinas [...] o período técnico vê a emergência dos objetos técnicos e do espaço mecanizado". Com o advento da revolução industrial o território torna-se cada vez mais mecanizado, onde ocorre uma brutal substituição do meio natural pelo artificial. Regiões inteiras passam por uma profunda transformação em sua forma e conteúdo. Esta revolução promoveu uma mecanização sem precedentes nos territórios onde se estabeleceu, permitindo ao homem a sua libertação das amarras da natureza, onde com o uso das técnicas industriais passou a dominar a natureza.

A segunda metade do século XVII marca a introdução do período técnico no Brasil. No Baixo Tocantins a existência de engenhos de cana-de-açúcar, principalmente em Igarapé Miri e Abaetetuba, reflete bem este período. Na colônia brasileira temos um modelo de "Brasil arquipélago", marcada por uma mecanização incompleta, onde as regiões mantinham poucas relações (SANTOS; SILVEIRA, 2001). 
Neste contexto, o Pará colonial, até a adesão a independência do Brasil em 1822, mantém mais relações com Portugal do que com o estado do Brasil. No Baixo Tocantins devido às suas especificidades territoriais, as relações com o exterior ocorrem somente via fluvial.

No Baixo Tocantins a ocupação mais efetiva do território ocorre por meio da pecuária, agricultura tradicional, extrativismo vegetal e da incipiente indústria de cachaça nos municípios de Abaetetuba e Igarapé Miri. A produção de cana foi a responsável pela mecanização do território no Baixo Tocantins, com o surgimento dos engenhos de cana-deaçúcar, em Abaetetuba e Igarapé Miri.

As atividades econômicas das drogas do sertão e da cana-de-açúcar são as responsáveis pela centralização exercida por cidades na região como Cametá, Abaetetuba e Igarapé Miri, que marcam o início de uma rede urbana centralizada no padrão dendrítico. No Baixo Tocantins a interiorização da ocupação do território ocorre fundamentalmente por meio da economia do cacau, da borracha e da pimenta-do-reino, no pós-1930.

As cidades de Abaetetuba e Cametá historicamente têm exercido uma função de polarização das atividades econômicas e administrativas no Baixo Tocantins. Abaetetuba exerce forte polarização nos municípios de Moju, Igarapé Miri e Barcarena. A forte influência de Abaetetuba ocorre em função da presença de um sistema diversificado de comércio, entreposto comercial entre Belém e Marajó, além da presença de instituições públicas federais e estaduais. A cidade de Barcarena devido sua importância econômica vem rivalizando com Abaetetuba pela influência neste subterritório (SUDAM, 1973a)

A cidade de Cametá exerce forte influência nos municípios de Mocajuba, Baião, Oeiras do Pará e Limoeiro do Ajuru. Esta influência justifica - se pelo fator de seu papel histórico como núcleo pioneiro na ocupação regional, além da centralidade que exerce sediando importantes instituições públicas federais e estaduais (SUDAM, 1973a).

Com a formação da região concentrada ${ }^{20}$ no Brasil e a urbanização interior, a partir da década de 1930 ocorre o impulso à industrialização no Sul e no Sudeste. Este processo foi responsável diretamente pela destruição da indústria de cachaça na região, que, por apresentar um padrão técnico obsoleto, não conseguiu competir com as indústrias da região concentrada (ANDERSON, 1991).

Com a difusão da revolução industrial inglesa a partir de 1850, ocorre uma mecanização seletiva no Brasil a partir das áreas de ocupação mais antigas do território. No

\footnotetext{
${ }^{20}$ Formada pelas atuais regiões Sudeste e Sul do Brasil (SANTOS; SILVEIRA, 2001).
} 
Pará este reflexo se faz presente na construção da estrada de ferro Belém-Bragança. No Baixo Tocantins tem início a difusão da navegação a vapor pelo rio Tocantins, a exemplo do vapor Coronel Sampaio (Figura 7), além da importação de máquinas para a montagem de engenhos de cana-de-açúcar, principalmente em Abaetetuba e Igarapé Miri.

Figura 7: Navio a vapor Coronel Sampaio

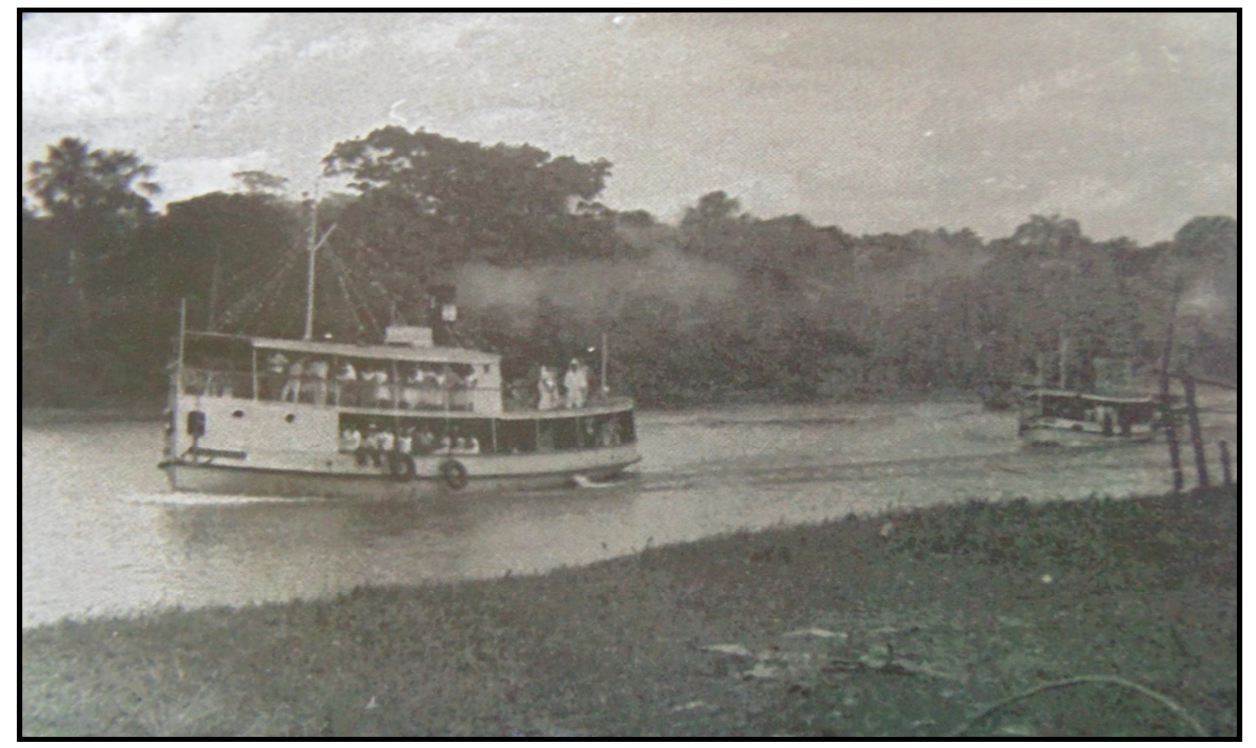

Fonte: Alcides Sampaio. Organizado por Garcia e Lobato (2011)

Em Abaetetuba é montada uma série de engenhos de aguardente nas regiões ribeirinhas de várzeas do município. Estes empreendimentos se justificam pela presença em solos da região da produção de cana-de-açúcar. Esta produção desenvolveu-se nas áreas de várzea do Baixo Tocantins. Seu transporte era realizado em batelões ${ }^{21}$ até os engenhos onde era produzida aguardente de cana (SUDAM, 1973a). A Figura 8 mostra detalhes do transporte de cana-de-açúcar sendo realizada por batelões em Abaetetuba.

\footnotetext{
${ }^{21}$ Barcos largos, sem motor que eram engatados, em número de cinco ou seis, a um barco a motor (SUDAM,
} 1973a, p. 78). 
Figura 8: Batelões carregados de cana aguardando a subida do nível das águas para prosseguir viagem em Abaetetuba, Pará

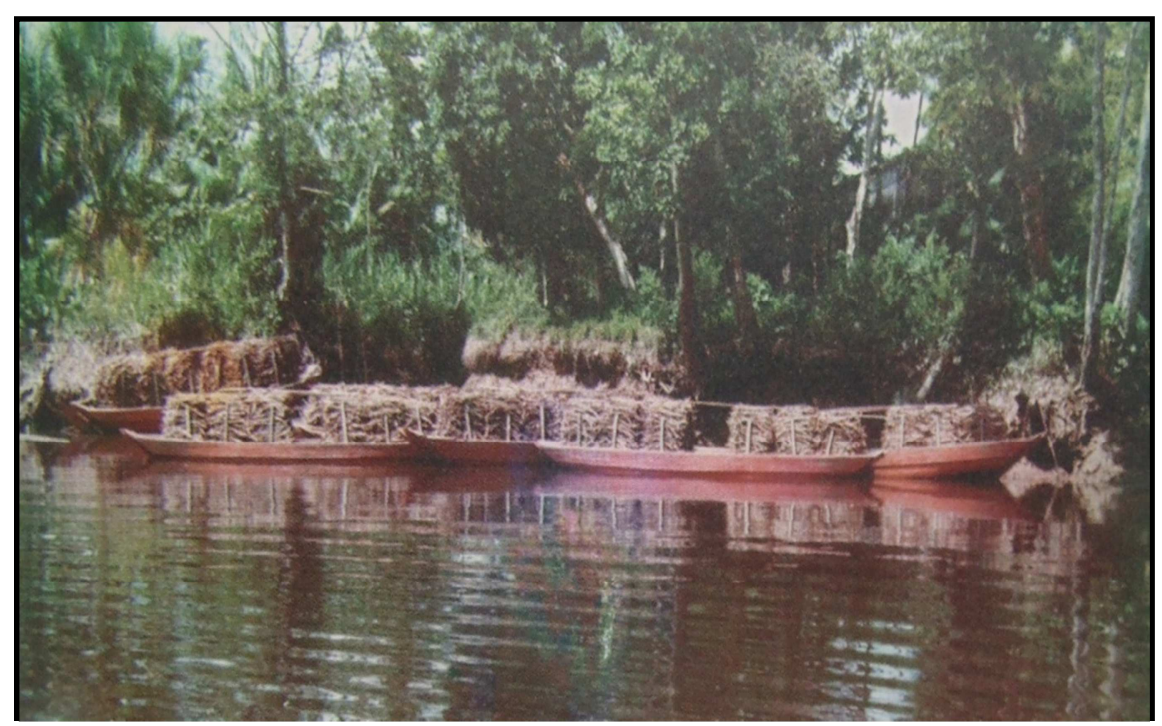

Fonte: Garibalde Parente. Organizado por Garcia e Lobato (2011)

Em Abaetetuba, Garcia e Lobato (2011) registraram diversos engenhos de açúcar como o Feliz \& Costa, de propriedade de Aprígio Veloso, no rio Paramajó (Figura 9).

\section{Figura 9: Engenho Feliz \& Costa em Abaetetuba}

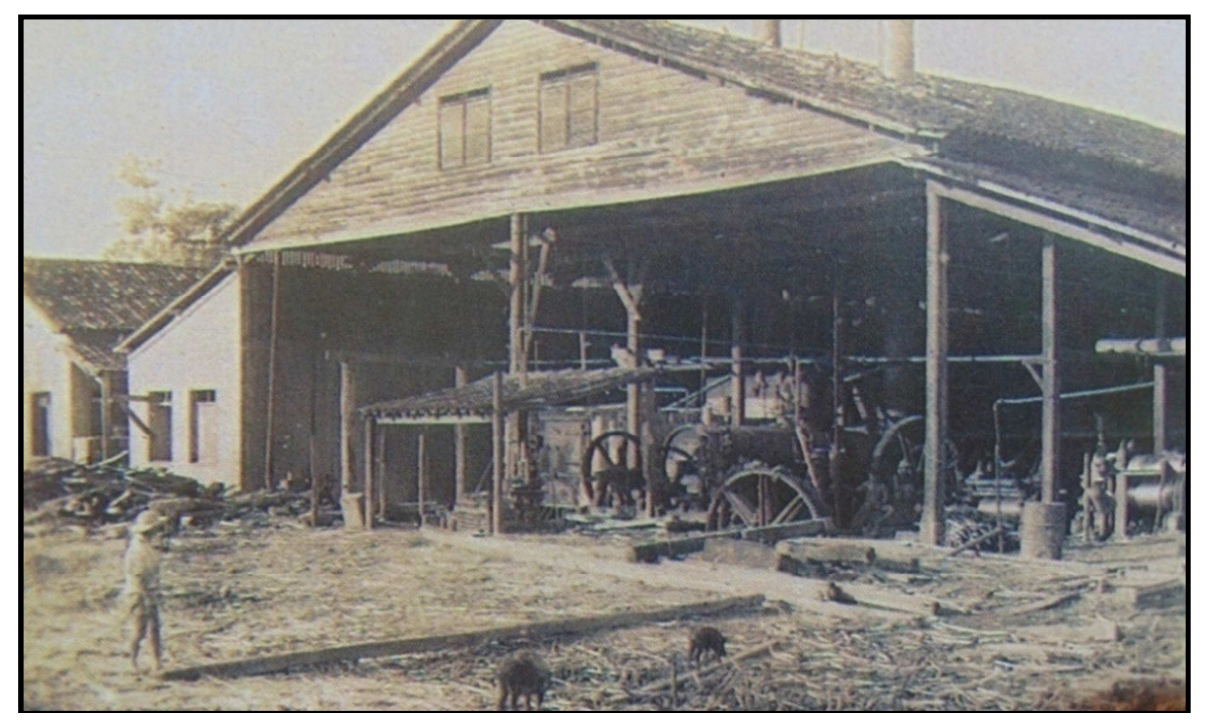

Fonte: Padre Adolfo Zon. Organizado por Garcia e Lobato (2011)

Em Abaetetuba, como em toda a região, o tempo dos engenhos passou. O único que resiste até o momento é o engenho Pacheco, de propriedade de João Marcelino Pacheco, localizado no rio Maratauira, conforme demonstra Figura 10. 
Figura 10: Engenho Pacheco, Abaetetuba, Pará

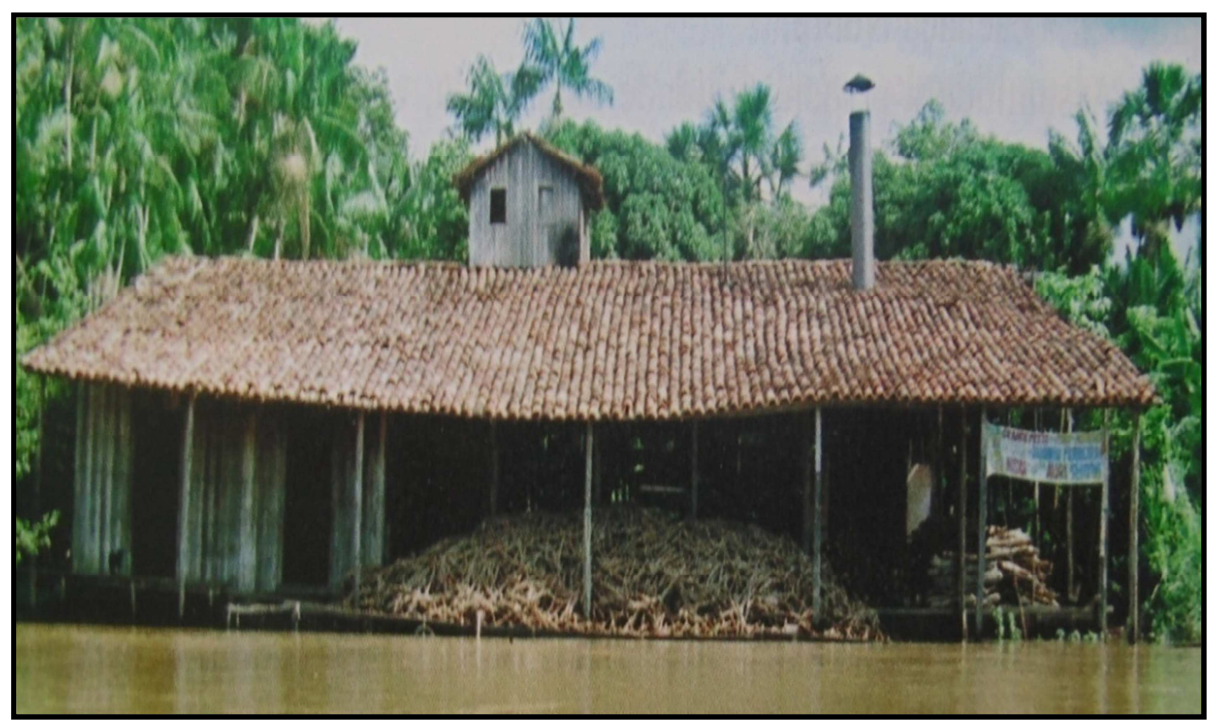

Fonte: Padre Adolfo Zon. Organizado por Garcia e Lobato (2011)

Em Igarapé Miri, Garcia e Lobato (2011) registraram apresença do engenho Nazaré, de propriedade de Humberto Pantoja (Figura 11).

Figura 11: Engelho Nazaré em Igarapé Miri

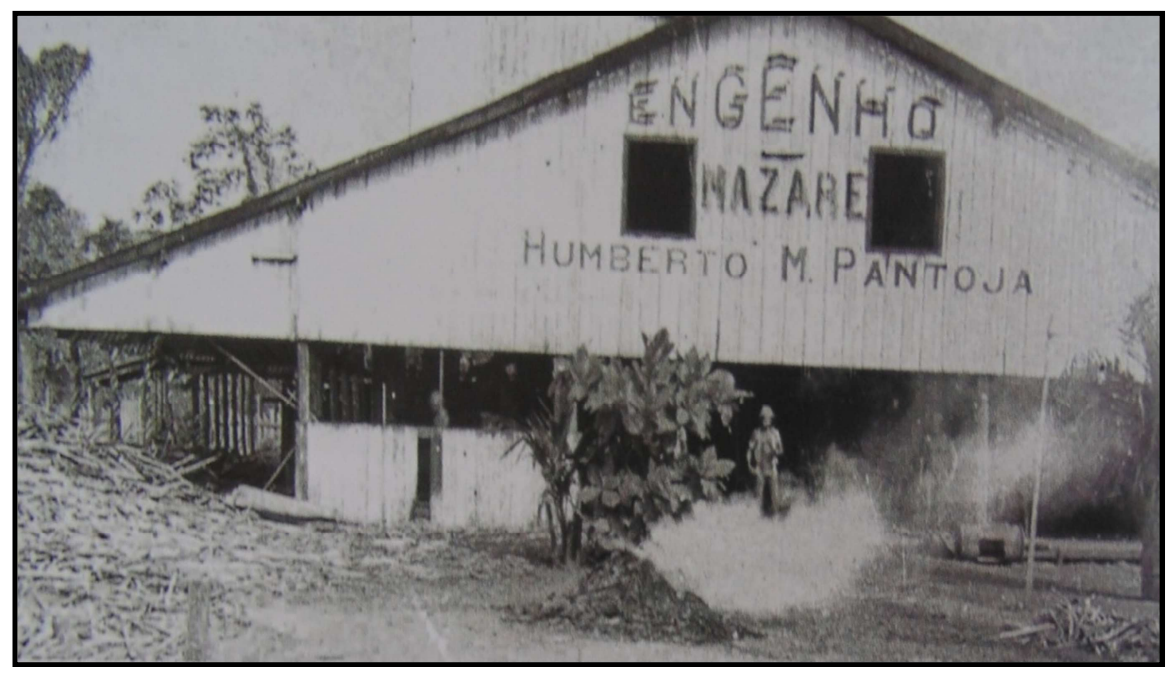

Fonte: Eládio Lobato. Organizado por Garcia e Lobato (2011)

A implantação de próteses no território brasileiro ocorre mediante a construção de rodovias, ferrovias e portos (SANTOS; SILVEIRA, 2001). Este processo ocorre no Pará por meio da implantação do porto de Belém, da ferrovia Belém-Bragança, da rodovia BelémBrasília. No Baixo Tocantins isto ocorre por meio da construção de portos municipais, aeroportos e rodovias estaduais e vicinais municipais. 
A integração do território Paraense ao resto do Brasil ocorre por meio dos transportes (portos, rodovias e ferrovias) onde o porto de Belém, inaugurado em 1907, e a rodovia Belém-Brasília, inaugurada em 1960, cumprem papel de destaque. No Baixo Tocantins esta conexão ocorre mediante os portos municipais e os aeroportos locais.

\subsection{Ocupação e uso agrícola do território do Baixo Tocantins no período técnico- científico-informacional}

O período técnico-científico-informacional surge após a segunda guerra mundial, com sua difusão mais intensa a partir da década de 1970. Segundo Milton Santos (1995, p.701) "neste período os objetos técnicos tendem a ser ao mesmo tempo técnico e informacionais, já que graças à intencionalidade de sua produção e de sua localização, eles já surgem como informação." No Brasil a partir dos anos de 1970 ocorre à difusão do período técnicocientífico-informacional em áreas específicas como, indústria, agricultura, mineração etc.(SANTOS; SILVEIRA, 2001). No Pará este período é marcado pela criação de grandes projetos rodoviários, de mineração, de pecuária, hidrelétricas etc. No Baixo Tocantins são introduzidos grandes projetos de beneficiamento mineral em Barcarena e de dendê em Moju e Tailândia.

Este período na Amazônia é caracterizado pela ação do governo federal a partir da Operação Amazônia. Neste padrão de ocupação denominado por Gonçalves (2005) de estrada-terra firme-subsolo, que tem início a partir da década de 1960, a Amazônia passa por uma nova redefinição de seu papel no país. Na Amazônia uma série de projetos estatais são colocados em prática, visando a incorporação regional à economia nacional e mesmo internacional. A economia passa por uma grande mudança, onde grandes investimentos de capitais nacionais e internacionais têm como atuação as áreas ao longo das rodovias existentes ou abertas, onde a agricultura e pecuária são atividades que passaram a contar com grandes incentivos fiscais estatais, mediante apoio da Sudam e do Basa, entre outros.

A partir de 1964, com a tomada do poder político pelos militares, a ocupação da Amazônia torna-se prioridade nacional, com a implantação de um conjunto de redes de integração espacial, que incluíam as redes rodoviárias, de comunicações e de hidrelétricas (BECKER, 1994).

Em 1974, é criado o Programa de Polos Agropecuários e Agroindustriais (Polamazônia), constituído por um conjunto de 15 grandes áreas selecionadas para implantação na região. A Amazônia neste momento representava uma região com grandes 
vantagens para o capital estatal, nacional e internacional, com a presença de grandes áreas de terras e recursos naturais abundantes como minérios, água, floresta etc.

Segundo Becker (1994, p. 67), "é com a criação do Programa Grande Carajás (PGC) ${ }^{22}$ no final dos anos 1970, que se configura a estratégia do Estado, para a nova fase de fronteira, e da indústria de exploração mineral em grande escala." A construção da infraestrutura do PGC envolvia a implantação de uma série de redes de transporte logístico, rede de hidrelétricas, além da construção de núcleos urbanos (BECKER, 1994).

Na sua concepção, este projeto previa a exploração dos recursos naturais minerais, florestais, pesqueiros, além da construção de um conjunto de infraestrutura de transportes, comunicações, energia, saneamento, e de uma usina hidrelétrica localizada a oito quilômetros à montante de Tucuruí. Este projeto previa também a construção de uma linha de transmissão ligando Tucuruí à Vila do Conde, em Barcarena, município selecionado para receber o projeto Albrás/Alunorte, parte integrante do PGC (SUDAM, 1976).

Entre os projetos de infraestrutura planejados para o novo território de Carajás, estava a construção da Usina Hidrelétrica de Tucuruí (UHT) ${ }^{23}$ (Figura 12), que seria responsável por abastecer de energia os grandes projetos de mineração em Marabá, Parauapebas e Barcarena. A construção da UHT provocou uma série de impactos territoriais na parte à jusante do rio Tocantins, pois a mesma promoveu o fechamento do rio, impedindo a sua navegabilidade, provocando alterações na pesca, na agricultura e no transporte da região do Baixo Tocantins, antes centralizado pelo modelo fluvial (BARROS, 2010; 2015; 2016).

Os impactos da UHT provocaram a destruição, com a inundação de cidades e comunidades ao longo do rio Tocantins, e promoveram a desorganização social com a introdução de novas técnicas de transporte como o rodoviário, em substituição ao fluvial. Não houve uma conexão dos grandes projetos com as comunidades locais, a exemplo da falta de energia em municípios onde o linhão atravessava seu território (BECKER, 1989).

\footnotetext{
${ }^{22}$ Programa criado em 1980 para a exploração mineral no sudeste do Pará. Este programa teve como atuação principalmente a cidade de Marabá (Médio Tocantins), onde então se localizava a província mineral de Carajás.

${ }^{23}$ O município de Tucuruí (Médio Tocantins) faz limite com o município de Baião, no Baixo Tocantins.
} 
Figura 12: Usina Hidrelétrica de Tucuruí, Pará

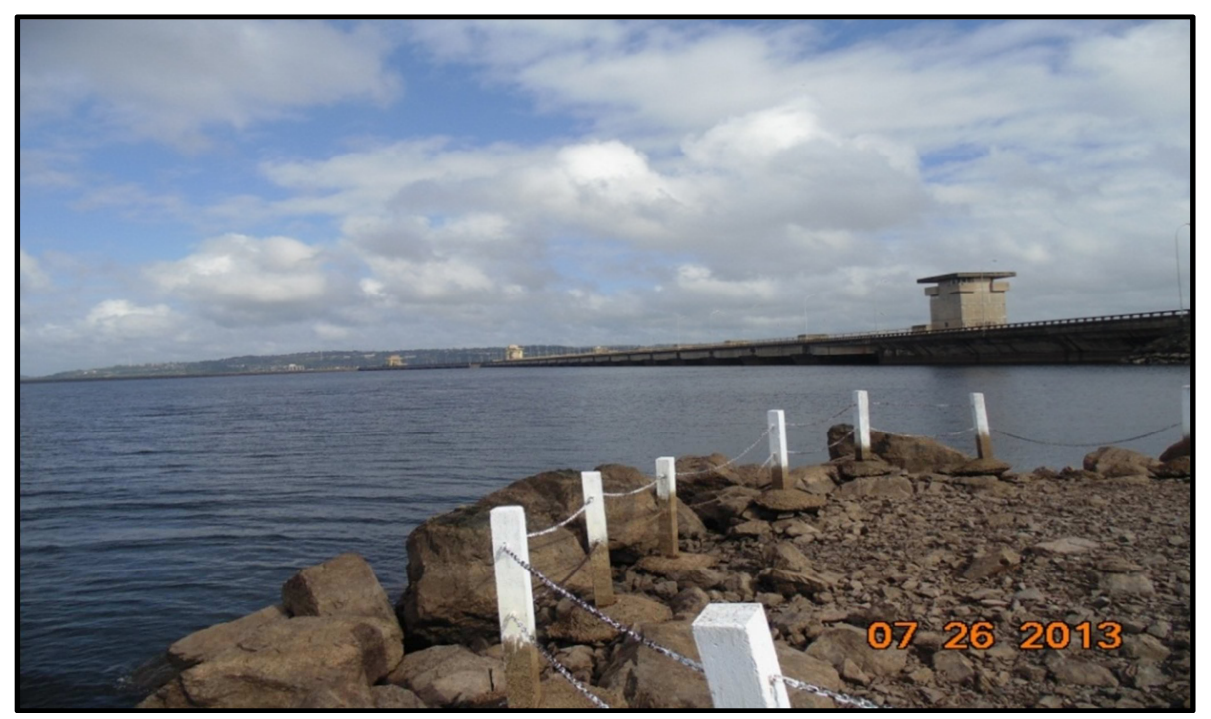

Fonte: Márcio Benassuly (2013)

Na década de 1980 teve início no Baixo Tocantins a construção de grandes projetos de mineração em Barcarena (Albrás/Alunorte) e de projetos agrícolas de dendê, em Moju e Tailândia. Esta fase marcou a presença da entrada do capital externo com mais intensidade no território (HÉBETTE, 1991). A chegada do estranho (MARTINS, 1991) representado pelo grande capital promoveu impactos de diversas naturezas no território do Baixo Tocantins (HÉBETTE, 1991; LEAL, 1982; MAGALHÃES, 1991; MITSCHEIN; MIRANDA; PARAENSE, 1991; CASTRO, 1989).

Neste período o cultivo do dendê é defendido, pois apresenta diversas vantagens de natureza ambiental, econômica e social para a Amazônia. Uma das vantagens apontadas é que esta cultura é intensiva em mão-de-obra "necessitando de um agricultor para cada 5 ha durante o ano ou para cada 10 ha, além de um grande número de trabalhadores braçais para a colheita, que é manual” (BECKER, 2010, p. 6). Ainda para Becker (2010, p. 6), esta cultura "poderia ser uma alternativa de grande valia para a agricultura familiar, contribuindo para a formação de uma classe de pequenos produtores mais estáveis e, portanto, para avançar no processo de reforma agrária".

Este período marca a influência do capital externo das empresas transnacionais no Brasil, provocando uma nova divisão territorial do trabalho. No Pará esta presença do capital externo ocorre fundamentalmente por meio de grandes projetos como $\mathrm{Jari}^{24}$, Alcoa ${ }^{25}$ etc. No Baixo Tocantins, isto se materializa na década de 1980 pelos grandes investimentos de capitais japoneses em sociedade com a antiga Companhia Vale do Rio Doce (CVRD) no

\footnotetext{
${ }^{24}$ Empresa de celulose localizada no município de Almeirim, estado do Pará.

${ }^{25}$ Empresa de mineração localizada no município de Juruti, estado do Pará.
} 
grande complexo alumínico-alumina Albrás/Alunorte. A partir de 2010, o Baixo Tocantins atrai grandes empresas como a Vale ${ }^{26}$ e a Petrobras Biocombustíveis que passam a promover um uso agrícola de parcelas significativas do território do Pará. Estes grandes projetos agrícolas de dendê constituem-se verdadeiros espaços luminosos implantados em meio a uma agricultura tradicional de subsistência marcando verdadeiros espaços opacos (SANTOS; SILVEIRA, 2001). A expansão da fronteira agrícola na Amazônia (MACHADO, 1995) se deve a um conjunto de ações estatais e empresariais efetivadas a partir da década de 1960.

Desta forma, o território nacional torna-se parte da economia internacional, onde o Brasil é organizado para servir às grandes empresas hegemônicas. No Pará, a Vale torna-se a principal empresa do estado controlando grandes territórios de mineração e mais recentemente de dendê. No Baixo Tocantins empresas de dendê como a Biopalma (Vale+Msp) e Belém Bioenergia Brasil (Pbio+Galp) passam a controlar grandes áreas agrícolas nos municípios da região. A esta lista, também podemos acrescentar a empresa chinesa Guanfeng Group, com áreas de dendê em Moju e Abaetetuba.

Neste período assistimos a aplicação de grandes capitais no agronegócio, principalmente da soja em nível nacional. No Pará, o dendê e a soja são os destaques. No Baixo Tocantins a cultura de dendê vem ampliando sua área plantada, por meio de uma série de políticas públicas que tentam ampliar a produção de dendê no Brasil, para fins alimentícios e mais recentemente para a produção de biodiesel.

As inovações técnicas criam um novo tempo e um novo uso da terra. No Baixo Tocantins novas culturas agrícolas são introduzidas como coco-da-baía, que vem ganhando destaque na região principalmente no município de Moju, onde a empresa Sococo S. A. vem investindo grandes recursos nesta cultura.

A partir da década de 1950 acontece a expansão do sistema de transportes e de comunicações como suporte à produção, à circulação e ao consumo demandado pelo grande capital. No Pará, rodovias federais como a Belém-Brasília, a Transamazônica, e a SantarémCuiabá, entre outras, passam a integrar o estado à economia nacional.

No Baixo Tocantins são implantadas rodovias paralelas ao rio Tocantins como a PA150 (Moju-Marabá), a PA-150 (Barcarena-Baião) e a Transcametá (Cametá-Tucuruí). Parte deste sistema rodoviário está fortemente ligado ao rio Tocantins e seus principais afluentes.

\footnotetext{
${ }^{26}$ Em 2011, a Vale comprou por US\$173,5 milhões, a Biopalma, empresa produtora de óleo de dendê, matériaprima para produção de biodiesel (Estado de São Paulo, 02.02.2011).
} 
No entanto a ligação mais expressiva ocorre em 2002 com a inauguração da Alça Viária ${ }^{27}$ que interliga o Baixo Tocantins a Belém. Com esta rodovia, o que antes demorava dias para ser transportado, agora pode ser realizado em questão de horas. Em 2015, como parte das ações do Programa Estadual de Óleo de Palma é inaugurada a ponte sobre o rio Igarapé Miri, acelerando ainda mais a fluidez territorial entre os municípios do Baixo Tocantins e a capital estadual.

A construção de um sistema de engenharia como estradas, portos e aeroportos dota o território do Baixo Tocantins de fluidez. Desta forma, o território ganha novos conteúdos, ampliando a fluidez territorial, com as novas rodovias, como a Alça Viária, além da ampliação de pequenos e grandes portos como o complexo portuário de Vila do Conde em Barcarena, responsável pela exportação de alumínio da Albrás/Alunorte e demais produtos.

Neste período ocorre uma redefinição da nova divisão territorial do trabalho no Brasil, que assume um papel de grande produtor de minério, agricultura e pecuária etc. (SANTOS; SILVEIRA, 2001). O Pará torna-se grande produtor de energia hidrelétrica, pecuária, madeira e dendê. O Baixo Tocantins assume liderança na produção de dendê, coco-da-baía, mandioca, pimenta do reino etc.

Nesta fase acontece uma modernização da agricultura com destaque para a incorporação do cerrado brasileiro, como área de produção agrícola nacional. No Pará ocorre a introdução da soja, principalmente na região de Santarém e Paragominas. No Baixo Tocantins, o destaque é para a produção por grandes empresas agrícolas de dendê.

Seguindo uma tendência nacional, no Baixo Tocantins ocorre uma maior penetração de capital externo em diversas atividades. O território ganha novos conteúdos e usos múltiplos dos recursos territoriais como mineração, agricultura, pecuária, indústria etc. Neste sentido, alguns territórios municipais são selecionados para receber estes investimentos. Estes investimentos seguem a densidade técnica disponível no território. Desta forma, Barcarena (mineração, atividade portuária), Moju (dendê, coco), Tailândia (dendê, pecuária) e Abaetetuba (dendê) são os municípios que mais se destacam na captação de recursos externos. Já outros municípios como Oeiras do Pará e Limoeiro do Ajuru apresentam uma rarefação técnica, sendo penalizados na atração de recursos externos para seus territórios.

\footnotetext{
${ }^{27}$ Rodovia estadual que inicia em Marituba, município da Região Metropolitana de Belém, e termina em Barcarena, no Baixo Tocantins.
} 
1.5.1 Uso agrícola do território no Baixo Tocantins: uma ênfase nas lavouras permanentes e temporárias, 2013.

A produção agrícola no Brasil está classificada em lavoura permanente ${ }^{28}$ e lavoura temporária $^{29}$. No Brasil o Instituto Brasileiro de Geografia e Estatística (IBGE) anualmente promove a pesquisa intitulada Produção Agrícola Municipal (PAM), a qual usamos como fonte de dados sobre as variáveis área colhida e quantidade produzida disponibilizados no Sistema IBGE de Recuperação Automática $(\text { SIDRA })^{30}$.

As lavouras permanentes no Baixo Tocantins: área colhida (ha) e quantidade produzida (t) em2013. Tendo como base os dados do IBGE-SIDRA (2015) $)^{31}$ constatamos que no Baixo Tocantins a área colhida ${ }^{32}$ (ha) da lavoura permanente está distribuída em seis culturas: banana, cacau, coco-da-baía, dendê, laranja e pimenta-do-reino.

A cultura do dendê ocupa a maior parte do território do Baixo Tocantins. Esta produção agrícola permanente foi responsável pelo uso de 35.480 hectares das terras do Baixo Tocantins. Este uso do território pela dendeicultura está concentrado em quadro municípios: Abaetetuba (2.000), Acará (7.000), Moju (7.093) e Tailândia (19.387).

O uso do território agrícola pela dendeicultura é três vezes maior que o segundo colocado, coco-da-baía, responsável pelo uso de 11.378 hectares do território regional destinado à produção agrícola permanente.

Em terceiro lugar no uso agrícola do território aparece o cacau, que ocupa 9.309 hectares, seguido da pimenta-do-reino, com 3.087 hectares, e da laranja, que ocupa 290 hectares do território destinado à produção permanente (Quadro 3).

\footnotetext{
${ }^{28}$ É "constituída por cultura de longa duração, capaz de proporcionar colheita por vários anos sucessivos, sem a necessidade de novo plantio, como exemplo o abacate, a ameixa, o cacau, o café, a laranja, a seringueira, o ervamate, o açaí dentre outros" (IBGE, 2007, p.149).

${ }^{29}$ É "constituída por cultura de curta duração, que normalmente necessita de um novo plantio após a colheita, como o arroz, o abacaxi, o algodão, o feijão, o milho, a soja, o tomate industrial, dente outros" (IBGE, 2007, p.150).

${ }_{30}^{30}$ Dados disponíveis em: www.sidra.ibge.gov.br. Acesso em: 30/12/2015.

${ }^{31}$ Em 2015, a pesquisa mais recente disponibilizada pelo IBGE-SIDRA neste setor era do ano de 2013.

${ }^{32}$ Parcela da área pautada de cada produto agrícola efetivamente colhida na data de referência da pesquisa. No caso de culturas temporárias de curta duração e média duração, e não ocorrendo perda de área por fatores adversos de ordem climática, fitossanitária ou econômica, correspondente à área plantada; para culturas temporárias de longa duração, corresponde à área em que foi colhida a produção; para culturas permanentes, corresponde à área ocupada com pés em produção no ano de referência da pesquisa. Utilizar como unidade de superfície somente o hectare (ha) (IBGE, 2002, p. 19).
} 
Quadro 3: Área colhida (ha) da lavoura permanente nos municípios do território do Baixo Tocantins, 2013.

\begin{tabular}{|c|c|c|c|c|c|c|}
\hline Municípios & Banana & Cacau & $\begin{array}{l}\text { Coco-da- } \\
\text { baía }\end{array}$ & Dendê & Laranja & $\begin{array}{l}\text { Pimenta-do- } \\
\text { reino }\end{array}$ \\
\hline Abaetetuba & 60 & 80 & 350 & 2.000 & 20 & 30 \\
\hline Acará & 110 & 800 & 2.500 & 7.000 & 60 & 400 \\
\hline Baião & - & 240 & 130 & - & - & 1.150 \\
\hline Barcarena & 80 & 350 & 365 & - & 60 & 80 \\
\hline Cametá & 10 & 6.346 & 10 & - & 20 & 380 \\
\hline Igarapé-Miri & 50 & 208 & 80 & - & 10 & 10 \\
\hline Limoeiro do Ajuru & 6 & 70 & 3 & - & - & 3 \\
\hline Mocajuba & 10 & 1.125 & 150 & - & 5 & 469 \\
\hline Moju & 800 & 40 & 7.500 & 7.093 & 80 & 300 \\
\hline Oeiras do Pará & 152 & 50 & - & - & 27 & 235 \\
\hline Tailândia & 25 & - & 290 & 19.387 & 8 & 30 \\
\hline Total & 1.303 & 9.309 & 11.378 & 35.480 & 290 & 3.087 \\
\hline
\end{tabular}

Fonte: Organizado pelo autor com base em IBGE-SIDRA (2015)

No Mapa 3 podemos constatar a concentração do uso agrícola do território pela dendeicultura nos municípios de Tailândia, Moju, Acará e Abaetetuba. Em Tailândia, por exemplo, o uso agrícola do território municipal pela cultutra do dendê é bastante acentuado em relação às demais culturas agrícolas. A cultura do cacaué destaque no uso agrícola do território dos municípios de Cametá, Mocajuba e Barcarena. A cultura da pimenta-do-reino é responsável por parcela importante do uso agrícola dos territórios de Baião e Oeiras do Pará. 
Mapa 3: Uso agrícola do território pela lavoura permanente nos municípios do Baixo Tocantins (PA), 2013

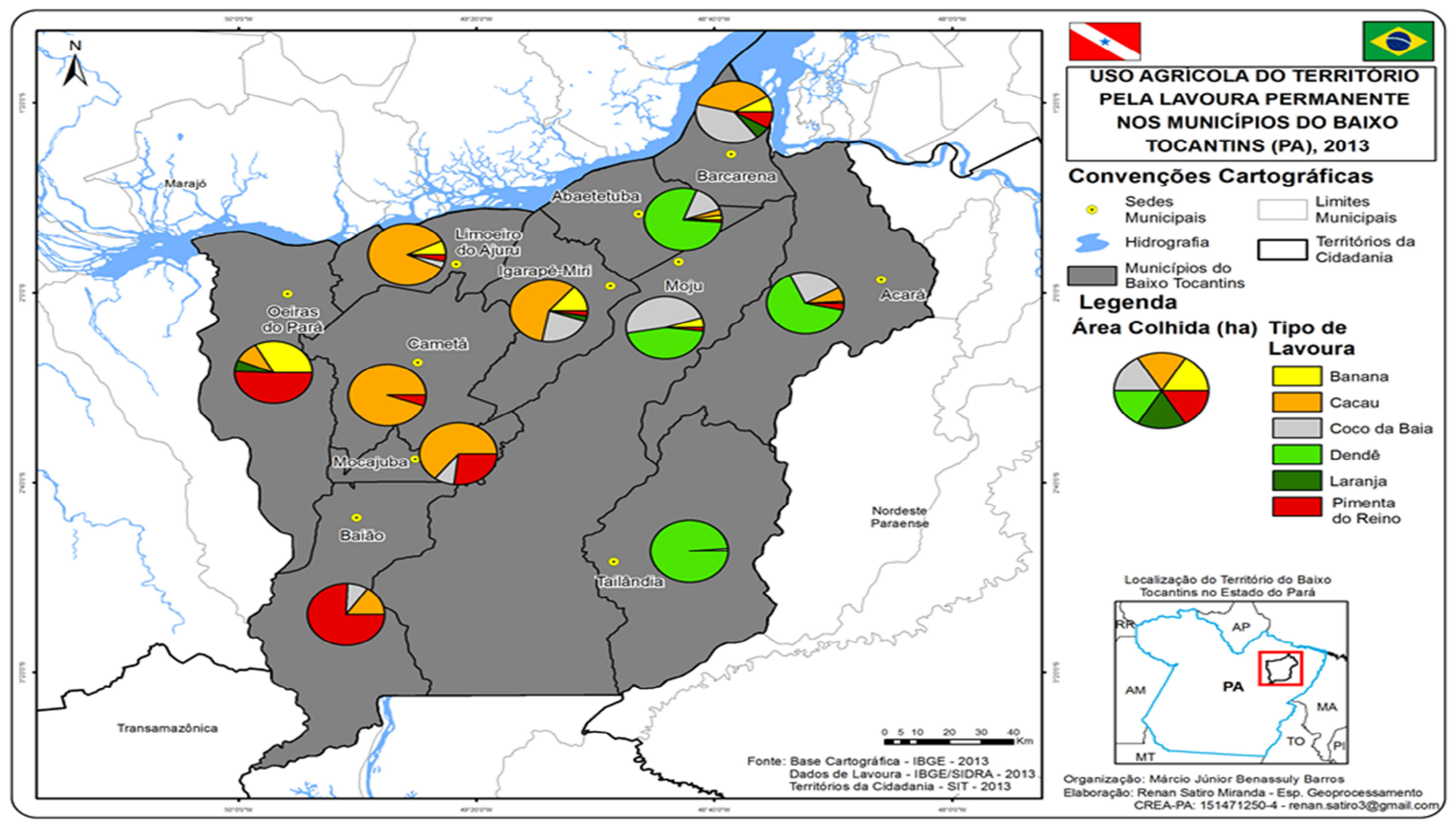


Quando analisamos a distribuição da área colhida (ha) por lavoura permanente, em 2013, no Baixo Tocantins, constatamos que a cultura do dendê ocupa 35.480 hectares, cocoda-baía 11.378 hectares, cacau 9.309 hectares, pimenta-do-reino 3.087 hectares, banana 1.303 hectares e laranja 290 hectares. Fica evidente a importância do dendê como a lavoura que ocupa a maior área do território agrícola da lavoura permanente no Baixo Tocantins em 2013, conforme registrado no Gráfico 1.

Gráfico 1: Área colhida (ha) por lavouras permanentes no Baixo Tocantins (PA), 2013

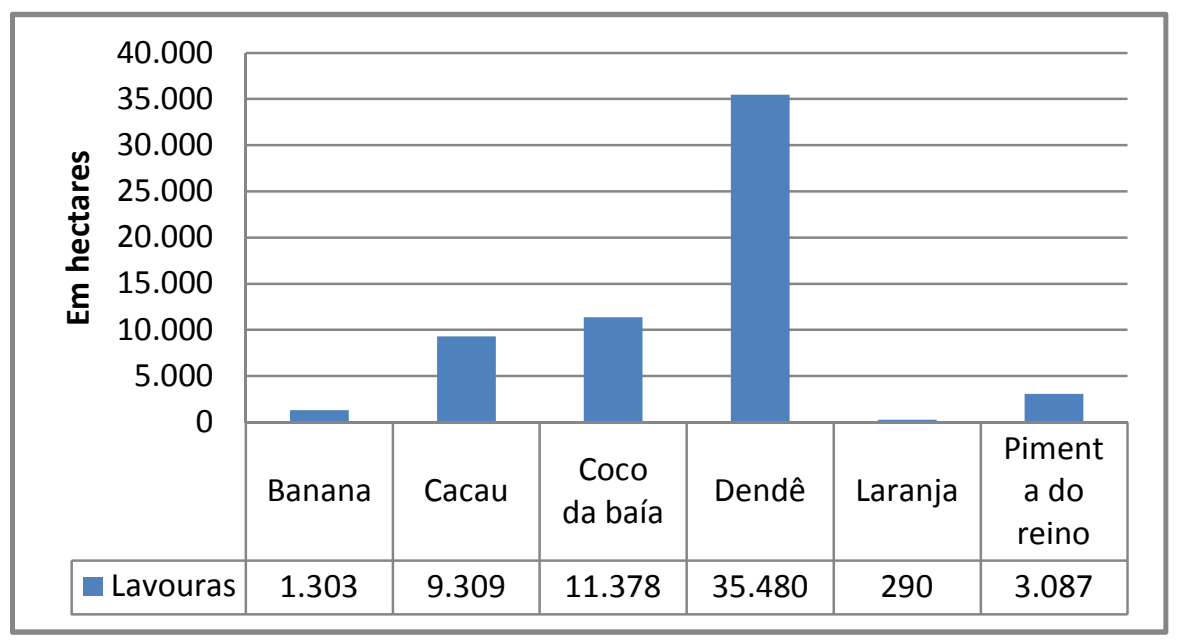

Fonte: Organizado pelo autor com base em IBGE-SIDRA (2015)

A participação desta área colhida de cada lavoura permanente no uso agrícola do território do Baixo Tocantins em 2013 foi a seguinte: dendê (58\%), coco-da-baía (19\%), cacau $(15 \%)$, pimenta-do-reino (5\%), laranja (2\%) e banana (1\%) (Gráfico 2).

Gráfico 2: Área colhida (ha) por lavouras permanentes no Baixo Tocantins (PA), 2013

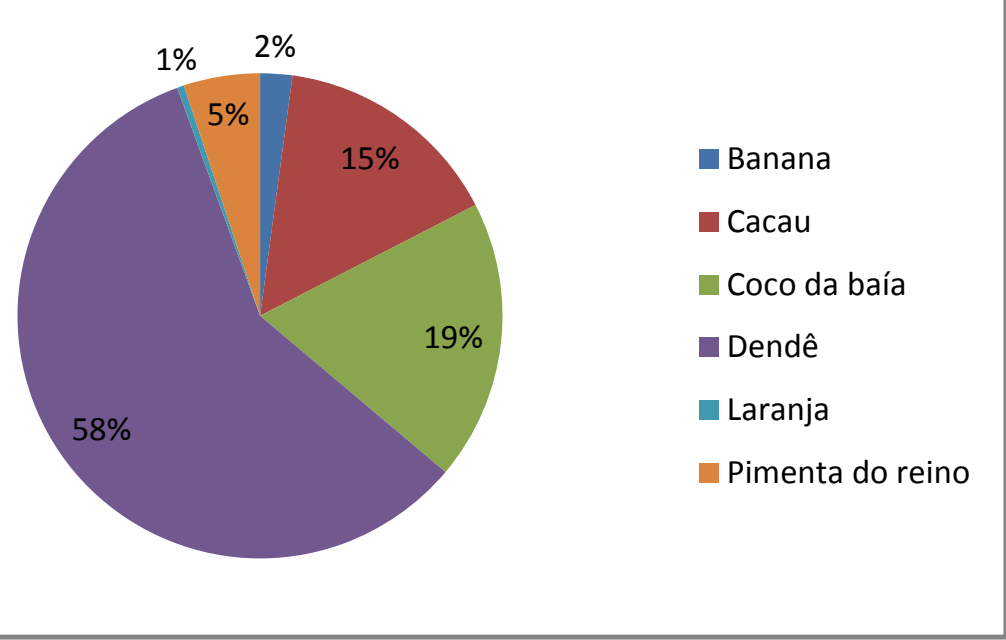

Fonte: Organizado pelo autor com base em IBGE-SIDRA (2015) 
Quanto à produtividade (t), a produção agrícola permanente está distribuída em todos os municípios do Baixo Tocantins. Nesta pesquisa registra-se a ausência de produção agrícola de banana em Baião, de cacau em Tailândia, de coco-da-baía em Oeiras do Pará, de laranja em Baião, Cametá e Limoeiro do Ajuru. A produção do dendê se concentra em quatro municípios da região, Abaetetuba, Acará, Moju, e Tailândia. Vale destacar que a produção de dendê no território de Abaetetuba é recente e está relacionada à presença em seu território das empresas Biopalma e Guanfeng Group que possuem plantação própria neste município. Já a produção de dendê nos municípios de Acará, Moju e Tailândia remonta a 1980, quando foram introduzidos projetos incentivados pela Sudam.

A lavoura com maior produção (t) foi o dendê, que em 2013 produziu 741.206 toneladas. Em seguida, a banana com uma produção de 15.386 toneladas e os municípios que mais se destacam nesta produção foram: Moju, Oeiras do Pará e Acará.

A produção de pimenta-do-reino totalizou 5.991 toneladas no Baixo Tocantins e Baião (Figura 13), Cametá e Acará foram os três principais produtores desta cultura agrícola.

Figura 13: Lavoura de pimenta-do-reino em Baião, Pará

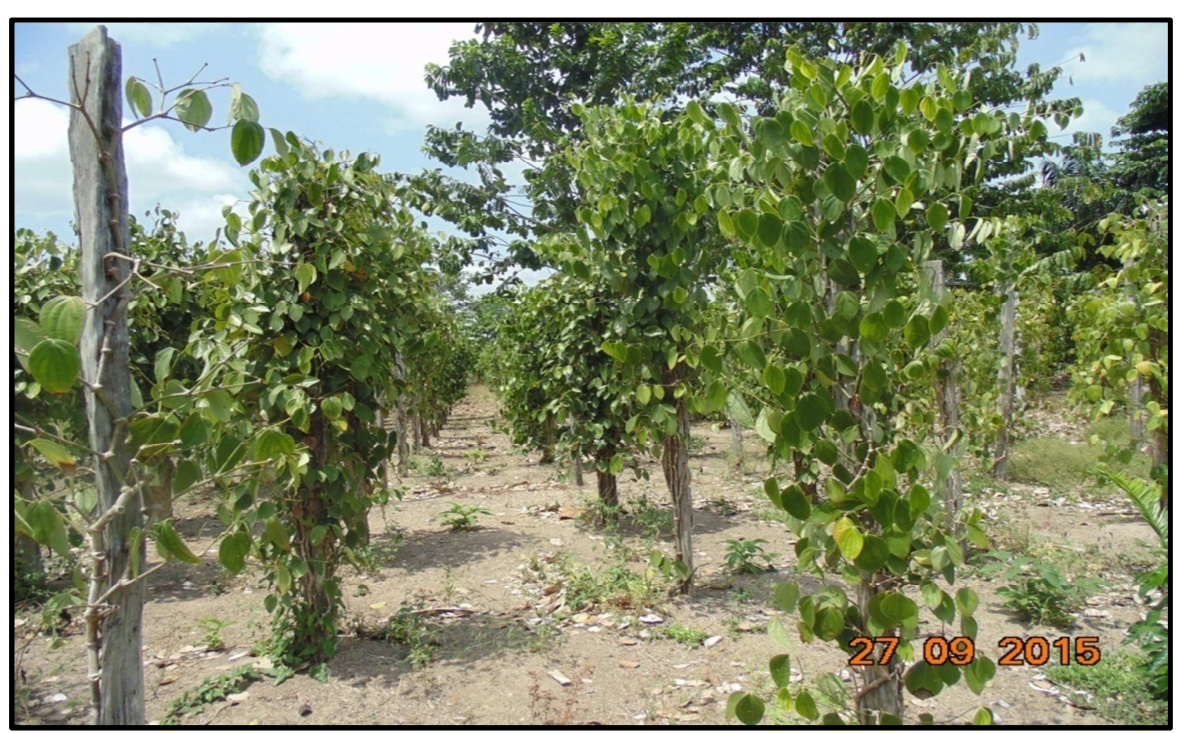

Fonte: Márcio Benassuly (2015)

A produção de laranja totalizou 2.734 toneladas no território em que Moju, Acará e Barcarena foram os principais produtores. A produção de cacau totalizou 2.257 toneladas onde os municípios que mais se destacaram foram: Cametá, Mocajuba, e Acará. A lavoura do coco-da-baía, ao contrário das demais, é medida em mil frutos, logo foi difícil fazer uma comparação com as demais lavouras. A empresa Sococo S.A. possui grandes plantações desta 
lavoura no município de Moju, de onde utiliza grandes carretas para o transporte desta produção (Figura 14)

Figura 14: Transporte de coco-da-baía pela empresa Sococo S.A., em Moju, Pará

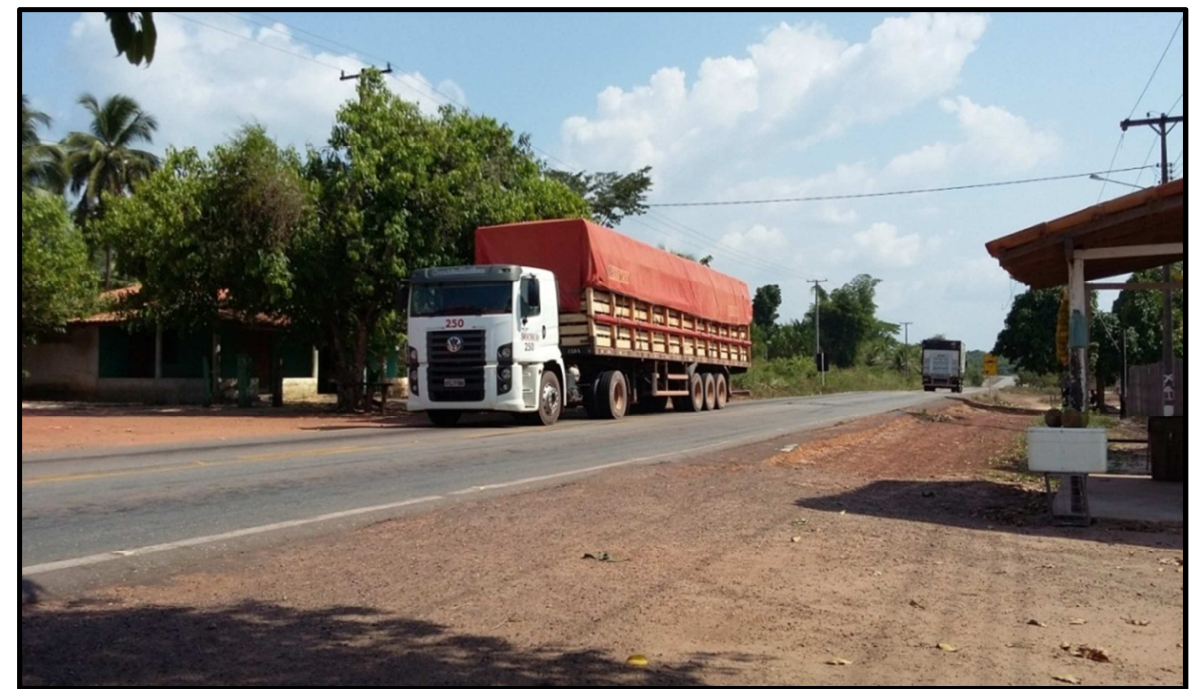

Fonte: Márcio Benassuly (2015)

A produção de coco-da-baía totalizou 110.377 mil frutos, em que o município de Moju produziu 75.000, seguido de Acará, com 25.000, e Abaetetuba, com 2.100, sendo estes os principais produtores no Baixo Tocantins (Quadro 4).

Quadro 4: Quantidade produzida ${ }^{33}$ (t) da lavoura permanente nos municípios do território do Baixo Tocantins, 2013.

\begin{tabular}{|l|c|c|c|c|c|c|}
\hline \multicolumn{1}{|c|}{ Municípios } & Banana (t) & Cacau (t) & $\begin{array}{c}\text { Coco-da-baía (mil } \\
\text { frutos) }\end{array}$ & Dendê (t) & Laranja (t) & $\begin{array}{c}\text { Pimenta- } \\
\text { do-reino } \\
(\mathrm{t})\end{array}$ \\
\hline Abaetetuba & 720 & 25 & 2.100 & 20.000 & 140 & 42 \\
\hline Acará & 1.129 & 510 & 25.000 & 175.000 & 720 & 800 \\
\hline Baião & - & 109 & 780 & - & - & 1.840 \\
\hline Barcarena & 960 & 123 & 3.650 & - & 480 & 160 \\
\hline Cametá & 120 & 825 & 60 & - & - & 1.235 \\
\hline Igarapé-Miri & 600 & 73 & 1.000 & - & 70 & 36 \\
\hline Limoeiro do Ajuru & 100 & 32 & 24 & - & - & 6 \\
\hline Mocajuba & 132 & 512 & 900 & - & 50 & 750 \\
\hline Moju & 10.000 & 18 & 75.000 & 141.151 & 952 & 600 \\
\hline Oeiras do Pará & 1.250 & 30 & - & - & 270 & 470 \\
\hline Tailândia & 375 & - & 1.863 & 405.055 & 52 & 60 \\
\hline Total & 15.386 & 2.257 & 110.377 & 741.206 & 2.734 & 5.999 \\
\hline
\end{tabular}

Fonte: Organizado pelo autor com base em IBGE-SIDRA (2015)

\footnotetext{
${ }^{33}$ Variável utilizada nas pesquisas agrícolas do IBGE.
} 
Em termos de quantidade produzida $(\mathrm{t})$, o dendê destaca-se como a principal lavoura em produção. Este desempenho do dendê está associado às políticas públicas de fomento da expansão desta cultura, que nos últimos anos tem realizado grandes aportes de recursos financeiros.

As lavouras temporárias no Baixo Tocantins: área colhida (ha) e quantidade produzida (t) em 2013. As lavouras temporárias que mais se destacam nos municípios do Baixo Tocantins são: o abacaxi, o arroz, a cana-de-açúcar, o feijão, a mandioca e o milho. Assim como foi realizado na analise da lavoura permanente, faremos uma análise das variáveis, área colhida (ha) e quantidade produzida(t) da lavoura temporária.

A lavoura da mandioca (Figura 15) ocupa a maior área agrícola do território do Baixo Tocantins destinado à produção temporária.

Em 2013, esta lavoura ocupou 36.335 hectares, distribuídos nos 11 municípios do Baixo Tocantins, com destaque para Acará (20.200), Moju (4.000), Oeiras do Pará (3.200) e Abaetetuba (2.500).

Figura 15: Lavoura de mandioca em Baião, Pará

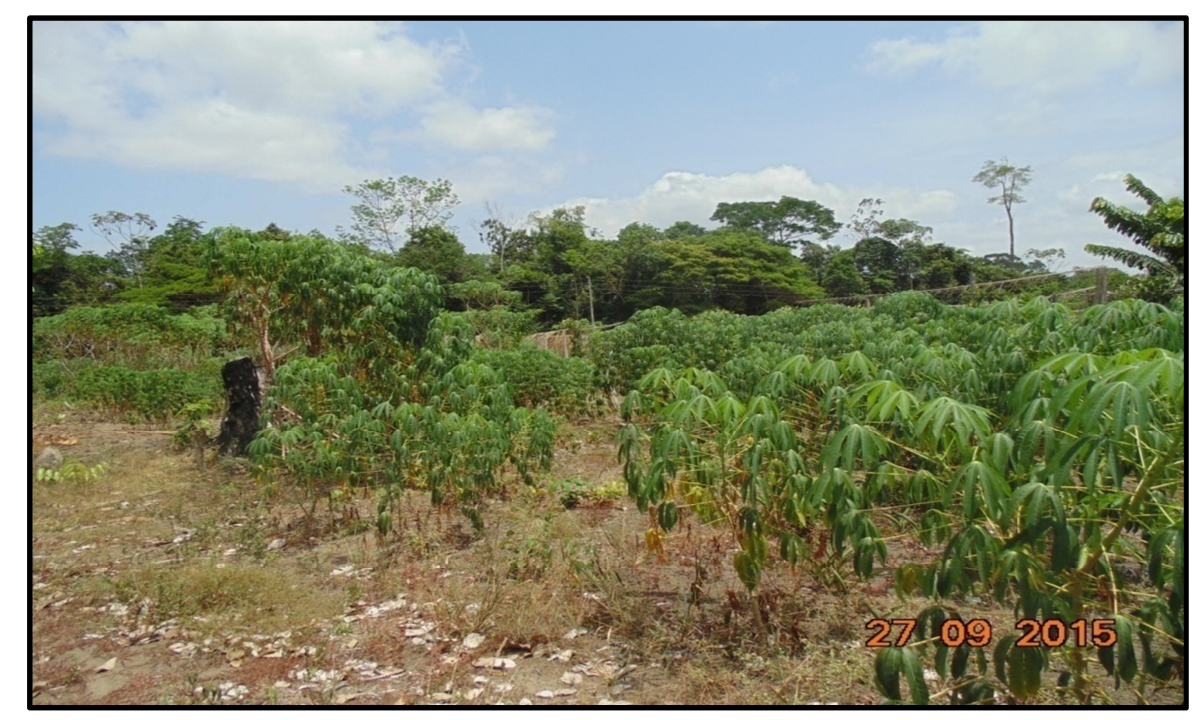

Fonte: Márcio Benassuly (2015)

O município do Acará destaca-se pelo tamanho da área colhida, bem como pela produção de farinha de mandioca que é vendida para diversos municípios do Pará e do Brasil. A Figura 16 mostra o transporte de farinha de mandioca no trapiche do porto da cidade de Acará. 
Figura 16: Transporte de farinha de mandioca no porto da cidade de Acará

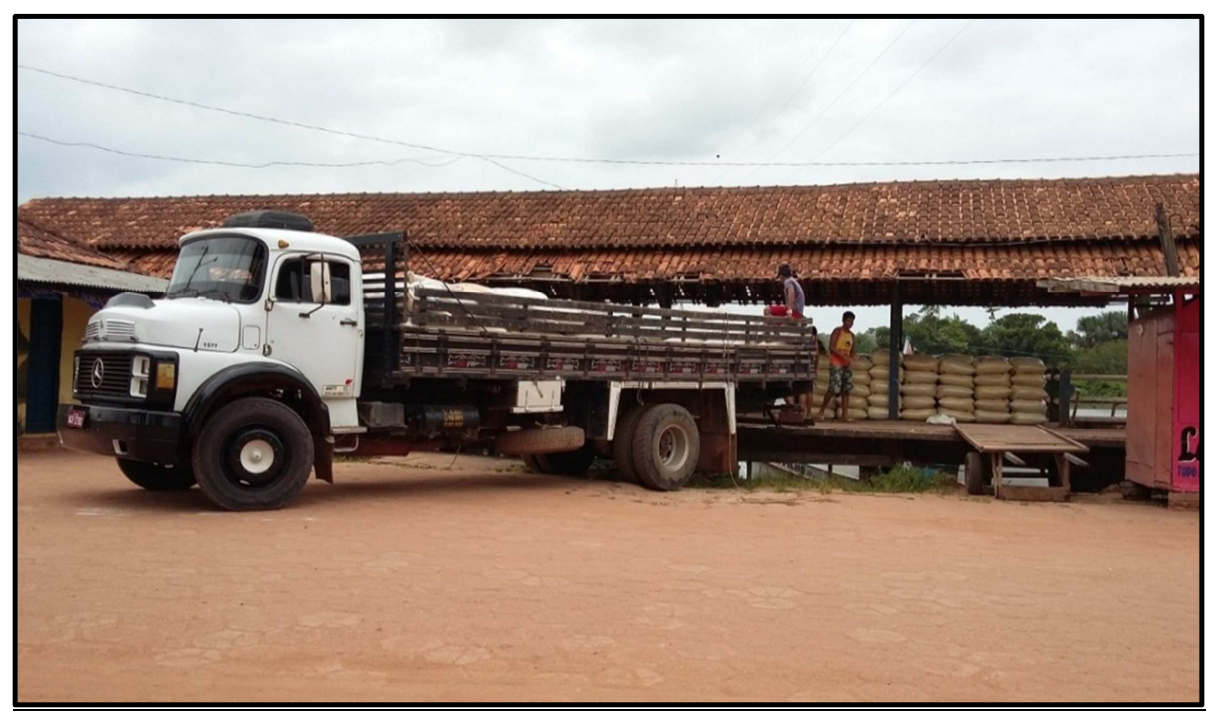

Fonte: Márcio Benassuly (2015)

A lavoura do milho é a segunda em área colhida no Baixo Tocantins, com 7.045 hectares. Em 2013, assim como ocorreu com a mandioca, o milho possuía área colhida em todos os 11 municípios do território pesquisado. As maiores áreas colhidas desta cultura foram registradas em Tailândia (3.660), Baião (1.250), Moju (800) e Acará (500). A área colhida total da região representou neste ano 7.045 hectares. Por sua vez, a área colhida total de arroz na região somou 1.920 hectares, de feijão 695 hectares, de abacaxi 214 hectares e de cana de açúcar 145 hectares (Quadro 5).

Quadro 5: Área colhida (ha) da lavoura temporária nos municípios do território do Baixo Tocantins, 2013

\begin{tabular}{|l|c|c|c|c|c|c|}
\hline \multicolumn{1}{|c|}{ Municípios } & Abacaxi & Arroz & Cana-de-açúcar & Feijão & Mandioca & Milho \\
\hline Abaetetuba & 5 & 20 & 100 & 100 & 2.500 & 150 \\
\hline Acará & - & 160 & 5 & 70 & 20.200 & 500 \\
\hline Baião & - & 180 & - & - & 820 & 1.250 \\
\hline Barcarena & 100 & 10 & 30 & 80 & 1.000 & 350 \\
\hline Cametá & 6 & 100 & - & 60 & 1.000 & 100 \\
\hline Igarapé-Miri & 5 & 20 & 10 & 30 & 1.500 & 50 \\
\hline Limoeiro do Ajuru & 18 & 30 & - & 5 & 55 & 15 \\
\hline Mocajuba & - & 50 & - & - & 700 & 50 \\
\hline Moju & 80 & 100 & - & 150 & 4.000 & 800 \\
\hline Oeiras do Pará & - & 250 & - & - & 3.200 & 120 \\
\hline Tailândia & - & 1.000 & - & 200 & 1.360 & 3.660 \\
\hline Total & 214 & 1.920 & 145 & 695 & 36.335 & 7.045 \\
\hline
\end{tabular}

Fonte: Organizado pelo autor com base em IBGE-Sidra (2015) 
O Mapa 4 demonstra a presença da área colhida dos tipos de lavouras da agricultura temporária por municípios. A mandioca e o milho são as duas culturas agrícolas que se destacam no uso agrícola do território no Baixo Tocantins.

Quando analisamos a área colhida por tipo de lavoura, fica evidente o peso que a mandioca exerce no uso agrícola do território do Baixo Tocantins (Gráfico 3).

\section{Gráfico 3: Área colhida (ha) por lavouras temporárias no Baixo Tocantins (PA), 2013}

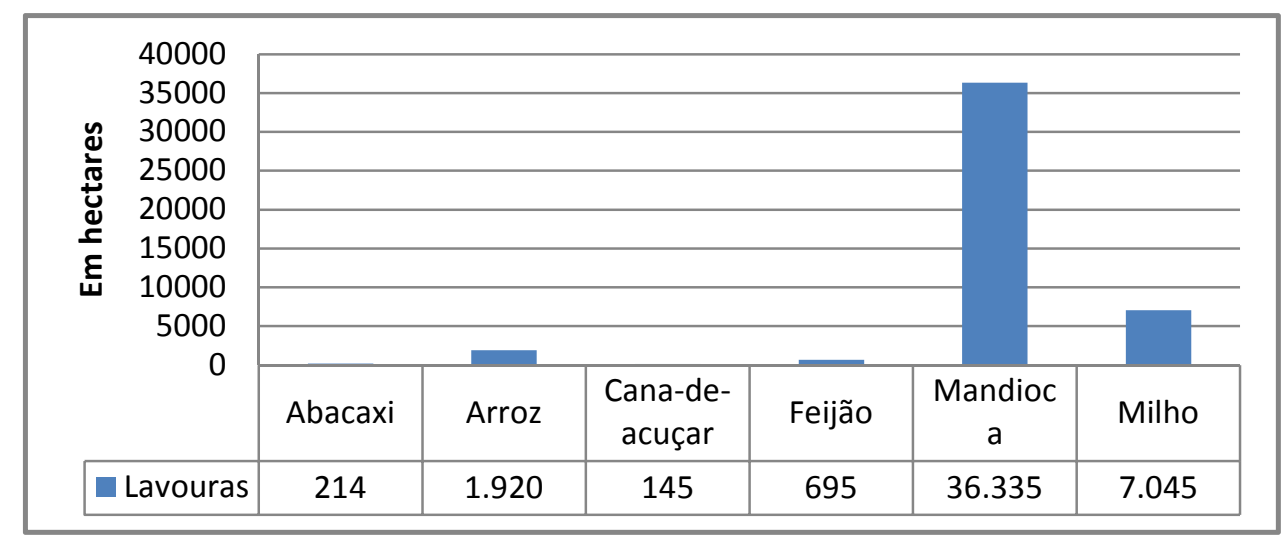

Fonte: Organizado pelo autor com base em IBGE-Sidra (2015)

Em 2013, em termos de porcentagem de área colhida, a mandioca ocupou 78\% do uso agrícola do território em estudo. Em seguida temos o milho (15\%), o arroz (4\%), o feijão (2\%) e o abacaxi (1\%) (Gráfico 4).

Gráfico 4: Área colhida (ha) por lavouras temporárias no Baixo Tocantins (PA), 2013

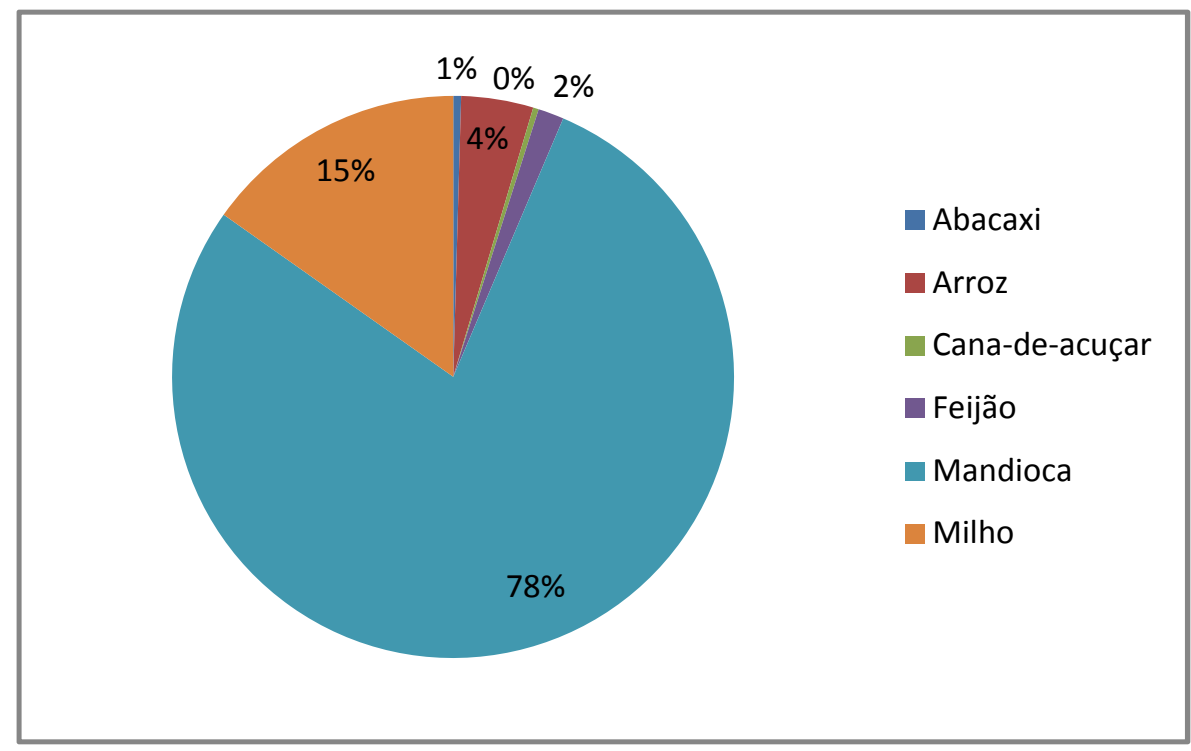

Fonte: Organizado pelo autor com base em IBGE-Sidra (2015) 
Mapa 4: Uso agrícola do território pela lavoura temporária nos municípios do Baixo Tocantins (PA), 2013

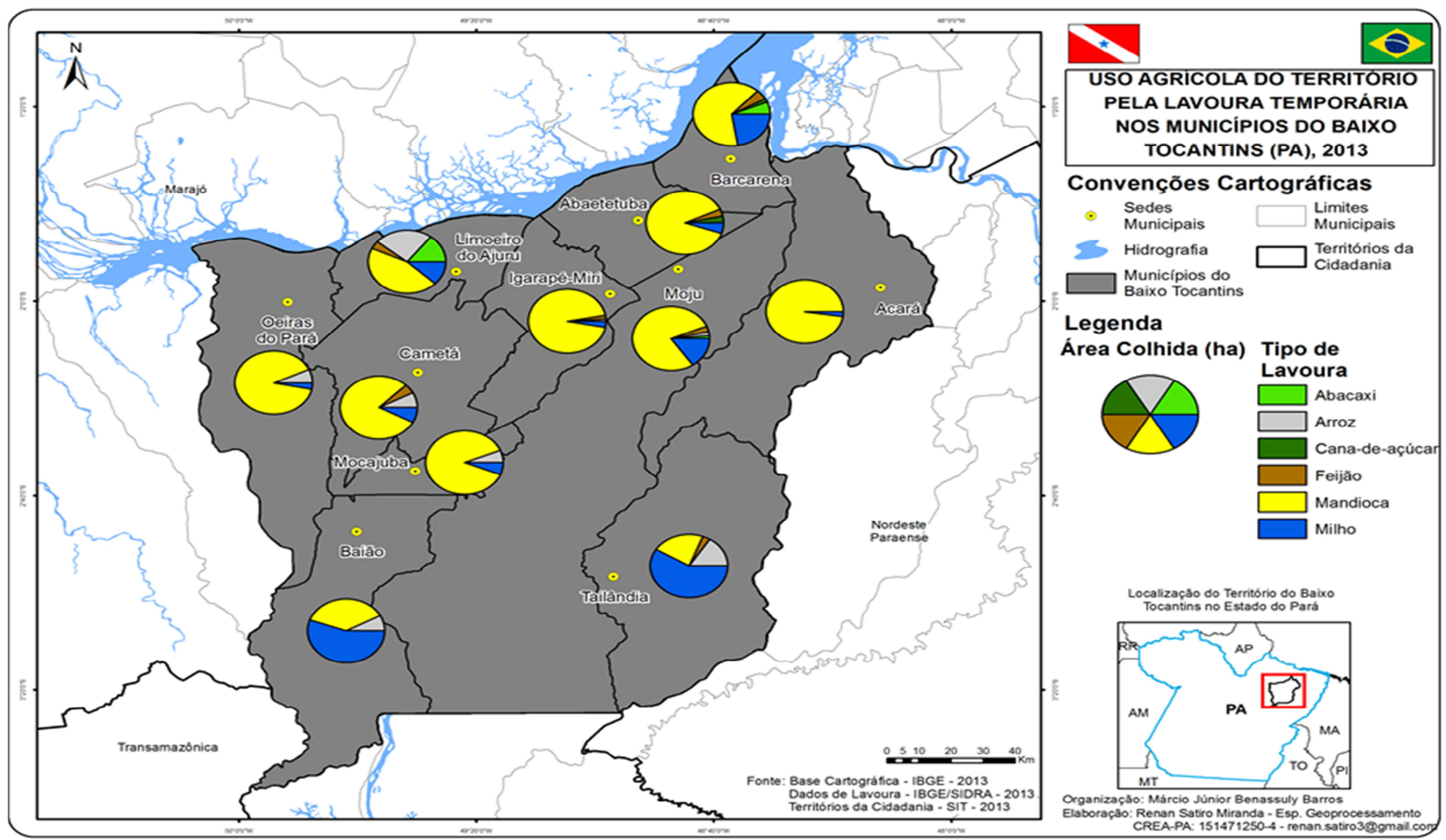


A segunda variável analisada em relação à lavoura temporária é a quantidade produzida (t) pelos tipos de culturas agrícolas. Seguindo sua participação na área colhida, as lavouras de mandioca e milho apresentam também as maiores quantidades produzidas entre todos os tipos de culturas agrícolas selecionadas aqui.

A produção total de mandioca em 2013 foi da ordem de 543.195 toneladas, onde podemos destacar o município de Acará com 304.000 toneladas, Moju com 80.000 toneladas e Oeiras do Pará com 43.920 toneladas. A produção de total de milho foi de 22.077 toneladas, onde Tailândia contribuiu com 19.764 toneladas.

A quantidade produzida de cana-de-açúcar em 2013 foi de 4.725, representando a terceira entre os tipos de lavouras temporárias na região. Em seguida, a produção de abacaxi (3.201 toneladas), arroz (2.267 toneladas) e feijão (382 toneladas), como demonstra o Quadro 6.

\section{Quadro 6: Quantidade produzida (toneladas) da lavoura temporária nos municípios do território do Baixo Tocantins, 2013.}

\begin{tabular}{|c|c|c|c|c|c|c|}
\hline Municípios & $\begin{array}{l}\text { Abacaxi (mil } \\
\text { frutos) }\end{array}$ & Arroz (t) & $\begin{array}{l}\text { Cana-de-açúcar } \\
\text { (t) }\end{array}$ & Feijão (t) & Mandioca (t) & Milho (t) \\
\hline Abaetetuba & 60 & 12 & 3.000 & 60 & 37.500 & 60 \\
\hline Acará & - & 96 & 125 & 42 & 304.000 & 500 \\
\hline Baião & - & 82 & - & - & 7.200 & 1.000 \\
\hline Barcarena & 1.200 & 6 & 1.200 & - & 15.600 & 210 \\
\hline Cametá & 120 & 60 & - & 36 & 12.000 & 60 \\
\hline Igarapé-Miri & 75 & 16 & 400 & 15 & 18.000 & 25 \\
\hline $\begin{array}{ll}\text { Limoeiro do } \\
\text { Ajuru }\end{array}$ & 306 & 15 & - & 2 & 495 & 12 \\
\hline Mocajuba & - & 30 & - & - & 8.400 & 30 \\
\hline Moju & 1.440 & 100 & - & 90 & 80.00 & 320 \\
\hline Oeiras do Pará & - & 250 & - & - & 43.920 & 96 \\
\hline Tailândia & - & 1.600 & - & 137 & 16.080 & 19.764 \\
\hline Total & 3.201 & 2.267 & 4.725 & 382 & 543.195 & 22.077 \\
\hline
\end{tabular}

Fonte: Organizado pelo autor com base em IBGE-Sidra (2015)

A análise do uso agrícola do território pelas lavouras permanentes e temporárias para o ano de 2013 revela que a área total usada pelas lavouras permanentes foi de 63.784 hectares, dos quais o dendê é a principal cultura em ocupação do território agrícola nos municípios de Abaetetuba (2.000), Acará (7.000) e Tailândia (19.389), além de ser a segunda cultura em ocupação do território no Moju (7.093). O território usado pela dendeicultura como principal 
cultura agrícola nestes três municípios foi da ordem de 28.339 hectares, que se somado este valor com o território utilizado em Moju, chega a 35.482 hectares, ocupando desta forma, a maior parcela do território agrícola do Baixo Tocantins, em 2013.

Já o uso agrícola do território pela lavoura temporária é dominado pela presença da mandioca que aparece como a principal cultura em uso do território nos municípios de Abaetetuba (2.500), Acará (20.200), Barcarena (1.000), Cametá (1.000), Igarapé Miri (1.500), Limoeiro do Ajuru (55), Mocajuba (700), Moju (3.200) e Oeiras do Pará (3.200). O território ocupado pela mandioca como principal cultura nestes municípios totalizou 34.155 hectares de um total de 124.304 de área total destinada à lavoura temporária no Baixo Tocantins. O milho é a principal cultura temporária ocupando o maior território agrícola nos municípios de Baião (1.250) e Tailândia (3.660), totalizando 4.910 hectares (Quadro 7).

\section{Quadro 7: Uso do território agrícola em hectares nos municípios do território do Baixo} Tocantins, 2013.

\begin{tabular}{|c|c|c|c|c|}
\hline \multirow{3}{*}{ Municípios } & \multicolumn{4}{|c|}{ Uso do território agrícola em hectares } \\
\hline & \multicolumn{2}{|r|}{ Agricultura permanente } & \multicolumn{2}{|c|}{ Agricultura temporária } \\
\hline & Área total & Área da principal cultura & $\begin{array}{l}\text { Área } \\
\text { total }\end{array}$ & $\begin{array}{l}\text { Área da principal } \\
\text { cultura }\end{array}$ \\
\hline Abaetetuba & 2.600 & 2.000 (dendê) & 2.880 & 2.500 (mandioca) \\
\hline Acará & 10.905 & 7.000 (dendê) & 20.935 & 20.200 (mandioca) \\
\hline Baião & 1.760 & 1.150 (pimenta do reino) & 2.250 & 1.250 (milho) \\
\hline Barcarena & 1.045 & 365 (coco-da-baía) & 1.580 & 1.000 (mandioca) \\
\hline Cametá & 6.782 & 6.346 (cacau) & 1.266 & 1.000 (mandioca) \\
\hline Igarapé-Miri & 2.059 & 1.000 (coco-da-baía) & 1.625 & 1.500 (mandioca) \\
\hline $\begin{array}{l}\text { Limoeiro do } \\
\text { Ajuru }\end{array}$ & 82 & 70 (cacau) & 123 & 55 (mandioca) \\
\hline Mocajuba & 1.759 & 1.125 (cacau) & 800 & 700 (mandioca) \\
\hline Moju & 16.123 & 7.500 (coco-da-baía). 7.093 (dendê) & 82.150 & 4.000 (mandioca) \\
\hline Oeiras do Pará & 464 & 235 (pimenta do reino) & 3.570 & 3.200 (mandioca) \\
\hline Tailândia & 20.205 & 19.389 (dendê) & 7.125 & 3.660 (milho) \\
\hline Total & $\begin{array}{l}63.784 . \\
\text { Dendê } \\
(35.482)\end{array}$ & $\begin{array}{l}\text { Dendê (28.339). Coco-da-baía (8.865). Cacau } \\
\text { (7.541). Pimenta-do-reino (1.385). }\end{array}$ & 124.304 & $\begin{array}{l}\text { Mandioca }(34.155) . \\
\text { Milho (4.910) }\end{array}$ \\
\hline
\end{tabular}

Fonte: Organizado pelo autor com base em IBGE-Sidra (2015) 
O Mapa 5 destaca o uso do território pela principal lavoura permanente nos municípios do Baixo Tocantins em 2013. O dendê figura como a principal lavoura permanente em Abaetetuba, Acará e Moju. O coco-da-baía aparece como a principal lavoura permanente em Barcarena, Igarapé Miri e Moju. O cacau é registrado como a principal cultura agrícola permanente em Cametá, Mocajuba e Limoeiro do Ajuru. E a pimenta-do-reino como a principal lavoura em Baião e Oeiras do Pará. Este mapa reflete uma territorialização da principal lavoura permanente nos municípios do Baixo Tocantins no ano em análise.

O Mapa 6 analisa o uso agrícola do território pela principal lavoura temporária em 2013 no Baixo Tocantins. A mandioca é a principal cultura de Abaetetuba, Acará, Barcarena, Cametá, Igarapé Miri, Limoeiro do Ajuru, Mocajuba, Moju e Oeiras do Pará. Já o milho é registrado como a principal lavoura temporária em Baião e Tailândia. 
Mapa 5: Uso agrícola do território pela principal lavoura permanente nos municípios do Baixo Tocantins (PA), 2013
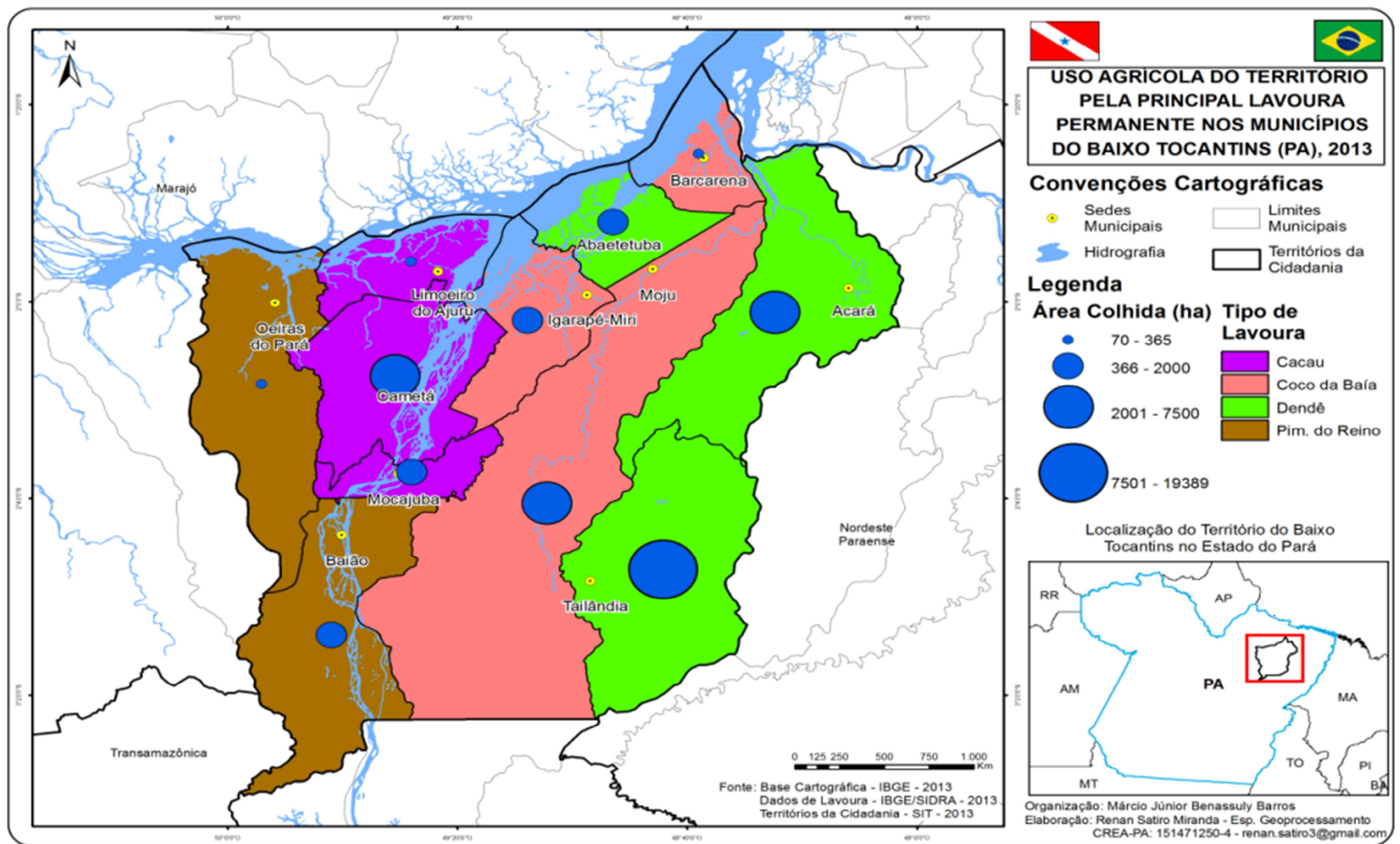
Mapa 6: Uso agrícola do território pela principal lavoura temporária nos municípios do Baixo Tocantins (PA), 2013

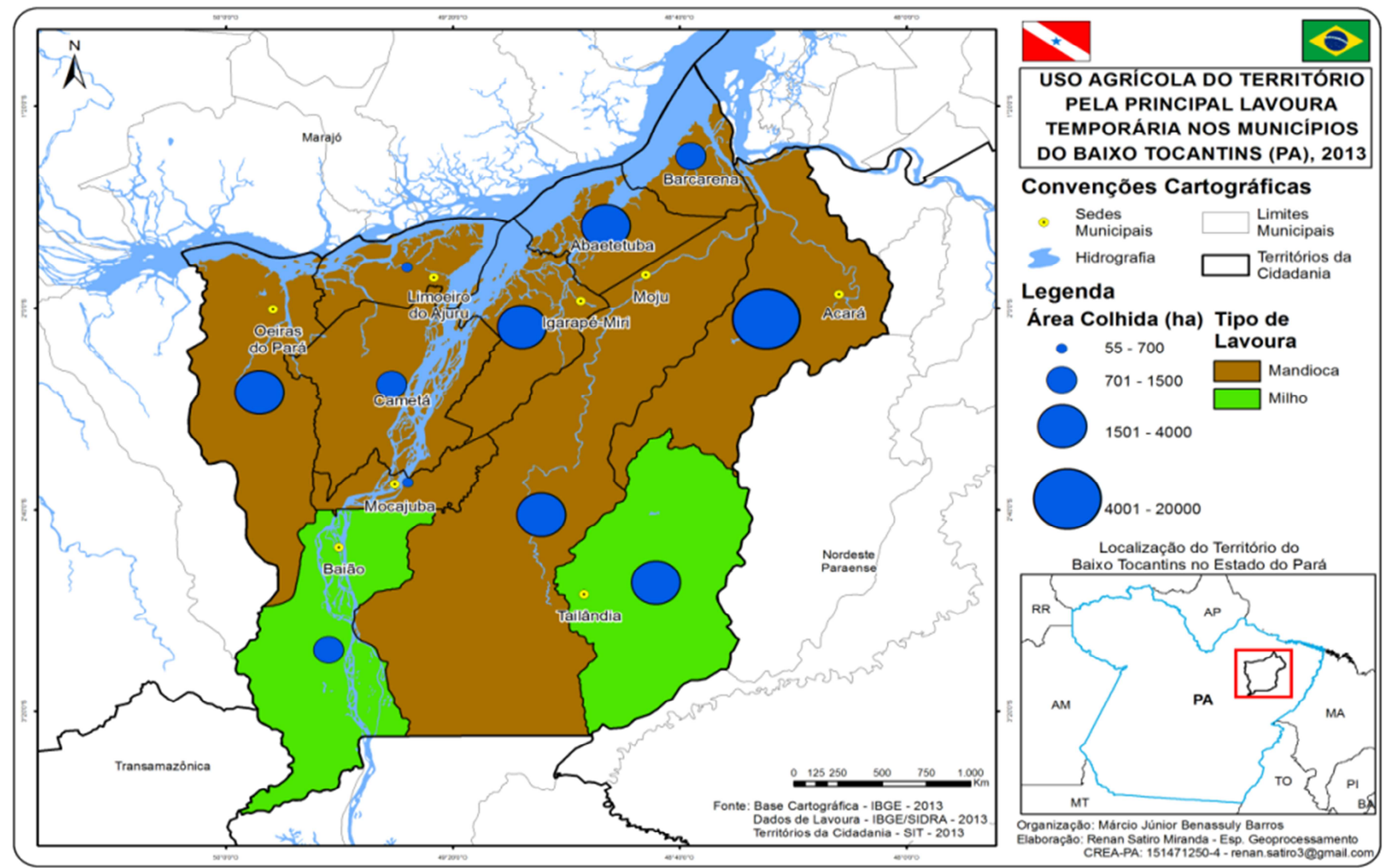


Os Mapas 5 e 6 refletem o uso agrícola do território pelos tipos de lavoura da agricultura permanente e temporária. Estes dados demonstram uma territorialização de tipos de lavouras em um conjunto de municípios como a formada pela presença do dendê (lavoura permanente) e da mandioca (lavoura temporária).

1.5.2 Uso agrícola do território pela dendeicultura no Baixo Tocantins: áreas, produtividade e fomento da produção

Área colhida (há) de dendê no Baixo Tocantins. O uso do território pela cultura do dendê apresenta um crescimento no período 2004-2013. Em 2004 a área destinada à colheita de dendê era de 31.452 hectares, em 2013 passou para 35.450 hectares. Entre 2004 a 2012 três municípios dominavam a produção de dendê, Acará, Moju e Tailândia. Em 2013, Abaetetuba inicia sua produção em 2.000 hectares de seu território (Quadro 8).

Quadro 8: Área colhida (ha) de dendê no Baixo Tocantins entre 2004-2013

\begin{tabular}{|l|r|r|r|r|r|r|r|r|r|r|}
\hline Municípios & \multicolumn{1}{|c|}{2004} & 2005 & \multicolumn{1}{|c|}{2006} & 2007 & 2008 & 2009 & 2010 & 2011 & 2012 & 2013 \\
\hline Abaetetuba & - & - & - & - & - & - & - & - & - & 2.000 \\
\hline Acará & 6.700 & 6.700 & 7.000 & 7.000 & 7.000 & 7.100 & 7.200 & 7.000 & 7.000 & 7.000 \\
\hline Moju & 7.678 & 7.678 & 7.678 & 7.679 & 7.678 & 8.000 & 7.993 & 7.093 & 13.288 & 7.093 \\
\hline Tailândia & 17.074 & 17.074 & 19.980 & 17.074 & 17.074 & 17.074 & 19.387 & 20.893 & 19.387 & 19.397 \\
\hline Total & 31.452 & 31.422 & 34.658 & 31.753 & 31.752 & 32.174 & 34.580 & 34.986 & 39.675 & 35.450 \\
\hline
\end{tabular}

Fonte: Organizado pelo autor com base em IBGE-Sidra (2015)

O Mapa 7 enfatiza o uso agrícola do território pela dendeicultura no Baixo Tocantins em 2013. Neste ano os dados do IBGE-Sidra registram uma área colhida apenas nos quatro municípios citados. A maior área colhida do território de produção agrícola de dendê está localizada em Tailândia, com 19.387 hectares. Em seguida, Moju com 7.093 hectares, Acará com 7.000 hectares e finalmente Abaetetuba com 2.000 hectares. 
Mapa 7: Uso agrícola do território pela dendeicultura no Baixo Tocantins (PA), 2013
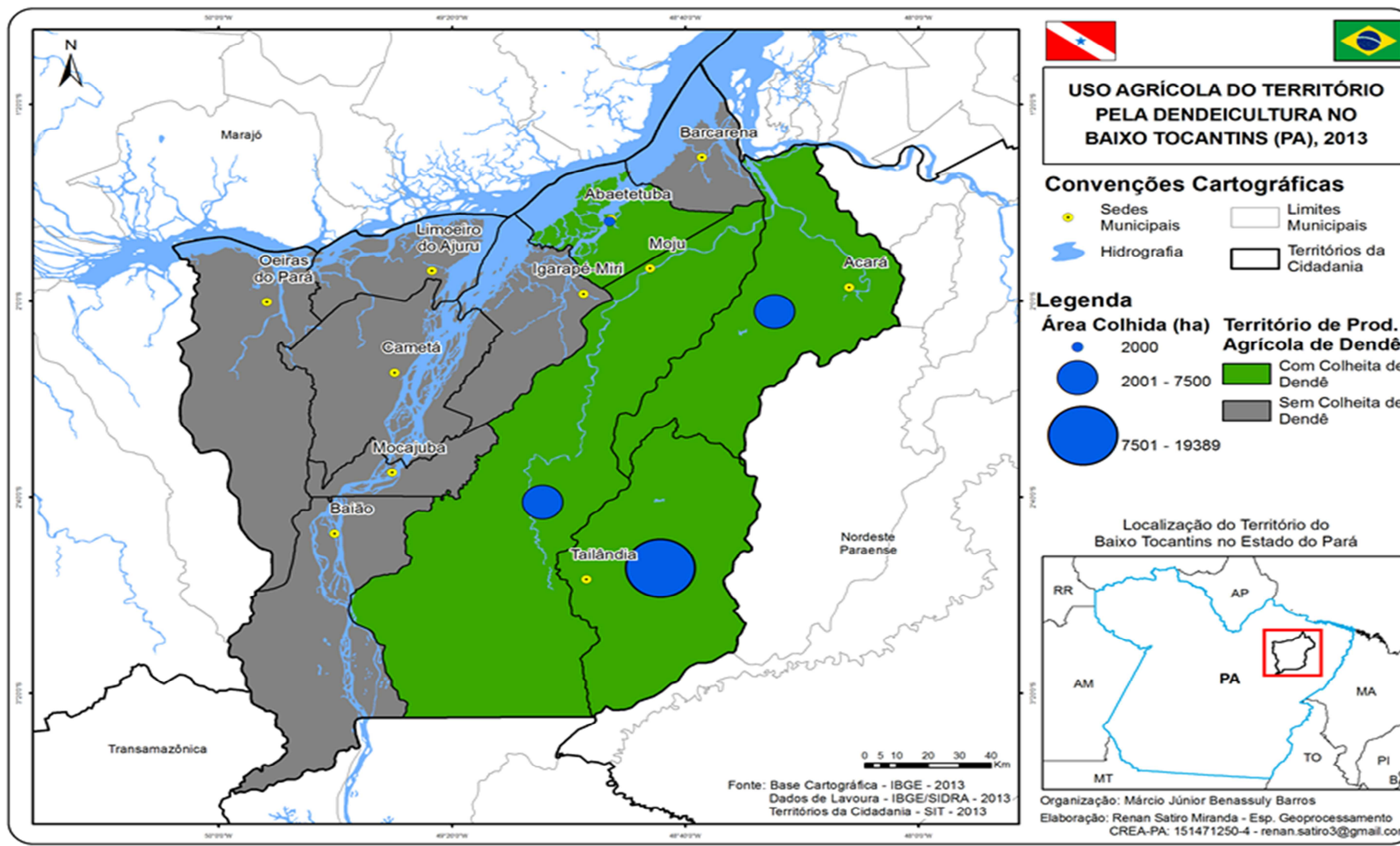

\section{Legenda}

Área Colhida (ha) Território de Prod.

- 2000

2000

Agrícola de Dendê

$\overbrace{}^{\circ}$

$2001-7500$

Agrícola de Dendê

$\square$ Dendê $7501-19389$

章

Localização do Território do Baixo Tocantins no Estado do Pará

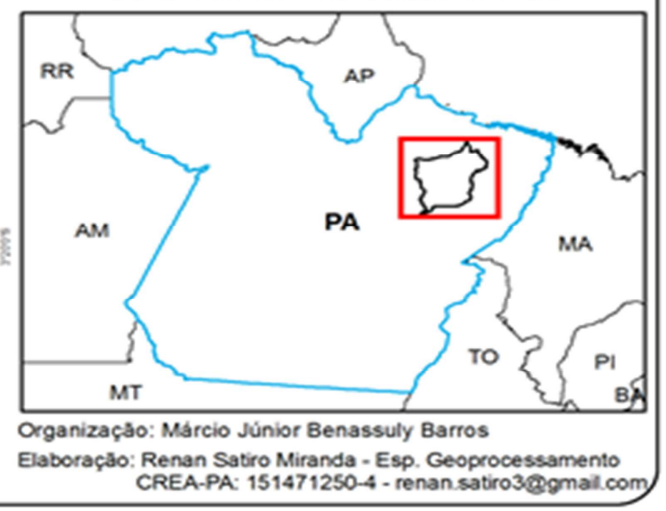


O Mapa 7 destaca também os municípios sem colheita de dendê registrado pelo IBGESIDRA em 2013: Baião, Barcarena, Cametá, Igarapé Miri, Mocajuba, Oeiras do Pará e Limoeiro do Ajuru.

Quantidade produzida (t) de dendê no Baixo Tocantins. Em 2004 foram produzidos no Baixo Tocantins 536.134 toneladas. Esta produção teve como origem os municípios de Acará, Moju e Tailândia. Em 2013 esta produção passou de 741.206 toneladas, sendo acrescentados a esta lista de três municípios produtores anteriores citados a produção de 20.000 de Abaetetuba, que realizou sua primeira produção neste ano (Quadro 9).

Quadro 9: Quantidade produzida (t) de dendê no Baixo Tocantins, entre 2004-2013

\begin{tabular}{|l|c|c|c|c|c|c|c|c|c|c|}
\hline Municípios & 2004 & 2005 & 2006 & 2007 & 2008 & 2009 & 2010 & 2011 & 2012 & 2013 \\
\hline Abaetetuba & - & - & - & - & - & - & - & - & - & 20.000 \\
\hline Acará & 100.500 & 100.500 & 182.000 & 182.000 & 182.000 & 184.6000 & 185.200 & 175.000 & 175.000 & 175.000 \\
\hline Moju & 135.132 & 135.132 & 135.132 & 135.132 & 135.132 & 140.800 & 141.151 & 141.151 & 153.356 & 141.151 \\
\hline Tailândia & 300.502 & 300.502 & 464.735 & 300.502 & 300.502 & 300.502 & 450.554 & 474.601 & 405.055 & 405.055 \\
\hline Total & 536.134 & 536.134 & 781.867 & 617.634 & 617.634 & 625.902 & 776.905 & 790.752 & 733.411 & 741.206 \\
\hline
\end{tabular}

Fonte: Organizado pelo autor com base em IBGE-SIDRA (2015)

O período (2004-2013) analisado da quantidade produzida de dendê acima justifica-se da seguinte maneira: 1) 2004 foi o ano da criação do PNPB, a política pública que promoveu esforços para a incorporação da agricultura familiar no agronegócio de dendê no Pará; 2) 2010 foi criado o PPSOP, com o objetivo de ampliar a expansão da produção agrícola de dendê no Brasil, do qual o Pará é o maior produtor; 3) nossa análise termina em 2013, ano mais atualizado disponível no banco de dados do IBGE-Sidra até dezembro de 2015.

1.5.3 Fomento da produção agrícola de dendê no Baixo Tocantins: uma ênfase na territorialização do Pronaf Eco-Dendê

No Baixo Tocantins, dos onze municípios que fazem parte do território, sete municípios são beneficiados pelo Pronaf Eco-Dendê (Abaetetuba, Acará, Baião, Cametá, Mocajuba, Moju e Tailândia). Os municípios de Barcarena, Igarapé Miri, Limoeiro do Ajuru e Oeiras do Pará não possuem agricultura familiar de dendê beneficiada por esta linha de crédito agrícola.

Em 2010 quando a linha de crédito foi criada, apenas Acará (2) e Moju (45) acessaram este crédito. O mesmo ocorreu em 2011. A partir de 2012 com a chegada das empresas entrantes (Petrobras Biocombustível e Biopalma) ocorre um aumento do número de contratos junto ao Banco da Amazônia que opera esta linha de financiamento na região. 
Em 2012, além de Acará e Moju, que já tinham financiamento desde 2010, passam a acessar este tipo de política de crédito rural os municípios de Abaetetuba (1), Baião (1), Cametá (3) Mocajuba (1) e Tailândia (94). Como percebemos, o ano de 2012 marca a entrada de novos municípios na produção familiar de dendê no Baixo Tocantins. As empresas entrantes estavam organizadas de forma territorial, onde a Petrobras Biocombustível comandava o Projeto Pará, com atuação nos municípios de Baião, Cametá, Igarapé Miri e Mocajuba. Desta forma os contratos celebrados em Baião (1) Cametá (3) Mocajuba (1) fazem parte de estratégias da empresa em estruturar o chamado Projeto Pará.

A Belém Bioenergia Brasil (Pbio + Galp) comandava o chamado Projeto Belém, que tem como um dos seus polos o município de Tailândia, onde foram celebrados 94 contratos com a agricultura familiar.

A Biopalma tem como um de seus polos o município de Moju, onde foi celebrado o maior número de contratos neste ano, totalizando 109. Em Abaetetuba apenas um contrato foi firmado. Em 2013 ocorre a ampliação dos contratos de agricultura familiar de dendê em Baião (3) Cametá (8) Mocajuba (7) e Moju (150), em detrimento de Tailândia (44) que diminuíram em relação ao ano de 2012. Acará permanece com a mesma quantidade de contratos (41) do ano anterior.

Em 2014, os contratos diminuíram em todos os municípios do território. No contexto geral do Baixo Tocantins, os contratos do Pronaf Eco-Dendê têm oscilado entre crescimento e decrescimento no período de 2010-2014. Em 2010, o total de contratos foi de 47, baixou para 23 em 2011, subiu para 250 em 2012, mantém crescimento em 2013, com 253 contratos celebrados, e diminuiu, em 2014, para 164 contratos celebrados (Quadro 10).

Quadro 10: Evolução das aplicações de recurso do Pronaf Eco-Dendê nos municípios do território do Baixo Tocantins, 2010-2014.

\begin{tabular}{|l|c|c|c|c|c|c|}
\hline \multicolumn{1}{|c|}{ Municípios } & 2010 & 2011 & 2012 & 2013 & 2014 & Total \\
\hline Abaetetuba & & & 1 & & & 1 \\
\hline Acará & 2 & 1 & 41 & 41 & 35 & 120 \\
\hline Baião & & & 1 & 3 & & 4 \\
\hline Cametá & & & 3 & 8 & & 11 \\
\hline Mocajuba & & & 1 & 7 & & 8 \\
\hline Moju & 45 & 22 & 109 & 150 & 115 & 441 \\
\hline Tailândia & & & 94 & 44 & 14 & 152 \\
\hline
\end{tabular}

Fonte: Organizado pelo autor com base em Basa (2012c) e Bacen (2016)

Nota: Para os anos de 2010, 2011 e 2012, utilizamos os dados do Basa (2012c). Para os anos de 2013 e 2014, utilizamos os dados do Bacen (2016). 
O Mapa 8 procura enfatizar a territorialização do Pronaf Eco-Dendê no Baixo Tocantins. Para tanto, promovemos uma divisão territorial que consideraa existência de quatro subterritórios: subterritório 1 (Barcarena, Abaetetuba e Igarapé Miri), subterritório 2 (Acará, Moju e Tailândia), subterritório 3 (Mocajuba e Baião), subterritório 4 (Cametá, Limoeiro e Oeiras do Pará). Os contratos do Pronaf Eco-Dendê estão concentrados nos municípios que integram o subterritório 2, onde no período de 2010-2014, em Moju, foram firmados 441 contratos. Em Tailândia foram realizados outros 152 e em Acará, mais 120 contratos com o Basa. No subterritório1 foi celebrado apenas um contrato em Abaetetuba. No subterritório 3 foram celebrados 12 contratos, sendo 4 em Baião e 8 em Mocajuba. No subterritório 4 foram celebrados 11 contratos em Cametá. 
Mapa 8:Territorialização do Pronaf Eco-Dendê no Baixo Tocantins (PA), 2010-2014

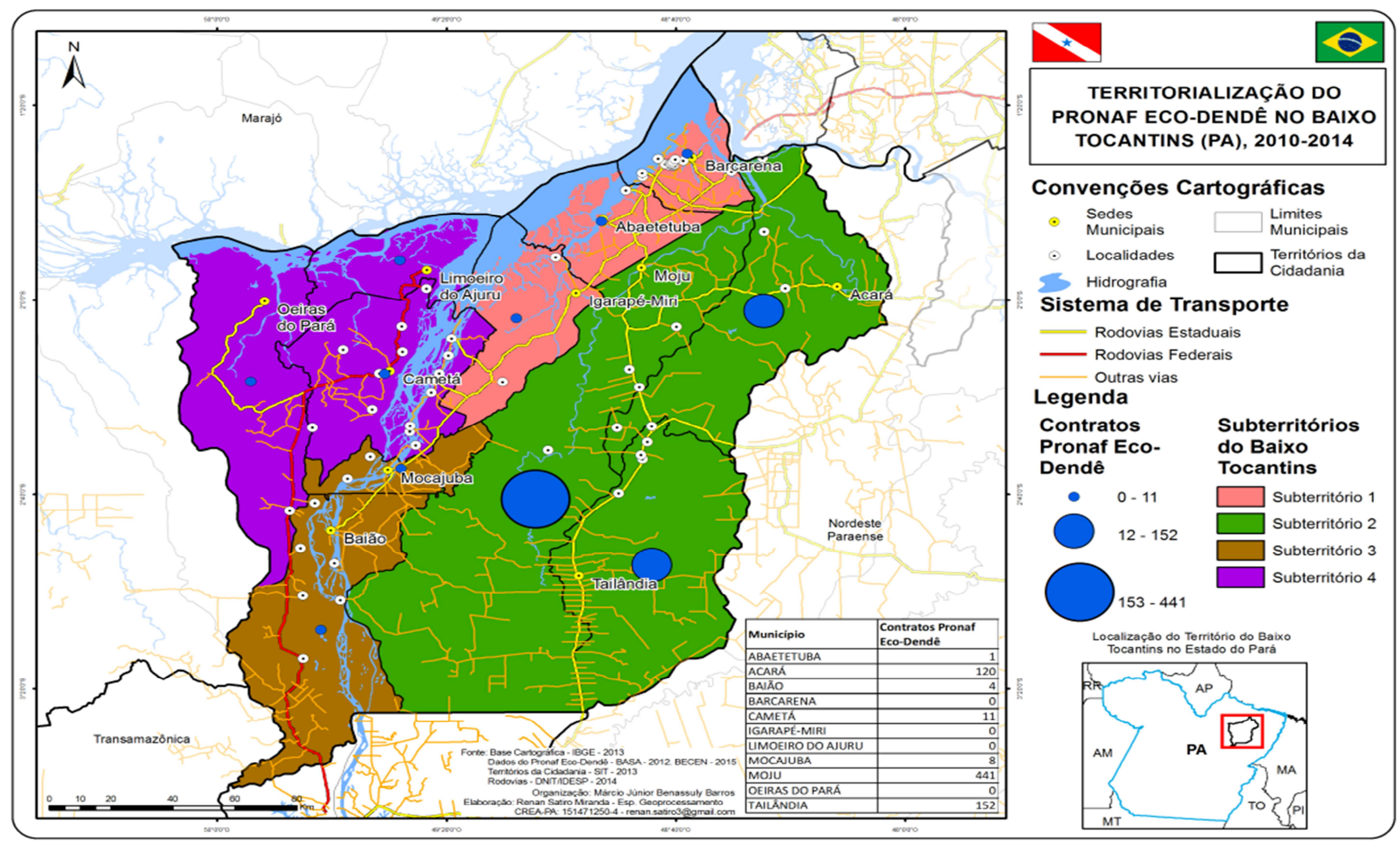


Ao analisar o valor dos contratos de investimentos do Pronaf Eco-Dendê no Baixo Tocantins, constatamos que em 2010 os 47 contratos celebrados nos municípios de Acará (2) e Moju (45) totalizaram um investimento de R \$ 683.134,18. Em 2011 estes valores reduziram para $\mathrm{R} \$ 215.457,34$, distribuídos entre Acará (1) e Moju (22).

Em 2012, ocorre o grande crescimento tanto do número de contratos quanto do valor de investimento do Pronaf Eco-Dendê. Neste ano foram celebrados 250 contratos de agricultores familiares de dendê, em que foram investidos $\mathrm{R} \$ 423.969 .687,97$ em sete municípios do Baixo Tocantins.

O crescimento de 2011 para 2012 foi exponencial para o número de contratos que passaram de 23, em 2011, para 250, em 2012. Já os investimentos passaram de R\$ 215.457,34, em 2011, para $\mathrm{R} \$ 423.969 .687,97$, em 2012 (Quadro 11).

Quadro 11: Quantidade e valor dos contratos de investimentos do Pronaf Eco-Dendê em municípios do Baixo Tocantins, 2010-2012.

\begin{tabular}{|c|c|c|c|c|c|c|}
\hline \multirow[b]{2}{*}{ Municípios } & \multicolumn{2}{|c|}{2010} & \multicolumn{2}{|c|}{2011} & \multicolumn{2}{|c|}{2012} \\
\hline & Quantidade & Valores (R\$) & Quantidade & Valores (R\$) & Quantidade & Valores (R\$) \\
\hline Abaetetuba & & & & & 1 & $8.445,60$ \\
\hline Acará & 2 & $104.468,00$ & 1 & $64.631,00$ & 41 & $2.857 .352,50$ \\
\hline Baião & & & & & 1 & $79.712,90$ \\
\hline Cametá & & & & & 3 & $239.138,70$ \\
\hline Mocajuba & & & & & 1 & $79.712,90$ \\
\hline Moju & 45 & $578.666,18$ & 22 & $150.826,34$ & 109 & $7.032 .922,13$ \\
\hline Tailândia & & & & & 94 & $7.069 .313,34$ \\
\hline Total & 47 & $683.134,18$ & 23 & $215.457,34$ & 250 & $423.969 .687,97$ \\
\hline
\end{tabular}

Fonte: Organizado pelo autor com base em Basa (2012c) e Homma et al.(2014)

Nota: A quantidade de contratos para os anos de 2010, 2011, 2012 tem como referências os dados de Basa (2012c), bem como os valores dos contratos para os anos de 2010 e 2011. Os valores dos contratos do ano de 2012 têm como referência dados do Basa organizados por Hommaet al.(2014).

Em 2013, foram celebrados 253 contratos do Pronaf para a agricultura familiar de dendê, envolvendo um investimento de $\mathrm{R} \$$ 1.436.017.415,08, o maior registrado no período analisado (2010-2014).

Em 2014, houve uma redução tanto da quantidade dos contratos celebrados quanto dos valores investidos. Neste ano foram 164 contratos distribuídos em apenas três municípios (Acará, Moju e Tailândia), com a aplicação de R\$ 12.673.563,81 (Quadro 12). 
Quadro 12: Quantidade e valor dos contratos de investimentos do Pronaf Eco-Dendê em municípios do Baixo Tocantins, 2013-2014.

\begin{tabular}{|l|c|c|c|c|}
\hline \multirow{2}{*}{ Municípios } & \multicolumn{2}{|c|}{2013} & \multicolumn{2}{|c|}{2014} \\
\cline { 2 - 5 } & Quantidade & Valores (R\$) & Quantidade & Valores (R\$) \\
\hline Abaetetuba & & & & \\
\hline Acará & 41 & $3.163 .777,50$ & 35 & $2.674 .087,51$ \\
\hline Baião & 3 & $232.335,80$ & & \\
\hline Cametá & 8 & $630.652,90$ & & \\
\hline Mocajuba & 7 & $554.750,00$ & & $1.896 .842,30$ \\
\hline Moju & 150 & $11.712 .878,63$ & 115 & $12.673 .563,00$ \\
\hline Tailândia & 44 & $3.402 .058,95$ & 14 & 164 \\
\hline Total & 253 & $19.696 .443,78$ & & 12.67 \\
\hline
\end{tabular}

Fonte: Organizado pelo autor com base em Bacen (2016)

Desta forma, os investimentos realizados no fomento da lavoura familiar do dendê, por meio do Pronaf Eco-Dendê, fazem parte de uma estratégia estatal-empresarial que objetiva a expansão da produção agrícola de dendê no Brasil. Seguindo orientação desta estratégia, são disponibilizados grandes recursos financeiros para viabilizar a integração da agricultura familiar no agronegócio de dendê, como será discutido no próximo capítulo desta tese, onde analisamos duas políticas públicas (PNPB e PPSOP) que visam à expansão do cultivo de dendê no Brasil. 


\section{CAPÍtULO 2: DO PROGRAMA NACIONAL DE PRODUÇÃO E USO DO BIODIESEL (PNPB) AO PROGRAMA DE PRODUÇÃO SUSTENTÁVEL DE ÓLEO DE PALMA (PPSOP)}

Este capítulo tem como objetivo discutir a categoria políticas públicas, em que enfatizamos os seguintes elementos: gênese e definições. Na sequência apresentamos as duas políticas públicas selecionadas na pesquisa (Programa Nacional de Produção e Uso do Biodiesel e o Programa de Produção Sustentável de Óleo de Palma) políticas que visam à expansão da produção agrícola de dendê, bem como a integração da agricultura familiar no agronegócio no Brasil. Neste sentido, analisamos o contexto político-econômico que levou à criação destas políticas, assim como os instrumentos de incentivos para a expansão da produção de dendê no Brasil.

\subsection{Políticas públicas}

O surgimento das políticas públicas como campo acadêmico focada nos estudos da análise da produção governamental surge nos Estados Unidos com Harold D. Lasswell que introduz a expressão policy analysis (análise de política pública) tendo como foco a ação dos governos (RODRIGUES, 2013; SOUZA, 2006; MARQUES; FARIA, 2013). Desta forma, desde suas origens as políticas públicas estiveram ligadas as ações estatais, nas mais diversas áreas de atuação.

O pioneirismo de Lasswell no campo acadêmico das políticas públicas é destacado por Eduardo Marques (2013, p. 24), em As políticas púbicas na ciência política, quando afirma que "o momento inicial de constituição da preocupação com as políticas é usualmente datado pelo trabalho do cientista político norte-americano Harold Lasswell, ativo especialmente em estudos sobre a mídia e as comunidades entre os anos 1930 e 1970”.

Segundo Marques (2013), se reportando a Lasswell, "o autor defendeu a constituição de uma análise científica do governo no que denominou de policy analysis, de forma dispersa ao longo de suas obras publicadas nos anos 1930 e 1940 e mais claramente a partir do fim dos anos 1940" (MARQUES, 2013, p. 26). A proposição da "análise científica do governo" foi de grande importância para os estudos na Ciência Política principalmente nos Estados Unidos, onde o caráter propositivo pioneiro de Lasswell foi determinante para a constituição deste campo acadêmico. Para Eduardo Marques (2013, p. 26), "no centro da formulação de tal 'ciência do governo' estava a busca de compreensão dos efeitos dos contextos sociais e políticos que cercam as políticas, assim como a centralidade da racionalidade nos processos 
de decisão". Outros trabalhos pioneiros foram propostos por Herbert Simon, David Easton, Charles Lindblom, Theodore Lowi na Ciência Política (MARQUES, 2013).

Este pensamento da origem das políticas públicas como campo acadêmico é compartilhado por Celina Souza (2007, p. 66-67) em Estado da arte da pesquisa em políticas públicas, quando argumenta que "a política pública como área de conhecimento e disciplina acadêmica nasce nos Estados Unidos [...] seguida pela tradição europeia de estudos e pesquisas nessa área”.

Na literatura especializada não existe um consenso (SOUZA, 2007; MELAZZO, 2010; SECCHI, 2012) sobre uma definição consensual e amplamente aceitável de políticas públicas. Desta forma, apresentamos algumas definições sobre este conceito para situar o que a literatura tem definido. Em Dicionário de políticas públicas, as políticas públicas são definidas como "decisões que envolvem questões de ordem pública com abrangência ampla e que visam à satisfação do interesse de uma coletividade" (CASTRO et al., 2012, p. 390). Como podemos perceber no conceito citado este deve abordar as questões que tratam do interesse e da coletividade pública, temas que são da exclusividade do Estado (SENADO FEDERAL, 2010).

Leonardo Secchi (2012, p. 1), em Políticas públicas: conceitos, esquemas de análises, casos práticos, afirma que "políticas públicas tratam do conteúdo concreto e do conteúdo simbólico de decisões políticas, e do processo de construção e atuação dessas decisões”. Para este autor o conceito deve focar nos conteúdos, decisões e processos que estão relacionados à tomada de decisões destas políticas. Para ele, "uma política pública é uma diretriz elaborada para enfrentar um problema público" (SECCHI, 2012, p. 2). Toda política deve partir da existência de um problema que deva merecer atenção do governo. Segundo ele, "a razão para o estabelecimento de uma política pública é o tratamento ou a resolução de um problema entendido como coletivamente relevante" (p. 2).

Enrique Saravia (2006, p. 28), em Introdução a teoria da política pública, afirma que política pública "trata-se de um fluxo de decisões públicas, orientado a manter o equilíbrio social ou a introduzir desequilíbrios destinados a modificar essa realidade". Para este autor, o foco deste conceito deve está relacionado às decisões públicas que afetam uma determinada realidade.

Everaldo Melazzo (2010, p. 11), em Problematizando o conceito de políticas públicas: desafios a análises e a prática do planejamento e da gestão, argumenta que "a política pública pode ser compreendida como um campo de investigação que nasce da ciência política, como o seriam as investigações em torno do estudo de governos, administração pública, 
relações internacionais e comportamento político". Para ele o foco do conceito está relacionado ao Estado e suas instituições. Ainda para este autor, "podemos definir política pública como toda ação permanente e abrangente do poder público em uma determinada área de atuação, seja econômica, ambiental, urbana ou outras" (MELAZZO, 2010, p. 14).

Klaus Frey (2000), em Políticas públicas: um debate conceitual e reflexões a práticas da análise de políticas públicas no Brasil, apresenta uma sistematização de políticas públicas em três dimensões: a dimensão institucional, a dimensão processual e a dimensão material. Segundo ele, "essas três dimensões tem-se adotado na ciência política o emprego dos conceitos em inglês de 'polity' para denominar as instituições políticas, 'politics' para os processos políticos e, por fim, 'policy’ para os conteúdos da política” (FREY, 2000, p. 216).

Para ele a dimensão institucional 'polity' se refere à ordem do sistema político, delineada pelo sistema jurídico, e à estrutura institucional do sistema político-administrativo. No sistema da dimensão processual 'politics' tem-se em vista o processo político, frequentemente de caráter conflituoso, no que diz respeito à imposição de objetivos, aos conteúdos e às decisões de distribuição. A dimensão material 'policy’ refere-se aos conteúdos concretos, isto é, à configuração dos programas políticos, aos problemas técnicos e ao conteúdo material das decisões políticas (FREY, 2000, p. 216-217). Estas três dimensões levantadas pelo autor são de grande importância para a compreensão analítica das políticas públicas.

Howlett, Ramesh e Perl (2013, p. 5), em Políticas públicas: seus ciclos e subsistemas: uma abordagem integradora, afirmam que "a policy-making trata fundamentalmente de atores cercados por definições que tenta compatibilizar objetivos políticos (policygoals) como meios políticos (policymeans), num processo que pode ser caracterizado como 'resolução aplicada de problemas"”. Para eles, "quando falamos em políticas púbicas, estamos sempre nos referindo às iniciativas sancionadas por governos" (HOWLETT; RAMESH; PERL 2013, p.7). Estes autores reafirmam a ênfase que as ações governamentais possuem nas análises das políticas públicas. Esta análise deve enfatizar o que fazem ou o que deixam de fazer os governos nos mais variados setores de atuação governamental.

Eduardo Marques (2013, p. 24), em As políticas púbicas na ciência política, argumenta que políticas públicas "trata do conjunto de ações implementadas pelo Estado e pelas autoridades governamentais em um sentido amplo". Como podemos perceber, o autor foca sua análise na atuação do governo como legítimo representante do Estado. Segundo ele, “as políticas públicas envolvem a consideração de ao menos dois tipos de causalidade - um sobre as causas do problema a ser objeto da política e outro sobre o efeito pretendido da 
política sobre tal problema" (MARQUES, 2013, p. 25). Estas constatações são importantes para o estudo analítico das políticas públicas, que têm no ator estatal objeto de investigação. $\mathrm{O}$ Estado ao elaborar suas políticas públicas demonstra suas reais intencionalidades por meio destes documentos que são criados com a finalidade de solucionar um determinado problema.

Celina Souza (2006, p. 26), em Políticas púbicas: uma revisão de literatura, resume políticas públicas como “colocar o governo em ação”. Neste sentido, este conceito está fortemente relacionado à ação política do governo ao enfrentar um determinado problema público.

\subsection{Antecedentes ligados ao biodiesel no Brasil}

A história do biodiesel (BNDES; CGEE, 2008; GENTIL, 2011; KNOTHE et al, 2006; FONTANA, 2011) está ligada a dois pioneiros da industrialização, Henri Ford inventor do primeiro automóvel, Ford T, e Rudolf Diesel inventor do motor de combustão interna, o motor diesel. A primeira tentativa de se utilizar óleo de origem vegetal em motores ocorre no início do século XX quando “o Dr. Diesel, em 1900, apresentou um motor na Exposição Internacional de Paris, queimando óleo de amendoim" (GENTIL, 2011, p, 117).

No entanto o uso do óleo vegetal de amendoim acabava reduzindo a vida útil destes equipamentos, problema este superado somente em 1937 pelo Belga George Chavanne da Universidade de Bruxelas descobridor do processo de transesterificação.

Desde a experiência do Dr. Diesel utilizando óleo de amendoim como combustível em seu motor várias tentativa foram realizadas no mundo tendo como objetivo o uso de óleo vegetal em motores.

O biodiesel tem sido empregado nos transportes veiculares (BNDES; CGEE, 2008) de combustão interna desde o século XIX. O seu emprego foi substituído "pelo óleo diesel à medida que os combustíveis derivados de petróleo passaram a ser abundantes e baratos, a partir do início do século passado" (BNDES; CGEE, 2008, p. 25).

O desenvolvimento da indústria de biocombustiveis trará profundas alterações geopolíticas paras as relações dos países no campo da energia. A oferta de agroenergia colocará em cena os grandes produtores agrícolas dentre os quais o Brasil, que conta com condições excepcionais de disponibilidade de terras, mão de obra, sol, água etc. Desta forma a limitação geológica petrolífera existente em muitos países dará lugar à possibilidade de geração de energia em novas bases, no caso a agroenergia. Neste sentido, "no caso da energia 
[...] haverá uma revolução profunda, comparável a que se seguiu ao uso do carvão ao petróleo. O uso de novas fontes de energia poderá libertar muitos países da maioria de suas limitações geográficas" (CONANT; GOLD, 1981, p.17).

O contexto econômico mundial durante a década de 1970 foi marcado pelas crises do petróleo em dois momentos, 1973 e 1979. Esta crise fez com que medidas fossem adotadas pelos governos de países dependentes do petróleo, entre os quais figurava o Brasil naquele momento histórico.

A reestruturação da economia energética mundial afetou o Brasil contribuindo para a criação da sua política pública de etanol em 1974 e de biodiesel em 2004. Desta forma, o país responde à crise energética de 1973 e 1979, criando a primeira política de etanol do mundo por meio do Programa Nacional de Álcool (Proálcool) ${ }^{34}$, criada no governo Médici. Esta ação em pouco tempo se tornou uma referência mundial de sucesso com a conversão de carros para o uso de álcool, porém esta política teve descontinuidade durante as décadas de 1980/1990, o que fez com que a opção por etanol fosse completamente abandonada, só sendo retomada no início dos anos 2000.

A crise do petróleo da década de 1970 foi determinante para a criação do Proálcool no Brasil, o que ajudou na redução da dependência brasileira do petróleo naquele momento. Atualmente o país é o maior produtor e exportador de etanol do mundo.

Desta forma o desenvolvimento de novas matrizes energéticas como o etanol e o biodiesel é uma resposta do Brasil à conjuntura externa (crise do petróleo) aliados a fatores internos como a disponibilidade de terras, água, capitais e mão-de-obra, que dá ao país grandes vantagens em relação aos demais países do mundo em matéria de agroenergia.

Como lembra Sachs (2005, p.202) "se há um país onde se pode pensar em construir uma civilização moderna da biomassa, este país é o Brasil". Vale destacar que o território brasileiro apresenta vantagens excepcionais para o desenvolvimento de energia de biomassa, como o etanol e o biodiesel.

A história de nosso país tem sido marcada desde os primeiros anos da fase do Brasil Colônia pela exploração da cana-de-açúcar (ANTONIL, 1982), a principal matéria-prima do etanol no país. No período colonial a cana-de-açúcar era usada para alimentos, e bastante solicitada pela Europa. Na atualidade grande parte deste produto cultivado em nosso país tem como uso a produção de etanol.

\footnotetext{
${ }^{34}$ Programa governamental criado a partir do Decreto $\mathrm{n}^{\mathrm{o}} 76.593$, de 14.11 .1975 , posteriormente modificado pelo Decreto $\mathrm{n}^{\circ}$ 80.762, de 1977, para conter gastos com importação de petróleo devido à crise ocasionada pela OPEP (BRASIL, 2005a, p. 10).
} 
A energia de biomassa constitui a mais antiga forma de energia já utilizada pelo homem com o uso da lenha para as atividades domésticas, aquecimento e iluminação (BNDES; CGEE, 2008, p.33).

A história do etanol no Brasil data do ano de 1920, quando o extinto Instituto do Açúcar e do Álcool (IAA) e a Escola Superior de Agricultura Luiz de Queiroz (Esalq) tiveram papel central neste setor. Porém é somente a partir da década de 1970 que o país teve na criação do Proálcool uma política pública explícita para este setor de biocombustível.

O contexto externo relacionado à crise do petróleo de 1973, o aumento dos dispêndios do Brasil com a importação de petróleo e a capacidade ociosa da indústria canavieira foram os pontos determinantes para a criação do Proálcool (IPEA, 2010, p. 2). Porém, o aumento da oferta interna e a redução dos preços do petróleo, verificados na década de 1980, levaram o governo a retirar por completo os subsídios ao álcool em 1986, o que provocou uma retração do setor.

Durante as décadas de 1980 e 1990 a conjuntura do Proálcool levou ao desestímulo de uso do álcool no país. Desta forma, "o carro movido a álcool hidratado [...] perdeu competitividade em relação aos carros a gasolina. Porém, a obrigatoriedade de uso do álcool anidro $^{35}$ na mistura com a gasolina, [...] mantiveram o programa vivo" (IPEA, 2010, p. 2). Em 2003, com o lançamento do carro flexfuel $^{36}$ o consumo de etanol hidratado ${ }^{37}$ voltou a crescer com grande velocidade, dando novo impulso ao setor de etanol no Brasil. Desde o lançamento do carro flex, o setor canavieiro passou por grandes transformações no Brasil. Esta conjuntura permitiu ao país se tornar uma referência mundial em etanol ao lado dos Estados Unidos, abrindo grandes possibilidades de inserções geopolítica do Brasil no mercado internacional de agroenergia.

Neste sentido, "a vantagem comparativa do Brasil em relação aos biocombustíveis pode ser fundamental para a consolidação do desenvolvimento do país e do seu novo papel no mundo" (SIMÕES, 2007, p. 11). No país importantes políticas públicas de agroenergia (BRASIL, 2005a; 2005b; 2010a) apontam para a necessidade de atuação do Estado no direcionamento do setor.

Em nosso país "as primeiras referências de uso de óleos vegetais no Brasil datam da década de 1920” (NAE, 2004, p.95). No entanto, esta política de uso de óleo vegetal não teve

\footnotetext{
${ }^{35}$ Possui menos de 99,6\% de graduação alcoólica, dessa forma o álcool anidro é praticamente etanol puro. A palavra anidro tem origem na palavra grega e significa "sem água" (www.novacana.com).

${ }^{36}$ Veículos flexíveis que permitem a utilização de álcool hidratado, gasolina ou qualquer mistura entre os dois combustíveis (BRASIL, 2005a, p. 10).

${ }^{37}$ Possui em sua composição entre $95,1 \%$ e $96 \%$ de etanol e o restante de água (www.novacana.com).
} 
continuidade, só sendo retomada na década de 1980, quando foi criado o Programa Nacional de Produção de Óleos Vegetais pra Fins Energéticos $\left(\right.$ Proóleo $^{38}$ ). Paralelamente na Universidade Federal do Ceará (UFC), o professor Expedito Parente ${ }^{39}$ dava passos importantes para o domínio do biodiesel. Como destaca Simões (2007, p. 22), “é preciso registrar o pioneirismo do professor Expedito Parente, cearense detentor da primeira patente mundial do biodiesel". O pioneirismo do professor Expedito Parente no setor de biodiesel poderia ter sido mais bem incentivado pelo Estado brasileiro que perdeu ali uma excelente oportunidade de colocar o Brasil na liderança mundial desta fonte de energia renovável.

Segundo Silva (2013, p. 20) "nesse período, o Ceará ganhou destaque por meio da empresa PROERG ${ }^{40}$, que desenvolveu dois tipos de óleos combustíveis derivados de sementes de maracujá e de origem animal, extraídos de peixes". Mesmo com estes avanços esta empresa foi extinta na década de 1970, deixando um grande vácuo que somente no início dos anos 2000 seria retomada. Desta forma o Brasil perdeu uma grande oportunidade de consolidar-se como grande potência de biodiesel. Concluído o contrato da Proerg com o Ministério da Aeronáutica, o projeto foi paralisado completamente.

Este processo foi descrito pelo próprio professor Expedito Parente (2006), quando afirma que "[...] todo o acervo de equipamentos da Proerg foi transferido para a sede do CTA em São José dos Campos-SP e, por várias razões [...] as atividades de produção experimental de óleo diesel vegetal foram paralisadas" (PARENTE, 2006, p.92).

Em 1986, devido à grave crise econômica que passava o país, os programas de biocombustíveis (Proálcool e Proóleo) foram abandonados pelo governo federal (IPEA, 2010; SILVA, 2013). Neste ano o governo retira os últimos subsídios do Proálcool (IPEA, 2010) bem como abandona por completo o Proóleo (SILVA, 2013). A questão do biodiesel retorna a pauta das políticas públicas somente em 2002 com a criação do Programa Brasileiro de Biocombustíveis (Probiodiesel ${ }^{41}$ ).

\footnotetext{
${ }^{38}$ Antigo Plano de Produção de Óleos Vegetais para Fins Energéticos.

${ }^{39}$ Professor aposentado da Universidade Federal do Ceará, detentor da patente PI- 08007957 de 1980, que foi a primeira patente mundial do biodiesel e do querosene de aviação (bioquerosene), a qual entrou em domínio público, pelo tempo e desuso. No final de 1982 o querosene vegetal para aviões a jato estava pronto. Após exaustivos testes, o bioquerosene foi aprovado e homologado pelo Centro Técnico Aeroespacial (CTA), e, no dia do aviador (24 de outubro de 1984), uma aeronave nacional "Bandeirante" de fabricação Embraer, decolou de São José dos Campos para sobrevoar Brasília (PARENTE, 2006, p. 92).

${ }^{40}$ Produtora de Sistemas Energéticos Ltda. que implantou uma unidade piloto industrial com a capacidade produtiva de 200 litros por hora em FortalezalCeará. A referida planta piloto foi financiada pela Financiadora de Estudos e Projetos (FINEP) e recebeu apoio do Ministério da Aeronáutica (PARENTE, 2006, p. 92).

${ }^{41}$ Instituído pela Portaria MCT no 702, de 30.10.2002, o Programa Brasileiro de Desenvolvimento Tecnológico de Biodiesel (Probiodiesel) tem como objetivo promover o desenvolvimento científico e tecnológico de biodiesel, a partir de ésteres etílicos de óleos vegetais puros e/ou residuais.
} 
Mediante o Decreto Presidencial não numerado de dois de julho de 2003 o governo federal instituiu o Grupo de Trabalho Interministerial (GTI) encarregado de analisar a viabilidade da introdução do biodiesel na matriz energética nacional como energia alternativa ao uso do petróleo.

No documento oficial ${ }^{42}$ apresentado pelo grupo de trabalho do biodiesel, o Relatório do grupo de trabalho interministerial encarregado de apresentar estudos sobre a viabilidade de utilização de óleo de vegetal: biodiesel como fonte alternativa de energiarecomenda-seque os benefícios do uso do biodiesel no Brasil devem contemplar a inclusão social, os aspectos econômicos e ambientais (BRASIL, 2003a).

Em seu artigo $1^{\circ}$, o referido decreto dispõe que o GTI "será encarregado de apresentar estudos sobre a viabilidade de utilização de óleo vegetal - biodiesel como fonte alternativa de energia, propondo, caso necessário, as ações necessárias para o uso do biodiesel".

Ao analisar as Atas das reuniões do grupo de trabalho interministerial biodiesel, constata-se que os motivos que levaram à constituição do GTI foram, entre outras ações políticas, a "melhora da balança de pagamentos, tendo em vista a possível redução deimportação de óleo diesel; utilização do biodiesel como vetor de crescimento econômico, geração deempregos e desenvolvimento do país" (BRASIL, 2003c, p.2). Este documento destaca pontos de grande relevância para a introdução do biodiesel na matriz energética brasileira, dentre eles a importação de óleo diesel para atender a demanda nacional deste produto.

Os Relatórios finais dos subgrupos do grupo de trabalho interministerial biodiesel apontam que "as ações de governo precisam ser priorizadas para a região Nordeste por concentrar o maior número de agricultores familiares e para a região Norte pelo potencial da terra [...]" (BRASIL, 2003d, p.7).

Este relatório recomenda a introdução do biodiesel na matriz energética brasileira, o que ocorre mediante a lei 11.097/2005. Este documento sugere a criação da Comissão Executiva Interministerial do Biodiesel (CEIB) e de um Grupo Gestor, que seria responsável pela execução das políticas e da criação de um marco regulatório para o setor de biodiesel no Brasil (BRASIL, 2003d).

As recomendações do GTI foram acolhidas pelo governo que mediante o decreto não numerado, de 23 de dezembro e 2003, criou o CEIB e o Grupo Gestor do Biodiesel. O PNPB

${ }^{42}$ O GTI apresentou os seguintes documentos conclusivos: Relatório final (BRASIL, 2003a); Resumo do posicionamento dos órgãos e entidades. Anexo I (BRASIL, 2003b); Atas das reuniões. Anexo II. (BRASIL, 2003c). Relatórios finais dos subgrupos. Anexo III (BRASIL, 2003d). 
é considerado uma política agroenergética. Este programa é resultado dos interesses do agronegócio (MAPA) de criar novas oportunidades de mercado para a soja, somados a interesse da pasta energética (MME) que procurava enfrentar o problema da importação e os dispêndios com a importação de petróleo. Na formulação da agenda do PNPB os então ministros Roberto Rodrigues (MAPA) e Dilma Rousseff (MME) tiveram um papel proativo nesta política no âmbito do Executivo Federal.

No âmbito das discussões do Congresso Nacional os deputados federais da base governista Mariângela Duarte e Rubens Otoni, do PT, e o deputadofederal da oposiçãoAriosto de Holanda, do PSDB, atuaram em diferentes frentes durante a criação do PNPB. Os deputados Mariângela Duarte e Rubens Otoni representando a Câmara dos Deputados participaram dos ciclos de audiências promovidas pelo GTI. Estas audiências tiveram como objetivo uniformizar os membros do GTI sobre a existência de estudos e experiências sobre o biodiesel no Brasil e no mundo (BRASIL, 2003b).

Já o deputado Ariosto de Holanda ${ }^{43}$ ficou encarregado da relatoria que detalha o tema do biodiesel e inclusão social da Câmara dos Deputados. Os principais atores representados na formulação da agenda do PNPB estão representados no Quadro 13.

Quadro 13: Atores presentes no processo de formulação da agenda do PNPB

\begin{tabular}{|c|c|c|c|}
\hline Ator & Representação & Representantes & Interesses \\
\hline \multirow{2}{*}{$\begin{array}{l}\text { Executivo } \\
\text { Federal }\end{array}$} & $\begin{array}{l}\text { Ministério da } \\
\text { Agricultura, Pecuária e } \\
\text { Abastecimento }\end{array}$ & Ministro Roberto Rodrigues & $\begin{array}{l}\text { Incentivar mercado para } \\
\text { óleo de soja. }\end{array}$ \\
\hline & $\begin{array}{l}\text { Ministério de Minas e } \\
\text { Energia }\end{array}$ & Ministra Dilma Rousseff & $\begin{array}{l}\text { Promover independência } \\
\text { energética }\end{array}$ \\
\hline \multirow{3}{*}{$\begin{array}{l}\text { Congresso } \\
\text { Nacional }\end{array}$} & \multirow{2}{*}{$\begin{array}{l}\text { Deputados federais da } \\
\text { base governista }\end{array}$} & $\begin{array}{l}\text { Deputada federal Mariângela } \\
\text { Duarte } \\
\text { Partido: PT }\end{array}$ & $\begin{array}{l}\text { Apoio a ciência e } \\
\text { tecnologia }\end{array}$ \\
\hline & & $\begin{array}{l}\text { Deputado federal Rubens Otoni } \\
\text { Partido: PT }\end{array}$ & $\begin{array}{l}\text { Movimento sindical e } \\
\text { apoio a ciência e } \\
\text { tecnologia }\end{array}$ \\
\hline & $\begin{array}{l}\text { Deputados federais da } \\
\text { oposição }\end{array}$ & $\begin{array}{l}\text { Deputado federal Ariosto de } \\
\text { Holanda } \\
\text { Partido: PSDB }\end{array}$ & $\begin{array}{l}\text { Apoio à ciência e } \\
\text { tecnologia }\end{array}$ \\
\hline
\end{tabular}

Fonte: Pedroti (2011)

A formulação da agenda do PNPB, representada pela criação do GTI, contou com a participação do setor público e privado. Podemos agrupar em seis grandes grupos (Executivo

\footnotetext{
${ }^{43}$ O relatório apresentado pelo deputado foi publicado com o título "Biodiesel e inclusão social", pela Câmara dos Deputados, em 2004 (Série Cadernos de Altos Estudos, n. 1).
} 
Federal, Congresso Nacional, Universidades, Setor Privado, Movimentos Sociais Organizados e Outros) presentes nas audiências promovidas pelo GTI. O Executivo Federal esteve representado pela ANP, Embrapa, MDA, Petrobras e MME. Seus representantes destacam dentre os outros fatores a necessidade da introdução do biodiesel na matriz energética nacional com aproveitamento das potencialidades regionais e gerando emprego e renda para a população atendida.

O Congresso Nacional esteve representado pelos deputados federais Mariângela Duarte e Rubens Otoni que destacaram a necessidades de combater a nossa dependência energética. O segmento das universidades foi representado pela UnB, USP e UFRJ que destacaram pesquisas realizadas por elas. O setor privado foi representado pela ABIOVE, Anfavea, CNA, Enguia Power, Sindaçucar, SVC, Soyminas, Tecbio e Única. O setor privado destacou, entre outras questões, os benefícios econômicos, sociais, ambientais que o biodiesel pode trazer ao Brasil. O setordos movimentos sociais organizados esteve representado pela CUT, que destacou a necessidade de se promover a inclusão social no biodiesel. E por fim o segmento outros representados pela Famen e pela SECTI destacaram que a implantação do biodiesel poderia trazer diversos benefícios para os estados do Maranhão e Bahia, respectivamente.

A presença destes setores no ciclo de audiências promovidas pelo GTI indica a existência de três grandes grupos temáticos que viriam a ter presença permanente no PNPB. Como apontam Flexor et al. (2011, p. 84-86), é possível verificar três grupos de atores na formulação do PNPB, o grupo de atores da área energética, o grupo de atores do agronegócio e o grupo de atores do desenvolvimento agrário". Estes três grupos de atores dão a direção das políticas que o PNPB tem tomado desde a sua criação, em 2004.

Os resultados finais do GTI apontaram para a enorme capacidade produtiva de biomassa no país; a possibilidade de redução das importações de óleo diesel; a disponibilidade de áreas agrícolas não utilizadas e a ótima chance de se criar mecanismos de participação de agricultores familiares da cadeia produtiva do biodiesel (BRASIL, 2010a). Os resultados apresentados pelo GTI subsidiaram a criação do PNPB, em 2004, e do Plano Nacional de Agroenergia (PNA ${ }^{44}$ ), em 2005

\footnotetext{
${ }^{44}$ Este plano define a atuação para o setor de agroenergia, tendo como objetivos específicos, vinculados ao atendimento das pressões sociais, das demandas dos clientes e das políticas públicas, são: a) apoiar a mudança da matriz energética, com vistas à sua sustentabilidade; b) propiciar condições para o aumento da participação de fontes de agroenergia na composição da matriz energética; c) gerar condições para permitir a interiorização e regionalização do desenvolvimento, fundadas na expansão da agricultura de energia e na agregação de valor na cadeia produtiva; d) suportar oportunidades de expansão do emprego no âmbito do agronegócio; e) permitir a ampliação das oportunidades de renda, com distribuição mais equiitativa entre os atores; f) contribuir para a
} 


\subsection{Programa Nacional de Produção e Uso do Biodiesel (PNPB)}

O PNPB foi criado em 2004 como política pública tendo como objetivos a "produção e o uso do biodiesel, com ênfase no caráter social dado ao programa, por meio da inclusão de agricultores familiares, com perspectivas de gerar emprego e renda e, portanto, proporcionar o desenvolvimento regional" (SILVA, 2013, p.21).

Durante o lançamento oficial do PNPB (Figura 17), ocorrido no Palácio do Planalto (Brasília), em 6 de dezembro de 2004, o então presidente Luiz Inácio Lula da Silva afirmou que "o programa está dirigido num primeiro momento para a gente tentar resolver os graves problemas sociais de uma região do Brasil que há muitos e muitos anos está esquecida. Por isto estamos privilegiando a mamona e a palma do Nordeste e do Norte do país" (AGÊNCIA BRASIL, 06.12.2004).Nesta solenidade, o então presidente elogiou sua equipe de trabalho afirmando que "eu penso que agora vocês conseguiram produzir um projeto, que ele pode significar muita coisa para as regiões mais pobres do Brasil" (AGÊNCIA BRASIL, 06.12.2004).Pelo que contatamos no discurso presidencial, o PNPB foi concebido para atender inicialmente as regiões mais carentes do Brasil, o Nordeste e o Norte, onde a expansão agrícola da mamona e do dendê figura como parte da estratégia de consolidação deste programa.

Figura 17: Cerimônia de lançamento do Programa Nacional de Biodiesel

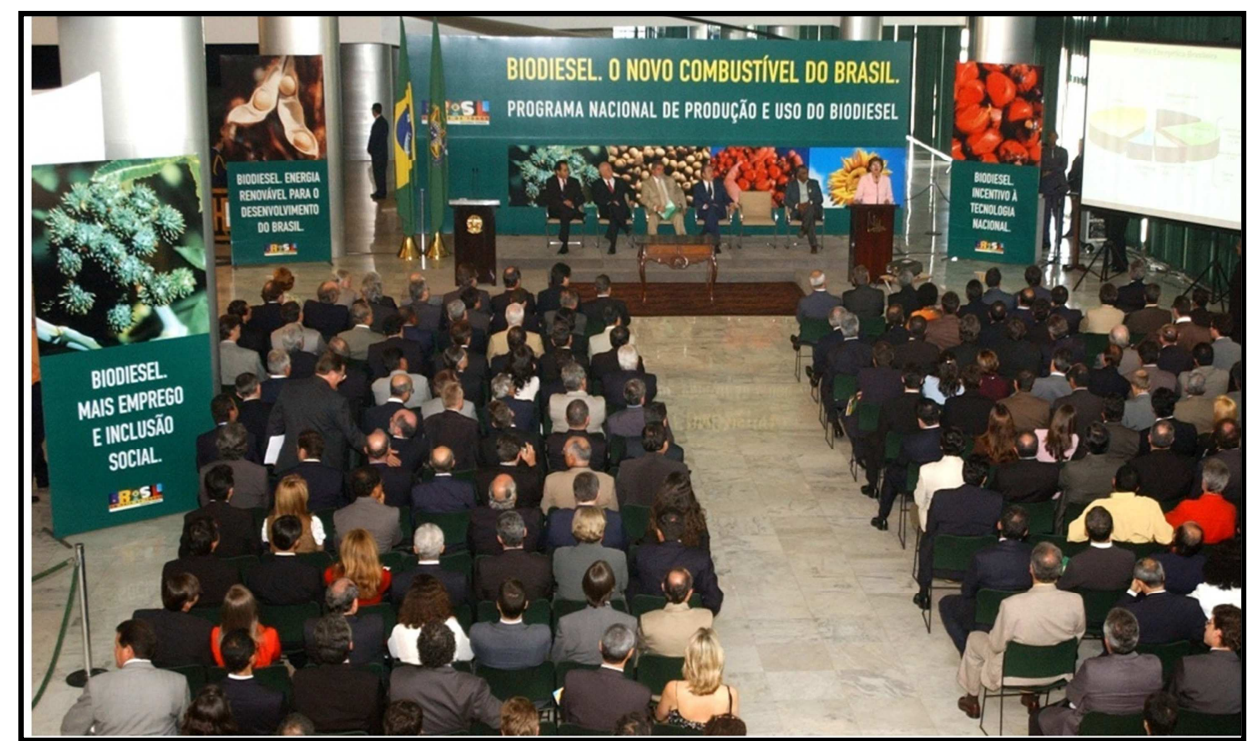

Fonte: Wilson Dias (2004). Agência Brasil

Desta forma, o PNPB nasce fortemente comprometido em promover o desenvolvimento social e regional das regiões mais carentes do Brasil.

redução das emissões de gases de efeito estufa; g) contribuir para a redução das importações de petróleo; $h$ ) contribuir para o aumento das exportações de biocombustíveis (BRASIL, 2005a). 
Em entrevista ao programa quinzenal de rádio Café com Presidente, a então ministra de Minas e Energia Dilma Rousseff afirmou que "em 2005, iríamos importar 4 bilhões de litros. Com esse programa, nós vamos poupar. Vamos gerar 800 milhões de litros de origem vegetal. Esses 800 milhões de litros vão ficar aqui no Brasil”(AGÊNCIA BRASIL, 13.12.2004). Ela ainda completou nesta entrevista que esta política iria "gerar emprego e renda nas regiões mais pobres do Brasil, no Nordeste, na região do semi-árido, no Norte, nas regiões do semiárido, nos outros cantos do Brasil" (AGÊNCIA BRASIL, 13.12.2004).

Para cumprir as orientações governamentais o PNPB está estruturado em diretrizes. Segundo Brasil (2010a, p.3), as principais diretrizes do programa são: a) implantar um programa sustentável, promovendo inclusão social por meio da geração de renda e emprego; b) garantir preços competitivos, qualidade e suprimento; c) produzir o biodiesel a partir de diferentes fontes oleaginosas, fortalecendo as potencialidades regionais para a produção de matéria-prima.

O desenho original de criação do PNPB não impõe qualquer restrição ao uso de matérias-primas e rotas tecnológicas. Como lembra Brasil (2004, p. 4), “o PNPB é, essencialmente, um programa não restritivo. A sua implantação contempla as especificidades regionais no que se refere ao tipo de oleaginosas, não excluída qualquer alternativa”.

Como lembra Castro (2011, p. 9), “as regras permitem a produção a partir de diferentes oleaginosas e rotas tecnológicas, possibilitando a participação do agronegócio e da agricultura familiar". No desenho original do PNPB afirma-se que "além do agronegócio, o programa privilegia a participação da agricultura familiar, estimulando a formação de cooperativas e consórcios entre produtores" (BRASIL, 2004, p. 4). Este programa contempla a participação do agronegócio e da agricultura familiar e tem ações que visam a produção de biodiesel.

Neste sentido, o programa visa estimular a presença das especificidades regionais por meio de diferentes culturas agrícolas presentes nestas regiões. No Norte, a aposta é o dendê (óleo de palma); no Nordeste, a mamona, a soja, o algodão, o pinhão manso e o amendoim; no Centro-Oeste, a soja, a mamona, o girassol, o pinhão manso e o amendoim; no Sudeste, a soja, a mamona, o algodão, o girassol e o amendoim e; no Sul, a soja, a canola, o girassol e o algodão. O PNPB tem como foco contribuir para o desenvolvimento regional.

No Norte, o programa tem como meta contribuir para a geração de energia em comunidades isoladas que têm dificuldades na obtenção de óleo diesel para a geração de energia elétrica. No Nordeste o foco tem sido a inclusão social por meio da geração de emprego e renda no campo. No Centro-Oeste, o foco está relacionado ao aproveitamento 
comercial da soja, grande reivindicação do setor de agronegócio da região. No Sudeste, o foco é a melhoria das condições ambientais das cidades. No Sul, as melhorias das condições ambientais a geração de renda principalmente para a agricultura familiar organizada, como se pode verificar no Quadro 14.

Quadro 14: Motivações regionais na produção de biodiesel no Brasil

\begin{tabular}{|l|l|l|}
\hline \multicolumn{1}{|c|}{ Região } & \multicolumn{1}{|c|}{ Motivações regionais } & \multicolumn{1}{c|}{ Matéria-prima } \\
\hline Norte & $\begin{array}{l}\text { Geração de energia elétrica em áreas } \\
\text { remotas e de difícil acesso. Atender barcos } \\
\text { e embarcações. }\end{array}$ & Dendê \\
\hline Nordeste & $\begin{array}{l}\text { Promoção de políticas públicas de inclusão } \\
\text { social }\end{array}$ & $\begin{array}{l}\text { Mamona, soja, algodão, } \\
\text { pinhão manso e amendoim }\end{array}$ \\
\hline Centro-Oeste & $\begin{array}{l}\text { Aproveitamento local da soja. Redução do } \\
\text { frete para o transporte do diesel das regiões } \\
\text { litorâneas }\end{array}$ & $\begin{array}{l}\text { Soja, mamona, girassol, } \\
\text { pinhão manso e amendoim }\end{array}$ \\
\hline Sudeste & $\begin{array}{l}\text { Melhoramento da qualidade do ar nas } \\
\text { grandes cidades com a redução das } \\
\text { emissões do diesel }\end{array}$ & $\begin{array}{l}\text { Soja, mamona, algodão, } \\
\text { girassol e amendoim }\end{array}$ \\
\hline Sul & $\begin{array}{l}\text { Melhoramento da qualidade do ar nas } \\
\text { grandes cidades com a redução das } \\
\text { emissões do diesel }\end{array}$ & $\begin{array}{l}\text { Soja, canola, girassol e } \\
\text { algodão }\end{array}$ \\
\hline
\end{tabular}

Fonte: Elaborado pelo autor com base em Abreu; Vieira; Ramos (2006).

Entre os critérios da Lei $n^{-}$11.097/2005, que introduziu o biodiesel na matriz energética brasileira, está a participação da agricultura familiar na oferta de matérias-primas e a redução das desigualdades regionais. Esta mesma lei definiu biodiesel como "biocombustível derivado de biomassa renovável para uso em motores a combustão interna e com ignição por compressão". O foco do biodiesel no Brasil está voltado para atender veículos pesados (ciclo diesel) que contempla, caminhões, ônibus, máquinas agrícolas, locomotivas e embarcações além de atender comunidades isoladas principalmente na região Norte onde o suprimento de óleo diesel pode durar meses.

A produção do biodiesel pode ser realizada por meio de diferentes rotas tecnológicas como a transesterificação ${ }^{45}$, o craqueamento $^{46}$ e a esterificação ${ }^{47}$. No Brasil não há restrição

\footnotetext{
${ }^{45}$ Transesterificação: reação química de triglicerídeos (óleos e gorduras vegetais ou animais, em que os ácidos graxos formam ésteres com o glicerol) com alguns alcoóis (metanol ou etanol), na presença de um catalisador (acido, base ou enzima), resultando na substituição do grupo éster do glicerol pelo grupo do etanol ou metanol (ABREU; VIEIRA; RAMOS, 2006).

${ }^{46}$ Craqueamento catalítico ou térmico: reação que provoca a quebra de moléculas por aquecimento a altas temperaturas, formando uma mistura de compostos químicos com propriedades muito semelhantes às dos derivados de petróleo (ABREU; VIEIRA; RAMOS, 2006).

${ }^{47}$ Esterificação: reação que envolve a obtenção de ésteres (biodiesel) a partir de alcoóis e ácidos graxos ou seus derivados (ABREU; VIEIRA; RAMOS, 2006).
} 
quanto à rota tecnológica a ser utilizada. Segundo Holanda (2004, p.26), "a inclusão social e o desenvolvimento regional, especialmente via geração de emprego e renda, devem ser os princípios básicos das ações direcionadas ao biodiesel". Para ele, "o que implica dizer que sua produção e consumo devem ser promovidos de forma descentralizada e não excludente em termos de rotas tecnológicas e matérias-primas utilizadas" (p.26).

Em 2004, ano de lançamento do PNPB, a então ministra de Minas e Energia Dilma Rousseff afirmava "que metade da produção de biodiesel no país será a partir de mamona. E em 2005 serão investidos US\$ 62 milhões na instalação de três plantas industriais para a produção do biodiesel" (HOLANDA, 2004, p.54).

A Lei $n^{\circ}$ 11.097/2005 dispôs sobre a introdução do biodiesel na matriz energética nacional, determina que em três anos a partir da publicação da lei, o óleo diesel deveria ser comercializado com $2 \%$ de biodiesel, e a partir de junho este valor passou a ser de $4 \%$ e a partir de janeiro de 2010 todos os veículos movidos a diesel passaram a utilizar a mistura de 5\% de biodiesel (CASTRO, 2011, p.11). Esta determinação temporal da porcentagem de adição do biodiesel ao diesel acabou sendo antecipada pelo CNPE que determinou que a partir de janeiro a junho de 2008, a mistura seria de 2\%; de julho de 2008 a junho de 2009, a mistura seria de 3\%; de julho a dezembro de 2009, a mistura seria de 4\%; a partir de janeiro de 2010, a mistura seria de 5\%.A Lei ${ }^{\mathrm{o}} 13.033 / 2014$, de 25 de setembro de 2014, determina que a partir de julho de 2014, a mistura passa a ser de 6\%; a partir de novembro de 2014, a mesma passa para7\% na adição do biodiesel ao óleo diesel (Quadro 15).

Quadro 15: Adição de biodiesel ao diesel no Brasil segundo atos normativos 2005-2014

\begin{tabular}{|c|c|c|c|c|c|c|c|c|c|}
\hline \multicolumn{3}{|c|}{ Lei $n^{\circ} 11.097 / 2005$} & \multicolumn{5}{|c|}{ Antecipação de metas pelo $\mathrm{CNPE}^{48}$} & \multicolumn{2}{|c|}{ Lei $\mathrm{n}^{\mathrm{o}} 13.033 / 2014$} \\
\hline $\begin{array}{r}2005 \\
\text { a2007 }\end{array}$ & $\begin{array}{c}2008 \\
\text { a } \\
2012\end{array}$ & $\begin{array}{c}\text { A partir } \\
\text { de } \\
2013\end{array}$ & $\begin{array}{l}\text { Jan.- } \\
\text { jun. } \\
2008\end{array}$ & $\begin{array}{c}\text { Jul.- } \\
\text { dez. } \\
2008\end{array}$ & $\begin{array}{l}\text { Jan.- } \\
\text { jun. } \\
2009\end{array}$ & $\begin{array}{l}\text { Jul.- } \\
\text { dez. } \\
2009\end{array}$ & $\begin{array}{c}\text { A partir } \\
\text { de jan. } \\
2010\end{array}$ & $\begin{array}{c}\text { A partir } \\
\text { de jul. } \\
2014\end{array}$ & $\begin{array}{c}\text { A partir } \\
\text { de nov. } \\
2014\end{array}$ \\
\hline $2 \%$ & $2 \%$ & $5 \%$ & $2 \%$ & $3 \%$ & $3 \%$ & $4 \%$ & $5 \%$ & $6 \%$ & $7 \%$ \\
\hline
\end{tabular}

Fonte: Organizado pelo autor com base em Brasil (2005e; 2014b).

No desenho original do PNPB determinou-se que a comercialização do biodiesel no Brasil se daria por meio de leilões que seriam realizados pela ANP. Como lembra Castro (2011, p.11), “com relação aos leilões de biodiesel, a ANP, por meio da resolução $\mathrm{n}^{\mathrm{o}}$ 31, regulamenta a realização de leilões públicos para aquisição de biodiesel. A ANP realiza, desde 2005, os leilões de biodiesel".

\footnotetext{
${ }^{48}$ Conselho Nacional de Política Energética.
} 
As políticas públicas do biodiesel no Brasil estão centralizadas nas dimensões econômicas, sociais e ambientais. Em Biodiesel: o novo combustível do Brasil, Brasil (2004, p. 2) registra que a introdução do biodiesel na matriz energética do Brasil "vai gerar expressiva economia para o Brasil, reduzindo as importações do óleo diesel de petróleo, além de contribuir para preservar o meio ambiente e promover a inclusão social de milhares de brasileiros".

A dimensão econômica visa a redução de custos de importação de óleo diesel. Para Brasil (2010a, p.1), "a entrada do biodiesel no mercado nacional vai gerar uma expressiva economia para o Brasil, reduzindo as importações do diesel de petróleo, além de contribuir para preservar o meio ambiente e promover a inclusão social". Neste sentido, "o biodiesel destaca o papel do Brasil como referência mundial no uso de fontes renováveis. Essa posição foi conquistada a partir da década de 1970, com o início da utilização do álcool em veículos automotivos" (BRASIL, 2010a, p.1).

De acordo com o site ${ }^{49}$ oficial do PNPB, "desde o lançamento do PNPB até final de 2011, o Brasil produziu 8,3 bilhões de litros de biodiesel, reduzindo as importações de diesel em um montante de 5,3 bilhões de dólares".

Esta dimensão econômica é destacada por este site eletrônico que afirma que somente com "o uso do B2 (mistura de $2 \%$ do biodiesel ao diesel) cria um mercado potencial para a comercialização de 800 milhões de litros de biodiesel/ano, o que representa uma economia da ordem de U\$\$ 160 milhões na importação de biodiesel".

A dimensão social visa à incorporação de milhares de pequenos agricultores. Segundo Fabrini (2010, p. 77), o PNPB "visa incorporar 100 mil famílias de pequenos agricultores a produção, evitando a pobreza no campo e o deslocamento da população para as grandes cidades em busca de empregos".

Enquanto que a dimensão ambiental visa à redução de emissões de gases poluentes e a incorporação de milhares de hectares de terras já desmatadas. As três vertentes do PNPB seguem as recomendações sugeridas pelo GTI, como se verifica no Quadro 16.

\footnotetext{
${ }^{49}$ Disponível em: www.mme.gov.br/programa/biodiesel. Acesso em: 22 nov. 2014.
} 
Quadro 16: As vertentes do PNPB

\begin{tabular}{|l|l|}
\hline \multicolumn{1}{|c|}{ Vertentes } & \multicolumn{1}{c|}{ Objetivos } \\
\hline Econômica & Redução da importação de petróleo \\
\hline Social & Selo combustível social \\
\hline Ambiental & Protocolo de Kyoto. \\
\hline
\end{tabular}

Fonte: Elaborado pelo autor com base em Brasil (2004)

As vertentes do PNPB, representadas no tripé econômico/social/ambiental, visam atender as três grandes áreas que justificam a criação e execução desta política pública agroenergética.

\subsubsection{Arenas decisórias do PNPB: CEIB e Grupo Gestor}

Do ponto de vista da engenharia política, o PNPB constitui-se em um importante espaço de atuação dos diferentes atores governamentais. Como lembra Pedroti (2013, p.14), "há necessidade de se coordenar tanto os diferentes atores governamentais e sociais que participam de uma gestão como também os diversos interesses que permeiam a política pública".

Vale destacar que a criação do PNPB como política pública visou contemplar a presença do agronegócio, da agricultura familiar e da indústria de biodiesel na formação da cadeia e mercado do biodiesel no Brasil. Este três segmentos precisavam ser contemplados com uma política que pudesse atender o setor. Desta forma, "a preocupação era elaborar uma política eficaz, tanto do ponto de vista econômico como energético, e que agregasse em seus objetivos a temática de inclusão social" (PEDROTI, 2013, p. 15).

Para implantar as ações do biodiesel como fonte alternativa de energia, o governo federal publicou o Decreto de 23 de dezembro de 2003, que instituiu a CEIB e o Grupo Gestor, responsáveis pela gestão do programa. Em seu artigo segundo, este decreto descreve que compete à CEIB: 1) Coordenar a implantação das recomendações constantes do relatório do grupo de trabalho interministerial; 2) Elaborar, implementar e monitorar programa integrado para a viabilização do biodiesel; 3) Propor atos normativos que se fizerem necessários à implantação do programa e 4) Analisar, avaliar e propor outras recomendações e ações, diretrizes e políticas públicas não previstas no relatório do GTI. Para isto, foi instituído 
a CEIB que é coordenada pela Casa Civil da Presidência da República e demais órgãos da administração federal ${ }^{50}$.

Este mesmo decreto descreve que a CEIB terá como unidade executiva um Grupo Gestor, sendo encarregado da execução das ações operacionais e administrativas voltadas para o cumprimento das estratégias e diretrizes estabelecidas pela CEIB. O Grupo Gestor é composto por integrantes de diferentes órgãos da administração federal ${ }^{51}$.

A execução da política de biodiesel no Brasil passa pela atuação de diversos setores públicos representados pelo Executivo Federal e pelo Congresso Nacional. O papel destes setores se deve ao fato de que a questão do biodiesel perpassa por uma ampla temática que envolve a política energética, gestão, meio ambiente, competitividade, planejamento, foro de consulta, cooperação internacional, criação de marco legal, infraestrutura, fiscalização e controle legislativo. No âmbito do Executivo Federal ${ }^{52}$, oito representações atuam em diferentes temáticas, mesmo número de representações presentes no Congresso Nacional ${ }^{53}$.

A formulação de alternativas sociais para o PNPB passa por três grupos de atores. Como afirmam Abramovay e Magalhães (2007, p. 14), “a formação do mercado de biodiesel, com a dimensão da responsabilidade social, é o resultado da coalizão de interesses de três atores: empresas e movimentos sociais, sob a coordenação do governo federal”. Neste jogo político cada ator desempenha um papel importante na cadeia do biodiesel, “[...] empresas passam a adotar a responsabilidade social como núcleos de seus negócios, movimentos

\footnotetext{
${ }^{50}$ Casa Civil da Presidência da República/Coordenação, Secretaria de Comunicação de Governo e Gestão Estratégica da Presidência da República, Ministério da Fazenda (MF), Ministério dos Transportes (MT), Ministério da Agricultura, Pecuária e Abastecimento (MAPA), Ministério do Trabalho e Emprego (MTE), Ministério do Desenvolvimento, Indústria e Comercio Exterior (MDIC), Ministério de Minas e Energia (MME), Ministério do Planejamento, Orçamento e Gestão (MPOG), Ministério de Ciência e Tecnologia (MCT), Ministério do Meio Ambiente (MMA), Ministério do Desenvolvimento Agrário (MDA), Ministério da Integração Nacional (MI) (BRASIL, 2003e).

${ }^{51}$ Ministério de Minas e Energia (MME)/Coordenação, Casa Civil da Presidência da República, Ministério de Ciência e Tecnologia (MCT), Ministério do Desenvolvimento Agrário (MDA), Ministério do Desenvolvimento, Indústria e Comercio Exterior (MDIC), Ministério do Planejamento, Orçamento e Gestão (MPOG), Ministério da Fazenda (MF), Ministério do Meio Ambiente (MMA), Ministério da Integração Nacional (MI), Ministério da Agricultura, Pecuária e Abastecimento (MAPA), Banco Nacional de Desenvolvimento Econômico e Social (BNDES), Agência Nacional do Petróleo (ANP), Petróleo Brasileiro (Petrobras) e Empresa Brasileira de Pesquisa Agropecuária (EMBRAPA)(BRASIL, 2003e).

${ }^{52}$ Conselho Nacional de Política Energética (CNPE), Comissão Executiva Interministerial do Biodiesel (CEIB), Conselho Nacional de Meio Ambiente (CONAMA), Conselho de Competitividade Setorial (Plano Brasil Maior), Conselho Assessor Externo (CAE)- Embrapa Agroenergia, Câmara Setorial de Oleaginosas e Biodiesel (MAPA), Câmara Setorial da Cadeia Produtiva da Palma de Óleo (MAPA), Dialogo Regular de Política Entre o Brasil e União Europeia do Ministério das Relações Exteriores (UBRABIO, 2012)

${ }^{53}$ No Senado Federal: Comissão de Serviços de Infraestrutura, Comissão de Meio Ambiente, Defesa do Consumidor e Fiscalização e Controle. Comissão de Agricultura e Reforma Agrária. Na Câmara dos Deputados: Frente Parlamentar do Biodiesel, Comissão de Minas e Energia, Comissão de Agricultura, Pecuária e Abastecimento e Desenvolvimento Rural, Comissão de Ambiente e Desenvolvimento Sustentável, Subcomissão Especial Sobre Biocombustíveis (UBRABIO, 2012).
} 
sociais trocam a contestação pela parceria com empresas e o governo passou a exercer o papel de catalisador de agentes" (ABRAMOVAY; MAGALHÃES, 2007, p. 14).

A posse de Luiz Inácio Lula da Silva em 2003, para a presidência da república contribuiu para um novo contexto político no Brasil, onde várias lideranças sindicais e trabalhistas passaram a ocupar vários cargos no governo federal. Tal fato contribuiu para uma maior aproximação entre empresas, movimentos sociais e governo. Desta forma em muitas experiências do PNPB, governo, empresas e movimentos sociais passaram a atuar em "parcerias" nos projetos agrícolas destinados a produção de biodiesel no Brasil.

Para eles, "a política governamental promoveu a formação de "laços fortes" entre os atores sociais que se encontram em lados opostos da arena social" (ABRAMOVAY; MAGALHÃES, 2007, p. 14). Esta formatação do PNPB não é aceito por todos os movimentos sociais organizados onde “[...] alguns seguimentos (a FETRAF e parte do MST) não querem depender das empresas para participar do PNPB e procuram implantar unidades cooperativas geridas pelos próprios trabalhadores" (ABRAMOVAY; MAGALHÃES, 2007, p. 18).

Esta constatação levantada por Abramovay e Magalhães (2007) está presente no movimento social onde alguns setores defendem a não participação no programa da forma como está sendo executado.

\subsubsection{Vertente social do PNPB: o papel do MDA e o Selo Combustível Social}

A vertente social do PNPB está sob a responsabilidade do MDA. Segundo Brasil (2010a, p.4), “ao MDA coube a responsabilidade de projetar e operacionalizar a estratégia social do PNPB, criando formas de promover a inserção qualificada de agricultores familiares na cadeia de produção do biodiesel". A participação do MDA no programa visa a geração de emprego e renda para os agricultores familiares integrados a empresas agrícolas inseridas no contexto do PNPB.

Segundo Pedroti (2013, p. 46), "a temática social sempre acompanhou as discussões em torno do PNPB. Entre os principais desafios colocados aos formuladores [...], a inclusão do agricultor familiar em um mercado altamente competitivo". A criação do PNPB representou para o setor do agronegócio e para a agricultura familiar um grande mercado para a compra de produção agrícola tendo como destino a produção de biodiesel.

Para Pedroti (2013, p. 38), “o PNPB é considerado uma política pública inédita no cenário agroenergético brasileiro por ser, simultaneamente, uma política energética e social”. 
Para executar esta missão, o MDA atua em duas frentes no PNPB: o Selo Combustível Social (SCS) e o Projeto Polos de Biodiesel (PPB) (BRASIL, 2010a). O PNPB está vinculado à Secretaria de Agricultura Família (SAF) deste ministério (Fluxograma 1).

\section{Fluxograma 1: Atuação do MDA no PNPB}

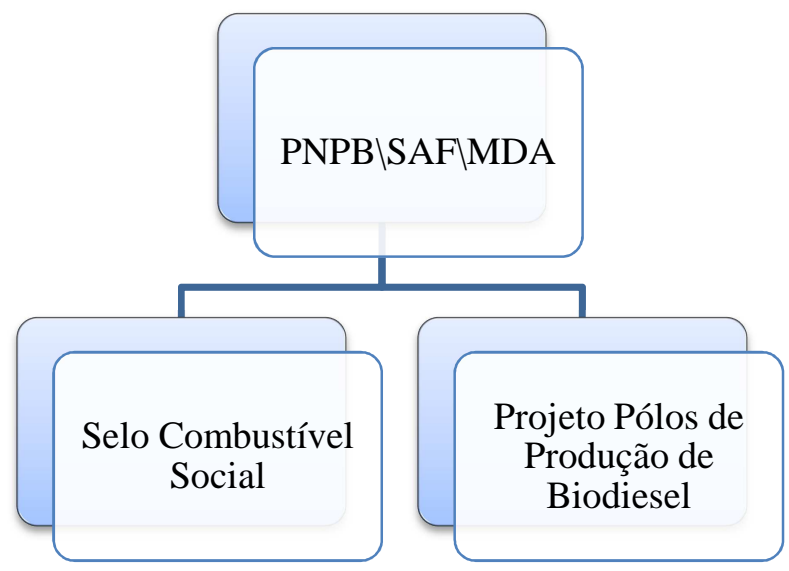

Fonte: Elaborado pelo autor com base em Brasil (2011a, p. 31)

Um dos maiores defensores mundiais deste selo é o ecossocioeconomista francês de origem polonesa Ignacy Sachs. Para ele, “o selo social integra o feixe de políticas convergentes de discriminação positiva dos agricultores familiares, o tratamento dos desiguais, essencial para a sua inclusão social pelo trabalho decente" (SACHS, 2009, p. 175).

Sachs tem pregado a necessidade de pensar a relação bioenergias/alimentos não a partir de sua competição, mas sim do que tem chamado de "sistemas integrados de produção alimentos e bioenergia". Segundo ele, "em vez de pensar em termos de justaposição de cadeias de produção isoladas, deve-se raciocinar em termos de sistemas integrados de produção de alimentos e bioenergia" (SACHS, 2009, p. 162).

A concepção como política pública do PNPB apresenta uma inovação ao inserir a agricultura familiar na cadeia do agronegócio do biodiesel. Esta inclusão dos agricultores familiares ocorre por meio do mecanismo da instituição do Selo Combustível Social ${ }^{54}$.

Segundo Silva (2013, p. 19), "diferentemente dos programas internacionais de estímulo à produção do biodiesel, o PNPB se destaca pelo seu aspecto social: inserção da

\footnotetext{
${ }^{54}$ É um conjunto de medidas específicas para estimular a inclusão social da agricultura familiar na cadeia produtiva do biodiesel. A concessão e o gerenciamento do Selo Combustível Social é a identificação concedida pelo MDA ao produtor de biodiesel que cumpre os critérios estabelecidos pelo Programa e que confere status de promotor de inclusão social dos agricultores familiares enquadrados no Programa Nacional de Fortalecimento da Agricultura Familiar (Pronaf) (BRASIL, 2010a, p. 4).
} 
agricultura familiar na produção de oleaginosas, gerando emprego e renda". No aspecto da inclusão social de agricultores familiares, o Brasil por meio do PNPB é referência mundial neste setor, pois este programa tem como objetivo a inclusão da agricultura familiar no agronegócio de matérias-primas agrícolas usadas na produção de biodiesel.

Para ele, o Selo Combustível Social torna possível "um vínculo inédito entre diversos atores: estado, agricultores (sindicatos) e empresas" (SILVA, 2013, p. 19). Neste sentido, a concepção e a execução do selo combustível socialé o instrumento que permite a integração entre os três atores indicados anteriormente. A atuação do Selo Combustível Social “desempenha um importante papel de articulação entre os diferentes atores envolvidos nessa dinâmica, essencial para que o propósito social seja alcançado" (PEDROTI, 2013, p. 46-47).

Para tornar o programa atrativo para o setor empresarial, o governo federal criou uma série de benefícios fiscais, onde "para uma grande escala de produção, a redução de encargos em 89,6\% (soma do PIS/Pasep e Confins) para o uso da soja oleaginosa [...] é um grande estímulo" (IPEA, 2010, p. 28). O PNPB é uma política que está estruturada em uma série de benefícios fiscais que foram criados para atender o setor empresarial. Estes benefícios fiscais são concedidos à empresa integradora que promove a integração de agricultores familiares em sua cadeia de produção agrícola. O instrumento que a empresa utiliza para promover a integração da agricultura familiar em sua cadeia de produção é o selo combustível social. Por meio do acesso do selo combustível social a empresa é beneficiada com os benefícios fiscais anteriormente citados.

Conforme aponta Silva (2013, p. 19), “o Estado cria incentivos fiscais interessantes para as empresas privadas adquirirem as oleaginosas dos agricultores familiares e, ao mesmo tempo, garante a demanda pelo biodiesel produzido por essas empresas privadas". Os benefícios fiscais do setor é certamente um grande estímulo para as empresas investirem no setor, onde as atividades produtivas ligadas à agricultura familiar no Norte, Nordeste e Semiárido passaram a receber incentivos com relação a diversos impostos federais como o Imposto sobre Produtos Industrializados (IPI), a Contribuição de Intervenção no Domínio Econômico (CIDE), Programa de Integração Social (PIS), o Programa de Formação do Patrimônio do Servidor Público (Pasep) e a Contribuição para o Financiamento da Seguridade Social (Cofins).

Com relação à agricultura familiar no Norte, Nordeste e Semiárido para o plantio da mamona ou palma (dendê) os benefícios do IPI (alíquota zero), a CIDE (inexistente), PIS/Pasep (redução de 100\%) tentam estimular o setor empresarial nestas regiões. Outras 
atividades ligadas à agricultura familiar no Brasil, como o cultivo da mamona e da palma também passaram a receber tratamento diferenciado (Quadro 17).

Quadro 17: Regime tributário aplicado ao biodiesel no Brasil

\begin{tabular}{|c|c|c|c|c|c|}
\hline \multirow[b]{2}{*}{$\begin{array}{l}\text { Tributos } \\
\text { federais }\end{array}$} & \multicolumn{4}{|c|}{ Biodiesel } & \multirow[b]{2}{*}{$\begin{array}{c}\text { Diesel de } \\
\text { petróleo }\end{array}$} \\
\hline & $\begin{array}{l}\text { Agricultura familiar } \\
\text { no Norte, Nordeste e } \\
\text { Semiárido com } \\
\text { mamona ou palma }\end{array}$ & $\begin{array}{l}\text { Agricultura } \\
\text { familiar }\end{array}$ & $\begin{array}{l}\text { Norte e Nordeste } \\
\text { e Semiárido com } \\
\text { mamona ou } \\
\text { palma }\end{array}$ & $\begin{array}{l}\text { Regra } \\
\text { geral }\end{array}$ & \\
\hline IPI & Alíquota zero & $\begin{array}{l}\text { Alíquota } \\
\text { zero }\end{array}$ & Alíquota zero & $\begin{array}{l}\text { Alíquota } \\
\text { zero }\end{array}$ & $\begin{array}{l}\text { Alíquota } \\
\text { zero }\end{array}$ \\
\hline CIDE & Inexistente & Inexistente & Inexistente & Inexistente & $\mathrm{R} \$ 0,07$ \\
\hline PIS\Cofins & Redução de $100 \%$ & $\begin{array}{l}\text { Redução de } \\
68 \%\end{array}$ & Redução de $31 \%$ & $\mathrm{R} \$ 0,22$ & $\mathrm{R} \$ 0,15$ \\
\hline \multirow{2}{*}{$\begin{array}{ll}\text { Total } & \text { de } \\
\text { tributos } & \\
\text { federais } & \end{array}$} & $\mathrm{R} \$$ Vlitro & $\mathrm{R} \$$ Vlitro & $\mathrm{R} \$$ Vlitro & $\mathrm{R} \$$ Vlitro & R\$ Vitro \\
\hline & $\mathrm{R} \$ 0,00$ & $\mathrm{R} \$ 0,07$ & $\mathrm{R} \$ 0,15$ & 0,22 & $\mathrm{R} \$ 0,22$ \\
\hline
\end{tabular}

Fonte: BNDES (2007)

O modelo de integração da agricultura familiar no agronegócio do biodiesel no Brasil atende a uma racionalidade hegemônica em que o Estado, mediante um conjunto de instrumentos de renuncia fiscal passa a induzir a participação de empresas no setor. Desta forma, tal política só acontece por intermédio dos incentivos estatais que permitem as empresas reduzirem seus riscos e ampliarem seus lucros com tal experiência.

Segundo Rodrigues e Accarini (2007, p.78), “o selo combustível social proporciona condições tributárias diferenciadas as empresas que empregam matérias-primas produzidas por agricultores e oriundos das regiões mais carentes do Brasil”. Este selo tornou-se uma importante estratégia para a inserção da agricultura familiar no agronegócio do biodiesel no Brasil, suapolítica fiscal torna este instrumento bastante atrativo para o setor empresarial (Quadro 18).

Quadro 18: Principais vantagens do Selo Combustível Social para as empresas de biodiesel no Brasil

\begin{tabular}{|c|c|}
\hline Público & Vantagens \\
\hline \multirow{4}{*}{ Empresa } & Diferenciaçãolisenção nos tributos PIS\PASEP e COFINS \\
\hline & Participação assegurada de $80 \%$ nos leilões da ANP \\
\hline & $\begin{array}{l}\text { Acesso a melhores condições de financiamentos junto a bancos que operam com o } \\
\text { programa }\end{array}$ \\
\hline & Possibilidade de uso do Selo Combustível Social para promover sua imagem no mercado \\
\hline
\end{tabular}

Fonte: Elaborado pelo autor com base em Brasil (2010a, p. 5) 
Para ter direito ao Selo Combustível Social, o produtor de biodiesel ${ }^{55}$ deve estar legalmente constituído e apresentar projeto específico junto ao MDA, encarregado pela avaliação segundo as normas elencadas Instrução Normativa do MDA n⿳ำ 01/2005 e da Portaria do MDA nº 60/2012.

Em contrapartida, o produtor de biodiesel tem como benefícios a isenção de alguns impostos, melhores condições de financiamento de projetos junto ao Banco Nacional Desenvolvimento Econômico e Social (BNDES) e instituições financeiras credencias como o Banco do Brasil (BB), o Banco da Amazônia (Basa) e o Banco do Nordeste (BNB). Os benefícios também contemplam a reserva de $80 \%$ dos lotes para oferta exclusiva para os produtores de biodiesel que possuem o Selo Combustível Social.

As empresas para terem acesso aos benefícios fiscais do Selo Combustível Social devem cumprir uma série de obrigações legais para garantir acesso dos pequenos produtores familiares ao mercado de compras da produção agrícola da empresa integradora (Quadro 19).

Quadro 19: Principais obrigações da empresa de biodiesel com o Selo Combustível Social no Brasil

\begin{tabular}{|c|l|}
\hline \multicolumn{1}{|c|}{ Público } & \multicolumn{1}{|c|}{ Obrigações da empresa } \\
\hline \multirow{5}{*}{ Pequeno agricultor } & $\begin{array}{l}\text { Firmar contratos com os agricultores familiares negociados com a } \\
\text { participação de uma entidade representativa dos mesmos (sindicatos e } \\
\text { federações) }\end{array}$ \\
\cline { 2 - 2 } & $\begin{array}{l}\text { Repassar cópia dos contratos devidamente assinados pelas partes para o } \\
\text { agricultor contratado e para a entidade representativa (sindicato, federação) }\end{array}$ \\
\cline { 2 - 3 } & $\begin{array}{l}\text { Assegurar assistência técnica gratuita aos agricultores familiares } \\
\text { contratados }\end{array}$ \\
\cline { 2 - 2 } & $\begin{array}{l}\text { Capacitar os agricultores e as agricultoras familiares para a produção de } \\
\text { oleaginosas }\end{array}$ \\
\cline { 2 - 2 } & $\begin{array}{l}\text { Repassar ao agricultor assistido pelo técnico, cópia do laudo de visita } \\
\text { devidamente assinado }\end{array}$ \\
\cline { 2 - 2 } & $\begin{array}{l}\text { Adquirir um percentual mínimo de matéria-prima da agricultura familiar, } \\
\text { que varia de região para região }\end{array}$ \\
\hline
\end{tabular}

Fonte: Elaborado pelo autor com base em Brasil (2010a, p. 6)

A participação dos agricultores familiares no PNPB ocorre de diferentes formas: produzindo sementes e mudas de oleaginosas; fornecendo os grãos das oleaginosas (mamona,

\footnotetext{
${ }^{55}$ Pessoa jurídica constituída na forma de sociedade sob as leis brasileiras, com sede e administração no país, beneficiadas de autorização da Agência Nacional de Petróleo, Gás Natural e Biocombustíveis (ANP) e possuidora de Registro Especial de Produtor de Biodiesel junto à Secretaria da Receita Federal do Ministério da Fazenda (BRASIL, 2005c).
} 
dendê, girassol, soja etc.) para as indústrias processadoras; extraindo óleo vegetal dos grãos e separando-os do farelo; organizando suas próprias usinas para a produção do biodiesel (BRASIL, 2010a, p.17).

Visando estimular a aquisição de matérias-primas nas diferentes regiões, o MDA, por meio da Instrução Normativa do MDA $n^{-} 01$, estabeleceu um percentual mínimo de compras nas regiões Norte (10\%), Nordeste (50\%), Centro-Oeste (10\%), Sudeste (30\%) e Sul (30\%). Esta exigência vigorou até de 06 de setembro de 2012, quando foi publicada a Portaria do $M D A n^{\circ} 60$ alterando estes percentuais para as regiões Norte (15\%), Nordeste (30\%), CentroOeste (15\%), Sudeste (30\%) e Sul (35\%) para as safras de 2012/2013 e 40\% para as safras de $2013 / 2014$.

Ao analisar o quadro de aquisições mínimas deste selo para as regiões, constatamos que o aumento de $10 \%$ para $15 \%$ na região Norte certamente está ligado ao esforço do governo para emplacar o programa na região, fato que não tem acontecido. Das cinco regiões, o Norte é a única que não tem apresentado resultados satisfatórios com o PNPB.

Este fato foi reconhecido pelo coordenador geral do programa de biocombustíveis do MDA, André Grossi Machado, em entrevista à revista Biodiesel em foco, da União Brasileira do Biodiesel e Bioquerosene (Ubrabio). Segundo ele, "infelizmente não temos nada na região Norte [...] a expectativa é que com o programa da palma de óleo do dendê possamos ativar aquela região" (UBRABIO, 2012, p.18).

Na mesma publicação, Antoninho Bovaris, Secretário da Confederação Nacional dos Trabalhadores na Agricultura (Contag), reconhece esta situação ao afirmar que "a dificuldade de acesso a crédito e ao seguro agrícola, por exemplo, pelos produtores de mamona no Nordeste e de dendê no Norte do país" (UBRABIO, 2012, p. 19). Para ele, avançar no Norte e no Nordeste é o desafio do PNPB.

As avaliações oficiais realizadas sobre o Selo Combustível Social têm demonstrado que "[...] as fragilidades na sistemática ocorrem exatamente por não atingir os objetivos desta inserção no Norte/Nordeste, onde há problemas operacionais e estruturais com quebra de contratos [...], de assistência técnica e de aquisição da matéria-prima” (IPEA, 2010, p. 38). A execução do programa nas regiões Norte e Nordeste é dificultada ainda por questões ligadas à formação histórica regional, em que a logística quando existente dificulta a realização das ações no contexto do PNPB.

Quando analisamos a realidade da região Norte última na participação dos agricultores no PNPB, verificamos que esta "produção de dendê é prejudicada pela dificuldade de crédito, pela falta de tecnologia e pela legislação ambiental na Amazônia” (SILVA, 2013, p. 19). 
Desta forma, a produção agrícola de dendê na região Norte possui diversas dificuldades que fazem com o PNPB encontre obstáculos para o pleno desenvolvimento das ações nesta região. No Norte onde existem empresas do setor nos estados de Rondônia, Pará e Tocantins, apenas as empresas Biotins e Granol, do estado do Tocantins, mantêm o selo que é certificado pelo MDA.

No Nordeste os percentuais mínimos deste selo caíram de 50\%, em 2005, para 30\%, a partir de 2012. O fato pode ser explicado em parte pelo avanço da demanda de outras oleaginosas, como a soja em regiões como o Centro-Oeste, o Sudeste e o Sul. Criado com foco na matéria-prima da mamona produzida no Nordeste o programa do biodiesel foi dominado pela oferta da soja como matéria-prima dominante do programa onde a região Centro-Oeste tem um papel de destaque.

Como lembra Silva (2013, p.27), “a soja ainda representa cerca de 94\% das aquisições realizadas pelo programa. Oleaginosas como a mamona e o dendê, que deveriam ser o carro chefe do programa, ainda não tem participações importantes”. Em seu desenho original o PNPB visa à expansão da produção agrícola da mamona no Nordeste e do dendê no Norte, porém o que aconteceu ao longo do tempo foi que a soja produzida no Centro-Oeste e Sul do Brasil acabou dominando a produção e a venda para o programa.

Para Castro (2011, p. 44), “essa pequena participação do Norte e do Nordeste na produção brasileira de biodiesel é um indício significativo do descompasso existente entre as diretrizes originais do PNPB [...] e o que ocorre na prática”. Esta constatação da hegemonização da produção da soja como matéria-prima absoluta nas aquisições por parte do PNPB demonstra que o incentivo ao desenvolvimento regional defendido pelo programa para as regiões Norte e Nordeste não foi concretizado.

O programa foi criado para atender fundamentalmente a agricultura familiar no Nordeste, tendo a mamona como a matéria-prima de destaque. Neste sentido, durante a execução desta política pública, temos uma completa inversão dos objetivos do programa. $\mathrm{O}$ Nordeste e o Norte, que deveriam ter atendimento central, foram superados pelas regiões Centro-Oeste e Sul, onde a soja galgou lugar de destaque entre as matérias-primas do PNPB.

Para Castro (2011, p. 30), "um entrave para a produção de mamona no Nordeste é o pequeno montante de crédito rural disponível para esta cultura [...] a inadimplência de alguns agricultores e a burocracia bancária, são os principais entraves para a obtenção desse benefício". As dificuldades apresentadas na região Nordeste são semelhantes às da região Norte. 
Por meio de uma engenharia de comercialização do biodiesel que está estruturada por meio de leilões de produção "[...] somente as empresas que possuem o selo social podem participar dos leilões organizados pela Agência Nacional de Petróleo, Gás Natural e Biocombustível (ANP)" (SILVA, 2013, p. 19). A realidade tem demonstrado que para as indústrias que aderem ao Selo Combustível Social, esta tem se tornado uma exigência para a participação nos leilões realizados pela ANP.

No Nordeste existem empresas com selo no Ceará (Petrobras) e Bahia (V- Biodiesel e Petrobras). No Maranhão a única empresa Brasil Ecodiesel não aparece na lista fornecida pelo MDA com as empresas detentoras de Selo Combustível Social no Brasil (BRASIL, 2014a).

No Centro-Oeste os percentuais mínimos da aquisição deste selo subiram de $10 \%$ em 2005, para 15\%, em 2012. Para André Grossi Machado, “hoje o Centro-Oeste é o segundo maior produtor depois da região Sul, com maior volume de aquisições" (UBRABIO, 2012, p.18).

Segundo Pedroti (2013, p.53), “diferentes fatores, como custo, regularidade de entrega, facilidades de negociação, acesso, transporte, logística são considerados nessa escolha. E, nessa análise, a aquisição de soja [...] mostra-se a opção mais atrativa".

No Centro-Oeste existem empresas nos três estados da região, Mato Grosso do Sul, Mato Grosso e Goiás. Esta região apresenta a maior quantidade de empresas com o selo. De um total de trinta empresas atuantes no setor, dezenove apresentam o selo. O estado de Mato Grosso apresenta onze empresas certificadas com o selo, Goiás cinco e Mato Grosso do Sul com três. Grandes multinacionais do agronegócio como ADM, Cargill e Bunge possuem este selo, o que implica considerável renúncia fiscal por parte do governo federal (BRASIL, 2014a).

Para Santos e Wehrmann (2010, p. 8), "diante da maior competitividade da soja no Centro-Oeste, da escala industrial nessa região e da falta de matéria-prima regional, o biodiesel não decola nas regiões Norte e Nordeste". Ainda para eles, "na região Centro-Oeste, a indústria é altamente capitalizada e integrada ao mercado da commodity óleo vegetal, fato que induz a grande capacidade ociosa da indústria de biodiesel" (SANTOS; WEHRMANN, 2010, p. 9-10). A presença de grandes empresas agrícolas com atuação global no CentroOeste tem contribuído para o sucesso da soja como matéria-prima agrícola hegemônica do PNPB.

O crescimento da região Centro-Oeste está relacionado à participação do setor de agronegócio que está estruturado. Neste sentido, “com relação à soja verifica-se a concentração dos negócios nas mãos de meia dúzia: as multinacionais norte-americanas 
Bunge, Cargill e ADM e a francesa Dreyfus (no Brasil adota o nome de Coimbra); e as nacionais Magi e Caramuru alimentos” (FASE, 2005, p. 8). Estas grandes empresas agrícolas produtoras de soja presentes na região são estimuladas mediante os benefícios fiscais estatais a adotarem a integração da agricultura familiar em sua cadeia de produção.

Segundo Lima (2007, p. 19), "na nova frente do agronegócio na área energética, a tendência é de que o papel da agricultura na economia global será claramente fortalecido, na medida em que se estará diante de um vasto mercado mundial de biocombustíveis". Nesta ordem global a produção de biocombustíveis (etanol e biodiesel) passa a ser um grande mercado consumidor para o agronegócio no Brasil. Desta forma a produção do agronegócio pode ser direcionado para atender o setor de alimentos e de bioenergia.

O Sudeste foi a única região que manteve os percentuais mínimos de aquisição da agricultura familiar em $30 \%$ no período de análise. Nessa região os volumes de aquisições são semelhantes aos da região Nordeste (UBRABIO, 2012, p. 18).

Ao longo do tempo, o Selo Combustível Social vem apresentando resultados para as empresas detentoras do mesmo que movimentaram em compras da agricultura familiar em 2006, R\$ 70 milhões, e em 2011, alcançam R\$ 1,5 bilhão. Nesse último ano, 95\% do biodiesel comercializado no Brasil foram produzidos por empresas detentoras do Selo Combustível Social (UBRABIO, 2012, p. 18).

No Sudeste existem empresas nos estados de Minas Gerais, Rio de Janeiro e São Paulo. Em Minas Gerais a Petrobras possui o selo e, em São Paulo, por meio das empresas Brejeiros, JBS, Fertibom e SPBio. No Sul, os três estados da região possuem empresas com selo: Bsbios Marialva, Biopar, Potencial no Paraná; ADM, em Santa Catarina; e no Rio Grande do Sul, temos Bianchini, Bsbios, Câmera Ijuí, Três Tentos, Bocchi, Granol, Olfar, Oleoplan e Fuga Couros (BRASIL, 2014a).

A concentração da inserção da agricultura familiar no Sul do país reflete as condições materiais e a realidade enfrentada pelos agricultores familiares nas regiões do Brasil. "De fato, a atual configuração da inserção dos agricultores familiares na cadeia do biodiesel pode ser explicada tanto pelas regras do selo como pelas especificidades da agricultura familiar de cada região do Brasil” (PEDROTI, 2013, p. 53).

Quando analisamos a participação das aquisições de oleaginosas pelo PNPB, percebemos que a soja contribuiu com 94,06\%, em 2010. Enquanto que a mamona (Nordeste), com 4,38\%, e dendê (Norte) com $0,32 \%$, demonstrando que os objetivos originais do PNBP de ser indutor do desenvolvimento regional com foco no Norte/Nordeste não passam de retórica na atualidade (SILVA, 2013) 
A adoção do Selo Combustível Social tem recebido muitas críticas dos movimentos sociais, pois, "embora importante para viabilizar o sistema de produção, o Selo Combustível Social tem significado um mecanismo de incentivo para a indústria, mas não de suporte dos objetivos de inclusão com o PNPB” (IPEA, 2010, p. 38).

Uma das maiores críticas feitas ao PNPB é referente à concentração da produção na soja, em detrimento das demais matérias-primas, como a mamona e o dendê. Desta forma, "a diversificação de oleaginosas é, no curto prazo, um grande desafio para a cadeia do biodiesel, não apenas para sair da dependência da soja, mas também para a inserção social a partir da diversificação nas cinco regiões" (IPEA, 2010, p. 47).

Para que o PNPB cumpra seu desenho original deverá criar as condições necessárias para o desenvolvimento das ações do programa nas regiões Norte e Nordeste do Brasil. Estas condições devem estimular a expansão da produção agrícola da mamona no Nordeste e do dendê no Norte. Além do mais são necessários investimentos que beneficiem toda a cadeia produtiva do biodiesel não somente a empresa, mas fundamentalmente o agricultor familiar.

A permanência do Selo Combustível Social tem sido um desafio a ser enfrentado para a manutenção do PNPB, “é desafiadora, pois seus alcances não atingiram os resultados inicialmente estabelecidos, todavia as conquistas obtidas ao longo desses sete anos não podem ser desconsideradas" (PEDROTI, 2013, p. 10).

A continuidade do PNPB é um desafio para o governo e para a sociedade, pois "quando a política pública foi formulada em 2003 e 2004, visava-se estruturar um sistema agroenergético capaz de contemplar, de um lado, os anseios de eficiência energética e, de outro, os de inclusão social e de desenvolvimento regional” (PEDROTI, 2013, p. 10).

Quando analisamos os dados das matérias-primas usadas para a produção de biodiesel no Brasil em 2013, constatamos que o PNPB não cumpriu os objetivos iniciais que eram estimular a utilização da mamona do Nordeste como vetor de geração de emprego e renda da região. O que constatamos é que o programa tornou-se praticamente um programa da soja, onde 74\% das matérias-primas usadas na produção do biodiesel em 2013 tiveram como origem o óleo de soja. Em seguida vem a gordura bovina com 20\%, seguidas de óleos de algodão com $2 \%$, óleo de fritura com $1 \%$, o óleo de palma (dendê) com apenas $0,31 \%$ (ANP, 2013).

Estes dados apontam que as regiões mais fragilizadas como o Norte e Nordeste não estão sendo beneficiadas como era a ideia inicial do PNPB. As regiões onde o seguimento do agronegócio principalmente da soja é mais forte como o Centro-Oeste, Sudeste e Sul têm apresentado ganhos em relação ao Norte e Nordeste (ANP, 2013). 
Medidas estruturantes precisariam ser aplicadas tendo em vista a correção de possíveis falhas do programa, "para complementar os alcances desses instrumentos é necessário, portanto, adotar políticas públicas específicas para cada região, capazes de lidar com os problemas locais que desestimulam o investimento privado" (PEDROTI, 2013, p.53). As ações do PNPB precisam levar em conta as diferenças regionais e criar mecanismos para a atração de capital para estas regiões.

Como lembra Pedroti (2013, p. 55) sobre o PNPB, "trata-se, portanto, de uma política agroenergética com caráter social, algo inédito no ambiente da agroenergia, e inovador, do ponto de vista institucional". A formulação e a implementação enquanto política pública presente no PNPB reflete a conjuntura e o amadurecimento das instituições no contexto político presente em 2004, ano de sua criação. Desta forma, forças internas organizadas representadas pelos setores do agronegócio, da agricultura familiar e das empresas de biodiesel tiveram um papel central neste processo.

No entanto, fatores ligados à conjuntura político-econômica interferem na condução do programa, pois, o setor do agronegócio e das indústrias de biodiesel só investem no programa se o mesmo apresentar vantagens para este segmento econômico.

Como lembra Fabrini (2010, p. 56), “a inserção da pequena agricultura na produção de agroenergia está colocada como se fosse possível obter vantagens na produção em cadeia controlada por corporações nacionais e estrangeiras globalizadas”. Desta forma os desafios do PNPB passam pela conciliação dos setores envolvidos na cadeia do biodiesel (governo, agronegócio, agricultores familiares e indústria de biodiesel).

Além deste desafio o governo precisa estimular o desenvolvimento da geração de emprego e renda no campo brasileiro onde o PNPB pode ajudar nesta meta governamental. Para Fabrini (2010, p. 77), “de acordo com o discurso oficial ainda, o biodiesel não é apenas uma alternativa de geração de renda e emprego, mas um caminho para o desenvolvimento, erguido a partir de bases locais (dsenvolvimento local)".

O discurso oficial do PNPB está fundamentado na necessidade da promoção do desenvolvimento regional com ênfase no Norte e Nordeste do Brasil. Na prática o PNPB acabou sendo dominado pelos interesses de mercado de grandes empresas do setor que passaram a controlar a dinâmica deste programa estatal. Desta forma vários fatores podem ser destacados que justificam uma racionalidade que pouco se aproxima da produção agrícola familiar. Primeiro o setor de biodiesel é fortemente dependente do mercado mundial de energia, onde os interesses de governos e empresas energéticas são divergentes dos interesses de segmentos da produção agrícola familiar. Segundo a cotação do biodiesel têm como 
referências de preços bolsas especializadas como Rotterdam (Holanda) e Malásia que seguem a influência do mercado de biocombustível no mundo. A estratégia estatal do PNPB transforma a agricultura brasileira em verdadeiro "poço de petróleo verde" em alusão a produção agrícola para biocombustível em detrimento da produção agrícola para alimentos que poderiam ser comercializados no próprio mercado interno.

A inserção da agricultura familiar na cadeia do agronegócio do biodiesel subordina os pequenos produtores aos interesses dos empresários do agronegócio. Desta forma, o agronegócio subordina a pequena agricultura e ainda passa a lucrar com esta associação por meio das vantagens fiscais decorrentes do Selo Combustível Social. Segundo Fabrini (2010, p. 78), “verifica-se que o sentido social e de inclusão do programa está vinculado à inserção e integração dos camponeses produtores de matérias-primas às cadeias produtivas [...] acoplada aos interesses de 'agroindustriais'”. A vertente social do PNPB cumpre um papel relevante na geração de emprego e renda para as populações rurais no Brasil. A relação dialética da integração entre agronegócio e agricultura familiar é o ponto central que o PNPB procura conciliar.

Como lembra Fabrini (2010, p. 78), “o biodiesel está tomando caminho semelhante ao etanol, pois aproximadamente $95 \%$ desse agrocombustível é proveniente da soja, tradicionalmente cultivada no sistema de monocultura do agronegócio”. Na atualidade, as aquisições da agricultura familiar para o PNPB são dominadas pela cultura da soja, centralizadas por empresas agrícolas integradoras de grande poder econômico.

Com o passar dos anos o setor do agronegócio da soja passou a dominar a produção de matérias-primas do PNPB. Desta forma, atualmente o programa esta centralizado na soja como matéria-prima hegemônica, ação esta que contraria as metas iniciais do PNPB onde a prioridade seria a compra de matérias-primas de regiões carentes, como a mamona do Nordeste e o dendê do Norte do país.

Não restam dúvidas que a participação da agricultura familiar no PNPB tem sido um sucesso pelos números apresentados a cada ano pelo governo federal. No período de 2005 a 2010 os estabelecimentos da agricultura familiar participantes do PNPB no Brasil cresceram de 16.328, para 100.371 estabelecimentos. Em todas as regiões do país cresceu esta presença com exceção do Norte, que apresentou redução de 414 para 246 estabelecimentos da agricultura familiar inseridos no PNPB. Estes dados refletem as dificuldades para emplacar a integração da agricultura familiar no agronegócio nesta região (BRASIL, 2010a). 


\subsubsection{Projeto Polos de Biodiesel}

Tendo como objetivo a expansão da produção agrícola de matérias-primas ligadas à produção de biodiesel, o governo federal, por intermédio do MDA, tem estimulado a criação de polos de biodiesel no Brasil.

O Projeto Polos de Biodiesel "são espaços geográficos compostos por diversos municípios, com a presença de agricultores familiares, produtores ou potenciais produtores de matérias-primas para fins de produção de biodiesel nos termos do PNPB" (BRASIL, 2010a, p.30).São nesses polos de biodiesel que o MDA centraliza suas ações para o desenvolvimento da produção agrícola, agroindustrial e industrial da cadeia do biodiesel no Brasil. Nesses polos estão presentes os principais atores ligados a temática da produção de biodiesel.

A formação de um polo deve levar em consideração os seguintes aspectos: a presença de agricultores familiares com vocação para plantio de oleaginosas; a identidade coletiva territorial; a presença de áreas consideradas aptas para o plantio com zoneamento agrícola; atuação e/ou interesses de atuação de empresas detentoras do Selo Combustível Social; a presença de atores sociais, políticos e econômicos interessados no desenvolvimento desta cadeia produtiva (BRASIL, 2010a, p. 30). Desta forma, o polo de biodiesel deve possuir todas as condições necessárias para o desenvolvimento das atividades da cadeia produtiva do biodiesel.

O Projeto Polos de Biodiesel "tem como objetivo articular a base produtiva da agricultura familiar que fornece matéria-prima para a produção de biodiesel e os diversos atores estaduais e territoriais envolvidos na temática" (BRASIL, 2010a, p. 4). São nestes polos de produção que ocorrem as ações do PNPB nos estados da federação no Brasil.

Como parte da metodologia de fortalecimento deste projeto, o MDA trabalha com a formação de Grupos de Trabalhos (GT) tendo como objetivo criar um arranjo territorial, agregando instituições parceiras tendo em vista o fortalecimento do projeto. A criação deste arranjo territorial produtivo envolve a participação de diversas instituições estatais, empresariais e sociais. As estruturas de poder nos polos de biodiesel no Brasil envolvem a presença de instituições estatais (MDA, INCRA, EMATER, bancos públicos etc.), instituições empresariais (Empresas com Selo Combustível Social) e instituições sociais (Federação de agricultores, sindicatos de trabalhadores rurais, cooperativas, associações etc.), conforme se podeverificar no Esquema 1. 
Esquema 1:Estrutura e relações do Projeto Polos de Biodiesel

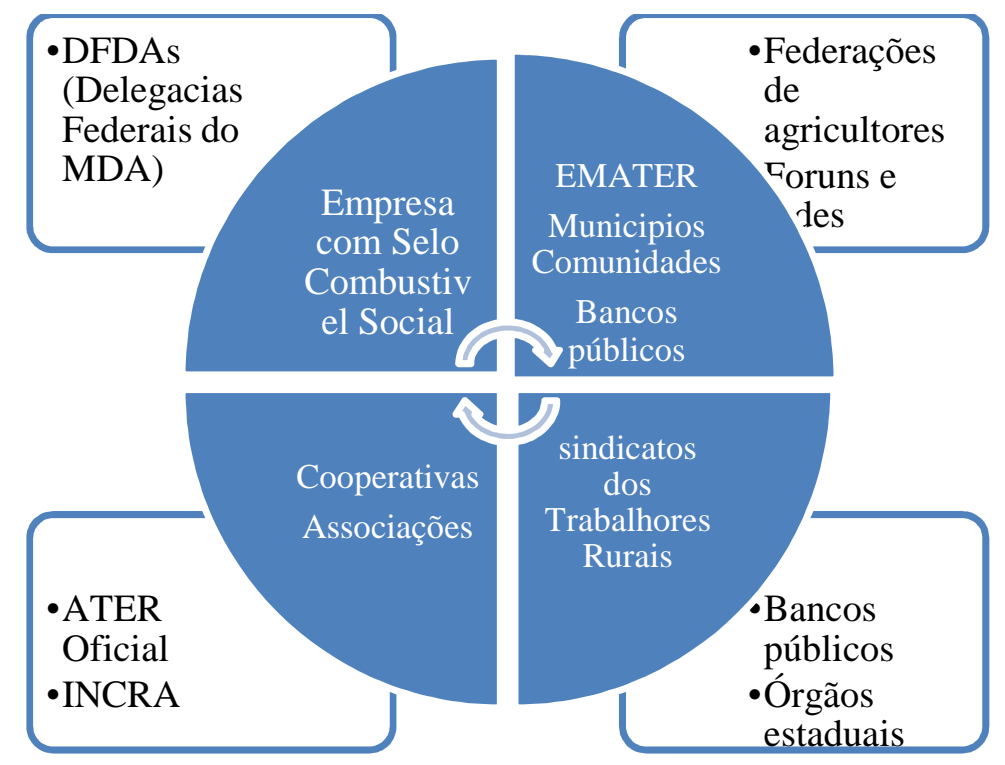

Fonte: Elaborado pelo autor com base em Brasil (2010a)

Quando este programa foi iniciado, em 2006, havia apenas 30 polos de biodiesel no país, em 2010, o número passou para 1.091 espalhados pelo Brasil. Esses números demonstram que a presença de polos de biodiesel no Brasil ampliou em curto espaço de tempo. Dados de 2010 mostram que o Norte apresentava apenas um polo, localizado no estado do Pará. No Nordeste havia 32 polos com destaque para a Bahia e Ceará com oito cada. No Centro-Oeste os dados apontam para a existência de 13 polos, com destaque para Goiás com seis polos. No Sudeste havia nove polos com destaque para Minas Gerais com seis. No Sul havia oito polos com destaque para o Rio Grande do Sul com seis (BRASIL, 2010a).

O crescimento das atividades ligadas aos polos de biodiesel no Brasil promove um uso agrícola do território brasileiro. Esse uso ocorre de forma seletiva em parcelas do território nacional, onde as vantagens (principalmente fiscais) decorrentes das políticas setoriais acabam por orientar de certa forma a ação do setor privado.

No Pará, o PNPB está presente no polo de dendê Pará, que compreende 36municípios paraenses: Abaetetuba, Acará, Ananindeua, Aurora do Pará, Baião, Barcarena, Belém, Benevides, Bonito, Cametá, Capanema, Capitão Poço, Castanhal, Concórdia do Pará, Garrafão do Norte, Igarapé-Miri, Igarapé-Açu, Inhangapi, Irituia, Marituba, Mãe do Rio, Mocajuba, Moju, Nova Timboteua, Ourém, Peixe-Boi, Santa Bárbara do Pará, Santa Izabel do Pará, Santa Maria do Pará, Santo Antônio do Pará, São Domingos do Capim, São Francisco do Pará, São Miguel do Guamá, Tailândia, Tomé-Açu e Tracuateua (PARÁ, 2013), conforme o Mapa 9. 
Mapa 9: Polo de dendê no estado do Pará, MDA-PNPB, 2003

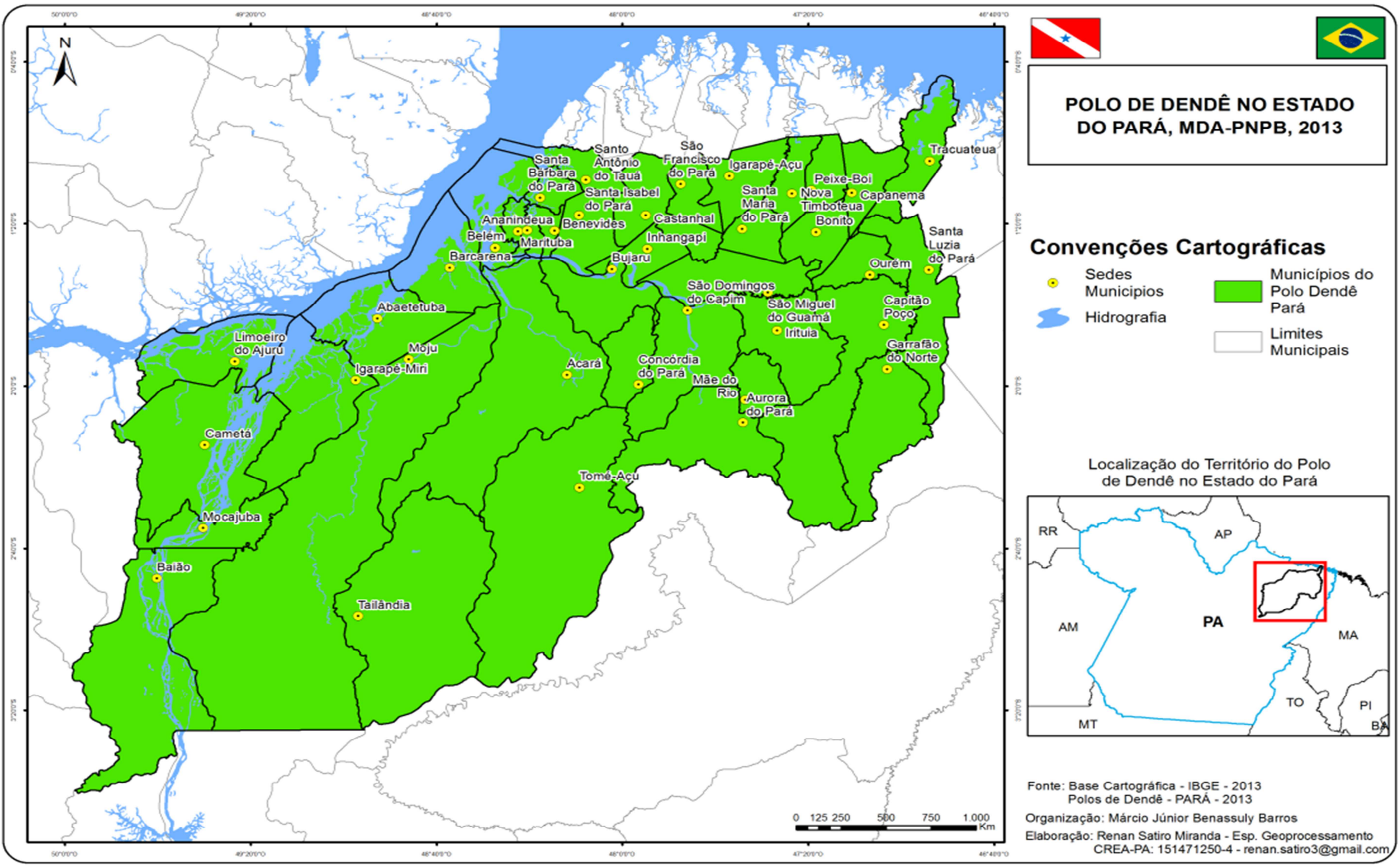


O Polo de dendê Pará é o território que concentra os municípios selecionados para integrar a produção agrícola do dendê no estado do Pará. Nesse polo estão presentes as empresas agrícolas além dos agricultores integrados de dendê com produção desta cultura agrícola no Pará.

\subsection{Programa de Produção Sustentável de Óleo de Palma (PPSOP)}

Nesta seção tratamos do Programa de Produção Sustentável de Óleo de Palma (PPSOP), uma política pública criada para estimular a expansão da produção agrícola de dendê no Brasil.

\subsubsection{Lançamento do PPSOP no contexto político-econômico nacional}

O PPSOP foi lançado em 06.05.2010 na cidade de Tomé-Açu, no Pará pelo então presidente Luiz Inácio Lula da Silva. Este programa surge da necessidade de aumentar a participação da cultura do dendê na produção nacional de óleo de palma e óleo de palmiste, em que a participação na produção do Brasil neste segmento é insuficiente para atender ao mercado consumidor interno. Além desses fatores a questão da produção de biodiesel a partir de dendê também foi determinante na criação do programa, uma vez que, a participação do dendê no PNPB é pequena, se comparada como as demais culturas oleaginosas das regiões do país.

Esta cerimônia de lançamento do PPSOP no Pará contou com presença de diferentes autoridades do governo federal, estadual, municípios do Polo de dendê Pará, bem como, do setor empresarial ligado à dendeicultura no estado e dos movimentos sociais organizados. Durante esta cerimônia, a Petrobras Bicombustível (Pbio) apresentou seu projeto de produção sustentável de biodiesel para o estado do Pará, onde a cultura a ser utilizada seria o dendê. A Figura 18 mostra detalhes do lançamento de ações do PPSOP em Belém no ano de 2010. 
Figura 18: Ações de lançamento e esclarecimentos sobre o Programa de Produção Sustentável de Palma de Óleo em Belém do Pará, maio de 2010

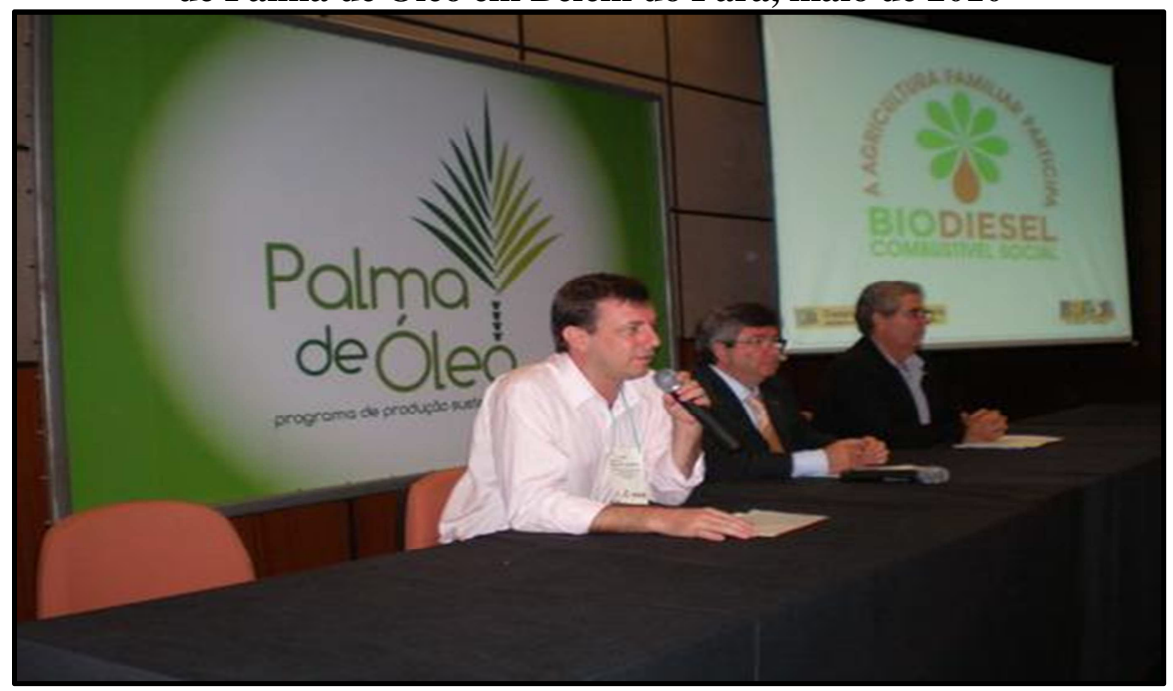

Fonte: MDA (2010)

Desta forma, o ano de 2010 foi marcado por um conjunto de ações ligado a estruturação do Polo de dendê Pará, com ações dos governos federal, estadual e de diversos municípios inseridos nessa iniciativa. O governo federal, por meio de suas políticas públicas (PNPB e PPSOP) procura estimular a expansão da produção agrícola de dendê e das bases para a produção agroindustrial de óleo de dendê, óleo de palmiste, bem como da produção industrial de biodiesel no estado do Pará.

Estimulado pelas ações do biodiesel do governo federal, o governo paraense na gestão da governadora Ana Júlia de Vasconcelos Carepa (2007-2011) passou a trabalhar a possibilidade de transformar o Pará no maior polo nacional de biodiesel. Estas ações foram inseridas no Programa Paraense de Incentivo à Produção de Biodiesel (Parábiodiesel) que teve como objetivo o fomento do dendê para a produção de biodiesel no estado do Pará (PARÁ, 2010).

O PPSOP como política pública de estímulo à expansão da produção agrícola do dendê estimula suas ações mediante uma série de atos normativos e políticas de expansão do dendê no Brasil.

2.4.2 Atos normativos e instrumentos de incentivos para a expansão da produção de dendê no Brasil

O PPSOP contempla financiamento junto ao Pronaf Eco-Dendê de até 10 hectares, com empréstimos de até $\mathrm{R} \$ 65$ mil, com juros de até $2 \%$ ao ano e prazo de até 20 anos para quitação. O PPSOP procura incentivar a integração da agricultura familiar ao agronegócio do 
dendê. Este programa criou uma linha de crédito chamada de Pronaf Eco-Dendê para energia renovável e sustentabilidade ambiental. Posteriormente este valor de financiamento da cultura do dendê para a agricultura familiar foi alterado para $\mathrm{R} \$ 80.000,00$.

O Pronaf Eco-Dendê “condiciona o crédito a existência de contrato de fornecimento para a indústria, incluindo compromisso de compra da produção, fornecimento de mudas e assistência técnica" (BRASIL, 2010b, p.9). Segundo dados do Banco da Amazônia (BASA), que opera o Pronaf Eco-Dendê, só no Baixo Tocantins entre 2010 e 2012 foram realizados 257 novos contratos de agricultores integrados ao dendê. Os maiores destaques ficam para os municípios de Moju, com 115 contratos, seguido de Tailândia, com 95 contratos e Acará, com 42 contratos (REPÓRTER BRASIL, 2010).

O Banco da Amazônia (Basa), como principal agente de fomento do crédito agrícola na Amazônia, tem um papel central na execução do Pronaf na Região Amazônica. Em 2010, no contexto do PPSOP, o Manual de Crédito Rural foi alterado para a criação do Pronaf com foco na produção familiar de dendê.

O pronaf Eco-Dende está regulamentado pelo Banco Central do Brasil (Bacen), por meio do Manual de Crétito Rural (MCR). Neste documento, no capítulo 10, seção 16, destaca-se que os projetos de investimento para as culturas do dendê terão como limite de crédito por beneficiário até $\mathrm{R} \$ 80.000,00$. O prazo para o reembolso será de até 14 (quatorze) anos, incluídos até 6 (seis) anos de carência (BACEN, 2015).

No contexto do PPSOP, foram criados um conjunto de atos normativos e políticas de incentivos para a expansão da produção de dendê no Brasil, em especial na Amazônia. Os principais atos e instrumentos de incentivosforam: a criação da linha de crédito do Pronaf Eco-Dendê, do Programa Plantio Comercial e Recuperação de Florestas (Propflora), do Programa de Incentivo a Produção Sustentável do Agronegócio (Produsa), da Câmara Setorial da Palma (MAPA), além da elaboração do Zoneamento Agroecológico da Palma de Óleo (ZAE-PALMA), realizado pela Embrapa.

A criação de todos esses instrumentos teve como objetivos dar segurança a expansão da produção da palma de óleo de dendê no Brasil. Desta forma diversos segmentos envolvidos na cadeia produtiva do dendê foram contemplados. Para atender os agricultores familiares foi criada a linha de fomento do Pronaf Eco-Dendê. Para atender o plantio comercial da palma foram alteradas as regras do Propflora, que anteriormente limitavam o financiamento da palma a destinação de biocombustível. Para atender o segmento do agronegócio de dendê foi estimulado o plantio de palma para recuperação de áreas já degradadas no contexto do 
Produza (BRASIL, 2010b). O Quadro 20 apresenta detalhes dos principais instrumentos de fomento para a produção de palma no contexto do PPSOP.

Quadro 20: Instrumentos para financiamento da produção de palma no Brasil, segundo o PPSOP

\begin{tabular}{|c|c|c|c|}
\hline & PRONAF ECO-DENDÊ & PROPFLORA & PRODUZA \\
\hline PÚBLICO & $\begin{array}{l}\text { Agricultores familiares } \\
\text { enquadrados no Pronaf, } \\
\text { exceto os classificados } \\
\text { no grupo "A", "A/C" e } \\
\text { "B" }\end{array}$ & $\begin{array}{l}\text { Produtores rurais (pessoas } \\
\text { físicas ou jurídicas), suas } \\
\text { associações e cooperativas. }\end{array}$ & $\begin{array}{l}\text { Produtores rurais e suas } \\
\text { cooperativas, inclusive } \\
\text { para repasse a } \\
\text { cooperados. }\end{array}$ \\
\hline Finalidade & $\begin{array}{l}\text { Investimentos para } \\
\text { implantação da cultura } \\
\text { da palma de óleo, com } \\
\text { custeio associado para a } \\
\text { manutenção da cultura } \\
\text { até o quarto ano }\end{array}$ & $\begin{array}{l}\text { Implantação de plantios de } \\
\text { palma de óleo, incluindo } \\
\text { investimentos, custeio } \\
\text { associado ao projeto de } \\
\text { investimento; despesas } \\
\text { relacionadas ao uso de mão- } \\
\text { de-obra própria; implantação } \\
\text { de viveiros de mudas } \\
\text { florestais. }\end{array}$ & $\begin{array}{l}\text { Investimentos fixos e } \\
\text { semifixos e custeio } \\
\text { associado ao } \\
\text { investimento. }\end{array}$ \\
\hline $\begin{array}{l}\text { Limite do } \\
\text { financiamento }\end{array}$ & $\begin{array}{l}\text { Até } \mathrm{R} \$ 6.500,00 \text { por } \\
\text { hectare, limitado a } \mathrm{R} \$ \\
65.000,00 \text { por } \\
\text { beneficiários }\end{array}$ & Até $\mathrm{R} \$ 300 \mathrm{mil}$ & $\begin{array}{l}\text { Até } \mathrm{R} \$ 400 \text { mil para } \\
\text { projetos destinados a } \\
\text { recuperação de áreas } \\
\text { degradadas-até } \mathrm{R} \$ 300 \\
\text { mil nos demais casos. }\end{array}$ \\
\hline Juros & $\begin{array}{l}\text { Taxa efetiva de } 2 \% \text { ao } \\
\text { ano }\end{array}$ & $6,75 \%$ ao ano & $\begin{array}{l}5,75 \% \text { ao ano para } \\
\text { projetos em áreas } \\
\text { degradadas }-6,75 \% \text { ao } \\
\text { ano nos demais casos. }\end{array}$ \\
\hline $\begin{array}{l}\text { Prazo para } \\
\text { pagamento }\end{array}$ & Até 14 anos & Até 12 anos & Até 12 anos \\
\hline Carência & Até 6 anos & Até 6 anos & Até 6 anos \\
\hline
\end{tabular}

Fonte: Organizado pelo autor com base em Brasil (2010b, p. 11)

Os instrumentos previstos no PPSOP em suas diretrizes estabelecem um conjunto de condicionalidades que devem ser observadas pelos agentes de fomento e pelos beneficiários destas políticas. No caso do Pronaf Eco-Dendê condiciona à liberação de financiamento a existência de celebração de contrato do agricultor com a empresa integradora, além da compra da produção, do fornecimento de mudas e da assistência técnica garantidos pela empresa, bem como a observância do Zoneamento Agroecológico da Palma de Óleo. O Quadro 21 detalha esses instrumentos apresentando suas condicionalidades para o acesso aos incentivos a produção de dendê no Brasil. 


\section{Quadro 21: Instrumentos e condicionalidades para financiar a expansão da produção de palma de óleo no Brasil}

\begin{tabular}{|l|l|}
\hline \multirow{4}{*}{ Instrumentos } & \multicolumn{1}{c|}{ Condicionalidades } \\
\hline \multirow{4}{*}{$\begin{array}{l}\text { Pronaf Eco - } \\
\text { Dendê }\end{array}$} & Condiciona o crédito à existência de contrato de fornecimento para a indústria \\
\cline { 2 - 2 } & Compromisso de compra da produção \\
\cline { 2 - 2 } & Fornecimento de mudas e assistência técnica \\
\cline { 2 - 2 } & Observância do Zoneamento Agroecológico estabelecido para a cultura \\
\cline { 2 - 2 } & $\begin{array}{l}\text { Prevê a liberação de recursos, durante os primeiros anos do projeto, para } \\
\text { remunerar a mão-de-obra familiar }\end{array}$ \\
\hline Propflora & $\begin{array}{l}\text { Voltada para produtores rurais (pessoas físicas ou jurídicas), suas associações } \\
\text { e cooperativas [...] somente quando destinado à produção de biocombustível }\end{array}$ \\
\hline Produsa & $\begin{array}{l}\text { Destinada a produtores rurais e suas cooperativas, que possuam projetos de } \\
\text { implantação da cultura de palma em áreas com algum nível de degradação }\end{array}$ \\
\hline
\end{tabular}

Fonte: Organizado pelo autor com base em Brasil (2010c, p. 10)

Para promover o ordenamento territorial da cultura da palma de óleo no Brasil, o governo federal, por intermédio da Embrapa, elaborou o Zoneamento Agroecológico da Palma de Óleo (ZAE-PALMA), com o objetivo de identificar as áreas mais adequadas à expansão sustentável do seu cultivo.

Na safra agrícola de 2010/2011, o governo federal autorizou o plantio de palma de óleo em áreas antropizadas aptas dos estados: Acre, Amazonas, Amapá, Maranhão, Mato Grosso, Pará, Rondônia, Roraima, Alagoas, Bahia, Pernambuco, Sergipe, Rio de Janeiro e Espírito Santo (BRASIL, 2010b).

$\mathrm{Na}$ construção do ZAE-PALMA adotou-se a estrutura classificatória que considera níveis tecnológicos de manejo, B (nível médio) e C (nível alto) e de classes de manejocomo preferencial (terras sem limitações), regular (terras com limitações moderadas), marginal (terras com limitações fortes) e inapta (terras com limitações muito fortes), conforme se verifica com mais detalhes nos Quadros 22 e 23. 


\section{Quadro 22: Características dos níveis de manejo do Zoneamento Agroecológicoda Palma de Óleo no Brasil.}

\begin{tabular}{|c|l|}
\hline $\begin{array}{c}\text { Nível de } \\
\text { manejo }\end{array}$ & \multicolumn{1}{|c|}{ Características } \\
\hline B & $\begin{array}{l}\text { Emprega práticas agrícolas que refletem um nível tecnológico médio, havendo } \\
\text { modesta aplicação de capital e de resultados de pesquisas para manejo, } \\
\text { melhoramento conservação das condições das terras e das lavouras. As práticas } \\
\text { agrícolas estão condicionadas, principalmente, à tração animal. Motomecanização, } \\
\text { portanto, é mais intensa no preparo inicial dosolo e em alguns tipos de tratos } \\
\text { culturais compatíveis com implementos agrícolas mais simples. }\end{array}$ \\
\hline C & $\begin{array}{l}\text { Emprega práticas agrícolas que refletem um alto nível tecnológico; caracterizando- } \\
\text { se pela aplicação intensiva de capital e de tecnologias para manejo, melhoramento e } \\
\text { conservação das condições das terras e das lavouras. A motomecanização está } \\
\text { presente nas diversas fases da operação agrícola. }\end{array}$ \\
\hline
\end{tabular}

Fonte: Embrapa (2010, p. 11)

Mediante o Decreto $n^{-}$7.172, de 7de maio de 2010, foi aprovado o Zoneamento Agroecológico da Cultura da Palma de Óleo (ZAE-PALMA) no Brasil. Constitui-se em um marco para a implantação sustentável da cadeia de produção de óleo de palma no país, tendo como objetivos orientar a expansão da produção de palma em bases sustentáveis, observandose os aspectos econômicos, sociais e ambientais dos projetos implantados. As diretrizes do ZAE-PALMA foram implementadas já na safra agrícola de 2010/2011.

Para o cultivo da palma de óleo no Brasil, o ZAE-PALMA elegeu como áreas aptas para o desenvolvimento desta cultura agrícola as áreas antropizadas até $2007^{56}$, segundo dados fornecidos pelo banco de dados do INPE/Prodes. Sendo retiradas posteriormente desta lista as áreas de vegetação nativa, as unidades de conservação, as terras indígenas, as áreas urbanas e de serventia pública. Na elaboração do ZAE-PALMA foram observadas a aptidão climática e a aptidão das terras para o cultivo da palma (BRASIL, 2010c).

O ZAE-PALMA definiu como classes de zoneamento, de acordo com suas limitações ambientais (clima e terras) para a cultura do dendê. Esta classificação foi: preferencial, regular, marginal e inapta. A classe preferencial foi considerada como terras sem limitação para o cultivo do dendê. A classe regular foi identificada como sendo as de terras com limitações para o cultivo de dendê. A classe marginal foi caracterizada como sendo constituída por terras com limitações fortes para a produção agrícola de dendê e finalmente a classe inapta foi identificada como sendo constituída por terras com limitações muito fortes (EMBRAPA, 2010). O Quadro 23 apresenta mais detalhes destas classes.

\footnotetext{
${ }^{56}$ Como o zoneamento agroecológico utiliza imagens de 2007, o mapa das áreas antropizadas ficou congelado naquele ano e qualquer nova área não pôde ser incorporada à produção (BRASIL, 2010b, p. 7).
} 


\section{Quadro 23: Características das classes do manejo do Zoneamento Agroecológicoda Palma de Óleo no Brasil.}

\begin{tabular}{|l|l|}
\hline \multicolumn{1}{|c|}{$\begin{array}{c}\text { Classes de } \\
\text { manejo }\end{array}$} & \multicolumn{1}{c|}{ Características } \\
\hline $\begin{array}{l}\text { Preferencial } \\
\text { (potencial } \\
\text { alto) }\end{array}$ & $\begin{array}{l}\text { Terras sem limitações significativas para a produção sustentada da palma de } \\
\text { óleo. O clima, preferencial, apresenta déficit hídrico menor que 200 mm e até } \\
\text { três meses secos consecutivos (<50mm). Esse mínimo de restrições não } \\
\text { reduz, expressivamente, a produtividade ou os benefícios e não aumenta a } \\
\text { necessidade de insumos e práticas mitigadoras acima de um nível aceitável. }\end{array}$ \\
\hline $\begin{array}{l}\text { Regular } \\
\text { (potencial } \\
\text { médio) }\end{array}$ & $\begin{array}{l}\text { Terras com limitações moderadas para a produção sustentada da palma de } \\
\text { óleo. O clima, regular, apresenta déficit hídrico entre 200 mm e 350 mm, } \\
\text { com até três meses secos consecutivos (<50 mm). As limitações reduzem a } \\
\text { produtividade ou os benefícios ou elavam a necessidade de insumos e } \\
\text { praticas para aumentar o entendimento da cultura. }\end{array}$ \\
\hline $\begin{array}{l}\text { Marginal } \\
\text { (potencial } \\
\text { baixo) }\end{array}$ & $\begin{array}{l}\text { Terras com limitações fortes para a produção sustentada da palma de óleo. O } \\
\text { clima marginal apresenta déficit hídrico entre 350 mm e 450 mm, com até } \\
\text { três meses secos }(<50 \text { mm). }\end{array}$ \\
\hline $\begin{array}{l}\text { Inapta } \\
\text { (potencial } \\
\text { muito baixo) }\end{array}$ & $\begin{array}{l}\text { Terras com limitações muito fortes e clima desfavorável que impedem a } \\
\text { produção econômica da palma de óleo. }\end{array}$ \\
\hline
\end{tabular}

Fonte: Organizado pelo autor com base em Brasil (2010c, p. 10)

O Mapa 10, produzido pelo ZAE-PALMA, espacializa as terras aptas para o cultivo de dendê na Amazônia legal, do nível tecnológico B, onde são destacadas as classes: preferencial (verde), regular (marrom), marginal (amarelo) e inapta (cinza). O presente mapa deixa clara a localização das áreas aptas das classes preferencial (verde), onde os estados que mais se destacam são Rondônia, Pará e Amazonas. As áreas aptas da classe marginal (marrom) estão fundamentalmente localizadas nos estados do Pará, Rondônia e Amazonas (EMBRAPA, 2010). 
Mapa 10: Zoneamento agroecológico do dendezeiro nas áreas desmatadas da Amazônia legal, nível de manejo B

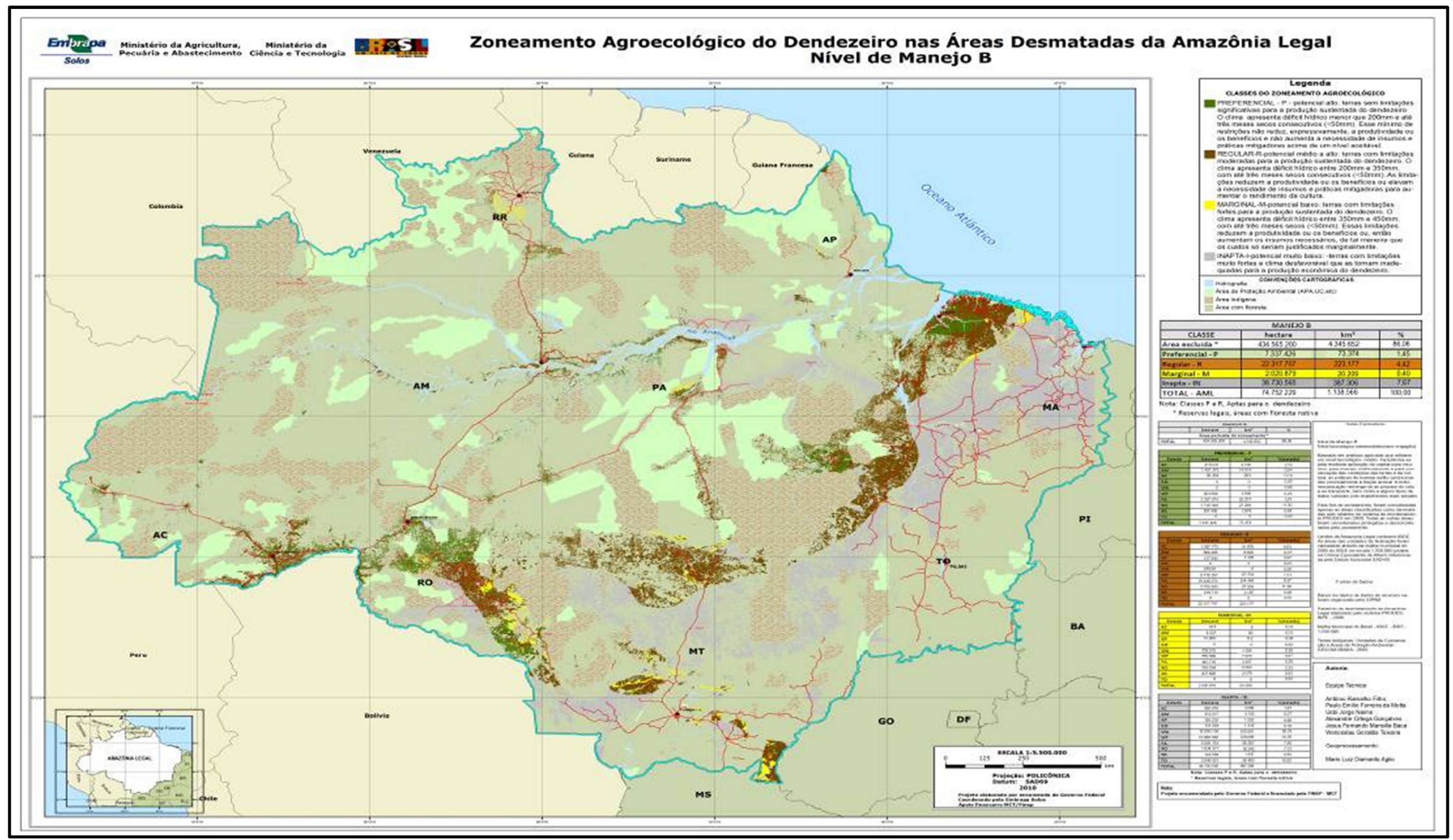


O Mapa 11espacializa as terras aptas para o cultivo de dendê na Amazônia legal, do nível tecnológico $\mathrm{C}$, com as quatro classes anteriormente citadas. As áreas aptas da classe preferencial estão concentradas nos estados de Rondônia, Pará e Amazonas. Já as áreas aptas da classe marginal estão fundamentalmente localizadas nos estados do Pará, Mato Grosso e Rondônia (EMBRAPA, 2010).

Além da produção do mapa regional foram elaborados mapas estaduais pela equipe do ZAE-PALMA. O Pará é o principal estado produtor de dendê do Brasil e o que apresenta a segunda maior área disponível da classe preferencial do nível B, com 2.327.674 hectares aptos para o cultivo de dendê no estado. O estado de Rondônia apresenta a maior área agrícola apta nesta classe e nível, com 2.720.638 hectares disponíveis para produção de dendê. A área apta do Pará compreende a parte leste do território paraense (EMBRAPA, 2010) (Mapa 12).

Já no nível C, na classe preferencial o estado do Pará é o segundo em área agrícola disponível para o cultivo do dendê, com 1.666.831 hectares, ficando atrás apenas de Rondônia que possui 2.930.252 hectares de terras aptas para o plantio de dendê nesta classe e nível tecnológico. Na classe regular o estado do Pará apresenta a maior quantidade de terras aptas do Brasil para a produção de dendê com 10.608.430 hectares. A espacialização deste nível compreende o leste do Pará (EMBRAPA, 2010) (Mapa 13). 
Mapa 11: Zoneamento agroecológico do dendezeiro nas áreas desmatadas da Amazônia legal, nível de manejo C

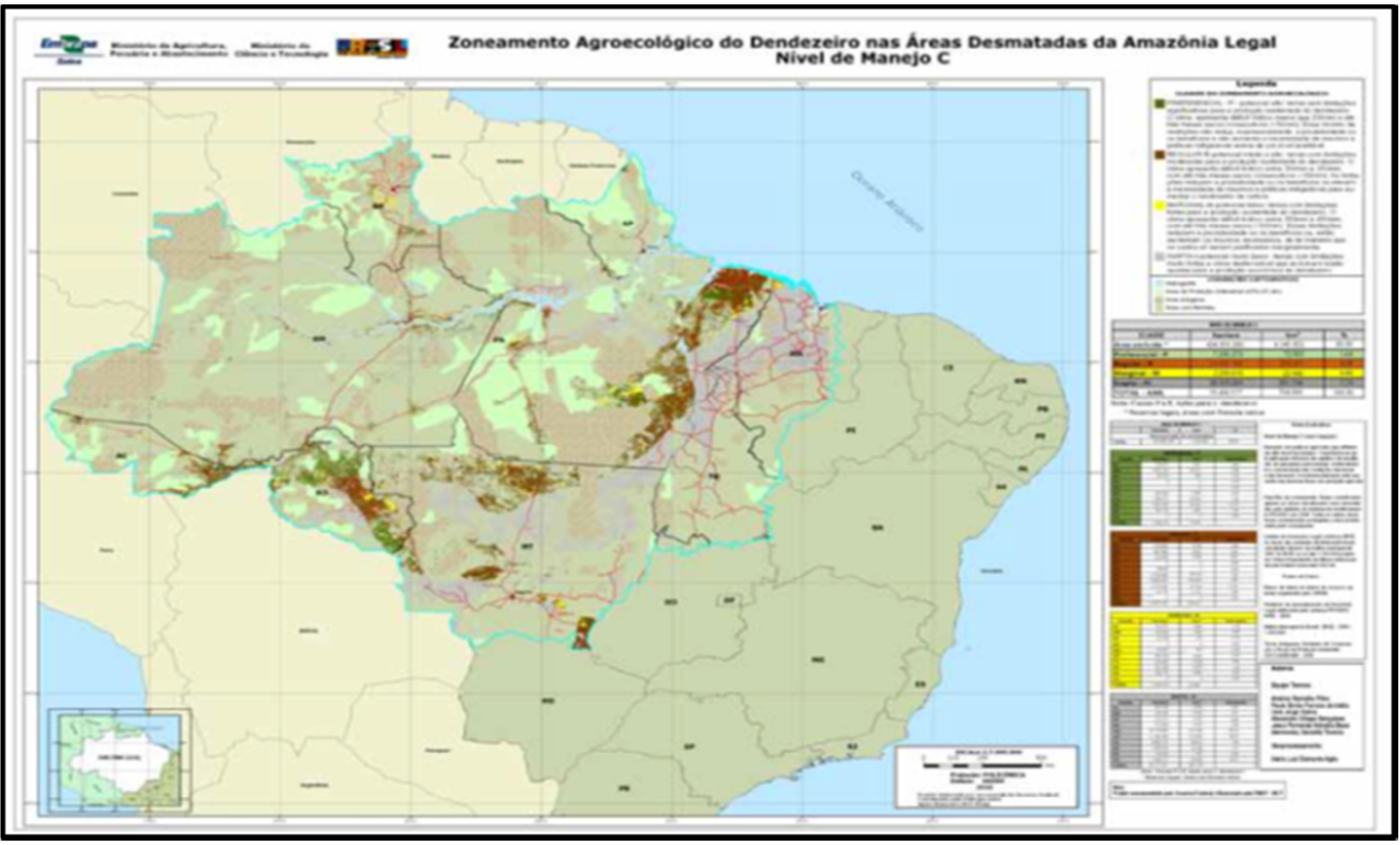


Mapa 12: Zoneamento agroecológico do dendezeiro nas áreas desmatadas da Amazônia legal,estado do Pará- nível de manejo B

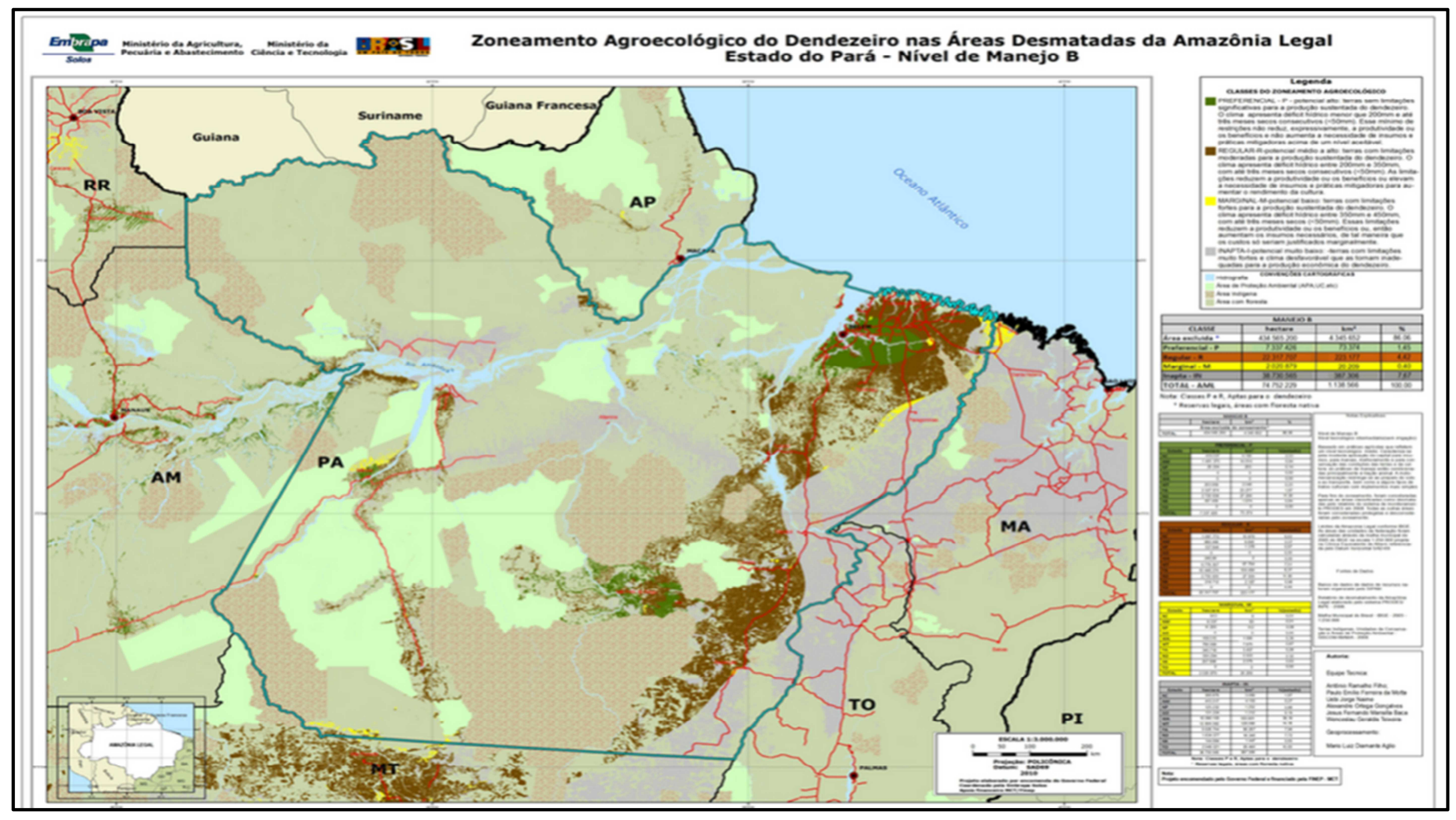


Mapa 13: Zoneamento agroecológico do dendezeiro nas áreas desmatadas da Amazônia legal, estado do Pará- nível de manejo C

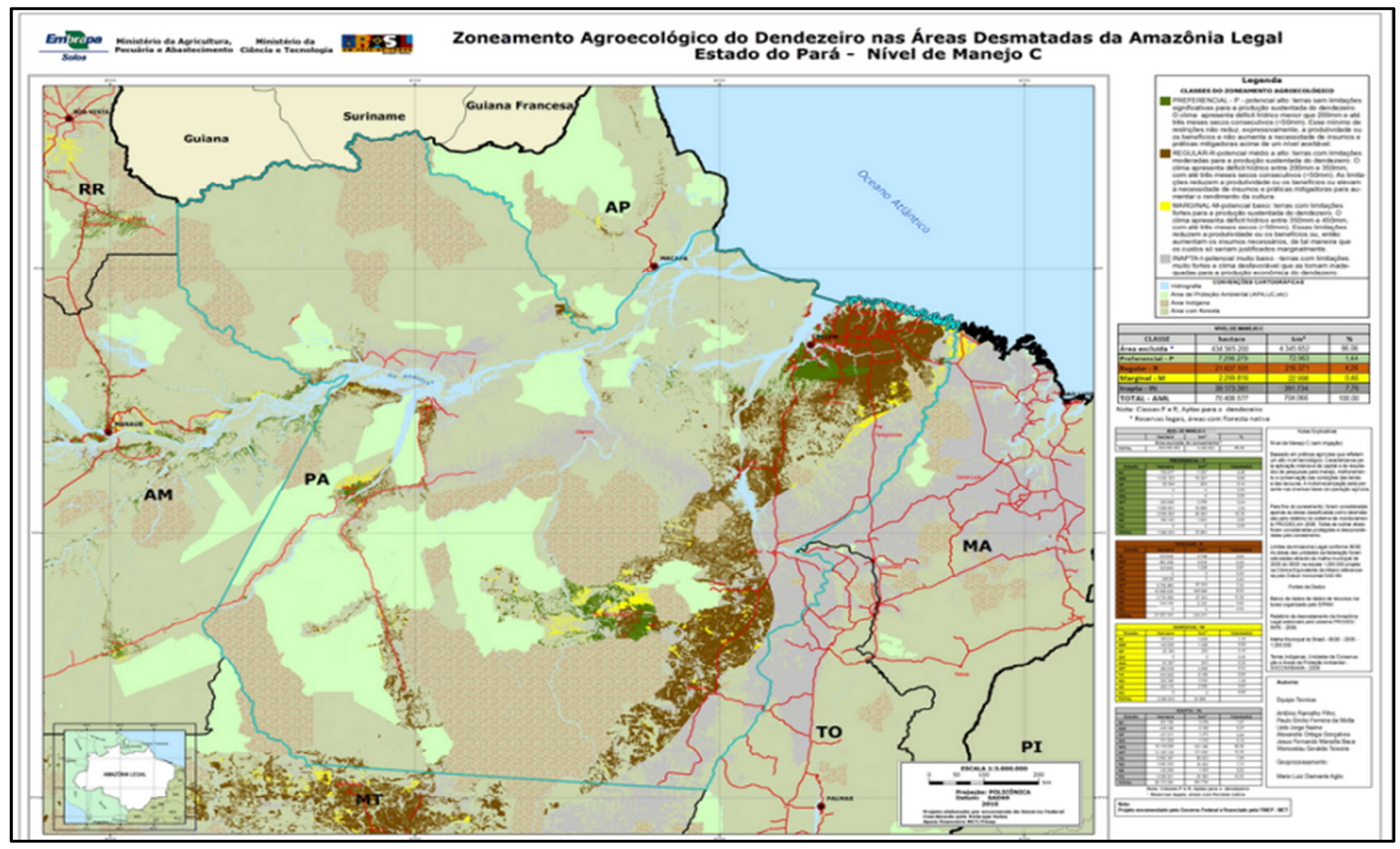


Para restringir a expansão da palma no território nacional, o governo federal enviou ao Congresso Nacional projeto de lei que veda o desmatamento de vegetação para o plantio de palma no Brasil. Estas medidas visam coibir o desmatamento para o plantio de palma principalmente na Amazônia. O marco temporal das áreas antropizadas é 2007, ano base das imagens do ZAE-PALMA, isto impõe que os desmatamentos após esta data não serão permitidos para o plantio da palma no país. Para acompanhar o desenvolvimento da cadeia produtiva da palma e articular as ações estatais e empresariais do setor foi criada a Câmara Setorial da Palma de Óleo. A câmara reúne representantes estatais, empresariais e sociais (BRASIL, 2010b).

A aptidão das terras para o dendê presentes nos dados do ZAE-PALMA indica as áreas aptas para o desenvolvimento desta cultura agrícola na Amazônia legal nos dois níveis tecnológicos (B, C) selecionados para o manejo agrícola. Ao analisar o quadro abaixo constatamos que no nível $\mathrm{B}$, na classe preferencial os estados que apresentam as maiores áreas em hectares aptos para ao plantio de dendê são: Rondônia (2.720.638), Pará (2.327.674) e Amazonas (1.461.375). Já na classe regular do mesmo nível as maiores áreas disponíveis para o plantio de dendê localizam-se no Pará (10.448.374), Rondônia (2.755.935) e Amazonas (1.087.772).

No nível C, na classe preferencial os estados com maiores áreas aptos para o plantio de dendê são Rondônia (2.930.252), Pará (1.666.831) e Amazonas (1.532.123). Já na classe regular do mesmo nível, os destaques são para o Pará (10.608.430), Mato Grosso (6.700.985) e Rondônia (2.733.292), conforme o Quadro 24.

Quadro 24: Áreas aptas das classes de zoneamento para produção de dendê nível B e C nos estados da Amazônia legal.

\begin{tabular}{|c|c|c|c|c|c|c|c|c|}
\hline \multirow{3}{*}{ Estados } & \multicolumn{4}{|c|}{ Nível B } & \multicolumn{4}{|c|}{ Nível C } \\
\hline & \multicolumn{2}{|c|}{ Preferencial } & \multicolumn{2}{|c|}{ Regular } & \multicolumn{2}{|c|}{ Preferencial } & \multicolumn{2}{|c|}{ Regular } \\
\hline & Hectares & $\%$ & Hectares & $\%$ & Hectares & $\%$ & Hectares & $\%$ \\
\hline $\mathrm{AC}$ & 416.037 & 2,53 & 1.087 .772 & 6.63 & 735.677 & 4,48 & 574.630 & 3,50 \\
\hline $\mathrm{AM}$ & 1.461 .375 & 0,94 & 889.466 & 0,57 & 1.532 .123 & 0,98 & 681.556 & 0,44 \\
\hline AP & 20.334 & 0,14 & 137.844 & 0.97 & 20.334 & 0,14 & 123.843 & 0,87 \\
\hline MA & 0 & 0,0 & 246,96 & 0,00 & 0 & 0,00 & 246,96 & 0,0 \\
\hline MT & 203.959 & 0,23 & 6.779 .357 & 7,51 & 220.920 & 0,24 & 6.700 .985 & 7,42 \\
\hline PA & 2.327 .674 & 1,87 & 10.448 .374 & 8,37 & 1.666 .831 & 1,34 & 10.608 .430 & 8,50 \\
\hline $\mathrm{RO}$ & 2.720 .638 & 11,50 & 2.755 .935 & 11,60 & 2.930 .252 & 12,33 & 2.733 .292 & 11,50 \\
\hline RR & 187.409 & 0,84 & 218.712 & 0,98 & 190.143 & 0,85 & 214.119 & 0,95 \\
\hline
\end{tabular}

Fonte: Modificado pelo autor com base em Embrapa (2010) 
O documento Zoneamento agroecológico do dendezeiro para as áreas desmatadas da Amazônia legal, lançado pela Embrapa (2010), indicou a existência de $296.551 \mathrm{~km}$, equivalentes a 29.655.133 hectares de terras aptas para o plantio de dendê no manejo do nível B, o que compreende 5,87\% das terras desmatadas na Amazônia legal, até o ano de 2007. Já as terras aptas para o cultivo do dendê no manejo de nível C correspondem $289.344 \mathrm{~km}$, equivalentes a 28.933.380 hectares que compreende 5,72\% das áreas desmatadas da Amazônia legal até 2007. O mesmo estudo conclui que não houve diferença significativa no total das áreas das terras cultivadas de dendê para o nível B e para o nível C(EMBRAPA, 2010).

O Decreto $n^{\circ} 7.172 / 2010$ que instituiu o ZAE-PALMA trouxe como anexo a lista dos municípios cujos territórios foram considerados aptos para o cultivo de dendê no Brasil. Nestes dados constam os níveis B e C, a classe preferencial e regular, além dos dados das áreas agrícolas aptas em quilômetros quadrados e hectares. Tendo como base estes dados, o Quadro 25 reflete as áreas aptas dos municípios do Baixo Tocantins para o cultivo de dendê no estado do Pará.

Desta forma, no nível B da classe preferencial a maior quantidade das terras aptas estão localizadas nos territórios agrícolas de Acará (233.883.00), Moju (155.803,32) e Abaetetuba $(64.246,32)$. Já na classe regular do mesmo nível as principais áreas aptas localizam-se em Moju (245.466.36), Tailândia (194.526,36) e Baião (123.960,24).

No nível C, na classe preferencial, as maiores áreas disponíveis para o plantio de dendê estão localizadas nos municípios do Acará (209.028,96), Moju (155.803,32) e Abaetetuba (64.246,32). Já na classe regular os destaques são para Moju (245.466,36), Tailândia (194.526,36) e Acará (123.960,24). Quando somamos as áreas aptas da classe preferencial e regular do nível B, constatamos que as maiores áreas aptas para a produção de dendê estão localizadas em Moju (401.269,68), Acará $(301.442,76)$ e Tailândia $(194.526,36)$. Já a somatória do nível C (preferencial e regular) as maiores áreas aptas estão localizadas em Moju (401.269,68), Acará (301.442,76) e Tailândia (194.526,36) (Quadro 25). 
Quadro 25: Áreas aptas das classes de zoneamento para produção de dendê nível B e C nos municípios do Baixo Tocantins (PA)

\begin{tabular}{|c|c|c|c|c|c|c|c|c|}
\hline \multirow{3}{*}{ Municípios } & \multicolumn{4}{|c|}{ Nível B } & \multicolumn{4}{|c|}{ Nível C } \\
\hline & \multicolumn{2}{|c|}{ Preferencial } & \multicolumn{2}{|c|}{ Regular } & \multicolumn{2}{|c|}{ Preferencial } & \multicolumn{2}{|c|}{ Regular } \\
\hline & $\mathrm{Km}^{2}$ & Hectares & $\mathrm{Km}^{2}$ & Hectares & $\mathbf{K m}^{2}$ & Hectares & $\mathrm{Km}^{2}$ & Hectares \\
\hline Abaetetuba & 642,46 & $64.246,32$ & 0,00 & 0,00 & 642,46 & $64.246,32$ & 0,00 & 0,00 \\
\hline Acará & $2.338,83$ & $233,883,00$ & 675,60 & $67.559,76$ & $2.090,29$ & $209.028,96$ & 924,14 & $92.413,80$ \\
\hline Baião & 0,00 & 0,00 & $1.239,60$ & $123.960,24$ & 0,00 & 0,00 & $1.239,60$ & $123.960,24$ \\
\hline Barcarena & 533,32 & $53.331,84$ & 0,00 & 0,00 & 533,32 & 0,00 & 0,00 & 0,00 \\
\hline Cametá & 203,61 & $20.361,24$ & 379,82 & $37.981,80$ & 203,61 & $20.361,24$ & 379,82 & $37.981,80$ \\
\hline Igarapé-Miri & 335,12 & $33.512,40$ & 12,55 & $1.254,96$ & 335,12 & $33.512,40$ & 12,55 & $1.254,96$ \\
\hline Limoeiro do Ajuru & 0,37 & 36,72 & 0,00 & 0,00 & 0,37 & 36,72 & 0,00 & 0,00 \\
\hline Mocajuba & 0,00 & 0,00 & 454,80 & $45.479,88$ & 0,00 & 0,00 & 454,80 & $45.479,88$ \\
\hline Moju & $1.558,03$ & $155.803,32$ & $2.454,66$ & $245.466,36$ & $1.558,03$ & $155.803,32$ & $2.454,66$ & $245.466,36$ \\
\hline Oeiras do Pará & 166,92 & $16.692,12$ & 416,07 & $41.607,36$ & 166,92 & $16.692,12$ & 416,82 & $41.681,88$ \\
\hline Tailândia & 0,00 & 0,00 & $1.945,26$ & $194.526,36$ & 0,00 & 0,00 & $1.945,26$ & $194.526,36$ \\
\hline
\end{tabular}

Fonte: Organizado pelo autor com base em Brasil (2010c)

Os dados apresentados no Quadro 25 demonstram o grande potencial de terras aptas para o cultivo da cultura do dendê no território do Baixo Tocantins.

2.4.3 Criação da linha Eco-Dendê no Programa Nacional de Fortalecimento da Agricultura Familiar (Pronaf)

Em 1996, mediante o Decreto $\mathrm{n}^{\mathrm{o}}$ 1.946/1996 foi criado o Programa Nacional de Fortalecimento da Agricultura Familiar (Pronaf), tendo como finalidade "promover o desenvolvimento sustentável do segmento rural constituído pelos agricultores familiares, de modo a propiciar-lhes o aumento da capacidade produtiva, a geração de empregos e a melhora de renda". O Pronaf foi à primeira política pública especifica da agricultura familiar criada no Brasil. Este programa se beneficiou de um conjunto de estudos já realizados, principalmente os do convênio FAO/Incra que estabeleceram as primeiras tipologias dos estabelecimentos familiares no Brasil.

Em 2006, a Lei $n^{\circ} 11.326 / 2006$ define agricultores familiares e empreendedores rurais familiares. Esta lei foi sancionada em 24 de junho de 2006 permitindo a criação de marco legal com a delimitação conceitual de agricultura familiar, que logo foi incorporado à execução de políticas púbicas de agricultura familiar em todo o Brasil.

A Lei $\mathrm{n}^{\mathrm{o}} 11.326$ estabelece as diretrizes da Política Nacional da Agricultura Familiar e Empreendimentos Familiares Rurais, definindo agricultor familiar: 
Artigo $3^{\circ}$ - Para os efeitos desta lei considera-se agricultor familiar e empreendedor familiar rural aquele que pratica atividades no meio rural, atendendo simultaneamente, aos seguintes requisitos:

I. Não detenha, a qualquer titulo, área maior do que 4 (quatro) módulos fiscais;

II. Utilize predominantemente mão-de-obra da própria família nas atividades econômicas do seu estabelecimento ou empreendimento;

III. Tenha renda familiar predominantemente originada de atividades econômicas ao próprio estabelecimento ou empreendimento

IV. Dirija seu estabelecimento ou empreendimento com sua família.

A conceituação acima de agricultor familiar é a que atualmente o governo federal tem utilizado como referência em suas políticas públicas, bem como na inserção em estatísticas oficiais. A ação do Estado por meio da criação de políticas públicas para a agricultura familiar foi fundamental para a consolidação desta categoria analítica no Brasil. A criação do Pronaf, em 1995, e da Lei da Agricultura Familiar (Lei n⿳ำ 11.326/2006) são marcos importantes nesta construção.

Alinha do Pronaf destinado ao fomento familiar do cultivo agrícola de dendê é recente no Brasil.Visando fomentar a expansão da produção de palma de óleo no Brasil, o Conselho Monetário Nacional (CMN), por recomendação do governo federal, aprovou em 28.10.2009, a criação da linha de crédito para o cultivo do dendê junto ao Pronaf. Esta decisão estabelece as normativas de limites de crédito, valor do financiamento, juros e prazo de carência para os beneficiários desta política de crédito rural. Esta nova linha de crédito foi criada no interior do Programa Nacional de Fortalecimento da Agricultura Familiar (Pronaf) e recebeu o nome de Pronaf Eco-Dendê, tendo como finalidade fomentar a produção de dendê no Brasil. A medida prevê a condicionalidade de contrato entre o agricultor familiar e a empresa integradora para o credenciamento do agricultor familiar junto à linha do Pronaf Eco-Dendê. Esta ação destinase a um esforço do Brasil em reduzir sua dependência de importação de óleo de dendê, considerado o segundo óleo vegetal mais consumido no mundo, bem como o seu uso na produção de biodiesel (AGÊNCIA BRASIL, 28.10.2009).

O Manual de Crédito Rural (MCR) do Banco Central do Brasil é o documento que normatiza o fomento do crédito rural no Brasil. Este documento considera como condições para o acesso ao Pronaf Eco-Dendê a observância por parte dos beneficiários desta política que o crédito deve ser empregado no cultivo de dendê, onde o limite de financiamento bancário para esta modalidade é de até $\mathrm{R} \$ 80.000,00$ e prazo de 14 anos para desembolso do financiamento como podemos verificar no Quadro 26 que detalhes as condições de acesso ao Pronaf Eco-Dendê (BACEN, 2015). 
Quadro 26: Condições do Pronaf Eco-Dendê

\begin{tabular}{|l|l|}
\hline \multicolumn{1}{|c|}{ Condições } & \multicolumn{1}{c|}{ Agricultores familiares enquadrados no Pronaf } \\
\hline Finalidade & $\begin{array}{l}\text { Investimento para implantação das culturas do dendê com custeio } \\
\text { associado para a manutenção da cultura até o quarto ano }\end{array}$ \\
\hline $\begin{array}{l}\text { Limite de crédito por } \\
\text { beneficiários }\end{array}$ & $\mathrm{R} \$ 80.000,00$ (oitenta mil reais) \\
\hline Prazo para desembolso & Até 14 (quatorze) anos, incluídos até 6 (seis) anos de carência \\
\hline
\end{tabular}

Fonte: Organizado pelo autor com base em Bacen (2015)

As condições normativas do financiamento do programa para o agricultor familiar exigem o cumprimento de algumas condicionalidades por parte dos beneficiários do Pronaf Eco-Dendê.

A instrução normativa do Pronaf Eco-Dendê (Manual de Crédito Rural) impõe condicionalidade ambiental para o acesso a este financiamento rural, pois o cultivo do dendê deve ser obrigatoriamente realizado apenas em áreas já desmatadas até o ano de 2007. Outra condicionalidade para o acesso ao financiamento bancário do Pronaf Eco-Dendê diz respeito à obrigatoriedade de contrato de fornecimento da produção familiar a uma empresa integradora de dendê. No contrato do agricultor com a empresa integradora deve ficar claro o fornecimento das mudas e da assistência técnica que são de responsabilidade da empresa, como se pode verificar no Quadro 27.

\section{Quadro 27: Condicionalidades para acesso ao Pronaf Eco-Dendê}

\begin{tabular}{|l|l|}
\hline Pronaf Eco-Dendê & \multicolumn{1}{c|}{ Condicionalidade } \\
\hline \multirow{3}{*}{ Beneficiários } & $\begin{array}{l}\text { Observância do Zoneamento Agrícola de Risco Climático elaborado } \\
\text { pelo Ministério da Agricultura, Pecuária e Abastecimento }\end{array}$ \\
\cline { 2 - 3 } & $\begin{array}{l}\text { A apresentação de contrato ou instrumento similar de fornecimento } \\
\text { da produção para indústria de processamento ou beneficiamento do } \\
\text { produto no qual fiquem expressos os compromissos desta com a } \\
\text { compra da produção, com o fornecimento de mudas de qualidade e } \\
\text { com a prestação de assistência técnica }\end{array}$ \\
\hline
\end{tabular}

Fonte: Organizado pelo autor com base em Bacen (2015)

O Pronaf Eco-Dendê prevê recursos para a mão-de-obra e a assistência técnica na plantação de dendê nos quatro primeiros anos do plantio. Vale destacar que até o terceiro ano do plantio o dendezal encontra-se na fase improdutiva, o que justifica a liberação de parcelas mensais no banco para a realização de serviços de mão-de-obra e assistência técnica no dendezal. 
O Quadro 28 detalha os recursos liberados para o agricultor familiar beneficiário do Pronaf Eco-Dendê para os serviços de mão-de-obra e assistência técnica durante os quatro primeiros anos do plantio do dendê. As parcelas liberadas para a mão-de-obra destinam-se a atividades de manutenção do dendezal, o que geralmente é realizado pela própria família envolvida no plantio. Das parcelas liberadas para a mão-de-obra o agricultor familiar poderá contratar terceiros para a realização de serviços necessários que a familiar não possa realizar. Do segundo ao quarto ano, estas parcelas para mão-de-obra são liberadas pelo banco a cada três meses.

Quadro 28: Recursos destinados à mão-de-obra e assistência técnica do Pronaf Eco-Dendê durante os quatro primeiros anos do projeto

\begin{tabular}{|c|c|}
\hline Finalidade & Aplicação de parcelas de recursos \\
\hline \multirow[b]{2}{*}{ Mão-de-obra } & $\begin{array}{l}\text { No } 1^{\circ} \text { (primeiro) ano, liberação conforme orçamento e cronograma previstos no } \\
\text { projeto }\end{array}$ \\
\hline & $\begin{array}{l}\text { Do } 2^{-} \text {(segundo) ao } 4^{0} \text { (quarto) ano, até } \mathrm{R} \$ 600,00 \text { (seiscentos reais) por } \\
\text { hectare/ano, com liberação em parcelas trimestrais, condicionadas à correta } \\
\text { execução das atividades previstas para o período no projeto de financiamento }\end{array}$ \\
\hline \multirow{2}{*}{$\begin{array}{l}\text { Assistência } \\
\text { técnica }\end{array}$} & $\begin{array}{l}\text { Até } \mathrm{R} \$ 50,00 \text { (cinquenta reais) por hectare/ano, durante os quatro primeiros anos } \\
\text { de implantação do projeto, não se aplicando, nessas operações }\end{array}$ \\
\hline & $\begin{array}{l}\text { Pagamento dos serviços de assistência técnica mediante apresentação de laudo } \\
\text { semestral de acompanhamento do empreendimento, podendo o pagamento ser } \\
\text { feito diretamente ao prestador dos serviços, mediante autorização do mutuário }\end{array}$ \\
\hline
\end{tabular}

Fonte: Organizado pelo autor com base em Bacen (2015)

$\mathrm{O}$ acesso ao financiamento bancário do Pronaf Eco-Dendê impõe uma série de condicionalidades por parte do agricultor familiar que devem ser observadas no ato da celebração do contrato junto à agência bancária. $\mathrm{O}$ acesso ao financiamento desse programa de fomento a produção familiar rural tem contribuído para a expansão da produção do dendê no estado do Pará. A criação da linha de crédito do Pronaf Eco-Dendê está inserida no contexto de incentivo ao cultivo de matérias-primas para a produção de biodiesel de dendê. As ações do PNPB têm estimulado a produção de biodiesel no Brasil contribuindo de forma decisiva para o uso do território brasileiro pelos atores envolvidos nesta política. 


\subsubsection{Produção de biodiesel no Brasil}

O uso do território brasileiro pelo PNPB tem gerado um conjunto de contradições entre os setores estatais, empresarias e sociais. Neste sentido, é possível verificar a presença de atores hegemônicos, como o Estado e as empresas e os atores hegemonizados, como os

agricultores familiares integrados presentes nesta política do PNPB. Desse modo, "a implantação das políticas públicas do PNPB aprofunda as desigualdades, gerando maiores oportunidades e lucros que são apropriadas pelo capital hegemônico" (BERNARDES, 2011, p. 69). O PNPB com uma política pública resultante da participação do setor energético, do agronegócio e da agricultura familiar tem ampliado a competição entre as regiões brasileiras, onde o setor do agronegócio é o que mais recebe benefícios fiscais estatais.

Para ela, "enquanto as políticas do PNPB beneficiam os empresários com as melhores condições [...] das alíquotas do PIS/Pasep e Cofins, o acesso da agricultura familiar se limita aos escassos recursos do Pronaf" (BERNARDES, 2011, p. 69).

Ao que tudo indica a velha dicotomia existente agricultura tradicional (agricultura familiar) e agricultura científica (agronegócio) tende a se acentuar no âmbito do PNPB. Como aponta Bernardes (2011, p. 71), "se antes eram nos confrontos entre latifúndio e minifúndio, hoje ocorrem entre grandes empresas e agricultura familiar, no âmbito do programa do biodiesel e do selo social".

Neste sentido, o PNPB como uma política pública concebida para a integração da agricultura familiar no agronegócio do biodiesel no Brasil acaba fomentando as desigualdades regionais e sociais entre agronegócio e agricultura familiar.

Nesse modelo, denominado por Sachs (2009) de sistema integração de produção de alimentos e bioenergia, o lado mais fraco é certamente o do pequeno agricultor familiar que fica vulnerável a uma série de condições da empresa onde está integrado. É neste sentido que Milton Santos (2008c) fala dos homens lentos que resistem frente aos atores hegemônicos. "A força é dos lentos e não dos que detém a velocidade" (SANTOS, 2008c, p. 80). A organização dos movimentos sociais representa certamente um importante instrumento para a luta por mais direitos frente às empresas integradoras.

A produção de biodiesel segundo as regiões brasileiras entre 2005 a 2010 tem crescido em todas as cinco regiões. No Norte a produção passou de 510 metros cúbicos em 2005 para 95.105 metros cúbicos, em 2010. No Nordeste este valor cresceu de 145 metros cúbicos em 2005, para 176.994 metros cúbicos, em 2010. No Centro-Oeste ocorre o maior crescimento entre as regiões do país, no ano de 2005 não apresenta produção passa para 1.018 .303 metros 
cúbicos em 2010. No Sudeste sua produção passa de 44 metros cúbicos em 2005 para 420.328 metros cúbicos, em 2010. E o Sul a produção passou de 26 metros cúbicos, em 2005, para 605.998 metros cúbicos em 2010. No Brasil esta produção passou de 736 metros cúbicos, em 2005, para 2.386.399, em 2010 (ANP, 2013).

Ao analisarmos as empresas que atuam no setor de biodiesel no Brasil, constamos que este segmento vem sendo cada vez mais dominado pela presença de grandes empresas de atuação global do setor de produção de alimentos. Estas empresas lideradas pelo bloco ABC (ADM, Cargill e Bunge) além da atuação em outros segmentos da produção agrícola de alimentos voltam-se cada vez mais para o setor de biocombustíveis (etanol e biodiesel). A ADM está presente em Rondonópolis (MT) e em Joaçaba (SC), a Cargill está instalada em Três Lagoas (MS) e a Bunge possui uma unidade em Nova Mutum (MT) (ANP, 2013).

Todas estas unidades da ADM, Cargill e Bunge descritas acima constam na lista de empresas de biodiesel detentoras do Selo Combustível Social do MDA, o que indica que foram contempladas com recursos públicos como parte dos benefícios fiscais do PNPB como o PIS/Pasep e o Cofins (BRASIL, 2014a). Estas empresas são lideres na produção e esmagamento de soja no mundo.

Além dos grupos globais no setor, temos a presença de grupos nacionais consolidados como a Petrobras, Granol e Caramuru. A Petrobras é a principal empresa nacional do setor com usinas de biodiesel em Candeias (BA), Quixadá (CE) e Montes Claros (MG). A Granol possui unidades em Anápolis em Goiás, Porto Nacional no Tocantins e Cachoeira do Sul no Rio Grande do Sul. A Caramuru com unidades em Ipameri e São Simão em Goiás. Estas são empresas de destaque no país (ANP, 2013).

O estado de Mato Grosso lidera o número de empresas instaladas em seu território que ao todo perfazem vinte empresas. Rio Grande do Sul e São Paulo apresentam sete empresas instaladas para produção de biodiesel. Já Pará, Maranhão, Ceará, Rio de Janeiro e Santa Catarina apresentam apenas uma empresa instalada em seus territórios (ANP, 2013).

Em 2012 a capacidade instalada para produção do B100 em metros cúbicos nas regiões brasileiras apresenta a seguinte situação: Norte (650), Nordeste (2.058), Centro- Oeste (10.264), Sudeste (2.453) e Sul (6.125) (ANP, 2013). Como se percebe, as regiões prioritárias do PNPB, Norte (última posição) e Nordeste (penúltima posição), foram superadas pelas demais regiões do país como o Centro-Oeste (primeira posição), Sul (segunda posição) e Sudeste (terceira posição). Esta realidade aponta para uma série de fatores que a política oficial não foi capaz de efetivar na promoção do desenvolvimento regional das regiões mais carentes como era o objetivo original do PNPB. 
A execução do PNPB revela uma série de resultados ao longo do tempo. Como lembra Castro (2011, p. 44), “com base nas análises realizadas, pode-se afirmar que não existe nenhum indício de que os incentivos criados pelo PNPB para a produção de biodiesel a partir do óleo de mamona e de dendê surtiram efeito significativo". O PNPB foi criado com foco na inclusão social e no desenvolvimento regional tendo o Norte e o Nordeste como regiões diferenciadas. Os resultados apontam que esta recomendação não tem sido cumprida, onde a soja principalmente do Centro-Oeste se tornou a matéria-prima hegemônica do PNPB.

Em análise do setor de biodiesel, o estudo do IPEA (2012, p. 5) constatou que "há uma defasagem entre as diretrizes do biodiesel (PNA e PNPB) e os resultados alcançados (baixa inserção social, fracasso dos objetivos e metas para o Norte e Nordeste, falta de alternativa à soja, baixo impacto no desenvolvimento regional)". A avaliação da política pública do PNPB elaborada pelo IPEA demonstra o descompasso entre as concepções originais do programa e a realidade, onde as regiões Norte e Nordeste de regiões prioritárias do programa acabaram por transforma-se em regiões periféricas desta política.

Para o IPEA (2012, p. 5), “consolidou-se a dinâmica da larga escala de produção, com aumento do capital estrangeiro, do porte das indústrias do biodiesel e da capacidade excedente de produção". Esta constatação permite explicar a presença de grandes empresas globais, como ADM, Cargill e Bunge, sendo beneficiadas com a política de renuncia fiscal de diversos impostos federais como PIS/Pasep e Cofins, entre outras. Esta situação demonstra que "há em parte, uma inversão do papel do selo combustível social (seus benefícios servem muito mais às indústrias do que aos pequenos agricultores familiares)” (IPEA, 2012, p. 5).

Os recursos aportados por meio das renúncias fiscais no contexto do PNPB têm beneficiado fundamentalmente as empresas agrícolas em detrimento dos agricultores familiares, cujo financiamento bancário junto ao Pronaf penaliza o titular do empréstimo, no caso o agricultor familiar. Os benefícios aos pequenos agricultores familiares se limitam aos escassos recursos do Pronaf, e nas regiões Norte e Nordeste o seu acesso ainda é bastante deficiente.

Atualmente o que se constata é que o PNPB se tornou refém do agronegócio da soja do Centro-Oeste. Neste sentido, John Wilkimson (2008, p.5) apresenta dois cenários territoriais para o biodiesel. O primeiro teria como foco o desenvolvimento local/regional onde ocorreria um "aproveitamento de oleaginosas tradicionais". O segundo estaria vinculado à ampliação da fronteira da soja, onde "o protagonismo se desloca da agricultura familiar e das comunidades tradicionais no Nordeste e do Norte para os agronegócios do Centro-Oeste”. 
Com o decorrer do tempo é o segundo cenário que se consolida no Brasil. O setor do agronegócio passou a dominar o PNPB como ocorreu com o etanol do Proálcool.

No caso do Pará as ações do PNPB destinadas à produção industrial de biodiesel de palma (Palmdiesel) tiveram início em 2005, com a inauguração da usina de biodiesel da empresa Agropalma no bairro do Tapanã, em Belém. Esta empresa fez um investimento da ordem de R 4 milhões na construção da usina, que tem uma capacidade de produção da ordem de 8 milhões de litros de biodiesel por ano (AGÊNCIA BRASIL, 13.12.2004). A Figura 19 mostra detalhes da cerimônia de inauguração da usina de biodiesel da Agroplama em 2005.

Figura 19: Inauguração da usina de biodiesel da Agropalma, em Belém do Pará, 2005

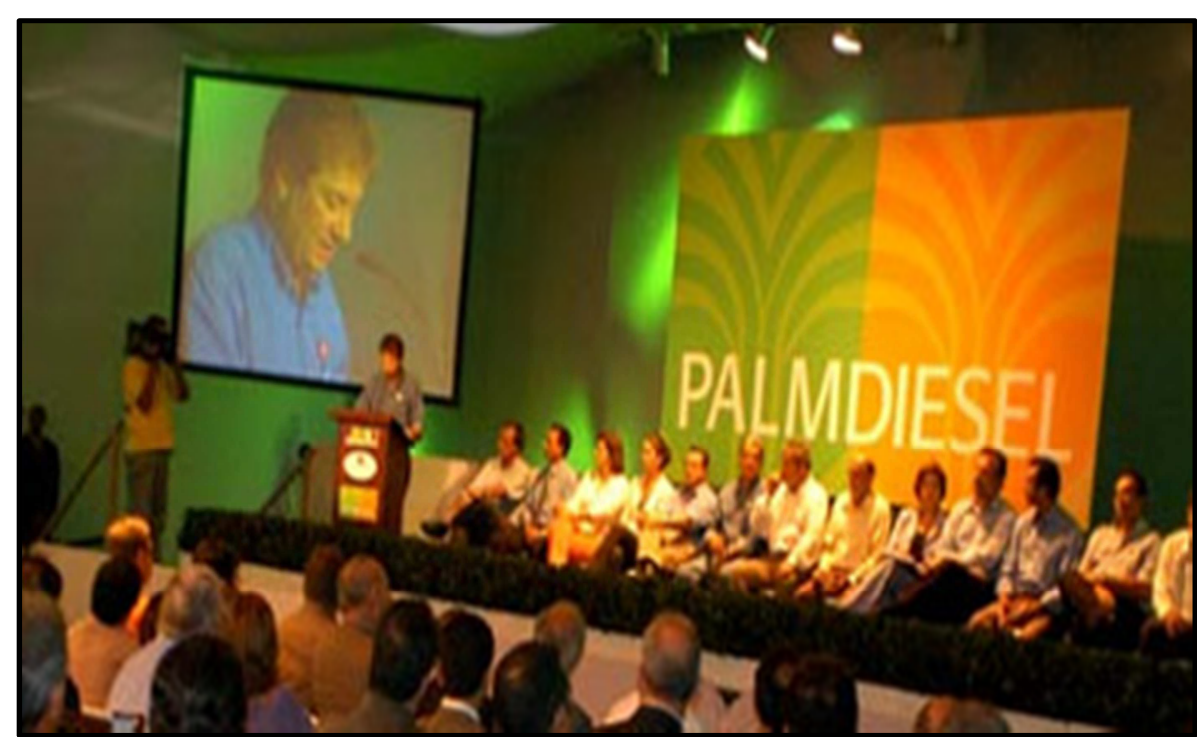

Fonte: http://planetaorganico.com.br

Neste período, como produtora de biodiesel (2005-2010) a Agropalma foi beneficiada com o Selo Combustível Social, por promover a integração da agricultura familiar em seu negócio. O Quadro 29 demonstra a produção paraense de biodiesel no período realizado pela empresa Agropalma. Em 2010 alegando dificuldades em participar dos leilões da ANP a empresa abandonou a produção de biodiesel, e concentrou suas atividades no mercado de alimentos, setor em que é líder na América Latina.

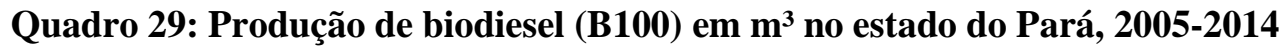

\begin{tabular}{|l|l|l|l|l|l|l|l|l|l|}
\hline 2005 & 2006 & 2007 & 2008 & 2009 & 2010 & 2011 & 2012 & 2013 & 2014 \\
\hline 510 & 2.421 & 3.717 & 2.625 & 3.494 & 2.345 & - & - & - & - \\
\hline
\end{tabular}

Fonte: ANP (2015), com modificações do autor 
Com a saída da Agropalma do setor de biodiesel, o estado do Pará deixou de produzir este biocombustível. Na atualidade duas empresas objetos de nossa análise nesta tese, a Belém Bioenergia Brasil (Pbio + Galp) e a Biopalma (Vale + Msp), possuem projetos em andamento para a produção de biodiesel a partir do dendê produzido no território paraense.

Desta forma, na atualidadea produção agrícola de dendê do estado é destinada à produção de alimentos, tendo em vista que a única usina de produção de biodiesel (Agropalma) encontra-se com a produção paralisada.

A cadeia produtiva do dendê no estado do Pará é constituída de diversas instituições estatais, empresárias e sociais como veremos no próximo capítulo desta tese. 


\section{CAPÍTULO 3: CADEIA PRODUTIVA E O PAPEL DO MDA, BASA, EMPRESAS, FETAGRI E AGRICULTORES NA INTEGRAC ÃO DA AGRICULTURA FAMILIAR NO AGRONEGÓCIO DE BIODIESEL DE DENDÊ NO BAIXO TOCANTINS (PA)}

Este capítulo visa analisar a cadeia produtiva e o papel desempenhado por instituições estatais (MDA e BASA), empresas (Petrobras Biocombustível, Belém Bioenergia Brasil e Biopalma), Fetagri e agricultoresna integração da agricultura familiar no agronegócio de biodiesel de dendê no Baixo Tocantins (PA).

\subsection{História do dendê}

Acredita-se que a introdução do dendê (Elaeis guineensis) no Brasil ocorreu pelos escravos africanos por volta de 1616, no estado da Bahia, fato que deu origem aos dendezais espontâneos do litoral baiano (VALOIS, 1997).

No Pará sua introdução deve-se à ação do Estado por meio do antigo Instituto Agronômico do Norte (IAN), em 1951. No entanto, sua introdução comercial ocorre somenteem 1965 por iniciativa da Superintendência do Plano de Valorização Econômica da Amazônia (SPVEA), mediante acordo de cooperação técnica com o Institut de Recherchespour lês Huiles et Oléagineux (IRHO) da França, visando implantar um projeto piloto de dendê no Pará. Em 1967 já sob o controle da Superintendência de Desenvolvimento da Amazônia (Sudam) foram realizados os primeiros plantios comerciais de 1.500 hectares na PA-391 no município de Benevides (EMBRAPA, 2006; MÜLLER; FURLAN JUNIOR, 2001).

No Baixo Tocantins a participação do Estado está na origem dos principais projetos implantados de dendê. Em 1980, a Reflorestadora da Amazônia S.A. (Reasa) teve um projeto de 3.000 hectares aprovados com recursos do Fundo de Investimento Setoriais (FISET) no município de Moju. Em 1990 este projeto foi incorporado pela empresa Marborges, que em 1992 instalou uma usina de beneficiamento de óleo de palma. Em 1981 a Mendes Júnior Agrícola do Pará S.A. (Agromendes) obteve um projeto financiado de 6.000 hectares com recursos da Sudam no município de Acará. Este projeto foi incorporado posteriormente pela empresa Agropalma. Em 1982 a Companhia Real Agro-Industrial (CRAI) obteve um projeto aprovado de 5.000 hectares com recursos da Sudam no município do Acará. Este projeto foi posteriormente incorporado pela Agropalma (VEIJA; FURLAN JUNIOR; KALTNER, 2005; EMBRAPA, 2006). 


\subsection{Produção mundial de dendê}

O agronegócio do dendê no mundo é uma atividade extremante promissora, pois existe um grande mercado consumidor mundial que cresce a cada ano (ADA, 2002). A produção mundial de óleo de palma está concentrada em dois países (Indonésia e Malásia), que em 2014 responderam por 86,46\% da produção mundial. Outros países como Tailândia, Colômbia, Nigéria, Papua Nova Guiné, Honduras, Costa do Marfim, Guatemala e Brasil também apresentam produção agrícola de dendê em seus territórios. Vale destacar que a produção de óleo, bem como a área plantada de dendê, estão concentradas nos dois países da Ásia. Em 2014, a Indonésia produziu 53,33\% da produção mundial de óleo de palma, seguida da Malásia, com 33,13\%. Esta concentração territorial da presença de dendê se reflete na área plantada nestes dois países asiáticos (FEAPA, 2015).

Em 2014, a Indonésia detinha 50,17\% da área plantada mundial de dendê, a Malásia detinha 31,58\%. A participação do Brasil neste segmento foi de apenas 1,23\% da área plantada mundial de dendê no mundo. Este dado indica a baixa participação do Brasil no cultivo mundial de dendê, apesar de apresentar uma grande disponibilidade de terras agriculturáveis, mão-de-obra, além de condições naturais ideais para o desenvolvimento e a expansão dessa cultura agrícola. A participação tímida do Brasil neste segmento agrícola indica o quanto o país pode expandir a sua produção agrícola de dendê, inclusive para abastecer o mercado interno que é dependente de importações. O Quadro 30 indica com mais detalhes os principais produtores de óleo de palma do mundo.

Quadro 30: Principais produtores de óleo de palma do mundo em 2014

\begin{tabular}{|l|c|c|c|r|}
\hline \multirow{2}{*}{\multicolumn{1}{c|}{ Países }} & \multicolumn{2}{c|}{ Produção de óleo } & \multicolumn{2}{c|}{ Área plantada } \\
\cline { 2 - 5 } & Toneladas & \multicolumn{1}{c|}{$\%$} & Hectares & \multicolumn{1}{c|}{} \\
\hline Indonésia & 33.000 .000 & 53,33 & 8.565 .957 & 50,17 \\
\hline Malásia & 20.500 .000 & 33,13 & 5.392 .235 & 31,58 \\
\hline Tailândia & 2.250 .000 & 3,64 & 856.200 & 5,01 \\
\hline Colômbia & 1.108 .000 & 1,79 & 427.368 & 2,50 \\
\hline Nigéria & 930.000 & 1,50 & 337.120 & 1,97 \\
\hline Papua Nova Guiné & 630.000 & 1,01 & 108.000 & 0,63 \\
\hline Honduras & 440.000 & 0,71 & 170.120 & 0,99 \\
\hline Costa do Marfim & 400.000 & 0,64 & 191.272 & 1,12 \\
\hline Guatemala & 355.000 & 0,57 & 168.443 & 0,99 \\
\hline Brasil & 340.000 & 0,54 & 210.000 & 1,23 \\
\hline Outros & 1.918 .000 & 3,09 & 644.545 & 3,77 \\
\hline Total & 61.871 .000 & 100,00 & 17.071 .260 & 100,00 \\
\hline
\end{tabular}

Fonte: Departamento de Agricultura dos Estados Unidos (USDA). Organizado por Faepa (2015) 
O Brasil é um dos países que apresentam as maiores condições (disponibilidade de terras, clima e mão-de-obra) para ampliar sua participação no mercado de óleo de dendê. Embora a produção seja insuficiente para o abastecimento do mercado interno, uma parte da produção de óleo de palma e de óleo de palmiste produzido no Brasil é exportada, o que agrava nossa dependência de importação destes produtos.

O comércio exterior brasileiro de óleo de palma está distribuído em produção, importação, exportação e consumo. No período 2010-2013 a produção nacional de óleo de palma foi de 1.293 .7 mil toneladas. Já a importação foi de 847.8 mil toneladas. A exportação foi de 200.6 mil toneladas e o consumo nacional foi da ordem de 1.940 .9 mil toneladas (Quadro 31).

Quadro 31: Produção, importação, exportação e consumo de óleo de palma no Brasil, 2010-2013

\begin{tabular}{|l|c|c|c|c|}
\hline \multirow{2}{*}{ Anos } & \multicolumn{4}{|c|}{ Mil toneladas } \\
\cline { 2 - 5 } & Produção & Importação & Exportação & Consumo \\
\hline 2010 & 323,2 & 155,8 & 16,5 & 462,5 \\
\hline 2011 & 325,3 & 214,5 & 46,5 & 493,2 \\
\hline 2012 & 310,2 & 227,4 & 65,2 & 472,5 \\
\hline 2013 & 335,0 & 250,1 & 72,4 & 512,7 \\
\hline Total & 1.293 .7 & 847.8 & 200.6 & 1.940 .9 \\
\hline
\end{tabular}

Fonte: Brasil (2015), com modificações do autor

A situação do comércio exterior de óleo de palma indica que, enquanto nossa produção nacional foi de 1.293.70 mil toneladas, nosso consumo foi da ordem de 1.940 .9 mil toneladas. Estes dados indicam que o país não é autossuficiente na produção de óleo de palma, sendo necessário recorrer à importação para suprir a demanda interna. Neste período foram importadas 847,8 mil toneladas para completar o consumo nacional (BRASIL, 2015).

A produção de óleo de palmiste no período de 2010-2013 no Brasil foi de 77.6 mil toneladas, já a importação foi de 679.2 mil toneladas, a exportação foi de 21.3 mil toneladas e o consumo nacional foi da ordem de 735.5 mil toneladas, como podemos constatar no Quadro 32. 
Quadro 32: Produção, importação, exportação e consumo de óleo de palmiste no Brasil 2010-2013

\begin{tabular}{|l|c|c|c|c|}
\hline \multirow{2}{*}{ Anos } & \multicolumn{4}{|c|}{ Mil toneladas } \\
\cline { 2 - 5 } & Produção & Importação & Exportação & Consumo \\
\hline 2010 & 19,4 & 176,8 & 0,8 & 195,4 \\
\hline 2011 & 19,5 & 155,5 & 6,0 & 169,0 \\
\hline 2012 & 18,6 & 166,3 & 4,2 & 180,7 \\
\hline 2013 & 20,1 & 180,6 & 10,3 & 190,4 \\
\hline Total & 77,6 & 679,2 & 21,3 & 735,5 \\
\hline
\end{tabular}

Fonte: Brasil (2015), com modificações do autor

Os dados apontados acima demonstram a dependência do Brasil da importação de óleo de palma e de óleo de palmiste para atender o consumo nacional (BRASIL, 2015).

\subsection{Produção nacional de dendê}

A produção nacional de dendê está concentrada em três estados: Pará, Bahia e Amazonas. De acordo com os dados apresentados no Quadro 33, em 2011, a Bahia apresentava a maior área colhida de dendê do Brasil. A partir de 2012, o Pará ampliou sua participação neste setor, superando a Bahia em área colhida. Quanto à variável da quantidade produzida, o Pará é o principal produtor de dendê do Brasil. A participação do Amazonas é pequena, se comparada à dos dois outros estados produtores citados (Quadro 33).

Quadro 33: Área e quantidade produzida dos principais estados produtores de dendê no Brasil, 2011-2013

\begin{tabular}{|l|c|c|c|c|c|c|}
\hline \multirow{2}{*}{ Estados } & \multicolumn{2}{|c|}{$\mathbf{2 0 1 1}$} & \multicolumn{2}{c|}{$\mathbf{2 0 1 2}$} & \multicolumn{2}{c|}{$\mathbf{2 0 1 3}$} \\
\cline { 2 - 7 } & $\begin{array}{c}\text { Área colhida } \\
\text { (h) }\end{array}$ & $\begin{array}{c}\text { Quantidade } \\
\text { (t) }\end{array}$ & $\begin{array}{c}\text { Área colhida } \\
(\mathbf{h})\end{array}$ & $\begin{array}{c}\text { Quantidade } \\
\text { (t) }\end{array}$ & $\begin{array}{c}\text { Área colhida } \\
\text { (h) }\end{array}$ & $\begin{array}{c}\text { Quantidade } \\
\text { (t) }\end{array}$ \\
\hline Pará & 53.968 & 1.082 .348 & 58.795 & 1.034 .361 & 54.475 & 1.040 .538 \\
\hline Bahia & 54.662 & 215.784 & 53.943 & 204.353 & 53.773 & 203.979 \\
\hline Amazonas & 450 & 3.060 & 397 & 2.278 & 387 & 2.318 \\
\hline
\end{tabular}

Fonte: Elaborado pelo autor com base em IBGE-Sidra (2015)

No período de vinte anos (1993-2013), a área colhida de dendê no Pará passou de 35.277 hectares, em 1993, para 54.475 hectares, em 2013. No estado da Bahia no mesmo período esta área passou de 30.437 hectares para 53.773 hectares de área colhida de dendê. Área colhida do estado do Amazonas foi menor em relação aos dois estados citados anteriormente, chegando a apenas 387 hectares de área colhida em 2013 (Gráfico 5). 
Gráfico 5: Evolução da área colhida (h) dos principais estados produtores de dendê do Brasil (1993 -2013)

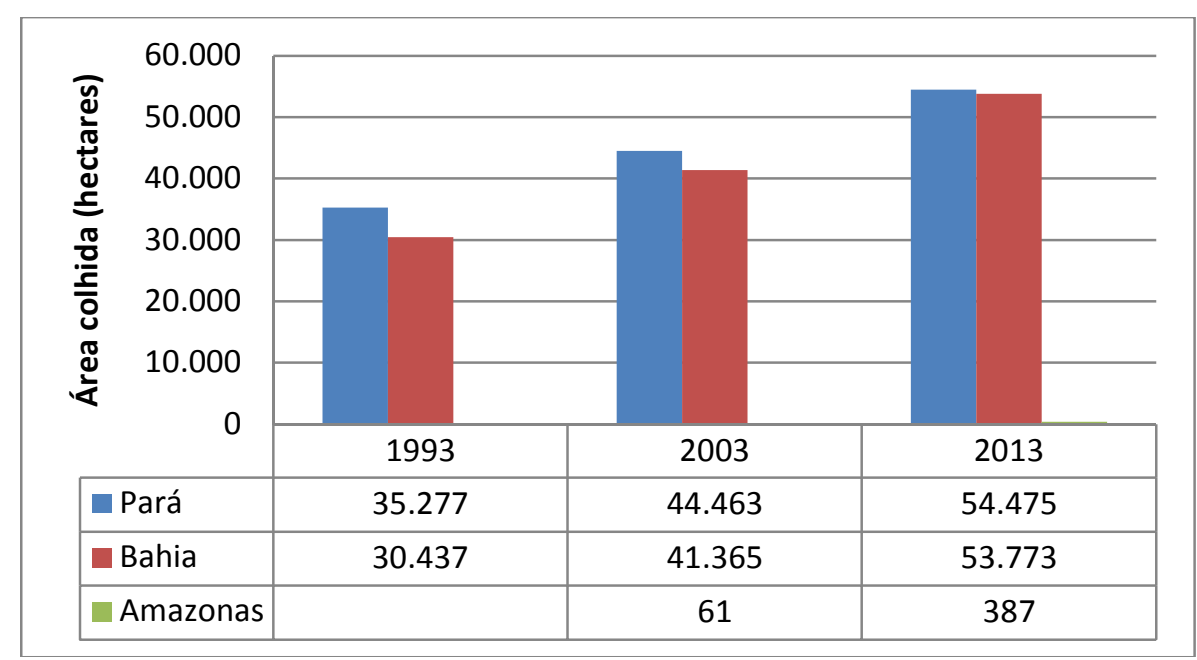

Fonte: Elaborado pelo autor com base em IBGE-Sidra (2015)

A segunda variável pesquisada foi a quantidade produzida de dendê no período de 1993-2013 nestes três estados da federação. Em 1993, o Pará produziu 482.818 toneladas, e em 2013 esta produção passou para 1.040.538 toneladas, um crescimento bastante acentuado. A produção da Bahia foi bem menor, passando de 134.016 toneladas, em 1993, para 203.979 toneladas, em 2013. Em 2006, segundo dados da Conab (2006), no estado da Bahia a principal área plantada de dendê estava concentrada nos municípios de Valença, Taperoá, Camamu, Itaberá, Nilo Peçanha, Uma e Egrapiúna. A produção do Amazonas atingiu 2.318 toneladas em 2013, como podemos verificar no Gráfico 6.

\section{Gráfico 6: Evolução da quantidade produzida (t) dos principais estados produtores} de dendê do Brasil (1993-2013)

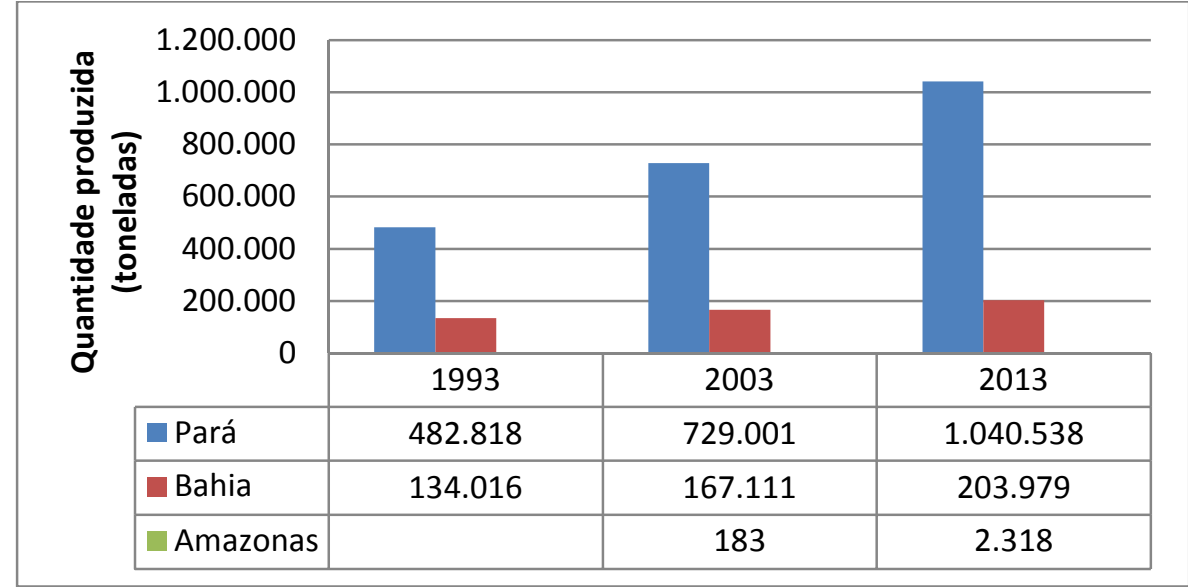

Fonte: Elaborado pelo autor com base em IBGE-Sidra (2015) 
Os dados oficiais (IBGE) apontam para uma concentração territorial de área colhida e da produção de dendê nos estados do Pará e da Bahia, que apresentam terras aptas para o desenvolvimento desta cultura agrícola no Brasil.

\subsection{Produção paraense de dendê}

O estado do Pará é o maior produtor de dendê do Brasil. Esta produção esta distribuída territorialmente em cinco regiões ${ }^{57}$ de integração do estado: Tocantins, Guamá, Capim, Caeté e Metropolitana.

A principal região produtora é o Tocantins (Baixo Tocantins) que vem ampliando sua participação em área colhida no período de 2004 (31.452 hectares) a 2013 (35.480 hectares). Os municípios com área colhida de dendê são: Abaetetuba, Acará, Moju e Tailândia. Em segundo lugar, em área colhida, aparece a região do Guamá que apresentou um crescimento de 2004 (8.406 hectares) para 2013 (9.635 hectares). Em terceiro lugar, em área colhida, vem a região do Capim que passou de 1.080 hectares, em 2004, para 4.910 hectares, em 2013. Em quarto lugar em área colhida de dendê, encontra-se a região do Caeté que passou de 2.125 hectares, em 2004, para 4.250 hectares, em 2013. E finalmente em quinto lugar em área colhida de dendê aparece a Região Metropolitana de Belém, região pioneira, onde em 1967 o dendê foi introduzido comercialmente pela Sudam no município de Santa Barbara do Pará, desmembrado do município de Benevides. Nesta região, os dados oficiais registram apenas os dados para 2004 no município de Santa Bárbara do Pará com 3.100 hectares de área colhida de dendê neste ano. Em 2013 não foi registrada esta variável. O Quadro 34 apresenta mais detalhes da área colhida de dendê nos municípios do Pará.

Quadro 34: Área colhida de dendê no estado do Pará entre 2004-2013

\begin{tabular}{|l|c|c|c|}
\hline \multicolumn{1}{|c|}{ Municípios } & $\begin{array}{c}\text { Área colhida } \\
\mathbf{2 0 0 4}\end{array}$ & $\begin{array}{c}\text { Área colhida em } \\
\mathbf{2 0 1 3}\end{array}$ & $\begin{array}{c}\text { Região de } \\
\text { integração }^{\mathbf{5 9}}\end{array}$ \\
\hline Abaetetuba & - & 2.000 & Tocantins \\
\hline Acará & 6.700 & 7.000 & Tocantins \\
\hline Moju & 7.678 & 7.093 & Tocantins \\
\hline Tailândia & 17.074 & 19.387 & Tocantins \\
\hline Total & $\mathbf{3 1 . 4 5 2}$ & $\mathbf{3 5 . 4 8 0}$ & Tocantins \\
\hline Castanhal & 1.500 & 1.000 & Guamá \\
\hline Curuçá & - & 65 & Guamá \\
\hline Igarapé-Açu & 2.500 & 4.200 & Guamá \\
\hline
\end{tabular}

57 Divisão administrativa adotada pelo Governo do Estado do Pará. A região de integração do Tocantins corresponde ao território do Baixo Tocantins, objeto de nossa análise.

${ }^{58}$ Em hectares.

${ }^{59}$ Regionalização adotada pelo Governo do Estado Pará, a região de integração do Tocantins, corresponde o território da cidadania do Baixo Tocantins, regionalização adotada neste trabalho. 


\begin{tabular}{|l|r|r|c|}
\hline Inhangapi & 16 & - & Guamá \\
\hline Maracanã & 100 & 100 & Guamá \\
\hline Santa Izabel do Pará & 1.200 & 400 & Guamá \\
\hline Santa Maria do Pará & 50 & 350 & Guamá \\
\hline Santo Antônio do Tauá & 2.600 & 2.900 & Guamá \\
\hline São Francisco do Pará & 190 & 270 & Guamá \\
\hline Terra Alta & - & 100 & Guamá \\
\hline Vigia & 250 & 250 & Guamá \\
\hline Total & $\mathbf{8 . 4 0 6}$ & $\mathbf{9 . 6 3 5}$ & Guamá \\
\hline Bujaru & 280 & 310 & Capim \\
\hline Concórdia do Pará & 0 & 2.000 & Capim \\
\hline Tomé-Açu & 800 & 2.600 & Capim \\
\hline Total & $\mathbf{1 . 0 8 0}$ & $\mathbf{4 . 9 1 0}$ & Capim \\
\hline Bonito & 2.000 & 4.200 & Caeté \\
\hline Nova Timboteua & 90 & 250 & Caeté \\
\hline Santa Luzia do Pará & 35 & - & Caeté \\
\hline Total & $\mathbf{2 . 1 2 5}$ & $\mathbf{4 . 4 5 0}$ & Caeté \\
\hline Santa Bárbara & 3.100 & - & Metropolitana \\
\hline Total & $\mathbf{3 . 1 0 0}$ & - & Metropolitana \\
\hline
\end{tabular}

Fonte: Elaborado pelo autor com base em IBGE-Sidra (2015)

A produção paraense de dendê em 2014 estava concentrada em um território de 187.044 hectares, onde as maiores áreas estavam em poder das seguintes empresas: Biopalma $^{60}$ (62.062 hectares), Agropalma ${ }^{61}$ (50.513 hectares), Belém Bioenergia Brasil ${ }^{62}$ (27.150 hectares), Mejers (16.128 hectares), ADM (7.500 hectares), Marborges (7.140 hectares), Palmasa (5.954 hectares) e Dentauá (5.997 hectares). Esta produção de dendê estávoltada principalmente para abastecer o mercado nacional alimentos ${ }^{63}$ e mais recentemente para o biodiesel (Quadro 35).

Quadro 35: Principais empresas produtoras de óleo de palma no Pará em 2014

\begin{tabular}{|l|c|c|}
\hline \multirow{2}{*}{\multicolumn{1}{|c|}{ Empresas }} & \multicolumn{2}{c|}{ Área } \\
\cline { 2 - 3 } & Plantada & Expansão \\
\hline Agropalma & 50.513 & 60.000 \\
\hline Biopalma - Vale & 62.062 & 80.000 \\
\hline Mejers & 16.128 & 30.000 \\
\hline Dentauá & 5.997 & 10.000 \\
\hline
\end{tabular}

\footnotetext{
${ }^{60}$ Empresa formada pela associação da Vale e da MSP.

${ }^{61}$ Empresa do grupo Alfa foi fundada em 1982 no município de Tailândia (PA). Em 2005 aderiu ao PNPB, permanecendo até 2010 .

${ }^{62}$ Empresa formada pela associação da empresa brasileira Petrobras e da portuguesa Galp Energia. Até o ano de 2012 tinha como atuação no Baixo Tocantins os municípios de Abaetetuba, Acará, Moju e Tailândia. Depois deste ano com o abandono do projeto Pará pela Petrobras, a empresa incorporou estes projetos passando a atuar também nos municípios de Baião, Cametá, Igarapé Miri e Mocajuba (BELÉM BIOENERGIA BRASIL, 2013; CÂMARA DOS DEPUTADOS, 2014).

${ }^{63}$ Margarinas, massas de sorvete, achocolatados, gorduras para fritura, panificação, biscoitos etc. a empresa Agropalma é a maior produtora de óleo de palma da América Latina. Disponível em: www. agropalma.com.br. Acesso em: 20 maio 2016.
} 


\begin{tabular}{|l|c|c|}
\hline Pbio + Galp (BBB) & 27.150 & 75.000 \\
\hline ADM & 7.500 & 50.000 \\
\hline Denpasa & 3.900 & 10.000 \\
\hline Marborges & 7.140 & 10.000 \\
\hline Palmasa & 5.954 & 10.000 \\
\hline Outros & 700 & 20.000 \\
\hline Total & 187.044 & 355.000 \\
\hline
\end{tabular}

Fonte: Faepa (2015)

Estas empresas apresentavam em 2012 uma capacidade instalada de processamento de óleo de palma e óleo de palmiste distribuída da seguinte forma: a) A Agropalma tinha cinco usinas de beneficiamento que produziram neste ano 165.000 toneladas de óleo de palma e 16.000 toneladas de óleo de palmiste; b) A Dentauá tinha duas usinas de beneficiamento que produziram neste ano 12.600 toneladas de óleo de palma e 940 toneladas de óleo de palmiste; c) As demais empresas (Biopalma, Denpasa, Marborges e Palmasa) tinham uma unidade de beneficiamento de óleo de palma e de palmiste (Quadro 36).

Quadro 36: Capacidade instalada de usinas e produção de óleo de palma e palmiste no Pará, em 2012

\begin{tabular}{|l|c|c|c|c|}
\hline \multirow{3}{*}{ Empresa } & \multicolumn{4}{|c|}{ Usinas } \\
\cline { 2 - 5 } & \multicolumn{2}{|c|}{ Unidades } & \multicolumn{2}{c|}{ Produção de óleo (t) } \\
\cline { 2 - 5 } & $\begin{array}{c}\text { Unidades de } \\
\text { processamento }\end{array}$ & $\begin{array}{c}\text { Capacidade } \\
\text { instalada (t) }\end{array}$ & Palma & Palmiste \\
\hline Agropalma & 5 & 201 & 165.000 & 16.000 \\
\hline Biopalma - Vale & 1 & 40 & 130.000 & 11.000 \\
\hline Dentauá & 2 & 39 & 12.600 & 940 \\
\hline Denpasa & 1 & 12 & 6.000 & 190 \\
\hline Marborges & 1 & 20 & 15.500 & 1.300 \\
\hline Palmasa & 1 & 28 & 13.500 & 1.350 \\
\hline Total & 11 & 340 & 228.600 & 19.780 \\
\hline
\end{tabular}

Fonte: Pará (2013), com modificações do autor

\subsection{Cultura do dendê: práticas agrícolas, transporte e beneficiamento}

O dendê apresenta uma vida econômica de 25 anos quanto tratado de forma correta. Trata-se de uma cultura agrícola que requer temperaturas mínimas superiores a $24^{\circ} \mathrm{C}$, onde o litoral da Bahia e alguns pontos selecionados da Amazônia apresentam temperaturas ideais para o desenvolvimento agrícola. As variedades mais utilizadas no Brasil são: Dura, Pisifera e Tenera (EMBRAPA, 1995).

Suas práticas agrícolas envolvem o pré-viveiro, viveiro, plantio definitivo e tratos culturais. O pré-viveiro tem início com a introdução das sementes germinadas em sacos de 
plástico de $10 \times 20 \mathrm{~cm}$ por $5 \mathrm{~mm}$ de espessura e termina com o plantio das mudas em sacos maiores no viveiro. Esta etapa dura aproximadamente quatro meses.

$\mathrm{Na}$ fase seguinte as mudas são transportadas para o viveiro que deve ser construído em local aberto e próximo a fontes de água que facilitem a irrigação das mudas. Os sacos utilizados no viveiro são de 40x40 cm com $20 \mathrm{~mm}$ de espessura (EMBRAPA, 1995). As mudas permanecem no viveiro por um período médio de oito meses (MULLER, 1980).

Depois de oito meses no viveiro, as mudas são levadas para o local do plantio definitivo cuja área que receberá as mudas deve ser preparada com a devida limpeza. O plantio definitivo deve ser realizado no período chuvoso, onde são utilizados 143 plantas/hectares em espaçamento de 9 metros em triângulo equilátero (EMBRAPA, 1995).

Uma vez plantadas as mudas no local definitivo, o dendezeiro necessita de uma série de tratos culturais para seu desenvolvimento. Os principais tratos culturais são: coroamento, roçagem, adubação e controle fitossanitário (EMBRAPA, 1995; MULLER, 1980). O coroamento consiste na retirada das plantas que crescem em volta do dendezeiro, são necessários em média oito coroamentos por ano. A roçagem consiste na limpeza da vegetação existente nas entrelinhas do dendezal. A adubação consiste no emprego de adubo principalmente utilizando-se o fósforo e o potássio. O controle fitossanitário é destinado ao combate de pragas e doenças.

A colheita dos frutos de dendê ocorre no terceiro ano, atingindo sua plenitude da produção no oitavo ano, estendendo esta colheita até o vigésimo quinto ano depois do plantio (MULLER, 1980). A colheita dos frutos de dendê é realizada durante o ano inteiro. O sacho (parecido com ferro de cova) e a foice malasiana são os instrumentos mais utilizados para fazer a coleta dos frutos nos dendezeiros. A escolha do instrumento mais apropriado para este trabalho depende da idade da plantação e da altura da mesma. Em dendezais de até quatro metros utiliza-se o ferro de cova para fazer a coletas dos frutos. Em dendezais com mais de quatro metros de altura utiliza-se a foice malasiana para a coleta dos frutos. A seleção para a colheita dos frutos de dendê ocorre quando este apresenta pelo menos cinco frutos soltos, com intervalos de colheita que variam de 10 a 15 dias (EMBRAPA, 1995; PINA, 2010).

Uma vez realizada a colheita os frutos devem ser imediatamente transportados para a usina de extração de óleo. Este transporte dos dendezais para os pontos de coletas pode ser realizado tanto por animais como burros, mulas, bois e búfalos, quanto por pequenas máquinas como micro-tratores. Para a usina são utilizados caminhões ou carretas basculantes (EMBRAPA, 1995). 
Obeneficiamento dos cachos de dendê deve ser realizado em no máximo 24 horas após a sua colheita. Esta etapa do beneficiamento tem início com a esterilização dos cachos, seguindo para o debulhador onde os frutos são separados dos cachos. Em seguida já no digestor ocorre a quebra da estrutura das células da polpa, com a liberação do óleo. Desta forma obtêm dois tipos de óleos: o óleo de dendê e o óleo de palmiste (EMBRAPA, 1995; MULLER, 1980).

Quanto ao seu emprego, o dendê serve tanto para fins alimentares quanto industriais. O óleo de dendê é empregado para fins alimentares, sendo utilizado na fabricação de biscoitos, margarinas, glicerinas e azeite de mesa, frituras de alimentos, de panificação, na elaboração de doces, torta e bolos em geral. Este óleo apresenta um grande potencial para produção de biodiesel. Já o óleo de palmisteé utilizado na indústria para a fabricação de sabonetes, sabões, detergente, glicerina, maionese, pomadas, margarina, ácidos graxos, aditivos, como detergentes industriais, como ingredientes de cosméticos, na fabricação de bactericidas, entre outras aplicações (MULLER, 1980; KITAMURA, 1990).

\subsection{Sistema de integração de dendê no Baixo Tocantins}

No Brasil o sistema de integração da agricultura familiar no agronegócio começa em 1918 com a integração de agricultores familiares de fumo no Rio Grande do Sul. Em A cadeia produtiva do fumo, publicação da Revista do Departamento de Estudos Socioeconômicos Rurais (DETER, 2005) afirma que a integração do fumo teve início, em 1918, em Santa Cruz do Sul, no Rio Grande do Sul, cidade hoje considerada a "capital mundial do fumo". A iniciativa foi da empresa Souza $\mathrm{Cruz}^{64}$ cuja ação foi seguida na região, que com o passar do tempo os produtores integrados passaram a celebrar contratos com a empresa, visando manter o controle de qualidade do fumo entregue, além da assistência técnica. No estudo destacam-se ainda os atores da produção integrada de fumo (agricultores, empresas, sindicatos e bancos).

No modelo de integração agricultura familiar no agronegócio de fumo implantado pela Souza Cruz a empresa ficava responsável pelo fornecimento de sementes, fertilizantes, financiamento e secagem da produção de fumo familiar, bem como da assistência técnica. Por

\footnotetext{
${ }^{64}$ A Souza Cruz foi fundada em 1903 no Rio de Janeiro. [...] Em 1920, a empresa iniciou o processo de fomento da produção de fumo na região Sul e instalou sua primeira usina de beneficiamento de fumo em Santa Cruz do Sul [...] A Souza Cruz é hoje um dos cinco maiores grupos privados brasileiros, subsidiaria do grupo British American Tobacco (BAT), o segundo maior grupo no mercado de tabaco, com atuação em cerca de 180 países [...] A empresa atua de maneira integrada com cerca de 45 mil agricultores, principalmente nos estados do sul do Brasil. A maior parte da produção é processada em Santa Cruz do Sul, o maior e mais moderno complexo de beneficiamento do mundo (DETER, 2005, p. 32).
} 
sua vez, os agricultores integrados se comprometiam com a venda integral da produção com exclusividade regulada pela assinatura de contratos (DETER, 2005).

A relação entre agricultor familiar integrado e empresa é regulada pela existência do contrato celebrado entre as partes envolvidas. Desta forma, o contrato passa a regular direitos e obrigações entre agricultores integrados e empresas integradoras. Depois da experiência pioneira da integração da agricultura familiar no agronegócio desenvolvido pela Souza Cruz, outras empresas como a Sadia e a Perdigão passaram a adotar este sistema em sua produção.

No estado do Pará, na dendeicultura a periodização do sistema de integração da agricultura familiar no agronegócio de dendê está dividida em dois momentos. O primeiro momentoteve início em 2002, por iniciativa pioneira da Agropalma que viabilizou uma parceria com 50 famílias da comunidade de Soledade, município de Moju, Baixo Tocantins. O segundo momento está associado aos estímulos do governo federal no contexto do Programa Nacional de Produção e Uso do Biodiesel (PNPB), lançado em 2004. Neste contexto do PNPB, novas empresas instalaram-se no estado do Pará visando a produção de biodiesel, como ADM, Biopalma/Vale, Belém Bioenergia Brasil, Petrobras Biocombustíveis (BASA, 2012a;BECKER, 2010). A este grupo de empresas somam-se as que já atuavam no Baixo Tocantins: Agropalma e Marborges (BASA, 2012b).

Segundo as diretrizes do PNPB na Amazônia, a palma de óleo (dendê) é a matériaprima destinada à produção de biodiesel. Nos dois momentos descritos anteriormente, os recursos financeiros destinados para a implantação do projeto foram bancados pelo Estado, por meio do Basa. No primeiro momento os recursos utilizados foram do Prorural ${ }^{65}$, e no segundo e atual momento, os recursos são do Programa Nacional de Fortalecimento da Agricultura Familiar (Pronaf).

No sistema de produção integrada de dendê é realizada uma parceria com a celebração de um contrato entre a indústria (integradora) e o produtor (integrado) (BASA, 2012a). No setor da dendeicultura no estado do Pará este modelo tem seu início em 2002 com uma parceria entre atores públicos (Governo do Estado do Pará, Prefeitura Municipal de Moju e Banco da Amazônia), atores privados (Agropalma) e atores sociais (Sindicato dos Trabalhadores Rurais do Moju) no município de Moju. Neste modelo, integradora (fornecimento de insumos e assistência técnica, entre outros) e agricultor integrado (tratos culturais necessários para o desenvolvimento da cultura) assumem compromissos estabelecidos em contrato (BASA, 2012a).

\footnotetext{
${ }^{65}$ Com 12 anos de prazo total, 5 anos de carência, juros de 4,0\% a.a. (BASA, 2012a).
} 
Em $2004^{66}$ e $2005^{67}$ novos projetos foram implantados pela Agropalma nos moldes do projeto pioneiro de integração iniciado pela empresa, em 2002, em Moju. Em 2006 o Ministério do Desenvolvimento Agrário (MDA) no contexto do PNPB e da Instrução Normativa $\mathrm{n}^{\mathrm{o}}$ 01/MDA que visa introduzir a agricultura familiar na cadeia do biodiesel articula a implantação do projeto de dendê familiar na comunidade de Calmaria II, também em Moju. Os recursos necessários para a execução do projeto foram bancados pela Agropalma e pelo Basa, por meio do Pronaf ${ }^{68}$ (BASA, 2012a).

O projeto de dendê familiar da comunidade de Calmaria II marca definitivamente a integração da agricultura familiar na cadeia do agronegócio do biodiesel na região. Em 2010 e 2011 novas empresas anunciam projetos na área de dendê voltados para a produção de biodiesel no estado do Pará. No Baixo Tocantins, principal região produtora de dendê no Pará, novas empresas como a Biopalma e a Petrobras Biocombustível anunciam investimentos no setor.

A Biopalma tem como objetivo atender a própria demanda misturando $20 \%$ de biodiesel (B20) ao óleo diesel em sua frota de locomotivas, equipamentos e máquinas pesadas da Vale. A empresa visa atender inicialmente a frota do grupo em Carajás (PA) para posteriormente em 2015 estender a toda frota do grupo no Brasil. Para cumprir com este objetivo a empresa pretende implantar no Pará, um cultivo ${ }^{69}$ de 60 mil hectares de produção própria e 20 mil hectares com a agricultura familiar, por meio da integração de 2.000 famílias com projeto de 10 hectares por família (BASA, 2012a).

A Petrobras Biocombustível (PBIO) está presente no Pará em dois projetos na área de dendê. O primeiro é o projeto Belém formado por uma holding entre a Petrobras e a Galp Energia de Portugal. Desta parceria foi criada a empresa Belém Bioenergia Brasil (BBB). Este projeto tem como objetivo a produção de óleo de palma no Pará e sua exportação para Portugal, onde seria refinado e comercializado no mercado europeu. Tem como polos de dendê os municípios de Tailândia e Tomé-Açu onde pretende envolver 1.000 famílias, utilizando recursos oriundos do Pronaf Eco-Dendê. O segundo é o projeto Pará tem como objetivo abastecer a região Norte de biodiesel (BASA, 2012a).

\footnotetext{
${ }^{66}$ Foram investidos $\mathrm{R} \$ 1.123 .759,00$ em uma área de 500 hectares beneficiando 50 famílias da comunidade de Arauaí I, com recursos do Pronaf D, com um prazo de 12 anos e 5 anos de carências para o pagamentos do empréstimo (BASA, 2012a).

${ }^{67}$ Foram investidos R $\$ 1.343 .238,00$ em uma área de 500 hectares beneficiando 50 famílias da comunidade de Arauaí II, com recursos do Pronaf D, com um prazo de 12 anos e 5 anos de carências para o pagamentos do empréstimo (BASA, 2012a).

${ }^{68}$ Foram investidos $\mathrm{R} \$ 567.901,25$ em uma área de 210 hectares beneficiando 35 famílias (BASA, 2012a).

${ }^{69}$ Os plantios estão sendo realizados nos municípios de Abaetetuba, Acará, Concórdia do Pará, Moju e ToméAçu (BASA, 2012a).
} 
A integração da agricultura familiar de dendê por estas empresas será realizada pelo Pronaf Eco-Dendê. Cada produtor terá até $\mathrm{R} \$$ 80.000,00 para implantar sua cultura, com prazo de cinco anos e mais nove para liquidar o contrato. A empresa fica responsável pela assistência técnica e o fornecimento dos insumos necessários. Os agricultores assinam um contrato de compra e venda da produção com a empresa integradora (BASA, 2012a).

No contexto do PNPB o governo federal criou o Programa Sustentável de Produção de Óleo de Palma (PPSOP), em 2010, em Tomé-Açu visando a expansão do cultivo da palma de óleo para a produção de biodiesel com a participação da agricultura familiar (BASA, 2012b, BECKER, 2010).

O PPSOP veio criar condições ambientais (ZAE-PALMA) e de fomento (Pronaf EcoDendê) para a expansão do dendê na Amazônia. A execução do Zoneamento Agroecológico para a cultura da palma na Amazônia (ZAE-PALMA), conduzida pela Embrapa foi fundamental para criar as condições do ordenamento da área destinada para sua produção. Com relação ao Pronaf Eco-Dendê, segundo Becker (2010, p. 7), "para ter acesso a crédito oficial, o produtor terá que firmar contrato de longa duração com a indústria, de quem terá garantia de receber a cotação internacional do dia".

Para Becker (2010, p.10), “apesar de constituir uma renda para os pequenos produtores que tem dificuldades para atuar isoladamente frente ao custo de implantação, os contratos criam um processo de dependência em relação às empresas [...]”. A participação da produção familiar de dendê assume cada vez mais destaque no total da produção das empresas agrícolas deste produto no Pará. Em 2012 cerca de 20\% da origem dos frutos de dendê da Agropalma eram da agricultura familiar (AGROPALMA, 2013).

Um estudo realizado pelo Basa (2012b) conclui que de janeiro de 2000 a maio de 2012 foram alocados R\$ 34,3 milhões em projetos de dendê no Pará, onde deste valor, 86,36\% foram destinados a agricultores familiares em projetos integrados principalmente das empresas ADM, Agropalma, BBB e Biopalma. Entre os principais municípios beneficiados estão Moju (15,50\%), Tailândia (13,39\%) e Acará (4,13\%), na região do Baixo Tocantins.

Em 2010 o Pará respondeu por 82,87\% da produção nacional de palma de óleo no Brasil. Esta produção estava concentrada em dezoito municípios paraenses, com destaque para Tailândia (42,57\%), Acará (17,50\%) e Moju (13,34\%), que juntos somaram 73,41\% da produção estadual (BASA, 2012b). 
A integração da agricultura familiar na cadeia do agronegócio do dendê, este incentivado para a produção de biodiesel $^{70}$, é bastante recente no Baixo Tocantins. Esta situação tem no PNPB um forte indutor desta realidade neste território. Este modelo de integração muda radicalmente o modo de trabalhar a agricultura familiar que historicamente na região obedece a uma prática para consumo local. Esta mudança introduz uma agricultura familiar integrada a grandes empresas de agroenergia como a Biopalma, a Petrobras, a Agropalma e a Marborges na região do Baixo Tocantins.

A participação da agricultura familiar no agronegócio de dendê no Pará atingiu em 2012, 889 famílias em todo o estado. As empresas que mais possuem projetos de integração (Pronaf Eco-Dendê) são Biopalma (280), Agropalma (234), ADM (146), Belém Bioenergia Brasil (85), Denpasa (53), Palmasa (40), Dentauá (27), e Marborges (24), como podemos verificar no Quadro 37.

Quadro 37: Produção agrícola familiar de dendê no Pará em 2012

\begin{tabular}{|l|c|c|}
\hline \multirow{2}{*}{ Empresas } & \multicolumn{2}{c|}{ Pequenos produtores } \\
\cline { 2 - 3 } & 234 & 10.924 \\
\hline Agropalma & 53 & 3.558 \\
\hline Denpasa & 40 & 3.353 \\
\hline Palmasa & 27 & 3.211 \\
\hline Dentauá & 280 & 3.800 \\
\hline Biopalma - Vale & 146 & 1.102 \\
\hline ADM & 85 & 850 \\
\hline Pbio + Galp (BBB) & 24 & 240 \\
\hline Marborges & 889 & 26.038 \\
\hline Total & & \\
\hline
\end{tabular}

Fonte: Pará (2013), com modificações do autor

Os projetos de agricultura familiar de dendê executados pelas empresas integradoras levam em consideração uma série de variáveis antes da execução. No território do Baixo Tocantins, a agricultura tradicional está fortemente pautada na cultura da mandioca, que tem como principal produto a farinha, uma das fontes diárias de alimentação do paraense.

Para o agricultor familiar estar habilitado para o financiamento do crédito do Pronaf Eco-Dendê, deve comprovar a existência de uma área de aproximadamente 25 hectares de propriedade. Isto se justifica, pois o financiamento do banco pode chegar até 10 hectares de

\footnotetext{
${ }^{70} \mathrm{O}$ biodiesel é um combustível biodegradável derivado de fontes renováveis como óleos vegetais e gorduras animais. No Pará a matéria-prima usada é o dendê.
} 
área. Do total dos 25 hectares, 12,5 hectares são reservados para reserva legal exigido pelo programa. Sobrando apenas 2,5 hectares que são utilizados em outros cultivos como a mandioca, que é a principal cultura agrícola na região.

A atuação das empresas no Pronaf Eco-Dendê ocorre de diferentes formas. A habilitação do agricultor familiar é necessária a partir da obtenção da Declaração de Aptidão ao Pronaf (DAP) que é emitida pelos STTR e pela Emater no Pará. Este documento é necessário para o acesso ao crédito no Basa. Os contratos celebrados são de 25 anos, com a garantia da compra da produção do agricultor. Nos contratos, a assistência fica sob a responsabilidade das empresas integradoras. É importante registrar que uma grande parcela de agricultores familiares que solicitam o financiamento junto ao banco têm seus pedidos indeferidos por uma série de questões, como a falta de documentos e áreas disponíveis, entre outros.

\subsection{O papel do MDA, BASA, Empresas, Fetragi e agricultores na integração agricultura familiares no agronegócio do biodiesel de dendê no Baixo Tocantins.}

\subsubsection{Ministério do Desenvolvimento Agrário (MDA)}

O Ministério do Desenvolvimento Agrário $(\mathrm{MDA})^{71}$ tem um papel central na integração da agricultura familiar no agronegócio de biodiesel no Brasil. No desenho do PNPB, o MDA desempenha um papel na vertente social do programa, atuando na melhoria da renda de agricultores familiares em todo o território nacional. Por meio do Selo Combustível Social, este ministério visa incentivar as empresas produtoras ou com projetos de produção de biodiesel a promoverem a integração de agricultores familiares à cadeia produtiva de matérias-primas utilizadas na produção de biodiesel no Brasil. No estado do Pará, o MDA está presente por intermédio da Delegacia Federal do Desenvolvimento Agrário no Pará (DFDA-PA).

O MDA atua na estratégia de criação de polos de biodiesel, no crédito rural para a cultura, por meio do Pronaf Eco-Dendê, na capacitação de técnicos agrícolas, na regularização fundiária e na regularização ambiental.

Em entrevista, Dvandro Pedro de Oliveira, consultor de biocombustível da região Norte, lotado DFDA-PA, em Belém, fala sobre a participação do MDA no PNPB:

\footnotetext{
${ }^{71}$ Mediante provisória 726/16 de 12/05/2016 editada no governo interino de Michel Temer, o MDA foi fundido com o Ministério do Desenvolvimento Social (MDS) dando origem ao Ministério do Desenvolvimento Social e Agrário (MDSA).
} 


\begin{abstract}
A atuação do MDA sobre a palma, mas, especificamente sobre o Programa Nacional de Produção e Uso de Bicombustível (PNPB), está estritamente vinculada à Coordenação Geral de Bicombustível (CGBIO) em Brasília, tendo a Delegacia do MDA a representação do Ministro no Estado, onde envolvem todas as políticas do Ministério. $O$ relacionamento formal com as empresas se dá na medida em que elas conseguem o Selo Combustível Social (SCS) do MDA, que é a ação específica nossa no PNPB.Muitas empresas têm parceria com a agricultura familiar, mas não têm vínculo formal com o MDA, porque não produzem biodiesel e não têm SCS. As questões de crédito são uma relação bancária com os agentes financeiros, fundiário com a Sema ou Ibama, o fundiário com o Iterpaou Incra (que faz parte do MDA, mas é uma autarquia com plenos poderes de implementação da política).A partir do momento que a empresa tem o SCS, ela é obrigada a nos dar informações sobre o plantio, processamento da produção, relação com os agricultores familiares (ATER, compra da produção etc.). Mas, independentemente se a empresa que tem parceria ou não com os agricultores, produzirão ou não biodiesel, ela deverá seguir algumas regras para que os agricultores sejam financiados pelo Pronaf Eco-Dendê:1 - A empresa tem que fazer um contrato de compra e venda antecipado com os agricultores, onde deverá ter no mínimo: tempo de compra da produção; garantia de ATER até a vigência do contrato; preço mínimo. E para aquelas que querem obter o SCS do MDA, ela deverá ter uma anuência de uma representação sindical, STTR, Fetagri, Fetraf etc., validando o contrato dos agricultores (Entrevista respondida por e-mail ao pesquisador pelo consultor de biocombustível da região Norte do MDA, Dvandro Pedro de Oliveira, em 19.10.2015, grifo nosso).
\end{abstract}

A formalização da participação estatal por intermédio do MDA com as empresas integradoras como observadas pelo entrevistado ocorre quando as empresas aderem à política de integração da agricultura familiar no agronegócio de biodiesel, fato este que é materializado quando da aquisição do Selo Combustível Social (SCS) pelo produtor de biodiesel. Em 2015 quando a entrevista foi realizada, não havia produção de biodiesel no território paraense, uma vez que, a única empresa com capacidade instalada para esta tarefa, a Agropalma, fez opção pela produção para o setor de alimentos em detrimento do setor de biocombustível.

Quanto às empresas objetos da pesquisa de tese (Belém Bioenergia Brasil e Biopalma) por não serem produtoras de biodiesel não possuem o SCS, apesar de possuírem projetos agrícolas de integração da agricultura familiar vinculado a cada empresa. Desta forma o MDA é o responsável pela gestão do SCS, sendo que no Baixo Tocantins não existiam empresas detentoras deste selo em 2015.

Quanto ao financiamento da produção agrícola familiar de dendê, o entrevistado destaca o contrato de compra e venda da produção que deve ser formalizada entre o agricultor familiar e a empresa. Aqui cabe destacar que quanto ao requisito do preço mínimo, esta prática não foi confirmada nas entrevistas com representantes dos Sindicatos dos Trabalhadores e Trabalhadoras Rurais dos municípios visitados e tão pouco pelos agricultores 
familiares integrados entrevistados das duas empresas pesquisadas, uma vez que o preço da produção familiar integrada de dendê obdece a cotação de bolsas internacionais.

Segundo o entrevistado, as únicas empresas que atuam no Pará que possuem o SCS são a Archer Daniels Midland (ADM), em São Domingos do Capim, e a Cargill, em Santarém, como podemos verificar nas informações abaixo.

Tem duas empresas que têm SCS, ADM em São Domingos do Capim e a Cargill em Santarém. Ambas não produzem ainda biodiesel no Pará, mas, elas podem contabilizar os agricultores que estão prestando assistência técnica e comprando a produção para outro polo de produção que produz. Exemplo, a ADM pode contabilizar os agricultores do Pará para compor a obtenção do selo para a agroindústria em São Paulo.

A empresa só pode ter selo se ela é uma produtora de biodiesel. No caso do Pronaf Eco-Dendê, tem a finalidade do agricultor plantar a cultura da palma, mas não necessariamente as empresas vão produzir biodiesel. Isso independe. Boa parte das empresas que têm palma não produz biodiesel, exemplo da Agropalma que produzia parte da produção para biodiesel, mas acabou deixando em função do preço do óleo que é mais viável para ela (Entrevista respondida por e-mail ao pesquisador pelo consultor de biocombustível da região Norte do MDA, Dvandro Pedro de Oliveira em 19.10.2015, grifo nosso).

A política de integração da agricultura familiar no agronegócio de biodiesel tem como sustentação um conjunto de incentivos estatais que visam à expansão da produção empresarial de dendê no Baixo Tocantins. Como produtora de biodiesel a empresa integradora é beneficiada por um conjunto de incentivos fiscais estatais. No caso das empresas não produtoras de biodiesel, podem contar com diferentes incentivos para a produção agrícola como o dendê no Baixo Tocantins. Já o agricultor familiar assumir todos os riscos do empréstimo bancário para a produção familiar integrada de dendê.

Quanto às ações do MDA no setor de dendê no Pará, o entrevistado afirma que:

Participamos de vários fóruns de discussão, como encontros, seminários, palestras etc. Tivemos e temos várias ações de parceria, dentre elas, durante os anos de 2010, 2011 e 2012, capacitamos por meio da Embrapa, com recursos do MDA e MAPA, 120 técnicos de várias empresas, movimento social e da Emater no intuito de compreenderem a cultura da palma, bem como compreender a categoria social da agricultura familiar. Tivemos outros projetos como o Diagnóstico Rápido e Participativo (DRP) com a Petrobras Biocombustível para identificação dos desafios e potencialidades de realização de parcerias com os agricultores familiares. Fizemos parceria com a Embrapa para capacitação de jovens por meio do Instituto Federal do Pará (IFPA)-Polo Castanhal. Também com a Embrapa fizemos convênio para pesquisa sobre a produção de culturas alimentares nas entrelinhas da palma, assim como pesquisa sobre indutores de resistência e combate a doenças utilizando-se produtos naturais (em andamento) (Entrevista respondida por e-mail ao pesquisador pelo consultor de biocombustível da região Norte do MDA, Dvandro Pedro de Oliveira em 19.10.2015, grifo nosso).

A expansão da produção agrícola de dendê no Pará no contexto do PNPB e do PPSOP trouxe grandes desafios relacionados à estruturação da dendeicultura no estado que passa por 
diferentes setores como a logística do escoamento da produção o que exige ações para dotar o território de maior fluidez, da capacitação de mão de obra para atuar nas empresas e nas instituições estatais de assistência técnica, capacitação dos agricultores integrados para os tratos culturais dos dendezais, uma vez que esta é uma cultura agrícola que foi introduzida no Pará. Com relação à pesquisa da lavoura de dendê, cadê destacar o papel pioneiro da Embrapa Amazônia Oriental que vem realizando um trabalho na produção de mudas, combate a pragas, capacitação de recursos humanos para as empresas e instituições estatais no Brasil.

No caso do dendê na Amazônia, o MDA tem estimulado ações para a produção de mudas de dendê por meio de convênios com a Embrapa. Quanto aos projetos de agricultura familiar de dendê incentivado pelo MDA no Baixo Tocantins, o entrevistado aponta que:

O Ministério não tem a atuação de incentivar a agricultura familiar a plantar a palma, ele esclarece as vantagens e desvantagens. Mostra a política da palma e do PNPB, e a segurança jurídica. A relação se estabelece entre as empresas e os agricultores familiares e algumas vezes com suas representações sindicais (Entrevista respondida por e-mail ao pesquisador pelo consultor de biocombustível da região Norte do MDA, Dvandro Pedro de Oliveira, em 19.10.2015, grifo nosso).

O MDA atua no incentivo da agricultura familiar de dendê através do fomento agrícola oficial do Pronaf Eco-Dendê do qual é o gestor. Este crédito agrícola bancário estatal é o principal responsável pelo financiamento da produção familiar integrada de dendê nos municípios do Baixo Tocantins.

Quando questionamos de que forma o MDA participa do Pronaf Eco-Dendê, afirma que:

O MDA é o gestor do Pronaf de uma maneira geral, é quem faz as regras
gerais, cabendo os agricultores, as empresas e os agentes financeiros realizarem
a parceria e liberação dos recursos. Quando há entrave em aprovação de projetos
pelos bancos; dificuldades na emissão de DAP etc., algumas empresas e agricultores
solicitam nossa colaboração (Entrevista respondida por e-mail ao pesquisador pelo
consultor de biocombustível da região Norte do MDA, Dvandro Pedro de Oliveira
em 19.10.2015, grifo nosso).

Como contatamos pelas afirmações do entrevistado, o MDA possui um papel central na política da integração da agricultura familiar na cadeia do agronegócio do dendê no estado do Pará. Vale destacar, como apontado pelo entrevistado, que o Pará até o presente momento (2016) não produz biodiesel de dendê.

\subsubsection{Banco da Amazônia (Basa)}

Outra instituição de grande importância para a integração da agricultura familiar no agronegócio de dendê no Pará é o Basa. No estado, o Basa é o principal agente de fomento 
das diversas linhas do Pronaf, dentre as quais se destaca a linha do Pronaf Eco-Dendê, criado na safra agrícola de 2008/2009. No entanto, o banco já atua no financiamento agrícola de dendê desde 2002 em parceria com a Agropalma, que de forma pioneira criou projetos de agricultura familiar de dendê no município de Moju. O sucesso das experiências da Agropalma com a agricultura familiar de dendê integrada serviu de modelo para a criação do Pronaf Eco-Dendê pelo governo federal, em 2009. A Figura 20 mostra detalhes da agência do Basa em Abaetetuba, onde agricultores integrados do Baixo Tocantins possuem financiamentos de integração de dendê.

Figura 20: Agência do Basa em Abaetetuba, 2015

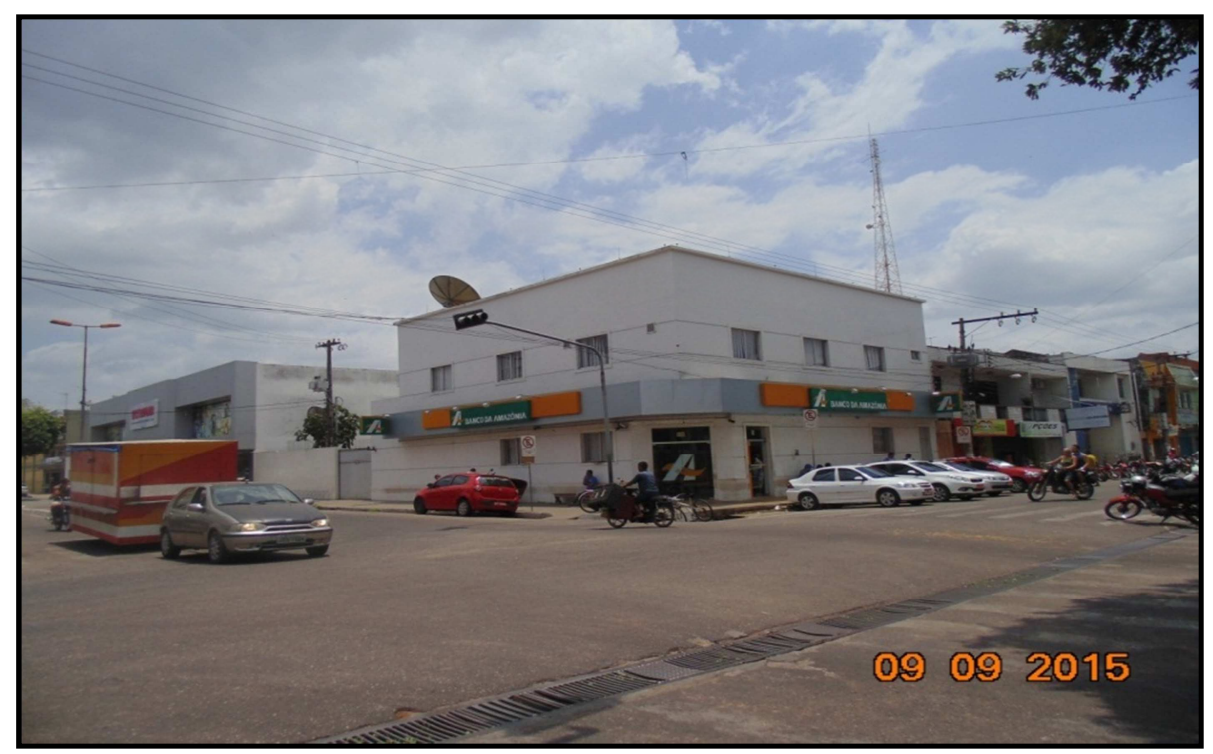

Fonte: Márcio Benassuly (2015)

A história do Basa está fortemente ligada ao fomento do desenvolvimento regional dos principais segmentos produtivos da Amazônia desde sua fundação em 1966, quando no contexto da Operação Amazônia foi extinta a Superintendência do Plano de Valorização Econômica da Amazônia (SPVEA) ${ }^{72}$ e criada a Superintendência de Desenvolvimento da Amazônia (Sudam). É neste contexto que houve a transformação do Banco de Crédito da Amazônia (BCA) em Banco da Amazônia (BASA) (COSTA, 2002).

Segundo Costa (2002, p. 291), "além de agente financeiro da Sudam, o Basa passou a se caracterizar como um banco agropecuário, comercial e de desenvolvimento [...]”. Nesta nova condição o Basa como banco regional passa a ter um papel de destaque em diversos setores da economia amazônica, dentre as quais as ligadas à agricultura tradicional (agricultura familiar) e à agricultura moderna (agronegócio).

\footnotetext{
${ }^{72}$ A SPVEA foi criada pela lei $\mathrm{n}^{\mathrm{o}}$ 1.806, de 06 de janeiro de 1953. Foi instalada em 23.09.1953, com sede na cidade de Belém do Pará (COSTA, 2002).
} 
Como principal agente estatal de fomento do crédito rural da agricultura familiar de dendê na Amazônia, o BASA tem como bases legais para a execução do Pronaf Eco-Dendê as diretrizes do Manual de Crédito Rural (MCR) do Banco Central do Brasil (Bacen). No Pará, o Banco da Amazônia trabalha com demandas de seis empresas integradoras (Agropalma, Biopalma-Vale, Petrobras Biocombustíveis, Belém Bioenergia Brasil, ADM e Marborges) (BASA, 2014b).

Para a execução das ações do Pronaf Eco-Dendê no Pará, o Basa e as empresas celebraram diversos convênios de cooperação técnica (garantia no fornecimento de mudas certificadas, gratuidade na assistência técnica, compromissos de compra e venda de CFF), realização de aditamentos (dispensa da vistoria prévia), reuniões de planejamento integrado (banco, assistência técnica e empresas) (BASA, 2014b).

O banco tem desempenhado seu papel mediante a realização de convênio de cooperação técnica, na contratação e liberação dos recursos do programa, na implantação e acompanhamento dos projetos além de incentivos a verticalização agroindustrial da cadeia produtiva do dendê na região Amazônica (BASA, 2014b).

Quanto à participação do Pronaf Eco-Dendê, com recursos investidos pelo banco, esta linha de crédito, em 2013, figurou como a terceira que mais financiou a produção da agricultura familiar no Pará. As linhas que mais aplicaram recurso neste ano foram: Pronaf Mais Alimentos, que investiu R \$ 72.030.572,64, Pronaf A (assentamentos), que aportou R\$ 35.994.098,12, e Pronaf Eco-Dendê, que financiou R\$32.635.155,24(Quadro 38).

Quadro 38: Distribuição das linhas do Pronaf em 2013

\begin{tabular}{|l|c|c|}
\hline \multicolumn{1}{|c|}{ Linhas do Pronaf } & Quantidade & Valores (R\$-1,00) \\
\hline Pronaf A (Assentamentos) & 1.733 & $35.994 .098,12$ \\
\hline Pronaf AlC (Custeio Assentado) & 56 & $262.252,18$ \\
\hline Pronaf Custeio Isolado & 318 & $4.517 .470,77$ \\
\hline Pronaf B & 6.425 & 16.652 .044 .10 \\
\hline Pronaf Eco Dendê & 444 & $32.635 .155,24$ \\
\hline Pronaf Floresta & 1.002 & $17.798 .255,94$ \\
\hline Pronaf Mais Alimentos & 1.538 & $72.030 .572,64$ \\
\hline Pronaf Mulher & 353 & $3.779 .148,22$ \\
\hline Totais & 11.869 & $183.668 .897,21$ \\
\hline
\end{tabular}

Fonte: BASA (2014b) 
Sobre as ações do BASA no Pronaf Eco-dendê no Pará no período de 2010 a 2015, em entrevista, o superintendente regional no Pará, Luiz Euclides Feio, afirma que:

\begin{abstract}
Anualmente o banco trabalha por determinação do Ministério da Integração Nacional (MI) no planejamento dos recursos dos fundos constitucionais para o ano seguinte. Então a gente reuni entre junho e agosto, no caso estamos fazendo agora com todos os órgãos classistas para discutir a melhor forma de aplicar os recursos no fundo constitucional, onde o Pronaf de dendê esta dentro do Pronaf, a gente reuni com órgãos classistas. Aí a gente envolve Federação de Agricultura, Federação de Comercio, Federação de Indústria e no caso especifico do Pronaf dendê a gente houve as contribuições da Federação dos Trabalhadores na Agricultura e também á visão das indústrias através da Federação através da Federação das Indústrias que representam o outro lado que recebe a produção.

Aí sim a gente recolhe os subsídios seja das classes dos trabalhadores que é quem executa o programa seja dos órgãos de assistência e órgãos fundiários que no caso do Pronaf notadamente são os ATER que aquelas agências prestadoras de serviços e o INCRA que é o grande gestor dos processos de reforma agrária e de agricultura familiar também especifica dentro de assentamentos. Então a gente recolhe desses órgãos subsídios para a melhoria das aplicações de recursos do fundo, isso nos fazemos em todos os nove estados da região amazônica inclusive envolvendo Maranhão e Mato Grosso que são Amazônia Legal. Esse trabalho é condensado dentro do banco. [...] E aí dentro do Pronaf Eco-Dendê a gente faz um planejamento mais profundo dentro do dendê, a gente chama as seis integradoras, chama os gerentes das nossas agencias mais a assistência técnica e agente já expõe para eles qual é o planejamento deles. Então, eles trazem a quantidade de operações ou quantidades de produtores que eles querem atender por municípios. A gente tem orçamento por custo de um hectare de dendê, a gente já consegue ter o orçamento por município por integradora e esse bolo todo somado no final a gente chega ao total dos recursos que devem ser aplicadas no programa Pronaf Eco-Dendê de cada ano. Geralmente a gente acaba por uma outra razão fazendo mais por conta de outros ajustes, às vezes, falta de muda, e outras deficiência de assistência técnica, mas em geral ele fica muito próximo daquilo que a gente planeja (Entrevista realizada pelo pesquisador com o superintendente regional do Banco da Amazônia no Pará, Luiz Euclides Feio, em Belém-PA, em 18.08.2015, grifos nossos).
\end{abstract}

O Basa, como agente de fomento da produção agrícola de dendê no estado do Pará possui um papel de grande importância na integração da agricultura familiar de dendê no agronegócio nos municípios do Baixo Tocantins. No planejamento das ações para a execução do Pronaf Eco-Dendê, banco, instituições estatais, empresas integradoras e entidades de classes, participam da elaboração das ações destinadas à produção agrícola familiar de dendê. O planejamento realizado pelo banco para a execução das ações do Pronaf Eco-Dendê atende a uma racionalidade estatal do qual o banco é parte e onde as empresas integradoras possuem um papel de destaque segundo uma racionalidade que privilegia seus interesses de mercado.

No Pronaf Eco-Dendê, o Basa conseguiu evitar um dos grandes problemas relacionados ao crédito rural, que é o elevado índice de inadimplências por parte dos agricultores beneficiários desta política pública, como afirma o entrevistado.

[...] como é um programa novo e ele tem um projeto mais elástico quase todas as operações de dendê, à exceção das feitas com a Agropalma que foi a primeira, elas 
já estão sendo pagas. Então praticamente nós não temos inadimplência nesse programa, pois, nós financiamos o produtor selecionado pela integradora é ela acompanha ele na execução, ele entrega os cachos de fruto fresco para a indústria da empresa e ela faz o pagamento via banco de cada volume de tonelada de que é entregue. O banco vai tendo um percentual de forma que quando chega no vencimento o produtor tá com dinheiro para pagar a parcela então isso fecha o ciclo produtivo e o financeiro e faz com que o programa não tenha inadimplência (Entrevista realizada pelo pesquisador com o superintendente regional do Banco da Amazônia no Pará, Luiz Euclides Feio, em Belém-PA, em 18.08.2015, grifo nosso).

De fato na linha de crédito do Pronaf Eco-Dendê a inadimplência é muito pequena, pois o pagamento da produção familiar é depositado pela empresa integradora no banco que vai retendo parte do financiamento realizado pelo agricultor. Já a inadimplência é muito elevada nas demais linhas do Pronaf no Baixo Tocantins conforme foi relatado em entrevistas com representantes dos STTR nos municipios pesquisados.

As principais dificuldades na execução do Pronaf Eco-Dendê no Pará são “[...] a quantidade de muda em relação à quantidade de produtores a ser assistido [...]. A outra dificuldade diz respeito à situação financeira dos agricultores" (Entrevista realizada pelo pesquisador com o superintendente regional do Banco da Amazônia no Pará, Luiz Euclides Feio, em Belém-PA, em 18.08.2015).

O acesso as mudas com a expansão da produção de dendê no Pará tornou-se um problema, pois devido a grande procura as empresas integradoras têm encontrado dificuldades quanto à aquisição das sementes que em parte é importada de outros países. A Embrapa não tem conseguido atender a demanda por sementes para a produção de mudas pelas empresas paraenses. Outra questão destacada pelo entrevistado é a condição financeira dos agricultores integrados, onde as condições sócio-econômicas são bastante precárias.

O Pronaf Eco-Dendê no Pará tem sido usado como exemplo para a criação de outros projetos de integração de pequenos agricultores a empresas agropecuáriasno estado.

Quem diria que o programa do Eco-Dendê acabou dando origem a outras integrações, por exemplo, nós temos a integração por exemplo a integração com a Jarí na área de reflorestamento, nós incorporamos o pequeno no mesmo molde que a gente faz com o dendê. Nos incorporamos na área de frutas a Canta de Tomé-Açu no mesmo processo. A Floraplac de Paragominas na produção de madeira para o MDF e tem o Laticínio em Novo Repartimento, chamado Laticínio Ligia que integra produtores de leite e a mais recente foi um frigorífico de pequeno animais o frigorífico Fortefrigo em Paragominas que a gente vai trabalhar a integração de ovinos e suínos (Entrevista realizada pelo pesquisador com o superintendente regional do Banco da Amazônia no Pará, Luiz Euclides Feio, em Belém-PA, em 18.08.2015, grifo nosso). 
A experiência da integração familiar de dendê a empresas tem servido de modelo para outras formas de integração no estado do Pará. A integração do sistema de produção agrícola de dendê tem demonstrado que o crédito estatal só tem alcançado segmentos da agricultura familiar de forma ampliada somente quando ocorre pela integração com grandes empresas. A associação entre banco de fomento da produção e empresas integradoras tem ampliado as experiências de integração no Pará para outros setores como: florestal, fruticultura, madeira, leite, ovinocultura e suinocultura como demonstra a entrevista.

No Pronaf Eco-Dendê, as empresas integradoras possuem um papel a ser desempenhado nesta política de fomento da produção agrícola familiar de dendê, como afirma nosso entrevistado.

O papel da integradora é primeiro o de selecionar o produtor, eles têm um planejamento dentro de um raio que parece que é no máximo 20 a $30 \mathrm{~km}$, eles fornecem as mudas, eles fornecem todas as capacidades durante o processo produtivo, eles orientam sobre o financiamento, eles fazem também o gerenciamento da aquisição de toda matéria prima produzida, aí você completa o ciclo com isso (Entrevista realizada pelo pesquisador com o superintendente regional do Banco da Amazônia no Pará, Luiz Euclides Feio, em Belém-PA, em 18.08.2015, grifo nosso).

As empresas integradoras possuem um papel a ser desempenhado no sistema de integração que vai deste a seleção dos agricultores integrados, fornecimento de mudas, transporte e compra da produção. A produção agrícola dos agricultores deve está no máximo $30 \mathrm{~km}$ de distância da usina de beneficiamento da produção. A realidade do espaço amazônico impede uma fluidez do transporte da produção agrícola se comparada com outras regiões do Brasil. O sistema de produção integrada de dendê esta estruturado em uma lógica territorial, onde a localização das propriedades de produção familiar de dendê e usinas de beneficiamento de óleo deve permitir o processamento rápido da produção agrícola desta cultura.

$\mathrm{Na}$ divisão de papéis no âmbito do Pronaf Eco-Dendê, as empresas integradoras possuem convênio de cooperação e de responsabilidade com o Basa, onde ficam definidos os papéis de cada ator nesta cadeia produtiva.

O convênio foi construído, ajustado, melhorado foi editado em duas outras oportunidades. A primeira é que por conta das fraudes que eram comuns no passado no Pronaf. O banco não abriu mão de fazer a fiscalização previa. Se você é a integradora e me indicava um produtor eu tinha que ir até lá com meu agrônomo testar, fazer o cara crachá, ver se o cara morava na propriedade. Isso representava uma certa lentidão, pois a gente não tinha braço para atender tudo isso. A primeira evolução nesse sentido foi que a gente passou a delegar essa competência de seleção às integradoras e um segundo no sentido que as integradoras teriam responsabilidades sobre isso. Se algum produtor que ela indicasse não tivesse o perfil adequado, eles teriam $72 \mathrm{~h}$ para liquidar a operação (Entrevista realizada pelo 
pesquisador com o superintendente regional do Banco da Amazônia no Pará, Luiz Euclides Feio, em Belém-PA, em 18.08.2015, grifo nosso).

A execução das ações do Pronaf Eco-Dendê no estado Pará encontra muitos desafios inclusive de natureza da dimensão territorial dos municípios contemplados com projetos de integração de produção familiar de dendê. A realidade de acesso as propriedade dos agricultores integrados é bastante dificultada pelas condições das estradas e dos ramais que dependendo do período do ano podem ficar intransitáveis por bastante tempo. Na verificação da execução das atividades na propriedade dos agricultores as empresas integradoras possuem mais agilidade e recursos humanos para este acompanhamento do que as agências do Banco da Amazônia.

Para a execução do Pronaf Eco-Dendê é realizada uma série de planejamentos que incluem a participação do Basa e das empresas integradoras de dendê, como demonstra o entrevistado.

\begin{abstract}
Primeiro tem um planejamento a nível macro, a gente chama nossos gerentes aqui e a partir da quantidade de muda e da disponibilidade de insumos, eles partem para elaborar os projetos, na medida em que vão sendo apresentados problemas com alguns produtores eles lhes substituem e como nossos gerentes também participam das nossas reuniões aqui existe uma integração na ponta entre o gerente, os agrônomos da agência e o técnico ou o coordenador da empresa que atua lá. Atualmente tem uma área voltada para a agricultura familiar (Entrevista realizada pelo pesquisador com o superintendente regional do Banco da Amazônia no Pará, Luiz Euclides Feio, em Belém-PA, em 18.08.2015, grifo nosso).
\end{abstract}

O planejamento das ações do Pronaf Eco-Dendê entre banco e empresas é importante para o bom andamento da execução desta política. As empresas integradoras centralizam estas ações no setor de agricultura familiar, que é responsável pela integração da agricultura familiar a empresa. Desta forma, o Basa, como principal agente de fomento, possui um papel de destaque no planejamento e execução do Pronaf Eco-Dendê no estado do Pará.

\title{
3.7.3 Empresas integradoras de dendê
}

Nesta seção trataremos das empresas integradoras selecionadas para esta pesquisa no Baixo Tocantins: as empresas Petrobras Biocombustível (esta com participação na empresa Belém Bioenergia Brasil) e a empresa Biopalma.

Petrobras Biocombustível (Pbio). A Petrobras Biocombustível foi fundada em 2008 no contexto do PNPB. Possui projetos de produção e gestão de etanol e biodiesel no Brasil. $\mathrm{Na}$ produção de biodiesel, a empresa possui três usinas localizadas em Candeias (BA) 
Quixadá (CE) e Montes Claros (MG) e, duas em parceria, em Marialva (PR) e Passo Fundo (RS) (IOS, 2014, p. 32).

Durante o lançamento do PPSOP a Petrobras anunciou dois projetos na área de biodiesel para o estado do Pará. O primeiro trata-se do projeto Pará, em que estava prevista a construção de uma usina de extração de óleo de palma para a produção de biodiesel para atender a região Norte do país. O segundo é o projeto Belém, que visava a produção de biodiesel em Portugal a partir do óleo de palma para o grupo português Galp Energia. $\mathrm{O}$ projeto total previa a integração de 2.250 agricultores familiares no plantio de dendê (PETROBRAS, 06.05.2010) (Mapa 14).

O projeto Pará teria na região do Baixo Tocantins a sua principal atuação. Inicialmente foram cadastradas 3.338 famílias nos municípios de Igarapé Miri, Cametá, Mocajuba e Baião, com previsão do início do plantio para 2011 e início da colheita para 2014. Já o projeto Belém ${ }^{73}$ teria como polo o município de Tomé-Açu. Este projeto previa a produção de 250 mil toneladas de biodiesel/ano em Portugal em parceria com a empresa Galp $^{74}$ Energia (PETROBRAS, 06.05.2010). A Figura 21 mostra propaganda do governo paraense referente ao projeto de biodiesel no Pará, onde a empresa Petrobras aparece com destaque.

Figura 21: Propaganda do governo paraense sobre a implantação do polo de biodiesel no estado do Pará

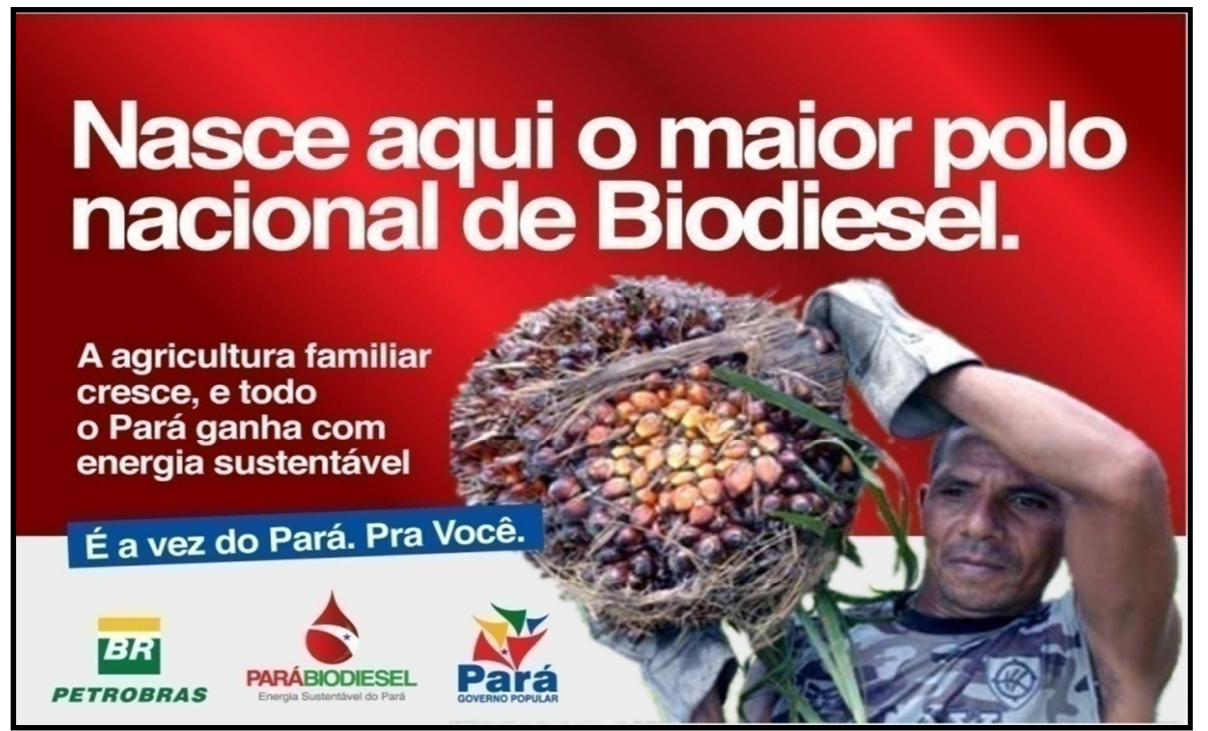

Fonte: Pará (2010b)

\footnotetext{
${ }^{73}$ Os investimentos previstos neste projeto eram de R\$ 1.017 milhões, sendo 554 milhões no Brasil para a produção de 300 mil toneladas de óleo de palma por ano e R \$ 463 milhões em Portugal para a implantação de uma usina de biodiesel a ser inaugurada em 2015 (PETROBRAS, 05.05.2010).

${ }^{74}$ Estatal portuguesa de petróleo e gás associada da Petrobras.
} 
Mapa 14: Concepção de projetos da Petrobrás Biocombustível no Baixo Tocantins (PA), 2010

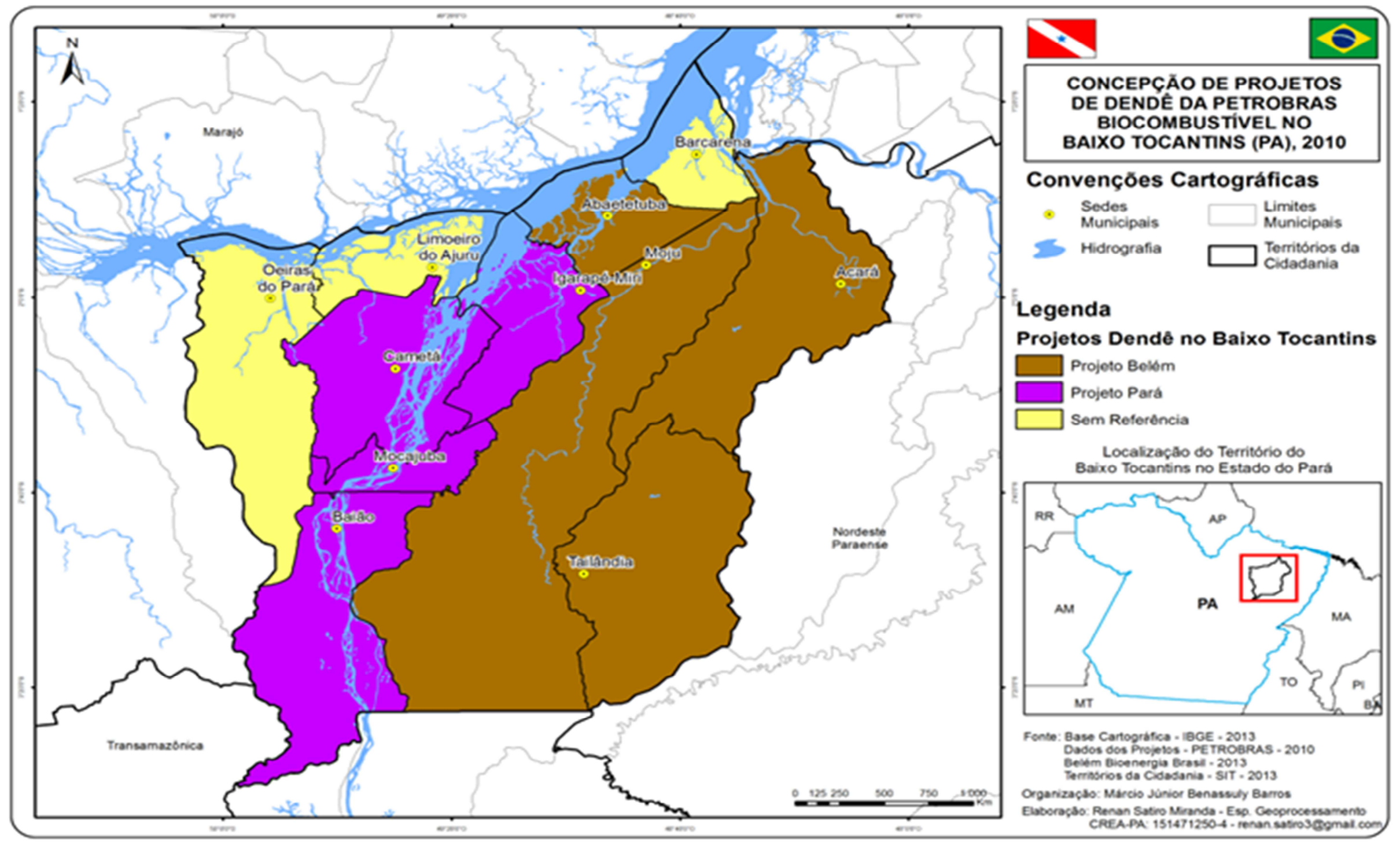


$\mathrm{Na}$ atuação do projeto Pará no Baixo Tocantins, o escritório da empresa ficaria localizado no município de Mocajuba. No município de Baião seria instalada uma esmagadora para atender o município e Mocajuba. Uma segunda esmagadora seria instalada em Igarapé Miri para atender este município e as demandas de Cametá.

A chegada da Petrobras nos municípios integrantes do projeto Pará de dendê foi recebida com muita expectativa pela sociedade regional. O projeto apresentado pela empresa para os municípios do Baixo Tocantins (Baião, Cametá, Igarapé Miri e Mocajuba) vinha em boa hora, pois todos estes municípios possuem limitadas oportunidades de emprego e renda.

O projeto contemplava a possibilidade do fechamento da cadeia produtiva do dendê, onde seriam investidos recursos na produção agrícola, agroindustrial, com a construção de duas usinas de extração de óleo de dendê e uma usina de produção de biodiesel que seria responsável para abastecer a região Norte do Brasil de biodiesel.

O escritório da empresa foi instalado em prédio alugado em Mocajuba de onde passou a comandar suas ações na região. Em trabalho de campo no município realizado no mês de agosto de 2015, diversos moradores informam que a empresa dispunha de uma grande frota de veículos incluindo motos que geralmente eram usadas pelos técnicos agrícolas que realizavam visitas a agricultores na região, além de outros veículos usados pela diretoria da empresa. A chegada dos funcionários da empresa na pequena cidade logo foi sentida pelo setor de comércio e aluguel de casas, apartamentos etc. A economia local recebeu positivamente a chegada dos funcionários da empresa que passaram a consumir uma série de serviços e produtos locais. Muitos comerciantes logo passaram a investirem na construção de casas e apartamentos para aluguel, porém o tempo de permanência da empresa na região teve pouca duração. Logo em junho de 2012 a empresa encerrou suas atividades na região.

O lançamento do projeto foi realizado em 2011 em Mocajuba e contou com a presença do então presidente da Pbio Miguel Rosseto e do diretor de suprimento da empresa, Janio Rosa, que foram recebidos com festa pelo prefeito de Mocajuba, Rosiel Costa. A chegada de uma grande empresa do porte da Pbio no município trazia muita expectativa para a economia de um município de pequeno porte que tem sua base econômica na agricultura, no pequeno comércio local e na administração pública.

O planejamento para a instalação do polo de dendê no Baixo Tocantins incluía a construção de seis portos para escoamento da produção, três pontes sobre os rios Igarapé Miri, Meruú e Acará, asfaltamento da rodovia PA-151, entre Mocajuba e Baião (48 km). A Embrapa investiria R\$ 38 milhões em assistência técnica e pesquisa (PARÁ, 2009). 
Em entrevista, o secretário municipal de agricultura de Mocajuba, Aldo Serrão, relata o início do projeto neste município que foi escolhido para abrigar o escritório e o viveiro de mudas de dendê da Petrobras Biocombustível na região do Baixo Tocantins.

\begin{abstract}
O que ocorre é que quando a Petrobras procurou os dirigentes dos municípios inclusive nos, mas também a gestão do próprio movimento social, eles vieram com o propósito de apresentar uma proposta do governo federal, uma proposta que teria nascido no Ministério do Desenvolvimento Agrário e que posteriormente veio a ser incorporado pela Petrobrás, a partir de uma subsidiaria que se pode dizer que é a Pbio, que á a Petrobras Biocombustível. Então foram eles que procuraram o município e o município acabou por conta da crise, que se alastravam por conta da pimenta-do-reino onde nós tivemos um ciclo de baixa e agora nós estamos numa alta, aí a proposta acabou chegando como uma esperança, mais o fato é que trazia embutido o fechamento de uma cadeia produtiva. A ideia era fazer a parceria no sentido da produção da palma e da comercialização dessa palma, inclusive com o compromisso de um contrato de 25 anos então a gestão pública na época deu todo suporte inclusive nós sedemos técnicos para ajudar num primeiro levantamento, que era para poder checar o numero de agricultores efetivamente dos municípios envolvidos no caso o nosso em particular, Mocajuba. Nós fizemos esse primeiro levantamento numa parceria com os técnicos que vieram do Ministério do Desenvolvimento Agrário, detectamos um número de agricultores realmente interessados com o perfil nesse primeiro contato com os agricultores, foi feito todo um processo de georreferenciamento e reunião setorizada com eles. E foi colocado inclusive pelos próprios agricultores algo que poderia ser um entrave já na liberação dos recursos institucionais que seria a inadimplência muito alta aqui no município em função da crise da pimenta-do-reino (Entrevista realizada pelo pesquisador com o secretário municipal de Agricultura de Mocajuba, Aldo Serrão, em 27.08.2015, grifo nosso).
\end{abstract}

A entrevista do secretário revela fatos relacionados ao contexto da chegada da Petrobras em Mocajuba, presença esta que foi recebida com "esperança" diante da situação econômica que o município se encontrava. A proposta apresentada pela empresa gerou bastante expectativa com a possibilidade da instalação de uma cadeia que contemplava projetos agrícolas, agroindustrial e industrial. A relação da empresa com os agricultores familiares seria realizada através de contrato de compra e venda da produção.

O trabalho em Mocajuba pela empresa foi também realizado nos demais municípios do projeto Pará: Baião, Cametá e Igarapé Miri. Este trabalho já vinha sendo realizado desde 2009 pela empresa por meio da realização do Diagnóstico Rápido Participativo (DRP). Foram selecionadas 7 etapas de execução do DRP: análise do $\mathrm{ZEE}^{75}$, análise do $\mathrm{ZARC}^{76}$, avaliação de potencial, avaliação da logística e do mercado, planejamento do diagnóstico, mapeamento de núcleos e pré-cadastro (PETROBRAS BIOCOMBUSTÍVEL, 2011).

\footnotetext{
${ }^{75}$ Zoneamento Ecológico e Econômico

${ }^{76}$ Zoneamento Agrícola de Risco Climático da Cultura
} 
As ações do DRP tiveram como objetivos a identificação das áreas agrícolas e dos agricultores aptos para participarem do projeto de integração da agricultura familiar de dendê à empresa integradora em questão.

Segundo dados da empresa, os resultados do DRP apontaram para a existência de 35.000 famílias potenciais, indicadas a partir de dados secundários oficiais como Incra, Iterpa e Emater. No diagnóstico de comunidades foram realizadas 3 reuniões em comunidades da região onde foram inicialmente identificadas 7.700 famílias potenciais. Já no diagnóstico de propriedades foram realizadas 120 reuniões e identificadas 3.300 famílias potenciais nos municípios envolvidos no projeto Pará (PETROBRAS BIOCOMBUSTÍVEL, 2011).

O resultado do levantamento do DRP realizado pela empresa com os apenas 23 projetos de integração contemplados com o Pronaf Eco-Dendê remanescente do projeto Pará, indica o completo fracasso das ações do projeto de dendê da Petrobras no Baixo Tocantins.

Sobre os contratos e a construção dos contratos e a situação de entrega da produção agrícola de dendê, Aldo Serrão afirma que:

Houve muitas polêmicas na construção do contrato e a Petrobras a todo
momento não abriu essa discussão no sentido da participação mais efetiva,
inclusive das instituições dos trabalhadores o que acaba gerando apesar da
desistência da Petrobras que eles alegam que é temporário, mais desativaram
tudo, nós temos agricultores que foram financiados e desde já começa a ter
problemas, pois eles assinaram que eles se responsabilizam a entregar a
produção na esmagadora mais próxima que fica em Tailândia. Isso já fica
complicado, pois como é que o agricultor familiar vai bancar o custo dessetransporte
dessa produção para essa esmagadora? Inicialmente a ideia era ficar nesse raio
menor no caso em torno de 20 km e fala-se inclusive da Petrobras processar esses
agricultores por quebra de contrato (Entrevista realizada pelo pesquisador com o
secretário municipal de Agricultura de Mocajuba, Aldo Serrão, em 27.08 .2015 , grifo
nosso).

A questão da descontinuidade das ações do projeto Pará pela Petrobras acarretou uma série de problemas para o agricultor integrado. Com o abandono do projeto pela empresa em 2012, não foram construídos as usinas extratoras de óleo de palma prevista no projeto, o que inviabiliza no presente a colheita da produção familiar com a entrega da produção por parte dos 23 agricultores remanescentes. Sem ter a quem recorrer parte desta produção dos dendezais já começa a ser perder.

Em 06.08.2010, a empresa assinou contrato de arrendamento de 300 hectares de terras de propriedade de Benedito Cunha para a implantação do centro de produção de mudas (viveiro) com capacidade de produzir 1.500.000 de mudas/ano de dendê. Esta propriedade está em uma localidade chamada Guariba, município de Mocajuba, onde a empresa fez a manutenção da estrada vicinal que dá acesso a este viveiro (PETROBRAS, 06.08.2010; 
PETROBRÁS BIOCOMBUSTÍVEL, 2011). Neste viveiro trabalharam funcionários residentes dos municípios de Mocajuba e Baião. Segundo informações do STTR de Baião ${ }^{77}$, quando em funcionamento, o viveiro da Petrobras em Mocajuba chegou a ter entre 80 a 90 funcionários residentes só de Baião.

No planejamento inicial da empresa o início do plantio das mudas nos municípios atendidos pelo projeto era dezembro de 2011, com o início das colheitas agrícolas de dendê a partir de 2014. As mudas seriam fornecidas aos integrados do projeto (PETROBRAS, 06.08.2010).

A partir de meados de 2012, as ações da empresa voltadas para o projeto foram reformuladas, o que implicou na paralisação das ações que vinham sendo realizadas. Os empregados do viveiro foram demitidos e a empresa passou suas ações para sua subsidiária no projeto Belém, a empresa Belém Bioenergia Brasil, que mantém um técnico na região para o acompanhamento dos 23 projetos herdeiros da atuação da Petrobras no Baixo Tocantins.

Em trabalho de campo realizado em agosto de 2015, visitamos a propriedade de Benedito Cunha, em Mocajuba, onde funcionou o viveiro. O contrato já havia sido encerrado e havia ainda poucos vestígios da atuação da Petrobras Biocombustível na propriedade como a estrutura do viveiro, e refeitório de trabalhadores do viveiro, mudas abandonadas (Figura 22).

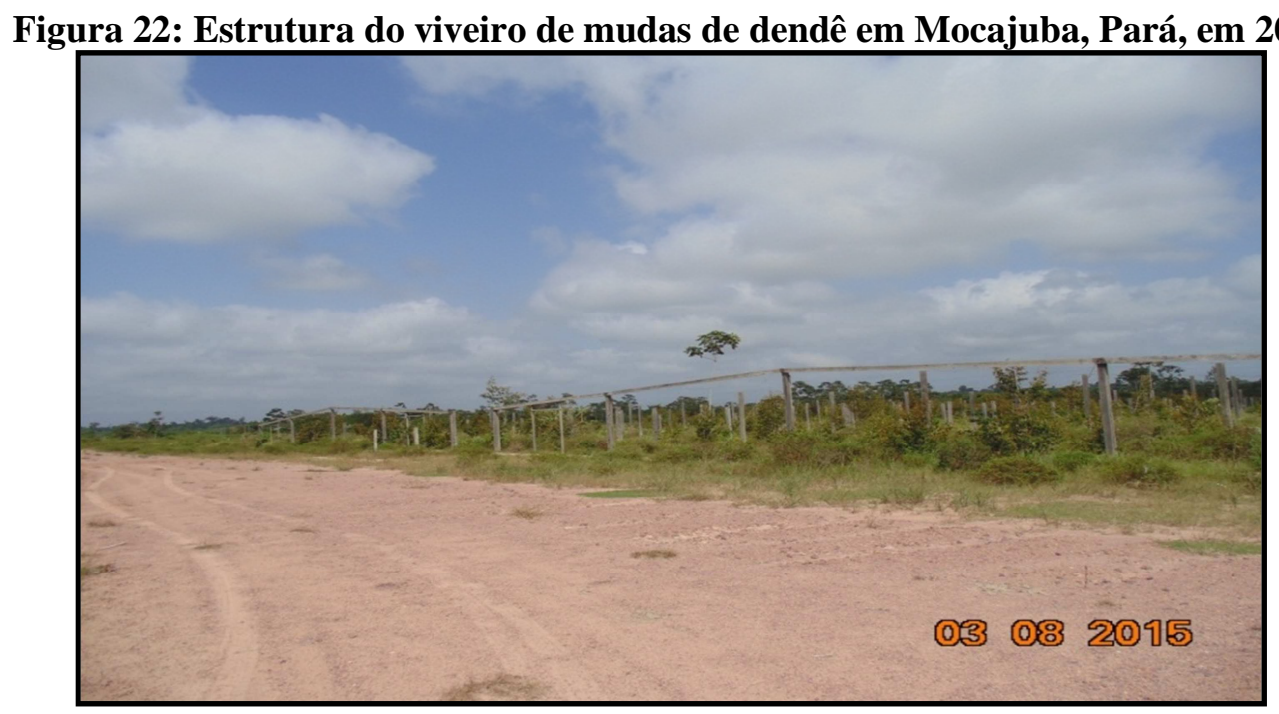

Fonte: Márcio Benassuly (2015)

Em nossa visita contatamos que a propriedade onde funcionou o viveiro possui suporte para a execução do projeto. A propriedade chegou a ter grandes motores bombas usados para

\footnotetext{
${ }^{77}$ Informação prestada em 29.09.2015 pelo presidente do Sindicato dos Trabalhadores e Trabalhadoras Rurais de Baião, Jose Nilton Serrão Farias.
} 
fazer a captação de água para molhar as mudas, estrutura para apoio de funcionários, técnicos agrícolas, parte gerencial do projeto, serviço de enfermagem etc.

Quando de seu funcionamento havia uma grande movimentação de trabalhadores na estrutura do viveiro. Com o fim das ações da empresa, toda a estrutura ficou abandonada, sendo que uma parte das mudas foi transferida para Tailândia, polo da empresa Belém Bioenergia Brasil, e as outras mudas, segundo informações coletadas no local, foram enterradas.

Para facilitar o acesso ao viveiro de mudas, a empresa fez a manutenção do ramal do Guariba, com aterramento de diversos pontos e terraplenagem. Segundo informações coletadas no município, quando do funcionamento do viveiro, o tráfego de carros entre o viveiro e a sede municipal era intensa em função dos serviços lá desenvolvidos.

Outro fator que chama atenção dosprojetos de dendê familiar implantados no projeto Pará é a dispersão territorial destes projetos, que foram instalados em localidades muito distantes umas das outras, o que irá dificultar a coleta dos frutos de dendê quando iniciar a colheita.

Pulverizaram esses projetos com comunidades distantes então tu tens projeto nessa região aqui do Açaizal, tu tens projetos em Igarapé Açu, tem o da margem do Arumanzal que é do Bueno. Tu tens no Angelim, então o que eu tô dizendo eles pulverizaram eles praticamente deixaram esses agricultores na mão essa que é a verdade (Entrevista realizada pelo pesquisador com o secretário municipal de Agricultura de Mocajuba, Aldo Serrão, em 27.08.2015, grifo nosso).

Em trabalho de campo nos municípios integrantes do projeto Pará, constamos a grande dispersão territorial e a dificuldade de acesso a estes projetos remanescentes. Tal situação compromete uma coleta de forma eficiente desta produção e o rápido processamento dos cachos de frutos de dendê.

A seleção dos agricultores envolveu a participação de diferentes instituições como STTR e secretarias municipais de agricultura. Como aponta Aldo Serrão, "nós mobilizamos agricultores num local aí eles participavam de uma reunião onde eram feitas a apresentação e quem manifestava interesse já recebia a visita de um técnico" (Entrevista realizada pelo pesquisador com o secretário municipal de Agricultura de Mocajuba, Aldo Serrão, em 27.08.2015).

Com relação à integração do agricultor familiar à lógica corporativa da empresa, Aldo Serrão afirma que.

A ideia do programa era um negócio pioneiro, quer dizer, você usava mão-de-obra familiar num programa dessa envergadura, naturalmente esse contrato deveria considerar isso. $O$ fato é que na hora da construção do projeto realmente, o que 
determinou as clausulas do contrato foram os interesses do mercado. Isso é verdadeiro, entretanto, nós tínhamos a expectativa de que esse contrato pudesse refletir esta relação considerando a especificidade da agricultura familiar. Uma das questões que a gente reivindicava que deveria estar no projeto, era o preço mínimo, porque na verdade você sabe que o preço do biocombustível está vinculado a uma bolsa que fica na Holanda e nós entendíamos que tinha que ter uma garantia de preço mínimo, justamente para proteger a agricultura familiar de qualquer eventualidade de mudança de rumo de mercado. Mais isso não foi considerado, ou seja, eles não aceitaram essa questão da logística de transporte por que era uma preocupação que nós tínhamos naquela época, ou seja, como é que o agricultor vai deslocar essa produção para as esmagadoras. De quem vai ser o custo disso? Nós queríamos que isso ficasse sobre a responsabilidade da empresa. $O$ fato é que esse contrato acabou contrariando todas aquelas expectativas, seria um bom negócio para agricultura familiar, o sonho que se tornou pesadelo. As análises que tem do contrato revelam que ele é um contrato totalmente desfavorável para os agricultores familiares. Nós não tivemos a oportunidade de participar ativamente da construção do contrato (Entrevista realizada pelo pesquisador com o secretário municipal de Agricultura de Mocajuba, Aldo Serrão, em 27.08.2015, grifos nossos).

O contrato de compra e venda realizado entre empresa e agricultor atende uma racionalidade que privilegia o mercado global de biocombustível. Neste mercado a cotação do preço do dendê segue as orientações das bolsas de valores de Rotterdam e da Malásia. Esta situação para o agricultor familiar é fonte de incertesas, pois esta cotação depende das condições do mercado global. O preço mínimo se previsto no contrato ajudaria o agricultor a melhor realizar seu planejamento garantindo uma estabilidade com relação aos preços da venda da produção.

Em participação em audiência pública realizada na Comissão de Integração Nacional, Desenvolvimento Regional da Amazônia da Câmera dos Deputados, realizada em Brasília, em 10.06.2014, organizada para debater sobre o programa de biocombustíveis no estado do Pará, Aldo Serrão relata alguns pontos de grande importância do projeto como o momento em que a empresa abandou o projeto.

Em junho de 2012, deu-se uma virada no programa. Ninguém conseguiu mais dialogar com a Petrobras, ninguém teve mais satisfação nenhuma acerca do programa. Um dia pareceu lá um pessoal de outra empresa, convocando os agricultores para apresentar uma proposta de arrendamento de terras, e não mais de parceria com a agricultura familiar. Essa proposta infelizmente foi rejeitada pelos nossos agricultores (CÂMARA DOS DEPUTADOS, 2014, p.8, grifo nosso).

Esta outra empresa que o secretário afirma em sua entrevista é a Belém Bioenergia Brasil, onde a Petrobras Biocombustível possui a metade de suas ações e que passou a incorporar em seus projetos os 23 agricultores integrados do projeto Pará abandonados pela Pbio na região. Com a saída da Pbio dos municípios de atuação do projeto Pará, a estruturajá montada foi desativada, inclusive o viveiro de mudas de dendê, em Mocajuba, em meados de 2013. 
Foi tudo desativado, parte desse material a BBB levou para Tailândia, uma parte das mudas inclusive produzidas aqui foram comercializadas para lá e os equipamentos também foram remanejados para lá, para o projeto Belém, foi feito uma rescisão de contrato nas terras do viveiro, eram lá do seu Benedito Cunha. No Benedito Cunha era o viveiro de mudas a proposta inicial trouxe algumas coisas interessantes, inclusive conduzidas pelo professor Kato, que são aqueles trituradores de capoeiras, por que a ideia era que o projeto fosse implantado em áreas degradáveis e nós tínhamos muitas aqui em relação ao cultivo da pimentado-reino (Entrevista realizada pelo pesquisador com o secretário municipal de Agricultura de Mocajuba, Aldo Serrão, em 27.08.2015, grifo nosso).

Desta forma, como conclui Aldo Serrão, em sua participação nesta audiência pública, em Brasília, o sonho virou pesadelo para nós (CÂMARA DOS DEPUTADOS, 2014, p. 9). De fato, em trabalho de campo constatamos a completa frustração dos agricultores, gestores e sociedade em geral nos municípios visitados do projeto Pará com o abandono das ações da empresa na região.

Projeto agrícola: a produção agrícola própria. Em seu projeto original a empresa não teria produção agrícola de dendê própria. O objetivo da empresa era implantar 24.000 hectares de dendê em parceria com a agricultura familiar (12.000 hectares) e demais parceiros, como médios produtores independentes (12.000 hectares) (PETROBRAS BIOCOMBUSTÍVEL, 2011).Em trabalho de campo, contatamos apenas um projeto independente localizado no município de Mocajuba de propriedade do produtor, conhecido como Bueno.

Projeto agrícola: a produção agrícola familiar. O planejamento da empresa era implantar cerca de 12.000 hectares em projetos de agricultura familiar de dendê integrada na região do Baixo Tocantins. Deste total, apenas 23 projetos acabaram efetivamente sendo implantados nos municípios de Baião (4), Cametá (11), Mocajuba (8). Em Igarapé Miri não foram instalados projetos registrados com financiamento do Pronaf Eco-Dendê pelo Banco da Amazônia. Para um planejamento de integrar 1.200 projetos de agricultura familiar de dendê a empresa só conseguiu implantar apenas 23 projetos, que se encontram em situação indefinida quanto à viabilidade econômica e de transporte de sua produção agrícola.

Em trabalho de campo, entrevistamos 6 agricultores integrados da Petrobras Biocombustível, que a partir de 2013 foram incorporados à empresa Belém Bioenergia Brasil. Estes dados foram incorporados a atuação desta última empresa que dá suporte a estes agricultores integrados ${ }^{78}$.

\footnotetext{
${ }^{78}$ Ver Capítulo 4.
} 
Em entrevista, o presidente do Sindicato dos Trabalhadores e Trabalhadoras Rurais de Cametá, Benedito Siqueira Nunes ${ }^{79}$, afirma: "nós temos gente hoje que entraram no dendê que estão trabalhando com patrão para manter a família. Não tem condições de fazer farinha e outra coisa, pois não tem o tempo" (Entrevista realizada pelo pesquisador com o presidente do STTR de Cametá, Benedito Siqueira Nunes, em 01.10.2015).

A cultura do dendê exige muita dedicação do agricultor familiar integrado na manutenção do dendezal. Desta forma torna-se muito difícil conciliar o cultivo do dendê com outras lavouras na propriedade, o que contribuiu para a redução da diversidade de culturas na terra familiar, atividade esta característica da agricultura familiar. Neste sentido, tem razão o entrevistado, pois os projetos de integração da agricultura familiar de dendê a empresas no Baixo Tocantins têm transformado a propriedade familiar em domínio hegemônico de cultivo de dendê em detrimento das demais lavouras.

O entrevistado, que tem uma visão crítica sobre a integração da agricultura familiar no agronegócio de dendê, acha que:

\begin{abstract}
O Pronaf Dendê é uma linha de beneficiamento da agricultura familiar dentro do agronegócio, porque o dendê na forma que foi plantado nessa região é uma porta para o agronegócio sendo beneficiado pelo Pronaf. Nesse processo o Pronaf Eco-Dendê é uma forma de contemplar o agronegócio através da agricultura familiar [...] Porque ela está sendo usada para beneficiar uma atividade que não tá vinculada à agricultura familiar, muito embora se discuta que o projeto seja para salvar a agricultura familiar, mas na prática a cada dia ele prejudica mais. Que salvação da agricultura é essa que tu não fortalece os agricultores, fortalece as empresas. Quem é que tá cuidando do dendê, então, ele não tá beneficiando o agricultor (Entrevista realizada pelo pesquisador com o presidente do Sindicato dos Trabalhadores e Trabalhadoras Rurais de Cametá, Benedito Siqueira Nunes, em 01.10.2015, grifo nosso).
\end{abstract}

A questão levantada pelo entrevistado é bastante pertinente sobre os verdadeiros beneficiados com o Pronaf Eco-Dendê, no caso a agricultura familiar ou o agronegócio. Esta linha do Pronaf foi criada para o fortalecimento da agricultura familiar de dendê, que por meio da integração agricultor-empresa destina recursos estatais para a produção familiar de dendê a empresas integradoras. Desta forma o agronegócio passa a ser também beneficiado com os recursos de fomento do Pronaf Eco-Dendê para ampliar a produção empresarial agrícola de dendê.

\footnotetext{
${ }^{79}$ O Sindicato dos Trabalhadores e Trabalhadoras Rurais de Cametá tem na região uma posição bastante crítica da questão da integração dos agricultores familiares na cadeia do dendê na região. Em 2011, este sindicato lançou o documento "Resistência do Movimento Sindical Rural por uma Agricultura Familiar Sustentável na Região do Baixo Tocantins" onde apresenta uma série de propostas para uma agricultura familiar ligada à realidade dos agricultores familiares locais (Anexo A).
} 
A integração da agricultura familiar a empresas de dendê é uma questão que vem sendo bastante criticada pelo STTR de Cametá que já promoveu uma série de debates junto à categoria dos agricultores do município para esclarecer o modelo da integração apresentado pela Petrobras aos agricultores da região.

Sobre a integração da agricultura familiar ao agronegócio de dendê, Benedito Nunes afirma que:

\begin{abstract}
A gente não considera esse processo de integração porque essa integração que a empresa só tem a agregar e os trabalhadores a perder. Isso eu não considero. Por que veja bem, quem financia o projeto pelo Pronaf Dendê é o agricultor. Quem produz a muda é a empresa, só que quando vai para o campo ela custa para o agricultor. A empresa fica com bônus e o agricultor com ônus. Nós queremos que o agricultor entre com 5 hectares e não com 10 hectares para cima. A agricultura familiar é uma área que tem vários tipos de produtos, monocultura não é viável (Entrevista realizada pelo pesquisador com o presidente do Sindicato dos Trabalhadores e Trabalhadoras Rurais de Cametá, Benedito Siqueira Nunes, em 01.10.2015, grifos nossos).
\end{abstract}

A relação na integração entre empresa e agricultor é uma questão que merece bastante atenção. Trata-se de uma relação entre mandar (empresas) e obedecer (agricultor), pois pelo contrato de compra e venda da produção agrícola, cabe ao agricultor seguir todas as normas estabelecidas pela empresa. A participação do agricultor no projeto de integração ocorre mediante o financiamento bancário de até $\mathrm{R} \$ 80.000,00$, por meio do Pronaf Eco-Dendê empréstimo este que cobre o pagamento de mudas, adubo, manutenção do dendezal etc. Quanto à empresa cabe realizar a compra da produção familiar de dendê, da qual obtém vantagem de mercado, já a participação do agricultor na integração é condicionada a um empréstimo a ser paga junto ao banco de fomento.

Para a integração dos agricultores familiares à empresa, foi assinado um contrato entre o Basa, a empresa e os agricultores familiares integrados que estabelece o papel de cada ator no processo. Em trabalho de campo junto aos agricultores familiares integrados, solicitamos cópias deste contrato, mas não tivemos acesso. Nahum e Santos (2015, p. 321-322) tiveram acesso a um destes contratos celebrados entre a Petrobras Biocombustível e um agricultor familiar do município de Baião onde constam as obrigações (encargos) da empresa e do agricultor familiar integrado de dendê.

\title{
Cláusula Terceira- Encargos
}

\section{São encargos da PBIO}

3.1.2. Preparar a área, fornecer mudas e insumo e apoiar o plantio na área do agricultor, utilizando as praticas comerciais usuais, sem ressarcimento destes custos; $[\ldots]$

3.1.3. O pagamento ao agricultor familiar de 1 (um) salário mínimo regional a título de ajuda de custo para o desenvolvimento do presente Termo de Cooperação até o 4 (quarto) ano do cultivo; 
3.1.4. Prestar assistência técnica ao agricultor familiar ao longo de todo o Termo de Cooperação;

3.1.5. Capacitar o agricultor familiar no trato do dendê;

$[\ldots]$

3.2. São encargos do agricultor:

3.2.1. A responsabilidade técnica e operacional pela manutenção das condições legais da sua propriedade (matrículas em cartório, licenças, cadastros e afins), de forma a permitir a consecução do objeto deste Termo de Cooperação, incluindo o endividamento de esforços para a regularização de sua posse e quitação de dívidas que impossibilitem a obtenção de crédito, fomento oficial, benefícios fiscais e demais facilidades para o cultivo do dendê;

3.2.2. Aplicar os recursos repassados pela PBIO exclusivamente nas atividades relacionadas à consecução do objeto deste Termo de Cooperação e de acordo com o plano de trabalho.

3.2.3. Informar a PBIO sobre eventuais mudanças com relação à propriedade da área objeto de estudo, pelo menos 30 dias antes da respectiva alteração da relação de propriedade;

3.2.4 Não alienar a propriedade objeto de estudo sem autorização expressa da PBIO. [...]

3.2.6. Realizar a parte que lhe cabe do plantio, na forma definida no Plano de Trabalho.

3.2.7. Arcar com os custos de mão-de-obra, após a fase de plantio, necessários ao bom desenvolvimento da cultura, colheita de cachos e sua entrega a PBIO, em ponto de coleta divulgado pela PBIO, que estará localizado em até 12 (doze) quilômetros de sua propriedade;

$[\ldots]$

5.1. O prazo de vigência deste termo de Contrato de Cooperação será de 7 (sete) anos, ponto de estabilização de produção, a contar da assinatura do documento, podendo ser prorrogado, mediante aditivo, a ser firmado pelos partícipes (PETROBRAS BIOCOMBUSTIVEIS, 2012 apud NAHUM; SANTOS, 2015, p.321-322, grifo nosso).

No contrato acima ficam claras as obrigações da empresa e do agricultor familiar integrado de dendê em Baião. O documento estabelece que a entrega da produção agrícola de dendê esteja localizada em até 12 quilômetros da propriedade do agricultor, mas na prática isto não ocorre, pois em Baião existem apenas 4 contratos de dendê familiar, fato que inviabiliza a coleta pela empresa.

A monocultura do dendê é bastante criticada pelos STTR visitados nos municípios do Baixo Tocantins, que consideram que a agricultura familiar só é viável se praticada a partir da diversificação da produção agrícola de lavouras diferenciadas que permitam ao agricultor a alimentação da família e a comercialização do excedente. Na visão do líder sindical de Cametá, Benedito Siqueira Nunes, o dendê é apenas mais uma cultura agrícola que o agricultor poderia cultivar em sua propriedade, não superando 5 hectares de área, pois acima desta área o agricultor tem dificuldades para conciliar as demais culturas da propriedade.

Em entrevista, o presidente do Sindicato dos Trabalhadores e Trabalhadoras Rurais de Mocajuba, Valdenes de Nazaré Viana Miranda, descreve a realidade e a renda do agricultor familiar em Mocajuba: 
Hoje os agricultores aprenderam um pouco de dividir a área deles. A plantarem um pouco do cacau, açaí e hoje pimenta-do-reino, hoje muita gente trabalha com a mandioca no setor de Areião ${ }^{80}$. Cenira ${ }^{81}$, é mais mandioca. Você vai lá e vê poucos pimentais, nós estamos bem no plantio de banana, mas temos uma barreira os comerciantes preferem comprar banana de fora do que a nossa. Essa é outra barreira, que precisamos quebrar (Entrevista realizada pelo pesquisador com o presidente do STTR de Mocajuba, Valdenes de Nazaré Viana Miranda, em 10.08.2015, grifo nosso).

A diversificação da produção agrícola levantada pelo líder sindical de Mocajuba foi constatada nas propriedades visitadas nos municípios do antigo projeto Pará. Como estes projetos familiares de dendê estão com uma situação indefinida, estes agricultores integrados foram obrigados a encontrarem outra fonte de renda para manter a família.

Sobre a lógica do financiamento agrícola, em entrevista, a secretária de política agrícola e meio ambiente do Sindicato dos Trabalhadores e Trabalhadoras Rurais de Tailândia, Cristiane Lopes, afirma que: "hoje o grande problema que a gente tem junto ao Banco, seria ele financiar além do dendê. Ele só quer financiar o dendê” (Entrevista realizada pelo pesquisador em 11.09.2015, grifo nosso).

A situação apontada pela líder sindical de Tailândia reflete a racionalidade do governo federal em associação com as empresas de privilegiarem algumas culturas agrícolas em detrimento de outras. No Pará a cultura do dendê a partir do lançamento do PNPB (2004) e principalmente do PPSOP (2010) vem recebendo grandes aportes de recursos em detrimento de outras culturas regionais como a mandioca, cujos valores por projetos são menores. Esta racionalidade de crédito bancário (Pronaf Eco-Dendê) direcionado para a cultura familiar de dendê tem ampliado a participação de agricultores familiares nesta cultura, em detrimento de outras culturas, em que o acesso ao crédito é dificultado.

A realidade fundiária dos municípios é outra questão a ser levada em consideração, o que contribui para a dificuldade da implantação do projeto de agricultura familiar de dendê no Baixo Tocantins.

Em entrevista, o presidente do Sindicato dos Trabalhadores e Trabalhadoras Rurais de Abaetetuba, Elias Kempner, afirma que:

A política em si, ela foi criada de uma forma sem levar em conta a realidade fundiária dos municípios. Tem município como Moju que a grande parte dos agricultores tem 100 hectares de terras, 70 hectares, 80 hectares. O nosso município é uma realidade diferente, todos são minifúndios e a famílias, às vezes, só tem 10 hectares, 12 hectares. $\mathbf{O}$ problema ainda maior, porque você tira tudo aquilo para plantar dendê e ficam poucos para plantar mandioca etc.(Entrevista

\footnotetext{
${ }^{80}$ Ramal de mesmo nome.

${ }^{81}$ Ramal visitado.
} 
realizada pelo pesquisador com o presidente do Sindicato dos Trabalhadores e

Trabalhadoras Rurais de Abaetetuba, Elias Kempner, em 24.09.2015, grifos nossos).

A questão apontada pelo líder sindical de Abaetetuba reflete a realidade fundiária de parte dos municípios do Baixo Tocantins, como Abaetetuba, Baião, Barcarena, Cametá, Igarapé Miri e Limoeiro do Ajuru, onde a maioria das propriedades possui menos de 10 hectares de área. Logo estas propriedades pelas normas do Pronaf Eco-Dendê estão fora das exigências da política. Já os municípios de Acará, Mocajuba, Moju, Oeiras do Pará, e Tailândia têm a maioria de suas áreas acima de 10 hectares, como podemos verificar no Quadro 39 que utiliza dados do censo agropecuário ${ }^{82}$ 1995-1996.

Quadro 39: Estabelecimentos por grupo de áreas total segundo municípios do Baixo Tocantins (PA) no Censo Agropecuário 1995-1996

\begin{tabular}{|c|c|c|c|c|c|c|c|}
\hline \multirow[b]{2}{*}{ Municípios } & \multicolumn{7}{|c|}{ Estabelecimentos segundo os grupos de áreas totais (ha), em 31.12.1995 } \\
\hline & $\begin{array}{c}\text { Menos } \\
\text { de } 10\end{array}$ & $\begin{array}{c}10 \text { a menos } \\
\text { de } 100\end{array}$ & $\begin{array}{c}100 \text { a menos } \\
\text { de } 200\end{array}$ & $\begin{array}{c}200 \text { a menos } \\
\text { de } 500\end{array}$ & $\begin{array}{c}500 \text { a menos } \\
\text { de } 2000\end{array}$ & $\begin{array}{c}2000 \text { e } \\
\text { mais }\end{array}$ & $\begin{array}{c}\text { Sem } \\
\text { declaração }\end{array}$ \\
\hline Abaetetuba & 2.894 & 1.244 & 54 & 31 & 8 & - & - \\
\hline Acará & 1.831 & 4.126 & 167 & 50 & 18 & 16 & - \\
\hline Baião & 949 & 638 & 30 & 16 & 14 & 2 & - \\
\hline Barcarena & 834 & 663 & 14 & 3 & 2 & - & - \\
\hline Cametá & 5.388 & 1.824 & 77 & 29 & 4 & - & - \\
\hline Igarapé-Miri & 1.395 & 720 & 74 & 7 & 3 & - & - \\
\hline $\begin{array}{l}\text { Limoeiro do } \\
\text { Ajuru }\end{array}$ & 1.028 & 605 & 49 & 22 & 5 & - & - \\
\hline Mocajuba & 558 & 724 & 29 & 10 & 1 & - & - \\
\hline Moju & 479 & 3.845 & 411 & 51 & 15 & 6 & - \\
\hline $\begin{array}{ll}\text { Oeiras } & \text { do } \\
\text { Pará } & \end{array}$ & 540 & 1.862 & 116 & 28 & 10 & - & - \\
\hline Tailândia & 26 & 240 & 70 & 42 & 30 & 23 & - \\
\hline Total & & & & & & & \\
\hline
\end{tabular}

Fonte: Organizado pelo autor com base em IBGE (1996)

Os dados acima demonstram também que a falta de conhecimento da estrutura fundiária de região contribuiu para a baixa adesão de propriedades aptas para o projeto de dendê familiar nos municípios de atuação do projeto Pará.

Projeto Agroindustrial: as usinas extratoras de óleo de palma. O projeto Pará havia planejado a construção de duas usinas de extração de óleo de palma com capacidade de

${ }^{82}$ Censo Agropecuário com os dados sobre a realidade fundiária municipal mais recente disponível em meio digital pelo IBGE. Disponível em: http://www.ibge.gov.br/home/estatistica/economia/ agropecuaria/censoagro/1995_1996/. Acesso em: jul. 2016. 
250.000 toneladas/ano localizadas nos municípios de Igarapé Miri e Baião. A usina I seria instalada na entrada da vila Santa Maria de Icatu, em Igarapé Miri, o que facilitaria o recebimento dos cachos de dendê tanto de Igarapé Miri quanto de Cametá. A usina II seria instalada em Baião próxima à localidade de Limãozinho e atenderia a produção de dendê de Mocajuba e Baião, respectivamente (PETROBRAS BIOCOMBUSTÍVEL, 2011). Estas ações não foram executadas, em vista da pouca adesão dos agricultores familiares ao projeto Pará.

Projeto Industrial: as usinas de produção de biodiesel. O planejamento inicial da empresa considerava a construção de uma usina de produção de biodiesel com capacidade de 100.000 toneladas/ano, que teria como finalidade o abastecimento de biodiesel da região Norte do Brasil (PETROBRAS BIOCOMBUSTÍVEL, 2011).

Os recursos necessários para a construção desta usina de produção de biodiesel estavam inicialmente orçados em $\mathrm{R} \$ 330$ milhões, com previsão de início de operação para julho de 2013 (PETROBRAS, 06.08.2010). Estas ações nunca foram concretizadas.

Projeto Belém. Entre os dois projetos anunciados pela Petrobras Biocombustível em 2010 para o setor de biodiesel para o Pará, o projeto Belém é o único que continua em operação, uma vez que o projeto Pará foi abandonado, tendo seus 23 agricultores familiares incorporados ao projeto Belém sob responsabilidade da empresa Belém Bioenergia Brasil. Na atualidade as ações da Pbio no setor da produção de dendê no Baixo Tocantins ocorrem mediante ações de sua subsidiária.

Belém Bioenergia Brasil (Pbio + Galp). A Belém Bioenergia Brasil foi fundada em 14 de janeiro de 2011. A empresa tem sua sede em Belém atuando na produção agrícola de dendê em dois polos: Tailândia e Tomé-Açu. Da composição acionária da Belém Bioenergia Brasil fazem parte a Petrobras Biocombustível (50\%) e a Galp Bioenergy (50\%), responsável pela execução do projeto Belém (BELÉM BIOENERGIA BRASIL, 2012; 2013a).

O projeto Belém é resultante dos entendimentos geopolíticos entre duas empresas energéticas, a Petrobrás do Brasil e a Galp de Portugal. Os primeiros entendimentos entre as duas empresas começam em 2007, quando foram estabelecidos os primeiros estudos de viabilização do projeto. Em 2008, tem início a implantação do primeiro pré-viveiro do projeto. Em 2009, são aprovados pelas duas empresas os entendimentos para a execução do projeto Belém (BELÉM BIOENERGIA BRASIL, 2013b).

Em 2011, a empresa realiza a sua primeira plantação de mudas de dendê totalizando uma área plantada de 3.143 hectares. Em 2012, a área plantada chegou a 8.526 hectares. Em 2013, esta área foi de 24.104 hectares, conforme demonstra o Quadro 40. 
Quadro 40: Área plantada de dendê pela Belém Bioenergia Brasil 2011-2013

\begin{tabular}{|c|c|}
\hline Anos & Área plantada (em hectares) \\
\hline 2011 & 3.143 \\
\hline 2012 & 8.526 \\
\hline 2013 & 24.104 \\
\hline
\end{tabular}

Fonte: Organizado pelo autor com base em Belém Bioenergia Brasil (2012; 2013a)

Em 2015 o site ${ }^{83}$ da empresa registrava que a área plantada naquele ano era de 36.800 hectares próprios. A agricultura familiar integrada somava 3.000 hectares e 340 hectares eram de parceiros empresariais, onde 18.500 hectares estavam localizados no polo de Tailândia e 18.300 hectares, no polo de Tomé-Açu, somando desta forma 40.140 hectares de dendê. A Figura 23 mostra detalhes do polo da empresa em Tailândia.

Figura 23: Sede do polo da Belém Bioenergia Brasil em Tailândia, 2015

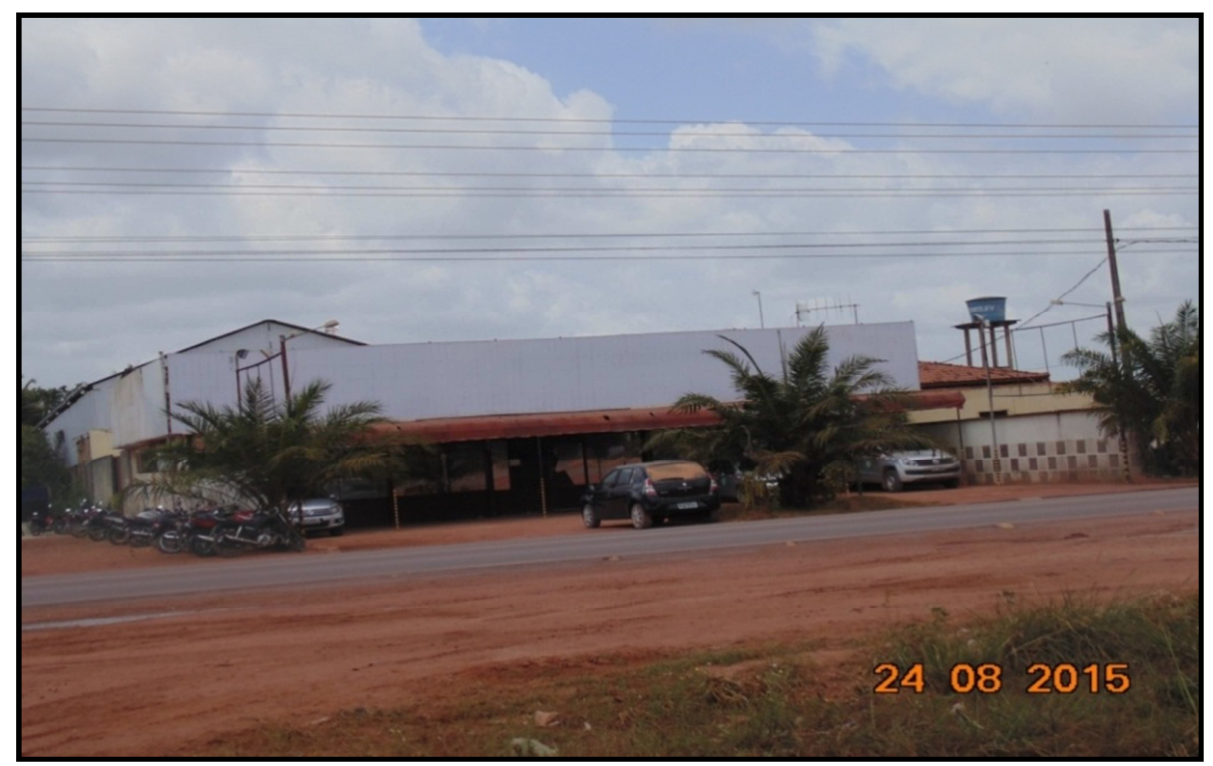

Fonte: Márcio Benassuly (2015)

O projeto Belém prevê a produção de óleo de palma no Pará e de biodiesel em Portugal. A atuação territorial do empreendimento originalmente compreende os municípios de Moju, Abaetetuba, Tailândia, Tomé-Açu, Acará, Concórdia do Pará e Bujaru. O projeto previa, além da produção própria a produção integrada de agricultores familiares com áreas entre 7 e 10 hectares, em áreas antropizadas até 2007. Todos os empreendimentos do projeto deveriam estar dentro dos territórios apontados pelo Zoneamento Econômico Ecológico do dendezeiro, elaborado pela Embrapa, em 2010.

\footnotetext{
${ }^{83}$ Disponível em: www.belembioenergia.com.br. Acesso em: jun. 2015.
} 
Projeto agrícola: a produção agrícola própria. A Belém Bioenergia Brasil possui uma produção agrícola de dendê própria, concentrada principalmente em Tailândia.

A empresa não possui terras de sua propriedade, a mesma realiza arrendamentos de fazendas na região, onde promove o cultivo de dendê. Uma destas propriedades arrendadas é a fazenda São Mateus (Figura 24), localizada às margens da rodovia PA-150, no município de Tailândia. A Figura 25 mostra detalhes do transporte de dendê pela empresa na rodovia PA 150.

Figura 24: Fazenda São Felipe onde a empresa Belém Bioenergia Brasil possui plantação própria de dendê em Tailândia

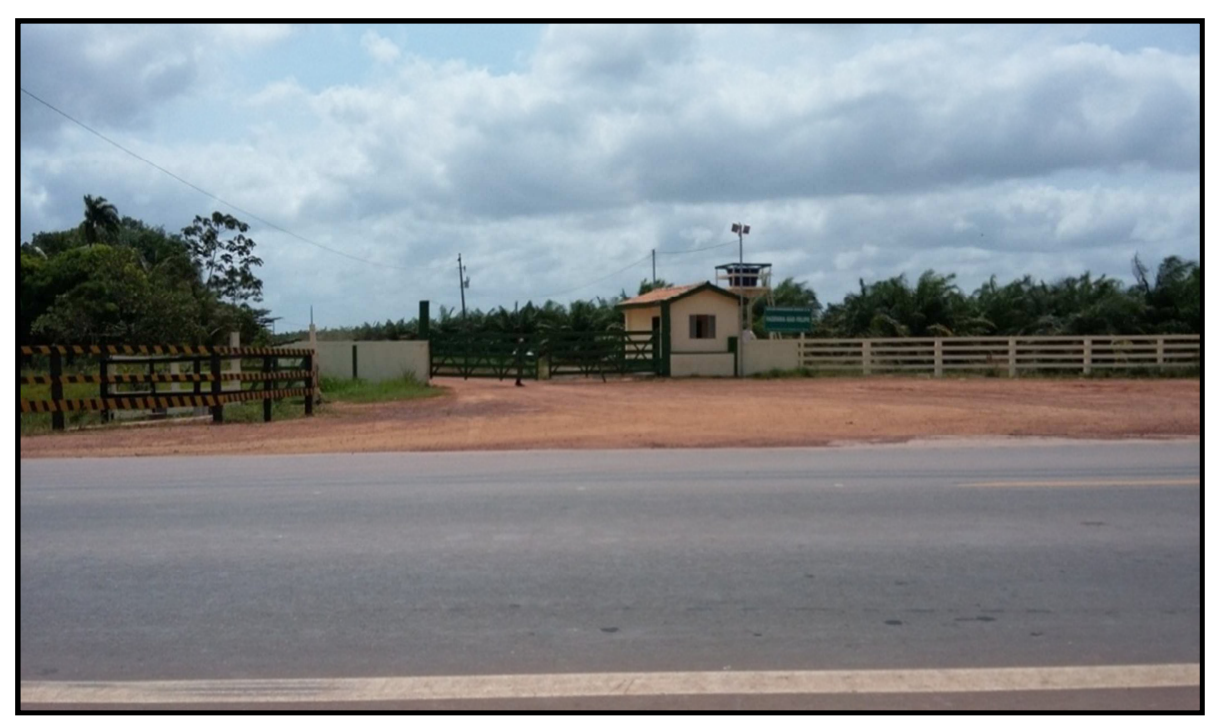

Fonte: Márcio Benassuly (2015)

Figura 25: Transporte de produção de dendê da empresa Belém Bioenergia Brasil em Tailândia.

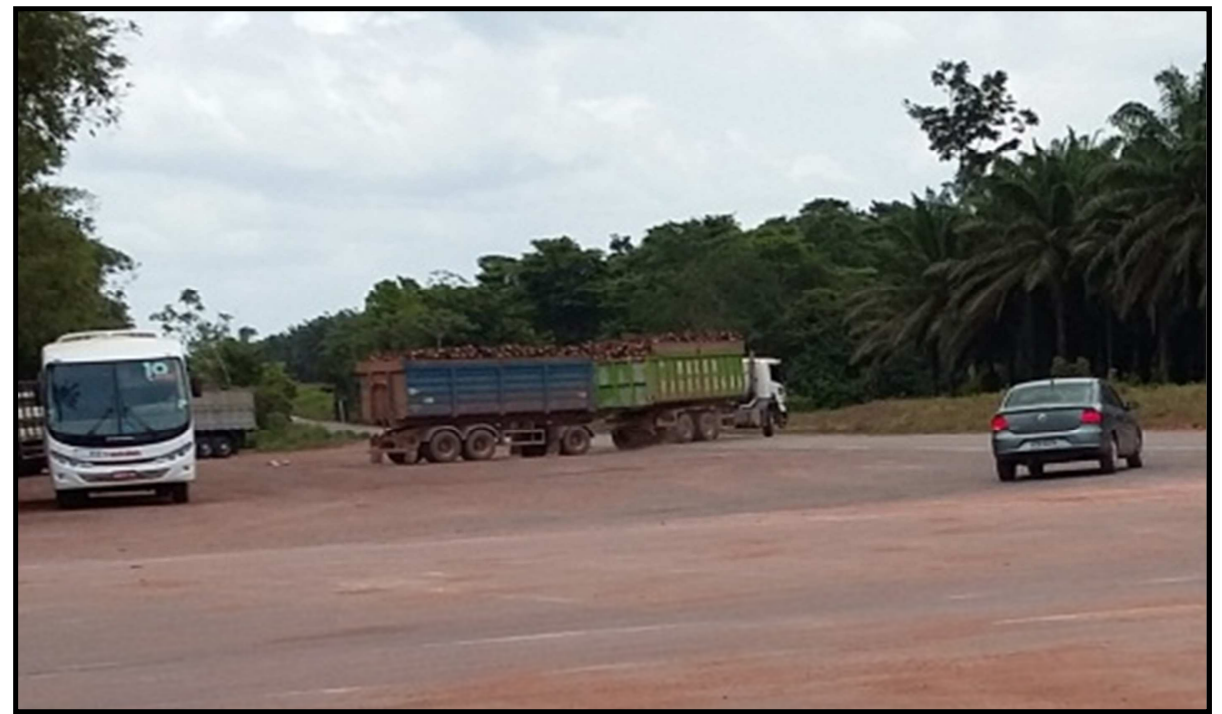

Fonte: Márcio Benassuly (2015) 
Projeto agrícola: a produção agrícola familiar ${ }^{84}$. A produção agrícola familiar da empresa teve início na safra agrícola 2011/2012. A vinculação do agricultor familiar com a empresa ocorreria por meio de contratos de crédito do Programa Nacional da Agricultura Familiar (Pronaf). Na Amazônia o Basa é o principal agente de fomento de programa.

Os critérios para seleção dos agricultores familiares de dendê envolvem diferentes etapas. O processo começa com a obtenção da Declaração da Aptidão ao Pronaf (DAP), de documentos individuais do agricultor, da terra e do cadastro ambiental rural. O contrato garante a compra futura dos frutos de dendê. A assistência técnica sob responsabilidade da empresa visa o repasse de técnicas para cultivos do plantio de dendê (BELÉM BIOENERGIA BRASIL, 2013b). O Quadro 41 mostra detalhes da quantidade de contratos firmados entre 2011 a 2013 pela empresa.

Quadro 41: Adesão de agricultores familiares no polo Tailândia da Belém Bioenergia Brasil
\begin{tabular}{|c|c|c|c|}
\hline Polo & Parceiros em 2011/2012 & Parceiros em 2012/2013 & Hectares \\
\hline Tailândia & 62 & 151 & 2.091 \\
\hline
\end{tabular}

Fonte: Belém Bioenergia Brasil (2013b)

O projeto previa uma renda para o agricultor familiar integrado para o modelo padrão de produção familiar de 10 hectares, pautados em ganhos de acordo com a fase produtiva do dendezeiro. Desta forma seguindo esta previsão no sétimo ano a renda do agricultor integrado deveria atingir $\mathrm{R} \$ 2.007,75$ mensais, ou seja, uma renda anual de $\mathrm{R} \$ 24.093,40$. Para a realidade local de muitos agricultores da região, torna-se uma excelente oportunidade da geração de renda familiar (BELÉM BIOENERGIA BRASIL, 2013b).

Para executar seu planejamento, a empresa realizou uma série de reuniões em diversas localidades de Tailândia, tendo como objetivo promover um levantamento de agricultores parceiros para o projeto de agricultura familiar da empresa.

Projeto agroindustrial: as usinas extratoras de óleo de palma. A empresa elencou em seu planejamento a construção de três usinas extratoras de óleo de palma com capacidade de 135 toneladas/hora (BELÉM BIOENERGIA BRASIL, 2013).

\footnotetext{
${ }^{84}$ Entregamos em 28.08.2015 no polo Tailândia, carta de apresentação da pesquisa de tese (Anexo B) com solicitação de informações sobre as experiências da empresa sobre os projetos de agricultura familiar de dendê integrados, a empresa contemplados com financiamento do Pronaf Eco-Dendê nos municípios do Baixo Tocantins (PA) no período de 2010-2015. Solicitamos ainda agendamento de entrevista com um representante da empresa para abordar sobre os projetos de agricultura familiar de dendê integrado a empresa no Baixo Tocantins (PA). Fomos informados que estas informações só poderiam ser fornecidas pela sede da empresa que fica localizada no edifício Village, em Belém do Pará. Estivemos neste local, mas ninguém pode atender as nossas solicitações.
} 
Em 2013, foram realizados estudos para a definição e instalação de sua primeira usina de extração de óleo de palma, concluindo pela escolha de Tailândia como local para instalação desta usina (BELÉM BIOENERGIA BRASIL, 2014).

Em 26.03.2014 foi aprovado pela SUDAM, o projeto da empresa Belém Bioenergia Brasil (Pbio + Galp) para produção de óleo vegetal (óleo de palma, óleo de palmiste e torta de palmiste) a ser implantado nos municípios de Tailândia, Tomé-Açu e Mãe do Rio, no valor de $\mathrm{R} \$ 1$ 1.359.810.996,00. A previsão da produção é de 335 mil toneladas de óleo de palma anual. O projeto prevê ainda a produção de 270 mil toneladas de biodiesel em Portugal que abastecerá parte da Espanha com óleo de palma produzido no Pará (SUDAM, 2014).

As informações divulgadas pela Sudam (2014) indicam ainda que dos 60 mil hectares de área plantada, seis mil serão destinados aos projetos de agricultura familiar integrada e mais seis mil para a parceria com produtores médios e grandes independentes. Em 2014 a empresa beneficiava 320 famílias de agricultores integrados nos polos de Tailândia e ToméAçu. O projeto prevê ainda que $80 \%$ da produção agrícola será própria e executada em fazendas arrendadas com contrato de cinco anos.

Projeto Industrial: as usinas de produção de biodiesel. A empresa prevê a construção de uma usina de biodiesel em Portugal. O prazo para a implantação deste projeto é até 2021 (SUDAM, 2014).

Na sequência tratamos da empresa Biopalma (Vale + Msp). A Biopalma foi fundada em 2007 pelo grupo MSP. Em 2009 ocorre a formação dajoint-venture com a entrada da Vale na empresa, onde em 2011 a Vale passa a controlar 70\% das ações da Biopalma. Em 2011, a empresa inaugura sua primeira usina de extração de óleo de palma, com capacidade inicial de processamento de 40 toneladas de cachos de dendê por hora, localizada no município de Moju. Em 2013 têm início as obras da segunda usina de extração de óleo de palma da empresa. A empresa previa para 2014 a conclusão de sua plantação própria de dendê. Para 2015 previa o funcionamento da segunda usina de extração de óleo de palma. Para 2017 prevê a utilização do uso do B20 em sua frota de veículos pesados e locomotivas (HERMAN, 2013).

A Biopalma tem como atuação territorial sete municípios no Pará (Abaetetuba, Acará, Moju, Concórdia do Pará, Bujaru, Tomé-Açu e São Domingos do Capim). Destes, três municípios fazem parte do Baixo Tocantins (Abaetetuba, Acará e Moju). A organização territorial da empresa está dividida em quatros polos de ação:1. Polo Vera Cruz/Acará; 2. Polo Concórdia; 3. Polo Moju/Abaetetuba; 4. Polo Tomé-Açu. Em 2015 a estrutura acionária da 
Biopalma está concentrada na Vale que detém 89,05\% das ações e da MSP, com 10,95\% (ABREU, 2015).

No planejamento da empresa o objetivo é fomentar um plantio próprio de dendê de 80 mil hectares de dendê, sendo de 60 mil hectares próprios e 20 mil hectares em parceria a com a agricultura familiar por intermédio do Pronaf Eco-Dendê. No campo da produção de biodiesel a empresa visa uma produção de 230 milhões de litros de biodiesel de dendê para atender a demanda de $\mathrm{B} 20^{85}$ da frota de veículos pesados e locomotivas da empresa do sistema Norte e Nordeste da empresa. A empresa visa a implantação de duas usinas de extração de óleo de palma e uma usina de produção de biodiesel no município de Acará. A empresa visa a produção tanto de óleo de palma quanto de óleo de palmiste, sendo que o último tem um valor agregado maior que o primeiro (HERMAN, 2013).

Os investimentos da empresa no projeto de plantação de dendê para produção de biodiesel é justificado pelo fator da empresa ser a maior consumidora individual de óleo diesel do Brasil, com um consumo de 1,6 milhões de toneladas de óleo diesel, em 2012. Outro fator que a empresa alega para os investimentos na produção de biodiesel está relacionado à questão ambiental em que a empresa visa reduzir suas emissões de $\mathrm{CO}_{2}$ em quase $17 \%$. De toda sua produção de óleo de palma, a empresa visa utilizar $70 \%$ para a produção de biodiesel e 30\% para o mercado de alimentos (HERMAN, 2013).

Em 2010 a empresa lançou o programa de agricultura familiar de dendê com o objetivo de integrar 2 mil famílias à empresa. Em 2012 contabilizava cerca de 350 famílias integradas à empresa. Neste ano a plantação própria de dendê da empresa atingiu 53 mil hectares (HERMAN, 2013).

Em 2015 anuncia as obras da segunda usina extratora de óleo no município de Acará. A empresa planeja para 2018 o funcionamento da primeira usina de biodiesel no Pará com capacidade de 200.000 toneladas e para 2021 da segunda usina de mesma capacidade. A empresa possui uma área total de cerca de 156.000 hectares de terras distribuídos pelos cinco municípios de sua atuação no Pará. Sua área própria plantada até dezembro de 2014 foi de 56.487 hectares. Seu programa de agricultura familiar já atinge em 2015, 650 famílias, ou seja, 6.500 hectares, de um planejamento de 1.000 famílias a serem integradas até 2018. A empresa possui uma usina extratora no Moju com cerca de 450.000 toneladas de cachos frescos de frutos (CFF) ano e uma segunda usina em construção no município de Acará com capacidade total de 1.500 toneladas de CFF (ABREU, 2015).

\footnotetext{
${ }^{85}$ Mistura de 20\% de biodiesel ao óleo diesel de petróleo.
} 
Projeto agrícola: a produção agrícola própria. Em 24 de junho de 2009 a Vale anuncia o consórcio com a Biopalma para a produção de óleo de palma, matéria prima a ser utilizada na produção de biodiesel. O projeto previa um investimento de U\$\$ 500 milhões onde a Vale entraria com R\$ 305 milhões. A área agrícola ocupada inicialmente pelo empreendimento é de 130 mil hectares com o plantio de 9,3 milhões de mudas de dendê até 2013. Neste lançamento do programa (Figura 26) se estimou para o ano de 2014 o início do uso do B20 na frota de locomotivas da estrada de ferro de Carajás (VALE, 2009).

Figura 26: Coletiva de imprensa durante o lançamento do projeto biodiesel da Vale

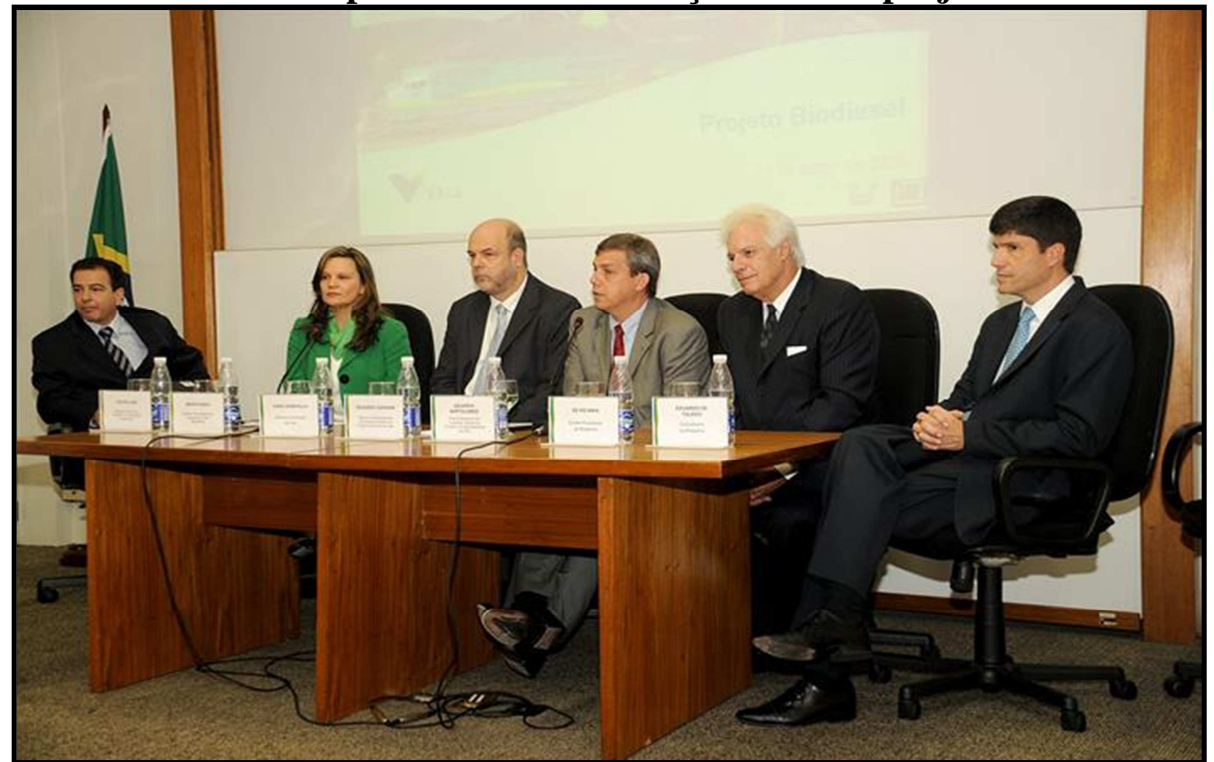

Fonte: VALE. Sala de Imprensa ${ }^{86},(2012)$

Pelo levantamento realizado por Nahum e Santos (2015), a partir de dados da Secretaria de Meio Ambiente do Pará (SEMA) sobre as propriedades da Biopalma no estado do Pará, constatou-se a presença de propriedade em 8 municípios paraenses. No Baixo Tocantins a empresa possui propriedades agrícolas em Abaetetuba (17), Acará (36) e Moju (11). Fora do Baixo Tocantins os municípios onde a empresa possui propriedades são: Concórdia do Pará (14), São Domingos do Capim (6), Tomé-Açu (24), Tailândia (2). No total a empresa possui 111 propriedades agrícolas, o que corresponde a 142.399,407 hectares no estado do Pará (NAHUM; SANTOS, 2015, p. 319).

A produção agrícola própria bem como a produção da agricultura familiar integrada é transportada do local da produção para a usina de extração de óleo de palma localizada na PA-151, no município de Moju, onde é transformada em óleo de palma e óleo de palmiste.

Depois da colheita, os frutos de dendê são transportados para a usina de extração de óleo, em Moju. A empresa utiliza diferentes estratégias de transporte para a produção dos

\footnotetext{
${ }^{86}$ Disponível em: http://saladeimprensa.vale.com/Paginas/ResultadoBusca.aspx. Acesso em: 20 dez. 2015.
} 
cachos de dendê para a usina de Moju. Para as localidades de acesso rodoviário usa geralmente caçambas.

Para as localidades dos municípios de Acará e Concórdia do Pará que ficam distantes da usina de Moju, o transporte ocorre geralmente em balsas que conseguem levar uma grande quantidade de cachos de dendê.

Projeto agrícola: a produção agrícola familiar $^{87}$. O planejamento da empresa é envolver 2 mil famílias de agricultores integrados de dendê, em um modelo de plantio de 10 hectares, financiados pelo Basa que considera a aquisição de mudas, manutenção do dendezal e a retirada de uma parcela durante os anos improdutivos do dendezal, ou seja, os três primeiros anos da cultura agrícola.

Segundo dados apresentados por Abreu (2015), a Biopalma, até dezembro de 2014, havia integrado ao seu programa de agricultura familiar de dendê 650 agricultores familiares, o que corresponde a 6.500 hectares de área ocupada com esta cultura agrícola. Cabe destacar que estes dados não informam a quantidade por municípios e sim os dados gerais alcançados pela empresa nos municípios de sua atuação territorial, fato que nos impossibilita afirmar a quantidade de contratos por municípios. O Quadro 42 mostra detalhes da área própria e integrada da empresa em 2014.

Quadro 42: Área plantada própria e integrada e metas de expansão da Biopalma

\begin{tabular}{|l|c|c|}
\hline \multirow{2}{*}{\multicolumn{1}{|c|}{ Empresas }} & \multicolumn{2}{|c|}{ Área em hectares } \\
\cline { 2 - 3 } & Plantada até dez. 2014 & Expansão para 2018 \\
\hline $\begin{array}{l}\text { Biopalma (produção } \\
\text { própria) }\end{array}$ & 56.487 & 66.487 \\
\hline $\begin{array}{l}\text { Agricultura familiar } \\
\text { integrada }\end{array}$ & 6.500 & 10.000 \\
\hline Total & 60.987 & 76.487 \\
\hline
\end{tabular}

Fonte: Abreu (2015), com modificações do autor

Cabe destacar que esses projetos são financiados pelo Basa com recursos do Pronaf Eco-Dendê, onde os municípios de Tailândia e Moju são os maiores tomadores deste tipo de

\footnotetext{
${ }^{87}$ Estivemos em 27.08.2015, no polo da empresa no município de Moju, onde entregamos no setor de agricultura familiar da empresa carta de apresentação da pesquisa de tese (Anexo B) com solicitação de informações sobre as experiências da empresa sobre os projetos de agricultura familiar de dendêintegrados, a empresa contemplados com financiamento do Pronaf Eco-Dendê nos municípios do Baixo Tocantins (PA) no período 2010-2015. Solicitamos ainda agendamento de entrevista com um representante da empresa para abordar sobre os projetos de agricultura familiar de dendê integrado a empresa no Baixo Tocantins (PA). O responsável técnico pelo setor de agricultura familiar nos informou que estas informações só poderiam ser fornecidas pela sede da empresa que fica localizada no edifício Empire Center em Belém. Estivemos no local indicado, mas ninguém pode atender as nossas solicitações.
} 
financiamento agrícola. Sobre a expansão ou "febre" do acesso do Pronaf Eco-Dendê em Moju a presidente do STTR do município, Salete Lima e Lima, afirma que:

\begin{abstract}
Esse aqui virou febre, então a nossa preocupação é em relação a essa forma. Eu sou completamente contra a monocultura, por que isso para mim não é agricultura familiar. Nós nunca passamos fome por que quando não tinha nada existia pelo menos um coco para comer com farinha. Então hoje o que vemos muitos vendendo a terra para ser empregado da empresa, na minha região aqui, quem faz farinha vende para o agricultor não vende para fora. $\mathbf{O}$ povo tá focando mais em dendê, então no meu ponto de vista eu tô sendo contra da forma que foi colocada o dendê. $\mathbf{O}$ meu problema é que os nossos agricultores não deixem a cultura para viver a cultura do outro, que nós vamos passar fome, morrer de fome. Por que tu faz sopa de dendê? Tu faz chibé ${ }^{88}$ de dendê? Quer dizer eu vou deixar a minha cultura para viver a cultura do outro. Não existe isso! Você quer plantar dendê, tudo bem, mais que a nossa cultura seja mantida! (Entrevista realizada pelo pesquisador com a presidente do Sindicato dos Trabalhadores e Trabalhadoras Rurais de Moju, Salete Lima e Lima, em 25.08.2015, grifos nossos).
\end{abstract}

A líder sindical de Moju aponta questões que precisam ser debatidas no atual modelo do Pronaf Eco-Dendê. O financiamento destinado à cultura do dendê tem privilegiado a monocultura em uma região onde a diversificação da produção agrícola é uma herança passada de geração para geração de agricultores familiares rurais. Uma vez contraído o financiamento bancário do Pronaf Eco-Dendê, o agricultor passa a focarseu trabalho e atenção na lavoura do dendê, o que acaba por comprometer as demais culturas. Uma consequência direta do acesso ao financiamento para a plantação de dendê é o abandono das demais culturas, como o plantio da mandioca, em que o agricultor passa a ter que comprar a farinha de mandioca para a alimentação de sua família.

No Pará a expansão da cultura do dendê tem coincidido com a elevação dos preços da farinha de mandioca. Outra questão levantada pela sindicalista rural é que o dendê é uma cultura que foi introduzida na região por grandes empresas e que tenta transformar o agricultor familiar em uma extensão do agronegócio empresarial. Para muitos entrevistados, o Pronaf Eco-Dendê pela sua racionalidade acaba por transformar a atividade do agricultor familiar em uma espécie de agronegócio familiar regulado pelo agronegócio empresarial. Certamente que a racionalidade do agricultor familiar difere da racionalidade da empresa capitalista.

A mudança de agricultor tradicional para agricultor integrado à lógica empresarial acaba por substituir uma série de ações que antes eram realizadas e que no novo modelo são ordenadas pela empresa integradora. No novo modelo, muitos agricultores integrados acabam por substituir por completo suas culturas agrícolas apenas pelo cultivo do dendê tendo que

\footnotetext{
${ }^{88}$ Mistura de farinha de mandioca com água.
} 
comprar o que antes produziam em suas propriedades. $\mathrm{Na}$ realidade dois modelos de agricultura estão em jogo: um modelo que considera a agricultura tradicional de base endógena, desenvolvida por população tradicional que historicamente pouca atenção recebeu das políticas estatais; de outro lado, temos um modelo da agricultura moderna de base exógena que conta com forte apoio das políticas estatais para o financiamento de culturas agrícolas selecionadas pelo Estado/empresas, como é o caso do dendê na Amazônia.

Desta forma, as ações hegemônicas do financiamento agrícola estatal acabam por impor um modelo de agricultura que atende a racionalidade do capital hegemônico da agricultura moderna. Deste modo, sem financiamento para as culturas agrícolas pouco atrativas para o capital, como a mandioca, o agricultor acaba aderindo ao modelo hegemônico do financiamento familiar do dendê na região, tornando-se agricultor regulado pela empresa integradora onde está associado.

Projeto agroindustrial: as usinas extratoras de óleo de palma. A Biopalma conta com uma usina de extração de óleo de palma inaugurada em 2012 (Figura 27), na rodovia PA-150, em Moju, para o processamento de frutos para a extração de óleo de palma bruto (CPO).

Figura 27: Inauguração da planta de produção de óleo de palma da Biopalma, polo Moju, Pará

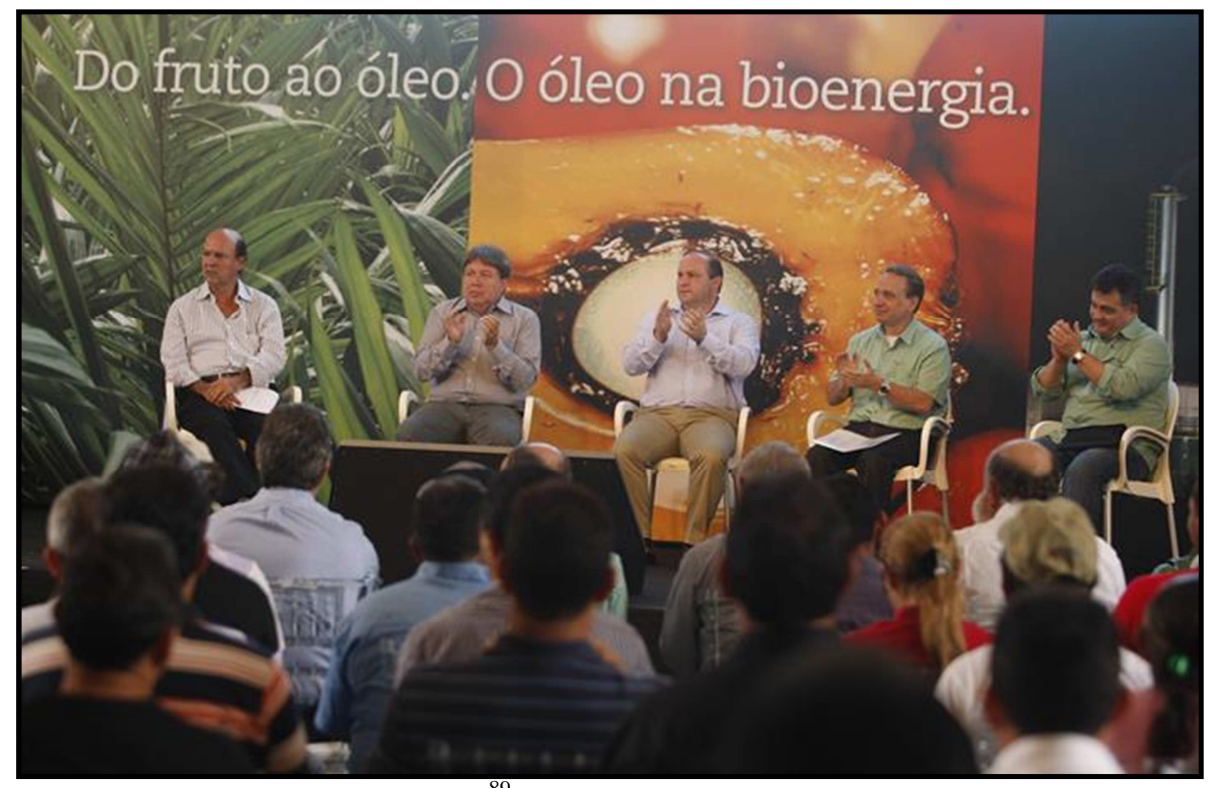

Fonte: Vale. Sala de Imprensa ${ }^{89}$ (2012)

Esta usina extratora de óleo de palma tem uma área total de 124.000 metros quadrados e uma área construída de 50.900 metros quadrados, com uma capacidade de 450.000 toneladas de cachos por ano (ABREU, 2015). A Figura 28 apresenta uma dimensão das

\footnotetext{
${ }^{89}$ Disponível em http://saladeimprensa.vale.com/Paginas/ResultadoBusca.aspx. Acesso em: 20 dez. 2015.
} 
instalações da parte externa desta unidade de processamento de óleo de palma construída pela empresa Biopalma, em Moju.

Figura 28: Vista geral da planta de produção de óleo de palma da Biopalma, Moju, Pará.

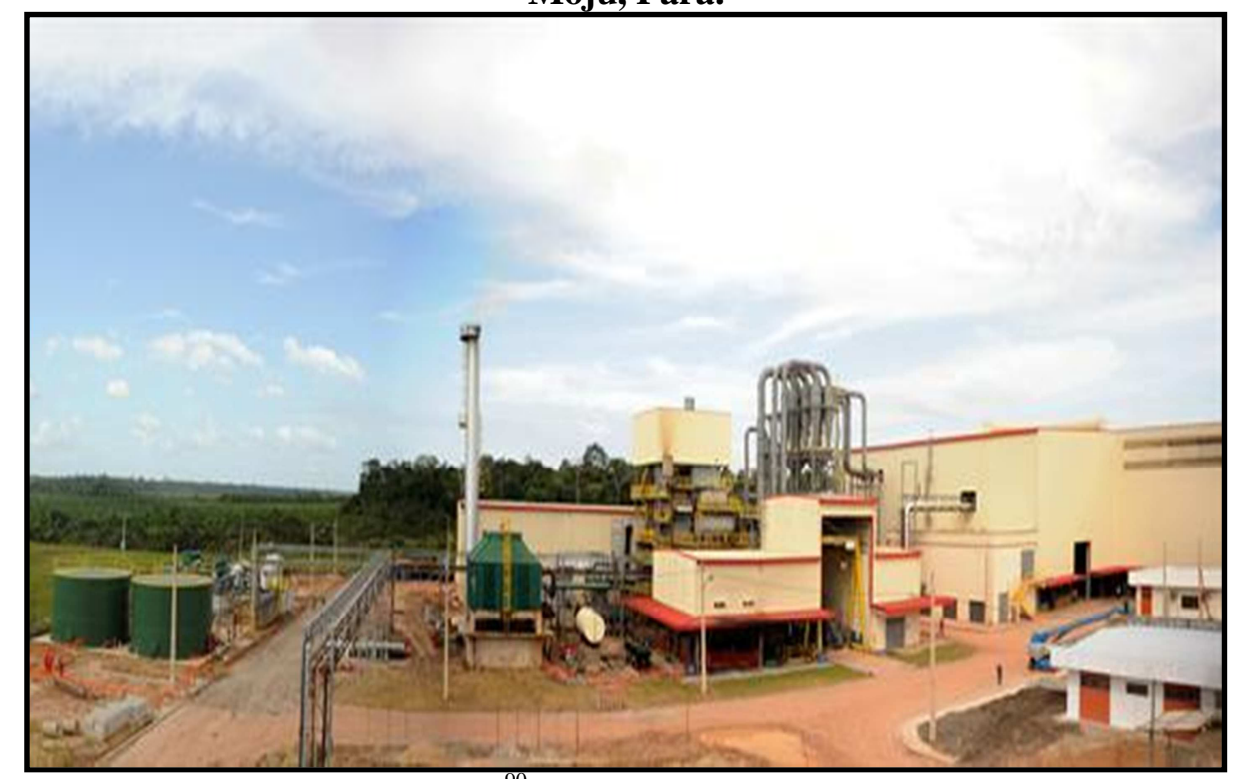

Fonte: Vale. Sala de Imprensa ${ }^{90}(2012)$

Em trabalho de campo, acompanhou-se a entrada e a saída de carros que a todo o momento chegam a esta usina de extração de óleo de palma. É comum encontrar diversos caminhões tanques que aguardam o momento para fazerem o carregamento de óleo de palma e de óleo de palmiste em frente ao portão principal desta usina.

A empresa está construindo em módulos, no município de Acará a segunda usina extratora de óleo de palma. Esta unidade vai processar os frutos para a extração de óleo de palma bruto (CPO) e de óleo de palmiste (CPKO). O primeiro módulo em construção com capacidade para 500.000 toneladas de CFF ao ano com previsão de iniciar suas operações em setembro de 2015. O segundo e terceiro modulo com capacidade também 500.000 toneladas com previsão para inicio das operações para outubro de 2016 e outubro de 2018, respectivamente. O início das obras do segundo módulo tem previsão para setembro de 2015. O segundo módulo visa a produção de óleo de palmiste. A capacidade total dos três módulos é de 1.500.000 toneladas de CFF ao ano. A área construída do empreendimento será de $193.700 \mathrm{~m}^{2}$ (ABREU, 2015).

Em trabalho de campo realizado em setembro de 2015, no município de Acará, constatamos que esta usina está em construção em local com acesso pelo rio Acará. A estrutura da construção do empreendimento é grandiosa, o que envolve a presença diária de

\footnotetext{
${ }^{90}$ Disponível em: http://saladeimprensa.vale.com/Paginas/ResultadoBusca.aspx.a. Acesso em: 17 dez. 2015.
} 
máquinas, equipamentos e operários na execução das atividades construtivas da usina (Figura 29)

Figura 29: Usina de extração de óleo de palma da Biopalma em construção no município de Acará, 2015.

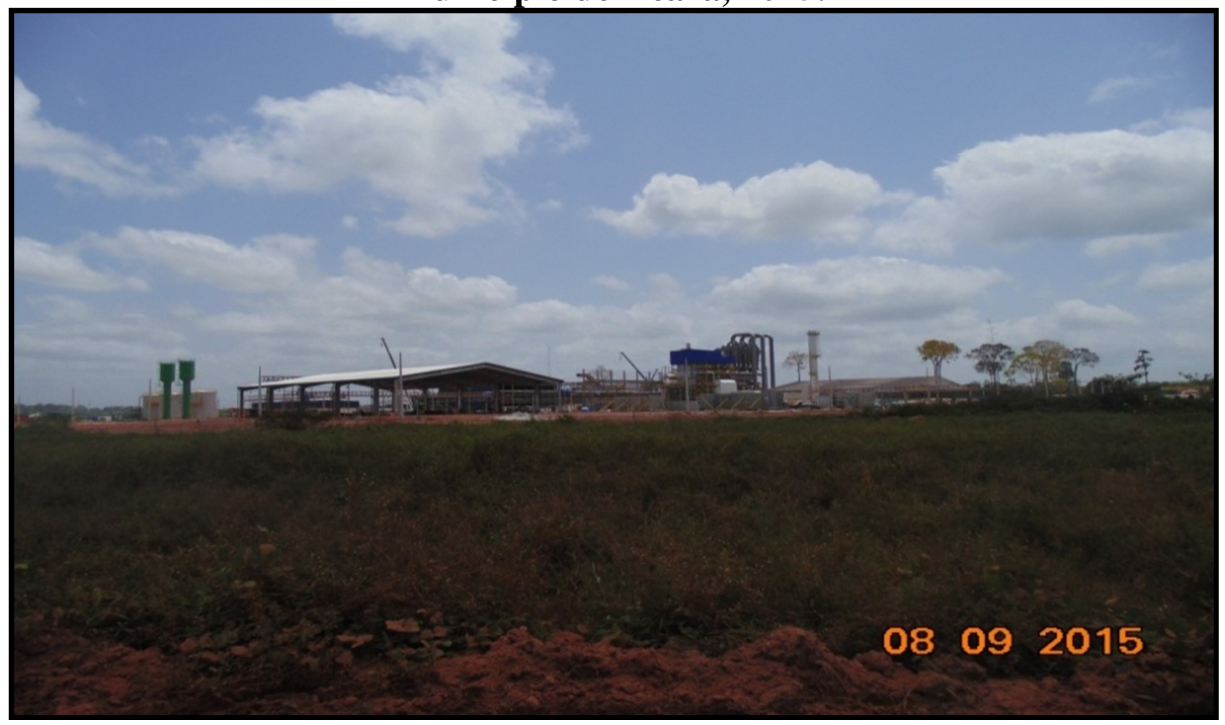

Fonte: Márcio Benassuly (2015)

O acesso à construção a partir da cidade de Acará é realizado pela PA-252, depois, segue por um ramal até o rio Acará, onde uma balsa mantida pela empresa faz o transporte de carros e operários de uma margem do rio para a outra onde está localizada a obra. Este local de travessia reúne os operários que trabalham na construção da usina e onde é possível sempre ouvir diversas histórias relacionadas à construção desta usina.

Projeto industrial: as usinas de produção de biodiesel. Ao lado da área destinada à construção da usina de extração de óleo de palma em Acará, está prevista a construção de duas usinas de biodiesel com capacidade de processamento de 20.000 toneladas por ano. Os investimentos no projeto das usinas de biodiesel são da ordem de 278 milhões se reais. A construção da usina do Acará está localizada na fazenda Vale Verde, na zona rural, às margens do rio Acará (ABREU, 2015).

Os projetos com as usinas da Biopalma no Pará fazem parte de uma estratégia mais ampla do grupo Vale que é a substituição de parte do óleo diesel pelo biodiesel em suas máquinas pesadas do sistema Norte e Nordeste. A logística a ser empregada na distribuição do biodiesel a ser produzido na usina de Acará ocorrerá via Marabá, onde será construída uma unidade de distribuição, local em que será realizada a mistura de B20 para atender os principais pontos de consumo (Onça Puma, Salobo, Marabá, Carajás, Sossego, S11D, São Luiz e Açailândia) da empresa no sistema Vale Norte (ABREU, 2015). 
Assim, conclui-se que das duas empresas pesquisadas com projetos de produção de biodiesel no Pará (Belém Bioenergia Brasil e Biopalma), a Biopalma é a empresa que mais avançou em seu projeto de viabilização da produção de biodiesel no estado do Pará.

3.7.4 Federação dos Trabalhadores e Trabalhadoras na Agricultura no Estado do Pará (Fetagri)

A Fetagri foi fundada em 1968 e é uma entidade sindical que representa os trabalhadores agrícolas no Pará (GUERRA, 2009). Durante sua história teve papel de destaque na luta pelos direitos dos trabalhadores agrícolas no acesso a recursos para o financiamento da produção familiar agrícola no Pará. Participou ativamente das lutas pelo acesso dos recursos do Fundo Constitucional de Financiamento do Norte (FNO), criado em 1988, e do Pronaf, em 1996, ocupando por diversas vezes instituições públicas como o Banco da Amazônia. Esta entidade tem participado ativamente dos principais movimentos de luta no campo como o Grito da Terra Pará e o Grito da Terra Brasil. A Figura 30 mostra detalhes da sede da Fetagri em Belém.

Figura 30: Sede da Federação dos Trabalhadores e Trabalhadoras na Agricultura no Estado do Pará em Belém

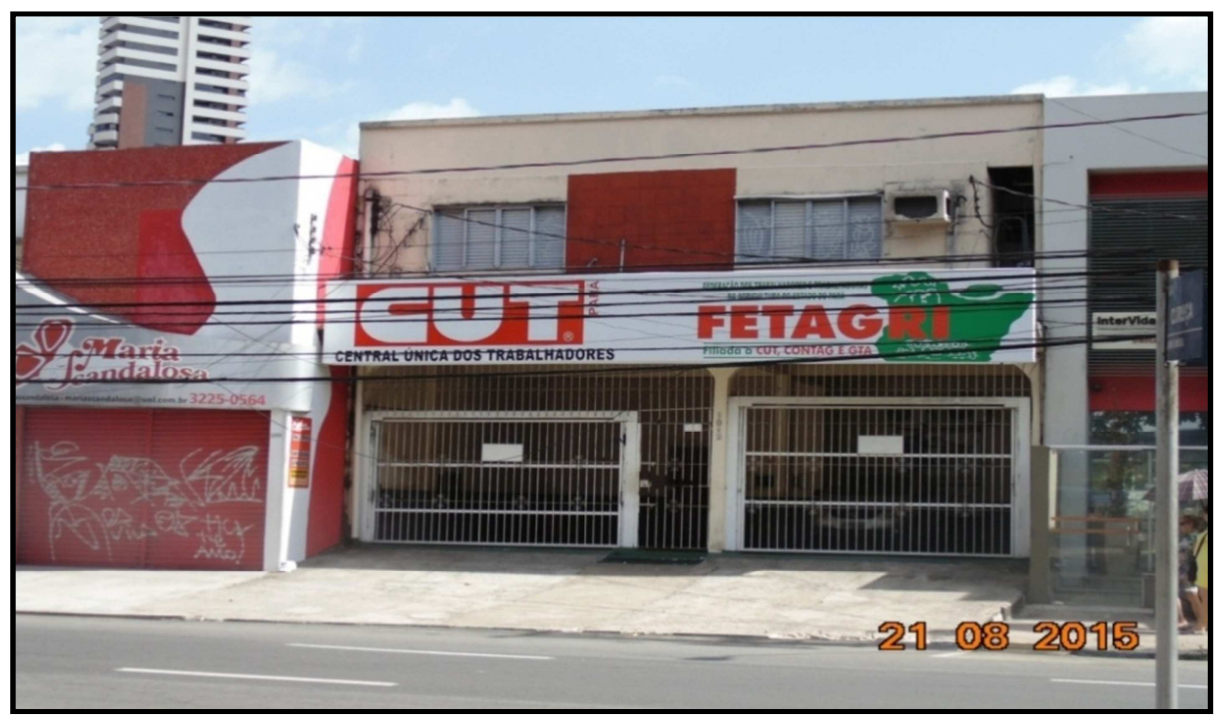

Fonte: Márcio Benassuly (2015)

Sobre as ações da Fetagri na agricultura familiar de dendê no Pará, em entrevista, o presidente da entidade, Francisco Dias Assis, afirma que:

Na verdade essa história da participação da Fetagri no dendê a gente faz isso por gestão, eu sou do período que a gente não tem conservado essa situação. A Fetagri já participou, fez debates, mobilizou gente, assinou contratos, mas nesse período que estou na gestão nós não temos encaminhado esse processo [...] Nós não temos orientado, incentivado, assinado contrato nesse processo, nós temos 
refletido muito nos problemas que os agricultores têm enfrentado. A gente tem analisado os contratos que já foram firmados particularmente, nos temos muita preocupação no que será o futuro desta região ai quando se fala de agricultura familiar com essa política, a gente já viu os primeiros sinais de problemas que vão surgindo então teve um processo inicial de mobilização, articulação que eu acho que deveria ser melhor analisado, essa é uma análise que eu faço,particularmente falando desse processo.Acho que os agricultores e suas organizações precisam ter muita consciência nesse processo de integração (Entrevista realizada pelo pesquisador com o presidente da Federação dos Trabalhadores e Trabalhadoras na Agricultura no Estado do Pará, Francisco Dias Assis, em Belém-PA, em 19.08.2015, grifo nosso).

$\mathrm{Na}$ entrevista concedida, o líder sindical confessa que a entidade, em gestões anteriores à sua, teve um papel de forte atuação na viabilização da execução do Pronaf EcoDendê no Pará. Seguindo orientação nacional da Confederação Nacional dos Trabalhadores na Agricultura (Contag) que apoia a integração da agricultura familiar no contexto do PNPB, a entidade sindical paraense que é filiada a Contag promoveu debates, mobilizou seus associados por meio dos STTR.

Também como entidade representativa dos trabalhadores assinou os contratos firmados com as instituições da integração da agricultura familiar no Pará (MDA, Basa e empresas integradoras). Em nossa visita a esta entidade, constatamos que a participação da Fetagri na integração da agricultura familiar a empresas de dendê é uma questão que divide opiniões, onde há posições favoráveis e desfavoráveis à participação da entidade nesta política de Estado por intermédio do Pronaf Eco-Dendê. Esta posição quanto à questão do sistema de integração é destacada pelo entrevistado, que afirma:

\footnotetext{
Há gente no interior da nossa federação que defende esse processo de integração, já foi até encaminhado, é avançado nas orientações para os agricultores, por outro lado há setores que tem muitas preocupações em torno desse processo de integração, o que se vê na região é o processo de centralização fundiária pesada por parte das empresas e uma facilitação das instituições para esse processo de agricultura familiar (Entrevista realizada pelo pesquisador com o presidente da Federação dos Trabalhadores e Trabalhadoras na Agricultura no Estado do Pará, Francisco Dias Assis, em Belém-PA, em 19.08.2015, grifo nosso).
}

A expansão da fronteira agrícola de dendê no Pará é o resultado de ações estatais, por intermédio de suas políticas públicas para o setor como o PNPB e o PPSOP em associação com empresas do setor visando ampliar a área destinada ao cultivo de dendê no Brasil em especial na Amazônia. Neste contexto há uma facilitação, no dizer do entrevistado, em que se passa a dispor de grandes somas de recursos para o financiamento estatal deste projeto de uma lavoura que é previamente selecionada pelo Estado em parceria com as empresas. Aos agricultores familiares resta apenas a decisão de aderir ou não a esta política. 
Os fortes incentivos estatais para o cultivo de dendê no Pará têm trazido como consequência a concentração fundiária de terras em empresas de dendê, como a Biopalma que possui 142.399,4077 hectares (NAHUM; SANTOS, 2015). A luta por terras para ampliar as plantações próprias das empresas é fonte de conflitos com populações tradicionais de camponeses, quilombolas etc. Aqui os modelos de agricultura tradicional versus agricultura moderna passam a disputar territórios que são usados com fins diferentes. Os territórios da empresa agrícola são usados como recurso, já os territórios de agricultores familiares são usados como abrigo (SANTOS, 1994). No modelo de integração da agricultura familiar ao agronegócio empresarial de dendê essa relação é quebrada transformando os territórios de agricultores familiares em territórios familiares agrícolas regulados pela empresa.

A questão da associação entre Estado e empresa é apontada pelo líder sindical da Fetagri quando questionado sobre o papel da entidade no crédito rural do Pronaf EcoDendê. Segundo ele:

\footnotetext{
Na verdade se você for a uma instituição financeira hoje há uma grande facilidade quando o assunto é dendê, por que é uma política de governo e uma relação forte empresarial, então há uma articulação em torno disso, então a Fetagri sempre lutou pela assistência técnica pelo financiamento agrícola para viabilizar a produção familiar. Na verdade há um interesse forte empresarial e governamental e uma articulação forte com os bancos para viabilizar essa estratégia de financiamento (Entrevista realizada pelo pesquisador com o presidente da Federação dos Trabalhadores e Trabalhadoras na Agricultura no Estado do Pará, Francisco Dias Assis, em Belém-PA, em 19.08.2015, grifo nosso).
}

O modelo de integração da agricultura familiar de dendê é permeado por uma forte relação entre Estado e empresas, cuja lógica determina os rumos desta política. Esta relação Estado/empresas contribui para o direcionamento do fomento estatal para as lavouras de interesses das empresas agrícolas que passam a lucrar com esta medida. Neste sentido, os grandes investimentos estatais alocados para a cultura do dendê objetiva a expansão da produção empresarial de dendê, uma vez que, a produção familiar de dendê passa a ser computada na produção de cada empresa integradora.

Sobre o financiamento da agricultura familiar, o entrevistado afirma que "precisa ter um financiamento que de fato atenda aos agricultores familiares, tu financia o agricultor familiar, mas tu beneficia o empresário, o cuidado é para o agricultor não ser barriga de aluguel nessa história" (Entrevista realizada pelo pesquisador com o presidente da Federação dos Trabalhadores e Trabalhadoras na Agricultura no Estado do Pará, Francisco Dias Assis, em Belém-PA, em 19.08.2015, grifo nosso). 
O sistema de produção integrada de dendê oferece uma série de riscos para o agricultor familiar, principalmente por conta do empréstimo bancário que o mesmo é obrigado a realizar para iniciar a produção. Este empréstimo estabelece uma série de obrigações financeiras que o agricultor tem que saldar com o banco.

$\mathrm{Na}$ entrevista fica evidente a preocupação do líder sindical com os benefícios do Pronaf Eco-Dendê, que na visão dele tem que beneficiar os agricultores familiares e não os empresários de dendê. Ao longo da entrevista demonstra preocupação em não transformar os agricultores familiares integrados em barriga de aluguel dos empresários do setor de dendê que seriam beneficiados com esta política estatal.

Sobre os contratos celebrados com os agricultores familiares integrados nosso entrevistado afirma que:

O contrato precisa ser contrato igual ao casamento, botar uma aliança no dedo, quer
dizer, é uma aliança não uma corrente. Esse contrato não pode se transformar
numa corrente para agricultores familiares, legitimar um contrato que não
defenda que não fortaleça os agricultores familiares é cometer um crime, é assim
que eu vejo. Tem algum contrato que acorrenta o agricultor familiar que
teoricamente falando será atendido beneficiado [...] Como eu já disse a relação nossa
é dizer ao Basa, tem que diversificar isso, não pode fazer uma agricultura familiar
monocultura do dendê. Então o Eco Dendê não pode ser um processo de interesse do
governo e do empresário. Ele tem que ser um processo de interesse do agricultor
familiar que vai ser beneficiado, por que se não o agricultor familiar vai
receber o financiamento, vai trabalhar, alugar a barriga e depois. Como eu
disse não pode ser uma barriga de aluguel nesse processo (Entrevista realizada
pelo pesquisador com o presidente da Federação dos Trabalhadores e Trabalhadoras
na Agricultura no Estado do Pará, Francisco Dias Assis, em Belém-PA, em
19.08 .2015 , grifos nossos).

Os contratos celebrados entre Basa, empresa e agricultores, na visão do líder sindical, não podem se transformar em uma corrente que aprisiona os agricultores integrados mediante suas cláusulas. Em trabalho de campo, constatamos que as empresas (Belém Bioenergia Brasil e Biopalma) utilizam bastante a palavra parceria para demonstrar esta relação entre empresa e agricultor. Independentemente do termo que utilize, aliança ou parceria, para reforçar a integração do agricultor familiar no agronegócio empresarial de dendê, o fato é que os agricultores acabam por imposição do contrato transformando-se em agricultores familiares regulados pelas normas da empresa integradora.

O sistema de produção integrada de dendê tem privilegiado uma racionalidade que atende aos interesses do Estado e das empresas. O Estado por intermédio do Basa tem investido grandes somas de recursos no financiamento da produção familiar de dendê onde as empresas têm sido beneficiadas com esta política de integração. O fomento estatal através do Pronaf Eco-Dendê precisa levar em consideração os interesses do agricultor familiar, pois os 
recursos deste programa visam o fortalecimento da agricultura familiar e não do agronegócio. Na prática os investimentos do Pronaf Eco-Dendê têm servido para fortalecer a produção do agronegócio de dendê no Baixo Tocantins, pois a produção familiar passa a ser contabilizada como produção da empresa integradora.

A integração do produtor rural ao agronegócio no Pará vem ganhando força em diferentes setores rurais como a soja, o eucalipto, o cacau, o leite, o pescado e o açaí, como podemos verificar as afirmativas do entrevistado.

Aqui na integração da história da soja, eles proporão no sul do Pará a
implantação do eucalipto. Tem uma proposta de integração do cacau vinculada
para o sul do Pará tem essa história do leite, do pescado. E tem várias experiências
do açaí no Baixo Tocantins (Entrevista realizada pelo pesquisador com o
presidente da Federação dos Trabalhadores e Trabalhadoras na Agricultura no
Estado do Pará, Francisco Dias Assis, em Belém-PA, em 19.08.2015, grifos nossos).

O sistema de produção integrada por apresentar inúmeras vantagens para as empresas tem avançado no estado do Pará. Com este sistema a empresa integra em sua cadeia produtiva um conjunto de produtores integrados que passam a ser regulados pelas normas da empresas, desta forma a empresa consegue reduzir custos e ampliar sua produção.

Durante a realização do II Workshop do Programa de Produção Sustentável da Palma de Óleo no Brasil, realizado em Tomé-Açu, em 2015, João de Jesus Sousa, representante da Fetagri, afirma que:

\footnotetext{
A Fetagri defende uma agricultura familiar e tem fortes parâmetros no âmbito de um projeto rural com solidariedade. O rural para a agricultura familiar, não é simplesmente a produção, mas também a vida das pessoas. Elas têm os seus costumes, a sua igreja, o seu time de futebol, a vida em comunidade que representa muito. Tem pessoas que residem há décadas na mesma propriedade. Na região da produção de palma de óleo, a Fetagri estima que $80 \%$ dos agricultores produziam farinha, milho, feijão, então existia na verdade uma diversificação da produção, fundamental nesse processo. O tamanho dos módulos fiscais também aparece como uma questão forte e é bom que estejam participando da produção de dendê os que têm entre 10 há, 20 há e até 100 ha (EMBRAPA, 2015, p.18, grifos nossos).
}

De fato, a agricultura familiar praticada nas localidades visitadas no Baixo Tocantins é marcada por uma forte solidariedade horizontal (SANTOS, 1996) entre os moradores locais. Nestes lugares, a solidariedade horizontal é marcada pela forte relação entre vizinhos que chegam a compartilhar dias de trabalho no cultivo de lavouras e ajuda mútua em muitas situações do cotidiano. Ademais, a presença humana é marcante e regada a muitas rodadas de conversas sobre o cotidiano, além da presença de espaços de fortalecimento das relações sociais cotidianas, como campos de futebol, igrejas, bares, centros comunitários etc. As 
relações de pertencimento são bastante fortes nestes lugares com moradores que aí vivem há décadas, em que se pratica uma produção agrícola diversificada para atender as necessidades da família em primeiro momento, sendo que o excedente é comercializado.

A chegada de projetos de agricultura familiar de dendê nestes lugares tem promovido transformações nas relações de trabalho e no uso e ocupação da terra, conforme aponta o representante da Fetagri, João de Jesus Sousa, no II Workshop do Programa de Produção Sustentável da Palma de Óleo no Brasil.

\begin{abstract}
Agricultores deixam automaticamente de plantar milho, arroz e feijão. Esses produtos são essenciais, tem que ter para o consumo, se não o lucro obtido com a palma do óleo vai ser para comprá-los. As políticas do governo federal devem contribuir para a coexistência do cultivo da palma de óleo com as culturas alimentares, objetivando a qualidade dos produtos e da vida no campo. A questão fundiária associada com a questão ambiental devem constar no foco das preocupações de todos. Os comentários quanto a qualidade da água dos igarapés devem ser considerados, assim como a sucessão rural porque muitos filhos de agricultores estão trabalhando como assalariados nas empresas. E importante que eles trabalhem na propriedade da família para garantir a sucessão. Os dados sobre estes temas devem ser vistos e discutidos. A maior parte dos agricultores esta satisfeita. Tem ganhos reais para quem optou pelo plantio da palma de óleo. A Fetagri está acompanhando todos esses debates como parceiro da Embrapa e do MDA. Mas uma das coisas que precisa ser feita é o processo de organização dos agricultores segundo o local onde ele está trabalhando. Um dos desafios da Fetagri é lidar com a relação entre os agricultores e as empresa porque não é adequado o agricultor negociar com a empresa individualmente (EMBRAPA, 2015, p.19, grifos nossos).
\end{abstract}

De fato, a chegada de projetos de agricultura familiar de dendê em localidades que passaram a adotar esta cultura agrícola tem causado transformações produtivas, sociais e até mesmo ambientais.

As transformações produtivas estão relacionadas ao abandono de culturas tradicionais que antes eram praticadas na localidade como a mandioca, o milho, o feijão e o arroz. Com um financiamento para pagar ao banco, o agricultor integrado passa a focar seu trabalho na lavoura de dendê e vai deixando de lado as culturas tradicionais. Sem a produção destas culturas tradicionais o agricultor integrado passa a comprar o que antes produzia.

As transformações sociais nestes lugares estão relacionadas às normas que são impostas pelas empresas de dendê e visam assegura a produção de dendê em condições técnicas e regulares. Desta forma, estas normas passam a regular o cotidiano dos agricultores que agora são integrados a uma racionalidade hegemônica de uma empresa que decide o que, quando e como será a produção na propriedade do agricultor integrado. Desta forma, o agricultor integrado perde sua independência de decisão sobre o que produzir, quando produzir e como produzir. Além do mais, as relações de produção passam a serem realizadas 
com a empresa que regula a terra do agricultor agora incorporada ao sistema produtivo da empresa integradora.

\subsubsection{Agricultores familiares beneficiários do Pronaf Eco-Dendê}

Os agricultores familiares são atores sociais (WANDERLEY, 2009) de fundamental importância na transformação da realidade social brasileira. No caso da dendeicultura no Pará, os agricultores familiares exercem um papel de destaque neste setor.

A integração da agricultura familiar no agronegócio do dendê (MULLER; FURLAN JÚNIOR, 2001; FURLAN JÚNIOR et al., 2006) promove uma inserção destes pequenos agricultores em uma escala de produção agroindustrial, algo que é novo na região. Vale destacar que a agricultura familiar no estado do Pará é caracterizada pela diversidade de produção para a subsistência familiar (HURTIENNE, 1999; 2005).

Os benefícios socioeconômicos da participação dos agricultores familiares de dendê no Baixo Tocantins tem sido objeto de análises de diversos estudos sobre esta temática. Os resultados apresentados por estes estudos têm divergido sobre os reais benefícios socioeconômicos para os agricultores familiares integrados neste território.

Os estudos realizados por pesquisadores da Embrapa Amazônia Oriental como o de Homma et al. (2014) e Santos et al. (2014) têm apontado que a participação dos agricultores familiares no sistema de integração do dendê tem gerado benefícios socioeconômicos no Baixo Tocantins.

Hommaet al.(2014), em Integração grande empresa e pequenos produtores de dendezeiro: o caso da comunidade de Arauaí, município de Moju, Pará, descrevem os efeitos socioeconômicos do plantio de dendê na comunidade de Arauaí, em Moju.O estudo demonstra um forte grau de satisfação dos agricultores familiares integrados de dendê à empresa Agropalma, cujos plantios tiveram início em 2002. Verificou-se também uma grande preocupação por parte dos agricultores integrados com o fim do ciclo produtivo dos dendezais, que já está em sua metade. Nesta experiência, foram formalizados contratos com 50 famílias com financiamento de dez hectares em cada propriedade.

Santos et al.(2014), em Desempenho socioeconômico do sistema produtivo familiar de dendê em Moju, estado do Pará, estudo também realizado entre os agricultores ${ }^{91}$ integrados de dendê na comunidade de Arauaí, em Moju, procuraram avaliar a rentabilidade econômica

\footnotetext{
${ }^{91}$ Plantio iniciado em 2002.
} 
deste sistema de integração da agricultura familiar à empresa Agropalma, onde se constatou que esta atividade proporciona uma renda mensal de $\mathrm{R} \$ 2.663,61$.

Os estudos realizados por pesquisadores independentes ligados à ONG Repórter Brasil e à Fase Amazônia têm revelado que os benefícios socioeconômicos do projeto para o pequeno agricultor são questionáveis. Há casos, por exemplo, onde o agricultor tem prejuízos com a produção de dendê familiar.

Em um relatório sobre os custos da expansão do dendê no nordeste do Pará, a pesquisadora Verena Glass (2013) questiona os benefícios do Pronaf Eco-Dendê para os agricultores familiares integrados de dendê. $\mathrm{Na}$ pesquisa constata-se que nos casos dos agricultores familiares entrevistados em início de colheita, houve casos em que o agricultor teve prejuízo em sua primeira colheita, pois os custos de manutenção do dendezal foram superiores à receita da produção de dendê. Para ela, "com o passar dos anos e o aumento da produção, também aumentará a renda" (GLASS, 2013, p. 3). Na pesquisa também se constatou que a renda com outras culturas como pimenta do reino e açaí foram superiores aos do dendê, em 2013.

A participação dos agricultores familiares na cadeia do agronegócio de dendê no território do Baixo Tocantins divide opiniões, quando abordamos a questão dos benefícios socioeconômicos. Em entrevista, José Domingos Pôro, secretário de política agrícola do STTR de Acará, afirma que:

\footnotetext{
Não é possível fazer uma avaliação socioeconômica do Pronaf Eco-Dendê, pois como é uma política recente, com início em 2011 na região, a maioria dos agricultores aindaestão na fase anterior a colheita, o que seria prematuro uma avaliação de tal política e experiência. Há casos de agricultores que relatam que estão tendo resultados com seus cortes de dendê, outros não (Entrevista realizada pelo pesquisador com o secretário de política agrícola do STTR de Acará, José Domingos Pôro, em 19.09.2015, grifo nosso).
}

Pelo que constatamos, as opiniões sobre os benefícios socioeconômicos para o agricultor familiar de dendê são divergentes nos estudos produzidos. A visão do líder sindical entrevistado do Acará traz uma questão importante de que os projetos, em sua maioria, estão realizando as primeiras colheitas e que com o passar do tempo a produção será ampliada e consequentemente os lucros com o dendê colhido.

No sistema de integração da agricultura familiar no agronegócio de dendê no Baixo Tocantins entre 2010 e 2014 existem 737 agricultores beneficiários com financiamentos do Pronaf Eco-Dendê, distribuídos em: Abaetetuba (1), Acará (120), Baião (4), Cametá (11), Mocajuba (8), Moju (441), Tailândia (152) (BASA, 2012c; BACEN 2015). Estes agricultores 
estão integrados no Baixo Tocantins a quatro empresas integradoras de dendê: Agropalma, Biopalma, Belém Bioenergia Brasil e Marborges (FAEPA, 2015).

O acesso aos dados da quantidade de contratos por município/empresa é uma questão que não foi possível obter junto às empresas pesquisadas. Os dados que são confirmados com precisão dos municípios é onde só existe uma empresa atuando com o Pronaf Eco-Dendê como Abaetetuba (1 contrato integrado à Biopalma), Baião (4 contratos integrados à Belém Bioenergia Brasil), Cametá (11 contratos integrados à Belém Bioenergia Brasil), Mocajuba (8 contratos integrados à Belém Bioenergia Brasil). Nos municípios de Acará, Moju e Tailândia não tivemos acesso a quantos contratos são efetivamente das empresas Biopalma e Belém Bioenergia Brasil.

Em trabalho de campo ${ }^{92}$, realizado em 2015, visitamos 31 agricultores das empresas Belém Bioenergia Brasil (18 agricultores entrevistados) e da empresa Biopalma (13 agricultores entrevistados) em seis municípios: Acará (1 contrato integrado à Biopalma), Baião (2 contratos integrados à Belém Bioenergia Brasil), Cametá (2 contratos integrados à Belém Bioenergia Brasil), Moju (11 contratos integrados à Biopalma), Mocajuba (2 contratos integrados à Belém Bioenergia Brasil) e Tailândia (12 contratos integrados à Belém Bioenergia Brasil).

\footnotetext{
${ }^{92}$ Os resultados das entrevistas do trabalho de campo são abordados no Capítulo 4.
} 


\section{CAPÍtULO 4: TERRITÓRIOS DA AGRICULTURA FAMILIAR DE DENDÊ REGULADOS PELO AGRONEGÓCIO NO BAIXO TOCANTINS (PA): AS EXPERIÊNCIAS DAS EMPRESAS BELÉM BIOENERGIA BRASIL E BIOPALMA}

Este capítulo tem como objetivo analisar as experiências da agricultura familiar de dendê integrado às empresas Belém Bioenergia Brasil e Biopalma no Baixo Tocantins.

\subsection{O sistema de integração da agricultura familiar no agronegócio de biodiesel de dendê como a fase mais recente do uso agrícola do território no Baixo Tocantins (PA)}

O desenvolvimento capitalista da agricultura processou-se por meio da atuação de empresas capitalistas e da empresa familiar (ABRAMOVAY, 1992). Para Wanderley (1996, p. 2) agricultura familiar é "“...] entendida como aquela em que a família, ao mesmo tempo em que é proprietária dos meios de produção, assume o trabalho no estabelecimento produtivo". A idéia hegemônica defendida por muitos autores é de que o agricultor familiar é produto da ação do Estado, que por meio de políticas públicas para este setor tem transformado este público em protagonista da produção agrícola familiar.

A agricultura familiar nas sociedades modernas é uma realidade multiforme, diversa, sendo produto de contextos sociais e políticos diversos (LAMARCHE, 1998). De fato a atividade agrícola familiar é bastante diferenciada nas sociedades modernas. No Brasil podemos a firmar a existência de agriculturas familiares, tal é a especificidade que a mesma assume no contexto das regiões brasileiras.

O sistema de integração de dendê ao longo do tempo vem se consolidando como a mais nova fase do uso agrícola do território no Baixo Tocantins, por parte das empresas de agronegócio de dendê. Esta nova fase tem sido marcada pala disputa do território entre empresas de um lado, e de outro os agricultores familiares, as populações tradicionais como os quilombolas.

Para as empresas o território é encarado como recurso. Para os agricultores familiares o território é sinônimo de abrigo (SANTOS et al., 2000). Esta tipologia de uso do território pelos atores hegemônicos (empresas) e pelos atores hegemonizados (agricultores familiares) reflete como o território é usado de modo diferente. As empresas têm como objetivo o uso do território como recurso, já para os agricultores familiares e as populações tradicionais encaram o território como abrigo, com um significado que vai além do material, pois as relações de pertencimento são bastante fortes para estas populações da Amazônia. Desta forma, na atualidade os movimentos sociais organizados da região lutam por seus territórios 
de abrigo. Estes são considerados fontes simbólicas de seus ancestrais, o que nem sempre é compreendido pelo Estado e pelas empresas.

A chegada das empresas de dendê tem promovido um cerco (HÉBETTE, 1991) aos territórios de camponeses no Baixo Tocantins, onde muitos camponeses têm sido afetados por estas transformações. Com a chegada destas empresas nas localidades, o cotidiano destes lugares é afetado pela presença e ações comandadas por estas empresas. A presença de grandes projetos agrícolas acaba gerando um cotidiano imposto de fora.

Neste novo tempo, um dos personagens que mais é afetado é o agricultor familiar, pois com a chegada das empresas de dendê tudo passa a girar em torno desta atividade. Neste novo momento o agricultor, que antes vivia fundamentalmente da produção de mandioca, é atraído para a produção de dendê. Este processo leva a uma mudança de sua condição de produtor de mandioca para produtor de dendê.

Como produtor autônomo, sua produção era ilimitada e tinha a liberdade de produzir o que desejasse. Na produção integrada o agricultor perde esta liberdade da escolha de sua plantação. Outro fator a considerar é que há uma profunda mudança na racionalidade de produtor autônomo para o produtor integrado, tendo este que seguir as normas da empresa. Também cabe destacar que esta forma de agricultura integrada é recente no contexto agrícola de muitos municípios do Baixo Tocantins, e que a adoção desta prática tem causado certo estranhamento, nas relações agricultor integrado/empresa integradora.

Diversas publicações têm apontado estas dinâmicas que estão acontecendo no contexto da introdução de projetos de agricultura familiar de dendê no Pará.

O Repórter Brasil (2010), em A agricultura familiar e o programa nacional de biodiesel: retrato do presente, perspectivas de futuro, destaca os dois projetos (Pará e Belém) anunciados pela Petrobras Biocombustível no Pará para a produção de biodiesel. O estudo realizou diversas entrevistas com agricultores integrados de dendê da localidade de Arauaí ${ }^{93}$, em Moju, onde constatou realidades diferentes com relação ao rendimento econômico da integração familiar de dendê. A agricultora Benedita Almeida do Nascimento, entusiasta do programa, afirma que tem diversas culturas alimentares como a mandioca e o açaí, criação de aves e de gado, além do plantio de dendê em sua propriedade de 50 hectares. "Seus ganhos variam de $\mathrm{R} \$ 900,00$ a $\mathrm{R} \$ 3.000,00$ ao mês, de acordo com estágio da safra" (REPÓRTER BRASIL, 2010, p. 18).

\footnotetext{
${ }^{93}$ Plantio iniciado em 2002.
} 
Visando ampliar a adesão de agricultores familiares, as empresas integradoras selecionam as melhores experiências de agricultores integrados com os maiores rendimentos econômicos existentes, para servir de vitrine para o sistema e promover a atração de mais agricultores para este sistema de produção integrada. Foi o que ocorreu com a agricultora Benedita Almeida do Nascimento, que pelos seus rendimentos econômicos com a produção familiar de dendê tornou-se um modelo usado em propaganda patrocinada por empresas e pelo governo federal em relação aos benefícios do sistema de integração de dendê no Pará.

$\mathrm{Na}$ prática nem todos os agricultores integrados que aderem a este sistema de integração conseguem manter a mesma produção e conseqüentemente o mesmo rendimento econômico que a agricultora Benedita Almeida do Nascimento afirma ter conseguido. Este conjunto de propaganda visa ampliar a adesão de novos agricultores integrados ao sistema bem como legitimar este modelo de produção junto à sociedade onde estas experiências acontecem

Já para a agricultora Maria Conceição de Oliveira e o filho Sérgio, as experiências com a integração do dendê familiar não são boas. Para o agricultor, "no final do mês, acabam sobrando $\mathrm{R} \$ 400,00, \mathrm{R} \$ 500,00$. Isso para manter uma família de 13 pessoas não dá” (REPÓRTER BRASIL, 2010, p. 19).

Outra questão que é destacada pela agricultora Maria é o ritmo de trabalho. "Quando eles trazem o adubo, temos obrigação de aplicar. Se não fizer o que eles mandam, se não passar veneno ou podar, eles seguram o nosso dinheiro no banco. Aqui tem cinco fiscais (técnicos da empresa) que ficam controlando tudo" (REPÓRTER BRASIL, 2010, p. 19).

O trabalho destacou como aspectos positivos da integração: renda, acesso ao crédito e garantia de mercado por meio da parceria. Já os aspectos negativos são alto custo da produção, dificuldades de comunicação, muito trabalho, intoxicação etc. (REPÓRTER BRASIL, 2010).

Em um segundo estudo intitulado Expansão do dendê na Amazônia brasileira: Elementos para uma análise dos impactos sobre a agricultura familiar no Nordeste do Pará, Repórter Brasil (2012) constatou que entre os trabalhadores terceirizados dos dendezais da localidade de Pontilhão, localizada às margens da PA-252, em Abaetetuba, o consumo de drogas tem aumentado. Muitos moradores atribuem este fator à presença das atividades de dendê da empresa Biopalma no entorno da comunidade, pois devido ao trabalho nos dendezais ser bastante penoso, muitos trabalhadores terceirizados pela empresa estariam usando drogas para aumentar sua produtividade. Um entrevistado confirmou esta prática (REPÓRTER BRASIL, 2012, p. 11). 
Outra denúncia feita à reportagem é sobre a contaminação de rios e igarapés com venenos usados nos plantios de dendê da Biopalma na comunidade de Murutinga, localizada às margens da PA-252, também em Abaetetuba. Segundo um morador de nome Sebastião, "já não dá mais pra usar a água do Murutinga, tá tudo envenenado" (REPÓRTER BRASIL, 2012, p. 12).

João Santos Nahum e Cleison Bastos dos Santos (2015), em Uma interpretação geográfica da dendeicultura na Amazônia paraense, analisaram a dendeicultura sob a ótica do território usado, onde constataram que:

\begin{abstract}
Nos lugares onde temos unidades familiares produzindo dendê associados às empresas desencadeia-se a subordinação do território ao capital. Nestas unidades os agricultores não perdem a propriedade jurídica da terra, tampouco as pessoas se tornam assalariadas. Continuam proprietários da terra enquanto meio de produção e força produtiva e sua força de trabalho não é vendida à empresa. Porém, os usos da terra e do trabalho não são organizados pelas demandas familiares dentro da equação trabalho versus necessidade. Desde que associadas a dendeicultura, o tempo, a terra e o trabalho familiares são ritmadas pelas empresas; a terra, por meio de contratos entre partes juridicamente iguais e em comum acordo, transformou-se em território usado para a monocultura (NAHUM; SANTOS, 2015, p.321).
\end{abstract}

As conclusões de Nahum e Santos (2015) refletem a situação das relações entre os agricultores familiares integrados e as empresas integradoras que passam a contabilizar como suas as produções realizadas nas propriedades familiares de dendê que são regidas pelo contrato celebrado entre estas partes.

Na edição de novembro/dezembro de 2013, o Jornal Aldeia, da Fase Amazônia, trouxe como matéria decapa a reportagem intitulada Amazônia: um território em disputa, em que dedicou duas páginas a investigar o que denominou de"dendê: oportunidade ou arapuca"e procurou detalhar a questão do dendê envolvendo a agricultura familiar integrada ao agronegócio de dendê no Baixo Tocantins.

$\mathrm{Na}$ matéria destaca-se o forte fomento das políticas de crédito para o setor, onde o Basa exerce um papel de destaque, pois é a instituição que centraliza as ações do Pronaf EcoDendê na região. Os contratos celebrados com agricultores familiares têm um modelo: com duração de 25 anos, plantio de 10 hectares, financiamento de até R $\$ 80.000,00$, com 14 anos para quitar a divida e carência de mais 6 anos. Para demonstrar a viabilidade econômica do projeto, a reportagem entrevistou um agricultor integrado à empresa Biopalma, que iniciou seu plantio de 10 hectares em 2010. Para isto realizou um empréstimo de $\mathrm{R} \$$ 57,5 mil do banco. Em 2013, ano da entrevista, a reportagem constatou que em alguns meses o agricultor teve que fazer investimento em seu dendezal do seu bolso, pois os recursos destinados para o 
plantio não foram suficientes nesta fase da produção, cabe destacar que com o passar dos anos a produção e consequentemente os ganhos aumentam (JORNAL ALDEIA, 2013)

A reportagem também destaca o uso de drogas entre funcionários prestadores de serviços de plantio e limpeza de dendê em plantação própria de empresas de dendê no município de Abaetetuba, que "para aguentar o tranco na frente de trabalho", estariam recorrendo às drogas (JORNAL ALDEIA, 2013).

A reportagem também questiona este modelo de agricultura.

\begin{abstract}
Mas antes de tudo é preciso questionar se a implantação do projeto do dendê é uma opção dos trabalhadores e agricultores familiares, ou se é uma decisão governamental e empresarial. Porque a farinha de mandioca anda tão cara na região? Muita gente tem se perguntado. Porque os agricultores não tem mais tempo de plantar alimentos? É uma escolha da agricultura familiar que o equivalente a $93 \%$ dos gastos do Pronaf em 2012 no Pará - R\$ 134,1 milhões - seja carimbado para o dendê este ano, uma vez que o Ecodendê prevê um recurso de R \$124,8 milhões só para a cultura? É comumacordo que mais de 320 mil ha sejam destinados a produção de biodiesel, combustível que pouco será comprado e usado pelas famílias paraenses, em detrimento do cultivo de alimentos para a população do Estado? (JORNAL ALDEIA, 2013, p. 7).
\end{abstract}

O modelo de investimentos adotado para a política de crédito rural na região tem priorizado a lavoura de dendê em detrimento de outras lavouras, como a mandioca, que conta com limitados recursos para o fomento da atividade de produção. Como lembra a reportagem acima, os projetos de dendê no Pará são resultados de uma estratégia de expansão que tem como atores hegemônicos o Estado e as empresas. Esta estratégia é responsável pelo emprego de grandes somas de recursos financeiros tanto na produção própria empresarial quanto da agricultura familiar que conta com o fomento do Pronaf Eco-Dendê.

$\mathrm{Na}$ edição do segundo semestre de 2014 do Jornal Aldeia, a promotora de justiça agrária da I Região do Pará, Eliene Cristina Pinto Moreira, escreveu um artigo intitulado de Os impactos socioambientais do plantio da palma de dendê no Pará, em que chamou a atenção para os conflitos envolvendo territórios quilombolas e empresas de dendê nos municípios de Tomé-Açu, Concórdia do Pará e Abaetetuba, este último no localizado no Baixo Tocantins. Segundo o depoimento prestado por vários quilombolas na referida promotoria existe casos de assassinatos de quilombolas em Tomé-Açu, onde o aquecimento da venda de terras na região para a implantação empresarial de dendê poderia ser o real motivo do crime.

$\mathrm{O}$ artigo destaca ainda relatos informais de moradores próximos aos projetos de dendê, que denunciam a contaminação da água de igarapés por agrotóxicos utilizados nos dendezais da região, entre as quais as localidades de Murutinga, município de Abaetetuba; Curuperé, 
Foz do Cravo e Castanhalzinho, município de Concórdia do Pará. Após solicitação de exames do Instituto Evandro Chagas, pela Promotoria Agrária, os resultados apontaram a presença de endossulfan, que é utilizado na produção agrícola de dendê. Ainda constatou-se na região o aumento de cianobactérias, o que justificaria os relatos de coceiras, problemas de pele e morte de diversos animais. O texto afirma que naquele momento não se pôde afirmar que estas questões fossem causadas pelas empresas de dendê instaladas no entorno destas localidades pesquisadas (MOREIRA, 2014).

\subsection{Racionalidade das empresas integradoras e dos agricultores familiares integrados de dendê no Baixo Tocantins (PA)}

O avanço da agroindústria no campo implica em uma subordinação do integrado ao capital. A relação de dependência e subordinação do pequeno produtor rural em relação à empresa é vista como um ponto negativo deste sistema de produção, que privilegia uma racionalidade econômica (ORLANDO, 1994)

Segundo Belato (1985, p. 262) "o tema da integração pode, então, receber desdobramentos que a ação do capital impõe a agricultura quando esta se encontra totalmente dominada pelo capital". A integração da agricultura familiar no agronegócio é analisada pelo autor como o reflexo da industrialização do campo, onde a formação das agroindústrias é a evidência do avanço da indústria sobre a agricultura.

O sistema de integração da agricultura familiar no agronegócio de dendê no Baixo Tocantins caracteriza uma atividade econômica onde estão presentes grandes empresas de atuação global, como a Vale (através da empresa controlada Biopalma), Petrobras e Galp (por meio da empresa controlada Belém Bioenergia Brasil). Desta forma, as ações dessas empresas refletem uma racionalidade que atende seus interesses de mercado, onde o agricultor familiar integrado passa a ser regulado pelas normas da empresa com quem mantém contratos de integração.

Cada empresa atua de maneira especifica em seu território de ação. O uso agrícola do território pelas empresas de dendê no Baixo Tocantins ocorre de modo seletivo de acordo com seus interesses. A ação empresarial obedece a uma lógica territorial para seus investimentos, no caso do setor de dendê no Baixo Tocantins esta ação se manifesta com a aquisição das melhores terras para a produção agrícola própria de dendê por parte das empresas deste setor.

As ações do agronegócio obedecem a uma racionalidade econômica que tem nos mercados mundiais sua maior referência, pois esta produção tem como destino os mercados 
consumidores globais. Desta forma, sua presença em determinados territórios impõe uma lógica que obedece a uma exigência de um mercado externo.

Segundo Cleps Júnior (2010, p. 47), “o agronegócio é uma instituição enraizada na história econômico-social e na estrutura de poder político do país". Este autor destaca o pacto entre o Estado e o agronegócio no Brasil, responsável pela criação de políticas agrícolas no país que historicamente têm atendido aos interesses do empresariado do agronegócio. Desta forma, é fácil compreender porque a maior parte dos recursos do crédito rural ainda é destinada ao agronegócio em detrimento da agricultura familiar no Brasil. Nestes dois modelos de agricultura encontramos especificidades que refletem as reais intencionalidades de cada modelo.

Com o advento da globalização "os atores mais poderosos se reservam os melhores pedaços do território e deixam o resto para os outros" (SANTOS, 2000, p. 79). Desta forma, a disputa por territórios para a produção agrícola de dendê no Baixo Tocantins esta inserido nesta lógica hegemônica em que as empresas buscam a apropriação das melhores terras que são utilizadas como recursos. Neste jogo de disputas por territórios de recursos entre os diferentes atores, os lugares definem-se como frações de onde partem resistências a esta racionalidade que impõe novos usos ao território. Estas racionalidades hegemônicas se manifestam por meio de um conjunto de normas e ações que alcançam os lugares de forma vertical e que encontram resistências de outras formas de racionalidades que tem origem nos lugares.

A realidade rural no Brasil tem sido marcada pela disputa de territórios entre os modelos da pequena e da grande produção agrícola no país para o desenvolvimento da agricultura. A disputa por territórios para a atividade agrícola no Brasil na atualidade ocorre de forma seletiva, onde frações do território nacional são objetos da ação do capital de forma decidida e explícita. A Amazônia desde meados da década de 1970 tem despertado a atenção do capital para uma exploração agrícola racional, por parte de grandes empresas ligadas à agricultura empresarial.

A Amazônia na atualidade tornou-se um campo de disputa por acesso a terras, onde populações tradicionais e empresários ligados à agricultura moderna passam a disputar territórios para a execução de projetos agrícolas que obedecem a uma racionalidade bastante diferenciada entre os segmentos envolvidos nesta disputa.

A ação estatal, por meio da execução de políticas públicas, tem estimulado o uso do território brasileiro como recurso para a produção capitalista, o que tem gerado uma série de conflitos com populações que tem no território uma referência de abrigo. 
A relação dialética entre a pequena e a grande produção agrícola gera a necessidade da formação de territórios específicos com uma racionalidade diferenciada de uso do território em questão. O território do agronegócio possui uma racionalidade que atende os interesses do capital, com uma produção em grande escala para atender o mercado externo. Os territórios da agricultura familiar possuem uma racionalidade pautada na escassez de capitais, com uma produção limitada e voltada para o abastecimento do mercado interno.

As ações e os objetos resultantes dos projetos, ligados à produção de dendê no Baixo Tocantins, foram pensados segundo uma intencionalidade que atende a lógica empresarial. Estas ações e objetos apresentam para a sociedade regional um discurso para justificar sua presença (SANTOS, 1991). Estes discursos são apresentados pela empresa como ações de modernidade, onde procura potencializar estas ações como se fossem benefícios aos municípios onde está instalada sua produção agrícola. Este discurso é facilmente constatado nas propagandas veiculadas nos meios de comunicação a serviço destas empresas.

A atuação das empresas de dendê no Baixo Tocantins só pode ser entendida a partir da lógica de mercado, em que as empresas cada vez mais buscam novas vantagens. Desta forma, o território é disputado pela empresa que usa este território como recurso para sua atuação empresarial. Por sua vez, o agricultor usa este território como abrigo para suas atividades. Nesta relação, devido à sua capacidade de recursos econômicos, a empresa assume um papel de ator hegemônico, enquanto que os agricultores são enquadrados em atores hegemonizados. Isto leva à formação de verdadeiros territórios corporativos onde as empresas passam a comandar uma vasta área de atuação privada.

No atual período da globalização os territórios são regulados por uma racionalidade que obedece a um comando centralizado. Esta racionalidade hegemônica passa a impor uma série de normas que transforma estes territórios em entes obedientes a um comando centralizado de onde partem as ordens e as normas.

No Baixo Tocantins constatamos em trabalho de campo uma racionalidade empresarial hegemônica, que assumem uma posição de comando presente nos territórios da agricultura familiar de dendê regulado pelo agronegócio. A empresa Belém Bionergia Brasil que controla projetos de integração familiar de dendê nos municípios de Baião, Cametá, Mocajuba e Tailândia têm como centro de comando o polo da empresa que esta localizada em Tailândia, de onde parte as ordens para os demais municípios onde existem produtores integrados a empresa. A empresa Biopalma está presente nos municípios de Acará e Moju. Existe um pólo da empresa em Acará e outro em Moju que centralizam as ações nestes municípios. As normas e diretrizes das empresas estão presentes nos contratos de compra e 
venda da produção e são reforçados pelos técnicos agrícolas que fazem o acompanhamento dos dendezeis familiares. Por sua vez, as ações racionais da empresa visam o acompanhamento da produção agrícola familiar dos produtores integrados (Quadro 43)

Quadro 43: Racionalidade nos territórios da agricultura familiar de dendê regulado pelo agronegócio no Baixo Tocantins (PA), visitados em 2015

\begin{tabular}{|l|c|l|l|l|}
\hline Município & $\begin{array}{c}\text { Centro de } \\
\text { comando da } \\
\text { empresa (polo) }\end{array}$ & \multicolumn{1}{|c|}{ Normas e diretrizes } & \multicolumn{1}{|c|}{$\begin{array}{c}\text { Açóes racionais } \\
\text { da empresa }\end{array}$} & $\begin{array}{c}\text { Objetos } \\
\text { racionais da } \\
\text { empresa }\end{array}$ \\
\hline Acará & $\begin{array}{c}\text { Biopalma } \\
\text { (Acará) }\end{array}$ & $\begin{array}{l}\text { Normas presentes nos } \\
\text { contratos e reforçados pelos } \\
\text { técnicos agrícolas }\end{array}$ & $\begin{array}{l}\text { Acompanhamento } \\
\text { da produção }\end{array}$ & $\begin{array}{l}\text { Polo da } \\
\text { empresa }\end{array}$ \\
\hline Baião & $\begin{array}{l}\text { BBB } \\
\text { (Tailândia) }\end{array}$ & $\begin{array}{l}\text { Normas presentes nos } \\
\text { contratos e reforçados pelos } \\
\text { técnicos agrícolas }\end{array}$ & $\begin{array}{l}\text { Acompanhamento } \\
\text { da produção }\end{array}$ & $\begin{array}{l}\text { Não } \\
\text { identificada }\end{array}$ \\
\hline Cametá & $\begin{array}{l}\text { BBB } \\
\text { (Tailândia) }\end{array}$ & $\begin{array}{l}\text { Normas presentes nos } \\
\text { contratos e reforçados pelos } \\
\text { técnicos agrícolas }\end{array}$ & $\begin{array}{l}\text { Acompanhamento } \\
\text { da produção }\end{array}$ & $\begin{array}{l}\text { Não } \\
\text { identificada }\end{array}$ \\
\hline Mocajuba & $\begin{array}{l}\text { BBB } \\
\text { (Tailândia) }\end{array}$ & $\begin{array}{l}\text { Normas presentes nos } \\
\text { contratos e reforçados pelos } \\
\text { técnicos agrícolas }\end{array}$ & $\begin{array}{l}\text { Acompanhamento } \\
\text { da produção }\end{array}$ & $\begin{array}{l}\text { Não } \\
\text { identificada }\end{array}$ \\
\hline Moju & $\begin{array}{l}\text { Biopalma } \\
\text { (Moju) }\end{array}$ & $\begin{array}{l}\text { Normas presentes nos } \\
\text { contratos e reforçados pelos } \\
\text { técnicos agrícolas }\end{array}$ & $\begin{array}{l}\text { Acompanhamento } \\
\text { da produção }\end{array}$ & $\begin{array}{l}\text { Polo da } \\
\text { empresa }\end{array}$ \\
\hline Tailândia & $\begin{array}{l}\text { BBB } \\
\text { Tailândia) }\end{array}$ & $\begin{array}{l}\text { Normas presentes nos } \\
\text { contratos e reforçados pelos } \\
\text { técnicos agrícolas }\end{array}$ & $\begin{array}{l}\text { Acompanhamento } \\
\text { da produção }\end{array}$ & $\begin{array}{l}\text { Polo da } \\
\text { empresa }\end{array}$ \\
\hline
\end{tabular}

Fonte: Adaptado de Santos (2006) e trabalho de campo (2015)

A ação hegemônica das empresas integradoras de dendê no Baixo Tocantins introduz um cotidiano imposto de fora, regido por normas, em que um dos elementos é o comportamento regulado dos agricultores familiares integrados. O sistema agrícola de produção integrada funciona mediante um conjunto de normas e diretrizes que são centralizadas pela empresa integradora, que ao exercer seu poder de mando passa a regular o cotidiano dos produtores que estão vinculados pelos contratos de compra e venda da produção de dendê. No Quadro 44 é demonstrada esta situação nas localidades visitadas em 2015.

Neste sentido, a integração entre agricultor familiar integrado e empresa integradora é uma relação dialética entre mandar e obedecer (SANTOS, 1992), em que de um lado temos a empresa que manda, que formula as normas e, do outro lado, temos o agricultor familiar que obedece às normas que são formuladas pela empresa. 
Quadro 44: Comportamentos regulados dos agricultores nos territórios da agricultura familiar de dendê regulado pelo agronegócio no Baixo Tocantins (PA)

\begin{tabular}{|c|c|c|c|}
\hline Município & Empresa (polo) & Localidade & $\begin{array}{c}\text { Comportamentos regulados dos } \\
\text { agricultores }\end{array}$ \\
\hline Acará & Biopalma (Acará) & Ramal do Ipitinga & Obediência às normas da empresa \\
\hline Baião & BBB (Tailândia) & $\begin{array}{l}\text { Ramal do Limãozinho e Ramal } \\
\text { do Cardoso }\end{array}$ & Obediência às normas da empresa \\
\hline Cametá & BBB (Tailândia) & $\begin{array}{l}\text { Ramal do Patauateua e Ramal } \\
\text { do Livramento }\end{array}$ & Obediência às normas da empresa \\
\hline Mocajuba & BBB (Tailândia) & $\begin{array}{l}\text { Ramal Cenira e Ramal Igarapé } \\
\text { do Meio }\end{array}$ & Obediência às normas da empresa \\
\hline Moju & Biopalma (Moju) & \begin{tabular}{|lrr} 
Ramal Bom & Futuro. \\
Comunidade & de & Boa \\
Esperança. & Assentamento Olho \\
D’Água I & &
\end{tabular} & Obediência às normas da empresa \\
\hline Tailândia & BBB (Tailândia) & $\begin{array}{l}\text { Comunidade Nova Paz ec } \\
\text { Comunidade Betel }\end{array}$ & Obediência às normas da empresa \\
\hline
\end{tabular}

Fonte: Adaptado de Santos (1999) e trabalho de campo (2015)

A presença de um comando que emite uma racionalidade hegemônica representada pela imposição de normas aos territórios encontra resistências que se manifestam em forma de contrarracionalidades (SANTOS, 1996). No Baixo Tocantins os territórios da agricultura familiar de dendê regulados, visitados em 2015, resistem à racionalidade das empresas de dendê de forma bastante tímida. A forma mais comum de contrarracionalidade identificada são os diálogos entre os agricultores integrados e a ajuda mútua na entrega da produção de dendê, conforme constatamos em trabalho de campo (Quadro 45). 
Quadro 45: Contrarracionalidade nos territórios da agricultura familiar de dendê regulado pelo agronegócio no Baixo Tocantins (PA), visitadas em 2015.

\begin{tabular}{|c|c|c|c|c|}
\hline Município & $\begin{array}{l}\text { Centro de comando da } \\
\text { empresa (polo) }\end{array}$ & Localidade & $\begin{array}{c}\text { Ações de } \\
\text { solidariedades }\end{array}$ & $\begin{array}{c}\text { Objetos de } \\
\text { solidariedades }\end{array}$ \\
\hline Acará & Biopalma (Acará) & Ramal do Ipitinga & Não identificada & Não identificada \\
\hline Baião & BBB (Tailândia) & $\begin{array}{l}\text { Ramal do Limãozinho } \\
\text { e Ramal do Cardoso }\end{array}$ & Não identificada & Não identificada \\
\hline Cametá & BBB (Tailândia) & $\begin{array}{l}\text { Ramal do Patauateua } \\
\text { e Ramal do } \\
\text { Livramento }\end{array}$ & $\begin{array}{l}\text { Diálogos entre os } \\
\text { integrados, bem } \\
\text { como ajuda } \\
\text { durante a entrega } \\
\text { da produção. }\end{array}$ & Não identificada \\
\hline Mocajuba & BBB (Tailândia) & $\begin{array}{l}\text { Ramal Cenira e Ramal } \\
\text { Igarapé do Meio. }\end{array}$ & Não identificada & Não identificada \\
\hline Moju & Biopalma (Moju) & $\begin{array}{l}\text { Ramal Bom Futuro. } \\
\text { Comunidade de Boa } \\
\text { Esperança. } \\
\text { Assentamento Olho } \\
\text { D’Água I }\end{array}$ & $\begin{array}{l}\text { Diálogos entre os } \\
\text { integrados, bem } \\
\text { como ajuda } \\
\text { durante a entrega } \\
\text { da produção. }\end{array}$ & Não identificada \\
\hline Tailândia & BBB (Tailândia) & $\begin{array}{l}\text { Comunidade Nova } \\
\text { Paz e Comunidade } \\
\text { Betel }\end{array}$ & $\begin{array}{l}\text { Diálogos entre os } \\
\text { integrados, bem } \\
\text { como ajuda } \\
\text { durante a entrega } \\
\text { da produção. }\end{array}$ & Não identificada \\
\hline
\end{tabular}

Fonte: Adaptado de Santos (2006) e trabalho de campo (2015)

A imposição de uma racionalidade acaba por impor uma solidariedade territorial entre espaços e populações afetadas, criando o que Milton Santos (1994) denominou de acontecer solidário, que se apresenta sob três formas: um acontecer homólogo, um acontecer complementar e um acontecer hierárquico.

De acordo com Santos (1994, p. 17), "no caso do acontecer homólogo e do acontecer complementar [...] o território atual é marcado por um cotidiano compartido mediante regras que são formuladas ou reformuladas localmente". No caso dos territórios da agricultura familiar de dendê regulados do Baixo Tocantins, as regras formuladas localmente são confrontadas pelas normas que são formuladas pelas empresas. Neste sentido, a racionalidade hegemônica da empresa acaba por limitar a solidariedade local.

Por sua vez, no "acontecer hierárquico trata-se, ao contrário, de um cotidiano imposto de fora, comandado por informação privilegiada, uma informação que é segredo e é poder. [...] temos a primazia das normas" (SANTOS, 1994, p. 17). As ações do acontecer hierárquico 
são bastante explícitas nos territórios agrícolas familiares regulados de dendê do Baixo Tocantins. As normas de produção familiar pela empresa acabam por impor um cotidiano imposto de fora de que nos fala o autor. Neste cotidiano as relações de produção agrícola são decididas pela empresa em detrimento do agricultor familiar integrado, que perde esta condição.

A chegada das empresas de dendê ao Baixo Tocantins promoveu uma quebra da solidariedade social, uma vez que desorganizou toda a dinâmica da vida local nos lugares onde foram instalados os projetos de dendê familiar (SANTOS, 2000). Nos territórios da agricultura familiar de dendê regulados pelo agronegócio foi introduzida a competitividade entre agricultores, o que contribuiu para minar a solidariedade entre os moradores ali estabelecidos. A Figura 31 mostra detalhes do cotidiano no entorno de dendezal empresarial em Tailândia.

Figura 31: Cotidiano marcado pela presença de empresas de dendê em Tailândia

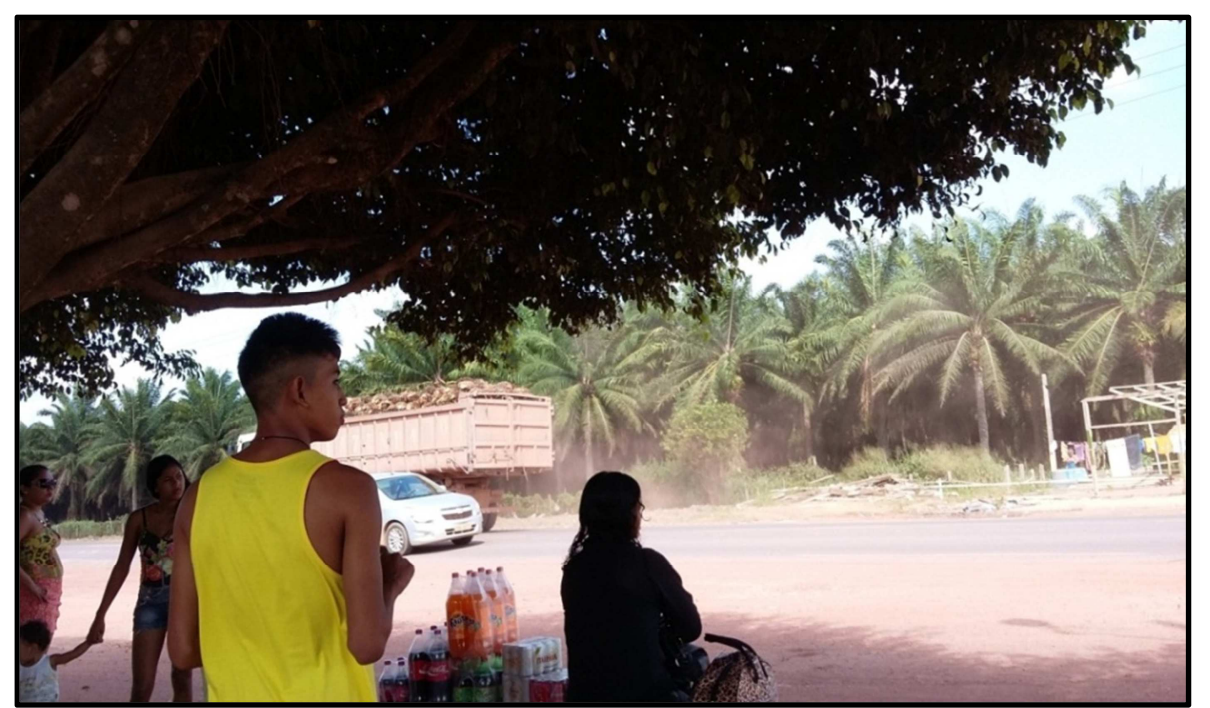

Fonte: Márcio Benassuly (2015)

Ao fazer a apresentação do artigo $O$ retorno do território, de Milton Santos, publicado em 2005 pela OSAL, Maria Adélia Aparecida de Souza afirma que "o uso do território se dá pela dinâmica dos lugares. O lugar é proposto por ele como sendo o espaço do acontecer solidário. Estas solidariedades definem usos e geram valores de múltiplas naturezas" (SOUZA, 2005, p. 253). Desta forma, território usado e lugar guardam uma profunda relação, pois no território encontramos as ações e objetos e o lugar destaca a resistência aos processos hegemônicos do capital. Sobre esta questão, Souza (2005, p.254) afirma que "este período se caracteriza pelo processo de resistência dos lugares às perversidades impostas a ele pelo mundo". Desta forma, o lugar procura destacar os processos de resistência as ações hegemônicas do capital onde a solidariedade é peça fundamental. 
A chegada das empresas de dendê no Baixo Tocantins faz parte de um conjunto de ações emanadas de políticas federais como o PNPB e o PPSOP que só podem ser entendidos se consideramos a dimensão do cotidiano. Desta forma, a chegada destas empresas ao Pará só pode ser entendida a partir de uma análise que considera o papel do Estado em ações na fronteira agrícola nacional (SANTOS; SILVEIRA, 2001).

O modelo de agricultura integrada impõe a criação de verdadeiros territórios regulados por normas e ações das empresas integradoras. Neste sistema as propriedades agrícolas dos pequenos agricultores integrados tornam-se territórios da agricultura familiar de dendê regulado pelo agronegócioonde o agricultor perde sua liberdade de produção, pois esta decisão do que produzir passa para o controle da empresa integradora. $\mathrm{O}$ agricultor passa a ser regulado por um conjunto de normas que têm como centro de ordens a empresa à qual está integrado. Este cenário cria um cotidiano obediente resultante das normas que são passadas pela empresa, com a criação de cotidiano imposto de fora. O sistema de produção integrada promove a criação de um cotidiano obediente, onde os integrados pelo contrato assinado são levados a obedecer às normas da empresa (SANTOS, 1991).

Este tipo de agricultura impõe uma lógica que deve ser seguida por todos os envolvidos na temática. Para o agricultor esta lógica impõe sua adesão a um modelo comandado por uma empresa hegemônica. Desta forma, segundo Santos (1999, p. 24), “a primeira coisa que o agricultor de uma área moderna terá que fazer se quiser sobreviver, é obedecer, como um exército, à palavra de ordem". Nesta publicação este autor cita o caso da produção integrada de frangos e porcos nos estados de Paraná e Santa Catarina onde o pequeno produtor é regulado por uma racionalidade hegemônica de grandes empresas agroindustriais. Para ele, a "obediência indispensável do produtor a uma cadeia técnica que responde a uma demanda econômica que cria nele comportamentos regulados, de tal forma que excluem a idéia que se possa ter de prática da solidariedade” (SANTOS, 1999, p. 24).

A racionalidade da agricultura moderna impõe um cotidiano normatizado e obediente às diretrizes de um comando de decisões centralizado.

Segundo Santos (1991, p. 37),

Nas áreas da agricultura moderna, as cidades são o ponto de intersecção entre verticalidades e horizontalidades. As verticalidades são vetores de uma racionalidade superior e de seu discurso pragmático, criando um cotidiano obediente. As horizontalidades são tanto o lugar da finalidadeimposta de fora, de longe e de cima, quanto o da contra finalidade, localmente gerada, o teatro de um cotidiano conforme, mas não obrigatoriamente conformista e, desse modo, simultaneamente, o lugar da cegueira e da descoberta, da complacência e da revolta. 
O segmento produtivo da cadeia do dendê no Baixo Tocantins está dividido em: produção empresarial e produção familiar integrada. No caso da produção familiar, objeto de análise neste capítulo, apresenta algumas características que diferem da produção empresarial, como demonstra o Quadro 46.

Quadro 46: Características dos segmentos produtivos agrícolas da cadeia produtiva do dendê

\begin{tabular}{|c|c|c|}
\hline Características & Empresa familiar & Empresas capitalistas \\
\hline Residência & $\begin{array}{|llll|}\begin{array}{l}\text { Proprietários } \\
\text { produtiva }\end{array} & \text { residem na unidade } \\
\end{array}$ & Proprietários não residem na unidade produtiva \\
\hline Posse da terra & $\begin{array}{l}\text { Assentados na reforma agrária com } \\
\text { domínio de posse de terra e pequenos } \\
\text { proprietários ou arrendatários }\end{array}$ & Grandes e médios proprietários de terra \\
\hline $\begin{array}{l}\text { Participação no } \\
\text { mercado }\end{array}$ & Nenhuma ou pequena & Total participação no mercado \\
\hline $\begin{array}{l}\text { Capital de } \\
\text { exploração }\end{array}$ & $\begin{array}{l}\text { Maior utilização de linhas de crédito } \\
\text { bancário oficial }\end{array}$ & $\begin{array}{l}\text { Elevado uso de capital de exploração que pode ser } \\
\text { próprio, crédito bancário de agência de } \\
\text { desenvolvimento ou financiamento de parcerias } \\
\text { internacionais }\end{array}$ \\
\hline $\begin{array}{l}\text { Nível } \\
\text { tecnológico }\end{array}$ & $\begin{array}{l}\text { Baixo a médio } \\
\text { As empresas integradas normalmente } \\
\text { oferecem assistência técnica para a: } \\
\text { exploração. } \\
\text { Mão-de-obra, familiar e pouquíssima } \\
\text { mecanização agrícola. }\end{array}$ & $\begin{array}{l}\text { Alto } \\
\text { Uso de insumos e de mecanização agrícola nas } \\
\text { atividades que sejam possíveis. } \\
\text { Mão-de-obra assalariada }\end{array}$ \\
\hline Especialização & $\begin{array}{|llll|}\text { Especializadas ou em vias de } & \text { eu } \\
\text { especialização, com poucas linhas de } & \\
\text { exploração destinadas ao mercado. }\end{array}$ & $\begin{array}{l}\text { Especializada em uma ou poucas linhas de exploração } \\
\text { destinadas ao mercado, complementares e integradas }\end{array}$ \\
\hline $\begin{array}{l}\text { Tipo de mão-de- } \\
\text { obra }\end{array}$ & $\begin{array}{l}\text { Essencialmente familiar com contraçãol } \\
\text { de mão de obra sazonal }\end{array}$ & $\begin{array}{l}\text { Permanente e assalariada, raríssima contratação } \\
\text { sazonal }\end{array}$ \\
\hline
\end{tabular}

Fonte: Macedo et al. (2010), com adaptações do autor

Quanto às tecnologias utilizadas pelos segmentos da produção empresarial e da produção familiar integrada, consideram as seguintes etapas do processo produtivo: aquisição de sementes, pré-viveiro, viveiro, preparo do terreno, plantio, coroamento das plantas, roçagem e rebaixo da leguminosa, ronda e controle fitossanitário, adubação, poda das plantas, colheita e coleta dos cachos e transporte dos cachos para a usina (Quadro 47). 


\section{Quadro 47: Tecnologias utilizadas para a produção de dendê pelos segmentos das empresas capitalistas e empresa familiar}

\begin{tabular}{|c|c|c|}
\hline $\begin{array}{l}\text { Etapas do processo } \\
\text { produtivo }\end{array}$ & Empresa familiar & Empresa capitalista \\
\hline Aquisição de sementes & $\begin{array}{l}\text { Não realiza (adquirem as mudas } \\
\text { prontas das empresas capitalistas com } \\
\text { as quais se associam negociando o } \\
\text { pagamento com a produção de cachos) }\end{array}$ & $\begin{array}{l}\text { Geralmente adquirem as sementes pré- } \\
\text { germinadas em quantidades suficientes para } \\
\text { efetuar seleção das mudas para serem levadas ao } \\
\text { local definido }\end{array}$ \\
\hline Pré-viveiro & Não realiza & $\begin{array}{l}\text { São seguidas as recomendações técnicas de } \\
\text { manejo, seleção e eliminação das mudas }\end{array}$ \\
\hline Viveiro & Não realiza & $\begin{array}{l}\text { A maioria dos produtores segue as } \\
\text { recomendações da pesquisa em relação aos tratos } \\
\text { culturais, seleção e eliminação das mudas, para } \\
\text { garantir precocidade e boa produtividade das } \\
\text { plantas no local definitivo }\end{array}$ \\
\hline Preparo do terreno & $\begin{array}{l}\text { Efetuam a limpeza da área e o } \\
\text { enleiramento da } \\
\text { manualmente; } \\
\text { Com auxilio das empresas capitalistas, } \\
\text { efetuam a destoca da área, a abertura o } \\
\text { nivelamento e o empiçarramento de } \\
\text { estradas, utilizando máquinas pesadas }\end{array}$ & $\begin{array}{l}\text { Aproveitam as áreas já desmatadas da } \\
\text { propriedade (capoeira e pastagem). } \\
\text { Nestes casos procuram aproveitar ao máximo a } \\
\text { matéria orgânica dos restos vegetais existentes. } \\
\text { O preparo da área em geral é realizado } \\
\text { mecanicamente, utilizando trator de esteira, cuja } \\
\text { potência vai variar com o tipo de vegetação; } \\
\text { No preparo da área o terreno deve ser destocado } \\
\text { totalmente para permitir mecanização das } \\
\text { operações de manutenção }\end{array}$ \\
\hline Plantio & $\begin{array}{l}\text { Seguem as recomendações técnicas } \\
\text { definidas pela pesquisa }\end{array}$ & $\begin{array}{l}\text { Seguem as recomendações técnicas definidas } \\
\text { pela pesquisa }\end{array}$ \\
\hline Coroamento da & $\begin{array}{l}\text { Frequentemente utilizam o coroamento } \\
\text { manual e eventualmente o coroamento } \\
\text { químico }\end{array}$ & $\begin{array}{l}\text { Utilizam o coroamento misto até o terceiro ano } \\
\text { do plantio, alternando entre o uso de herbicidas e } \\
\text { o coroamento manual } \\
\text { A partir do quarto ano, somente coroamento } \\
\text { químico }\end{array}$ \\
\hline $\begin{array}{l}\text { Roçagem e } \\
\text { rebaixamento da } \\
\text { leguminosa }\end{array}$ & $\begin{array}{l}\text { Normalmente a atividade é feita } \\
\text { manualmente; em alguns casos } \\
\text { utilizam roçadeiras costais motorizadas }\end{array}$ & $\begin{array}{l}\mathrm{Na} \text { fase de estabelecimento utilizam roçagem } \\
\text { mecânica. Na fase adulta, empregam mão-de- } \\
\text { obra para efetuar a roçagem manual }\end{array}$ \\
\hline $\begin{array}{l}\text { Ronda e controle } \\
\text { fitossanitários }\end{array}$ & $\begin{array}{l}\text { Com auxílio técnico das empresas } \\
\text { capitalistas seguem as recomendações } \\
\text { técnicas }\end{array}$ & $\begin{array}{l}\text { Constituem uma equipe permanente que é } \\
\text { treinada para a realização da atividade }\end{array}$ \\
\hline Adubação & $\begin{array}{l}\text { Seguem as orientações técnicas } \\
\text { prestadas pelas empresas capitalistas } \\
\text { com as quais estão associadas }\end{array}$ & $\begin{array}{l}\text { Seguem as bases das recomendações técnicas } \\
\text { onde cada empresa estabelece sua política de } \\
\text { adubação em função da idade dos plantios, nível } \\
\text { de produtividade e estado nutricional das plantas }\end{array}$ \\
\hline Poda das plantas & $\begin{array}{l}\text { Seguem as recomendações técnicas; } \\
\text { com auxilio prestado pelas empresas } \\
\text { capitalistas }\end{array}$ & $\begin{array}{l}\text { Aproveitam os períodos do ano de menor } \\
\text { produção e utilizam a equipe de colheitas para a } \\
\text { realização da atividade }\end{array}$ \\
\hline $\begin{array}{l}\text { Colheita e coleta dos } \\
\text { cachos }\end{array}$ & $\begin{array}{l}\text { Empregam as técnicas de colheitas } \\
\text { recomendadas pela pesquisa; }\end{array}$ & $\begin{array}{l}\text { Empregam as técnicas de colheitas } \\
\text { recomendadas pela pesquisa. }\end{array}$ \\
\hline & $\begin{array}{l}\text { Transportam os cachos colhidos de } \\
\text { dentro da plantação para a bordadura } \\
\text { das parcelas por meio de tração animal }\end{array}$ & $\begin{array}{l}\text { Transportam os cachos colhidos de dentro da } \\
\text { plantação para a bordadura por meio de carretas } \\
\text { basculares adaptadas a microtratores }\end{array}$ \\
\hline $\begin{array}{l}\text { Transporte dos cachos } \\
\text { para a usina }\end{array}$ & $\begin{array}{l}\text { Empresas capitalistas disponibilizam o } \\
\text { transporte dos cachos até a usina }\end{array}$ & Realizam o transporte mecanizado dos cachos \\
\hline
\end{tabular}

Fonte: Macedo et al. (2010), com adaptações do autor 


\subsection{Experiências de integração da agricultura familiar de dendê da empresa Belém Bioenergia Brasil (Pbio + Galp) no Baixo Tocantins (PA)}

Nesta seção apresentamos a experiência da Belém Bioenergia Brasil em projetos de agricultura familiar de dendê integrado à empresa, visitados em trabalho de campo, em 2015.

4.3.1 Territórios da agricultura familiar de dendê regulados pela Belém Bioenergia Brasil (Pbio + Galp) visitados no Baixo Tocantins (PA).

No município de Baião ${ }^{94}$ os projetos situam-se nas localidades de vila de Calados (ramal do Cardoso), ramal do Limãozinho e Angu Pegado. No município de Cametá $^{95}$ os projetos estão nas localidades de Porto Grande, Belos Prazeres, Areião, Carapajó, entre outras. No município de Mocajuba ${ }^{96}$ os projetos de agricultura familiar de dendê integrado situam-se nas localidades de Açaizal, Igarapé-Açu, Cenira, Tambaí Miri, Ciloé, Baratinha, Angelim, Igarapé do Meio, entre outras.

Nomunicípio de $\mathrm{Moju}^{97} \mathrm{o}$ início do plantio de projetos de agricultura familiar de dendê integrada à empresa Belém Bioenergia Brasil se deu em 2011-2012. Os projetos estão localizados em diversas localidades como Apéi, São Vicente, Água Branca, Ramal do Miriti, Ramal Sócutuba, entre outras. Em muitos casos uma parte dos frutos de dendê estaria se perdendo por falta da unidade de processamento da empresa Belém Bioenergia Brasil. Por não ter usina de extração de óleo de palma, a empresa tem cooperação com a Dentaua, em Concórdia do Pará, para o beneficiamento de sua produção. A produção agrícola própria da empresa é realizada em fazendas arrendadas, o que é bastante criticado pelo movimento sindical na região.

No município de Tailândia ${ }^{98}$, os projetos de agricultura familiar de dendê integrado à empresa estão localizados nas comunidades de Nova Paz, São João, Pindorama, Borba Gato, Serra Negra, Vicinal 10, Betel, entre outras.

Em Barcarena ${ }^{99}$ e Igarapé Miri ${ }^{100}$ não existem projetos de agricultura familiar de dendê integrado à empresa. Barcarena vem se consolidando como território de descanso de gado vivo, onde são alugadas grandes fazendas para a engorda do gado, que é exportado para

\footnotetext{
${ }^{94}$ Informação concedida em entrevista realizada pelo pesquisador no STTR de Baião, em 29.09.2015.

${ }^{95}$ Informação concedida em entrevista realizada pelo pesquisador no STTR de Cametá, em 01.10.2015.

${ }^{96}$ Informação concedida em entrevista realizada pelo pesquisador no STTR de Mocajuba, em 10.09.2015.

${ }^{97}$ Informação concedida em entrevista realizada pelo pesquisador no STTR de Moju, em 25.08.2015.

${ }^{98}$ Informação concedida em entrevista realizada pelo pesquisador no STTR de Tailândia, em 11.09.2015.

${ }^{99}$ Informação concedida em entrevista realizada pelo pesquisador no STTR de Barcarena, em 06.10.2015.

${ }^{100}$ Informação concedida em entrevista realizada pelo pesquisador no STTR de Igarapé Miri, em 25.09.2015.
} 
o Líbano e a Venezuela a partir do porto de Vila do Conde localizado neste município. Igarapé Miri consolida-se como território de produção de açaí de várzea.

Tendo como base a localização dos projetos de agricultura familiar de dendê integrado à empresa, visitamos em trabalho de campo oito localidades de produção familiar integrada: ramal do Limãozinho, ramal do Cardoso (Baião), ramal do Patauateua, ramal Livramento (Cametá), ramal Cenira, ramal Igarapé do Meio (Mocajuba), comunidade Nova Paze comunidade Betel (Tailândia). (Quadro 48)

Quadro 48: Territórios da agricultura familiar de dendê regulado pela Belém Bioenergia Brasil (BBB) visitados no Baixo Tocantins (PA), 2015

\begin{tabular}{|l|l|c|}
\hline Município & \multicolumn{1}{|c|}{ Localidades } & Agricultores entrevistados \\
\hline \multirow{2}{*}{ Baião } & Ramal do Limãozinho & 01 \\
\cline { 2 - 3 } & Ramal do Cardoso & 01 \\
\hline \multirow{2}{*}{ Cametá } & Ramal do Patauateua & 01 \\
\cline { 2 - 3 } & Ramal Livramento & 01 \\
\hline \multirow{2}{*}{ Mocajuba } & Ramal Cenira & 01 \\
\cline { 2 - 3 } & Ramal Igarapé do Meio & 01 \\
\hline \multirow{2}{*}{ Tailândia } & Comunidade Nova Paz & 09 \\
\cline { 2 - 3 } & Comunidade Betel & 03 \\
\hline Total & & 18 \\
\hline
\end{tabular}

Fonte: Trabalho de campo (2015)

O Mapa 15 enfatiza o território de atuação da Belém Bioenergia Brasil e os territórios de agricultura familiar de dendê regulado pela empresa visitados em 2015. A empresa tem como território de atuação os municípios de Abaetetuba, Moju, Tailândia, Igarapé Miri, Mocajuba, Baião e Cametá. O polo-sede da empresa fica na cidade de Tailândia. 
Mapa 15: Território de atuação da Belém Bioenergia Brasil e territórios da agricultura familiar de dendê regulado pela empresa no Baixo Tocantins (PA), 2015

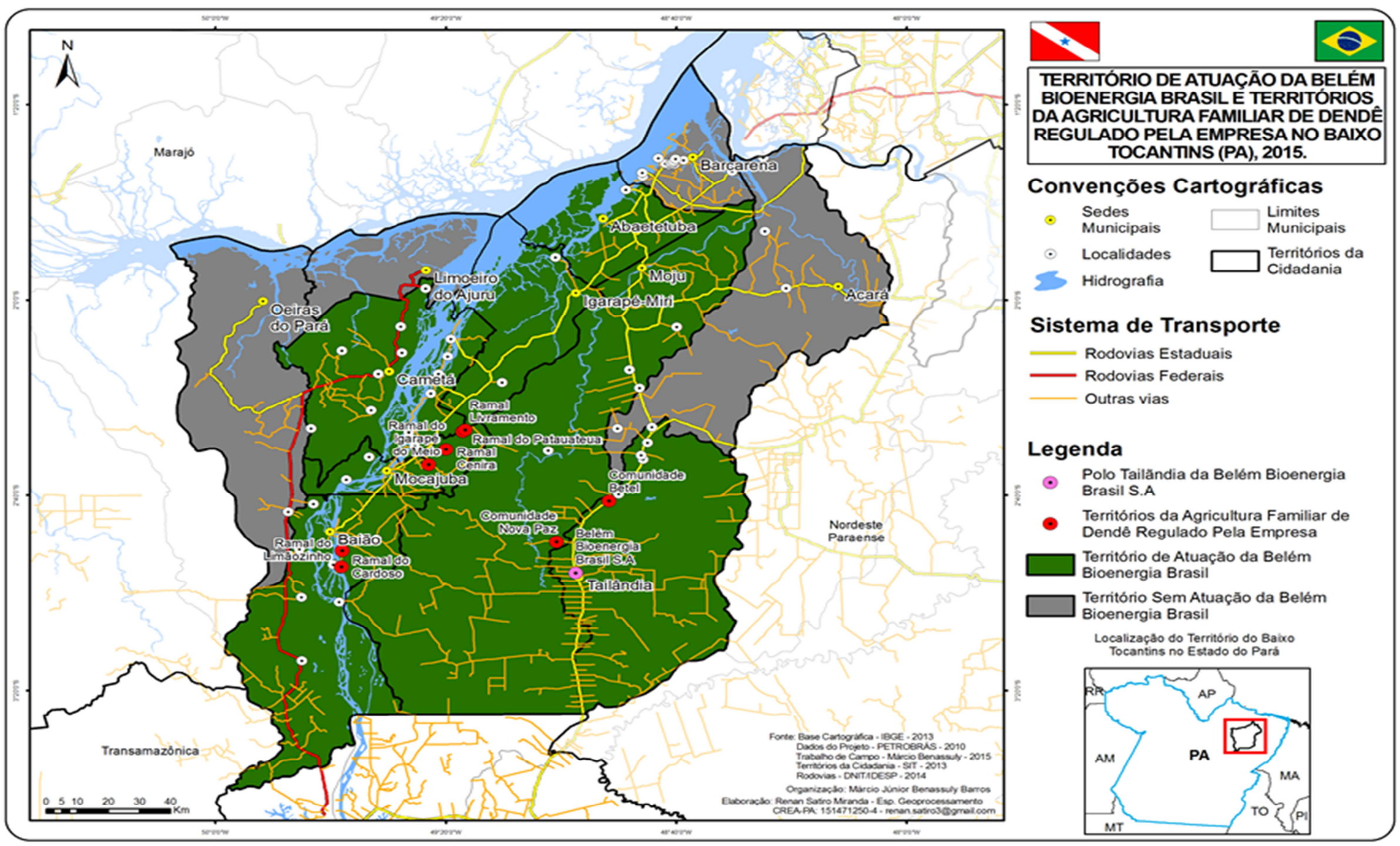


$\mathrm{Na}$ sequência passamos a descrever os territórios da agricultura familiar de dendê regulado pela empresa que foram visitados em trabalho de campo em 2015.

O ramal do Limãozinho, no município de Baião, é uma localidade onde agricultores familiares vivem fundamentalmente das lavouras de pimenta-do-reino e de mandioca (Figura $32)$.

Figura 32: Ramal do Limãozinho, em Baião

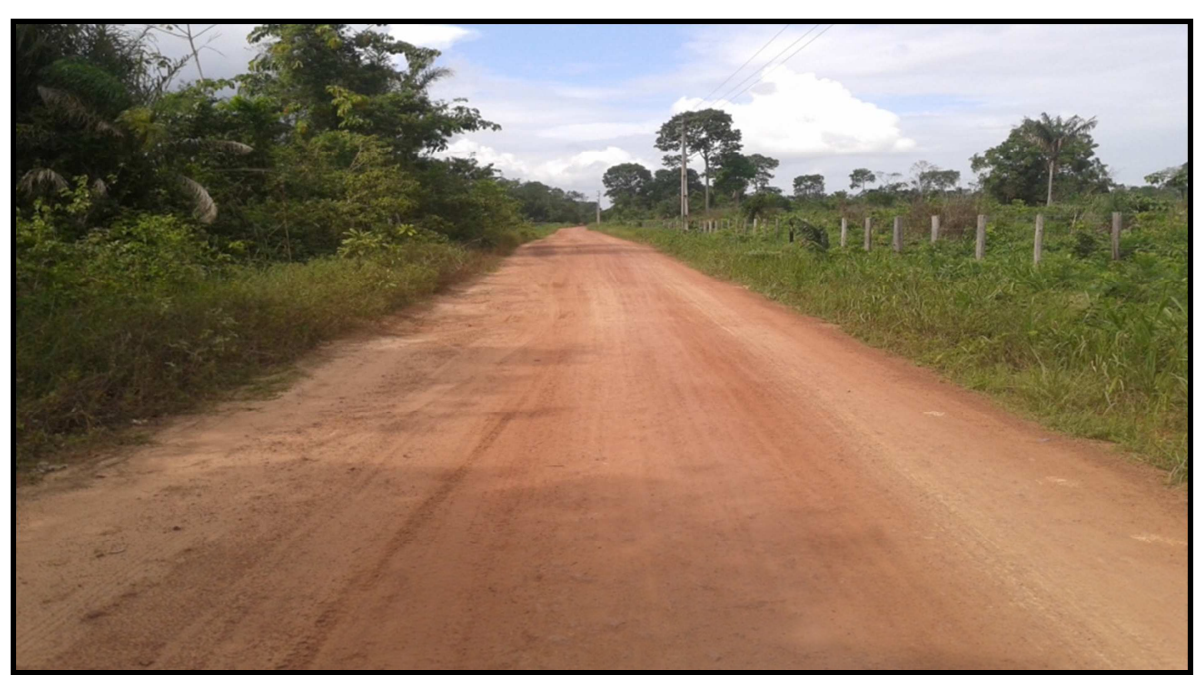

Fonte: Márcio Benassuly (2015)

O ramal do Cardoso, também em Baião, fica próximo à comunidade de Calados. O ramal do Patauateua, em Cametá, está localizado próximo à rodovia PA-151, entre os municípios de Igarapé Miri e Mocajuba (Figura 33). Trata-se de uma localidade onde residem agricultores que têm na lavoura da mandioca a sua principal ocupação.

Figura 33: Aspectos do ramal Patauateua, em Cametá

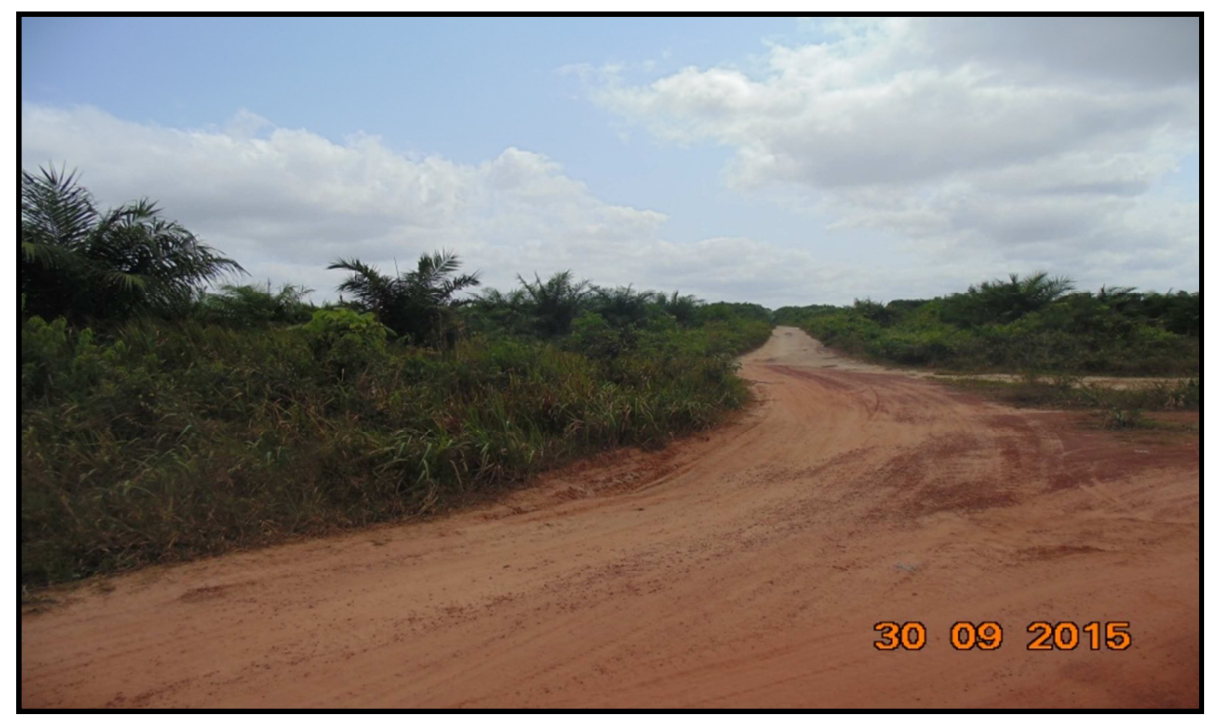

Fonte: Márcio Benassuly (2015) 
O ramal Livramento, em Cametá, localizado próximo ao ramal do Patauateua, tem características semelhantes a esta localidade. Em trabalho de campo, nossos dois entrevistados informaram que legalmente os ramais do Patauateua e Livramento pertencem ao município de Igarapé Miri, que prestaria poucos serviços nestas localidades. Segundo estes entrevistados, os projetos que possuem do Pronaf Eco-Dendê contemplam Cametá e não Igarapé Miri, pois as relações sindicais rurais destes ramais ocorrem mais com o primeiro município e até mesmo com Mocajuba, que estão mais próximos.

O ramal Cenira, em Mocajuba, está localizado próximo à PA-151, a poucos quilômetros da sede municipal. O ramal Igarapé do Meio, também em Mocajuba, localiza-se próximo ao ramal Cenira e tem características semelhantes a esta localidade (Figura 34).

Figura 34: Entrada para o ramal Igarapé do Meio, em Mocajuba

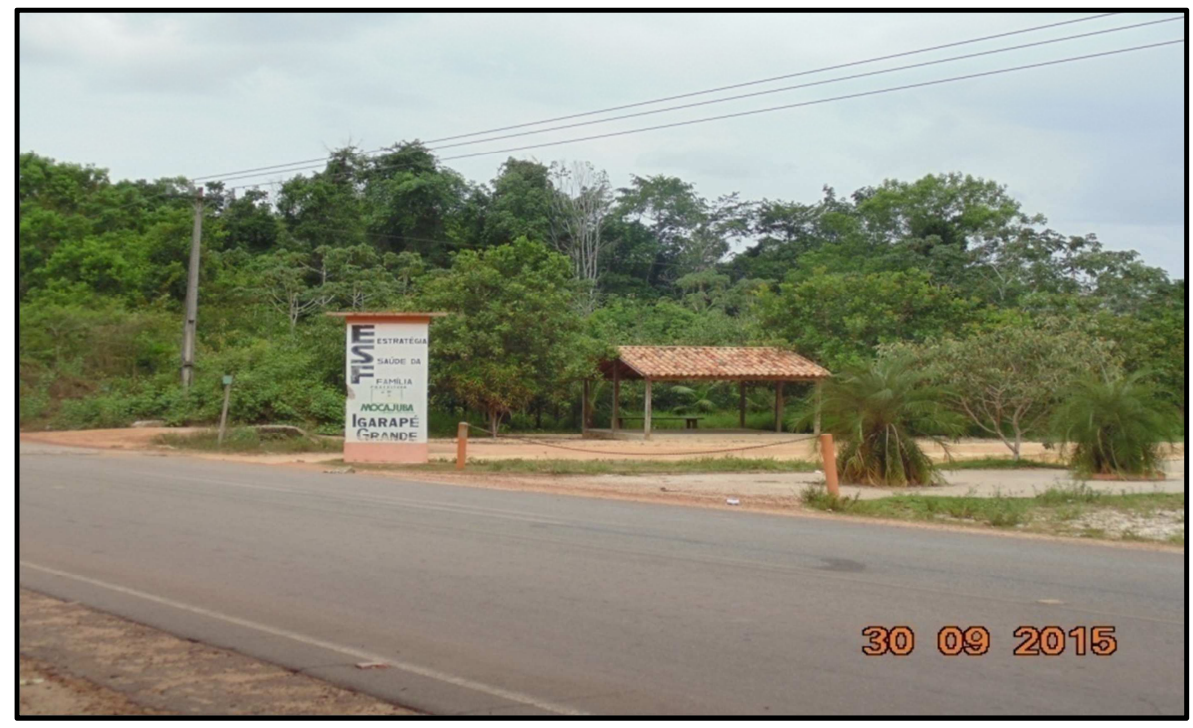

Fonte: Márcio Benassuly (2015)

A comunidade Nova Paz, em Tailândia, tem seu acesso pela PA-150, sentido MojuTailândia (Figura 35). Trata-se de uma localidade que segundo os moradores, legalmente pertence ao município de Moju, porém devido à proximidade territorial com a sede de Tailândia, este vem sendo atendido por serviços desta prefeitura que mantém escolas, postos de saúde, faz manutenção das vicinais, além de outros serviços. No trabalho de campo constatamos que a população local deseja que em breve esta disputa territorial entre os dois municípios seja resolvida, com a possível transferência desta localidade para o domínio territorial legal de Tailândia. Também afirmaram que pelo fato do município de Moju ser muito extenso territorialmente, a administração municipal não consegue atender com prestação de obras e serviços o seu território. 
Figura 35: Ramal de acesso à localidade de Nova Paz, PA-150, em Tailândia

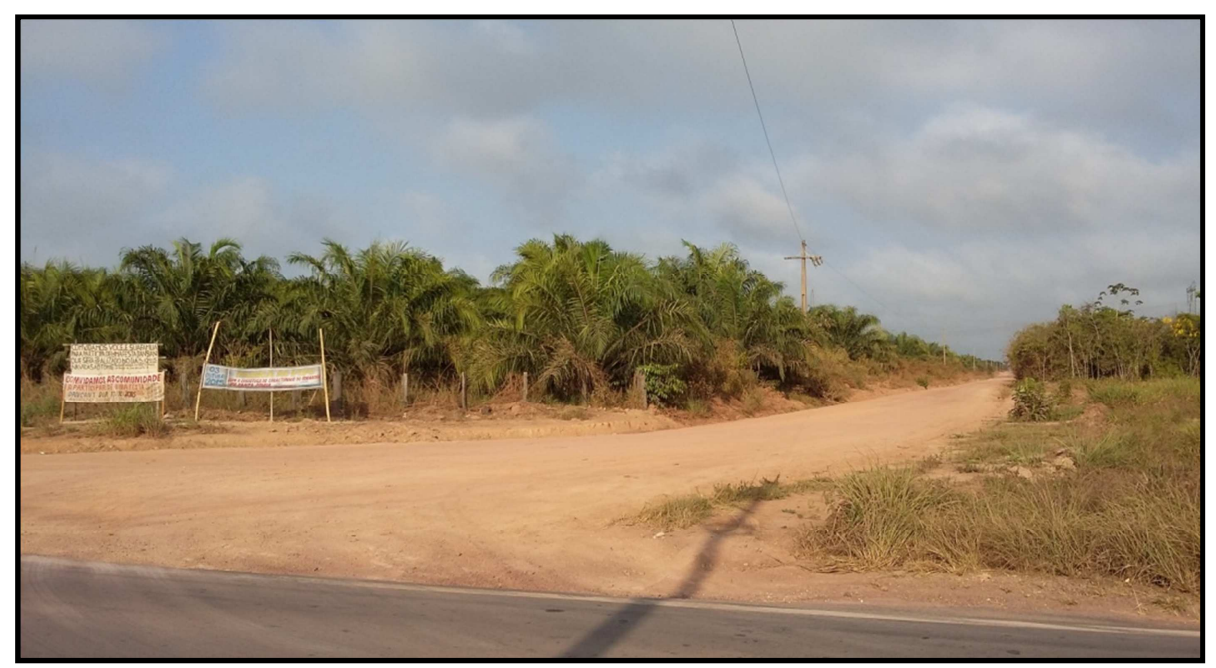

Fonte: Márcio Benassuly (2015)

A comunidade de Nova Paz tem um núcleo de residências onde também está o campo de futebol, a escola municipal, a Igreja Católica e a sede da Associação Agrícola dos Moradores da Comunidade Nova Paz (Agricompaz), que mantém uma escola de informática básica para a comunidade. Fora deste núcleo de residências, as casas estão dispersas ao longo dos diversos ramais existentes. O campo de futebol é o lugar onde os moradores se reúnem para a prática deste esporte sempre no final da tarde (Figura 36).

Figura 36: Aspectos da localidade de Nova Paz, em Tailândia.

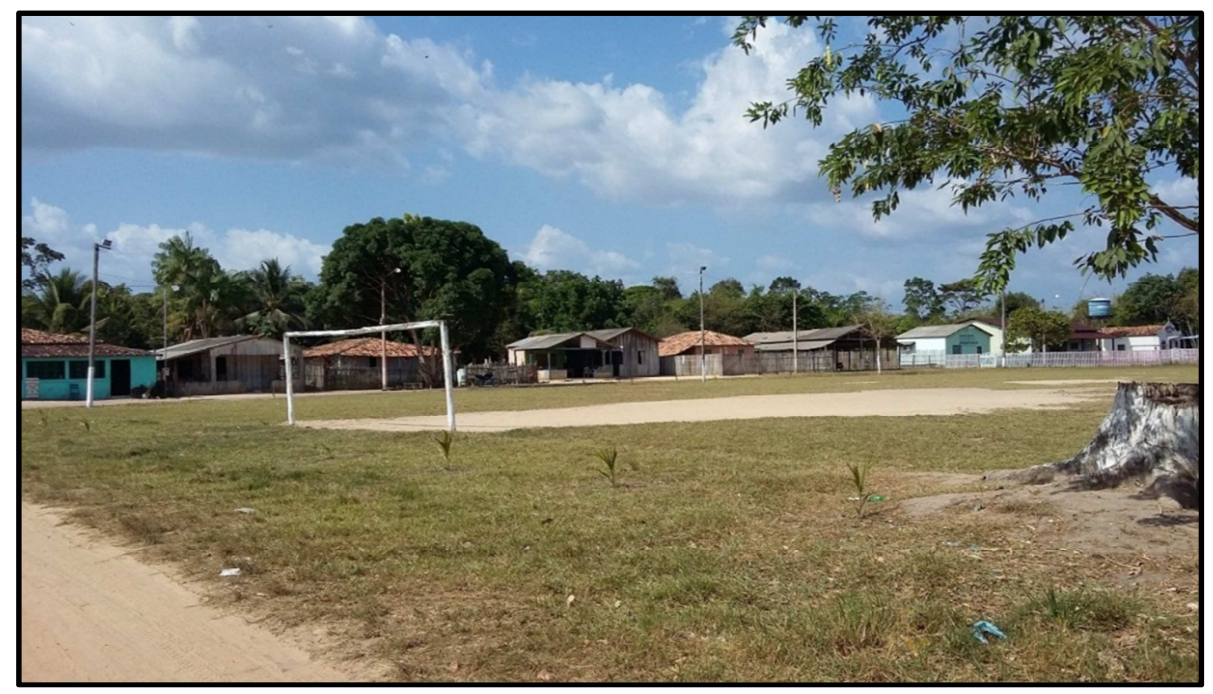

Fonte: Márcio Benassuly (2015)

Nesta comunidade, a Embrapa Amazônia Oriental, em associação com a Belém Bioenergia Brasil, vem promovendo experiências de consorciamento de várias culturas (macaxeira, feijão, milho e arroz) no dendezal. Em visita de campo, pudemos verificar duas unidades experimentais na propriedade do agricultor Oziel Ferreira Lima e uma segunda na 
propriedade do agricultor Élson Silva. Segundo este último entrevistado, os experimentos apresentaram bons resultados e que já plantou de forma consorciada mandioca e dendê e que os resultados foram bons, pois, no caso da mandioca a renda já começa no primeiro ano de plantio, já o dendê somente depois do terceiro ano. Estes experimentos de consorciamento de diferentes culturas agrícolas demonstraram, segundo o entrevistado, que é possível o plantio de mandioca, arroz, milho e feijão junto com o dendê. Segundo ele, no período improdutivo de três anos do dendê, os agricultores têm muitas dificuldades para manter a família sem atividades econômicas complementares.

A comunidade Betel, em Tailândia, localiza-se às margens dos km 94-95 da rodovia PA-150. Aí existe um núcleo de residências onde parte da população vive de atividades agrícolas (Figura 37).

\section{Figura 37: Aspectos da localidade de Betel, km 95 da PA-150, em Tailândia.}

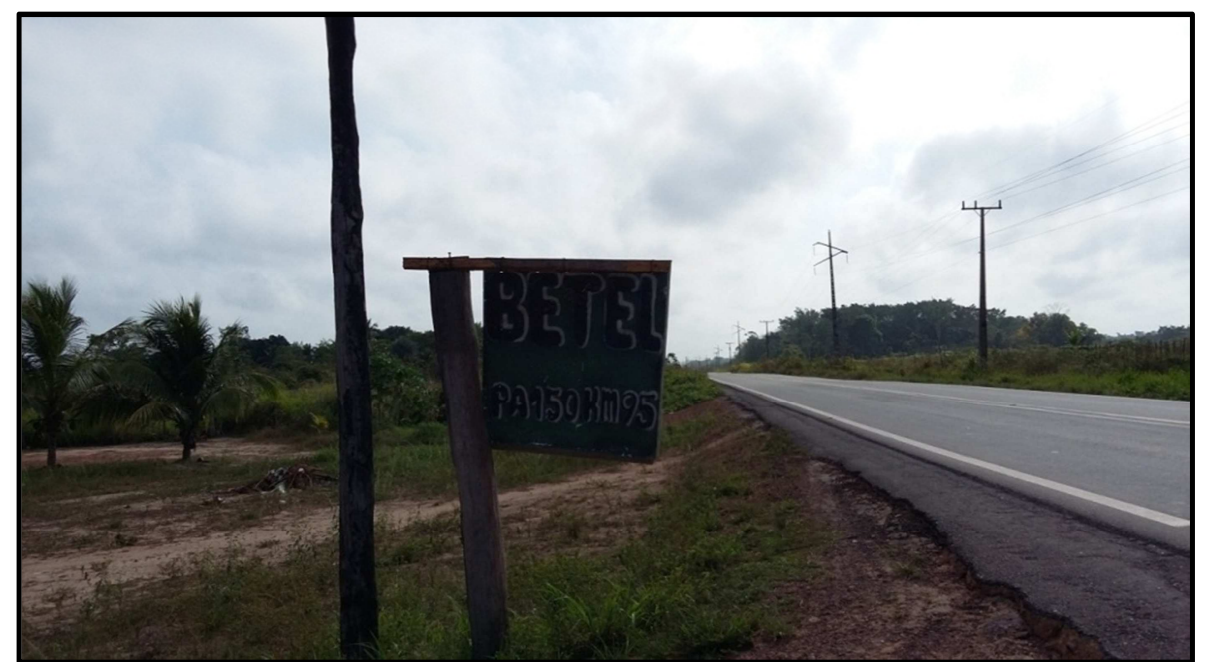

Fonte: Márcio Benassuly (2015)

As localidades anteriormente descritas apresentam uma especificidade que resulta do processo de ocupação de cada lugar em destaque. Em Baião, Cametá e Mocajuba, estas localidades visitadas se diferem das demais justamente pela presença de plantios de dendê que nestes municípios é uma cultura que foi introduzida somente em 2013, por meio de incentivos governamentais, tendo em vista a montagem de um polo de dendê na região para abastecer a região Norte do Brasil de biodiesel. Em todas estas localidades visitadas a agricultura é a principal atividade econômica. 


\subsubsection{Resultados da pesquisa empírica}

Tamanho das propriedades, área plantada e valor dos financiamentos dos agricultores familiares de dendê integrados à Belém Bioenergia Brasil. As propriedades visitadas variam de tamanho, com 38, 48, 50, 63 e 68 hectares, respectivamente. Este dado chama atenção para o fato de que em muitos municípios a estrutura fundiária está pautada no minifúndio, o que certamente foi fator de dificuldade para a adesão de agricultores com o tamanho de terras apropriadas para o projeto de dendê familiar. Nestas propriedades visitadas este tamanho da terra permite o uso de 10 hectares para o plantio de dendê e o restante é destinado para reserva legal e cultivo de outras culturas agrícolas. Até o início da colheita que ocorre a partir do terceiro ano, este agricultor vive de uma parcela do crédito do Pronaf Eco-Dendê e de outras atividades que tem que desenvolver, pois precisa atender as necessidades básicas de sua família.

A área plantada dos dezoito agricultores familiares entrevistados foi de 10 hectares financiados pelo Pronaf Eco-Dendê de $\mathrm{R} \$ 80.000,00$. Os financiamentos preveem parcelas que têm como objetivo a manutenção do dendezal. Em entrevista, um agricultor de Tailândia afirmou: "estou recebendo no banco $\mathrm{R} \$ 970,00$ de dois em dois meses para fazer a manutenção do dendezal" (Entrevista realizada pelo pesquisador com agricultor ${ }^{101}$ familiar integrado em Tailândia, em 10.09.2015). A Figura 38 mostra detalhes de plantio de dendê familiar na comunidade de Betel, já a Figura 39 mostra projetos de dendê na comunidade de Nova Paz em Tailândia.

Figura 38: Projeto de dendê familiar na comunidade de Betel, em Tailândia

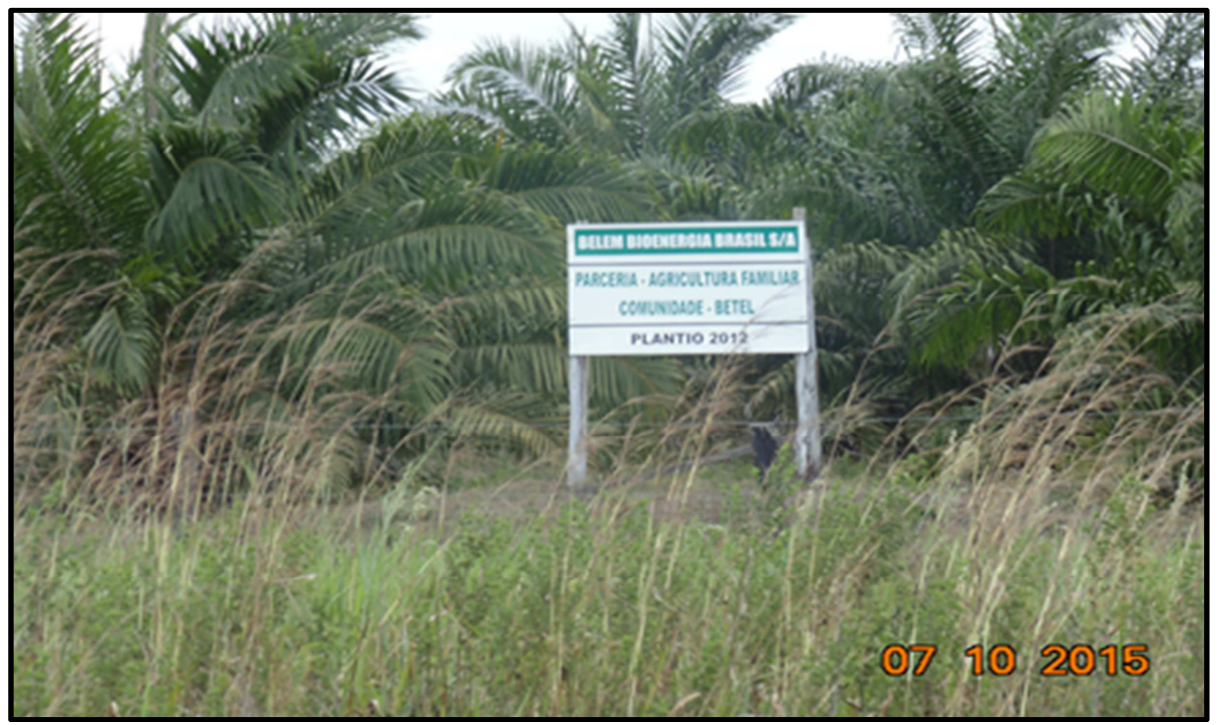

Fonte: Márcio Benassuly (2015)

\footnotetext{
${ }^{101}$ Para manter a privacidade dos agricultores, não serão citados seus nomes nesta pesquisa.
} 


\section{Figura 39: Projeto de dendê familiar na comunidade Nova Paz, em Tailândia}

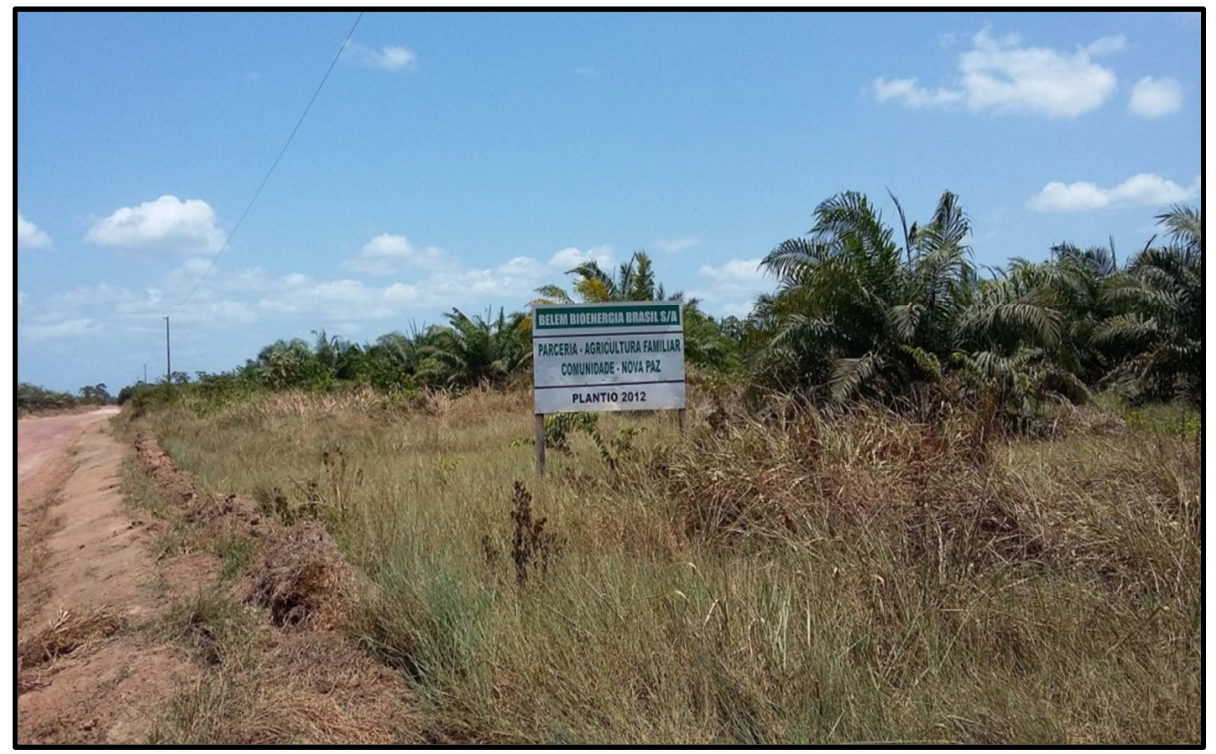

Fonte: Márcio Benassuly (2015)

Quantidade produzida na propriedade familiar de dendê integrado à Belém Bioenergia Brasil. A produção de dendêdos agricultores integrados à Belém Bioenergia Brasil no Baixo Tocantins (PA), pesquisados em 2015, apresenta uma variação de acordo com o ano de início do plantio, dos tratos culturais dedicados ao seu dendezal familiar, além do fator territorial em especial dos agricultores remanescentes do projeto Pará concebido pela Pbio e incorporado em 2012 pela BBB.

Foram entrevistados dezoito agricultores familiares com projetos integrados à Belém Bioenergia Brasil, em que constatamos que a produção destas propriedades varia. Desta forma, passamos a descrever a situação em cada projeto nas localidades visitadas em 2015.

No ramal do Limãozinho, em Baião, foi entrevistado um agricultor integrado. O início do plantio de dendê deste agricultor ocorreu em março de 2013. Em entrevista (29.09.2015), afirma que ainda não realizou colheita, pois nos projetos remanescentes do projeto Pará incorporados em 2012 pela BBB não há definição de como será realizada esta colheita e transporte, pois em municípios do projeto (Mocajuba, Cametá e Baião) seriam apenas 23 projetos, o que não justificaria a viabilidade econômica do transporte desta produção para a sede do polo da empresa que fica em Tailândia. Constatamos que uma parte desta produção já está se perdendo por falta de uma definição da colheita dos cachos de frutos no município de Baião (Figura 40). Esta situação se repete no ramal do Cardoso, também em Baião. 
Figura 40: Cachos de dendê em estado de colheita, em Baião

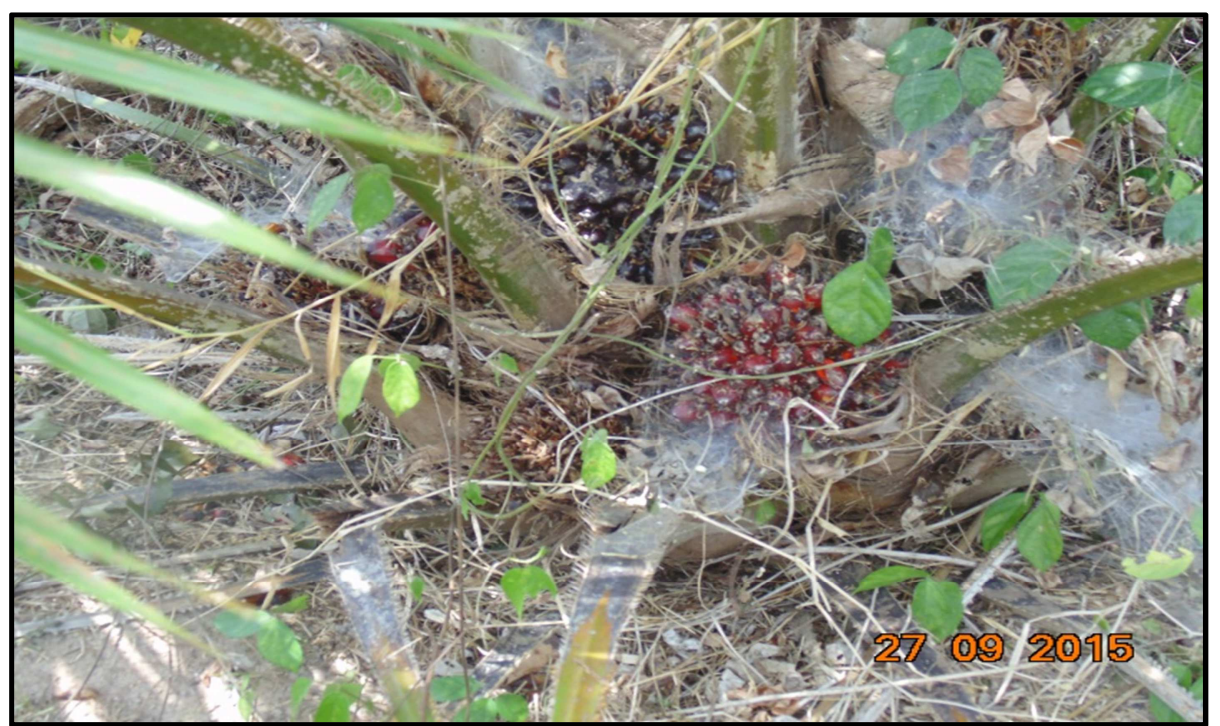

Fonte: Márcio Benassuly (2015)

No ramal do Patauateua, em Cametá, o início do plantio foi em abril de 2013 em que o entrevistado (30.09.2015) afirmou que ainda não realizou colheita, situação semelhante do agricultor (30.09.2015) do ramal do Livramento, também em Cametá.

No ramal Cenira, em Mocajuba, o início do plantio é de março de 2013 e o entrevistado (30.09.2015) afirma que ainda não realizou nenhuma colheita, situação semelhante do agricultor (30.09.2015) do ramal do Igarapé do Meio. O que se constata é que na prática os projetos remanescentes do projeto Pará de dendê da Pbio não apresentam viabilidade econômica que justifique na atualidade a colheita e o transporte dos cachos de dendê destes municípios para a usina de beneficiamento indicada pela BBB. Na prática, não se sabe ainda como ficará esta situação dos financiamentos do Pronaf Eco-Dendê dos agricultores junto ao Banco da Amazônia (Basa).

Na comunidade Nova Paz (Tailândia), que faz parte do projeto Belém, a situação é mais confortável que a realidade dos municípios de Cametá, Mocajuba e Baião. Nesta comunidade foram entrevistados nove agricultores familiares integrados, onde sete agricultores informaram que o início dos plantios em suas propriedades teve inicio em 2012 e dois informaram que o início do plantio em sua propriedade ocorreu em 2013, sendo que estes últimos ainda não realizaram colheita de frutos.

A produção dos sete agricultores com plantio iniciados em 2012 foram os seguintes. O primeiro agricultor entrevistado (09.09.2015) informou que sua colheita iniciou em 2015 e que já contabilizou 8 toneladas neste ano até a data da presente entrevista. A empresa paga em 
média $\mathrm{R} \$ 200,00$ por tonelada ${ }^{102}$ de dendê, o que rendeu $\mathrm{R} \$ 1.600,00$. O segundo agricultor entrevistado (09.09.2015) disse que sua colheita teve início em 2015 e que já realizou quatro coletas de frutos em sua propriedade. Na primeira colheita foram coletados 1.200 quilos, na segunda, 700 quilos, na terceira 800 quilos e na quarta colheita foram 780 quilos, o que totalizou 3.480 quilos e gerou uma renda de $\mathrm{R} \$ 696,00$. O terceiro agricultor entrevistado (09.09.2015) argumentou que sua colheita teve início em 2015 e que já realizou quatro colheitas que totalizaram 1.200 quilos de dendê, o que gerou uma renda de $\mathrm{R} \$ 240,00$.

O quarto agricultor entrevistado (10.09.2015) também informou que ainda não realizou colheita em sua plantação de dendê. O quinto agricultor entrevistado (10.09.2015) disse que ainda não realizou colheita em sua propriedade. O sexto entrevistado (09.09.2015) afirmou o mesmo. O sétimo agricultor entrevistado (09.09.2015) argumentou que sua colheita teve início em 2015 e que já realizou quatro colheitas. Na primeira coletou 1.367 quilos, na segunda 1.934 quilos, na terceira 1.509 quilos, na quarta 1.515 quilos de dendê. Esta produção totalizou 6.325 quilos, o que gerou uma renda de $\mathrm{R} \$ 1.265,00$, informou ainda que de dois em dois meses o Basa libera $\mathrm{R} \$ 1.000,00$ como parcela do financiamento que deve ser aplicada na manutenção do dendezal, em serviços de limpeza, coroamento etc.

Na comunidade de Betel (Tailândia), entrevistamos três agricultores integrados. O primeiro agricultor entrevistado (11.09.2015) disse que seu plantio teve início em 2012 e que ainda não realizou colheita. O segundo (11.09.2015) afirmou que ainda não fez colheita e que seu plantio teve início em 2012. O terceiro (11.09.2015) afirmou que seu plantio iniciou em 2012 e que já realizou quatro colheitas. Na primeira foram coletados 700 quilos, na segunda 800 quilos, na terceira 700 quilos e na quarta foram 2.282 quilos, o que totalizou 4.482 quilos, e gerou a renda de $\mathrm{R} \$ 896,40$.

Valor da cotação de dendê, diretrizes da empresa e avaliação do sistema de integração pelos agricultores integrados a Belém Bioenergia Brasil. Em sua totalidade os agricultores familiares de dendê afirmaram que não sabem como é feito o cálculo da cotação do preço pela bolsa de valores de Rotterdam, na Holanda. A empresa utiliza a bolsa como referência de pagamentos tendo como base o dólar, e como medida de referência a tonelada de dendê. As diretrizes da empresa para o dendezal são repassadas pelo profissional em assistência técnica da empresa. Todos os entrevistados afirmaram que seguem as orientações passadas pela empresa.

\footnotetext{
${ }^{102}$ Em trabalho de campo vários entrevistados nos apresentaram vários recibos de venda com a devida cotação da tonelada de dendê pagos pela empresa que segue a bolsa de Rotterdam onde consta o endereço www.oilword.biz e o valor desta cotação que é paga ao produtor.
} 
Os agricultores entrevistados fizeram ressalvas sobre este modelo de integração da agricultura familiar à cadeia do agronegócio, afirmando que existem deficiências na coletas dos cachos de dendê das propriedades, onde constatamos a insuficiência de caixas coletoras dos frutos em Tailândia.

Sobre a decisão de aderir a este sistema, um agricultor de Baião afirmou que:

Essa decisão começou com umas reuniões, a proposta deles era boa. O cara ficava ganhando um salário todo mês até começar a produzir, a muda eles diziam que era doada, eles não iam cobrar. Nessa reunião foi falado que seria doado aí eu fiquei. Já que é muito bom, eu vou ficar. Eles falavam que não tinha problemas dever para o banco (Entrevista realizada pelo pesquisador com agricultor familiar integrado em Baião, em 29.09.2015, grifos nossos).

Para conseguir a adesão de agricultores familiares para o projeto de integração à empresa fez uma série de promessas que não foram cumpridas. Desta forma, os agricultores foram penalizados pelo não cumprimento das promessas da empresa, fato que tem dificultado a continuidade do projeto na atualidade.

Assistência técnica, existência de outras culturas agrícolas, avaliação da assistência técnica e mão-de-obra utilizada nos dendezais de agricultores integrados à Belém Bioenergia Brasil. Os entrevistados afirmaram que a assistência técnicaé realizada mensalmente por técnico agrícola da empresa integradora. Sobre o trabalho deste profissional avaliam que é bom o que o mesmo realiza nos dendezais, com algumas ressalvas de que este profissional deveria escutar mais o agricultor, quando da imposição das normas da empresa.

Nos dois projetos de dendê familiar visitados em Baião, constatamosoutras culturas existentes nas propriedades como pimenta-do-reino e mandioca. Nos dois projetos visitados em Cametá foram mandioca e arroz. Nos dois projetos pesquisados de Mocajuba foram pimenta-do-reino e mandioca. E nos doze projetos visitados de Tailândia, mandioca, milho e pimenta-do-reino.

Quanto à avaliação da assistência técnica em todas as propriedades visitadas (Baião, Cametá, Mocajuba e Tailândia), os agricultores integrados afirmam que a assistência técnica é insuficiente para atender as necessidades do dendezal.

Quanto à mãodeobra utilizada nos dendezais, constatamos que é constituída normalmente por pai e filhos. Em determinadas situações utiliza-se trabalho assalariado em capinas e colheitas, quando a diária varia de $\mathrm{R} \$ 40,00$ a $\mathrm{R} \$ 50,00$. Outros preferem a empreita $^{103}$ de trabalhos, variando de acordo com o trabalho e o tempo a ser realizado.

\footnotetext{
${ }^{103}$ Trabalho onde é combinado previamente o valor do serviço.
} 
Atividades econômicas complementares, o dendê como a principal atividade econômica, e aspectos que a empresa deveria melhorar. Em trabalho de campo, constatamos que muitos dos agricultores familiares integrados à Belém Bioenergia Brasil exerciam atividades econômicas complementares ao dendezal. Na comunidade de Nova Paz, em Tailândia, por exemplo, foi formada uma agroindústria comunitária de beneficiamento de mandioca (Figura 41), onde é produzida farinha de mandioca, e a maior parte dos sócios são agricultores que também produzem dendê.

Figura 41: Agroindústria de beneficiamento de mandioca, comunidade Nova Paz, Tailândia, Pará

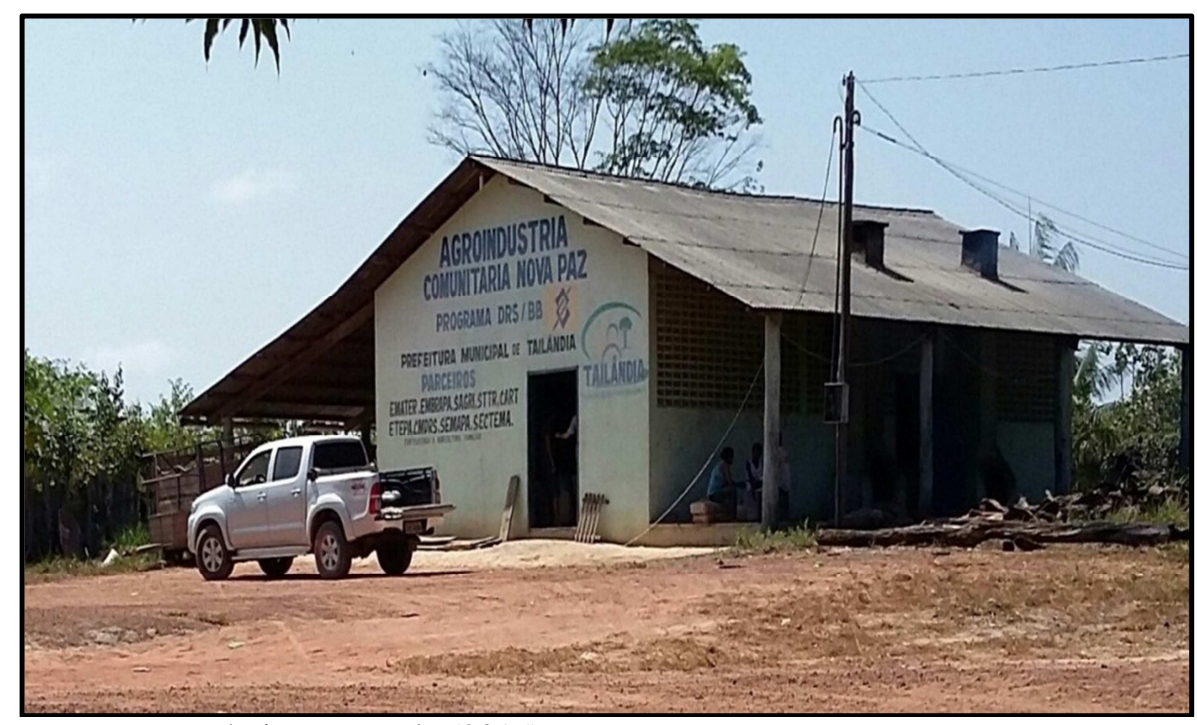

Fonte: Márcio Benassuly (2015)

Em Baião, a principal atividade econômica dos agricultores integrados de dendê é proveniente da lavoura da pimenta-do-reino. Em Cametá, é a mandioca. Em Mocajuba é a pimenta-do-reino. Vale destacar que os agricultores destes três municípios até 2015 não tinham realizado colheita da produção de dendê.

Mesmo em Tailândia, onde entrevistamos agricultores com plantio de 2012 e 2013, nenhum afirmou que o dendê é a principal atividade econômica. Neste município encontramos agricultores integrados com financiamento do Pronaf Eco-Dendê trabalhando com a cultura de mandioca, banana e laranja, da qual vinha a principal renda de suas famílias.

Segundo um agricultor de Tailândia ao ser questionado sobre a sua principal atividade econômica, afirmou que é "a mandioca, todo mês eu faço em média 30 a 40 sacos de mandioca" (Entrevista realizada pelo pesquisador com agricultor familiar integrado em Tailândia, em 09.09.2015).

Para os agricultores integrados entrevistados, a empresa deveria melhorar em aspectos como maior flexibilidade na imposição das normas de como produzir na agricultura familiar 
sobre as diretrizes da empresa de dendê. Vale destacar que os modelos de racionalidade na agricultura familiar são diferentes da agricultura empresarial. Os agricultores afirmam que o modo da empresa lidar como o agricultor precisaria de mais diálogo, o que não existe, pois a empresa apresenta suas normas geralmente por meio do técnico agrícola que devem ser cumpridas pelos agricultores integrados.

Neste aspecto, um agricultor integrado de Baião afirmou que:

\begin{abstract}
A relação da empresa logo que começou era bacana, depois eles deixaram a desejar, saíram daqui e levaram tudo para Tailândia. Logo no começo, era direto eles aqui, tanto os técnicos como a própria direção da empresa. Agora acabou. Às vezes vinham não só um técnico, às vezes vinha dez técnicos fazer a análise do dendezal (Entrevista realizada pelo pesquisador com agricultor familiar integrado em Baião, em 29.09.2015, grifo nosso).
\end{abstract}

Durante a execução das atividades do projeto de integração a empresa tem deixado de cumprir com uma série de compromissos que tem prejudicado os agricultores familiares.

Outro agricultor de Baião afirmou: "deveriam melhorar bastante o adubo que eles mandam, para gente fazer o coroamento e o adubo não chega. Desde o início só veio uma vez adubo" (Entrevista realizada pelo pesquisador com agricultor familiar integrado em Baião, em 29.09.2015).

No sistema de produção integrado de dendê a empresa exerce uma posição de mando, uma vez que, centraliza uma série de ações que nem sempre consegue exercer com eficiência, penalizando desta forma os agricultores integrados na execução das atividades nos dendezais familiares.

Outro agricultor de Tailândia afirmou que:

Primeiro eles falaram que iam apanhar o dendê perto, já agora já estão botando a caçamba lá longe. Aí a gente tem que pagar transporte até lá. Para mim acho que eles falharam nesse ponto até por que eles falaram que iam apanhar o dendê no pé da roça (Entrevista realizada pelo pesquisador com agricultor familiar integrado em Tailândia, em 09.09.2015).

Pelo relato do entrevistado a empresa na execução do projeto não tem cumprido com sua responsabilidade do transporte da produção com eficiência, onde em trabalho de campo constatamos a falta de caixas coletoras para atender todos os agricultores integrados.

Outro agricultor relatou: "a gente tem que levar até um local, só o trator para levar até lá é $\mathrm{R}$ \$ 70,00 é mais R\$ 30,00 por tonelada. Aí dificulta” (Entrevista realizada pelo pesquisador com agricultor familiar integrado em Tailândia, em 09.09.2015) 
Para reduzir custos na coleta dos cachos de frutos de dendê a empresa tem concentrado a localização das caixas coletoras em pontos estratégicos, o que para muitos agricultores implica em mais despesas de deslocamento da produção do dendezal para as referidas caixas coletoras.

Situação socioeconômica do agricultor do agricultor, colheita, regularização das propriedades e dúvidas do contrato assinado com a empresa. Em todos os projetos visitados, os entrevistados disseram que até o momento não melhorou a sua condição econômica. Os projetos implantados pela Pbio e posteriormente incorporados pela BBB nos municípios de Baião, Cametá e Mocajuba não têm perspectiva de fazer a coleta dos cachos de dendê, pois os custos de transporte até a cidade de Tailândia não justificam o investimento. Quanto à produção das comunidades de Betel e Nova Paz, em Tailândia, a situação da produção e consequentemente da renda depende de diversos fatores, tais como tratos culturais onde a limpeza da área e a adubação são fundamentais. Outro fator que contribui para esta avaliação é a idade do dendezeiro, que só começa a produção de frutos a partir do terceiro ano de vida

A colheita da produção de dendê é realizada de 15 em 15 dias, ou seja, duas vezes ao mês,durante todo o ano. Nesta fase da colheita, os cachos são retirados com ferro de cova e depois são transportados do dendezal para as caixas coletoras localizadas em pontos estratégicos para facilitar o maior número de agricultores nas localidades de produção familiar de dendê. Todas as propriedades possuem declarações de posse emitidas pelo Instituto de Terras do Pará (Iterpa) ou pelo Instituto Nacional de Colonização e Reforma Agrária (Incra), exigência legal para a concessão do financiamento agrícola do Pronaf Eco-Dendê.

Os entrevistados disseram que tinham dúvidas em diversas cláusulas do contrato ${ }^{104}$. Sem saber detalhar tais dúvidas, as mais comuns foram às relacionadas ao preço da tonelada de dendê. No sistema de integração, os agricultores familiares de dendê, por meio do contrato de compra e venda da produção agrícola celebrado com a empresa integradora, comprometem-se em produzir o dendê de acordo com as instruções técnicas, que são reguladas pela empresa mediante assistência técnica de controle do plantio familiar de dendê. Esta relação de integração fica evidente a subordinação dos agricultores familiares às empresas integradoras.

O sistema de produção integrada é regido pelo contrato de compra e venda da produção agrícola familiar, onde são estabelecidas cláusulas de controle da produção e outras

\footnotetext{
${ }^{104}$ Tivemos acesso para leitura a um contrato de agricultor familiar integrado a empresa Belém Bioenergia Brasil, onde contatamos que existe cláusulas de confidencialidade para informações a serem prestadas para pessoas não ligadas diretamente à execução do projeto de dendê familiar.
} 
exigências da empresa. "Os contratos de produção, também denominados contratos de integração, definem as tarefas, as responsabilidades, direitos e deveres entre dois contratantes (a empresa e o produtor integrado)" (BELATO, 1985, p. 322). A decisão do agricultor em aderir ao sistema de produção integrada deve ser tomada levando em consideração as relações do contrato em que se estabelecem as obrigações e os direitos entre integrado e integradora.

Sobre os contratos assinados, existem pontos ainda sem explicação definitiva dos contratos do projeto Pará da Pbio.

\begin{abstract}
Aqui era a Petrobras, depois mudou para a Belém Bioenergia Brasil. A Petrobras entregou para a BBB. Teve dois contratos. O primeiro assinado, o primeiro morreu e o segundo foi assinado e mudaram tudo. O primeiro foi uma coisa, ai quando veio o segundo, já foi outra coisa, aí o negócio já ficou difícil para nós. Agora tudo isto tá sendo da BBB [...] De primeiro eles vinham aqui, agora já mudou porque nesse novo contrato a gente tem que entregar daqui até onde tá a beira do asfalto. Olha era $\mathrm{R} \$ 1.000$ que a gente recebia e depois mudaram já não era mais $R \$ 1.000$ era $R \$ 900, R \$ 700$. Começou a variar no começo era mil de dois em dois meses, já fiz até uns empréstimos pela minha conta própria para ver se dou conta (Entrevista realizada pelo pesquisador com agricultor familiar integrado em Baião, em 29.09.2015, grifo nosso).
\end{abstract}

Os agricultores integrados remanescentes do projeto Pará (Pbio) que foi incorporado pela Belém Bioenergia Brasil em 2012, foram bastante afetados pela descontinuidade das ações do projeto. Esta questão na atualidade é um desafio para os 23 agricultores familiares que convivem com a incerteza do projeto. Segundo relato do entrevistado acima fica evidente as mudanças ao longo dos anos quanto aos recursos disponíveis para a manutenção do dendezal familiar.

Normas da empresa, filiação a sindicato, organização e resistências junto à empresa. De acordo com os agricultores entrevistados, as normas passadas pela empresa afetam suas condutas, pois a lógica da empresa obedece ao mercado onde o agricultor integrado passa a fazer parte da engrenagem do sistema. Estas informações são passadas de forma mais efetiva pelo técnico agrícola que faz visita à propriedade mensalmente.

A maioria dos entrevistados afirmaram que são filiados ao Sindicato dos Trabalhadores e Trabalhadoras Rurais (STTR) dos seus municípios (Baião, Cametá, Mocajuba e Tailândia). A Figura 42 mostra detalhes da sede do STTR de Cametá. 
Figura 42: Sindicato dos Trabalhadores e Trabalhadoras Rurais de Cametá

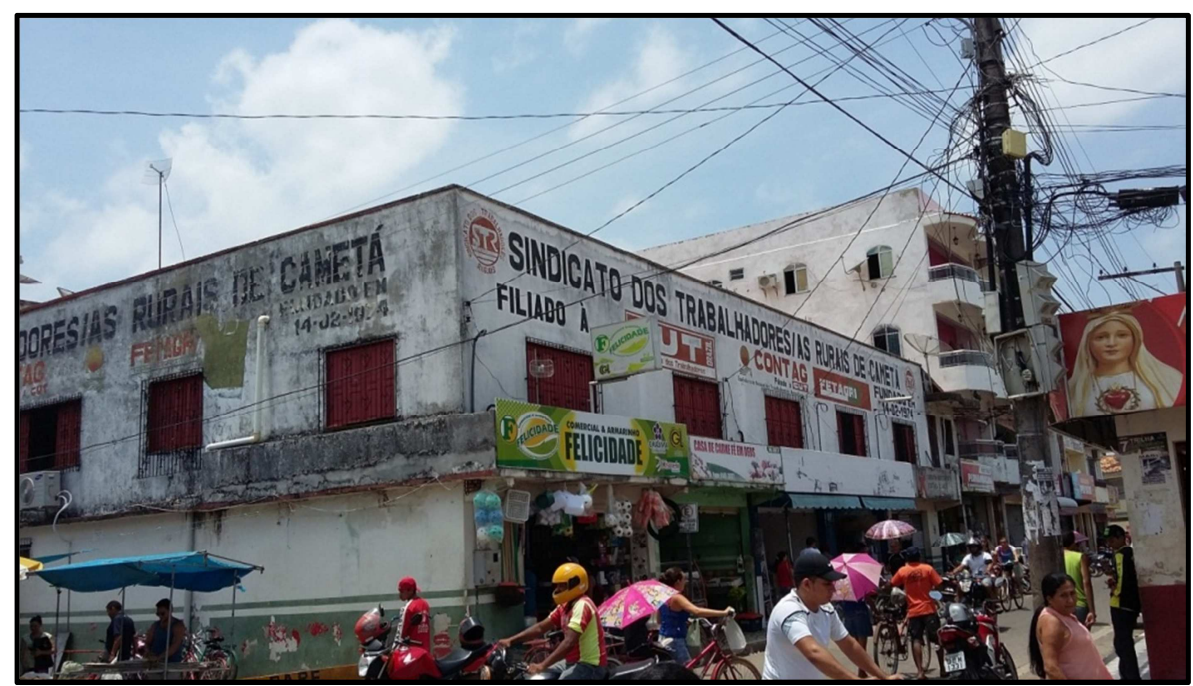

Fonte: Márcio Benassuly (2015)

Além dos STTR, muitos agricultores estão associados em organizações que funcionam nas localidades onde residem. No ramal do Cardoso, que fica próximo à Vila de Calados, em Baião, existe a Associação dos Mini e Pequenos Agricultores Rurais de Calados (AMPFARQ). Na comunidade de Nova Paz em Tailândia existe a Associação Agrícola dos Moradores da Comunidade Nova Paz (Agricompaz) como mostra a Figura 43.

Figura 43: Associação Agrícola dos Moradores da Comunidade Nova Paz, em Tailândia

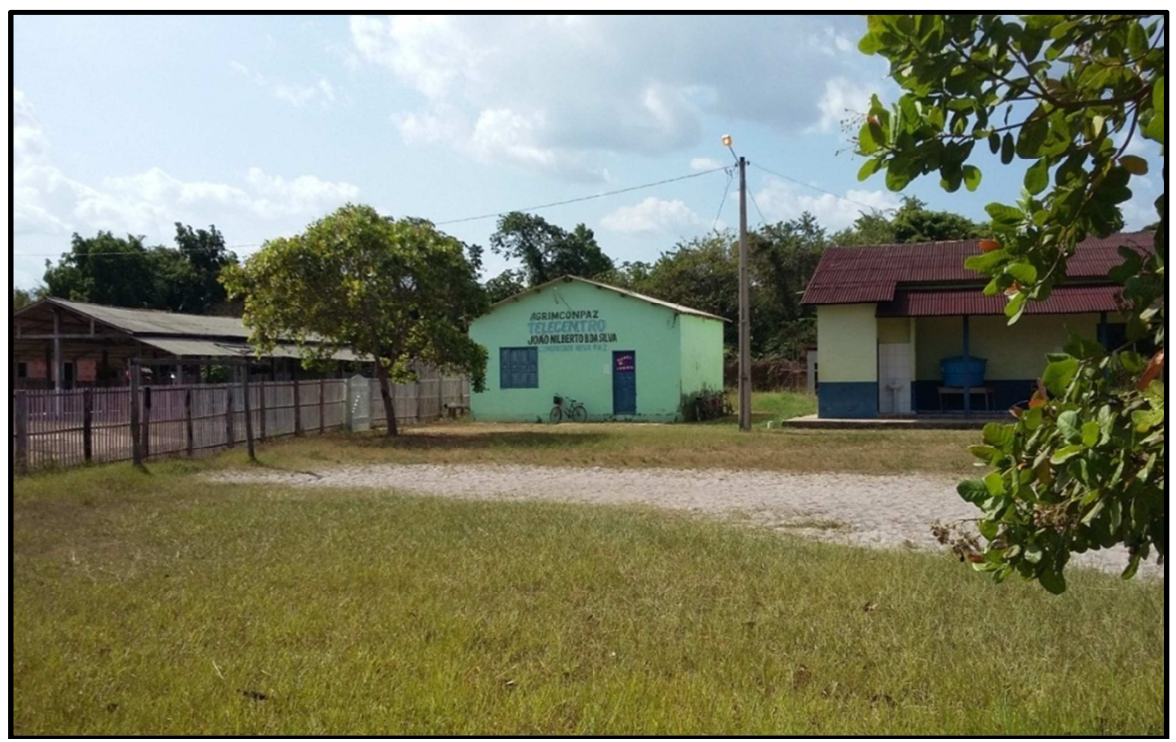

Fonte: Márcio Benassuly (2015)

Como não existe uma organização coletiva e representativa exclusiva dos agricultores familiares integrados de dendê frente à empresa, esses geralmente procuram os STTR nos 
municípios quando têm problemas. As resistências ocorrem de forma limitada, geralmente no âmbito da localidade onde estão presentes os plantios de dendê.

Estratégias de organização político-social, atividade econômica antes e depois da implantação dos projetos de agricultura familiar de dendê. No âmbito da localidade da produção de dendê familiar, as estratégias de organização político-social não passam de diálogos que os agricultores mantém entre si. Não identificamos nenhuma organização constituída capaz de aglutinar os agricultores familiares para fazer a representação junto à empresa integradora. Em Baião os agricultores entrevistados viviam antes da implantação dos projetos de dendê familiar em suas localidades da lavoura da pimenta-do-reino. Em Cametá, da mandioca. Em Mocajuba, da pimenta-do-reino e da mandioca. Em Tailândia, da mandioca.

\subsection{Experiências de integração da agricultura familiar de dendê da empresa Biopalma (Vale + Msp) no Baixo Tocantins (PA)}

Nesta seção apresentamos a experiência da Biopalma em projetos de agricultura familiar de dendê integrado à empresa, visitados em trabalho de campo em 2015.

4.4.1 Territórios da agricultura familiar de dendê regulados pela Biopalma (Vale + Msp) visitados no Baixo Tocantins (PA).

No município de Abaetetuba ${ }^{105}$ existe apenas um projeto de agricultura familiar de dendê integrado à empresa, localizado na comunidade de Camurituba Centro. No município, a Biopalma possui produção agrícola própria de dendê ao longo da PA-151 ${ }^{106}$, próxima das localidades de Murutinga e do Pontilhão.

No município de Acará ${ }^{107}$ existem projetos de agricultura familiar de dendê integrado à empresa nas localidades do ramaldo Ipitinga, ramal Vera Cruz, ramal Jupuuba, ramal da Mariquita, entre outras.

No município de $\mathrm{Moju}^{108}$ o plantio familiar de dendê da Biopalma no município iniciou em 2011. A empresa possui produção agrícola própria em terras de sua propriedade, além de projetos de agricultura familiar integrada. A empresa mantém parceria com projetos de agricultura familiar de dendê distribuídos em diversas localidades do município como: assentamentos do Incra (Olho D’Água I, Olho D’Água II e Calmaria II), localidade de

\footnotetext{
${ }^{105}$ Informação concedida em entrevista realizada pelo pesquisador no STTR de Abaetetuba, em 24.09.2015.

${ }^{106}$ Rodovia estadual no trecho entre os municípios de Abaetetuba e Igarapé Miri.

${ }^{107}$ Informação concedida em entrevista realizada pelo pesquisador no STTR de Acará, em 17.09.2015.

${ }^{108}$ Informação concedida em entrevista realizada pelo pesquisador no STTR de Moju, em 25.08.2015.
} 
Ateuazinho (ramal Bom Futuro), entre outras. No Moju, outras empresas como a Agropalma ${ }^{109}$ e a Marborges ${ }^{110}$ possuem projetos de agricultura familiar de dendê em diversas localidades.

De posse dos dados de localização dos projetos familiares integrados de dendê, visitamos quadro localidades onde funcionam projetos integrados à Biopalma.

Os territórios da agricultura familiar de dendê regulados pela empresa visitados em trabalho de campo, em 2015, foram quatro: ramal do Ipitinga (Acará), ramal Bom Futuro, comunidade Boa Esperança e assentamento Olho D’Água I (Moju), os quais apresentam particularidades. (Quadro 49) Quadro 49: Territórios da agricultura familiar de dendê regulado pela Biopalma
visitados no Baixo Tocantins (PA), 2015

\begin{tabular}{|l|l|c|}
\hline Município & \multicolumn{1}{|c|}{ Localidade } & Agricultores entrevistados \\
\hline Acará & Ramal do Ipitinga & 01 \\
\hline \multirow{3}{*}{ Moju } & Ramal Bom Futuro & 02 \\
\cline { 2 - 3 } & Comunidade de Boa Esperança & 02 \\
\cline { 2 - 3 } & Assentamento Olho D’água I & 08 \\
\hline Total & & 13 \\
\hline
\end{tabular}

Fonte: Trabalho de campo (2015)

O Mapa 16 enfoca o território de atuação da Biopalma e os territórios da agricultura da familiar de dendê regulados pela empresa no Baixo Tocantins em 2015. A empresa tem atuação direta nos municípios de Abaetetuba, Acará e Moju, onde possui projetos de agricultura familiar de dendê integrada.

\footnotetext{
109 A empresa mantém projetos de agricultura familiar de dendê nas comunidades de Arauaí I, Arauaí II, Soledade e assentamento Calmaria II.

${ }^{110}$ A empresa mantém projetos de agricultura familiar de dendê nas comunidades de São Pedro e Severo, localizadas ao longo da PA-252, estrada que liga Moju a Acará.
} 
Mapa 16: Território de atuação da Biopalma e territórios da agricultura familiarde dendê regulado pela empresa no Baixo Tocantins (PA), 2015

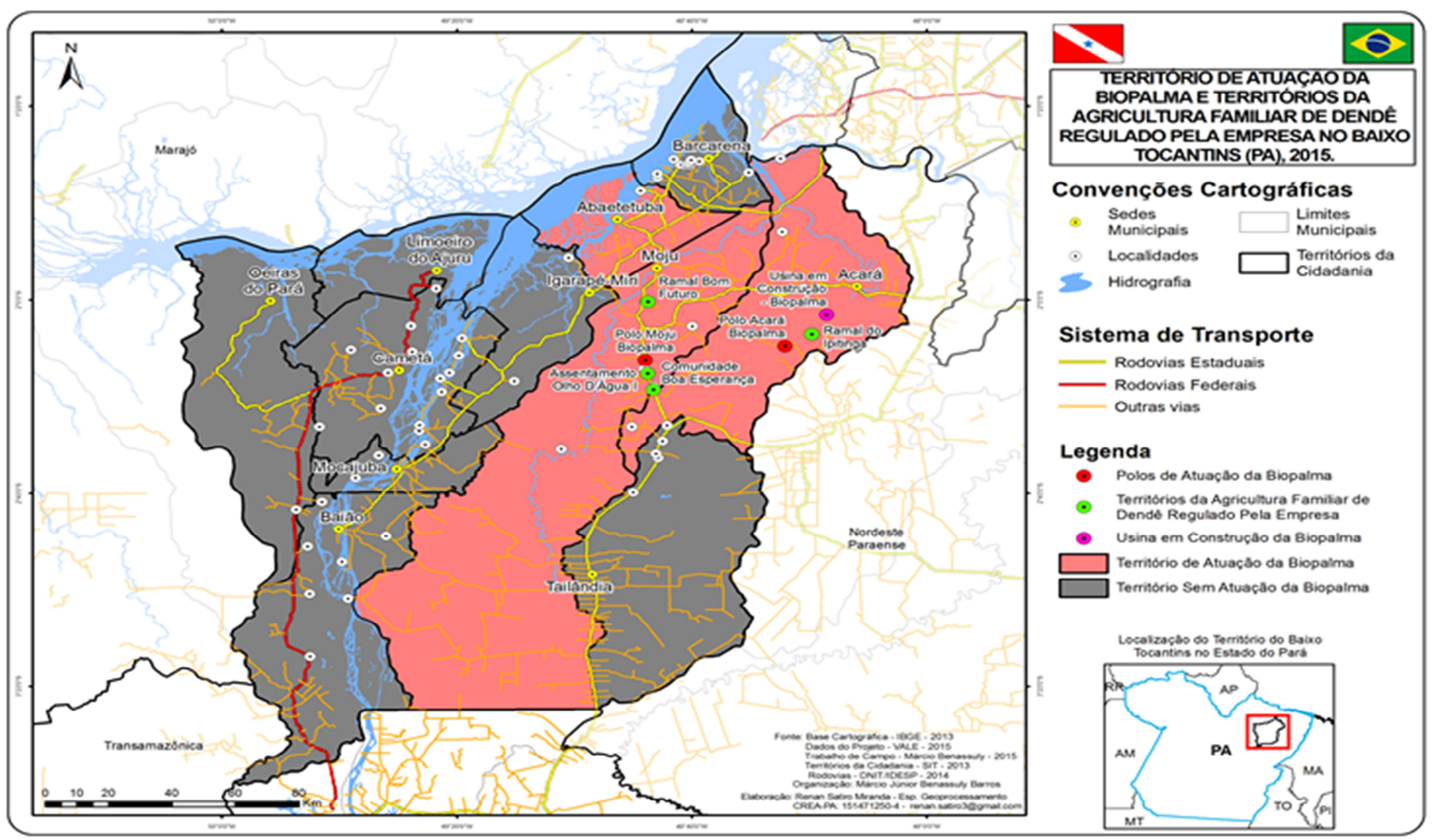


O ramal do Ipitinga localiza-se próximo a grandes plantações próprias e da usina de extração de óleo de palma em construção da Biopalma, no município de Acará. A Figura 44 mostra detalhes de acesso para o ramal do Ipitinga.

Figura 44: Vicinal de acesso para o ramal do Ipitinga, em Acará.

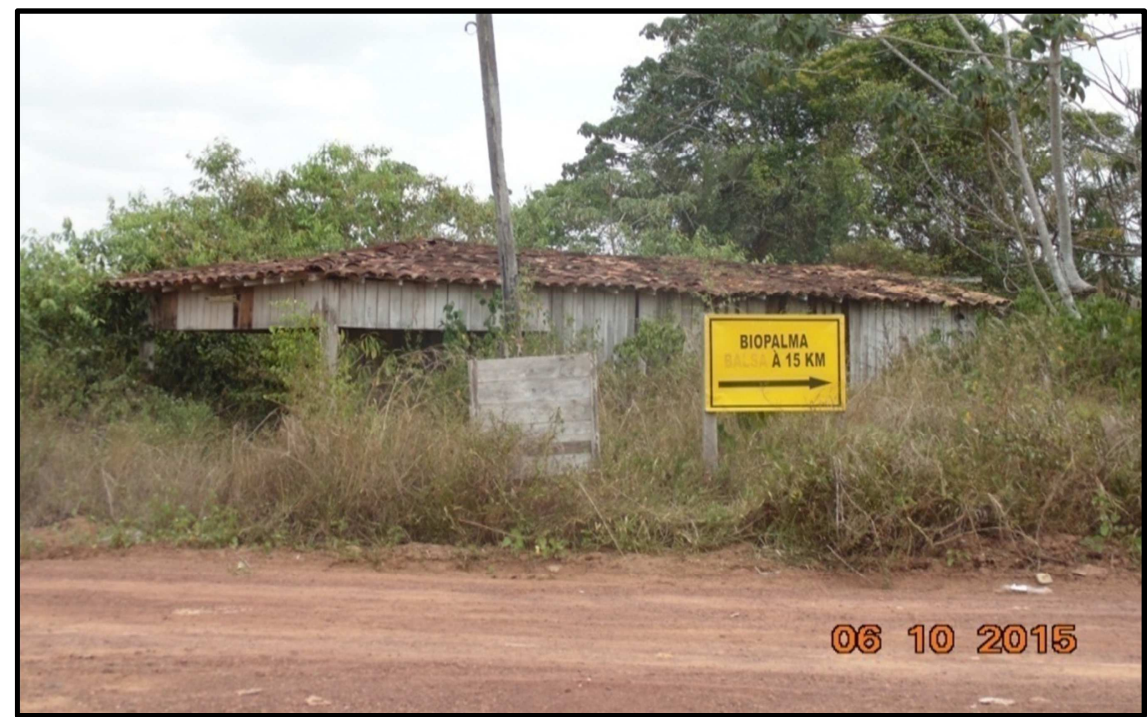

Fonte: Márcio Benassuly (2015)

O ramal do Ipitinga possui um núcleo de residências, onde está localizada a escola municipal, a Igreja Católica e o campo de futebol, como podemos verificar na Figura 45.

Figura 45: Aspecto da localidade de Ipitinga, em Acará.

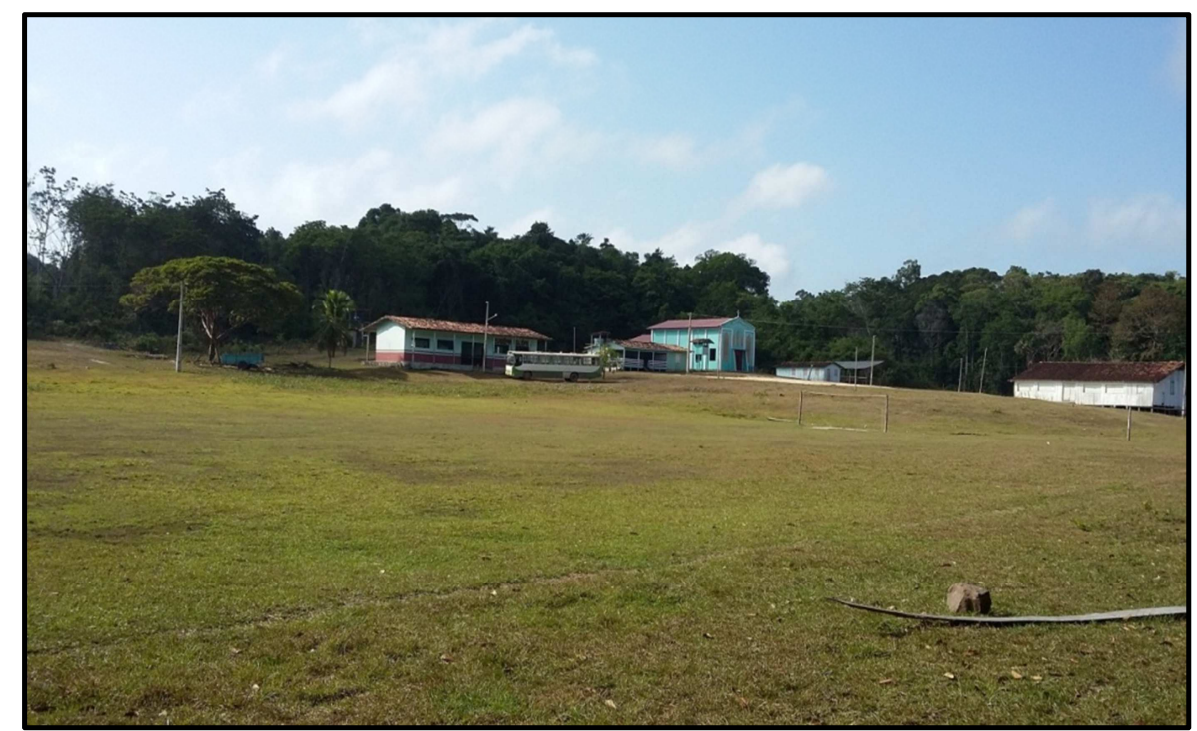

Fonte: Márcio Benassuly (2015)

O ramal Bom Futuro, em Moju (Figura 46), fica nas proximidades da comunidade de Ateuazinho, localizada às margens da PA-150. Em Ateuazinho estão localizadas grandes plantações próprias de dendê da empresa chinesa Guanfeng Group. Em trabalho de campo 
(setembro de 2015), constatamos que esta empresa havia paralisado suas atividades na localidade, o que ocasionou a demissão de muitos funcionários que são moradores da comunidade de Ateuazinho. Em entrevista, um destes funcionários demitidos alegava que ainda não havia recebido seus direitos trabalhistas.

Figura 46: Ramal Bom Futuro, em Moju.

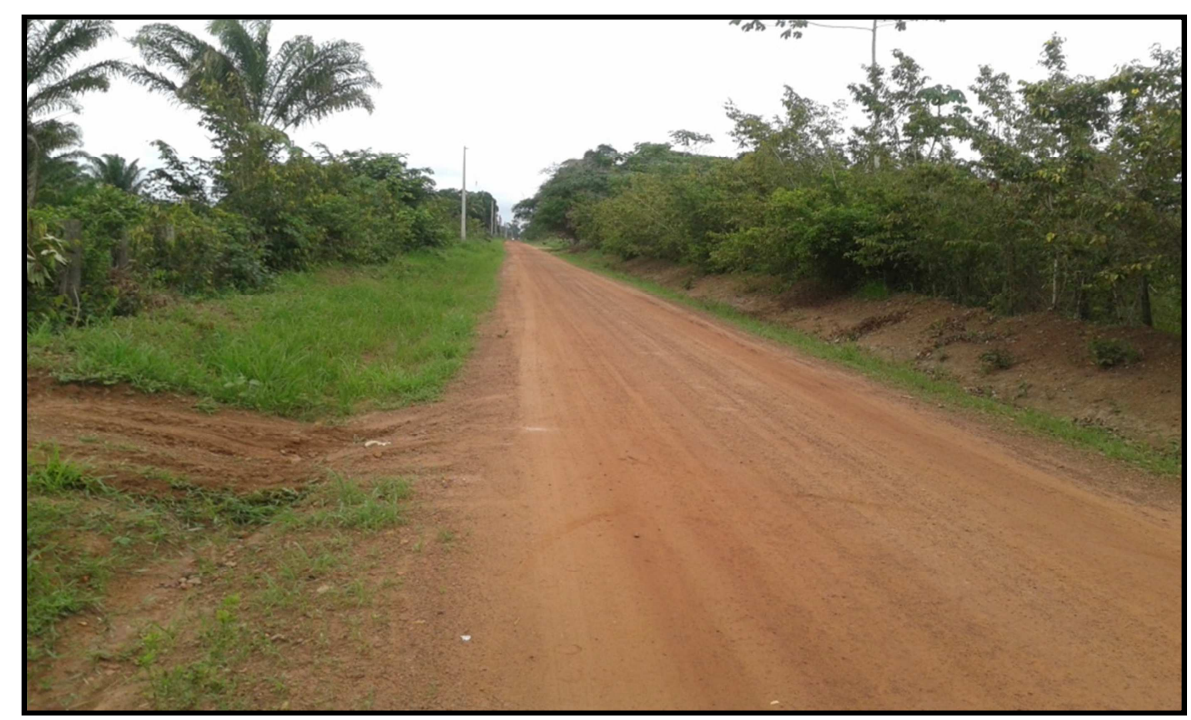

Fonte: Márcio Benassuly (2015)

O assentamento Olho D’Água I, em Moju está localizado às margens da PA-150 (Figura 47). Trata-se de um assentamento destinado à reforma agrária do Incra. Em visita constatamos uma série de problemas de caráter de infraestrutura, de conservação das vicinais existentes, fios de energia elétrica que foram subtraídos da localidade, entre outras questões.

Figura 47: Aspecto do assentamento Olho D’Água I, em Moju.

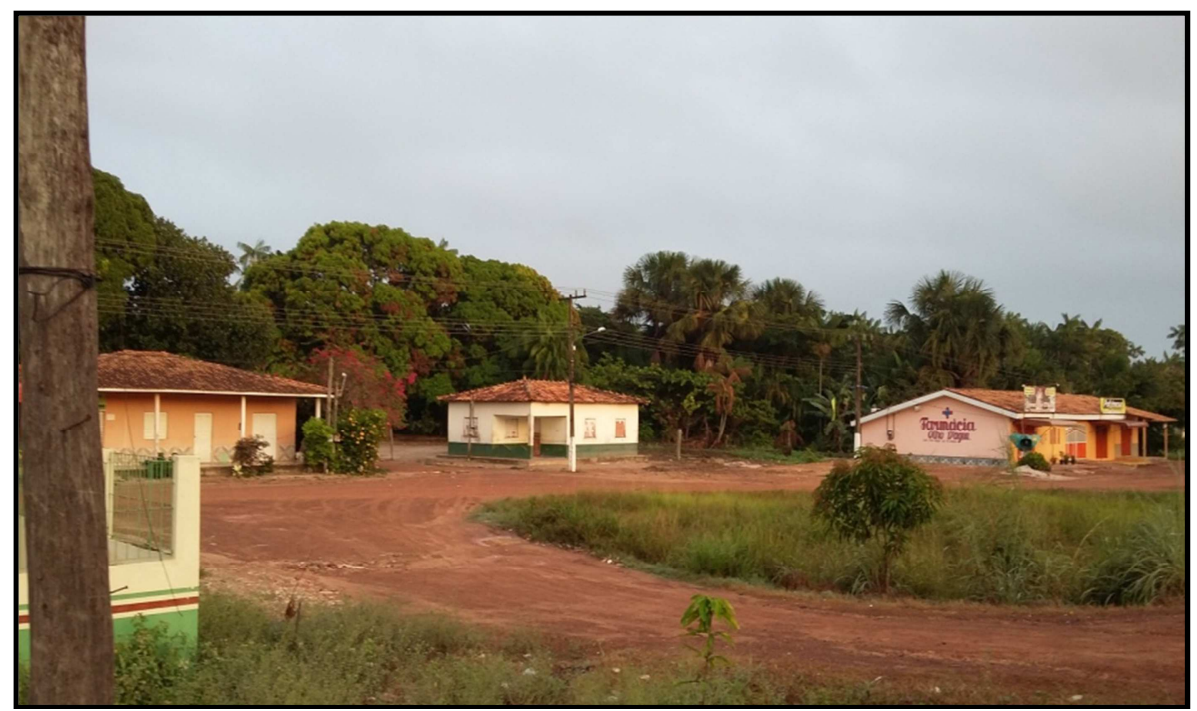

Fonte: Márcio Benassuly (2015) 
A comunidade de Boa Esperança, em Moju, está localizada às margens da PA-150, sentido Moju-Tailândia (Figura 48). Trata-se de uma comunidade cercada por grandes plantações de dendê da Agropalma.

Figura 48: Comunidade de Boa Esperança, em Moju

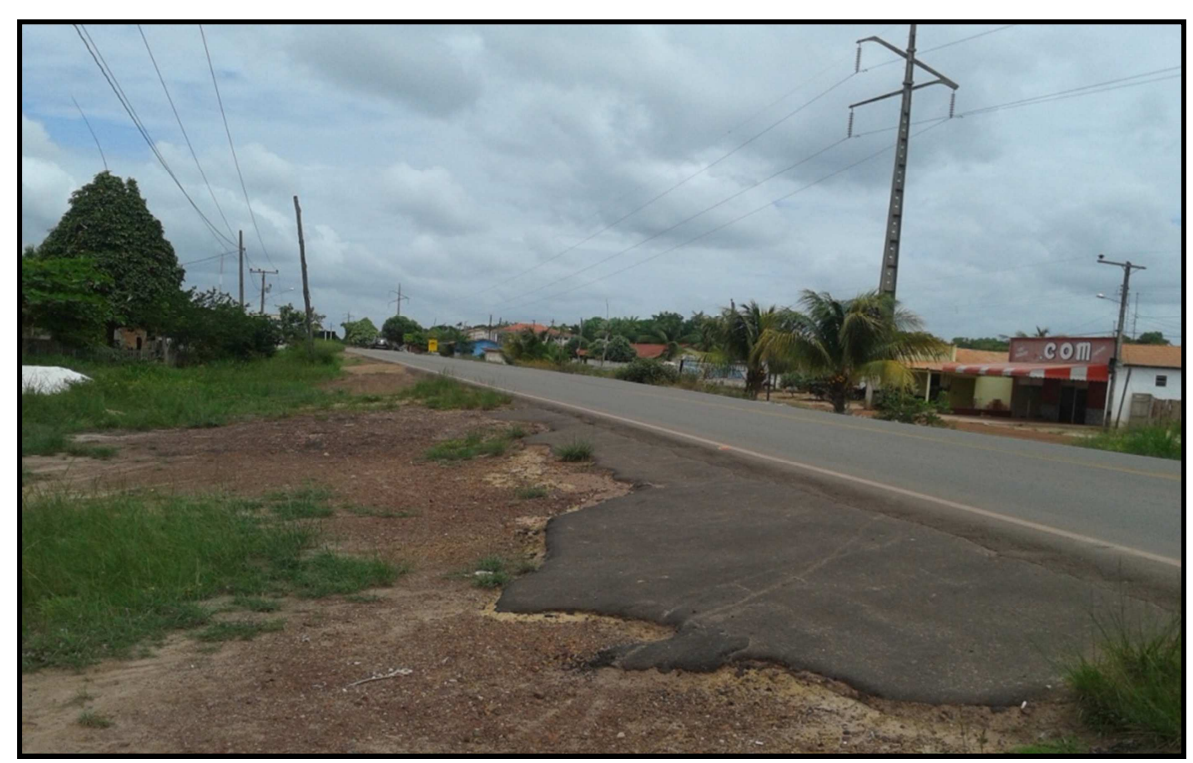

Fonte: Márcio Benassuly (2015)

Na comunidade de Boa Esperança, constatamos que muitos moradores trabalham nas empresas de dendê da região como Agropalma, Biopalma e Belém Bioenergia Brasil.

\subsubsection{Resultados da pesquisa empírica}

Tamanho das propriedades, área plantada evalor dos financiamentos dos agricultores familiares de dendê integrados à Biopalma. Nos treze projetos de dendê familiar visitados da Biopalma, o tamanho das propriedades variou de 25,27, 43, 50 e 61 hectares. Nas treze propriedades de dendê familiar visitadas da empresa, o tamanho dos projetos de dendê foi de 10 hectares financiados pelo Basa. O valor do financiamento do Pronaf Eco-Dendê é de R\$ 80.000,00. A Figura 49 mostra detalhes de plantação familiar de dendê no ramal Bom Futuro. 
Figura 49: Propriedade de dendê familiar no ramal Bom Futuro, em Moju

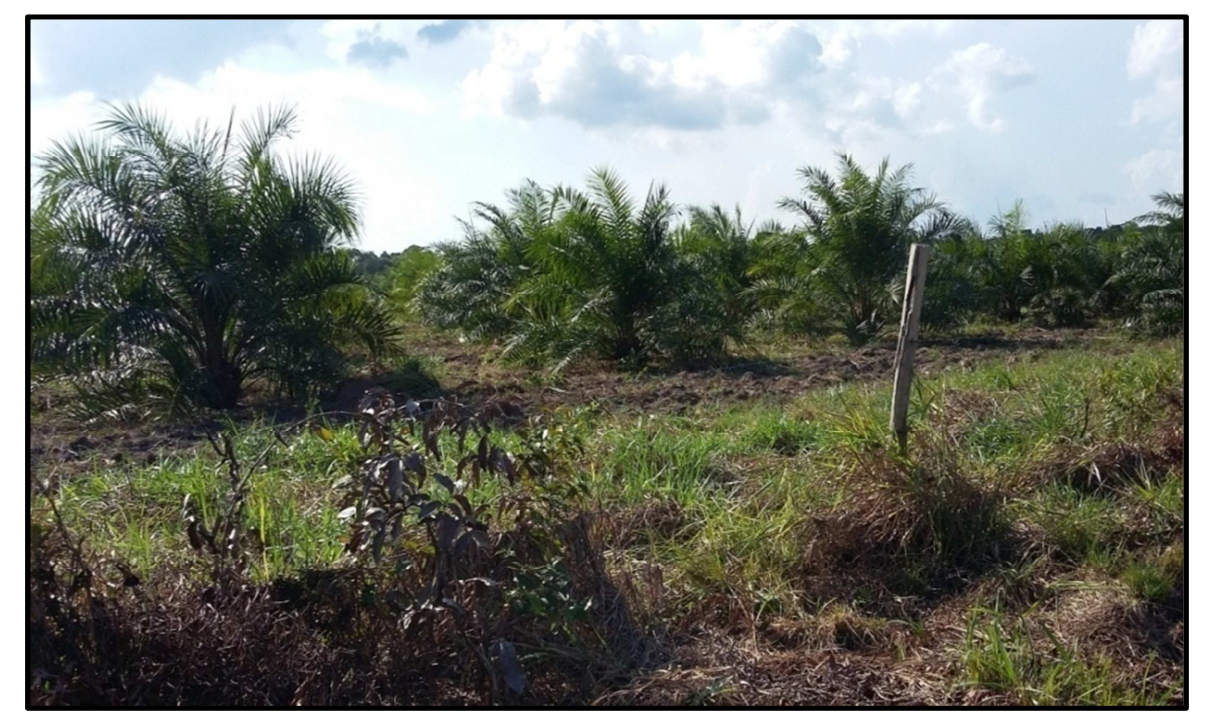

Fonte: Márcio Benassuly (2015)

Quantidade produzida na propriedade familiar de dendê integrada à Biopalma. A produção de dendêdos agricultores integrados da Biopalma no Baixo Tocantins (PA), pesquisados em 2015, apresenta uma variação de acordo com o ano de início do plantio e também sofre forte influência dos tratos culturais e cuidados que cada agricultor dedica a seu dendezal familiar. Desta forma nos treze projetos de agricultores familiares integrados à Biopalma pesquisados, ocorre uma variação de produção e consequentemente de renda entre estes integrados. Neste sentido, passamos a descrever cada localidade onde procuramos focalizar a situação de cada integrado.

No ramal do Ipitinga, em Acará, foi entrevistado um agricultor integrado, cujo plantio foi iniciado em julho-agosto de 2012 (Figura 50), com 900 mudas e, em janeiro de 2013, foram plantadas mais 530 mudas na propriedade. O início da colheita ocorreu em 2015, onde até o dia de nossa entrevista (23.09.2015) foram realizadas três colheitas com os seguintes pesos. Na primeira colheita foram coletados 1.200 quilos (08.07.2015), na segunda colheita, 2.500 quilos (31.07.2015), na terceira, 3.050 quilos (31.08.2015). O valor em média da tonelada paga pela empresa foi de $\mathrm{R} \$ 250,00$, o que totalizou uma renda de $\mathrm{R} \$ 1.687,50$ (Entrevista realizada pelo pesquisador com agricultor familiar integrado em Acará, em 23.09.2015). 
Figura 50: Dendezeiro em fase de colheita no ramal do Ipitinga em Acará

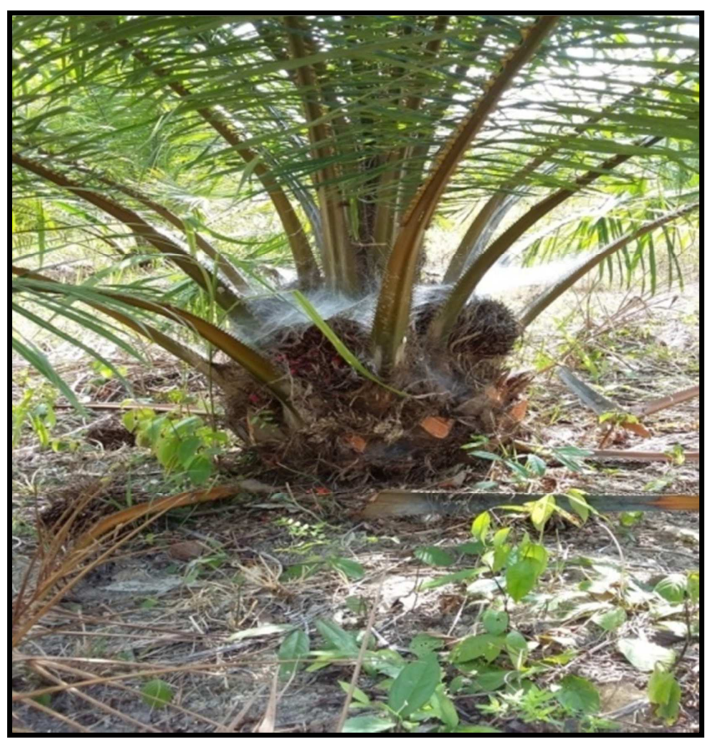

Fonte: Márcio Benassuly (2015)

No ramal Bom Futuro, em Moju, foram entrevistados dois agricultores integrados. O primeiro agricultor informou que seu plantio é de 2012 e que em 2015 teve início a fase de colheita de sua propriedade. Afirmou que já realizou até nossa entrevista (02.09.2015) quatro colheitas. Na primeira colheita foram coletados 2.550 quilos. Na segunda, 2.250 quilos. $\mathrm{Na}$ terceira, 1.598 quilos. Na quarta colheita foram coletados 2.600 quilos. Isto totalizou 8.998 quilos, que se multiplicado pelo preço da tonelada da empresa, que é em média $\mathrm{R} \$ 250,00^{111}$ teremos uma renda de $\mathrm{R} \$ 2.249,50$. Informou também que de três em três meses, o Basa faz a liberação de $\mathrm{R}$ \$ 1.300,00 para a manutenção do dendezal (Entrevista realizada pelo pesquisador com agricultor familiar integrado em Moju, em 02.09.2015).

Já osegundo entrevistado informou em entrevista (02.09.2015) que seu plantio teve início em janeiro de 2012 e que em 2015 começou a realizar as colheitas. Afirmou que já realizou quadro colheitas. Na primeira colheita foram coletados 750 quilos. Na segunda foram coletados 686 quilos. Na terceira, 810 quilos. Na quarta, 1.350 quilos. Isto totalizou 3.596 quilos que se multiplicado pelo preço da tonelada da empresa que é em media $\mathrm{R} \$ 250,00$, teremos uma renda de $\mathrm{R} \$ 899,00$ (Entrevista realizada pelo pesquisador com agricultor familiar integrado em Moju, em 02.09.2015). A Figura 51 mostra detalhes da produção familiar de dendê no ramal Bom Futuro aguardando transporte para a empresa.

\footnotetext{
${ }^{111}$ Em trabalho de campo tivemos acesso a vários comprovantes de pagamentos da produção de dendê. A cotação do preço do dendê varia de acordo com a bolsa da Malásia www.mpob.gov.my. Em agosto de 2015 a cotação paga pela empresa aos agricultores integrados de dendê foi de $\mathrm{R} \$ 249,85$. O preço negociado do óleo de palma nesta bolsa foi de US\$ 601,50. Cotação do dólar a R \$ 3,22 (Entrevista realizada pelo pesquisador com agricultor familiar integrado em Moju, em 02.09.2015).
} 
Figura 51: Cachos de dendê familiar à espera de transporte para a Biopalma próximo ao ramal de Bom Futuro, em Moju

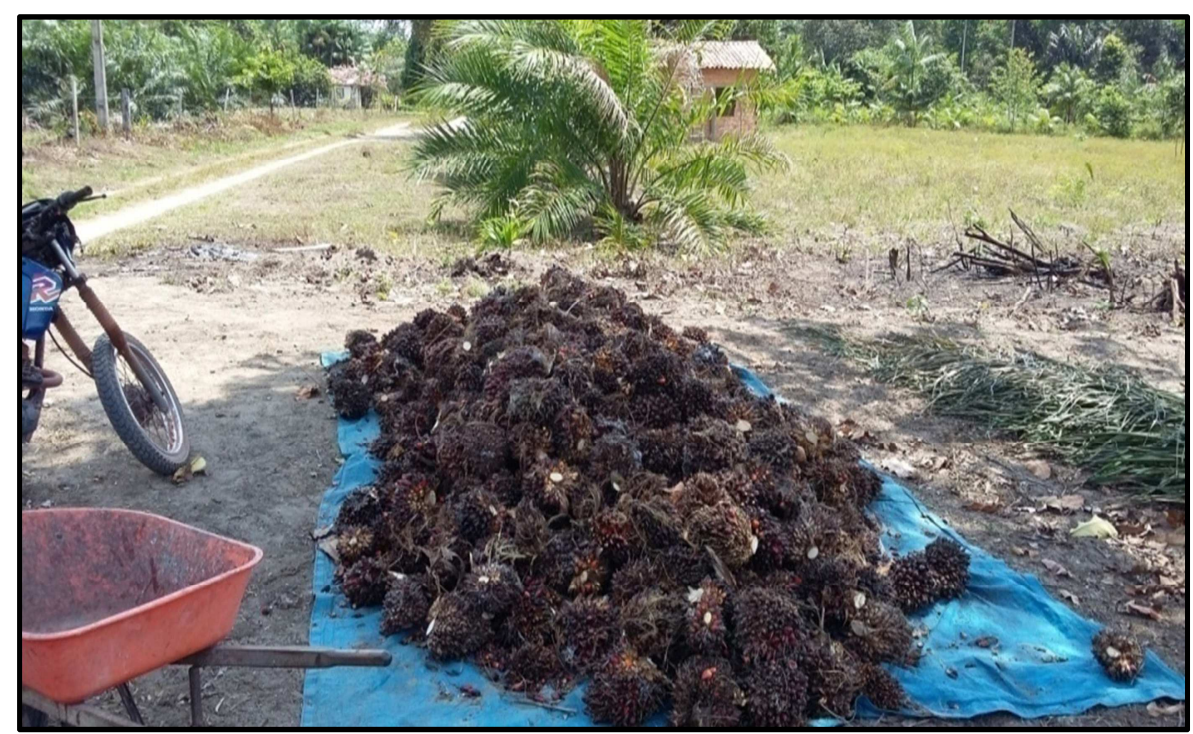

Fonte: Márcio Benassuly (2015)

Na comunidade de Boa Esperança, em Moju, foram entrevistados dois agricultores integrados. O primeiro agricultor informou que seu plantio teve início em 2013, e até a data da entrevista (16.09.2015) não realizou nenhuma colheita. Já o segundo entrevistado afirmou que sue plantio teve inicio em abril de 2012 e que sua colheita teve início em 2015, onde realizou duas colheitas. Na primeira colheita foram coletados 450 quilos. Na segunda, foram coletados 400 quilos, o que totalizou 850 quilos nas duas coletas dos frutos. Esta produção gerou uma renda de $R \$ 212,50$. Este entrevistado afirmou que de três em três meses o Basa libera $\mathrm{R} \$ 1.800,00$ destinados para a manutenção do dendezal, como limpeza, coroamento, entre outras tarefas.

No assentamento Olho D’Água I, em Moju, foram entrevistados oito agricultores integrados com início de plantio em 2012 (quatro agricultores) e 2013 (quatro agricultores, sem colheitas). A produção dos quatro agricultores que iniciaram seus plantios em 2012 é relatada em seguida. O primeiro agricultor entrevistado (15.09.2015) informou que sua colheita teve início em 2015 e que já realizou doze colheitas em sua propriedade. Na primeira colheita foram coletados 1.400 quilos; na segunda, 1.700 quilos; na terceira, 1.150 quilos; na quarta, 1.050 quilos; na quinta, 1.550 quilos; na sexta, 1.250 quilos; na sétima, 1.150 quilos; na oitava, 4.650 quilos; na nona, 3.150 quilos; na décima, 2.300 quilos; na décima primeira, 3.430 quilos; e na décima segunda, 4.270 quilos. O que totalizou neste ano uma produção de 27.050 quilos. Como o valor em média da tonelada paga pela empresa foi de $\mathrm{R} \$ 250,00$, recebeu $\mathrm{R} \$ 6.762,50$. 
O segundo agricultor entrevistado (16.09.2015), com início do plantio em 2012, informou que ainda não realizou colheita em sua plantação. O terceiro agricultor entrevistado (16.09.2015) informou que ainda não realizou colheita em sua propriedade. O quarto agricultor entrevistado (16.09.2015) também informou que ainda não realizou colheita.

Valor da cotação de dendê, diretrizes da empresa e avaliação do sistema de integração pelos agricultores de dendê integrados à Biopalma. Tal como ocorre com os agricultores integrados da BBB, os agricultores da Biopalma não sabem como são realizados os cálculos da cotação do preço da tonelada de dendê que tem como referência a bolsa da Malásia $^{112}$. As diretrizes da empresa estão presentes nos contratos e passados para o agricultor principalmente durante as visitas que os técnicos agrícolas fazem às propriedades familiares para acompanhar a produção de dendê.

O sistema de integração é avaliado pelos agricultores integrados como deficiente, pois existem muitos problemas como falta de redes para a coleta da produção de dendê familiar, atraso na entrega de adubos, além de que a empresa pouco ouve os agricultores.

Assistência técnica, existência de outras culturas agrícolas, avaliação da assistência técnica e mão de obra utilizada nos dendezais de agricultores integrados à Biopalma. Sobre a assistência técnica,os entrevistados afirmaram que é realizada mensalmente por um técnico da empresa, que visita o dendezal. Também foi ressaltado que nos três primeiros anos este técnico dá uma atenção maior para o plantio, depois deste tempo, faz visitas rápidas ao dendezal.

Como a cultura do dendê só começa a produzir a partir do terceiro ano, neste período os agricultores necessitam de outras fontes de renda para manter a família. Desta forma, todos os agricultores entrevistados possuem fontes complementares de renda.

No ramal Ipitinga, em Acará, existe na propriedade do agricultor integrado entrevistado lavoura de pimenta-do-reino, maracujá e mandioca. No ramal Bom Futuro, em Moju, as duas propriedades de agricultores integrados visitados possuem plantações além de dendê, tais como mandioca, pimenta-do-reino e açaí.

Nas duas propriedades da comunidade de Boa Esperança, em Moju, constatamos que na primeira propriedade, além da plantação de dendê, existe o cultivo de mandioca e pimentado-reino. Na segunda propriedade, o dendê é a única cultura existente.

\footnotetext{
${ }^{112}$ No mês de agosto de 2015 o preço médio do óleo de palma na bolsa da Malásia foi de US\$ 601,50. A cotação media dólar foi de $\mathrm{R} \$ 3,22$. O preço praticado para a compra dos Cachos Frescos de Frutos (CFF) de dendê foi de $\mathrm{R} \$ 249,85$ (Entrevista realizada pelo pesquisador com agricultor familiar integrado em Moju, em 02.09.2015).
} 
Das oito propriedades de agricultores integrados de dendê pesquisados existentes no assentamento Olho D’Água I, em cinco além da plantação de dendê, existem os cultivos de mandioca, pimenta-do-reino, maracujá e açaí. Em outras três propriedades só existe o plantio de dendê.

Os agricultores entrevistados afirmaram quea assistência técnica não é suficiente para atender as demandas dos agricultores existentes na região, pois em muitos meses tem ocorrido atraso na prestação destes serviços por parte da empresa integradora.

A mão-de-obra empregada nos dendezais familiares constitui-se do chefe da família, no caso o pai, e os filhos. Em diversas etapas do calendário agrícola do dendê utiliza-se trabalho em forma de diária, cujo valor varia de $\mathrm{R} \$ 40,00$ a $\mathrm{R} \$ 50,00$. Utiliza-se também a empreita de tarefas, cujo valor varia de acordo com o trabalho e o tempo a ser realizado.

Atividades econômicas complementares, o dendê como a principal atividade econômica easpectos que a empresa deveria melhorar. Como o dendê só começa a produzir a partir do terceiro ano, os agricultores familiares integrados à Biopalma entrevistados desenvolvem outras atividades econômicas que permitem a manutenção da família. Desta forma, muitos possuem uma pequena plantação de mandioca e outras culturas para o consumo familiar.

No ramal do Ipitinga, em Acará, a principal atividade econômica do agricultor integrado de dendê pesquisado é proveniente da lavoura de mandioca. Nas duas propriedades do ramal Bom Futuro, em Moju, a principal fonte de renda dos agricultores integrados de dendê vem da lavoura de mandioca.

Nas duas propriedades da comunidade de Boa Esperança, em Moju, a mandioca é a principal fonte de renda dos agricultores familiares integrados entrevistados.

Nas oito propriedades familiares de dendê pesquisadas do assentamento Olho D’Água I, o cultivo da mandioca é a principal fonte de renda para cinco agricultores entrevistados. Em dois entrevistados, a pimenta-do-reino é a principal fonte de renda. Somente para um entrevistado o dendê é a principal fonte de renda.

Segundo os agricultores familiares entrevistados, a empresa deveria melhorar na comunicação, entrega do adubo no prazo correto, assistência técnica. Para um agricultor de Moju, a empresa deveria melhorar "o número de redes que eles estão dando, não dá porque tem que ser no mínimo duas redes para cada um. Dinheiro e adubo que já tá atrasando, duas semanas de adubo" (Entrevista realizada pelo pesquisador com agricultor familiar integrado em Moju, em 02.09.2015). 
Outro agricultor do Moju afirma que a empresa deveria melhorar na "parceria de conhecimento e informação, por exemplo, a gente não sabe quanto ela leva em cima do nosso trabalho" (Entrevista realizada pelo pesquisador com agricultor familiar integrado em Moju, em 02.09.2015).

Situação socioeconômica do agricultor, colheita, regularização das propriedades e dúvidas do contrato assinado com a empresa. Dos treze agricultores entrevistados, seis afirmaram que a implantação de dendê familiar melhorou suas vidas e para sete não houve melhoria em suas vidas.

A colheita segue os mesmos padrões na BBB, sendo realizada duas vezes ao mês. A produção é coletada nos dendezais de onde é transportada por animais ou micro tratores até um ponto estabelecido pela empresa, onde é disponibilizada uma caixa coletora dos frutos de dendê dos integrados. Em nossa visita de campo houve muitas reclamações dos agricultores de que a empresa não teria as caixas coletoras suficientes para atender todos os agricultores. As propriedades dos agricultores entrevistados possuem documentos de ocupação de posse emitida pelo Iterpa ou pelo Incra.

Tal como ocorre como os integrados da BBB, os integrados da Biopalma afirmam possuírem diversas dúvidas sobre inúmeras cláusulas do contrato de integração. No entanto, não souberam determinar quais são as principais dúvidas. A que apareceu com mais frequência é a que se refere ao preço pago pela tonelada de dendê aos agricultores integrados.

Um agricultor de Moju afirma que "nós temos um pouco de dúvidas porque eles tão mandando o negócio do adubo e vem a nota. Aí chega aqui não dá, fica faltando, aí nós vamos lá para saber disso" (Entrevista realizada pelo pesquisador com agricultor familiar integrado em Moju, em 02.09.2015).

Ainda sobre o contrato, vários agricultores citaram a questão da dependência a uma única empresa, pois há dúvidas em caso da empresa falir ou abandonar o mercado de dendê, como aponta uma agricultor afirmando "o medo é da empresa quebrar" (Entrevista realizada pelo pesquisador com agricultor familiar integrado em Moju, em 02.09.2015). O “quebrar" na fala do agricultor é no sentido da empresa falir.

Normas da empresa, filiação a sindicato, organização eresistências junto à empresa.Para os agricultores integrados,suas vidas são afetadas pelas normas que são passadas pela empresa, pois o modelo de produção empresarial em muito difere da familiar. A lógica de trabalho empresarial acaba afetando o cotidiano dos agricultores, passando a modificar os hábitos de uso da terra que agora são comandados por uma lógica empresarial de mercado, onde este agricultor tem que se enquadrar nesta nova lógica de integração ao ramo 
empresarial do dendê. Segundo um agricultor, esta norma "modificou porque o que eu fazia eu não faço mais, a firma não quer que plante isso, ou melhor, os caras" (Entrevista realizada pelo pesquisador com agricultor familiar integrado em Moju, em 02.09.2015).

Em sua maioria os agricultores familiares entrevistados são filiados aos STTR dos municípios de Acará e Moju, onde suas localidades são ligadas territorialmente. Além do mais, existem outras organizações que são criadas para facilitar a organização e a busca de recursos para estas localidades. No ramal do Ipitinga (Acará) existe a Associação dos Moradores do Igarapé Ipitinga (Amairim). No ramal Bom Futuro (Moju), a Associação dos Produtores Rurais do Ramal Bom Futuro (Abraf). No Assentamento Olho D’Água I (Moju), a Associação dos Pequenos Agricultores do Olho D’Água e Vicinal I, I, I (Figura 52). Na comunidade de Boa Esperança (Moju), a Associação dos Agricultores de Boa Esperança.

\section{Figura 52: Associação dos Pequenos Agricultores do Olho D’Água e Vicinal I, I, II em Moju}

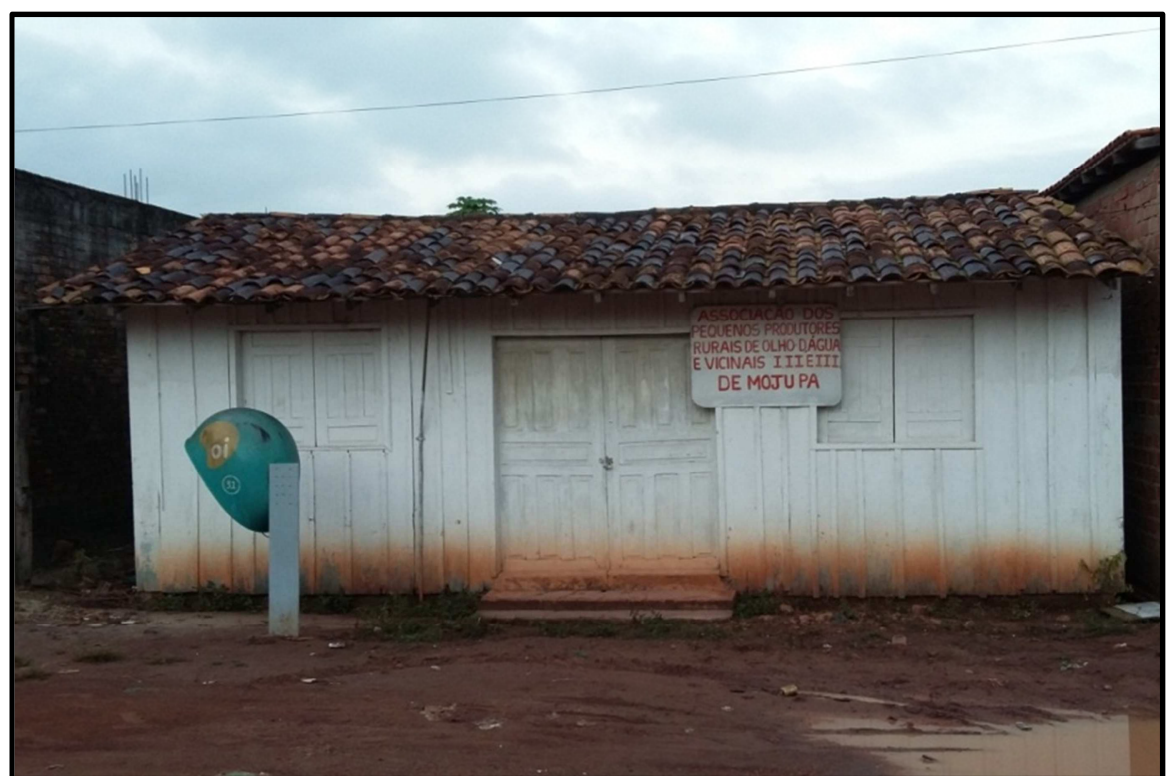

Fonte: Márcio Benassuly (2015)

Assim como os agricultores integrados da Belém Bioenergia Brasil, os agricultores associados à Biopalma não estão organizados em uma entidade representativa exclusiva. As resistências limitam-se ao âmbito da localidade onde o agricultor reside.

Estratégias de organização político-social, atividade econômica antes e depois da implantação dos projetos de agricultura familiar de dendê. Nas localidades onde o agricultor reside e mesmo na sede municipal destas localidades, não constatamos em trabalho de campo uma forma político-social mais organizada dos agricultores de dendê. Como ocorre com os 
integrados da BBB, os integrados da Biopalma estabelecem diálogos sobre os problemas que são comuns no âmbito das localidades onde possuem plantações.

Um agricultor de Moju afirmou sobre esta temática: “Tem sim. Não de organização, mas sim de conversa informal" (Entrevista realizada pelo pesquisador com agricultor familiar integrado em Moju, em 02.09.2015).

No ramal Ipitinga, no município de Acará, o agricultor entrevistado vivia do cultivo da mandioca, antes da implantação do dendê. No ramal Bom Futuro, os dois integrados viviam também da mandioca. Na comunidade de Boa Esperança, em Moju, viviam da mandioca e do arroz. No assentamento Olho D’Água I, da mandioca e do maracujá. 


\section{CONCLUSÕES}

Ao finalizar este percurso acadêmico é necessário apresentar alguns resultados da pesquisa. As conclusões desta tese retomam o objetivo geral, específicos, bem como a hipótese que nortearam o presente trabalho para na sequência apresentar os resultados que a pesquisa chegou.

A tese teve como objetivo geral analisar o uso agrícola do território com ênfase na integração da agricultura familiar no agronegócio de dendê no Baixo Tocantins, no contexto de políticas públicas que visam à expansão da produção de dendê no Brasil. A pesquisa constatou que o uso agrícola do território no Baixo Tocantins é ampliado pela ação de políticas públicas que visam à expansão do cultivo desta lavoura. Tais políticas (PNPB, PPSOP) passam a disponibilizar grandes somas de recursos financeiros para a produção agrícola empresarial e familiar integrada desta oleaginosa. O dendê ocupou a maior área colhida do território agrícola utilizado pela lavoura permanente no Baixo Tocantins em 2013.

Na sequência são apresentadas as conclusões relacionadas aos objetivos específicos.

Objetivo específico 1: Integração da agricultura familiar no agronegócio no contexto das políticas públicas de expansão da produção de dendê.

O agronegócio de biodiesel regula a agricultura familiar onde obtém vantagens com esta associação mediante os incentivos fiscais concedido pelo Selo Combustível Social a empresa integradora. Na atualidade o PNPB tornou-se um programa da soja onde cabe destacar a forte atuação do agronegócio da soja do Centro-Oeste em detrimento da agricultura familiar das regiões Nordeste e Norte do Brasil. No contexto do PNPB o Pará tornou-se estado produtor de biodiesel com a inauguração em 2005da fábrica da Agropalma em Belém, porém devido a dificuldades de mercado a produção de biodiesel da empresa foi paralisado, onde a empresa fez uma opção para a produção de alimentos em vez de biocombustível.

Cabe destacar que a partir de 2010 (ANP, 2015) o Pará deixou de produzir biodiesel na única fábrica (Agropalma) existente no estado com capacidade para esta produção. $\mathrm{Na}$ atualidade as empresas Belém Bioenergia Brasil e Biopalma possuem projetos em andamento para a produção de biodiesel a partir do dendê paraense. A primeira empresa visa à produção de biodiesel em Portugal a segunda visa à produção deste biocombustível no município de Acará. Com a desistência do negócio da produção de biodiesel de dendê pela Agropalma, o estado do Pará até para a presente data (2016) não conseguiu converter sua produção agrícola de dendê em biodiesel, conforme os projetos anunciados pelas empresas Petrobras (Belém Bioenergia Brasil) e Vale (Biopalma). A produção de biodiesel pela empresa Belém 
Bioenergia Brasil deve acontecer até 2021. A produção deste biocombustível pela Biopalma esta prevista somente para 2018 quando deve ser inaugurada a primeira usina, em 2021 deve entrar em funcionamento a segunda usina da empresa. Na atualidade toda a produção agrícola de dendê do Pará tem como destino o setor de alimentos e não o setor de biocombustíveis.

Objetivo específico 2: Racionalidade do Estado-Empresa e possíveis resistências do agricultor a estas diretrizes reguladoras.

O cultivo do dendê é defendido pelo Estado brasileiro como uma opção agrícola para a Amazônia por apresentar diversas vantagens ambientais, econômicas e sociais. Os incentivos estatais foram determinantes para o êxito desta lavoura na Amazônia, onde o território do Baixo Tocantins é o maior produtor desta cultura do estado do Pará. O projeto de dendê faz parte de uma estratégia entre Estado e empresas do agronegócio para viabilizar a expansão da produção agrícola desta oleaginosa. Desta forma os incentivos públicos para tornar o projeto viável, passa necessariamente pelo fomento da grande, média e pequena produção desta lavoura.

Os recursos disponíveis nas agências bancárias para o cultivo familiar de dendê promoveu uma rápida expansão desta cultura no estado do Pará após 2012. Este incentivo é parte de uma lógica do financiamento agrícola hegemônico que tem o Banco da Amazônia como o grande agente de credito agrícola desta política no estado do Pará. A racionalidade hegemônica da disponibilidade do financiamento familiar do dendê tem atraído muitos agricultores para o plantio desta cultura nos municípios do Baixo Tocantins.

Nos projetos dendê familiar integrado, a racionalidade da empresa, ocorre mediante um conjunto de normas que passam a regular a vida do agricultor onde o mesmo perde sua independência da decisão sobre o que produzir. Com o crédito disponível para o dendê e escassez para o cultivo de outras lavouras o pequeno agricultor acaba sendo atraído para o projeto de integração a empresas de agronegócio presentes na região.

A ação racional estatal-empresarial mediante a execução das políticas públicas destinadas a expansão agrícola de dendê passam a promover um conjunto de ações que tem contribuído para o crescimento das adesões de agricultores a projeto de fomento familiar a lavoura do dendê no Baixo Tocantins. A política estatal tem priorizado o incentivo familiar desta oleaginosa em detrimento de outras lavouras no recorte espacial pesquisado. Em trabalho de campo constatou-se que os investimentos de fomento para outras lavouras da pequena produção são muito limitados nos municípios percorridos. No caso do crédito rural para o dendê ocorre uma grande facilitação do acesso ao fomento para esta cultura nos municípios onde as empresas de dendê estão estruturadas. O ano de 2012 marca a expansão 
do incentivo estatal do Pronaf Eco-Dendê nos municípios do Baixo Tocantins processo este que reflete a entrada no agronegócio de dendê de grandes empresas como a Petrobras Biocombustível (projeto Pará + projeto Belém) e da Biopalma.

Contatou-se ainda que as resistências dos agricultores familiares as diretrizes da empresa são ações individuais, não existindo uma representação coletiva constituída para a defesa exclusiva destes agricultores junto às empresas integradoras.

Objetivo específico 3: Experiências de integração da agricultura familiar de dendê no agronegócio das empresas selecionadas.

Este processo implica na transformação de produtor autônomo para produtor integrado provocando uma mudança radical na produção e uso da terra familiar. Neste sistema o agricultor integrado perde a liberdade da produção em sua terra, esta decisão passa para o controle da empresa que impõe a quantidade, qualidade e o tempo de produção. Esta relação é regida pelo contrato de compra e venda da produção celebrada entre empresa e agricultor integrado. Também assistimos uma mudança de racionalidade de produtor autônomo para produtor integrado. Com um financiamento bancário para pagar e um contrato com a empresa o agricultor passa a trabalhar sob forte pressão dos compromissos com o banco e a empresa.

Esta experiência promove a criação de um cotidiano obediente onde a presença das empresas nas localidades promove uma quebra da solidariedade social existente, pois a dinâmica passa a ter como centralidade a produção familiar de dendê regulada pela empresa. A instalação deste projeto de integração na propriedade do agricultor transforma esta terra em unidade de produção associada à empresa, onde o produtor agrícola passa a ser regulado pelas normas da empresa, as quais deve obedecer.

$\mathrm{Na}$ pesquisa de campo constatou que somente os agricultores familiares com áreas maiores é que foram habilitados a firmarem parcerias com as empresas de dendê em análise, pois além da área destinada para o plantio do dendê existe a exigência da destinação de uma área destinada para reserva legal na propriedade do integrado. No caso dos agricultores vinculados a empresa Belém Bioenergia Brasil a área do tamanho da propriedade ficou entre 38 a 68 hectares, onde até 10 hectares são destinados para o plantio do dendê. Já os projetos associados à empresa Biopalma o tamanho das propriedades visitadas ficou entre 25 a 61 hectares.

Quanto à quantidade produzida e a renda obtida na produção de dendê familiar pesquisado nas duas empresas depende do início do plantio e dos cuidados do agricultor para com o dendezal. Nos dezoitos projetos pesquisados vinculados a Belém Bioenergia Brasil, em dez o plantio ocorreu em 2012. Destes plantios iniciados neste ano, cinco não apresentaram 
nenhuma colheita, nos cinco restantes as primeiras colheitas iniciaram no ano de 2015 onde a menor produção/rendimento foi de 1.200 quilos o que correspondeu a uma renda de $\mathrm{R} \$$ 240,00, já a maior produção/rendimento foi de 8.000 quilos o que correspondeu a uma receita de $\mathrm{R} \$$ 1. 600,00. Em oito projetos cujos plantios ocorreram em 2013, estão na fase improdutiva, não foi realizada colheita.

Nos treze projetos visitados da Biopalma, em oito o plantio ocorreu em 2012 e cinco iniciou o plantio em 2013. Nos plantios de 2012, três não apresentaram colheitas e em cinco a menor produção/renda foi de 850 quilos o que gerou uma renda de R \$212,00, a maior produção/renda foi de 27.050 quilos o que contabilizou a receita de $\mathrm{R} \$ 6.762,50$. Os plantios iniciados em 2013 não apresentaram produção. Como podemos constatar na pesquisa existem casos de agricultores integrados com grande produção agrícola o que conseqüentemente se reflete no rendimento, em outros casos a produção é pequena como demonstrado acima.

Quanto à situação socioeconômica dos agricultores familiares integrados a Belém Bioenergia Brasil, todos informaram que o dendê não melhorou sua condição econômica. Quanto aos integrados da Biopalma, dos treze agricultores pesquisados para seis a implantação do dendê melhorou sua condição de vida e para sete não houve melhoria. Dos trinta e um agricultores entrevistados das duas empresas pesquisadas, apenas um agricultor informou que o dendê é a sua principal fonte de renda.

Objetivo específico 4: Práticas de solidariedades entre os agricultores através da organização político-social.

Constatou-se que, a mesma é restrita a diálogos entre os agricultores em suas localidades não existindo uma entidade exclusiva de defesa dos agricultores familiares integrados de dendê nos municípios pesquisados.

Tendo como base os agricultores entrevistadosa tese confirmou a hipótese de trabalho, pois a análise das experiências de integração da agricultura familiar no agronegócio de dendê indica que os agricultores, até o momento da realização da pesquisa (outubro de 2015), não obtiveram maiores ganhos com esta política pública. Já as empresas têm sido beneficiadas, mediante incentivos estatais.

Esta confirmação, no entanto deve levar em consideração que somente em 2015, tem início a fase produtiva dos dendezais familiares cujos plantios ocorreram em 2012. E que somente a partir desta fase a renda dos agricultores familiares integrados poderá melhorar. A questão do fator início desta plantação impede neste momento uma avaliação mais consistente da produção e conseqüentemente da renda a ser obtida com a mesma. Esta situação requer 
novas pesquisas à medida que os plantios de dendê familiares forem consolidando sua produção agrícola ao longo dos próximos anos.

A questão das políticas públicas para agricultura familiar apresentada na presente tese, como o Pronaf Eco-Dendê, passa por um momento político de grandes incertezas quanto ao futuro. $\mathrm{O}$ atual contexto político apresenta alguns dilemas para o futuro do tema ligado à agricultura familiar no Brasil. O período de pesquisa da tese (2013-2016) coincide em partes com os dois mandatos da presidenta Dilma Rousseff (2011-2015; 2015-2016) que foi afastada temporariamente da presidência da república em 12.05.2016, onde assumiu como presidente interino Michel Temer e confirmado presidente da república em 31.08.2016 com o afastamento definitivo de Dilma pelo Senado Federal. Desde que assumiu a presidência do Brasil, Michel Temer vem realizando um conjunto de mudanças administrativas no Executivo federal que contribui para a indefinição quanto ao futuro da agricultura familiar no Brasil.

Inicialmente, por meio da medida provisória 726/16, editada em 12.05.2016, promoveu a extinção e fusão de várias pastas ministeriais que reduziu o número de ministérios de 31 para 24. Esta medida promoveu a fusão dos Ministérios do Desenvolvimento Agrário (MDA) com o Ministério do Desenvolvimento Social (MDS) resultando na criação do Ministério do Desenvolvimento Social e Agrário (MDSA). Posteriormente, em 30.05.2016, nova mudança transferiu do MDSA toda a atividade-fim da agricultura familiar para a Casa Civil. Em menos de um mês ocorrem mudanças radicais no segmento da agricultura familiar, pois neste curto tempo o novo governo promoveu o fim do ministério responsável pela agricultura familiar (MDA) e a Secretaria da Agricultura Familiar (SAF) foi transformada em Secretaria Especial de Agricultura Familiar e do Desenvolvimento Agrário inicialmente no MDSA e posteriormente transferida para a Casa Civil.

Com a perda de status de ministério (MDA) e sua incorporação ao recém criado MDSA e posterior transferência para a Casa Civil, a temática da agricultura familiar foi profundamente penalizada quanto ao futuro desta área que é responsável por $70 \%$ da produção de alimentos consumidos no Brasil.

$\mathrm{O}$ atual cenário político para a agricultura familiar no Brasil apresenta alguns dilemas para esta temática: Primeiro, este segmento produtivo terá força política e social para preservar as conquistas das políticas públicas para a agricultura familiar implementadas em governos anteriores? Segundo, qual o destino a ser dado a este segmento produtivo pelo atual governo, uma vez que os acordos políticos para a governabilidade têm transformado ministérios e diversas instituições em moeda de troca por apoio político no executivo federal?. Terceiro como ficará os programas sociais ligados à agricultura familiar? 
O contexto apresentado acima traz uma grande incerteza e indefinição quanto ao futuro das políticas públicas para a agricultura familiar no Brasil. Cabe ainda destacar que a criminalização dos movimentos sociais do campo tem aumentado, assim como a bancada ruralista organizada no Congresso Nacional tem demonstrado sinais de forma consistente na aprovação de várias matérias de seus interesses no legislativo nacional.

A extinção do MDA significa um profundo retrocesso para as políticas públicas de agricultura familiar, sendo preocupantes os novos rumos que este segmento tomou nos últimos meses no Brasil. Todas estas transformações na atual estrutura governamental têm contribuído para a redução da importância da agricultura familiar na presente agenda do governo federal.

Diante do atual contexto político vigente, fez-se necessário o aprofundamentode novos temas relacionados à agricultura familiar no Brasil. Estes temas passam pelo fortalecimento da temática, pois a mesmaé de vital importântcia para a geração de empregos no campo, bem como é responsável pela maior parte dos alimentos consumidos no mercado interno do país. Também é preciso resgatar o protagonismo que a temática já teve no passado, inclusive com a dotação orçamentária necessária para atender de forma mais eficiente todas as regiões do Brasil em suas especificidades, pois sabemos que a realidade do agricultor familiar é bastante diferenciada entre as regiões brasileiras.

Para concluirmos a presente tese, uma agenda política para o setor da agricultura familiar faz-se necessária na atualidade.

Primeiro, é preciso resgatar o papel que a agricultura familiar já teve em outros governos. Isto pressupõe a recriação do MDA com todas as bases que o mesmo possuía na gestão anterior do atual presidente da república. Vale destacar que o MDA era o presponsável pela gestão das políticas para a agricultura familiar como o crédito rural (Pronaf), assistência técnica, seguro agrícola, bem como pelos assentados da reforma agrária no Brasil.

Segundo, é necessário lutar contra a criminalização dos movimentos sociais do campo, uma vez que estes são de grande importância para o acesso de políticas públicas das populações do campo brasileiro, bem como pelo avanço da reforma agrária no país.

Por fim é preciso que os movimentos sociais organizados do campo estejam mobilizados para combater as medidas governamentais que procuram reduzir a importância da agricultura familiar no Brasil. 


\section{REFERÊNCIAS}

ABRAMOVAY, Ricardo (Org.). Bicombustíveis: a energia da controvérsia. São Paulo: Editora Senac, 2009.

. Agricultura familiar e uso do solo. São Paulo em Perspectiva, São Paulo, v. 11, n. 2, p. 73-78, 1997.

Paradigmas do capitalismo agrário em questão. São Paulo; Rio de Janeiro; Campinas-SP: Hucitec; Anpocs; Unicamp, 1992.

ABRAMOVAY, Ricardo; MAGALHÃES, Reinaldo. O acesso dos agricultores familiares aos mercados de biodiesel: parcerias entre grandes empresas e movimentos sociais.In: CONFERENCIA DA ASSOCIAÇÃO INTERNACIONAL DE ECONOMIA ALIMENTAR E AGROINDUSTRIAL, 2. (AIFA2). Londrina-PR, 2007. Anais...Londrina-PR, 2007.

ABREU, Cesar. Biopalma da Amazônia: produção sustentável de óleos vegetais para alimentos e bicombustíveis. Universidade Federal de Viçosa. Superintendência de Biodiesel da Vale, 2015. Apresentação em slide. Disponível em: http://pt.slideshare.net/equipeagroplus/workshop-produo-sustentvel-de-leos-vegetaisbiopalma. Acesso em: 10 out. 2015.

O biodiesel de palma: uma alternativa para o brasil. In: Sala de Imprensa da Vale, 2014. Disponível em: http://saladeimprensa.vale.com Acesso em: 14 out. 2015.

ABREU, Frederique Rosa; VIEIRA, José Nilton de Souza; RAMOS; Simone Yuri.Programa Nacional para a Produção e Uso do Biodiesel: diretrizes, desafios e perspectivas. Revista de Política Agrícola, v. 15, n. 3, p. 5-18, 2006.

ADA - Agência de Desenvolvimento da Amazônia. Bicombustíveis: atração de investimentos para o estado do Pará. Belém, 2007.

Desempenho da cadeia produtiva do dendê na Amazônia legal. Belém, 2002.

AGÊNCIA BRASIL. Dendê é incluído em linha de crédito do Pronaf. Brasília, 28.10.2009. Disponível em: <www.memoria.ebc.com.brlagenciabrasil>. Acesso em: 23 abr. 2015

Ministra diz que com biodiesel plantação vira poço de petróleo. Brasília, 13.12.2004. Disponível em: <www.memoria.ebc.com.brlagenciabrasil>. Acesso em: 08 jan. 2015.

Primeira usina de biodiesel do país começa a funcionar em janeiro de 2005 . Brasília, 13.12.2004.

Presidente Lula lança programa de incentivo ao biodiesel. Brasília, 06.12.2004.

Disponível em: <www.memoria.ebc.com.brlagenciabrasil>. Acesso em: 08 jan. 2015.

AGROPALMA. Relatório de sustentabilidade 2013. São Paulo, 2013. 
ALMEIDA, Maria do Fetal Carvalho Ferreira de. Uso agrícola do território e pedagogia do Movimento dos Sem Terra (MST): uma geografia do presente. 2007. Tese (Doutorado em Geografia) - Universidade de São Paulo, São Paulo, 2007.

ANDERSON, Scott Douglas. Engenhos na várzea: uma análise do declínio de um sistema de produção tradicional na Amazônia. In: LÉNA, Philippe; OLIVEIRA, Adélia Engrácia de. Amazônia: a fronteira agrícola 20 anos depois. Belém: MPEG, 1991. p.101-121. (Coleção Eduardo Galvão)

ANGELO-MENEZES, Maria de Nazaré. Aspectos conceituais do sistema agrário do vale do Tocantins colonial.Cadernos de Ciência \& Tecnologia, Brasília, v. 17, n. 1, p.91-122, 2000.

História social dos sistemas agrários do Vale do Tocantins - Pará - Brasil (16691800): rupturas e estabilidades. Paris, França, 1994. (Diploma de Estudos Aprofundados)

ANP - Agência Nacional do Petróleo, Gás Natural e Biocombustíveis. Anuário estatístico brasileiro do petróleo, gás natural e biocombustiveis 2015. Rio de Janeiro, 2015.

Anuário estatístico brasileiro do petróleo, gás natural e biocombustíveis: 2013. Rio de Janeiro, 2013.

ANTAS JR., Ricardo Mendes. Território e regulação: espaço geográfico, fonte material e não-formal do direito. São Paulo: Associação Editorial Humanitas; Fapesp, 2005.

Elementos para uma discussão epistemológica sobre a regulação no território. Geousp: Espaço e Tempo, São Paulo, n. 16, p. 81-86, 2004.

ANTONIL, A. J. Cultura e opulência no Brasil. 3. ed. Belo Horizonte: Itatiaia, 1982.

ARRETCHE, Martha. Dossiê agenda de pesquisa em políticas públicas. Revista Brasileira de Ciências Sociais, v. 18, n. 51, p. 7-9, 2003.

BACEN - Banco Central do Brasil. Matriz de Dados do Credito Rural. Brasília, 2016. Disponível em: <http://www.bcb.gov.br/m/micrrural>. Acesso em: 02 jan. 2016.

. Manual de Crédito Rural. Brasília, 2015. Disponível em: <http://www3.bcb.gov.br/mcr/>. Acesso em: 16 out. 2015.

BAENA, Antônio Ladislau Monteiro. Ensaio Corográfico sobre a província do Pará. Brasília: Senado Federal, 2014.

BARROS, Márcio Júnior Benassuly. Ação política e território no Baixo Tocantins: efeitos advindos da construção de dois projetos do Programa Grande Carajás (PGC). In: SILVA, Christian Nunes da (Org.).Produção do espaço e territorialidade na Amazônia paraense: elementos para a análise geográfica. 1. ed. Belém: GAPTA/UFPA, 2016. p. 45-60

O uso do território e políticas públicas territoriais no Baixo Tocantins, estado do Pará. In:ENANPUR, 16. Belo Horizonte, 2015.Anais...Belo Horizonte: ANPUR, 2015. 
Espaço, tempo e economia local no baixo rio Tocantins anterior e posterior à usina hidrelétrica de Tucuruí: o caso do município de Mocajuba-PA. In: ENCONTRO LATINOAMERICANO CIÊNCIAS SOCIAIS E BARRAGENS, 3. Belém, 2010 Anais...Belém, 2010.

BARROS, Márcio Júnior Benassuly; STEINBERGER, Marília. Uma nova geopolítica dos recursos agroenergeticos? In: CONGRESSO BRASILEIRO DE GEOGRAFIA POLÍTICA, GEOPOLÍTICA E GESTÃO DO TERRITÓRIO, 1. Rio de Janeiro, 2014. Anais... Rio de Janeiro: Editora Letral, 2014.

BASA - Banco da Amazônia. Apresentação em slide da Gerência de Microfinanças e Agricultura Familiar. Brasília, 2014a.

Apresentação em slide na oficina boas práticas socioambientais aplicadas à pequenos produtores na cadeia produtiva de óleo de palma na América latina. São Paulo, SP. Abril /2014b. (Superintendência Regional do Pará e Amapá).

A experiência do banco da Amazônia com projetos integrados de dendê familiar. Contexto Amazônico, Belém, n. 22, p.1-8, 2012a.

Perspectivas da palma de óleo na Amazônia. Contexto amazônico. Belém, v. 6, n. 25, p.1-8, 2012b.

BATES, Henry Walter. O naturalista no rio Amazonas. São Paulo: Companhia Editora Nacional, 1944. v. 1

BECKER, Bertha. Recuperação de áreas desflorestadas da Amazônia; será pertinente o cultivo da palma de óleo (dendê)? Revista Franco-Brasileira de Geografia, n. 10, p.1-21, 2010 . 2007.

Amazônia: geopolítica na virada do III milênio. 2. ed. Rio de Janeiro: Garamond,

Amazônia: mudanças estruturais e tendências na passagem do milênio. In MENDES, Armando Dias. A Amazônia e seu banco. Manaus: Editora Valer, 2002.p.71-94.

Amazônia. São Paulo: Ática, 1994.

Grandes projetos e produção de espaço transnacional: uma nova estratégia do Estado na Amazônia. Revista Brasileira de Geografia, Rio de Janeiro, v. 51, n. 4, p. 7-20, 1989. 1982.

Geopolítica da Amazônia: uma nova fronteira dos recursos. Rio de Janeiro: Zahar,

BECKER, Bertha; MIRANDA, Mariana; MACHADO, Lia Ozório. Fronteira amazônica: questões sobre a gestão do território. Brasília; Rio de Janeiro: UnB; UFRJ, 1990.

BELATO, Dinarte. Os camponeses integrados. 1985. Dissertação (Mestrado em História) Universidade Estadual de Campinas, Campinas-SP, 1985. 
BELÉM BIOENERGIA BRASIL. Notas explicativas as administração as demonstrações financeiras em 31 de dezembro de 2014. Belém, 2014.

. Relatório da Administração de 2013. In: Diário Oficial do Estado do Pará. Belém, PA, 02 de maio de 2014.

Notas explicativas as administração as demonstrações financeiras em 31 de dezembro de 2013. Belém, 2013a.

Apresentação em slide realizada por Antônio Eduardo Gonçalves Esmeraldo, Diretor Superintendente da Belém Bioenergia Brasil S. A. Belém, 2013b. Disponível em: http://www.globalbioenergy.org/fileadmin/user_upload/gbep/docs/2013_events/GBEP_Bioen ergy_Week_Brasilia_18-23_March_2013/3.6_ESMERALDO.pdf. Acesso em: 10 de jan. 2015

Notas explicativas as administração as demonstrações financeiras em 31 de dezembro de 2012. Belém, 2012.

BERNARDES, Julia Adão. Políticas públicas, selo combustível social e território usado. In: BERNARDES, Julia Adão; ARACRI, Luiz Angelo dos Santos. Novas fronteiras do biodiesel na Amazônia: limites e desafios da incorporação da pequena produção agrícola. Rio de Janeiro: Arquimedes, 2011.p.65-76.

Fronteiras da agricultura moderna no cerrado norte/nordeste: descontinuidades e permanências. In: BERNARDES, Julia Adão; BRANDÃO FILHO, José Bertoldo.A territorialidade do capital. Rio de Janeiro: Arquimedes Edições, 2009.p.13-39.

BIOPALMA. Diagnóstico territorial da Biopalma. 2012. (Diagonal). Disponível em: www.abrapalma.org.br. Acesso em: 20 fev. 2015.

BNDES - Banco Nacional de Desenvolvimento Econômico e Social. Formação do mercado de biodiesel no Brasil. BNDES setorial. Rio de Janeiro, 2007.

BNDES; CGEE - Centro de Gestão e estudos Estratégicos. Bioetanol de cana de açúcar: energia para desenvolvimento sustentável. Rio de Janeiro, 2008.

BOBBIO, Norberto. O significado da política. In: UNIVERSIDADE DE BRASÍLIA. Curso de introdução à ciência política. 2. ed. Brasília: UNB, 1984. p. 5-19

BOBBIO, Norberto; MATEUCCI, Nicola; PASQUINO, Gianfranco. Dicionário de política. 1. ed. Brasília: UNB, 1998.

BRASIL. Ministério da Agricultura, Pecuária e Abastecimento. Anuário Estatístico da Agroenergia 2014. Brasília, 2015.

Ministério do Desenvolvimento Agrário. Lista das empresas de biodiesel detentora do selo combustível social até 28/10/2014. Brasília, 2014a. Disponível em: www.mda.gov.br. Acesso em: 20 ago. 2015. 
Lei $\mathrm{n}^{\mathrm{o}} 13.033 / 2014$, de 24 de setembro de 2014. Dispõe sobre a adição obrigatória de biodiesel ao óleo diesel no Brasil. Diário Oficial da União. Brasília, DF, 15 set. 2014b.

. Ministério do Desenvolvimento Agrário. Programa nacional de produção e uso de biodiesel: inclusão social e desenvolvimento territorial. Brasília, 2010a.

Ministério da Agricultura, Pecuária e Abastecimento. Programa de Produção Sustentável Óleo de Palma. Brasília, 2010b.

Decreto $\mathrm{n}^{\mathrm{o}} 7.172$ de 7 de maio de 2010 que dispõe sobre o zoneamento agroecológico da cultura da palma de óleo no Brasil. Diário Oficial da União. Brasília, DF, 10 maio 2010c.

. Ministério do Desenvolvimento Agrário. Agricultura familiar no Brasil e o censo agropecuário 2006. Brasília, 2009a

Ministério do Desenvolvimento Agrário. Plano territorial de desenvolvimento rural sustentável do Baixo Tocantins. Brasília, 2009b.

Lei $\mathrm{n}^{\mathrm{o}}$ 11.1326, de 24 de julho de 2006. Estabelece as diretrizes para a formulação da Política Nacional de Agricultura Familiar e Empreendimentos Familiares Rurais. Diário Oficial da União. Brasília, DF, 23 jul. 2006.

Ministério da Agricultura, Pecuária e Abastecimento. Plano Nacional de Agroenergia. Brasília, 2005a.

Ministério da Ciência e Tecnologia. Ministério de Minas e Energia e Ministério do Desenvolvimento, Indústria e Comércio Exterior. Diretrizes de Política de Agroenergia. 2006-2011. Brasília, 2005b.

Ministério do Desenvolvimento Agrário. Instrução Normativa $\mathrm{n}^{\mathrm{o}}$ 01, de 05 de julho de 2005. Diário Oficial da União. Poder Executivo, Brasília, DF, 01 jul. 2005c.

Ministério do Desenvolvimento Agrário. Instrução Normativa $\mathrm{n}^{\mathrm{o}}$ 02, de 30 de setembro de 2005. Diário Oficial da União. Poder Executivo, Brasília, DF, 30 nov. 2005d

Lei $\mathrm{n}^{\mathrm{o}}$ 11.097/2005. Introduz o biodiesel na matriz energética brasileira. Diário Oficial da União. Poder Executivo, Brasília, DF, 14 jan. 2005 e.

2004.

Ministério de Minas e Energia. Biodiesel: o novo combustível do Brasil. Brasília,

Presidência da República. Relatório do grupo de trabalho interministerial encarregado de apresentar estudos sobre a viabilidade de utilização de óleo de vegetal: biodiesel como fonte alternativa de energia.Brasília, 2003a.

Presidência da República. Resumo do posicionamento dos órgãos e entidades convidados para o ciclo de audiências do grupo de trabalho interministerial biodiesel. Anexo I. Relatório final. Brasília, 2003b. 
Presidência da República. Atas das reuniões do grupo de trabalho interministerial biodiesel. Anexo II. Relatório final. Brasília, 2003c.

Presidência da República. Relatórios finais dos subgrupos do grupo de trabalho interministerial biodiesel. Anexo III. Relatório final. Brasília, 2003d.

Decreto de 23 de dezembro de 2003. Institui a Comissão Executiva Interministerial do Biodiesel - CEIB. Diário Oficial da União. 24 dez. 2003. Poder Executivo, Brasília, 2003 e.

Decreto $\mathrm{n}^{\mathrm{o}}$ 3.991, de 30 de outubro de 2001. Dispõe sobre Programa Nacional de Fortalecimento da Agricultura Familiar - Pronaf. Diário Oficial da União. Brasília, DF. 31 out. 2001.

Decreto $\mathrm{n}^{\mathrm{o}}$ 1.946, de 28 de julho de 1996. Dispõe sobre a criação do Programa Nacional de Fortalecimento da Agricultura Familiar - Pronaf. Diário Oficial da União. Brasília, DF, 01 jul. 1996.

Ministério do Interior. Diagnóstico da bacia do Araguaia - Tocantins. Regionalização. Brasília, PRODIAT, 1982a. v. 1

. Diagnóstico da bacia do Araguaia - Tocantins. Sócio - Economia. Brasília, PRODIAT, 1982b. v. 2

CÂMARA DOS DEPUTADOS. Comissão de Integração Nacional, Desenvolvimento Regional da Amazônia. Notas taquigráficas da audiência pública sobre o programa de biocombustíveis em municípios do Pará. Brasília, 10 jun. 2014.

CAMPOS, Arnaldo; CARMELIO, Edna de Cássia. Biodiesel e agricultura familiar no Brasil: resultados socioeconômicos e expectativa futura. In: FERREIRA, José Rincón; CRISTO, Carlos Manuel Pedroso Neves. O futuro da indústria: biodiesel. Brasília. 2006. p.49- 65

CARLOS, Ana Fani Alessandri. Ensaios de Geografia contemporânea: Milton Santos obra revisitada. São Paulo: Hucitec, 1996.

CASTRO, Carmem Lúcia Freitas de et al. Dicionário de políticas públicas. Barbacena-MG: EdUEMG,2012.

CASTRO, Cesar Nunes de. O Programa Nacional de Produção e Uso de Biodiesel (PNPB) e a produção de matéria-prima de óleo vegetal no Norte e Nordeste. Brasília: IPEA, 2011. (Texto para discussão número, 1613).

CASTRO, Edna Maria Ramos de. Resistência dos atingidos pela barragem de Tucuruí e construção de identidade. In: CASTRO, Edna Maria Ramos de; HÉBETTE, Jean (Org.). Na trilha dos grandes projetos: modernização e conflito na Amazônia. Belém: NAEA, 1989.p.41-70 (Cadernos NAEA 10)

CATAIA, Márcio Antônio. Território político: fundamento e fundação do estado.Sociedade \& Natureza, Uberlândia-MG, v. 23, n. 1, p. 115-125, abr. 2011. 
CAVALCANTE, Matuzalem; FERNANDES, Bernardo Mançano. Territorialização do agronegócio e concentração fundiária. Revista NERA, Presidente Prudente-SP, v. 11, n. 13, p. 16-25, 2008.

CHAmbouleyron, Rafael. Povoamento, ocupação e agricultura na Amazônia colonial. Belém: Editora Açaí, 2010.

Plantações, sesmarias e vilas. Uma reflexão sobre a ocupação da Amazônia

seiscentista. Novos Mundos/MundosNuevos, 2006. Disponível em: www.nuevomundo.revues.org/2260. Acesso em: 20 dez. 2015.

CHIAPETTI, Jorge. O uso corporativo do território brasileiro e o processo de formação de um espaço derivado: transformações e permanências na região cacaueira da Bahia. 2009. Tese (Doutorado em Geografia) - Universidade Estadual Paulista, Rio Claro-SP, 2009.

CLAVAL, Paul. O território na transição da pós-modernidade. Geographia, Niterói-RJ, v. 1, n. 2, p. 7-26, 1999.

CLEPS JÚNIOR, João. Questão agrária, estado e territórios em disputa: os enfoques sobre o agronegócio e a natureza dos conflitos no campo brasileiro. In: SAQUET, Marco Aurélio; SANTOS, Roseli Alves dos. Geografia agrária, território e desenvolvimento. São Paulo: Expressão Popular, 2010.p.35-54.

CONAB - Companhia Nacional de Abastecimento. Dendeicultura da Bahia. Salvador, 2006.

CONANT, Melvin. A; GOLD, Fern. Racine. A geopolítica energética. Rio de Janeiro, Atlântida, 1981

CONTEL, Fabio Betioli. Território e finanças. Técnicas, normas e topologias bancárias no Brasil. 2007. Tese (Doutorado em Geografia) - Universidade de São Paulo, São Paulo, 2007.

COSTA, José Marcelino Monteiro da. Ocupação, integração e desenvolvimento da Amazônia: 60 anos de ação federal. In: MENDES, Armando Dias. A Amazônia e seu banco. Manaus: Editora Valer, 2002.p.279-317.

COSTA, Wanderley Messias da.Geografia política e geopolítica: discursos sobre o território e o poder. São Paulo: EDUSP, 2010.

COUTO, Elisangela. As modernizações e as racionalidades na agricultura e o uso do território: temporalidades e espacialidades no município de Ibiúna (SP) São Paulo. 2007. Dissertação (Mestrado em Geografia) - Universidade de São Paulo, São Paulo, 2007.

CRESWELL, John W. Investigação quantitativa e projeto de pesquisa: escolhendo entre cinco abordagens. 3. ed. Porto Alegre: Penso, 2014.

Artmed, 2010.

Projeto de pesquisa: métodos qualitativo, quantitativo e misto. 3. ed. Porto Alegre:

CRESWELL, John W.; CLARK, Vicki L. P. Pesquisa de métodos mistos. 2. ed. Porto Alegre: Penso, 2013. 
CRUZ, Ernesto. História do Pará. Belém: EDUFPA, 1963. v. 1.

DAVID, Cesar de; CORREA, WalquiriaKruger. A política agrária e suas transformações na agricultura brasileira de 1960 aos dias atuais.Geosul, Florianópolis, v. 17, n.33, p. 23-43, jan./jun.2002.

DEMO, Pedro. Metodologia científica em ciências sociais. 3. ed. São Paulo: Atlas, 2014.

DETER. Revista do Departamento de Estudos Socioeconômicos Rurais. A cadeia produtiva do fumo. Curitiba, 2005.

DINIZ, João Fábio; FAVARETO, Arilson. Os desafios da inclusão da agricultura familiar no mercado de matéria-prima para o biodiesel no Brasil. Revista Estudo, Sociedade e Agricultura, Rio de Janeiro, v. 20, n.1, p. 139-187, 2012.

DUPAS, Gilberto. Atores e poderes na nova ordem global. São Paulo: UNESP, 2005.

ELIAS, Denise. Agronegócio e novas regionalizações no Brasil. Revista Brasileira de Estudos Urbanos e Regionais, Recife, v. 13, n. 2, p. 153-167, nov. 2011.

. Agronegócio e desigualdades socioespaciais. In: ELIAS, Denise; PEQUENO, Renato (Org.). Difusão do agronegócio e novas dinâmicas socioespaciais. Fortaleza: Banco do Nordeste do Brasil, 2006a.p.25-82.

Ensaios sobre os espaços agrícolas de exclusão. Revista NERA, Presidente Prudente-SP, v. 9, n. 8, p.29-51, jan./jun. 2006b.

Globalização e fragmentação do espaço agrícola do Brasil. Scripta nova. Revista electrónica de geografía y cienciassociales. Barcelona: Universidade de Barcelona, v. 10 , n. 218 (03), $2006 \mathrm{c}$.

Milton Santos: a construção da geografia cidadã.Geosul, Florianópolis, v. 18, n. 35, p. 131-148, jan./jun.2003.

. Globalização e agricultura. São Paulo: EDUSP, 2003.

Agricultura científica no Brasil: impactos territoriais e sociais. In: SOUZA, Maria Adélia Aparecida de (Org.). Território brasileiro: usos e abusos. Campinas-SP: Edições Territorial, 2003.p.315-340.

Desigualdade e pobreza no espaço agrário cearense. Mercator: Revista de Geografia da UFC, Fortaleza, v. 2, n. 3, p.61-69, 2003.

O Baixo Jaguaribe: entre a ordem global e a local. In: ELIAS, Denise (Org.). O novo espaço da produção globalizada: o Baixo Jaguaribe-CE. Fortaleza: FUNECE, 2002.p.11-21.

EMBRAPA - Empresa Brasileira de Pesquisa Agropecuária.Relatório do II Workshop do programa de produção sustentável da palma de óleo no Brasil. Belém: Embrapa Amazônia Oriental, 2015. 
Zoneamento agroecológico do dendezeiro para as áreas desmatadas da Amazônia legal. Rio de Janeiro: Embrapa Solos, 2010.

A Embrapa Amazônia Oriental e o agronegócio do dendê no estado do Pará. Belém: Embrapa Amazônia Oriental, 2006.

A cultura do dendê. Brasília: Embrapa Sede, 1995 (Coleção Plantar, 32)

ESTADO DE SÃO PAULO. Vale compra Biopalma da Amazônia por US\$ 173 milhões. São Paulo, 02 fev. 2011.

FABRINI, João Edmilson. O campesinato frente à expansão do agronegócio e do agrocombustível. In: SAQUET, Marcos Aurélio; SANTOS, Roseli Alves dos. Geografia agrária, território e desenvolvimento. São Paulo: Expressão Popular, 2010.p.55-88.

FAEPA - Federação da Agricultura do Estado do Pará. A cadeia produtiva da palma de óleo no Estado do Pará: uma avaliação crítica. Slide apresentado na audiência pública sobre o Programa Nacional de Produção Sustentável de Óleo de Palma. Brasília, 26 mar. 2015.

FAO/INCRA. Novo retrato da agricultura familiar e o Brasil redescoberto. Brasília, 2000.

. Perfil da agricultura familiar no Brasil: dossiê estatístico. Brasília, ago. 1996. Projeto UFT/BRA/036/BRA.

FARIA, Carlos Aurélio Pimenta de. A multidisciplinaridade nos estudos das políticas públicas. In: MARQUES, Eduardo; FARIA, Carlos Aurélio Pimenta de. A política como campo multidisciplinar. São Paulo: UNESP; Rio de Janeiro: Fiocruz, 2013.p.11-21.

Ideias, conhecimento e políticas púbicas: um inventário sucinto das principais vertentes analíticas recentes. Revista Brasileira de Ciências Sociais, v. 18, n. 51, p.21-29, 2003.

FREDERICO, Samuel. Modernização da agricultura e uso do território: a dialética entre o novo e o velho, o interno e o externo, mercado e o estado em áreas de cerrado. GEOUSPEspaço e Tempo, São Paulo, n. 34, 2013. Número Especial.

- Expansão da fronteira agrícola moderna e consolidação da cafeicultura científica globalizada no Oeste da Bahia. Boletim Campineiro de Geografia, v. 2, n. 2, p. 279-301, 2012.

FASE - Federação de Órgãos para Assistência Social e Educacional. Que negocio é este? Por que a agricultura e a pecuária crescem sem beneficiar a população brasileira. Rio de Janeiro, 2005.

FAVARETO, Arilson da Silva. Paradigmas do desenvolvimento agrário em questão: do agrário ao territorial.2006. Tese (Doutorado em Ciência Ambiental) - Universidadede São Paulo, São Paulo, 2006. 
FEIO, Luiz Euclides B. Estrutura, mecanismos e capacidades para operacionalizar o crédito agrícola da agricultura familiar na palma de óleo. In: WORKSHOP DO PROGRAMA DE PRODUÇÃO SUSTENTÁVEL DE PALMA DE ÓLEO NO BRASIL: AGRICULTURA FAMILIAR E PESQUISA, DESENVOLVIMENTO \& INOVAÇÃO, 1. Belém, PA: Apresentação em Power Point, BASA, 2013.

FERNANDES, Bernardo Mançano. Agronegócio e reforma agrária. In: FERNANDES, Bernardo Mançano. Construindo um estilo de pensamento na questão agrária: o debate paradigmático e o conhecimento geográfico. Presidente Prudente, 2013. v. 1.p.140-145.

Entrando nos territórios do território. In: PAULINO, Eliane Tomiasi; FABRINI, João Edmilson. Campesinato e territórios em disputa. São Paulo: Expressão Popular, 2008. p. 273-301.

FONTANA, José Domingos. Biodiesel: para leitores de 9 a 90 anos. Curitiba; Ed. UFPR, 2011.

FLEXOR, Georges et al. Políticas públicas, dinâmica institucional e conflitos de interesses: análise do Programa Nacional de Produção e Uso de Biodiesel. Rio de Janeiro: FAPERJ, 2011.

FLOHRSCHUTZ, Gerhard Hubert Herrmann; KITAMURA, Paulo Choji. A pequena agricultura na Amazônia oriental. Belém: Embrapa Amazônia Oriental, 1986.

FREITAS, Hingryd Inácio; GERMANI, Guimar Inez. O desenvolvimento territorial rural em questão. Mercator, Fortaleza, v.11, n. 25, p. 19-33, maio/ago. 2012.

FREY, K. Políticas públicas: um debate conceitual e reflexões a práticas da análise de políticas públicas no Brasil. Planejamento e Políticas Públicas no Brasil, Brasília, IPEA, n, 21, jun. 2000.

FURLAN JÚNIOR, José. Nova dinâmica da agricultura brasileira. Campinas-SP: Unicamp, 1996.

FURLAN JÚNIOR, José et al. Agricultura familiar e reforma agrária no século XXI. Rio de Janeiro: Garamond, 2009.

. Biodiesel: por que tem que ser dendê. Belém: Embrapa/Palmasa, 2006.

GARCEZ, Catherine AlianaGucciardi. Uma análise da política pública do Programa Nacional de Produção e Uso do Biodiesel (PNPB). 2008. Dissertação (Mestrado em Desenvolvimento Sustentável) - Universidadede Brasília, Brasília, 2008.

GARCIA, Graça Lobato; LOBATO, Eládio. Memória dos engenhos do Baixo Tocantins, Belém, 2011.

GENTIL. Luiz Vicente. 202 perguntas e respostas sobre biocombustiveis. Brasília. Editora Senac, 2011. 
GLASS, Verena. Relatório inédito aponta os custos da expansão do dendê no nordeste do Pará. Disponível em: www.reporterbrasil.org.br. Acesso em: 25 maio 2015.

GOMES, Maiara da Silva; STEINBERGER, Marília; BARBOSA, Renan Paixão. O potencial político da categoria território usado. In: STEINBERGER, Marília. Território, estado e políticas públicas espaciais. Brasília: Ler Editora, 2013.p.65-87.

GONÇALVES, Carlos Walter Porto. Amazônia, Amazônias. 2. ed. São Paulo: Contexto, 2005.

GONÇALVES NETO, Wenceslau. Estado e agricultura no Brasil: políticas agrícolas e modernização brasileira 1960-1980. São Paulo: Hucitec, 1997.

GONZAGA, Jaqueline do Carmo Silva; TOLEDO, Márcio Roberto. O uso agrícola do território na microrregião de São João del-Rei-MG: uma análise do cultivo da soja. Revista Territorium Terram, v. 3, n. 5, p. 24-31, jan./jun. 2015.

GRAZIANO DA SILVA, José. A nova dinâmica da agricultura brasileira. Campinas-SP: Unicamp. IE, 1996.

Amodernização dolorosa: estrutura agrária, fronteira agrícola e trabalhadores rurais no Brasil.Rio de Janeiro: Zahar Editores, 1981.

GRISA, Catia; SCHNEIDER, Sergio. Três gerações de políticas públicas para a agricultura familiar e formas de interação entre sociedade e Estado no Brasil. Revista de Economia e Sociologia Rural. Piracicaba-SP, v. 52, p. 125-146, 2015.

GUANZIROLI, Carlos E. Pronaf dez anos depois: resultados e perspectivas para o desenvolvimento rural. Revista de Economia e Sociologia Rural. Piracicaba-SP, v. 45, p.301-328,2007.

GUANZIROLI, Carlos E. et al. Agricultura familiar e reforma agrária no século XXI. Rio de Janeiro: Garamond, 2009.

GUERRA, Gutemberg Armando Diniz. Organizações rurais e camponesas no estado do Pará. In: FERNANDES, Bernardo Mançano; MEDEIROS, Leonilde Servolo; PAULILO, Maria Ignez. Lutas camponesas contemporâneas: condições, dilemas e conquistas. São Paulo: UNESP, Brasília: NEAD, 2009. p. 117-338.

HAESBAERT, Rogério. O mito da desterritorialização: do fim dos territórios a multiterritorialidade. Rio de Janeiro. Bertrand Brasil, 2006.

. Nossos Clássicos: La Blache, Ratzel e a "geografia política”. GEOgraphia, NiteróiRJ, v. 2, n. 4, p.1-3, 2002.

HOCHMAN, Gilberto (Org.). Políticas públicas no Brasil. Rio de Janeiro: Fiocruz, 2007.

HÉBETTE, Jean (Org.). O cerco está se fechando: o impacto do grande capital na Amazônia. Rio de Janeiro, Fase, 1991. 
HEGEL, Georg Wilhelm Friedrich. A razão na história: uma introdução geral à filosofia da história.Tradução de Beatriz Sidou.2.ed. São Paulo: Centauro. 2001.

HERMAN, Patrícia. Os planos da Vale. Biodiesel Br. Jan./jul. 2013. Disponível em:http://saladeimprensa.vale.com/Paginas/ImprensaDetalhe.aspx?t=Impressos\&iID=236

Acesso em: 20 nov. 2015

HOMMA, Alfredo Kingo Oyama et al. Integração grande empresa e pequenos produtores de dendezeiro: o caso da comunidade de Arauaí, município de Moju, Pará. Belém: Embrapa Amazônia Oriental, 2014. (Boletim de Pesquisa e Desenvolvimento, n. 92)

HNOTHE, Gerhard et al. Manual de biodiesel. São Paulo: Edgard Blucher, 2006

HOWLETT, Michael; RAMESH, M.; PERL, Anthony. Políticas públicas: seus ciclos e subsistemas: uma abordagem integradora. Rio de Janeiro: Elsevier, 2013.

HOLANDA. Ariosto. Biodiesel e inclusão social. Brasília: Câmara dos Deputados, 2004. (Série Cadernos de Altos Estudos, n. 1)

HUERTAS, Daniel Monteiro. Da fachada atlântica à imensidão amazônica: fronteira agrícola e integração nacional. São Paulo: Annablume; FAPESP; Belém: Banco da Amazônia, 2009.

HURTIENNE, Thomas. Agricultura familiar e desenvolvimento rural sustentável na Amazônia. Novos Cadernos do NAEA, Belém, v. 8, n. 1, p.19-71, 2005.

Agricultura familiar e desenvolvimento sustentável: problemas conceituais e metodológicos no contexto histórico da Amazônia. Revista Econômica do Nordeste, Fortaleza, v. 30, n. especial, 1999.

Agricultura familiar na Amazônia oriental: uma comparação dos resultados da pesquisa socioeconômica sobre fronteiras agrárias sob condições históricas e agroecológicas diversas. Novos Cadernos do NAEA, Belém, v. 2, n. 1, p.75-94, 1999.

IANNI, Otávio. Colonização e contra-reforma agrária na Amazônia. Petrópolis-RJ: Vozes, 1979 (Coleção Sociologia Brasileira, v.11)

IBGE. Produção Agrícola Municipal. Rio de Janeiro, 2015. Banco de dados SIDRA. Disponível em: http://www.sidra.ibge.gov.br. Acesso em: 30 dez.2015

Manual técnico das pesquisas agropecuárias municipais. Rio de Janeiro, 2014.

. Manual de uso da terra. 3. ed. Rio de Janeiro, 2013.

Manual do recenseador do censo agropecuário 2006. Rio de Janeiro, 2007.

Agricultura familiar: primeiros resultados. Rio de Janeiro, 2009. (Caderno do Censo Agropecuário 2006) 
Pesquisas agropecuárias. 2. ed. Rio de Janeiro, 2002 (Relatórios metodológicos, v.

6)

. Censo Agropecuário 1995-1996: Pará. Rio de Janeiro, 1996.

Sistema IBGE de recuperação automática - SIDRA. Vários anos e acessos. Disponível em:www.sidra.ibge.gov.br

INCRA/FAO. Novo retrato da agricultura familiar: o Brasil redescoberto. Brasília, 2000 (Projeto de cooperação técnica).

IPEA - Instituto de Pesquisa Econômica Aplicada. Biocombustíveis do Brasil: etanol e biodiesel. Brasília, 2010 (Comunicados do IPEA, n. 53)

Biodiesel no Brasil: desafios das políticas públicas para a dinamização da produção. Brasília, 2012. (Comunicados do IPEA, n. 137)

IOS - Instituto Observatório Social. O comportamento sócio-trabalhista na produção do óleo de palma do dendê no estado do Pará com foco nas empresas Agropalma, Biovale/Biopalma, Petrobras Combustíveis. São Paulo. 2014.

ITERPA - Instituto de Terras do Pará. Sesmarias. Belém, 2009.

JORNAL ALDEIA. Amazônia: um território em disputa. Belém: Fase Amazônia, nov./dez. 2013.

KAGEYAMA, Ângela; BERGAMASCO, Sonia M. P. A estrutura da produção no campo em 1980. Perspectiva, São Paulo, v. 12, n. 13, p. 55-72, 1989.

KITAMURA, Paulo Choji. Dendê: oferta e demanda no mercado internacional. Belém: Embrapa, 1990.

LAMARCHE, Hugues (Org.) Agricultura familiar: comparação internacional.Campinas-SP: Unicamp, 1998.

LARAIA, Roque de Barros; DA MATTA, Roberto. Índios e castanheiros: a empresa extrativa e os índios no médio Tocantins. 2. ed. Rio de Janeiro: Paz e Terra, 1978.

LEAL, Aluízio Lins. O caso Albrás/Alunorte: os primeiros impactos sociais de um polo metalúrgico na Amazônia.Revista Ciência da Terra, n.5, p. 45-56, jul./ago. 1982.

LEFEBVRE, Henri. Lógica formal. Lógica dialética. Trad.: Carlos Nelson Coutinho. 3. ed. Rio de Janeiro: Civilização Brasileira, 1983. (Coleção Perspectiva do Homem, v. 100)

LEITE, Sérgio Pereira. Estado, padrão de desenvolvimento e agricultura: o caso brasileiro. Revista Estudo, Sociedade e Agricultura, Rio de Janeiro, v. 13, n.2, p. 280-332, 2005.

LÉNA Philippe; OLIVEIRA Adélia Engrácia de.Amazônia. A fronteira agrícola 20 anos depois. Belém: CEJUP, 1992. 
LIMA, Arnoldo Santos de. Desafios a verticalização agroindustrial familiar de oleaginosas no semiárido baiano: direcionadores de competitividade das usinas de Lapão e Olindina. 2011. Dissertação (Mestrado em Desenvolvimento Sustentável) - Universidade de Brasília, Brasília, 2011.

LIMA, Paulo Cesar Ribeiro. Biocombustiveis, renda e alimentos. Brasília, 2007. (Consultoria da Câmara dos Deputados).

LOPES, Heloisa Santos Molina. Agricultura, modernização e uso coorporativo do território. 2006. Dissertação (Mestrado em Geografia) - Universidade de São Paulo, São Paulo, 2006.

MACEDO, Jeferson Luiz Vasconcelos de et al. Sistema produtivo de dendê para a produção de biodiesel. In: CASTRO, Antonio Maria Gomes; LIMA, Suzana Maria Valle; SILVA, João Flavio Veloso (Ed.) Complexo agroindustrial de biodiesel no Brasil: competitividade das cadeias produtivas de matérias-primas. Brasília: Embrapa Agroenergia, 2010.p.325-374.

MACHADO. Lia Ozório. A fronteira agrícola na Amazônia brasileira. In: BECKER, B. et al. (Org.). Geografia e meio ambiente no Brasil. São Paulo: Hucitec, 1995.p.181-217.

A fronteira agrícola na Amazônia. Revista Brasileira de Geografia, Rio de Janeiro, v. 54, n. 2, p.27-54, abr./jun. 1992.

MAGALHÃES, Sônia Barbosa. Expropriação e mobilização: a dupla face da relação entre os grandes projetos e a população camponesa. In: HÉBETTE. Jean (org.). O cerco está se fechando: os impactos do grande capital na Amazônia. Petrópolis-RJ; Rio de Janeiro; Belém: Vozes; Fase; NAEA, 1991.p.176-198.

MARQUES, Eduardo. As políticas públicas na ciência política.In: MARQUES, Eduardo;FARIA, Carlos Aurélio Pimenta de. A política como campo multidisciplinar. São Paulo: UNESP; Rio de Janeiro: Fiocruz, 2013.p.23-46.

MARQUES, Eduardo; FARIA, Carlos Aurélio Pimenta de (Org.). A política pública como campo multidisciplinar. São Paulo: Editora UNESP. Rio de Janeiro: Fiocruz, 2013.

MARTINS, José de Sousa. Caminhada no chão da noite: emancipação política e liberdade nos movimentos sociais no campo. São Paulo: Hucitec, 1989.

Os camponeses e a política no Brasil: as lutas sociais no campo e seu lugar no processo político. Petrópolis-RJ: Vozes, 1986.

A chegada do estranho. São Paulo: Hucitec, 1993.

Expropriação e violência: a questão política no campo. São Paulo: Hucitec, 1991.

Não há terra para plantar neste verão: o cerco das terras indígenas e das terras de trabalho no renascimento político do campo. Petrópolis-RJ: Vozes, 1988.

O tempo da fronteira. Revista de Sociologia, São Paulo: Universidade de São Paulo, n. 8, p.25-70, 1996. 
MATHIS, Armin et al. Estrutura de poder, atores sociais e políticas territoriais no Tocantins. In: MATHIS, Armin et al. Poder local e mudanças socioambientais. Belém: NAEA, 2007. p.7-19.

MEDEIROS, Leonilde Servolo de. Trabalhadores rurais, agricultura familiar e organização sindical. Perspectiva, São Paulo, v. 11, n. 2, p.65-72, 1997.

MELAZZO, Everaldo. Problematizando o conceito de políticas públicas: desafios a analises e a prática do planejamento e da gestão. Revista Tópos, v. 4, n. 2, p. 9-32, 2010.

MELAZZO, Everaldo et al.Relatório do GT Geografia e políticas públicas: Balanço e perspectivas. In: ENCONTRO NACIONAL DA ASSOCIAÇÃO NACIONAL DE PÓSGRADUAÇÃO E PESQUISA EM GEOGRAFIA (ENANPEGE), 10. Campinas-SP, 2013. Slide não publicado.

MELlO-THÉRY, Neli Aparecida de. Política (e ação) pública, território e o papel da geografia.Revista da ANPEGE, v.7, n. 1, número especial, p. 11-19, out. 2011.

MELO, Marcus André. Estado, governo e políticas públicas. In: O que ler na ciência social brasileira (1970-1995): Ciência política (volume III). São Paulo. Editora Sumaré: ANPOCS: Brasília. CAPES. 1999.

MITSCHEIN, Thomas A.; MIRANDA, Henrique R.; PARAENSE, Mariceli de C. Capitalismo de enclave e consciência camponesa no Baixo Tocantins (Pará). In: HÉBETTE. Jean (org.). O cerco está se fechando: os impactos do grande capital na Amazônia. Petrópolis-RJ; Rio de Janeiro; Belém: Vozes; Fase; NAEA, 1991.p.227-247.

MOCAJUBA, PREFEITURA MUNICIPAL DE. $4^{\text {a }}$ Conferência Municipal de Desenvolvimento Rural Sustentável de Mocajuba. Mocajuba-PA, 2011. Disponível em:http://mocajuba2011.blogspot.com.br/2011/05/secretariadeagricultura.html.Acesso em: 03 out. 2015.

MORAES, Antonio Carlos Robert. Ratzel. São Paulo: Ática, 1990. (Coleção Grandes Cientistas Sociais)

MOREIRA, Eliene Cristina Pinto Moreira. Os impactos socioambientais do plantio da palma de dendê no Pará. Jornal Aldeia, Belém: Fase Amazônia, 2. sem. 2014.

MOURA, Ignácio Baptista de. De Belém a São João do Araguaia: vale do rio Tocantins. Belém: SECULT, 1989. (Lendo o Pará, 4)

MULLER, Antonio Agostinho. A cultura do dendê. Belém: Embrapa, 1980.

MULLER, Antonio Agostinho; FURNAN JUNIOR, José. Agronegócio do dendê: uma alternativa social, econômica e ambiental para ao desenvolvimento da Amazônia. Belém: Embrapa Amazônia Oriental, 2001.

MÜLLER, Geraldo. Complexo agroindustrial e modernização agrária. São Paulo: Hucitec; Educ, 1989. (Estudos Rurais, 10) 
NAE - Núcleo de Assuntos Estratégicos da Presidência de República.Biocombustiveis. Brasília, 2004. (Cadernos do NAE, n. 2)

NAHUM, João Santos (Org.). Dendeicultura e dinâmicas territoriais do espaço agrário na Amazônia paraense. Belém: GAPTA/UFPA, 2014.

NAHUM, João Santos; SANTOS, Cleison Bastos dos. Uma interpretação geográfica da dendeicultura na Amazônia paraense. Revista da Anpege, n. 15, p. 309-331, 2015.

NASCIMENTO JUNIOR, Francisco C. Uso agrícola do território e trabalho científico para o campo moderno no Brasil. GEOUSP- Espaço e Tempo, São Paulo, n. 34, 2013. Numero Especial, p. 45-58.

O estado e o mercado na regulação da pesquisa agrícola no território brasileiro: notas sobre a atividade sojicultora. Campo-erritório: Revista de Geografia Agrária, v. 4, n. 8, p. 148-179, ago. 2009.

NASCIMENTO, Elimar Pinheiro do; VIANNA, João Nildo (Org.) Dilemas e desafios do desenvolvimento sustentável no Brasil. Rio de Janeiro: Garamond, 2007.

NEGRI, Sergio Sebastião. Uso desigual do território em Rondonópolis no processo de expansão do agronegócio da soja em Mato Grosso. 2010. Tese (Doutorado em Geografia) - Universidade Estadual Paulista, Rio Claro-SP, 2010.

NOGUEIRA, Octaciano. Vocabulário de política. Brasília: Senado Federal, Unilegis,2010.

OLIVEIRA, Ariovaldo Umbelino de. A geografia das lutas no campo. São Paulo: Contexto, 1988.

A longa marcha do campesinato brasileiro: movimentos sociais, conflitos e reforma agrária. Revista Estudos Avançados, São Paulo: USP, v. 14, n. 43, p.185-206, 2001.

ORLANDO, Alcibíades Luiz. Pequena propriedade e agroindústria. Cascavel-PR: Unioeste, 1994.

PARÁ. Instituto de Desenvolvimento Econômico, Social e Ambiental. Estatística municipal. Belém, PA, 2015a. Disponível em:http://www.idesp.pa.gov.br/index.php/estatistica-municipal Acesso em: 10 jan.2015.

Instituto de Desenvolvimento Econômico, Social e Ambiental. Retratos da década. Belém, PA, 2015b. Disponível em:http://www.idesp.pa.gov.br/retratodadecada.Acesso em: 10 jan.2015.

Secretaria de Estado de Agricultura. Programa de dendê: estado do Pará. Apresentação em slide feita de secretário de estado de agricultura Hildegardo Nunes. Belém, PA. 2013. Disponível em: www.sagri.pa.gov.br . Acesso em: 09 dez. 2015.

Secretaria de Estado de Integração Regional. Atlas de Integração Regional do Estado do Pará. Belém, 2010a. 
Secretaria de Estado de Projetos Estratégicos. Parábiodiesel: energia sustentável. Slide apresentado pelo secretário Marcílio de Abreu Monteiro. Belém, 2010b.

Secretaria de Estado de Integração Regional. Plano de desenvolvimento regional sustentável Tocantins. Belém, 2009.

PARENTE, Expedito José de Sá. Biodiesel no plural. In: MDIC - Ministério do Desenvolvimento, Indústria e Comercio Exterior. O futuro da indústria do biodiesel: coletânea de textos. Brasília, 2006. p. 91-104.

PEDROTI, Paula Maciel. Os desafios do desenvolvimento e da inclusão social: o caso do arranjo político - institucional do programa nacional de produção e uso do biodiesel. Brasília: Rio de Janeiro. IPEA, 2013 (Texto para discussão do IPEA, n. 1858)

Entre a estrutura institucional e a conjuntura política: o programa nacional de produção e uso do biodiesel (PNPB) e a combinação social - participação. 2011.Tese (Doutorado em Administração) - Escola de Administração de Empresas de São Paulo, Fundação Getúlio Vargas, São Paulo 2011.

PEREIRA, Mirlei Fachini Vicente. Trabalho no campo e território usado no sudoeste da Amazônia: atualizações técnico-normativas e resistências locais. GEOUSP- Espaço e Tempo, São Paulo, n. 34, 2013. Numero Especial.

Território e política: práxis invertidas e desafios da existência. Sociedade \& Natureza, Uberlândia-MG, v. 23, n. 1, p. 95-104, abr. 2011.

O processo recente de atualização do território no sudoeste da Amazônia: lógicas e dialéticas endógenas em Rondônia e Acre. 2009. Tese (Doutorado em Geografia) Universidade Estadual Paulista, Rio Claro-SP, 2009.

PEREIRA, Mirlei Fachini Vicente; KAHIL, Samira Peduti. Território e agricultura no sudoeste da Amazônia: campo não moderno e produção para o consumo local.Mercator, v. 9, n. 19, p. 47-64, 2010: maio/ago. 2010.

PETROBRAS. Petrobras biocombustível assina contrato para a produção de mudas de palma. In. Petrobras: fatos e dados. 06.08.2010. Disponível em: http://fatosedados.blogspetrobras.com.br/2010/08/06/petrobras-biocombustivel-assinacontrato-para-producao-de-mudas-de-palma/ Acesso em: 22 ago. 2016

PETROBRAS BIOCOMBUStíVEL. Projeto Pará. Apresentação em slide para a impressa. Mocajuba, Pará, 2011.

PICOLOTTO, Everton Lazzaretti. Os atores da construção da categoria agricultura familiar no Brasil. Revista de Economia e Sociologia Rural, Piracicaba-SP, v. 52, 2015.

PINA, Antonio José de Abreu. Experiência na produção para a cultura de palma de óleo na Amazônia: relato de experiência da Marborges Agroindústria S.A. (Moju-Pará) In: RAMALHO FILHO, Antonio et al.Zoneamento agroecológico, produção e manejo para a cultura da palma de óleo na Amazônia. Rio de Janeiro: Embrapa Solos, 2010.p.189-204. 
PROST, Gérard. História do Pará: do período da borracha aos dias atuais. Belém: SEDUC, 1998. (Estudo Paraense, v. 2)

História do Pará: das primeiras populações à Cabanagem. Belém: SEDUC, 1997. (Estudo Paraense, v. 1)

RAFFESTIN. Claude. Uma concepção de território, territorialidade e paisagem. In: PEREIRA, Silvia Regina et al. (Org.) Teorias e práticas territoriais: análises espaçotemporais.São Paulo: Expressão Popular, 2010.p.13-23.

A produção das estruturas e sua representação. In: SAQUET, Marcos Aurélio; SPOSITO, Eliseu Savério. Território e territorialidades: teorias, processos e conflitos. São Paulo: Expressão Popular, 2009.p.17-35.

. Entrevista. Revista Formação, Presidente Prudente: UNESP, n. 15, v. 1, 2008.

Por uma Geografia do poder. São Paulo: Ática, 1993.

RAMOS, Soraia de Fátima. Uso do território no vale do são Francisco: sistema técnico agrícola da fruticultura irrigada. Geousp: Espaço e Tempo, São Paulo, n. 34, Número Especial, 2013a.

O conceito de sistemas técnicos agrícolas como instrumento de análise para os usos do território em regiões metropolitanas. In:ENCONTRO NACIONAL DA ASSOCIAÇÃO NACIONAL DE PÓS-GRADUAÇÃO E PESQUISA EM GEOGRAFIA, 10.Campinas, 2013. Anais..., 2013b.

O uso do território como categoria de análise para compreensão das dinâmicas da agricultura em regiões metropolitanas. São Paulo: Instituto de Economia Agrícola de São Paulo, 2011. (Textos para Discussão, n. 29)

Uso do território brasileiro e sistemas técnicos agrícolas: a fruticultura irrigada em Petrolina (PE) /Juazeiro (BA). In: CONGRESSO DA SOBER, 43. Ribeirão Preto-SP, 2005. Anais... 2005.Disponível em: <www.sober.org/palestra/2/1045>. Acesso em: 20 mar. 2016

Sistemas técnicos agrícolas e meio técnico-científico-informacional no Brasil. In. SANTOS, Milton; SILVEIRA, Maria Laura. O Brasil: o território e sociedade no início do século XXI. Rio de Janeiro: Record, 2001.p.375-387.

RAMOS, Soraia de Fátima; CASTILLO, Ricardo. Sistemas técnicos agrícolas do algodão e uso do território brasileiro.Geografia, Rio Claro-SP, v.35, n.1, p. 101-114, jan./abr.2010.

RATZEL, Friedrich. [1987] A relação entre o solo e o estado: o estado como organismo ligado ao solo. Trad.: Matheus Pfrimer. Geousp: Tempo e Espaço, São Paulo, n. 29, p. 51$58,2011$.

[1914]. Geografia do homem (antropogeografia). In: MORAES, Antonio Carlos Robert. Ratzel. São Paulo: Ática, 1990.p.32-107. (Coleção Grandes Cientistas Sociais) 
[1898-1899] O solo, a sociedade e o estado. Trad.: Mário Antonio Eufrásio. Revista do Departamento de Geografia da USP, São Paulo, 1983.

REIS, Arthur Cezar Ferreira. A política de Portugal no valle amazônico. 2. ed. Belém: SECULT, 1993.

Ocupação da Amazônia e cobiça estrangeira. In: A Amazônia brasileira em foco. Rio de Janeiro: CNDA, 1973. (Boletim, n. 8)

Síntese de história do Pará. Belém, Manaus, Guanabara: Amazônia Edições Culturais Ltda., 1972.

SPVEA, 1960.

Aspectos econômicos da dominação lusitana na Amazônia. Rio de Janeiro:

REPÓRTER BRASIL. Expansão do dendê na Amazônia brasileira. Elementos para uma análise dos impactos sobre a agricultura familiar no nordeste do Pará. São Paulo, 2012.

A agricultura familiar e o programa nacional de biodiesel: retrato do presente, perspectivas de futuro. São Paulo, 2010.

RIBEIRO, Ana Clara Torres. Por uma sociologia do presente: ação, técnica e espaço. Rio de Janeiro: Letra Capital, 2012.

. Território da sociedade: por uma cartografia da ação. In: SILVA, CatiaAntonia da (Org.). Territórios e ação social: sentidos da apropriação urbana. Rio de Janeiro: Lamparina, 2011.p.19-34.

RIBEIRO, Luiz Henrique Leandro. Em contribuições da geografia às políticas públicas: território usado como condicionante dos programas de fitoterapia do sistema único de saúde (SUS). Boletim Goiano de Geografia, Goiânia, v. 2, p.381-397, 2014.

RODRIGUES, Marta M. Assumpção. Políticas públicas. São Paulo: Publifolha, 2013. (Folha Explica).

RODRIGUES, Rodrigo Augusto. Biodiesel no Brasil: diversificação energética e inclusão social com sustentabilidade. In: MDIC - Ministério do Desenvolvimento, Indústria e Comércio Exterior. O Futuro da indústria do biodiesel: coletânea de textos. Brasília, 2006. p. $15-25$.

RODRIGUES, Rodrigo Augusto; ACCARINI. José Honório. Programa Brasileiro de Biodiesel. In: BRASIL. Ministério das Relações Exteriores. Biocombustíveis no Brasil: realidades e perspectivas. Brasília, 2007.

ROLLO, Marco Aurélio Pereira. As novas dinâmicas do território brasileiro no período técnico-científico-informacional: o circuito espacial de produção do café e o respectivo círculo de cooperação no sul de Minas.2009. Tese (Doutorado em Geografia) - Universidade Estadual Paulista, Rio Claro-SP, 2009. 
RUDNICKI, Carlise Schneider; WAQUIL, Paulo Dabdab. Relações contratuais no sistema integrado de produção do tabaco (SIPT): relações de confiança e contratos. In: SILVEIRA, Rogério Lima da (Org.) Tabaco, sociedade e território: relações e contradições no sul do Brasil. Santa Cruz do Sul, EDUSC, 2013.p.89-122.

SACHS, Ignacy. Bioenergias: uma janela de oportunidade. In: ABRAMOVAY, Ricardo (Org.). Bicombustíveis: a energia da controvérsia. São Paulo: Editora Senac, 2009.p.143-181. p.21-38, 2007.

A revolução energética do século XXI. Estudos Avançados, São Paulo, v. 21, n. 59, Da civilização do petróleo a uma nova civilização verde. Estudos Avançados, São Paulo, v. 19, n. 55, p. 197-214, 2005.

SALGUEIRO, Tereza Barata. Tendências da urbanização em Portugal. In: SOUZA, Maria Adélia Aparecida de (Org.). O mundo do cidadão um cidadão do mundo. Editora Hucitec. São Paulo, 1996.p.139-148.

SANTOS, Jair Carvalho dos et al. Desempenho socioeconômico do sistema produtivo familiar de dendê em Moju, estado do Pará. Boletim de Pesquisa e Desenvolvimento. Belém: Embrapa Amazônia Oriental, n. 94, p.1-.37, 2014.

SANTOS, Cleison Bastos dos. Dendeicultura e comunidade camponesa na Amazônia paraense: uma análise do município de Moju. Ananindeua-Pa. 2015.

SANTOS, Gesmar; WEHRMANN, Magda Eva Soares de F. Agroenergia no Brasil: fragilidades, riscos e desafios para o desenvolvimento sustentável.Revista de La Red Iberoamericana de Economia Ecológica, p. 1-13, 2010.

SAQUET, Marcos Aurélio. Abordagens e concepções de território. São Paulo: Expressão Popular, 2007.

SARAVIA, Enrique. Introdução a teoria da política pública. In:SARAVIA,Enrique;FERRAREZI, Elisabete. Políticas públicas: coletânea.Brasília: ENAP, 2006.p.21-42

SCHNEIDER, Sérgio. Teoria social, agricultura familiar e pluriatividade. Revista Brasileira de Ciências Sociais, v. 18, n. 51, p.99-121. 2003.

SCHWARTZ, Losane; SALAMANI, Giancarla. A fumicultura e a reprodução social e territorial da agricultura familiar: um estudo de caso no município de São Lourenço do Sul RS. In: SILVEIRA, Rogério Lima da org. Tabaco, sociedade e território: relações e contradições no sul do Brasil. Santa Cruz do Sul: EDUSC, 2013.p.157-186.

SOUZA, Armando Lírio de. Desenvolvimento territorial rural e a dinâmica da agricultura familiar do Baixo Tocantins (PA). In: CONGRESSO DA SOCIEDADE BRASILEIRA DE ECONOMIA, ADMINISTRAÇÃO E SOCIOLOGIA RURAL, 51. Belém, 2013. Anais... Belém, 2013. 
Trabalho e desenvolvimento territorial na Amazônia oriental: a experiência da rede de desenvolvimento rural do Baixo Tocantins (PA). 2011. Tese (Doutorado em Desenvolvimento Rural) - Universidade Federal do Rio Grande do Sul, Porto Alegre, 2011.

SOUZA, Maria Adélia Aparecida de (Org.). O mundo do cidadão um cidadão do mundo. São Paulo: Hucitec, 1996.

SPOSITO, Eliseu Savério. Geografia e filosofia: contribuição para o ensino do pensamento geográfico. São Paulo: Editora UNESP, 2004.

SPIX; MARTIUS. Viagem pelo Brasil (1817-1820). São Paulo: Edições Melhoramento, 1976.

STEINBERGER, Marília (Org.). Território, estado e políticas públicas espaciais. Brasília: Ler, 2013a.

Território e federação na retomada da produção de políticas públicas espaciais pós 2002. In: BRANDÃO, Carlos; SIQUEIRA, Hipólita (Org.). Pacto federativo, integração nacional e desenvolvimento regional. São Paulo: Editora Fundação Perseu Abramo, 2013b.p.175-201.

Editora, 2006.

Território, ambiente e políticas públicas espaciais. Brasília: Paralelo 15; LGE

SUDAM - Superintendência de Desenvolvimento da Amazônia. Sudam e Petrobras assinam projeto para produção de óleo de palma. Belém, PA, 2014. Disponível em www.sudam.gov.br. Acesso em: 03 set. 2015.

Plano de desenvolvimento integrado de área da bacia do rio Tocantins: desenvolvimento econômico e social atual da região.Hidroservice, São Paulo, 1973a.v. 1

Plano de desenvolvimento integrado de área da bacia do rio Tocantins: organização social da região. Hidroservice, São Paulo,1973b. v. 3

Plano de desenvolvimento integrado de área da bacia do rio Tocantins: planejamento do desenvolvimento regional.Hidroservice, São Paulo, 1973c. v. 4

TOCANTINS, Leandro. O rio comanda a vida: uma interpretação da Amazônia. Rio de Janeiro: Biblioteca do Exército, 1973.

UBRABIO - União Brasileira do Biodiesel e Bioquerosene. Biodiesel em foco, Brasília, v. 5, n. 5, 2012.

SANTOS, Milton. O dinheiro e o território. In: SANTOS, Milton et al. Território, territórios: ensaios sobre o ordenamento territorial. Rio de Janeiro. Lamparina, 2011a.p.1321.

Geografia e planejamento: o uso do território - geopolítica. Revista eletrônica: Tempo - Técnica -Território, Brasília, v. 2, n. 2, p. 1-49, 2011 b. 
A urbanização brasileira. 5. ed. São Paulo: Edusp, 2009. (Coleção Milton Santos, 6)

Por uma geografia nova: da crítica da geografia a uma geografia crítica. São Paulo: Hucitec, 2008a. (Coleção Milton Santos, 2)

Santos, 10)

Metamorfoses do espaço habitado. São Paulo: Hucitec,2008b. (Coleção Milton

Técnica, espaço, tempo: Globalização e meio técnico científico informacional.São Paulo: Hucitec,2008c. (Coleção Milton Santos, 11)

Santos, 8)

Pensando o espaço do homem. 5. ed. São Paulo: Edusp,2007a. (Coleção Milton

O espaço do cidadão. 7. ed. São Paulo: Edusp,2007b. (Coleção Milton Santos, 8)

Território e sociedade. Entrevista com Milton Santos. Entrevistadores Odete Seabra, Mônica de Carvalho e José Corrêa Leite. São Paulo: Editora Fundação Perseu Abramo. 2007c.

Por uma outra globalização: do pensamento único a consciência universal.Rio de Janeiro: Record, 2000.

O papel ativo da Geografia: um manifesto.Revista Território. Rio de Janeiro, v. 5, n. 9, p.103-109, 2000. Publicado por ocasião do XII Encontro Nacional de Geógrafos. Florianópolis. Julho de 2000.

O território e o saber local: algumas categorias de análise.Cadernos IPPUR, Rio de Janeiro, v. 13, n. 2, p.15-26, 1999.

1996.

A Natureza do espaço: técnica e tempo, razão e emoção. São Paulo: Hucitec,

A questão do meio ambiente: desafios para a construção de uma perspectiva transdisciplinar. Anales de Geografia de la Universidad Complutense, Madrid: Servicio de Publicaciones. Universidad Complutense, n. 15, p. 695-705, 1995.

O retorno do território. In: SANTOS. Milton; SOUZA, M. A. de; SILVEIRA. M. L. Território: globalização e fragmentação. São Paulo: Hucitec; Anpur, 1994.p.15-20.

1992.

Objetos e ações: dinâmica espacial e dinâmica social. Geosul, v. 7, n. 14, 2 sem.

Por um novo planejamento urbano-regional. In: ENCONTRO NACIONAL DA ANPUR, 4. Salvador, 1991.Anais... Salvador, 1991.

Espaço e método. São Paulo: Nobel, 1985.

Espaço e sociedade. Petrópolis-RJ: Vozes, 1979. 
. O país distorcido: o Brasil, a globalização e a cidadania. São Paulo. Publifolha, 2002.

Testamento intelectual: Milton Santos entrevista. São Paulo: Editora UNESP, 2004.

Sociedade e espaço; a formação social como teoria e como método. Boletim Paulista de Geografia, n. 54. Associação dos Geógrafos Brasileiros, Seção São Paulo. São Paulo, 1977.

Relações espaço - temporais no mundo subdesenvolvido. In: Seleção de textos 1. Associação dos Geógrafos Brasileiros, Seção São Paulo. São Paulo, 1976.p.17-23.

Zona do cacau: introdução ao estudo geográfico. São Paulo: Companhia Editora Nacional, 1957.

SANTOS, Milton; SILVEIRA, Maria Laura. O Brasil: o território e sociedade no início do século XXI. Rio de Janeiro: Record, 2001.

SECCHI, Leonardo. Políticas públicas: conceitos, esquemas de análises, casos práticos. São Paulo: Cengage Learning, 2012.

SENADO FEDERAL. Constituição da República Federativa do Brasil de 1988. Brasília, 2010.

SILVA, Clayton Luiz da. A divisão política do território brasileiro: os compartimentos quilombolas no vale do Ribeira (SP). 2010. Tese (Doutorado em Geografia) - Universidade Estadual de Campinas, Campinas-SP, 2010.

SILVA, José Alderir da. Avaliação do programa nacional de produção e uso do biodiesel no Brasil - PNPB. Revista de Política Agrícola, Brasília: Secretaria Nacional de Política Agrícola, v. 22, n. 3, p. 18- 31, 2013.

SILVA, Sandro Pereira. Considerações analíticas e operacionais sobre a abordagem territorial em políticas públicas. In: Políticas sociais: acompanhamento e análise. Brasília: IPEA, 2013. p.549-570

A abordagem territorial no planejamento de políticas públicas e os desafios para uma nova relação entre estado e sociedade no Brasil. Cadernos Gestão Pública e Cidadania, São Paulo, v.17, n. 60, p.148-168, 2012.

SILVEIRA, María Laura.O Brasil: o território e sociedade no início do século 21 - a história de um livro. ACTA Geográfica, Boa Vista, Ed. Especial Cidade na Amazônia Brasileira, p. 151-163, 2011a.

Território usado: dinâmicas de especialização, dinâmicas de diversidade. Ciência Geográfica, Bauru-SP, n. 15, v. 15, p.4-12,jan./dez. 2011 b. 
Economia política e ordem espacial: circuitos da economia urbana. In: SILVA, Catia Antonia da (Org.). Território e ação social: sentidos da apropriação urbana. Rio de Janeiro: Lamparina, 2011c.p.35-51.

. Uma situação geográfica: do método à metodologia. Revista Território, v. 4, n. 6, p.21-28, jan/jun. 1999.

SILVEIRA, Rogério Leandro Lima da; DORNELLES, Mizael. A produção de tabaco no sul do Brasil: um olhar geográfico sobre sua dinâmica produtiva e organização territorial. In: SILVEIRA, Rogério Lima da (Org.). Tabaco, sociedade e território: relações e contradições no sul do Brasil. Santa Cruz do Sul: EDUSC, 2013.p.17-38.

SIMÕES, Antonio José ferreira. Biocombustíveis: a experiência brasileira e o desafio da consolidação do mercado internacional. In: BRASIL. Ministério das Relações Exteriores. Biocombustíveis no Brasil: realidades e perspectivas. Brasília, 2007. p.11-33

SORJ, Bernardo. Estado e classes sociais na agricultura brasileira. Rio de Janeiro: Zahar Editores, 1980.

SORJ, Bernardo; POMPERMAYER, Malori J.; CORADINI, Odacir Luis. Camponeses e agroindústria: transformação social e representação política na avicultura brasileira. Rio de Janeiro: Centro Edelstein de Pesquisas Sociais, 2008.

SOUSA, Raimundo Valdomiro de. Camponeses na Amazônia: da subordinação à luta pelo poder. Belém: NAEA, 2002.

SOUZA, Celina. Estado da arte da pesquisa em políticas públicas. In: HOCHMAN, Gilberto (Org.). Políticas públicas no Brasil. Rio de Janeiro: Editora Fiocruz, 2007.p.65-86.

Políticas públicas: uma revisão da literatura. Sociologias, Porto Alegre, v. 8, n.16, p.20-44, 2006.

Apresentação Milton Santos, um revolucionário. In: SANTOS, Milton. O retorno do território. OSAL, v. 6, n. 16, 2005.

(Org.) Território brasileiro: usos e abusos. Campinas-SP: Edições Territorial, 2003.

"Estado do campo" da pesquisa em políticas públicas no Brasil. Revista Brasileira de Ciências Sociais, v. 18, n. 51, p.15-20, 2003.

Política e território: a geografia das desigualdades. In: Fórum Brasil em questão. Brasília: UnB, 2002.

VALE. Vale vai investir na produção de biodiesel. In: Sala de Imprensa da Vale. 2009, Disponível em:http://saladeimprensa.vale.com. Acesso em: 14 out. 2015.

VALOIS, Afonso Celso Candeira. A possibilidade da cultura do dendê na Amazônia. Brasília: Embrapa, 1997. (Comunicado Técnico, n. 19) 
VARGAS, Marco Antonio. Cultivo do tabaco, agricultura familiar e estratégia de diversificação no Brasil: uma análise comparativa em áreas de cultivo de tabaco no Vale do rio Pardo. In: SILVEIRA, Rogério Lima da (Org.). Tabaco, sociedade e território: relações e contradições no sul do Brasil. Santa Cruz do Sul: EDUSC, 2013. p. 123-156.p.123-156.

VEIJA, Alexandre Sanz; FURLAN JUNIOR, José; KALTNER, Franz Josef. Políticas públicas na agroindústria do dendê na visão do produtor. Belém: Embrapa Amazônia Oriental, 2005.

VELHO, Otávio Guilherme. Frentes de expansão e estrutura agrária: estudo do processo de penetração numa área da transamazônica. Rio de Janeiro: Zahar Editores, 1972.

Capitalismo autoritário e campesinato.Rio de Janeiro: Difel, 1976.

VENTURIERI, Adriano. Evolução da área plantada com palma de óleo no Brasil, com ênfase do estado do Pará. Agroenergia em Revista, Brasília: Embrapa Agroenergia, v. 2, maio 2011.

WANDERLEY, Maria de Nazareth Baudel. O agricultor familiar no Brasil: um ator social da construção do futuro. Revista Agriculturas: Experiências em Agroecologia, Rio de Janeiro: AS-PTA, Edição Especial, p.33-45, 2009.

Agricultura familiar e campesinato: rupturas e continuidade. Estudos, Sociedade e Agricultura, Rio de Janeiro, v. 21, p. 41-61, out. 2003.

Raízes históricas do campesinato brasileiro. In: ENCONTRO ANUAL DA ANPOCS, 20. Caxambu-MG, 1996. Anais... Caxambu-MG: ANPOCS, 1996.

WILKINSON, John. Agroenergia a desenvolvimento territorial no Brasil. In: SEPULVEDA, Sergio. Agroenergia e desenvolvimento de comunidades rurais isoladas. Brasília: IICA, 2008. p.87-96 (Série Desenvolvimento Rural Sustentável; v. 7).

- Cadeias produtivas para a agricultura familiar. Organizações Rurais e Agroindustriais - Revista de Administração e Economia, Lavras-MG: UFLA, v. 1, n. 1, p. 34-41, 1999. 1986.

O estado, a agroindústria e a pequena produção. São Paulo: Hucitec-Cepa-BA,

WILKINSON, John; HERRARA, Selena. Os agrocombustíveis no Brasil: quais perspectivas para o campo? Rio de Janeiro: CPDA/UFRJ, 2008. 


\section{APÊNDICES}




\begin{abstract}
APÊNDICE A
Universidade de Brasília

Programa de Pós-Graduação em Geografia

Trabalho de campo da tese: O uso agrícola do território e a integração da agricultura familiar no agronegócio do biodiesel de dendê no Baixo Tocantins (PA)

Autor: Márcio Junior Benassuly Barros

Orientadora: Marília Steinberger
\end{abstract}

\title{
Roteiro de entrevista I, Ministério do Desenvolvimento Agrário (MDA)
}

\section{DADOS DE IDENTIFICAÇÃO}

Nome do entrevistado (a):

Função:

Local da entrevista: Data:

1. Quais são as ações do MDA no setor de dendê no Pará?

2. Quais são os polos de dendê no Pará que o MDA acompanha?

3. De que forma o MDA participa do Pronaf Eco-Dendê?

4. O MDA possui ações de regularização fundiária no Baixo Tocantins para atender os produtores de dendê?

5. A DFDA-PA/MDA possui estudos sobre a agricultura familiar de dendê no Baixo Tocantins?

6. Qual o papel da representação do MDA no Pará?

7. Que ações são desenvolvidas nos municípios do Baixo Tocantins no que se refere à plantação de dendê?

8. Quais os projetos de agricultura familiar de dendê são incentivados pelo MDA no Baixo Tocantins?

9. Quais as ações do MDA no setor de agricultura familiar de dendê no Baixo Tocantins?

10. Existem estudos, relatórios do MDA sobre a realidade agrícola do Baixo Tocantins?

11. No PTDRS/Baixo Tocantins constam ações para instalações de infraestrutura da cadeia produtiva de oleaginosas (dendê)? O que foi executado?

12. Quais as ações do PTDRS/Baixo Tocantins para a cadeia de biodiesel de dendê foram executadas? 
13. No PTDRS $\backslash$ Baixo Tocantins consta como meta a implantação de um banco de dados sobre a produção de dendê (oleaginosas). Esta meta foi executada?

14. Foram oferecidos cursos de capacitação técnica para os agricultores familiares de dendê beneficiários do Pronaf Eco-Dendê no Baixo Tocantins?

15. É possível o acesso aos relatórios de execução de ações do PTDRS/Baixo Tocantins? 


\section{APÊNDICE B}

Universidade de Brasília

Programa de Pós-Graduação em Geografia

Trabalho de campo da tese: O uso agrícola do território e a integração da agricultura familiar no agronegócio do biodiesel de dendê no Baixo Tocantins (PA)

Autor: Márcio Junior Benassuly Barros

Orientadora: Marília Steinberger

\section{Roteiro de entrevista II, Banco da Amazônia (Basa)}

\section{DADOS DE IDENTIFICAÇÃO}

Entrevistado:

Função:

Local da entrevista:

Data:

1. Quais são as ações do Basa no Pronaf Eco-Dendê no Pará no período 2010-2015?

2. Quais as principais ações do Basa no Pronaf Eco-Dendê desde 2010 no Baixo Tocantins?

3. Qual o número de agricultores familiares beneficiados com o Pronaf Eco-Dendê no período 2010-2015 no estado do Pará?

4. Qual o número de agricultores familiares beneficiados com o Pronaf Eco-Dendê nos municípios do Baixo Tocantins entre 2010 e 2015 ?

5. Qual o valor financiado por municípios do Baixo Tocantins entre 2010 e 2015 com o Pronaf Eco-Dendê?

6. Qual o número de contratos por municípios do Baixo Tocantins entre 2010 e 2015 com o Pronaf Eco-Dendê?

7. Quais são as principais dificuldades para a execução do Pronaf Eco-Dendê no Pará?

8. Quais são os principais parceiros na execução do Pronaf Eco-Dendê no Pará?

9. Qual o papel das empresas integradoras no Pronaf Eco-Dendê?

10. As empresas integradoras possuem convênios de cooperação ou responsabilidade com o Basa com relação ao Pronaf Eco-Dendê?

11. Como são atendidas as demandas das empresas integradoras de dendê?

12. Como é realizado o planejamento para o setor? Quem participa? 


\section{APÊNDICE C}

Universidade de Brasília

Programa de Pós-Graduação em Geografia

Trabalho de campo da tese: O uso agrícola do território e a integração da agricultura familiar no agronegócio do biodiesel de dendê no Baixo Tocantins (PA)

Autor: Márcio Junior Benassuly Barros

Orientadora: Marília Steinberger

\section{Roteiro de entrevista III, Secretaria Municipal de Agricultura de Mocajuba e Moju}

\section{DADOS DE IDENTIFICAÇÃO}

Entrevistado:

Função:

Local da entrevista: Data:

1. Quais as ações da SMA no setor de dendê no município?

2. Qual o papel da SMA na agricultura familiar de dendê no município?

3. Quais as ações da SMA na agricultura familiar de dendê no município?

4. Como a SMA avalia a agricultura familiar de dendê no município?

5. Quais são as comunidades atendidas pela agricultura familiar de dendê no município?

6. A SMA possui estudos sobre o programa de agricultura familiar de dendê no município?

7. De que forma a SMA apoia a agricultora familiar de dendê no município?

8. A SMA mantém parcerias com as empresas integradoras de dendê no município. Quais?

9. A SMA possui uma política municipal de incentivo à agricultura familiar de dendê?

10. Existem incentivos para a produção de dendê no município. Quais? 


\section{APÊNDICE D}

Universidade de Brasília

Programa de Pós-Graduação em Geografia

Trabalho de campo da tese: O uso agrícola do território e a integração da agricultura familiar no agronegócio do biodiesel de dendê no Baixo Tocantins (PA)

Autor: Márcio Junior Benassuly Barros

Orientadora: Marília Steinberger

\section{Roteiro de entrevista IV (não aplicado), Empresas Integradoras de Dendê (Belém Bioenergia Brasil e Biopalma)}

\section{DADOS DE IDENTIFICAÇÃO}

Nome da empresa:

Nome do entrevistado (a):

Função:

Local da entrevista:

Data:

1. A empresa possui contratos com agricultores integrados de dendê. Onde?

2. Qual o número de contratos com agricultores integrados de dendê mantidos pela empresa?

3. Como é realizada a assistência técnica junto aos agricultores integrados de dendê?

4. A expansão da integração da agricultura familiar de dendê está associada ao acesso às políticas de crédito rural (Pronaf Eco-Dendê). Como a empresa participa desta política junto ao Basa?

5. Qual a participação da empresa no financiamento do crédito rural (Pronaf Eco-Dendê),

6. Quais as ações da empresa no setor da integração de dendê?

7. Quais as obrigações da empresa para com o agricultor integrado?

8. A empresa tem projetos para exploração de biodiesel?

9. Quais os investimentos na produção de biodiesel da empresa?

10. Qual a avaliação da empresa sobre o biodiesel?

11. Como é feito o cálculo da compra do dendê entregue pelo agricultor integrado à empresa?

12. Quais os projetos futuros de agricultura familiar de dendê da empresa?

13. Qual a renda líquida das famílias atendidas pelo programa de agricultura familiar de dendê na empresa? 
14. Qual o período de vigência dos contratos da agricultura familiar de dendê atendido pela empresa?

15. Qual é a área própria plantada de dendê da empresa?

16. Qual é a área da agricultura familiar de dendê que a empresa mantém contratos?

17. Qual o principal mercado de comercialização da empresa? 


\begin{abstract}
APÊNDICE E
Universidade de Brasília

Programa de Pós-Graduação em Geografia

Trabalho de campo da tese: O uso agrícola do território e a integração da agricultura familiar no agronegócio do biodiesel de dendê no Baixo Tocantins (PA)

Autor: Márcio Junior Benassuly Barros

Orientadora: Marília Steinberger
\end{abstract}

\title{
Roteiro de entrevista V, Federação dos Trabalhadores na Agricultura do Estado do Pará (FETAGRI)
}

\section{DADOS DE IDENTIFICAÇÃO}

Entrevistado:

Função:

Local da entrevista:

Data:

1. Quais são as ações da Fetagri na agricultura familiar de dendê no Pará?

2. Quais são as ações da Fetagri na agricultura familiar de dendê no Baixo Tocantins?

3. Qual a posição da Fetagri com relação aos projetos na agricultura familiar de dendê no Baixo Tocantins?

4. Quais as principais ações sindicais desenvolvidas na agricultura familiar de dendê no Baixo Tocantins?

5. Qual o papel da Fetagri no crédito rural (Pronaf Eco-Dendê) no Pará?

6. Qual a relação da Fetagri com o governo federal no que se refere ao crédito rural?

7. Quais as principais bandeiras de luta da Fetagri?

8. A Fetagri é filiada a que instituições sindicais no Brasil?

9. Quais são as ações da Fetagri em busca de recursos do Pronaf Eco-Dendê no Pará?

10. De que forma a Fetagri mantém relações com as empresas de dendê no Baixo Tocantins. Como é esta relação?

11. Qual a relação da Fetagri com o Basa?

12. Qual a relação da Fetagri com o MDA?

13. Qual a posição da Fetagri no que se refere ao PNPB no Pará? 


\author{
APÊNDICE F \\ Universidade de Brasília \\ Programa de Pós-Graduação em Geografia \\ no agronegócio do biodiesel de dendê no Baixo Tocantins (PA) \\ Autor: Márcio Junior Benassuly Barros \\ Orientadora: Marília Steinberger
}

Trabalho de campo da tese: O uso agrícola do território e a integração da agricultura familiar

\title{
Roteiro de entrevista VI, Sindicato dos Trabalhadores Rurais de Abaetetuba, Acará, Baião, Barcarena, Cametá, Igarapé Miri, Mocajuba, Moju e Tailândia
}

\section{DADOS DE IDENTIFICAÇÃO}

Entrevistado:

Função:

Local da entrevista: Data:

1. Quais são as ações desenvolvidas junto à agricultura familiar de dendê no município?

2. Quais são as comunidades onde existem projetos de agricultura familiar de dendê no município?

3. Qual o número de beneficiados nestes projetos?

4. Como o sindicato avalia o Pronaf Eco-Dendê?

5. Quais as principais deficiências do Pronaf Eco-Dendê?

6. Quais as principais bandeiras de lutas do sindicato?

7. O STTR é filiado a que instituições sindicais no Brasil e no Pará?

8. De que forma o STTR participa do projeto de agricultura familiar de dendê no município?

9. Qual a relação do STTR com as empresa integradoras de dendê?

10. Qual a relação do STTR com o Basa no município?

11. Qual a relação do STTR com o MDA no município?

12. Qual a posição do STTR quanto ao Programa Nacional de Uso e Produção do Biodiesel (PNPB) no município? 


\begin{abstract}
APÊNDICE G
Universidade de Brasília

Programa de Pós-Graduação em Geografia

Trabalho de campo da tese: O uso agrícola do território e a integração da agricultura familiar no agronegócio do biodiesel de dendê no Baixo Tocantins (PA)

Autor: Márcio Junior Benassuly Barros

Orientadora: Marília Steinberger
\end{abstract}

\title{
Roteiro de entrevista VII, Agricultores Familiares Integrados de Dendê das empresas Belém Bioenergia Brasil e Biopalma
}

\section{DADOS DE IDENTIFICAÇÃO}

Nome do agricultor (a):

Localidade: Município:

Data: Empresa Integradora:

1. Qual o tamanho (hectares) de sua propriedade?

2. Qual a área plantada (hectares) de dendê de sua propriedade?

3. Qual a área colhida (hectares) de dendê em sua propriedade na última safra?

4. Qual a quantidade produzida (toneladas) de dendê em sua propriedade na última safra?

5. Possui outra cultura plantada? Se sim, qual?

6. Possui financiamento agrícola? Se sim, qual?

7. Qual a área plantada financiada? E qual valor?

8. O dendezal possui benfeitorias? Quais?

9. Qual a fonte de recursos financeiros utilizados no dendezal?

10. O senhor planta dendê para que empresa com contrato?

11. Porque optou por esta empresa?

12. Sabe como é feito o cálculo no contrato do valor da cotação do dendê?

13. Já fez entrega de alguma produção de dendê à empresa?

14. Se sim, em que ano? Lembra da quantidade entregue?

15. Que avaliação faz do sistema de entrega da produção?

16. A plantação de dendê conta com assistência técnica da empresa? Com que regularidade?

17. Como avalia o trabalho do profissional de assistência técnica no dendezal?

18. Quem da família ocupa-se do trato com o dendezal? 
19. Utiliza trabalho assalariado para cuidar do dendezal?

20. Quanto paga em média por trabalhador assalariado?

21. Por que o senhor resolveu plantar dendê integrado à empresa?

22. A plantação de dendê é a sua principal atividade econômica?

23. Você se dedica a outra atividade econômica além da plantação do dendê? Qual (is)?

24. Em que aspecto você acha que a empresa deveria melhorar?

25. Quais as obrigações do agricultor para com a empresa?

26. A assistência técnica é suficiente?

27. As condições financeiras melhoraram após a implantação do projeto integrado de dendê?

28. Como e quando é feita a colheita?

29. Qual a sua renda média mensal com a produção de dendê?

30. Você pretende continuar plantado dendê?

31. Sua terra é regularizada? Se sim, por que órgão?

32. Você entende o cálculo do preço do dendê constante no seu contrato com a empresa?

33. Você tem dúvidas sobre o pagamento de sua produção de dendê?

34. Você tem dúvidas sobre seu contrato assinado com a empresa. Quais pontos?

35. Você segue todas as diretrizes da empresa?

36. De que forma estas diretrizes passam a regular sua vida?

37. Quem e como são repassadas as orientações da empresa?

38. Você é filiado a alguma organização, sindicato ou associação? Se sim, qual?

39. Você concorda em tudo sobre o contrato que mantém com a empresa?

40. Em que discorda sobre o contrato com a empresa?

41. Existem resistências junto à empresa. Quais?

42. De que forma você se organiza?

43. Quais são as principais estratégias de organização político social dos agricultores de dendê em sua comunidade?

44. Do que você vivia antes da implantação do programa de agricultura familiar de dendê? 


\section{APÊNDICE H}

\section{Registro fotográfico}

Pesquisador em dois momentos da pesquisa, na Usina Hidrelétrica de Tucurui (2013) e Baião (2015) fazendo georrefenciamento

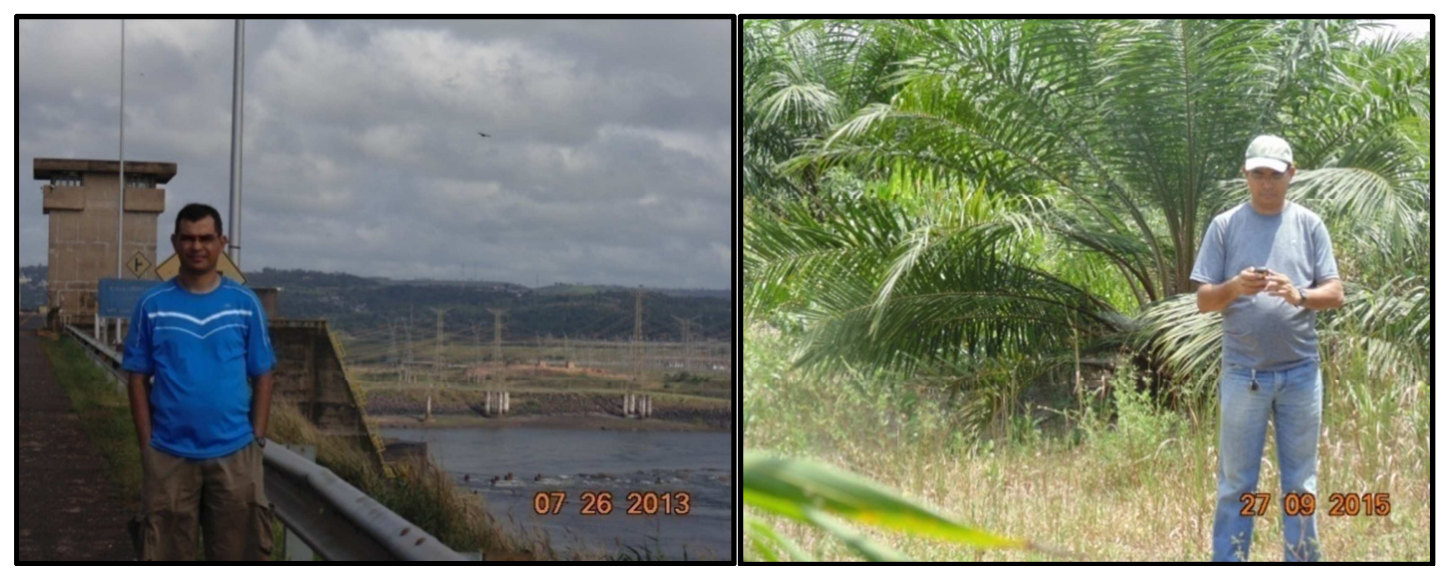

Fonte: Márcio Benassuly $(2013,2015)$

Aspectos da rodovia da PA-151 em Mocajuba e do rio Tocantins,em Cametá

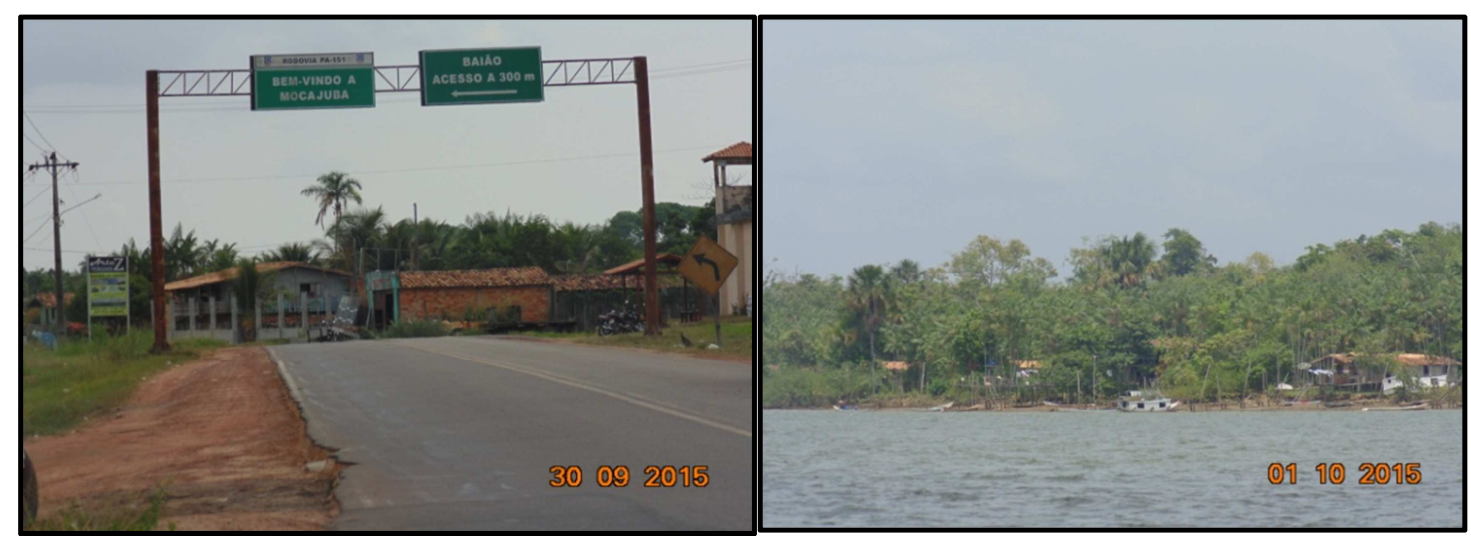

Fonte: Márcio Benassuly (2015)

Aspectos agrícolas do agronegócio em Tailândia e da feira de agricultura familiar de Moju

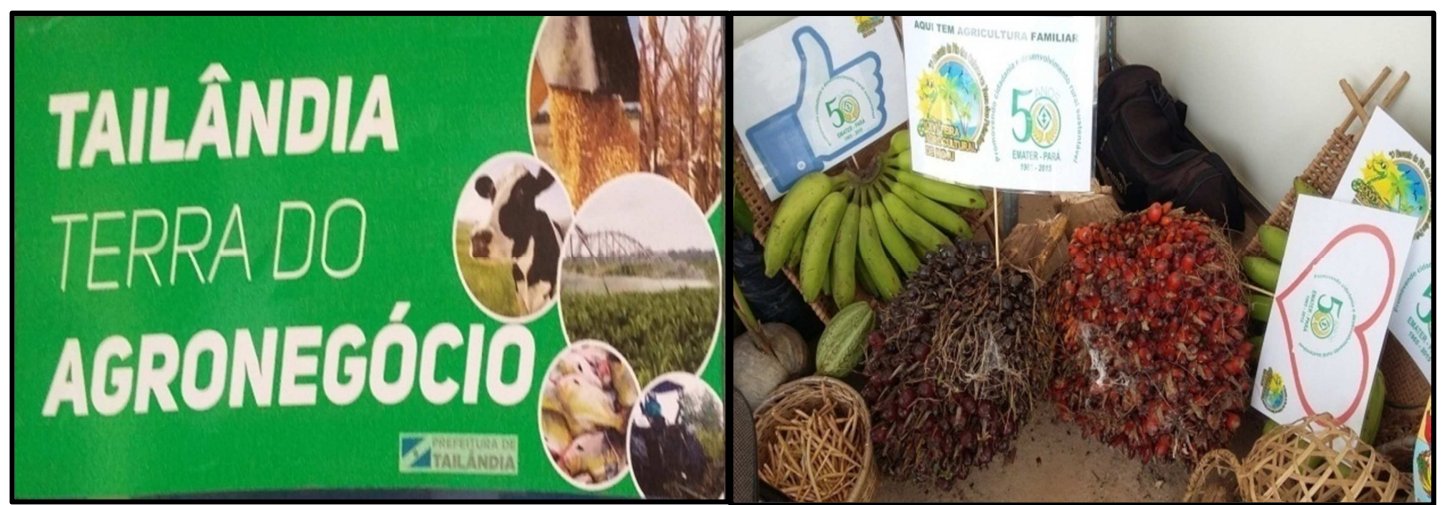

Fonte: Márcio Benassuly (2015) 
Estrutura abandonada da Petrobras, em Mocajuba

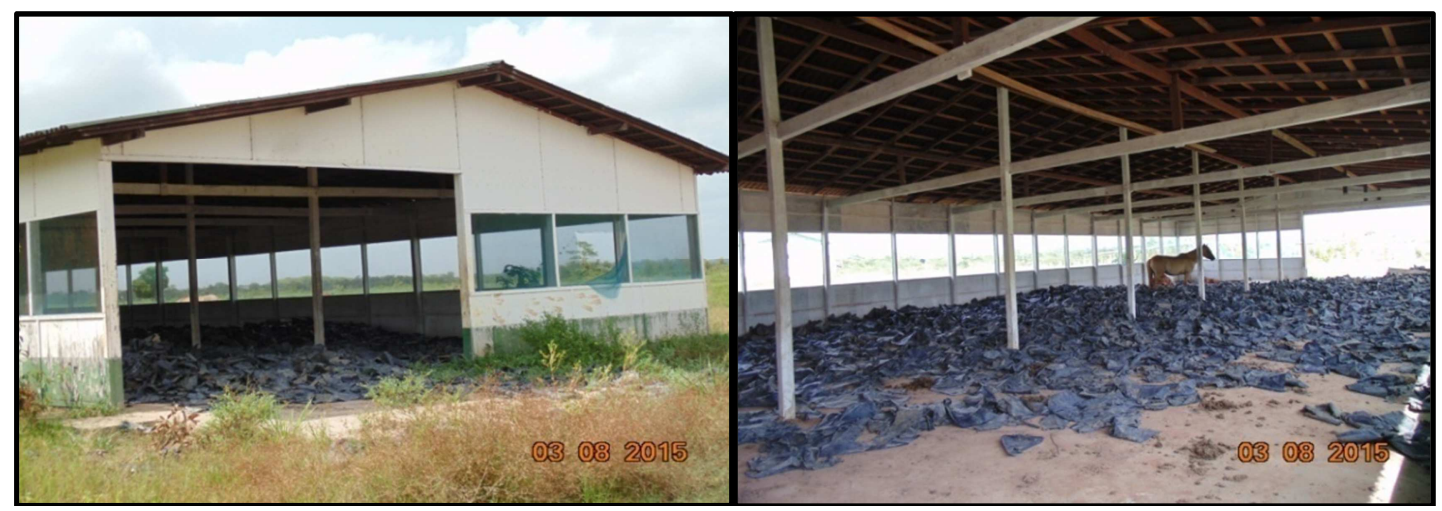

Fonte: Márcio Benassuly (2015)

Aspectos de casa de farinha abandonada em Baião e de transporte de dendê pelo rio Moju

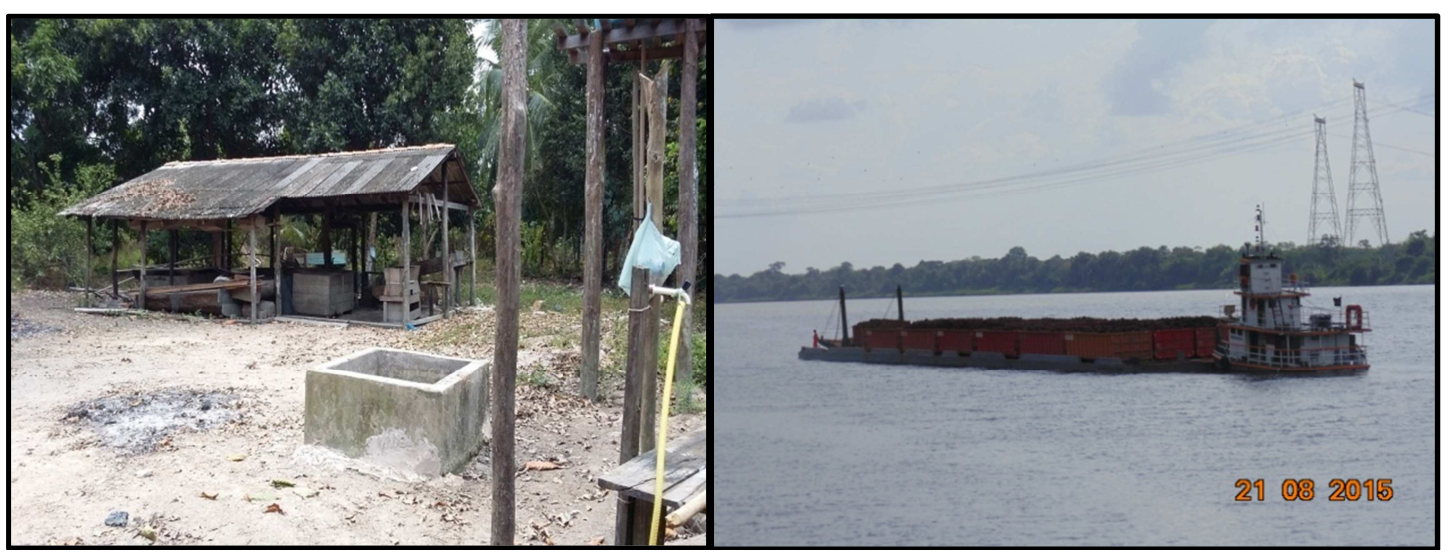

Fonte: Márcio Benassuly (2015)

Aspectos das cidades de Moju e Tailândia

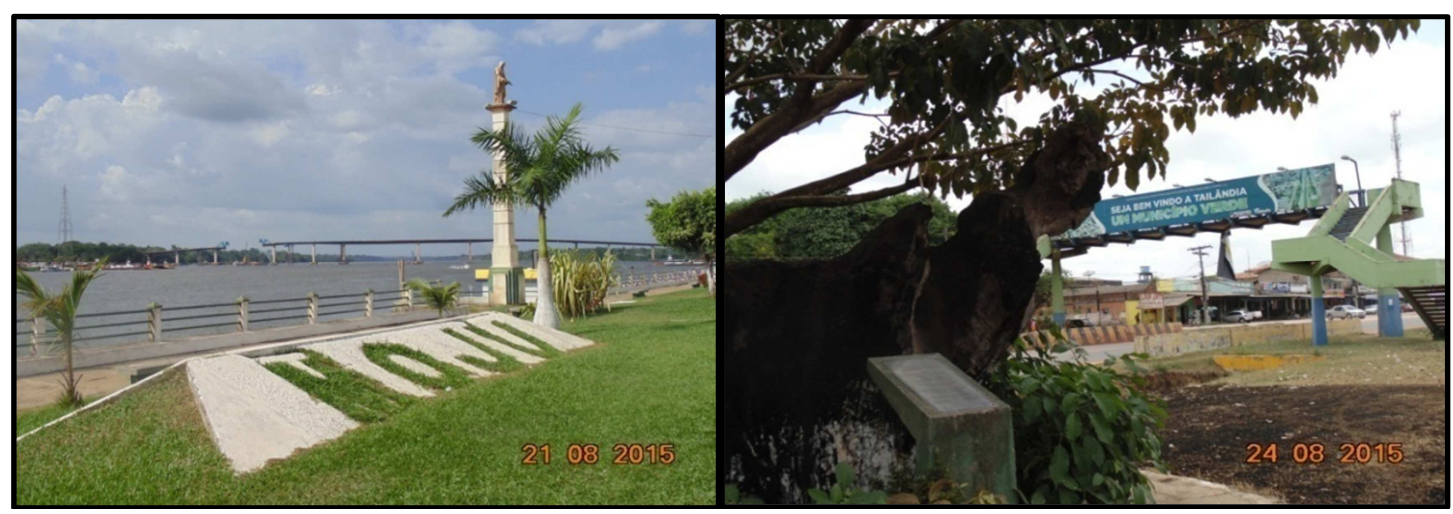

Fonte: Márcio Benassuly (2015) 
ANEXOS 


\title{
ANEXO A \\ Manifesto sobre a agricultura familiar lançado pelo Sindicado dos Trabalhadores e Trabalhadoras Rurais de Cametá
}

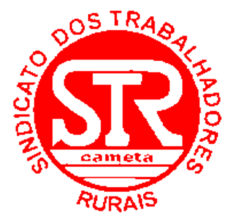 \\ SINDICATO DOS TRABALHADORES E DAS TRABALHADORAS \\ RURAIS DE CAMETÁ \\ Fundado em: 14-02-1974 - CNPJ: 05.845.698/0001-60
}

Direito não se dar: Conquista-se

\section{Resistência do Movimento Sindical Rural por uma Agricultura Familiar Sustentável na Região do Baixo Tocantins.}

O Movimento Sindical Rural da Região do Baixo Tocantins começa a se organizar na década de 1970 que culmina com a fundação da maioria dos Sindicatos dos Trabalhadores e Trabalhadoras Rurais da Região Tocantina nos demais municípios apresentando-se como legítimos representantes dos trabalhadores e trabalhadoras rurais da região, na busca por melhores condições de vida, que se transforma em várias bandeiras de lutas. Contudo, não podemos falar do povo do campo sem levantar a bandeira mais importante: o direito a terra, de nela morar, produzir e tirar as condições de vida para sua família de forma sustentável e racional. Assim, tem sido a vida de milhares de trabalhadores e trabalhadoras rurais desta região do Baixo Tocantins.

A Agricultura Familiar sustentável com bases agroecológicas e solidárias é o que se tem defendido nesta região. Porém, os grandes projetos e as políticas públicas desenvolvidas não conseguiram responder as necessidades destes trabalhadores, a pobreza na região só aumenta, e hoje, como relatou em um encontro o coordenador do Campus da UFPA da região Tocantina de Cametá: "o maior problema do nosso povo é a fome". Fome por justiça social, por cidadania, por direitos a terra, saúde, educação, assistência técnica de qualidade, estradas, moradia digna, transporte e uma agricultura familiar fortalecida. Estas são as bandeiras de lutas do povo do campo hoje.

Os grandes projetos mais uma vez são postos para nós como a salvação da lavoura, hoje é o DENDÊ, assim como os projetos: da Albrás Alunorte, Hidrelétrica de Tucuruí, que iria trazer emprego, luz elétrica e desenvolvimento para região. E o que temos hoje, rios assoreados e poluídos, o peixe praticamente sumiu, doenças, bolsões de miséria e o aumento do êxodo rural. Os grandes projetos nunca beneficiaram os pequenos, sua lógica e a do lucro, pergunta-se à custa de quem? O dendê que vem sendo "vendido" como o grande projeto do momento para a região e para agricultura familiar, a grande alternativa de geração de renda e 
desenvolvimento da região. Pergunta-se de novo: E os ônus deste projeto quais são? Seria o primeiro grande projeto sem impactos?

Infelizmente não é esta a verdade. Em alguns lugares ele avança forçando os trabalhadores a lhe venderem as suas terras, em outras, enganando o lavrador e convencendoo a plantar o dendê em sua própria terra. Em lugar da biodiversidade e de alimentos saborosos e essenciais à vida, vê-se a monotonia do dendê para o Agro combustível. A Mãe-Terra, onde o agronegócio domina já se encontra contaminada pelos agrotóxicos, dissecada pelo dendê que absorve seus lençóis freáticos e violada em sua missão social de alimentar seus filhos e filhas. Muitas roças que garantiam o sustento dos pequenos lavradores já foram ou estão, pouco a pouco, modificando-se em plantações de dendê que depois se transformarão em desespero como está acontecendo com o povo de Arauaí de Moju, primeira comunidade que aderiu ao "projeto do dendê-familiar" em 2001. "A "mídia se encarrega de anunciar propagandas enganosas em favor do "dendê-familiar" e de" suas vantagens lucrativas" para as famílias. E é assim que os agricultores familiares vão bebendo a ideologia capitalista neoliberal dos empresários do agronegócio, e aderindo, infelizmente a seus projetos. Quando resistem surgem então os conflitos por terra e pela agressão à natureza, como a extração irregular e desenfreada de seixo no rio Moju, o grande desmatamento e outras agressões que vêm acontecendo em inúmeras áreas de nossa região.O modelo de desenvolvimento no Brasil é concentrador de terras e riquezas, onde os pobres cada vez, mais pobres e os grandes empresários cada vez mais ricos.

Neste sentido, o Movimento Sindical Rural através dos seus Sindicato de Trabalhadores e Trabalhadoras Rurais vem debater com as empresas propostas que possam mitigar os impactos da implantação deste projeto na Região do Baixo Tocantins. Apresentamos abaixo algumas de nossas reivindicações que não resolverá nossos problemas, mais ajudarão em garantir estes trabalhadores e trabalhadoras em suas terras de forma mais digna e conseqüentemente ainda teremos uma Agricultura Familiar Sustentável garantindo a biodiversidade das nossas florestas e matas, a diversidade produtiva e a garantia da segurança alimentar e nutricional dos povos das florestas da Amazônia Tocantina.

Principais reivindicações de mitigação dos impactos sócias, econômicos, culturais por um fortalecimento da Agricultura Familiar:

- Estruturar redes de comercialização mais justa e que eliminem práticas de exploração de ribeirinhos, agricultores familiares e outras populações locais, e fortalecer cooperativas e associações;

- Realização de estudos de potenciais produtivos da agricultura familiar da região;

- Estruturar as cadeias produtivas sustentáveis que geram emprego e renda com agregação de valor local, principalmente da fruticultura e das oleaginosas;

- Promover a capacitação e qualificação dos recursos humanos para o desenvolvimento de projetos e de negócios sustentáveis no setor do turismo ecológico;

- Fortalecer a produção familiar e comunitária; consolidar e ampliar as iniciativas de economia popular e solidária; e estimular a integração entre a produção agroextrativista e os processos industriais e de comercialização, com vistas à dinamização de economias locais e regionais;

- Ampliar a infra-estrutura regional - energia, armazenagem, transformação, transportes e comunicações, e de prestação de serviços essenciais à qualidade de vida de seus habitantes - saneamento básico, destinação de resíduos sólidos, saúde, educação e segurança pública; 
- Promover a utilização de áreas já desmatadas, com aumento de produtividade e recuperação florestal e produtiva das áreas degradadas - conjuntamente com o fomento ao uso múltiplo das florestas em bases sustentáveis;

- Implantação de Centros de formação tecnológicas e apoio as Casas Familiares Rurais existentes na região para jovens da agricultura familiar.

Estas são as reivindicações do Movimento Sindical Rural do Baixo Tocantins.

Cametá, 15 de junho de 2011.

STTR de Cametá

STTR de Baião

STTR de Mocajuba

STTR de Igarapé Miri

FETAGRI Regional Tocantins 
ANEXO B

Documento de apresentação do pesquisador

Universidade de Brasilia

Instituto de Ciências Humanas

Departamento de Geografia

Programa de Pós-Graduaçấo em Geografia

A QUEM INTERESSAR POSSA

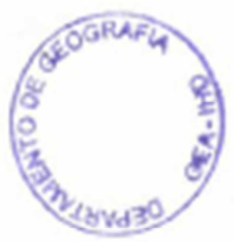

Apresentamos o Sr. Márcio Júnior Benassuly Barros, aluno de nível de doutorado do Programa de Pós-Graduação em Geografia da Universidade de Brasília (GEA-UnB) que está desenvolvendo seu trabalho de Tese de Doutorado, intitulado "Integração da agricultura familiar no agronegócio do biodiesel de dendê no Baixo Tocantins (PA)" sob a orientação da Professora Dra. Marilia Steinberger.

Solicitamos a colaboraçāo possível no sentido de possibilitar contato para entrevistas, disponibilizar dados técnicos e acesso a arquivos ou documentos com informaçóes, os quais serão de grande valor para a realizaçắo do referido trabalho.

Agradecemos a atençî́o dispensada ao nosso aluno, colocamo-nos à disposiçăo para esclarecimentos adicionais que se fizerem necessários.

Brasilia-DF., 20 de agosto de 2015

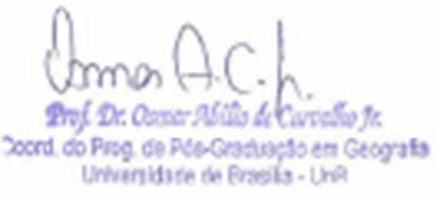

